\title{
6. SITE 433: SUIKO SEAMOUNT
}

\author{
Shipboard Scientific Party ${ }^{1}$
}

\section{SITE DATA, HOLE 433}

Date Occupied: 16 August 1977 (1000Z) (16 August 1977 [2100L])

Date Departed: 16 August 1977 (1600Z) (17 August 1977 [0300L])

Time on Hole: 6 hours 0 minutes

Position: $44^{\circ} 46.60^{\prime} \mathrm{N}, 170^{\circ} 01.26^{\prime} \mathrm{E}$

Water Depth (sea level): 1861.8 corrected meters, echo sounding

Water Depth (rig floor): 1871.8 corrected meters, echo sounding

Bottom Felt at: 1874.0 meters, drill pipe

Penetration: $\mathbf{4 5 . 0}$ meters

Number of Holes: 1

Number of Cores: 1

Total Length of Cored Section: 5.0 meters

Total Core Recovery: 5.0 meters

Percentage Core Recovery: 100.0

Oldest Sediment Cored:

Depth sub-bottom: 5.0 meters

Nature: Foraminifer-diatom ooze

Chronostratigraphy: Pliocene

Measured velocity: $1.52-1.60 \mathrm{~km} / \mathrm{s}$

Basement:

Not Reached

Principal Results: Hole 433 was drilled as a washdown test for a possible multiple re-entry hole at this site. A 5.0-meter core was carefully taken between 1874.0 and 1879.0 meters depth to establish the location of the mudline. A section of foraminiferal nannofossil and diatom nannofossil ooze 45.0 meters thick was then washed down in 18 minutes 30 seconds before resistance was felt at what later proved to be a chalk bed above a volcanic ash layer. Examination of the

${ }^{1}$ Everett D. Jackson (Co-Chief Scientist), United States Geological Survey, Menlo Park, California; Itaru Koizumi (Co-Chief Scientist), Osaka University, Osaka, Japan; R. James Kirkpatrick, Deep Sea Drilling Project, Scripps Institution of Oceanography, La Jolla, California (now at University of Illinois; Urbana, Illinois); Gennady Avdeiko, USSR Academy of Sciences, Petropavlovsk-Kamchatsky, USSR; David Clague, Middlebury College, Middlebury, Vermont; G. Brent Dalrymple, United States Geological Survey, Menlo Park, California; Anne-Marie Karpoff, Institut de Geologie, Strasbourg, France; Judith McKenzie, Eidg. Technische Hochschule, Zürich, Switzerland; Arif Butt, Universitat Tübingen, Tübingen, Federal Republic of German; Hsin Yi Ling, University of Washington, Seattle, Washington; Toshiaki Takayama, Kanazawa University, Kanazawa, Japan; H. Gary Greene, United States Geological Survey, Menlo Park, California; Jason Morgan, Princeton University, Princeton, New Jersey; and Masaru Kono, University of Tokyo, Tokyo, Japan. 5.0-meter core showed that the pelagic oozes are Pleistocene to upper Pliocene. Hole 433 showed that Site 433 was suitable for setting a re-entry cone.

\section{SITE DATA, HOLE 433A}

Date Occupied: 16 August 1977 (1600Z) (17 August 1977 [0300L])

Date Departed: 17 August 1977 (1915Z) (18 August 1977 [0615L])

Time on Hole: 27 hours 15 minutes

Position: $44^{\circ} 46.60^{\prime} \mathrm{N}, 170^{\circ} 01.26^{\prime} \mathrm{E}$

Water Depth (sea level): 1861.8 corrected meters, echo sounding

Water Depth (rig floor): $\mathbf{1 8 7 1 . 8}$ corrected meters, echo sounding

Bottom Felt at: 1874.0 meters, drill pipe

Penetration: 174.0 meters

Number of Holes: 1

Number of Cores: 21

Total Length of Cored Section: 174.0 meters

Total Core Recovery: 88.59 meters

Percentage Core Recovery: 50.9

Oldest Sediment Cored:

Depth sub-bottom: 163.5 meters

Nature: Reef limestone

Chronostratigraphy: Paleocene

Measured velocity: $4.72-4.74 \mathrm{~km} / \mathrm{s}$ (limestone)

Basement:

Depth sub-bottom: 163.5 meters

Nature: Basalt

Velocity range: $4.8-5.8 \mathrm{~km} / \mathrm{s}$

Principal Results: Hole 433A was drilled as a pilot hole for the re-entry hole. It was continuously cored to a sub-bottom depth of 174.0 meters before a wad of nylon fishing net and polyethylene filament line fouled the stern thrusters and forced us to abandon the hole. We recovered sedimentary rocks ranging from Pleistocene-Pliocene ooze at the surface to consolidated Paleocene limestone at $\mathbf{1 6 3 . 5}$ meters. Basalt lay directly beneath an erosional contact with limestone, and we cored 10.5 meters of basalt from a single flow type before abandoning the hole.

The sedimentary section was divided into six units. The upper three units, from 0 to $\mathbf{5 2 . 5}$ meters sub-bottom, range from Pliocene pelagic oozes downward to lower Miocene calcareous chalk. Fossils in this section are pelagic, and indicate a similar ecological environment throughout the period of their deposition. Unit 4, from 52.0 to 52.5 meters, consists of altered tuffaceous sandy mud, and contains lower Miocene pelagic fossils. Units 5 and 6 consist of reef carbonate sand, sandy mud with algal nodules, and reef 
calcarenite. The fossils of these units date from the middle Paleocene, and indicate a significant hiatus from Eocene through a major part of the Oligocene. The sediments deposited during this period contain biota of warm shallowwater habitat: benthic foraminifers, coralline algae, bryozoans, and ostracodes. These reef materials lie directly on the eroded surface of an alkalic basalt.

Suiko Seamount was therefore an island with fringing reefs by middle Paleocene time. Hole 433A penetrated shore and lagoonal zones of a back-reef region of a reef complex. The basalt flow at the base of the section was chemically analyzed and studied in thin section on board ship; it is an alkalic basalt of the Hawaiian type.

\section{SITE DATA, HOLE 433B}

Date Occupied: 18 August 1977 (0300Z) (18 August 1977 [1400L])

Date Departed: 18 August 1977 (1732Z) (19 August 1977 [0432L])

Time on Hole: 15 hours 32 minutes

Position: $44^{\circ} 46.63^{\prime} \mathrm{N}, 170^{\circ} 01.23^{\prime} \mathrm{E}$

Water Depth (sea level): 1861.8 corrected meters, echo sounding

Water Depth (rig floor): 1871.8 corrected meters, echo sounding

Bottom Felt at: 1874.0 meters, drill pipe

Penetration: 186.5 meters

Number of Holes: 1

Number of Cores: 7

Total Length of Cored Section: 58.0 meters

Total Core Recovery: 10.72 meters

Percentage Core Recovery: 18.5

Oldest Sediment Cored:

Depth sub-bottom: 157.0 meters

Nature: Reef sand and reef limestone

Chronostratigraphy: Middle Paleocene

Measured velocity: $1.8-1.9 \mathrm{~km} / \mathrm{s}$ (sand); $4.7 \mathrm{~km} / \mathrm{s}$ (limestone)

\section{Basement:}

Depth sub-bottom: 163.5 meters

Nature: Basalt

Velocity range: $4.3-5.4 \mathrm{~km} / \mathrm{s}$

Principal Results: Hole 433B was a single-bit hole in which we planned to finish the bit-wear tests of a pilot hole for reentry, inasmuch as Hole 433A had been terminated before completion. We washed the hole down to 157.0 meters subbottom to recore the lower portion of reef deposits occurring above basalt in Hole 433A. Reef carbonate sand containing benthic foraminifers, algal nodules, bryozoans, echinoid spines, and ostracodes, and as much as 15 per cent volcanic debris was recovered in the first three cores. The contact between reef calcarenites and basalt was recovered in Core 4. The drill penetrated at least 7.5 meters into the same alkalic basalt flow encountered in Hole 433A, and a total of 23.5 meters beneath the upper surface of the basalt, without further recovery. We then abandoned the hole because of a jammed bit.

Recoring of the lower reef section above basalt allowed close paleontological dating of the oldest sediments above basalt. Nannofossils show that the lowermost sediments are lower to middle Paleocene. The paleontologic data indicate that the oldest sediments on Suiko Seamount are younger than those found on Meiji Seamount (Site 309; Creager, Scholl, et al., 1973) and probably older than those from Ōjin Seamount (Site 430; Takayama et al., this volume).

\section{SITE DATA, HOLE 433C}

Date Occupied: 18 August 1977 (1732 Z) (19 August 1977 [0432 L])

Date Departed: 29 August 1977 (1152 Z) (29 August 1977 [2252 L])

Time on Hole: 258 hours 20 minutes

Position: $44^{\circ} 46.63^{\prime} \mathrm{N}, 170^{\circ} 01.23^{\prime} \mathrm{E}$

Water Depth (sea level): 1861.8 corrected meters, echo sounding

Water Depth (rig floor): 1871.8 corrected meters, echo sounding

Bottom Felt at: 1874.0 meters, drill pipe

Penetration: 550.5 meters

Number of Holes: 1

Number of Cores: 50

Total Length of Cored Section: 387.5 meters

Total Core Recovery: 250.15 meters

Percentage Core Recovery: 64.6

Oldest Sediment Cored:

Depth sub-bottom: Washed to basement

Nature: Sand interbedded in basaltic basement

Chronostratigraphy: Paleocene

Basement:

Depth sub-bottom: 163.0 meters

Nature: Basalt

Velocity range: $2.43-6.26 \mathrm{~km} / \mathrm{s}$

Principal Results: Hole $433 \mathrm{C}$ was spudded in as a multiple reentry hole. The cone was set and the sediments were washed down to the contact between the reef calcarenite and the basalt. The original bit jammed after we had cored part of Flow Unit 1, and in using the chisel bit to free it, we unexpectedly recovered 4.0 meters of beach sand lying between Flow Units 1 and 2. The sand is coarse and well sorted, and consists of about 70 per cent reef debris (foraminifers, coralline algae, bryozoans, coccoliths, etc.) and about 30 per cent volcanogenic debris. Beneath the sand we cored two more flow units of basalt and penetrated 39.5 meters beneath the upper surface of Flow Unit 1. The bit jammed, and was pulled. The second bit penetrated 59 meters of basalt, including Flow Units 4 through 13, before the bit jammed again, and was pulled. The third bit penetrated 179 meters of basalt, and we recovered parts of Flow Units 13 through $45 \mathrm{~b}$, before replacing it because of excessive hours of use. The fourth bit penetrated 95 meters of basalt; in this interval, we recovered parts of Flow Units 45b through 67. Then the bit jammed again, and not enough time remained for another re-entry. In all, we penetrated 387.5 meters of basalt; overall recovery was 50.9 per cent.

Visual descriptions, petrographic descriptions, and preliminary XRF analyses of the basalts showed that we had penetrated (proceeding downward) three flows of alkalic basalt and a thick sequence of tholeiitic flows. Many of the flow units are separated by highly vesicular, strongly oxidized, commonly brecciated tops, and less oxidized, commonly 
glassy bottoms, and were certainly erupted subaerially. Shipboard and shore-based chemical analyses of the fresher parts of the flow units show that both alkalic and tholeiitic basalts are in the compositional range of those known from the southeastern part of the Hawaiian Islands, and are distinctly different from mid-ocean ridge basalts. Their only chemical peculiarity appears to be strong depletion of barium, where the analyses include that element, and equally strong depletion of strontium. It appears that these elements may be slightly depleted at Nintoku as well.

More than 300 samples were measured on board to determine the magnetic inclinations of flow units, and the principal shipboard conclusions have been confirmed by shore-based studies (Kono, this volume). About ten cycles of inclination swings were observed. It seems likely, therefore, that a sufficient number of secular variation cycles have been observed that average inclinations are meaningful. The median inclination in the Suiko basalts from the shipboard measurements is $42^{\circ}$, which corresponds to a median latitude of formation of $25^{\circ}$. It seems very probable, therefore, that the volcanic rocks of Suiko Seamount crystallized at a latitude about $20^{\circ}$ south of their present position; and the measurements confirm the overall latitudinal transport required by the hot-spot hypothesis.

Subsequent K-Ar dating of the Suiko basalts (Dalrymple et al., this volume) shows that Suiko volcano is older than Ojin (Site 430) and Nintoku (Site 432) seamounts to the south. The K-Ar ages are consistent with the age of the oldest sediments above the basalt.

\section{BACKGROUND AND OBJECTIVES}

Site $55-2$, as originally proposed for Leg 55 , represented our northernmost drill site in the Emperor Seamount chain, and was designated not only to provide a point of lithologic information between our proposed Site 55-1 and Site 192 on Meiji Seamouont (Creager, Scholl, et al., 1973), but also as a prime re-entry site for determining the paleolatitude of part of the basaltic edifice of Suiko Seamount.

Our proposed re-entry site on Suiko Seamount was at $45^{\circ} 00^{\prime} \mathrm{N}, 169^{\circ} 45^{\prime} \mathrm{E}$, located on a crossing by the R/V S. $P$. Lee in October 1976 . The $80-\mathrm{kJ}$ sparker profile taken on the Lee showed a sediment pond about 200 meters thick, underlain by a clearly defined acoustic basement, at Site 55-2 on Suiko Seamount (see Figure 1). The site therefore seemed appropriate for a multiple re-entry hole aimed principally at recovery of basalt. The $3.5-\mathrm{kHz}$ profile taken by the Lee, however, showed no penetration at the site proper, although a transparent layer 5 to 60 meters thick (at water velocities) first appeared on the Lee profile about 10 nautical miles southeast of proposed Site 55-2, and extended several miles along the traverse (Figure 2). In Honolulu, we learned that the R/V Kana Keoki, from the University of Hawaii, had just completed a cruise in the northern Emperor chain, and that one of their profile lines (Figure 1) crossed Suiko Seamount quite near our proposed re-entry site. Dr. Loren Kroenke of the Hawaii Institute of Geophysics kindly supplied us a copy of this profile, and made the $3.5-\mathrm{kHz}$ records along this line available for our inspection on extremely short notice. We had no time to copy the $3.5-\mathrm{kHz}$ records before our departure on Leg 55, but we noted that transparent sur- face material occurred on the Kana Keoki profile near its crossing with the Lee profile.

After drilling at Sites 430, 431, and 432 - all of which showed little $3.5-\mathrm{kHz}$ penetration, and proved to have sandy or muddy Quaternary materials at the surface of the sea floor, immediately underlain by Eocene sediments - we decided to re-evaluate the location of our prime re-entry site on Suiko Seamount. We resolved to reoccupy the Lee profile line, in an attempt to measure sediment thickness above acoustic basement in areas known to show penetration at $3.5 \mathrm{kHz}$; and we decided to consider Sites 55-2A', 55-2A, and 55-2B (Figure 1), as well as our original Site 55-2, and to locate our prime site in the area where we encountered the thickest, softest surface materials.

\section{OPERATIONS}

\section{Pre-Drilling Site Survey}

The R/V S. P. Lee crossed Suiko Seamount on 6 October 1976 , on a course of $135^{\circ}$ true (Figure 1), and obtained an $80-\mathrm{kJ}$ sparker seismic reflection profile (Figure 2). This profile showed the seamount to be a flattopped guyot, consisting, apparently, of a broad, very slightly domed central platform surrounded by a lower, gently concave upward, topographic and structural depression and an outer, rounded, topographic and acoustic basement ridge. Subsurface structures in the seismic profile suggest that the central platform is composed of reef material laid down on eroded volcanic rock. Fringing reefs may have formed the outer scarps of the central platform. These relatively steep scarps make up an inner buttress that bounds the surrounding depression. This depression is filled with flat-lying well-layered lagoonal(?) sediments that lap onto the outer acoustic basement ridge and appear to be truncated at the base of the inner scarp. The outer edge of the top of the seamount is rounded and appears to consist locally of prograded and ponded sediments.

We proposed two drilling sites (55-2 and 55-2A) for Suiko Seamount; we selected the locations because 100 meters or more of sediments overlay an acoustic basement probably made up of volcanic rock. The prime site $(55-2)$ is at the northwest edge of the seamount (Figure 1 ), where over $1.5 \mathrm{~s}$ of sediment appear to be ponded above the acoustic basement (Figure 2). No transparent layer was shown in the Lee $3.5-\mathrm{kHz}$ profile crossing the site. The second site (55-2A) is at the center of the lagoon along the northwest part of the seamount, where the Lee $3.5-\mathrm{kHz}$ profile showed an overlying transparent layer of 30 to 60 meters of pelagic ooze. In the subsurface, over $0.5 \mathrm{~s}$ of well-layered strata appear to occur, but since no acoustic basement could be defined here, Site 55-2 appeared more promising for emplacement of a re-entry cone and successful drilling of a multiple re-entry hole.

On 30 June 1977, the R/V Kana Keoki of the Hawaiian Institute of Geophysics passed over Suiko Seamount on a course of $240^{\circ}$ true, and crossed the Lee line at a nearly perpendicular angle. About 4 nautical miles 


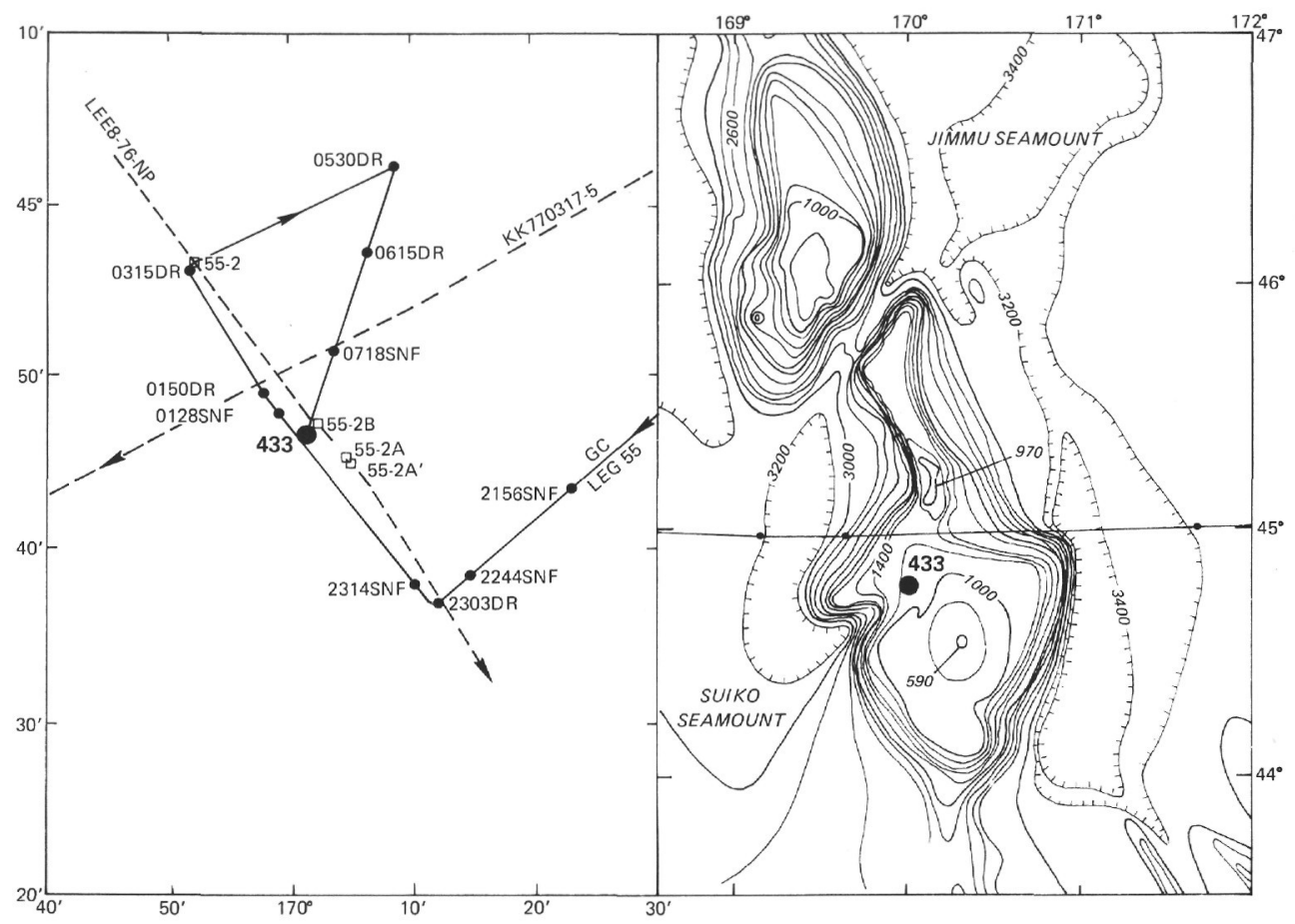

Figure 1. Bathymetry of the Emperor Seamount chain in the vicinity of Suiko Seamount, showing the tracks of the Glomar Challenger, the Kana Keoki, and the S. P. Lee. Prospective sites are shown by open squares. Depth contours in fathoms. Bathymetry after Chase et al. (1970).

northwest of Site 55-2A, the Kana Keoki obtained an airgun seismic reflection profile (Figure 3); this profile shows the central platform identified in the Lee profile to be a narrow, rounded acoustic basement ridge. The lagoon is not as symmetrical in the Kana Keoki profile as in the Lee profile; it is less well developed and narrower to the northeast of the ridge than to the southwest. Northeast of the central ridge and platform, lagoonal deposits appear to be thin and covered with terrace deposits sloping gently northeast. Near the northeast flank of the ridge, over $0.2 \mathrm{~s}$ of sediments overlie a faulted and eroded acoustic basement. To the southwest, a wide structural depression, filled with over $0.45 \mathrm{~s}$ of sediments, probably lagoonal, extends from the central ridge for over 10 nautical miles to a gently rounded topographic and acoustic basement ridge that marks the edge of the seamount top. Sediments within the depression lap onto the acoustic basement ridge, which appears to be locally capped with reefs.

We approached Suiko Seamount from Adak, Alas$\mathrm{ka}$, on a course of $231^{\circ}$ true at $9.6 \mathrm{knots}$, to intersect the survey line of the $S$. P. Lee at latitude $44^{\circ} 37.2^{\prime} \mathrm{N}$, longitude $170^{\circ} 11.9^{\prime} \mathrm{E}$ (Figure 1). Satellite navigation fixes at 2120Z, 2156Z, and 2244Z, 15 August 1977, showed the Challenger on the desired track; we slowed to 6 knots at 2237Z. At $2303 \mathrm{Z}$ (1003L, 16 August), we turned to $324^{\circ}$ true to reoccupy the Lee line. A satellite fix at $2314 \mathrm{Z}$ suggested a slight westerly set from the Lee track, and another fix at 0128Z, 16 August, confirmed that we had passed about 1.5 nautical miles southwest of the four prospective sites, 55-2, 55-2A, 55-2 $\mathrm{A}^{\prime}$, and 55-2B (Fig- ure 1). We threw a sonobuoy overboard at $0047 \mathrm{Z}$ and initiated a wide-angle seismic reflection profile. Reception was poor, however, and we had to terminate the run prematurely. At $0150 \mathrm{Z}$ we changed course to $324^{\circ}$ true. The seismic reflection profile obtained aboard the Glomar Challenger along this track shows the broad central platform to the south, with its steep north-facing scarp bounding the lagoonal(?) sediments of the structural depression. An erosional moat apparently has developed, probably from current scour, at the base of this scarp (Figure 4). Acoustic basement appears to lie beneath 0.18 to $0.20 \mathrm{~s}$ of stratified sediments near proposed Sites 55-2A and 55-2A' (see Figures 1 and 5). The $3.5-\mathrm{kHz}$ profile obtained along this track shows an acoustically well-layered to semitransparent cover of sediments (probably pelagic), overlying a very irregular and faulted strong reflector that acts as an acoustic basement in the $3.5-\mathrm{kHz}$ profile (Figure 6). In the vicinity of Site 433 these sediments are over $0.06 \mathrm{~s}$ thick, and appear to be ponded between the scarp on the southeast and an uplifted block of acoustically nontransparent rock to the northwest. The profile, continued northwest, shows acoustically transparent sediments ponded in small basins formed from down-faulted and backward-rotated bedrock steps (see Figure 7).

At $0315 \mathrm{Z}$ (1415L), we turned the Challenger to $065^{\circ}$ true, and at $0322 \mathrm{Z}$ passed directly over proposed site 55-2 at about 6 knots. Although we identified ponded sediments at Site 55-2 in the Challenger profiles, we found no acoustically transparent sediments similar to those along the previous Challenger track. We decided 

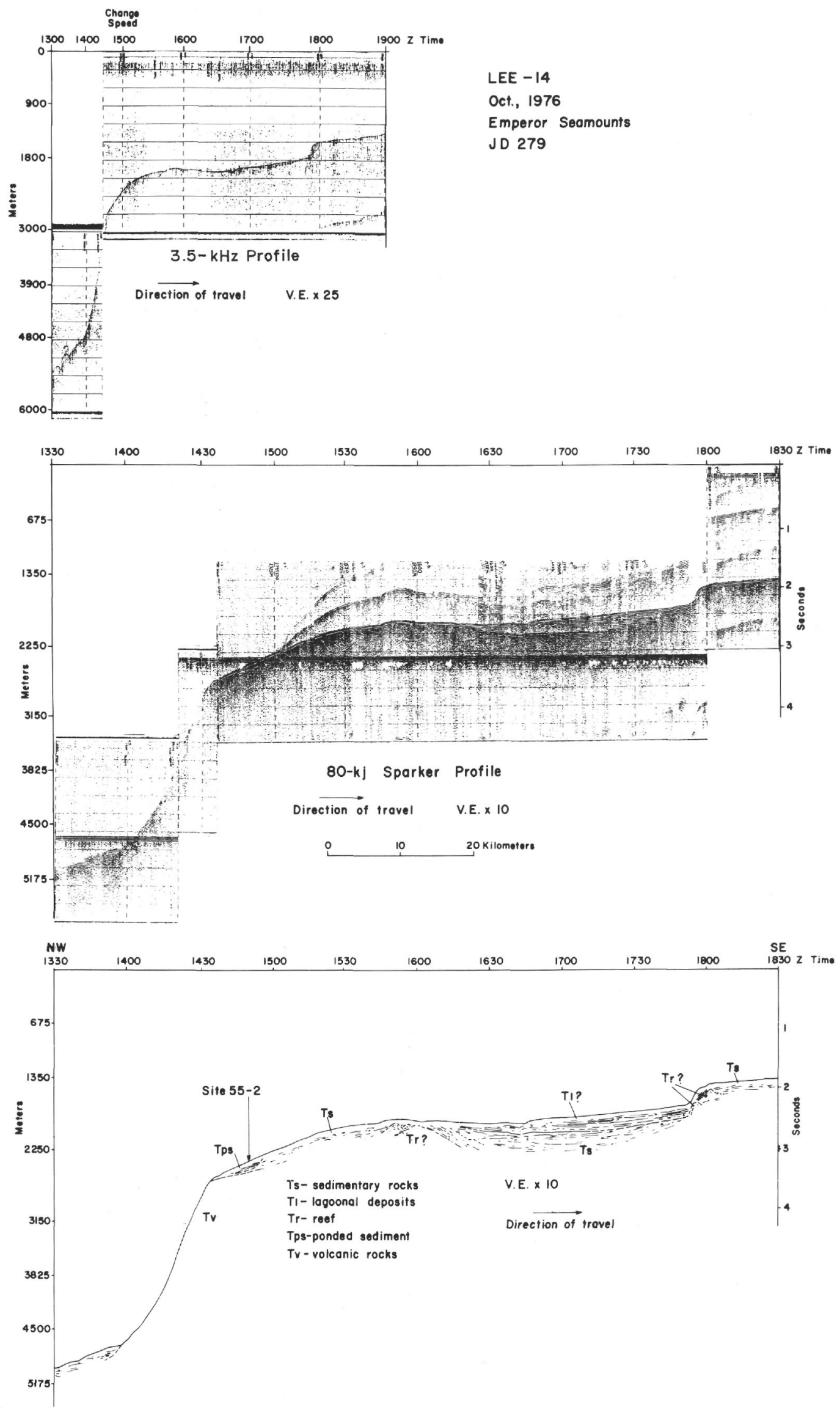

Figure 2. A portion of U.S. Geological Survey's S. P. Lee sparker seismic reflection and 3.5-kHz profiles, showing proposed Site 55-2 and geologic interpretation. 
SW

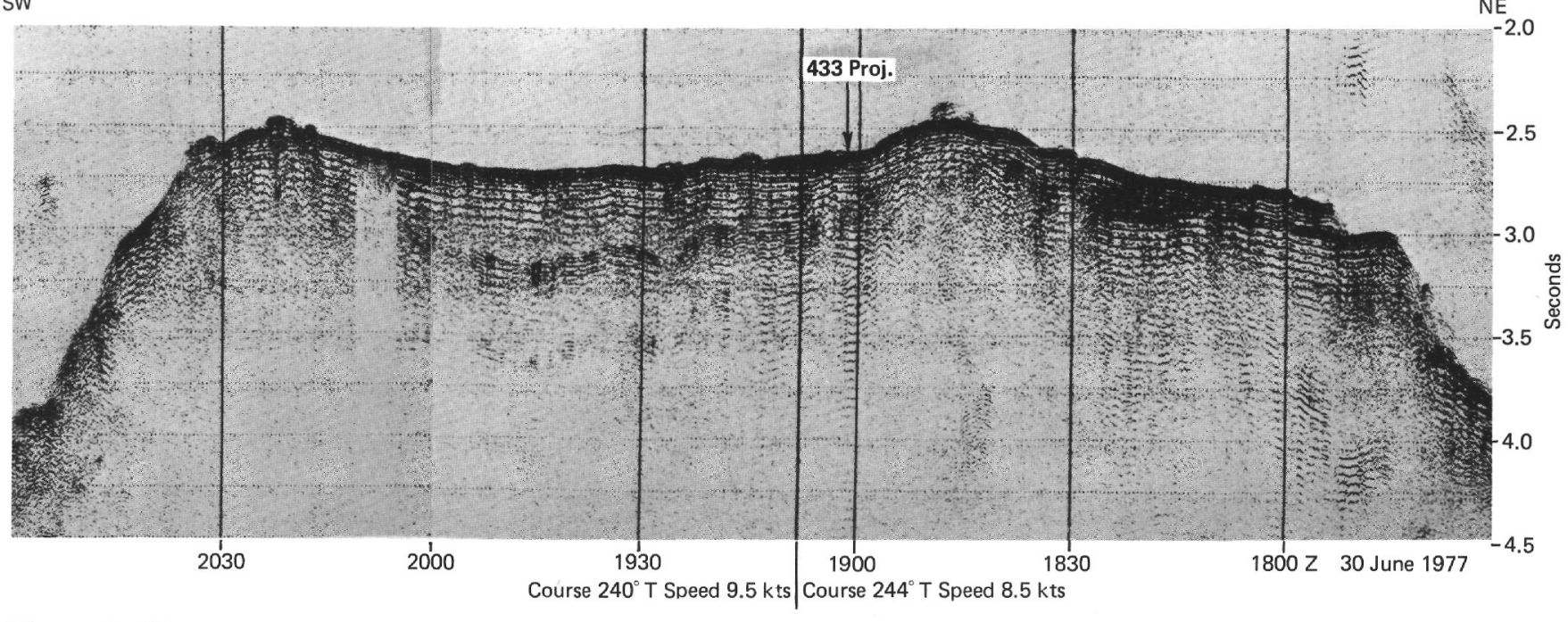

Figure 3. Hawaii Institute of Geophysics' Kana Keoki airgun seismic reflection profile across Suiko Seamount (courtesy Dr. Loren Kroenke, Hawaii Institute of Geophysics).

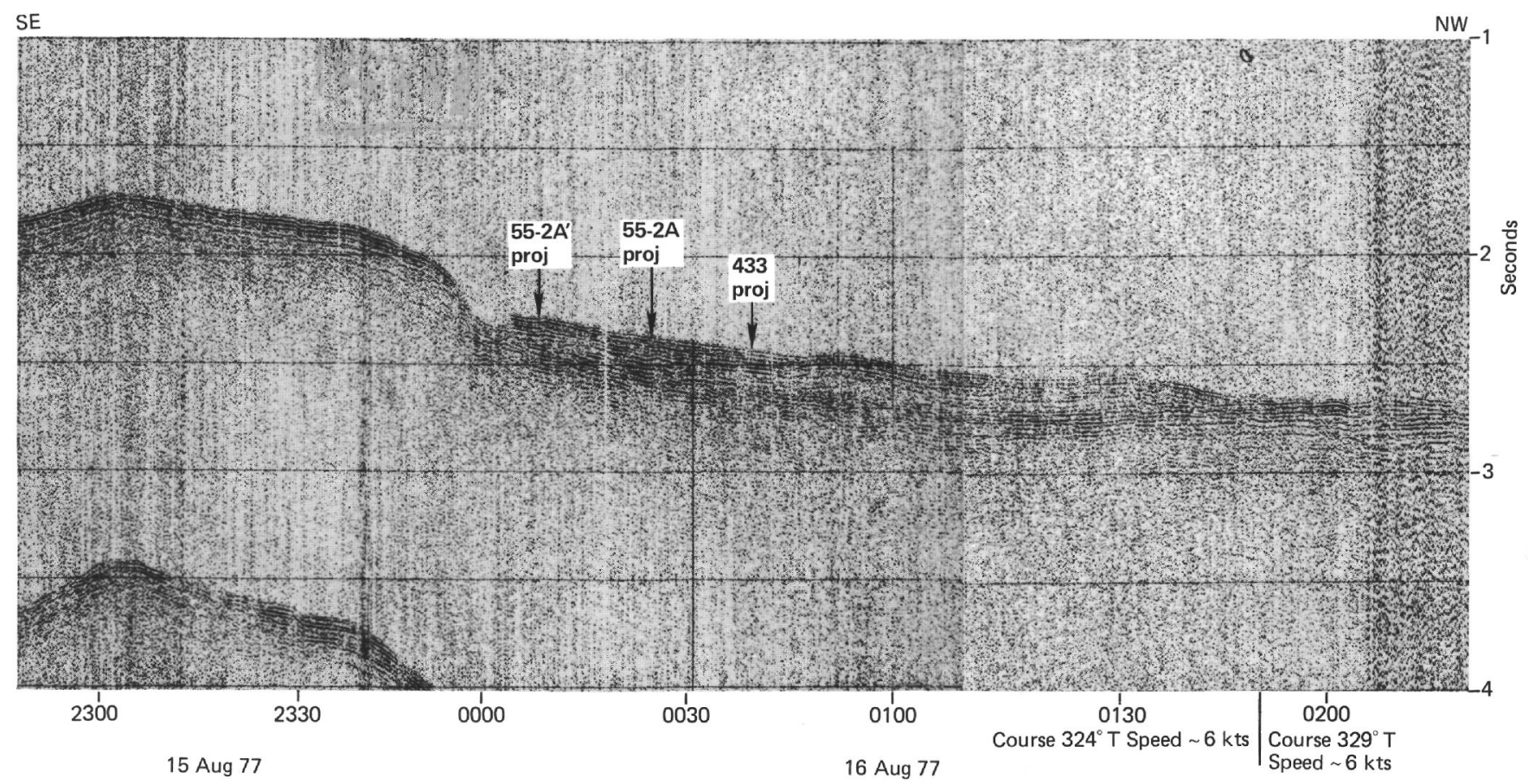

Figure 4. Glomar Challenger 5-s seismic reflection profile across proposed Sites 55-2A', 55-2A, and 55-2B.

to drill near Site $55-2 \mathrm{~B}$. We changed course at $0530 \mathrm{Z}$ (1630L) to $202^{\circ}$ true, and at $0615 \mathrm{Z}$ to $200^{\circ}$ true, to pass over the sediment pond identified in the Challenger $3.5-\mathrm{kHz}$ profile $(0110 \mathrm{Z}$, dead reckoning position, 16 August; see Figures 1 and 6). A satellite fix at $0736 \mathrm{Z}$ showed the Challenger to be within 0.2 nautical miles of the intended track. At $0810 \mathrm{Z}$, we changed course slightly to $205^{\circ}$ true and dropped at $16-\mathrm{kHz}$ beacon at $0818 \mathrm{Z}$ (Figure 8). Our seismic reflection profiles along this traverse show undulating topography on the approach to Site 433 (Figures 9 and 10). A buried acoustic basement ridge exists near this locality and well-stratified sedi- ments appear to lap onto the ridge from both the north and the south. Site 433 is south of this ridge, and appears to have $0.2 \mathrm{~s}$ of well-stratified sediments overlying a poorly defined acoustic basement. The $3.5-\mathrm{kHz}$ profile obtained aboard the Challenger along this track shows $0.06 \mathrm{~s}$ of flat to gently folded, well-stratified sediments lying over a highly faulted, and locally sharply folded, strong reflector that acts as an acoustic basement in the $3.5-\mathrm{kHz}$ profiles (Figure 11).

We continued on course $205^{\circ}$ true until $0833 \mathrm{Z}$, then turned east, retrieved the overboard geophysical gear, and headed back toward the beacon (Figure 8). The 


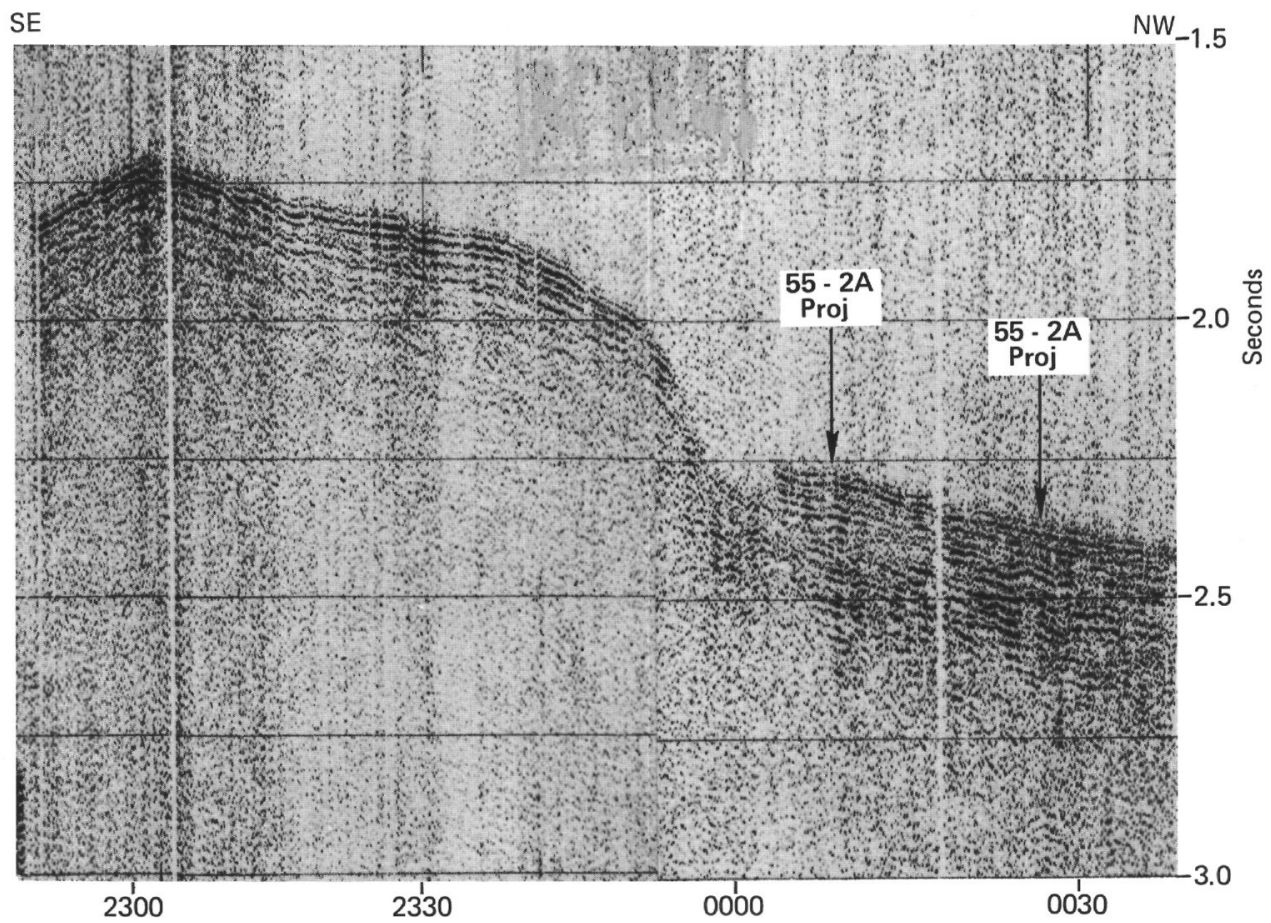

Course $324^{\circ} \mathrm{T}$

Speed $\sim 6$ kts

15 Aug 77

16 Aug 77

Figure 5. Glomar Challenger 2.5-s seismic reflection profile across proposed Sites 55- $2 A$ and $55-2 A$ '.

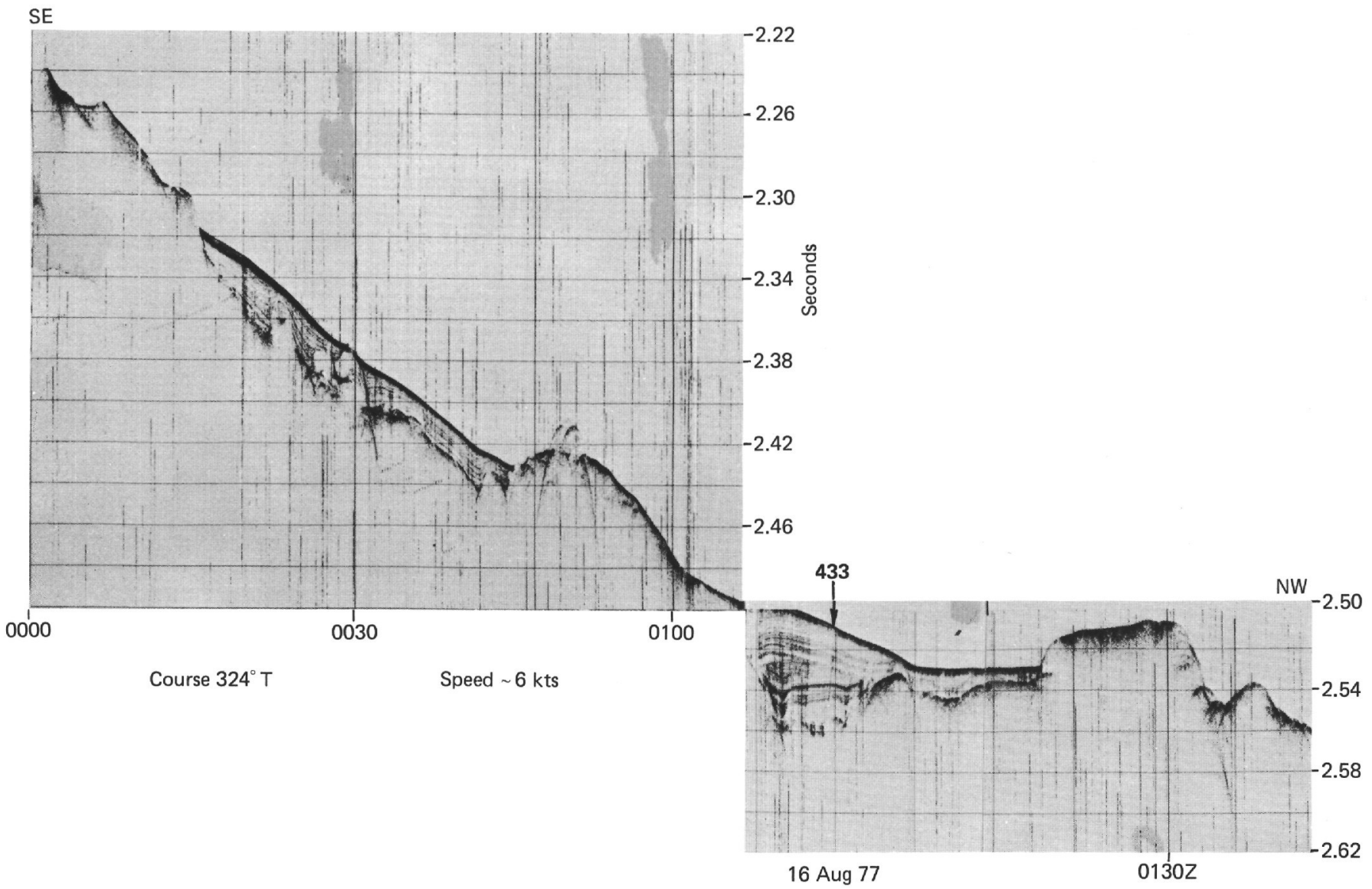

Figure 6. Glomar Challenger 3.5-kHz profile across Site 433, showing pelagic sediment pond. 


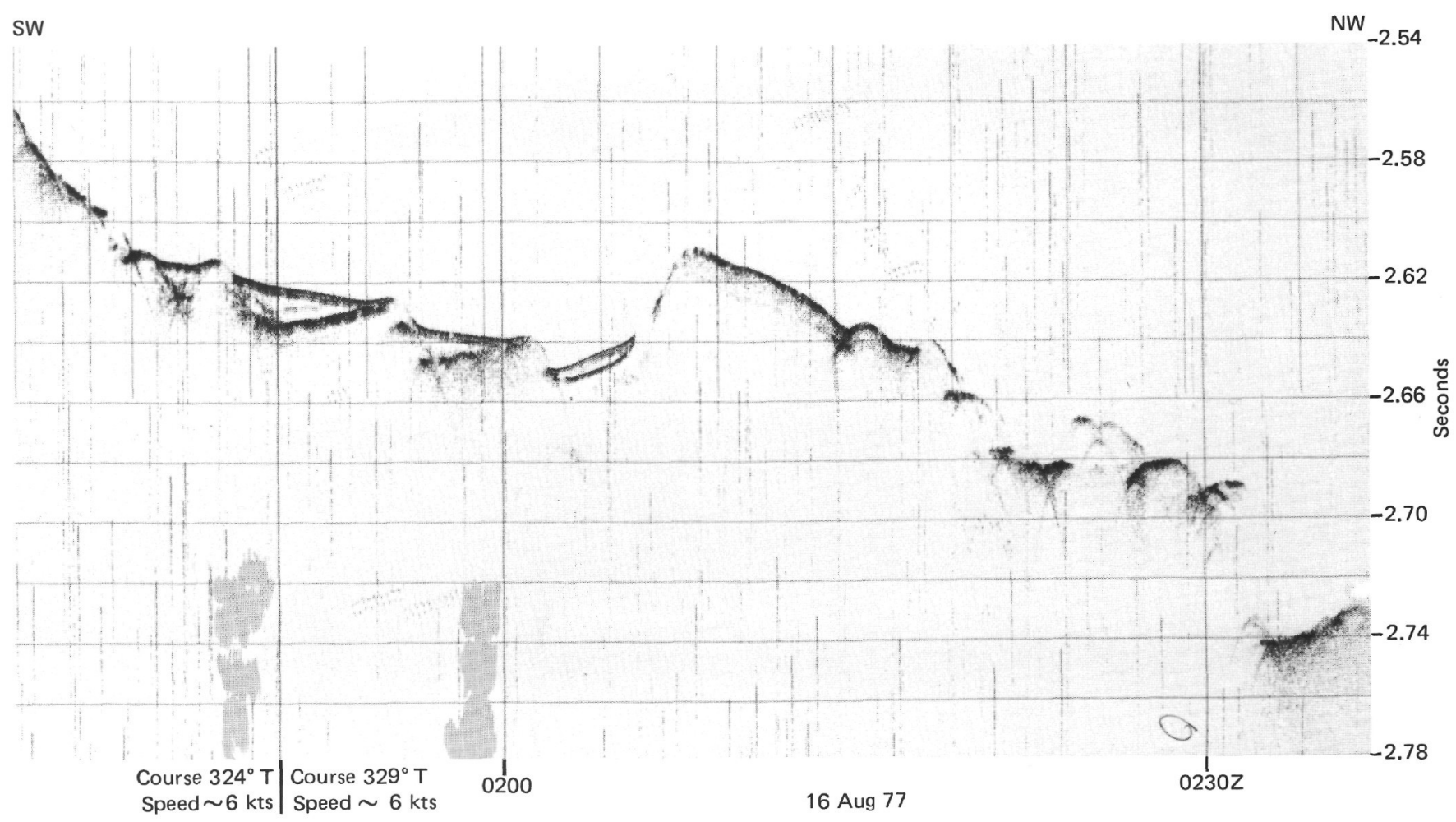

Figure 7. Glomar Challenger 3.5-kHz profile northwest of Site 433, showing pelagic sediments on faulted and backward-rotated bedrock steps.

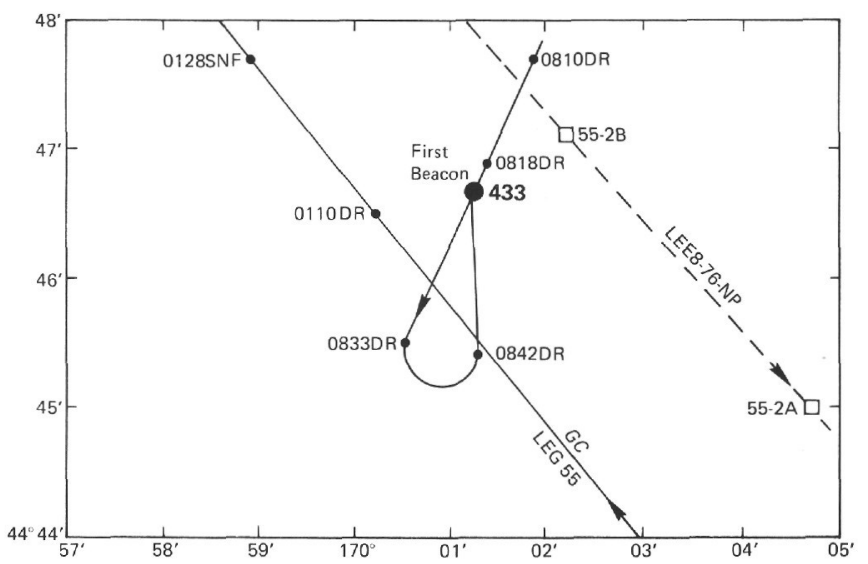

Figure 8. Detail of Site 433, showing the tracks of the Glomar Challenger and the S.P. Lee. Prospective sites are shown by open squares. The first beacon (16 $\mathrm{kHz}$ ) was dropped at 0818 on 16 August. Site 433 was selected 2200 feet, $205^{\circ}$ from the first beacon.

$3.5-\mathrm{kHz}$ profile showed that the first beacon had not been dropped in the location of thickest soft sediment, so we offset the Challenger 2200 feet (along $205^{\circ}$ true) from the $16-\mathrm{kHz}$ beacon, and dropped a second (13.5$\mathrm{kHz}$ ) beacon directly over the site of greatest softsediment thickness (Figure 11). Subsequent satellite data taken on site shows that Site 433 is about 1.2 nautical miles southwest of prospective Site 55-2B. The Challenger $3.5-\mathrm{kHz}$ profile (Figure 12) obtained during travel from the first beacon to the second shows many flat-lying, well-stratified reflectors down to a subsurface depth of $0.06 \mathrm{~s}(45 \mathrm{~m}$ at $1.5 \mathrm{~km} / \mathrm{s})$.

Site 433 is in a complexly deformed marginal structural basin associated with a fairly extensive lagoonal complex. This small basin lies along the southwest flank of the central ridge or platform of Suiko Seamount. It is bounded on the south by the steep, north-facing scarp of the central platform and on the north by a horst that separates it from the larger lagoonal complex to the north. The basin itself appears to be a graben, flanked by several faults, and filled with about 45 meters of soft, relatively unconsolidated sediments overlying about 160 meters of more consolidated sediments that rest on acoustic basement.

\section{Drilling Operations}

The Challenger was positioned over the $13.5-\mathrm{kHz}$ beacon at $1000 \mathrm{Z}(2100 \mathrm{~L})$ on 16 August 1977 , and pipe was strapped and dropped almost immediately. We spudded Hole 433 at 1530Z, 16 August (0230L, 17 August), pulled 5.0 meters of core to establish mudline, and carried out a wash test to determine whether the site was suitable for multiple re-entry. After retrieval of Core 1, Hole 433 (Table 1) surface material was washed down to a depth of 45.0 meters in 18.5 minutes, at a rate of nearly $2.5 \mathrm{~m} / \mathrm{min}$. Below 45.0 meters, the section would no longer easily wash, because of a dense, altered ash bed (the ash bed presumably also accounts for the deepest reflector in the $3.5-\mathrm{kHz}$ profile record at this site). We completed the washing test and spudded Hole 


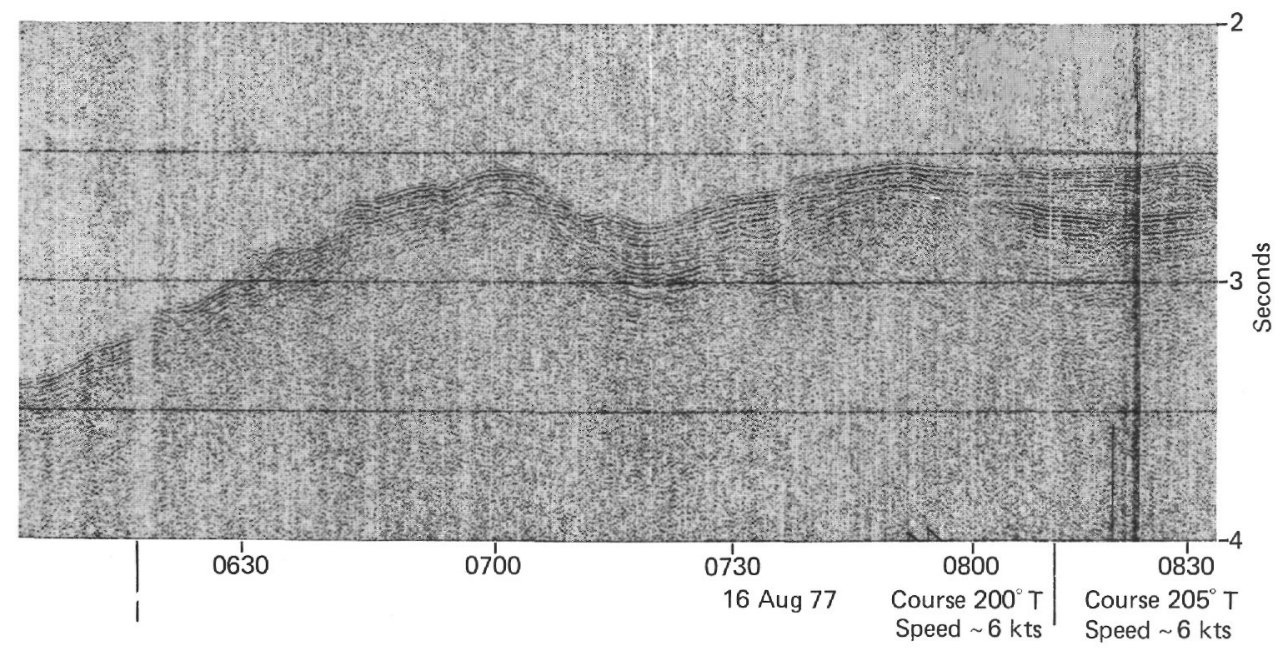

Figure 9. Glomar Challenger 5-s seismic reflection profile, showing a buried acoustic basement ridge at Site 433, with the northern and southern flanks.

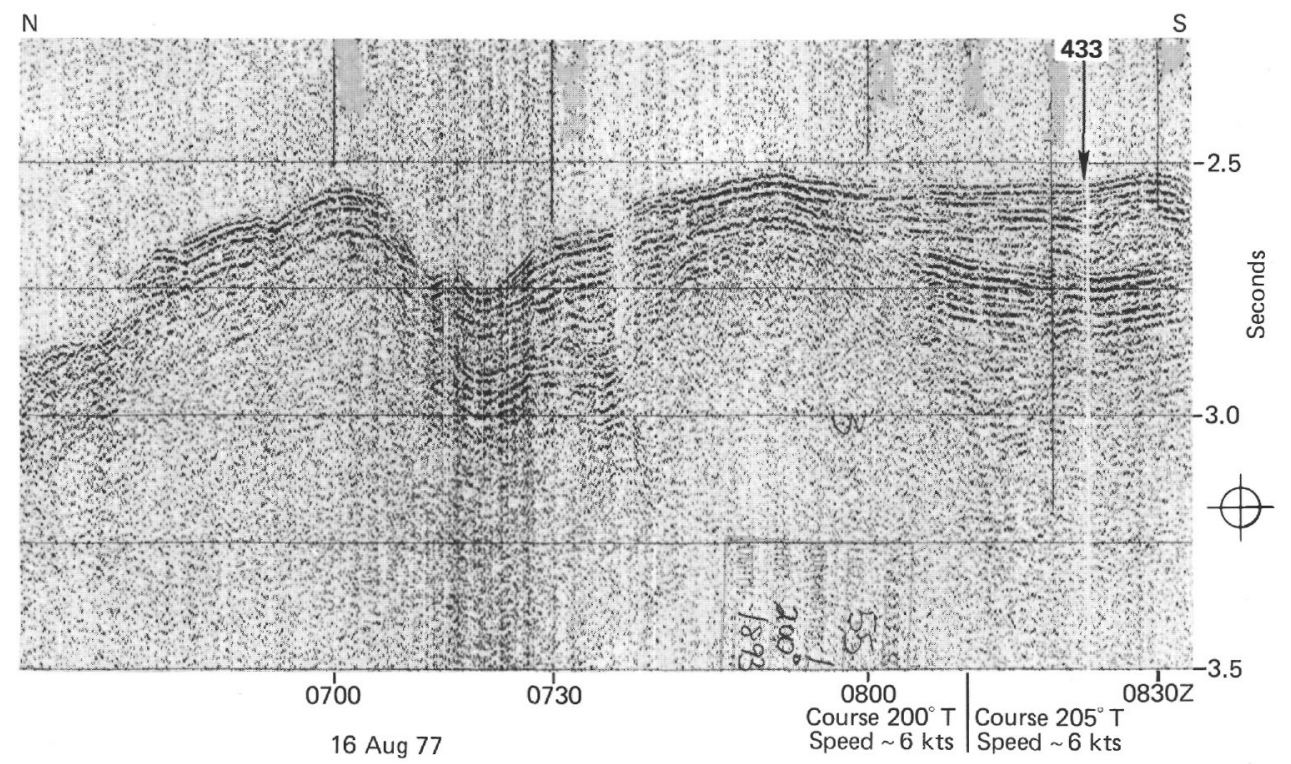

Figure 10. Glomar Challenger 2.5-s seismic reflection profile across Site 433, showing the sediment pond.

433A, the pilot hole for re-entry, at 1742Z, 16 August (0442L, 17 August).

Hole $433 \mathrm{~A}$ was continuously cored and penetrated 163.5 meters of sedimentary rocks ranging from Quaternary ooze at the surface to consolidated reef limestone at the base. Recovery was excellent in the pelagic oozes in the upper part of the hole (see Table 2) and very poor in the unconsolidated reef sands and silts in the interval 81 to 157 meters below mudline. We encountered basalt while drilling Core 19, but since the proper core catchers were not in the core barrel, we pulled out at 163.5 meters and used a new barrel (Core 20) to core the remaining 3.0 meters of basalt. We cored an additional 7.5 meters of basalt (Core 21) before warning the drillers to begin backing out of the hole at $1745 \mathrm{Z}$ on 17 August (0445L, 13 August) because of excessive amper- age on the stern thrusters. We had difficulty with the thruster; although we held the positioning system in manual for some time, we pulled the string above mudline at $1900 \mathrm{Z}(0600 \mathrm{~L})$ and finally recovered the last core at $1940 \mathrm{Z}(0604 \mathrm{~L})$.

Divers ultimately recovered a wad of nylon fishing net and polyethylene filament line from the aft stern thruster after the ship had been allowed to drift several miles off beacon. We tested the thrusters, found them undamaged, and positioned the ship over the $13.5-\mathrm{kHz}$ beacon at Site 433 at $0300 \mathrm{Z}$ (1400L), 18 August. Drill pipe was once again run to the bottom to complete the pilot hole, and the bit was respudded for Hole 433B and $0400 Z$ (1500L).

We washed Hole 433B to 28.5 meters below mudline and recored the three 9.5-meter intervals above base- 


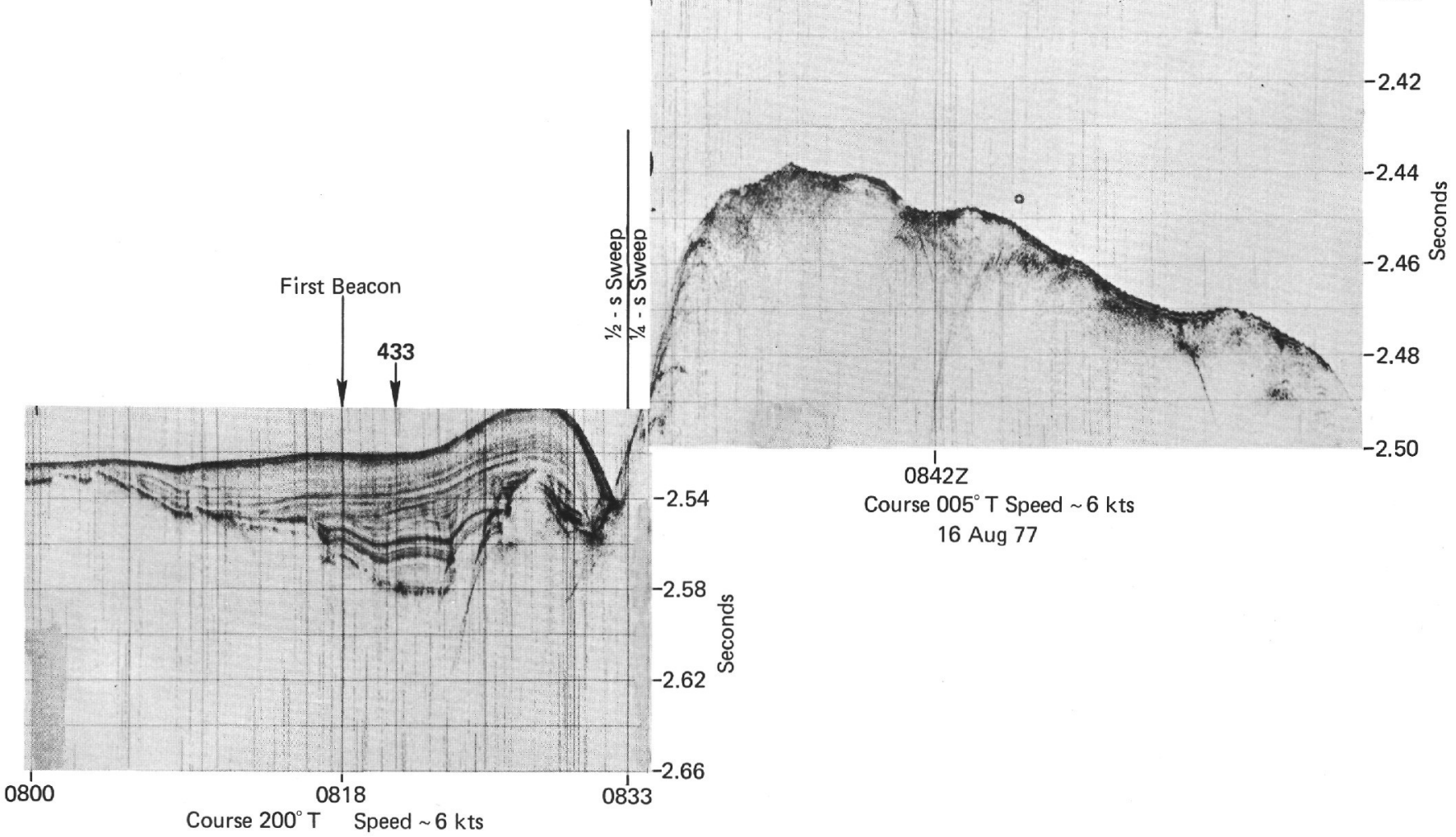

Figure 11. Glomar Challenger 3.5-kHz profile across Site 433, showing the graben basin filled with pelagic sediments.

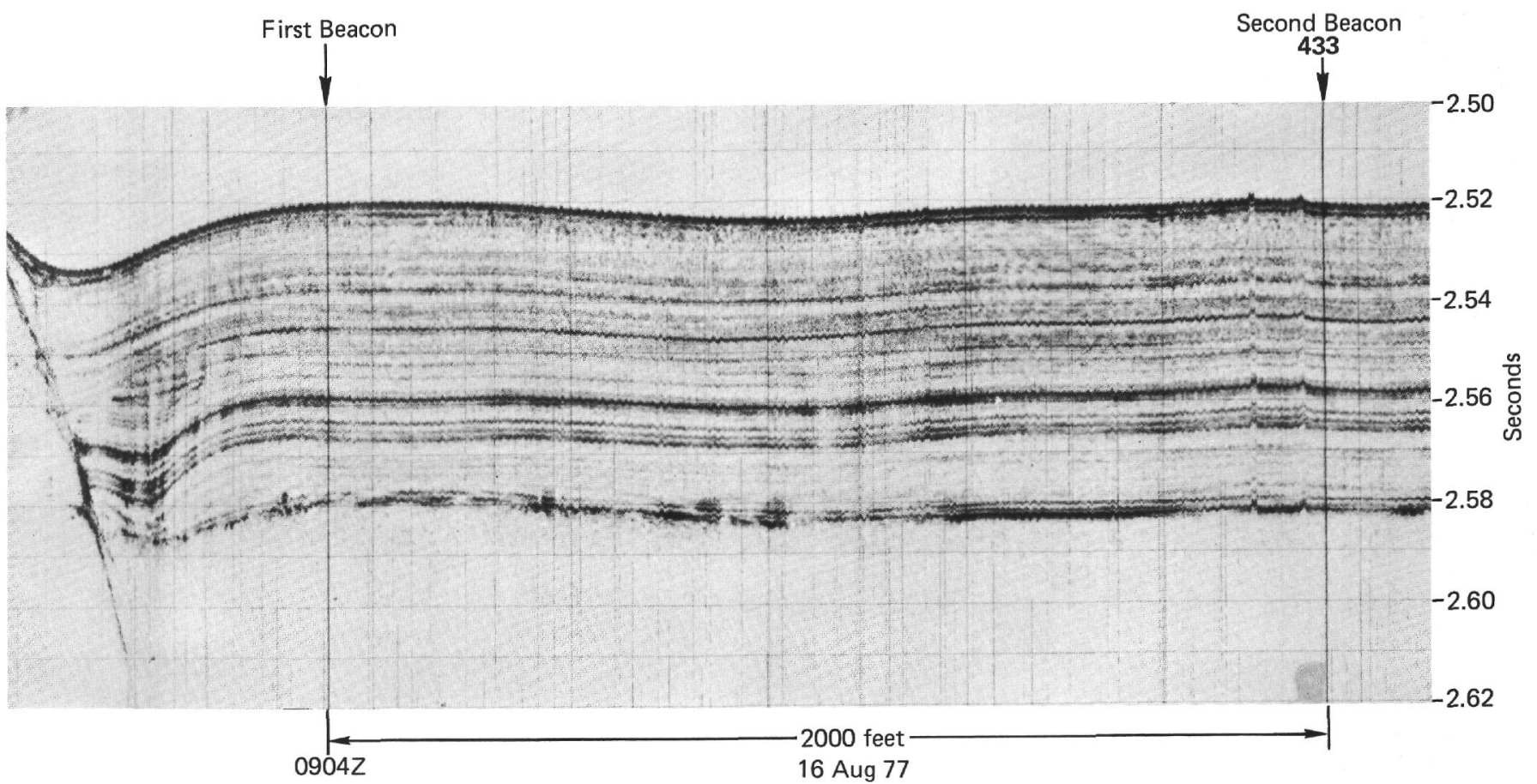

Figure 12. Glomar Challenger 3.5-kHz profile on approach to Site 433, showing well-layered pelagic sediments between the first $(16-\mathrm{kHz})$ and second $(13.5-\mathrm{kHz})$ beacons. 
TABLE 1

Coring Summary, Hole 433

\begin{tabular}{|c|c|c|c|c|c|c|c|}
\hline Core & $\begin{array}{l}\text { Date } \\
\text { (Aug. } \\
\text { 1977) }\end{array}$ & $\begin{array}{c}\text { Time } \\
\text { (L) }\end{array}$ & $\begin{array}{l}\text { Depth } \\
\text { from } \\
\text { Drill } \\
\text { Floor } \\
\text { (m) }\end{array}$ & $\begin{array}{c}\text { Depth } \\
\text { below } \\
\text { Sea } \\
\text { Floor } \\
\text { (m) }\end{array}$ & $\begin{array}{l}\text { Length } \\
\text { Cored } \\
\text { (m) }\end{array}$ & $\begin{array}{l}\text { Length } \\
\text { Recov- } \\
\text { ered } \\
\text { (m) }\end{array}$ & $\begin{array}{c}\text { Recov- } \\
\text { ery } \\
(\%)\end{array}$ \\
\hline 1 & 17 & 0300 & $\begin{array}{l}1874.0- \\
1879.0\end{array}$ & $\begin{array}{l}0.0- \\
5.0\end{array}$ & 5.0 & 5.0 & 100.0 \\
\hline Tota1 & & & & & 5.0 & 5.0 & 100.0 \\
\hline
\end{tabular}

TABLE 2

Coring Summary, Hole 433A

\begin{tabular}{|c|c|c|c|c|c|c|c|}
\hline \multirow[b]{2}{*}{ Core } & \multirow[b]{2}{*}{$\begin{array}{l}\text { Date } \\
\text { (Aug. } \\
1977 \text { ) }\end{array}$} & \multirow[b]{2}{*}{$\begin{array}{l}\text { Time } \\
\text { (L) }\end{array}$} & \multicolumn{2}{|l|}{ v } & \multirow[b]{2}{*}{$\begin{array}{l}\text { Length } \\
\text { Cored } \\
\text { (m) }\end{array}$} & \multirow{2}{*}{$\begin{array}{c}\text { Length } \\
\text { Recov- } \\
\text { ered } \\
\text { (m) }\end{array}$} & \multirow[b]{2}{*}{$\begin{array}{l}\text { Recov- } \\
\text { ery } \\
(\%)\end{array}$} \\
\hline & & & $\begin{array}{l}\text { Depth from } \\
\text { Drill Floor } \\
\text { (m) }\end{array}$ & $\begin{array}{l}\text { Depth below } \\
\text { Sea Floor } \\
\text { (m) }\end{array}$ & & & \\
\hline 1 & 17 & 0508 & $1874.0-1879.0$ & $0.0-5.0$ & 5.0 & 1.50 & 30.0 \\
\hline 2 & 17 & 0610 & $1879.0-1885.5$ & $5.0-14.5$ & 9.5 & 2.26 & 23.8 \\
\hline 3 & 17 & 0701 & $1885.5-1898.0$ & $14.5-24.0$ & 9.5 & 8.00 & 84.2 \\
\hline 4 & 17 & 0800 & $1898.0-1907.5$ & $24.0-33.5$ & 9.5 & 8.62 & 90.7 \\
\hline 5 & 17 & 0856 & $1907.5-1917.0$ & $33.5-43.0$ & 9.5 & 8.51 & 89.6 \\
\hline 6 & 17 & 0945 & $1917.0-1926.5$ & $43.0-52.5$ & 9.5 & 9.60 & 101.1 \\
\hline 7 & 17 & 1100 & $1926.5-1936.0$ & $52.5-62.0$ & 9.5 & 8.61 & 90.6 \\
\hline 8 & 17 & 1155 & $1936.0-1945.5$ & $62.0-71.5$ & 9.5 & 9.60 & 101.1 \\
\hline 9 & 17 & 1305 & $1945.5-1949.5$ & $71.5-75.5$ & 4.0 & 8.25 & 206.3 \\
\hline 10 & 17 & 1535 & $1949.5-1955.0$ & $75.5-81.0$ & 5.5 & 9.65 & 175.5 \\
\hline 11 & 17 & 1629 & $1955.0-1964.5$ & $81.0-90.5$ & 9.5 & 0.10 & 1.1 \\
\hline 12 & 17 & 1825 & $1964.5-1974.0$ & $90.5-100.0$ & 9.5 & 3.56 & 37.5 \\
\hline 13 & 17 & 1923 & $1974.0-1983.5$ & $100.0-109.5$ & 9.5 & 0.50 & 5.3 \\
\hline 14 & 17 & 2030 & $1983.5-1993.0$ & $109.5-119.0$ & 9.5 & 0.45 & 4.7 \\
\hline 15 & 17 & 2155 & 1993.0-2002.5 & $119.0-128.5$ & 9.5 & 0.02 & 0.2 \\
\hline 16 & 17 & 2245 & $2002.5-2012.0$ & $128.5-138.0$ & 9.5 & 0.73 & 7.7 \\
\hline 17 & 17 & 2325 & $2012.0-2021.5$ & $138.0-147.5$ & 9.5 & 0.03 & 0.3 \\
\hline 18 & 18 & 0015 & $2021.5-2031.0$ & $147.5-157.0$ & 9.5 & 0.04 & 0.4 \\
\hline 19 & 18 & 0107 & $2031.0-2037.5$ & $157.0-163.5$ & 6.5 & 0.43 & 6.9 \\
\hline 20 & 18 & 0240 & $2037.5-2040.5$ & $163.5-166.5$ & 3.0 & 2.30 & 76.7 \\
\hline 21 & 18 & 0640 & $2040.5-2048.0$ & $166.5-174.0$ & 7.5 & 5.83 & 77.7 \\
\hline Total & & & & & 174.0 & 88.59 & 50.9 \\
\hline
\end{tabular}

ment because recovery had been poor in Hole 433A, and also because we wished to establish the minimum basement age as closely as possible. We found basalt at a sub-bottom depth of 163.0 meters in Core 4 . We cut two more 9.5-meter cores in basalt beneath Core 4, but after retrieving Core 5, we found broken core-catcher teeth and a torn basal plastic core liner. We suspected that part of the basalt of Core $5^{\circ}$ had fallen back onto the bit cones; this same type of accident had terminated Hole 430A. We drilled Core 6 but recovered nothing; we drilled an additional 1.0 meter of basalt (Core 7), again with no recovery. At 1732Z, 18 August (0432L, $19 \mathrm{Au}-$ gust), we decided to pull the string. At 2215Z (0915L), the bit was found to be jammed with basalt fragments above the cones; these fragments were assigned to Core 5 (Table 3).

One of our objectives for the pilot hole was to determine bit life, so as to estimate the durability of the bit during re-entry. Although we had not changed bits while drilling Holes 433, 433A, and 433B, and so had drilled a total of 373.5 meters of sedimentary rocks and 37 meters of basalt, the bit cones showed little wear. Since bit life in the basaltic rocks seemed reasonably long, and since the bit had been through the 50-meter interval below mudline three times, we asked and received permission to set the re-entry cone without performing the 16-inch pipe washing test. The re-entry cone was
TABLE 3

Coring Summary, Hole 433B

\begin{tabular}{cccccccc}
\hline & $\begin{array}{c}\text { Date } \\
\text { (Aug. }\end{array}$ & $\begin{array}{c}\text { Time } \\
\text { Core }\end{array}$ & $\begin{array}{c}\text { Depth from } \\
\text { Drill Floor } \\
(\mathrm{m})\end{array}$ & $\begin{array}{c}\text { Depth below } \\
\text { Sea Floor } \\
(\mathrm{m})\end{array}$ & $\begin{array}{c}\text { Length } \\
\text { Cored } \\
(\mathrm{m})\end{array}$ & $\begin{array}{c}\text { Length } \\
\text { Recov- } \\
\text { ered } \\
(\mathrm{m})\end{array}$ & $\begin{array}{c}\text { Recov- } \\
\text { ery } \\
(\%)\end{array}$ \\
\hline 1 & 18 & 1702 & $2002.5-2012.0$ & $128.5-138.0$ & 9.5 & 4.01 & 42.2 \\
2 & 18 & 1745 & $2012.0-2021.5$ & $138.0-147.5$ & 9.5 & 1.38 & 14.5 \\
3 & 18 & 1839 & $2021.5-2031.0$ & $147.5-157.0$ & 9.5 & 0.42 & 4.4 \\
4 & 18 & 1936 & $2031.0-2040.5$ & $157.0-166.5$ & 9.5 & 0.66 & 6.9 \\
5 & 18 & 2235 & $2040.5-2050.0$ & $166.5-176.0$ & 9.5 & $4.25^{\mathrm{a}}$ & 44.7 \\
6 & 19 & 0215 & $2050.0-2059.5$ & $176.0-185.5$ & 9.5 & 0 & 0 \\
7 & 19 & 0423 & $2059.5-2061.5$ & $185.5-186.5$ & 1.0 & 0 & 0 \\
Total & & & & & 58.0 & 10.72 & 18.5 \\
\hline
\end{tabular}

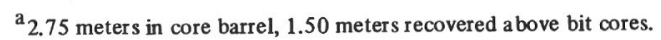

made up and keelhauled between 2230Z, 18 August (0930, 19 August) and 1800Z (0500L), 19 August. We secured four joints of 16-inch casing and a hedge shoe (a total of $39.25 \mathrm{~m}$ of pipe to the cone), dropped the assembly, and spudded in at mudline at 1445Z, 19 August (0145L, 20 August); we washed in the 16-inch casing by $1515 \mathrm{Z}(0215 \mathrm{~L})$, released the cone and string at $1525 \mathrm{Z}$ (0245L), and washed the bottom-hole assembly (BHA) in at 163.0 meters to within 0.5 meter of the top of the uppermost basalt flow. The BHA was made up as usual with three bumper subs, the only difference being that three drill collars and a lowering tool were inserted below the lower bumper sub. We placed a slip-type core catcher on the core barrel below two dog-type catchers to prevent the loss of core above the bit cones that had prematurely ended Holes 430A and 433B. The first core (1), containing some harder basal reef limestone and basalt (see Table 4) was cut in 5.0 meters, and came on deck at 1940Z, 19 August (0640L, 20 August). We pulled Core 2 at 2210Z, but recovered only 2 per cent because a twice-drilled basalt fragment jammed in the slip-type core catcher. For Core 3, the barrel arrived on deck empty; we suspected a jammed bit and ran in a chisel bit on the core barrel. To our surprise, the closed core barrel returned containing 4.26 meters of wellsorted, completely unconsolidated "salt and pepper" beach sand, which had apparently forced past the chisel bit through the valve holes in the core barrel. We penetrated 5 to 11 meters of this material between Flow Units 1 and 2, and began to core a dense basalt, recovered in Core 4. For Core 5 we replaced the slip-type core catchers by dog-type core catchers, but achieved little improvement in core recovery. Drilling rates suggest that we may have passed through a second beach sand 4 to 5 meters thick in the lower 3 meters of Core 4 and the upper 2 meters of Core 5 . We recovered only 0.12 meter of basalt core in Core 5 and 0.12 meter in Core 6. The barrel returned to the surface empty for Cores 7 and 8 , and in spite of vigorous use of the chisel bit, we recovered neither basalt nor sand. However, drilling rates for Core 6 suggested relatively soft layers at 193 to 195 meters; penetration was also relatively easy for the lower part of Core 7 and upper part of Core 8. At 1445Z, 20 August (0145L, 21 August), we decided the bit was plugged above the cones, and pulled the string. The bit arrived on deck at $1850 \mathrm{Z}(0550 \mathrm{~L})$, its teeth and 
TABLE 4

Coring Summary, Hole 433C

\begin{tabular}{|c|c|c|c|c|c|c|c|}
\hline Core & $\begin{array}{l}\text { Date } \\
\text { (Aug. } \\
\text { 1977) }\end{array}$ & $\begin{array}{c}\text { Time } \\
\text { (L) }\end{array}$ & $\begin{array}{l}\text { Depth from } \\
\text { Drill Floor } \\
\text { (m) }\end{array}$ & $\begin{array}{l}\text { Depth below } \\
\text { Sea Floor } \\
\text { (m) }\end{array}$ & $\begin{array}{l}\text { Length } \\
\text { Cored } \\
\text { (m) }\end{array}$ & $\begin{array}{l}\text { Length } \\
\text { Recov- } \\
\text { ered } \\
(\mathrm{m})\end{array}$ & $\begin{array}{l}\text { Recov- } \\
\text { ery } \\
(\%)\end{array}$ \\
\hline 1 & 20 & 0627 & $2037.0-2042.0$ & $163.0-168.0$ & 5.0 & 1.86 & 37.2 \\
\hline 2 & 20 & 0910 & $42.0-2051.5$ & $1080-1775$ & & 0.25 & .6 \\
\hline 3 & 20 & 1320 & $051.5-2055.5$ & $177.5-181.5$ & 4.0 & 4.26 & 115.0 \\
\hline 4 & 20 & 1455 & $2055.5-2061.0$ & $181.5-187.0$ & 5.5 & 1.19 & 21.6 \\
\hline 5 & 20 & 1733 & $2061.0-2064.0$ & $187.0-190.0$ & 3.0 & 0.12 & 4.0 \\
\hline 6 & 20 & 2100 & $2064.0-2070.5$ & $190.0-196.5$ & 6.5 & $0.70^{\mathrm{a}}$ & 10.8 \\
\hline 7 & 20 & 2300 & 5 & 196 & & & \\
\hline 8 & 21 & 0137 & $74.5-2076.5$ & 200.5 & 2.0 & 0 & 0 \\
\hline & 21 & 1745 & $2076.5-2078.5$ & $202.5-2$ & $2.0^{\mathrm{b}}$ & 0.39 & 9.5 \\
\hline \multicolumn{8}{|c|}{ (RE-ENTRY 1) } \\
\hline 10 & 21 & 2112 & 778.5-2088.5 & $204.5-214$ & 9. & 63 & 9.8 \\
\hline 11 & 21 & 23 & & & & & \\
\hline 12 & 22 & 0212 & $2097.5-2104.0$ & 223. & 6. & 88 & 75.1 \\
\hline 13 & 22 & 0545 & $2104.0-2107.0$ & $230.0-233.0$ & 3.0 & 35 & 111.7 \\
\hline 14 & 22 & 0730 & $2107.0-2116.5$ & $233.0-242.5$ & 9.5 & 76 & 50.1 \\
\hline 15 & & 1015 & & & 9. & & 3.2 \\
\hline 16 & 2 & & & & & & \\
\hline 17 & 22 & 1800 & $2129.5-2132.5$ & $255.5-258.5$ & 3. & 73 & 24.3 \\
\hline 18 & 22 & 2310 & $2132.5-2135.5$ & $258.5-261.5$ & 3.0 & $25^{\mathrm{c}}$ & 8.3 \\
\hline 19 & 24 & 0700 & 2135 . & 261.5 & 8. & 23 & 770 \\
\hline \multicolumn{8}{|c|}{ (RE-ENTRY 2) } \\
\hline 20 & 24 & 0920 & $2143.5-2153.0$ & $269.5-279.0$ & 9 & 2.45 & .9 \\
\hline 21 & 24 & 1230 & 162.5 & 279. & 9.5 & 85 & 61.6 \\
\hline 22 & & 1605 & 2 & & 9. & .02 & 63.4 \\
\hline 23 & & & & & & & 3.9 \\
\hline 24 & & & & & & & \\
\hline 25 & 25 & 0420 & 2191.0 & 317. & 9 & 55 & 100.5 \\
\hline 26 & & 0745 & 2. & 326. & 9 & 8.25 & 86.8 \\
\hline 27 & & & & & & & 4.6 \\
\hline 28 & & & & & & & \\
\hline 29 & 25 & 163 & 2229.0 & & & & 1.3 \\
\hline 30 & & & & & 9.5 & 85 & 30.0 \\
\hline 31 & & & & & & & 2.4 \\
\hline 32 & 2 & 03 & & & & & . \\
\hline 33 & & 0 & & & & & \\
\hline 34 & 2 & 10 & & & 9 & 9.64 & 101.5 \\
\hline 35 & & & & & & & \\
\hline 36 & & & & & & & 0 \\
\hline 37 & & & & & & & \\
\hline 38 & 27 & 225 & & & & & \\
\hline \multicolumn{8}{|c|}{ (RE-ENTRY 3) } \\
\hline 39 & & 03 & 2324. & & & 9.57 & \\
\hline 40 & & & & & & & \\
\hline 41 & & & & & & & \\
\hline 42 & & & & & & & \\
\hline 43 & & & & & & & \\
\hline 44 & & 2210 & $2371.5-2381.0$ & 497 & 9 & 34 & \\
\hline $\begin{array}{l}44 \\
45\end{array}$ & 2 & 0210 & & & 9 & 61 & 101.2 \\
\hline & & & & & & & \\
\hline & & & & & & & \\
\hline 48 & 29 & & 2419.0 & & & & \\
\hline 49 & 29 & 1110 & $2419.0-2423.0$ & $545.0-549.0$ & 4.0 & 2.60 & 65 \\
\hline 50 & 29 & 1345 & $2423.0-2424.5$ & $549.0-550.5$ & 1.5 & $0.40^{\mathrm{d}}$ & 26.7 \\
\hline \multicolumn{5}{|c|}{ Total } & 387.5 & 250.15 & 64.6 \\
\hline
\end{tabular}

${ }^{\mathrm{a}} 0.12$ meters core in bit, 0.58 meters recovered from above bit cones 0550 when string pulled. Not in stratigraphic order.

8.0 meters total of last 3 cores results from removal of latching tool before re-entry. ${ }^{2} 0.25$-meter core above bit cones recovered on deck 0330, 23 August, labeled "Core 18, Section 1" before re-entry.

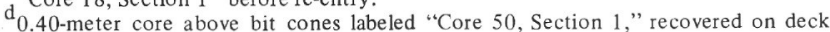
2130,29 August.

cones unworn, but with 0.58 meter of basalt jammed above the cones. All pieces save one were apparently identical to the basalt we had been recovering in Cores 4, 5, and 6 (Flow Unit 2); some had been cut as many as three times. The one odd piece was a $5-\mathrm{cm}$ piece of alkalic basalt, but we could not say whether this represented a previously unsampled unit between two sand layers or was the precursor of the next deeper flow unit.

Re-entry preparations started at 1850Z, 20 August, and were completed at $0245 \mathrm{Z}, 21$ August (0550 and $1345 \mathrm{~L}, 21$ August). The re-entry tool emerged from the drill string, and we began scanning at 1245Z, (2345L); at
$0331 \mathrm{Z}$ (1431L), 21 August, the re-entry cone was located and the pipe was dropped. Core 9, the first core of the first re-entry, was on deck at 0645Z (1745L), 21 August 1977. The total time elapsed from the last core on deck cut by bit number 1 (Core 8 ), Hole $433 \mathrm{C}$, to the first core on deck from bit number 2 (Core 9) after re-entry was 16 hours 8 minutes.

Between 0645Z (1745L) and 2315Z (1015L), 22 August, we penetrated 49.5 meters of basalt and recovered 30.98 meters, for a recovery average of 63 per cent. Core 15, however, came on deck at $2315 \mathrm{Z}$ (1015L), 21 August, with a torn plastic liner and damaged corecatcher teeth, symptoms we had by now learned to associate with basalt fragments lodged above the bit cones. Although we did not run the chisel bit immediately, the pump pressure soon began to fluctuate, indicating that the bit was jammed. During the period 2315Z, 21 August (1015L, 22 August) through 1210Z (2310L), we penetrated only 9.5 meters of basalt and recovered only 2.09 meters. During this period we ran in the chisel bit seven times, in vain attempts to clear the bit. By this time the cruise operations manager suspected that an inner barrel latch normally used during logging procedures was allowing the core barrel to become unlatched, and we decided to pull the string to clear the bit and check the latch. Mudline was cleared at 1325Z, 22 August (0025L, 23 August), and the bit was on deck at $1630 \mathrm{Z}(0330 \mathrm{~L})$. The inner cones, when placed in tubing, contained 0.25 meter of basalt whose mineralogy placed it in Core 18; it was logged in as part of this core.

By $1845 \mathrm{Z}(0545 \mathrm{~L})$, we were running string in the hole for re-entry number two; we began scanning at $0245 \mathrm{Z}$ (1345L), and finally made re-entry at 1430Z, 23 August (0130L, 24 August), in heavy weather. The first core from the second re-entry was on deck at $2000 \mathrm{Z}(0700 \mathrm{~L})$; a total time of 31 hours 50 minutes elapsed between Cores 18 and 19.

Our second re-entry into Hole $433 \mathrm{C}$ on Suiko Seamount proved especially productive. Bit number three penetrated Cores 19 through 37, and drilled 179.0 meters of basalt in 53 hours drilling time, with a recovery of 70.9 per cent. The bit entered the hole in Flow Unit 13, at 261.5 meters sub-bottom, and finally penetrated the upper part of Flow Unit 45, well within the central tholeiitic edifice of this part of Suiko Seamount. Although core diameter of Core 37 was still 5.7 to $5.8 \mathrm{~cm}$, we decided to remove the bit because of its excessive hours of work in hard rocks. The very large increase in percentage recovery (compared with basalt recoveries of 21.2 per cent using the first bit at Hole $\mathrm{C}$ and 56.5 per cent with the second bit) and the cessation of failures resulting from plugged bits were attributed to removal of the logging core latch and substitution of the standard core latch before bit number three was lowered. We pulled the string at $1300 \mathrm{Z}, 26$ August $(0000 \mathrm{~L}$, 27 August), and the bit was on deck at 1500Z (0400L). We began scanning for re-entry number three at $0015 \mathrm{Z}$ (1115L), 27 August, and had accomplished re-entry by $0515 \mathrm{Z}(1615 \mathrm{~L})$. Total elapsed re-entry time between recovery of Core 37 and recovery of Core 38 was 23 hours 40 minutes. 
Our third re-entry into Hole $433 \mathrm{C}$ penetrated 110.0 meters of basalt and recovered 81.37 meters, for a recovery percentage of 74.0. The bit entered in Flow Unit $45 \mathrm{~b}$, and penetrated as far as Flow Unit 67. At 0000Z, 29 August (1100L), the pump pressure and drilling rate indicated still another bit plugged with basalt above the cones. We tried repeatedly to clear the bit with the chisel bit attached to the core barrel. Two short cores were pulled, the second one empty. By 0245Z (1345L), the bit valves were hopelessly jammed open. An Eastman inclinometer was run in, and recorded an inclination in the bottom of the hole of $2.5^{\circ}$. The string was pulled and the bit was on deck at 1030Z (2130L). The top of the bit cones were jammed with basalt, and the center of the bit opening was jammed tight by a piece of rag (still recognizable as a pair of size 44 men's underpants) completely entwined about a $5-\mathrm{cm}$ piece of basalt core. The bit teeth were still in very serviceable condition (the underpants were not).

Hole $433 \mathrm{C}$ penetrated 550.5 meters, of which 387.5 meters, all basalt, were cored. Recovery was 250.15 meters, or 64.6 per cent of all basalt penetrated.

Total time on Site $\mathbf{4 3 3}$ was $\mathbf{3 1 3}$ hours $\mathbf{5 2}$ minutes.

To arrive at Yokohama on schedule we needed to pull string at $0700 \mathrm{Z}$ (1800L) on 30 August, and be underway by $1300 \mathrm{Z}$ on August (0000L, 31 August). At the time of bit failure we had 28 hours of drill time remaining. Since most of our previous re-entries had consumed about 26 hours, we felt that to re-enter and to request an extension would be pointless (the failure occurred on Sunday, San Diego time), especially since we had recovered core from about 114 flows and thus accomplished all our objectives. We therefore left Site 433 at $1152 \mathrm{Z}$ (2252L), 29 August, en route to Yokohama.

\section{On-Site Positioning}

The satellite navigation data received during our occupation of Site 433, through the drilling of Holes 433 and 433A, are tabulated in Table 5 and plotted chronologically in Figure 13. Apparent excursions from some average positions are large (as much as 600 feet in some cases); but as previously noted, we do not feel that these distances are real excursions. The excursions do appear to be random and not so consistently offset as those at Holes 431, 431A, and 432, where we lost part of the bottom-hole assembly and twisted the bumper subs. The Glomar Challenger was forced to abandon Hole 433A because of thruster problems (see section above); our direction of drift is apparent on Figure 13.

We reoccupied the site before drilling Hole 433B; the positions received between reoccupation and the spudding in of Hole $433 \mathrm{C}$ are tabulated in Table 6 and plotted in Figure 14. Again, the apparent excursions from some average position are random and relatively modest during the drilling of Hole 433B. A real excursion probably occurred between the failure of Hole 433 and the setting of the re-entry cone; but we have no evidence of this. Two beacons, heavily weighted, were dropped at Site 433; they did not change position during operation. In retrospect, we can only say that beacon movement along the bottom may have contributed to the loss of Holes 431, 431A, and 432.
TABLE 5

On-Site Satellite Navigation Positions, Holes 433 and 433A

\begin{tabular}{ccccccc}
\hline & Time $(\mathrm{Z})$ & $\begin{array}{c}\text { Latitude } \\
(\mathrm{N})\end{array}$ & $\begin{array}{c}\text { Longitude } \\
(\mathrm{E})\end{array}$ & $\begin{array}{c}\text { Satel- } \\
\text { lite }\end{array}$ & Statistics & $\begin{array}{c}\text { Alti- } \\
\text { tude }\end{array}$ \\
\hline Hole 433 & & & & & & \\
1 & 16 Aug. 0922 & $44^{\circ} 46.635$ & $170^{\circ} 01.239$ & 19 & Fair-good & $29^{\circ}$ \\
2 & 1044 & $44^{\circ} 46.620$ & $170^{\circ} 01.263$ & 20 & Excellent & $32^{\circ}$ \\
3 & 1116 & $4^{\circ} 46.604$ & $170^{\circ} 01.265$ & 13 & Good & $38^{\circ}$ \\
4 & 1230 & $44^{\circ} 46.610$ & $170^{\circ} 01.270$ & 20 & Good & $38^{\circ}$ \\
5 & 1652 & $44^{\circ} 46.589$ & $170^{\circ} 01.241$ & 12 & Good & $52^{\circ}$ \\
6 & 1836 & $44^{\circ} 46.602$ & $170^{\circ} 01.256$ & 12 & Good & $28^{\circ}$ \\
7 & 2010 & $44^{\circ} 46.604$ & $170^{\circ} 01.261$ & 14 & Excellent & $23^{\circ}$ \\
8 & 2032 & $44^{\circ} 46.592$ & $170^{\circ} 01.329$ & 19 & Good & $64^{\circ}$ \\
9 & 2156 & $44^{\circ} 46.588$ & $170^{\circ} 01.267$ & 14 & Good & $64^{\circ}$ \\
\hline
\end{tabular}

Hole 433A

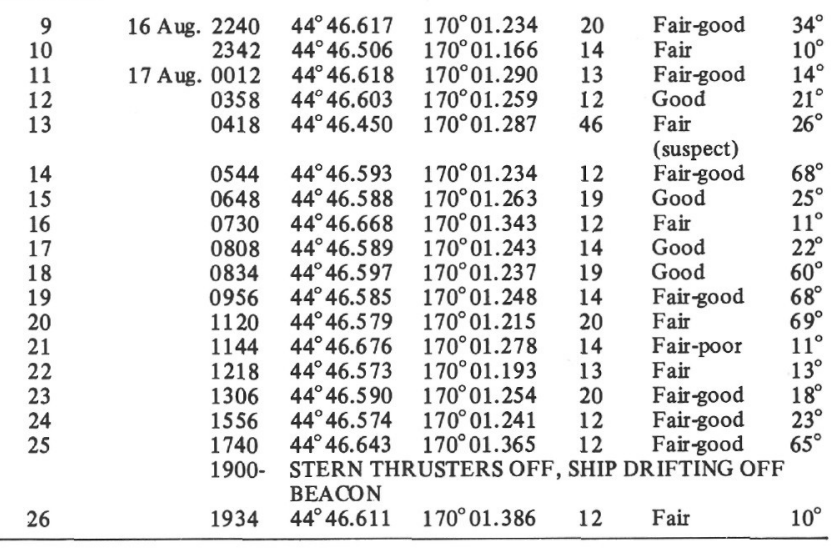

We thought that instabilities in the thermal structure of sea water above seamounts might have caused refraction between beacon and ship, and thus might account for our excursions at Holes 431, 431A, and 432. We examined the expendable bathythermograph (XBT) records taken along the Emperor Seamount chain. These records, taken generally before positioning over the beacon and after leaving a site, and underway between sites, give absolute temperatures from the surface to about 450 meters depth. Examination of 30 of these XBT records shows no correlation between temperature profiles of the upper $\mathbf{4 5 0}$ meters and bottom depth. Profiles taken south of Site 430, at Site 430, and up to 80 nautical miles north of Site 430 show stable concave decreases of water temperature with depth. A profile taken 170 nautical miles north of Site 430 shows at least 10 small irregular inversions of $0.1^{\circ}$ to $0.5^{\circ} \mathrm{C}$. Two profiles taken at Site 431 have irregular temperature distributions above 150 meters, and a temperature inversion of $0.8^{\circ}$ to $1.0^{\circ} \mathrm{C}$ between depths of 150 and 200 meters. Two drops at Site 432 show a marked $1{ }^{\circ} \mathrm{C}$ temperature inversion between depths of 90 and 180 meters. This inversion persists in water depths as great as $\mathbf{5 7 5 5}$ meters 50 nautical miles north of Site 432. Profiles taken during approach to Site 433 show $1^{\circ} \mathrm{C}$ temperature inversions beginning at 100 to 150 meters water depth, and persisting to 200 to 300 meters. The thrusters never stopped during drilling at Site 433, but on departure, a similar profile was observed. If temperature-salinity waves or lenses above seamounts directly lead to unacceptable excursions of ship from beacon, they cannot resadily be correlated with the simple XBT profiles available to us. 


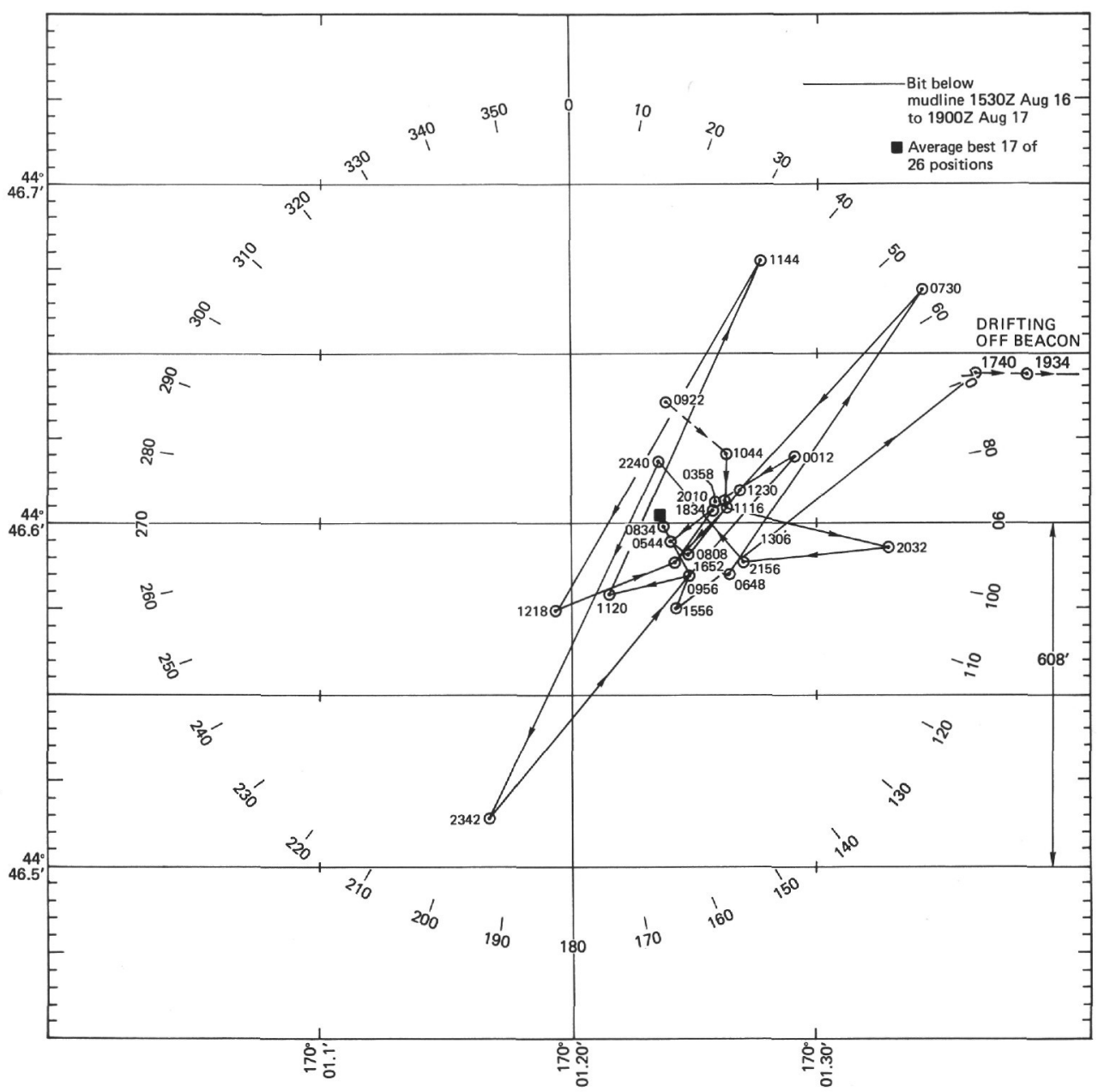

Figure 13. Mercator plot of satellite navigation locations during drilling of Holes 433 and $433 \mathrm{~A}$.

\section{Post-Drilling Operations}

In order to carry the subsurface stratigraphy identified in the Site 433 cores to the fringes of the seamount, and to relate these sedimentary and volcanic units to other geologic features in the area, we decided to cross previously unsurveyed parts of the seamount upon leaving the site. We left Site 433 at $1152 Z$ (2252L) on 29 August 1977, circled toward the west, and came about to pass over the site on a course of $070^{\circ}$ true at a speed of 7 knots. At 1232Z (0032L, 30 August), we passed over the $13.5-\mathrm{kHz}$ beacon and continued on a course of $090^{\circ}$ true. We maintained this course and speed until the Challenger was well past the western edge of the seamount and out over the abyssal plain. At $1532 \mathrm{Z}$ (0232L, 30 August), a satellite fix placed the Challenger at latitude $44^{\circ} 46.8^{\prime} \mathrm{N}$, longitude $170^{\circ} 30.6^{\prime} \mathrm{E}$. At $1602 Z$ we changed course to $236^{\circ}$ true and steamed back across Suiko Seamount at 6.2 knots. A satellite fix at $1936 \mathrm{Z}$ (0636L, 30 August) showed the Challenger to be at latitude $44^{\circ} 33.6^{\prime} \mathrm{N}$, longitude $170^{\circ} 07.3^{\prime} \mathrm{E}$. At $2100 \mathrm{Z}$ (0800L, 30 August) we were well out across the western flank of the seamount, and increased speed to about 9.5 knots for the trip to Yokohama.
TABLE 6

On-Site Satellite Navigation Positions, Hole 433B

\begin{tabular}{|c|c|c|c|c|c|c|}
\hline & Time (Z) & $\begin{array}{l}\text { Latitude } \\
(\mathrm{N})\end{array}$ & $\begin{array}{l}\text { Longitude } \\
\text { (E) }\end{array}$ & $\begin{array}{l}\text { Satel- } \\
\text { lite }\end{array}$ & Statistics & $\begin{array}{l}\text { Alti- } \\
\text { tude }\end{array}$ \\
\hline & 18 Aug. 0300, & \multicolumn{5}{|c|}{ 13.5-kHz BEACON REOCCUPIED } \\
\hline 1 & 0446 & $44^{\circ} 46.628$ & $170^{\circ} 01.263$ & 12 & Fair-good & 53 \\
\hline 2 & 0602 & $44^{\circ} 46.673$ & $170^{\circ} 01.190$ & 19 & Fair-poor & 11 \\
\hline 3 & 0634 & $44^{\circ} 46.679$ & $170^{\circ} 01.252$ & 12 & Good & 28 \\
\hline 4 & 0904 & $44^{\circ} 46.663$ & $170^{\circ} 01.235$ & 14 & Good & 58 \\
\hline 5 & 0934 & $44^{\circ} 46.675$ & $170^{\circ} 01.248$ & 12 & Good & 22 \\
\hline 6 & 1030 & $44^{\circ} 46.667$ & $170^{\circ} 01.217$ & 20 & Very good & 22 \\
\hline 7 & 1050 & $44^{\circ} 46.650$ & $170^{\circ} 01.235$ & 14 & Very good & 26 \\
\hline 8 & 1126 & $44^{\circ} 46.658$ & $170^{\circ} 01.206$ & 13 & Very good & 29 \\
\hline 9 & 1158 & $44^{\circ} 46$ & $170^{\circ} 01.268$ & 20 & Good & 55 \\
\hline 10 & 1648 & $44^{\circ} 46.598$ & $170^{\circ} 01.157$ & 12 & Fair-good & 55 \\
\hline 11 & 1832 & $44^{\circ} 46.592$ & $170^{\circ} 01.164$ & 12 & Good & 26 \\
\hline 12 & 1854 & $44^{\circ} 46.607$ & $170^{\circ} 01.157$ & 19 & Good & 26 \\
\hline 13 & 2010 & $44^{\circ} 46.626$ & $170^{\circ} 01.145$ & 14 & Very good & 27 \\
\hline 14 & 2042 & $44^{\circ} 46.621$ & $170^{\circ} 01.171$ & 19 & Fair-good & 47 \\
\hline 15 & 2158 & $44^{\circ} 46.612$ & $170^{\circ} 01.203$ & 14 & Good & 53 \\
\hline 16 & 19 Aug. 0100 & $44^{\circ} 46.479$ & $170^{\circ} 01.144$ & 13 & Poor & 10 \\
\hline 17 & 0140 & $44^{\circ} 46.463$ & $170^{\circ} 01.065$ & 20 & Poor & 10 \\
\hline 18 & 0352 & $44^{\circ} 46.627$ & $170^{\circ} 01.245$ & 12 & Fair-good & 23 \\
\hline 19 & 0658 & $44^{\circ} 46.610$ & $170^{\circ} 01.268$ & 19 & Very good & 32 \\
\hline 20 & 0726 & $44^{\circ} 46.684$ & $170^{\circ} 01.327$ & 12 & Poor & 11 \\
\hline 21 & 0820 & $44^{\circ} 46.597$ & $170^{\circ} 01.283$ & 14 & Very good & 27 \\
\hline 22 & 0844 & $44^{\circ} 46.611$ & $170^{\circ} 01.276$ & 19 & Very good & 45 \\
\hline 23 & 0958 & $44^{\circ} 46.604$ & $170^{\circ} 01.278$ & 14 & Fair-good & 56 \\
\hline 24 & 1056 & $44^{\circ} 46.601$ & $170^{\circ} 01.267$ & 20 & Good & 47 \\
\hline \multicolumn{7}{|c|}{ RE-ENTRY CONE SPUDDED IN 144519 AUGUST } \\
\hline 25 & 1552 & $44^{\circ} 46.603$ & $170^{\circ} 01.268$ & 12 & Good & 24 \\
\hline
\end{tabular}


Seismic reflection profiles obtained along the Challenger's eastern course from Site 433 show the continuation of the lagoonal and pelagic sediments to the eastern edge of Suiko Seamount, where they thin and wedge out against an acoustic basement buttress that marks the distal edge of the seamount's top (Figures 15 and 16). The $3.5-\mathrm{kHz}$ profile shows the pelagic sediments becoming thicker to the east of Site 433 and finally thinning near the outer edge (Figure 17). Seismic reflection and $3.5-\mathrm{kHz}$ profiles show little or no sedimentary cover and no pelagic sediments whatever (Figures 18, 19, and 20). Morphologically, the seamount appears to consist solely of the central platform. Protrusions of volcanic rock may occur near the gently rounded crest of the central platform, and steeply down-faulted, terrace-like features exist along the upper eastern flank of the seamount. We found no evidence that the lagoonal sediments drilled at Site $\mathbf{4 3 3}$ continue from the northern edge of the central platform around to the eastern and western edges. The preserved part of the lagoon appears, therefore, to be restricted to the northern part of the seamount.

\section{SEDIMENT LITHOSTRATIGRAPHY}

Sediments at the multiple re-entry site on Suiko Seamount were drilled successfully. A complete sequence of continuously cored sediments was recovered in the pilot hole, Hole 433A. The sedimentary cores obtained at Holes $433,433 \mathrm{~B}$, and $433 \mathrm{C}$ provided supplementary information. For example, the exposed contact between the lowest sedimentary rock (a calcarenite) and basalt was cored only in Hole 433B; and Unit 6, an intrabasalt sand, was recovered only in Hole 433C. Extreme deformation of the unconsolidated oozes, muds, and sands during coring obliterated sedimentary structures in these soft materials, except in those occurring in lithified zones. After examination of the cores, the sediments were divided into six lithologic units, as follows:

\begin{tabular}{|c|c|c|c|c|}
\hline Unit & Lithology & Hole & Cores & $\begin{array}{l}\text { Depth below } \\
\text { Surface }(\mathrm{m})\end{array}$ \\
\hline \multirow[t]{2}{*}{1} & $\begin{array}{l}\text { Foraminiferal- } \\
\text { nannofossil ooze }\end{array}$ & $433^{\circ}$ & $\begin{array}{l}1(0-1.3 \mathrm{~m}) \\
1(0-0.45 \mathrm{~m})\end{array}$ & $0-\quad 5.0$ \\
\hline & & $433 \mathrm{~A}$ & $2(0-1.15 \mathrm{~m})$ & \\
\hline \multirow[t]{2}{*}{2} & Diatom-nannofossil & 433 & $1(1.3-4.85 \mathrm{~m})$ & \\
\hline & $\begin{array}{l}\text { ooze to marly siliceous } \\
\text { nannofossil ooze }\end{array}$ & & $\begin{array}{l}1(0.45-15 \mathrm{~m}) \\
2(1.15-2.4 \mathrm{~m}) \\
3-5\end{array}$ & $5.0-43.0$ \\
\hline 3 & $\begin{array}{l}\text { Calcareous ooze to } \\
\text { calcareous chalk }\end{array}$ & $433 \mathrm{~A}$ & $6(0-9.15 \mathrm{~m})$ & $43.0-52.0$ \\
\hline 4 & $\begin{array}{l}\text { Tuffaceous sandy mud } \\
\text { a) siliceous and } \\
\text { b) volcanic }\end{array}$ & $433 \mathrm{~A}$ & $6(9.15-9.5 \mathrm{~m}), \mathrm{CC}$ & $52.0-52.5$ \\
\hline \multirow[t]{2}{*}{5} & $\begin{array}{l}\text { Reef carbonate sand } \\
\text { and sandy mud with } \\
\text { algal nodules to } \\
\text { reef calcarenite }\end{array}$ & $\begin{array}{l}433 \mathrm{~A} \\
433 \mathrm{~B} \\
433 \mathrm{C}\end{array}$ & $\begin{array}{l}7-19 \\
1-4 \\
1\end{array}$ & $52.5-163.5$ \\
\hline & $\begin{array}{c}\text { Basalt (Flow } \\
\text { Unit 1) }\end{array}$ & & & $163.5-177.5$ \\
\hline \multirow[t]{2}{*}{6} & $\begin{array}{l}\text { Reef carbonate sand, } \\
\text { rich in volcanic } \\
\text { material }\end{array}$ & $433 C$ & 3 & $177.5-181.5$ \\
\hline & $\begin{array}{c}\text { Basalt (Flow } \\
\text { Unit 2) }\end{array}$ & & & $181.5-$ \\
\hline
\end{tabular}

Figure 21 shows a composite of these lithologic units.

\section{Sediment Description}

\section{Hole 433}

Lithologic Units 1 and 2 are represented in Core 1. Unit 1 is an olive (5Y 5/4) to gray (10YR 6/1) foraminiferal nannofossil ooze. Microscopically, it contains foraminifers $(25 \%)$, calcareous nannofossils $(25 \%)$, carbonate particles $(25 \%)$, diatoms $(10 \%)$, fish remains $(5 \%)$, sponge spicules $(5 \%)$, and quartz $(5 \%)$, plus trace feldspars and micronodules. Unit 2 consists of a grayish brown (10YR 5/2) to olive-gray (5Y 5/2) sandy diatomnannofossil ooze, and a light brownish gray $(2.5 \mathrm{Y} 6 / 2)$ to white $(2.5 \mathrm{Y} 8 / 2)$ diatom-nannofossil ooze. The sandy sediment is composed of foraminifers ( 0 to $20 \%$ ), diatoms (10 to $30 \%)$, calcareous nannofossils $(20 \%)$, carbonate particles $(20 \%)$, sponge spicules and silicoflagellates $(5 \%)$, quartz $(10 \%)$, feldspars $(5 \%)$, and clay $(10 \%)$, plus traces of heavy minerals. The non-sandy sediment is entirely fossiliferous, and contains calcareous nannofossils $(65 \%)$, carbonate particles $(5 \%)$, diatoms $(25 \%)$, and sponge spicules $(5 \%)$.

\section{Hole 433A}

Unit 1 is represented at the tops of both Cores 1 and 2 , and is separated into two parts at the bottom of Core 1 by Unit 2 . This discrepancy probably occurred during drilling when a wash-down re-entry was made before drilling Core 2, and the overlying sediment of Unit 1 was not completely washed away. Unit 1 is a light brownish gray $(2.5 \mathrm{Y} 6 / 2)$ to olive $(5 \mathrm{Y} 4 / 3)$ silty to sandy foraminiferal nannofossil ooze. It contains calcareous nannofossils (40 to $50 \%$ ), foraminifers (10 to $25 \%$ ), carbonate particles $(10$ to $20 \%$ ), diatoms $(10 \%)$, sponge spicules $(5 \%)$, quartz ( 5 to $10 \%$ ), and feldspar ( 0 to $5 \%$ ).

In Cores 1 and 2, Unit 2 is a light gray $(2.5 \mathrm{Y} 7 / 2)$ to white $(2.5 \mathrm{Y} 8 / 2)$ diatom-nannofossil ooze composed of calcareous nannofossils $(65 \%)$, carbonate particles $(5 \%)$, diatoms $(25 \%)$, and sponge spicules $(5 \%)$. Unit 2 continues through Cores 3,4 , and 5 , but changes gradually from a diatom-nannofossil ooze to a marly siliceous nannofossil ooze. This change is reflected in both the color of the sediment and its composition. The white (5Y 8/1) to light gray (5Y 7/1) diatom-nannofossil ooze of Cores 3 and 4 is composed primarily of calcareous nannofossils (60 to $75 \%$ ), together with carbonate particles $(5 \%)$, diatoms $(10$ to $25 \%$ ), sponge spicules (5 to $10 \%)$, radiolarians $(0$ to $5 \%)$, and clay $(0$ to $5 \%)$. The color of the marly siliceous nannofossil ooze of Cores 4 and 5 is variable, and ranges from white $(5 \mathrm{Y} 8 / 1)$ to light gray (5Y $7 / 1$ and $5 \mathrm{Y} 7 / 2$ ), from light olive-gray $(5 \mathrm{Y} 6 / 2)$ to pale olive $(5 \mathrm{Y} 6 / 3)$, and from olive-gray (5Y $5 / 2$ and $5 Y H 4 / 2$ ) to olive (5Y $5 / 3$ and $5 Y 4 / 3$ ). The olive to gray coloring coincides with the presence of glauconite (up to $5 \%$ ) and clay in the ooze. The calcareous nannofossil content of the marly ooze gradually decreases with depth from a maximum of 60 per cent to a minimum of 25 per cent. This decrease is matched by an increase in the amount of unspecific carbonate particles from 5 to 30 per cent and of clay content from 5 to 15 per cent. The siliceous fraction remains relatively 


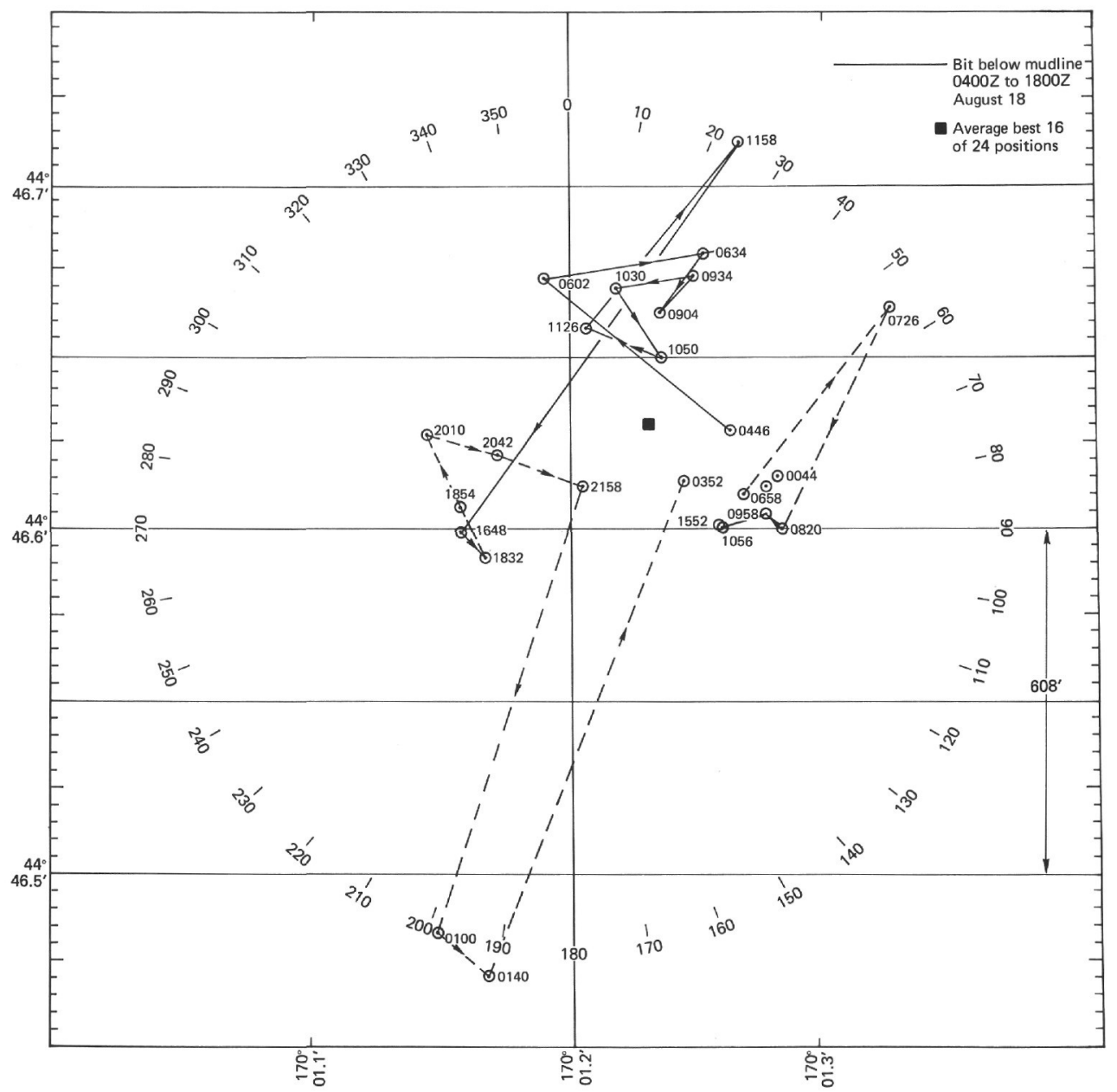

Figure 14. Mercator plot of satellite navigation locations during drilling of Hole 433B and spudding of Hole $433 C$.

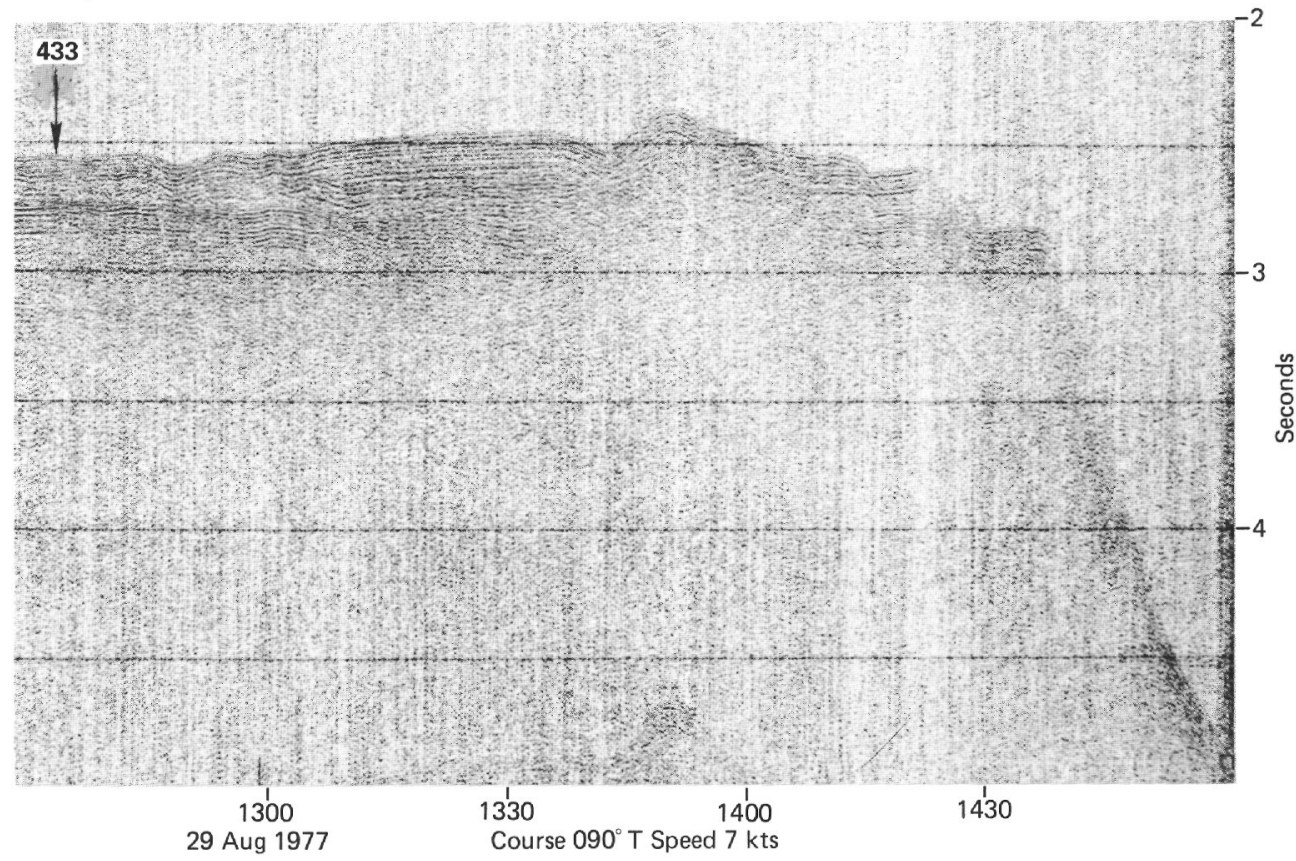

Figure 15. Glomar Challenger 5-s seismic reflection profile on departure from Site 433. 


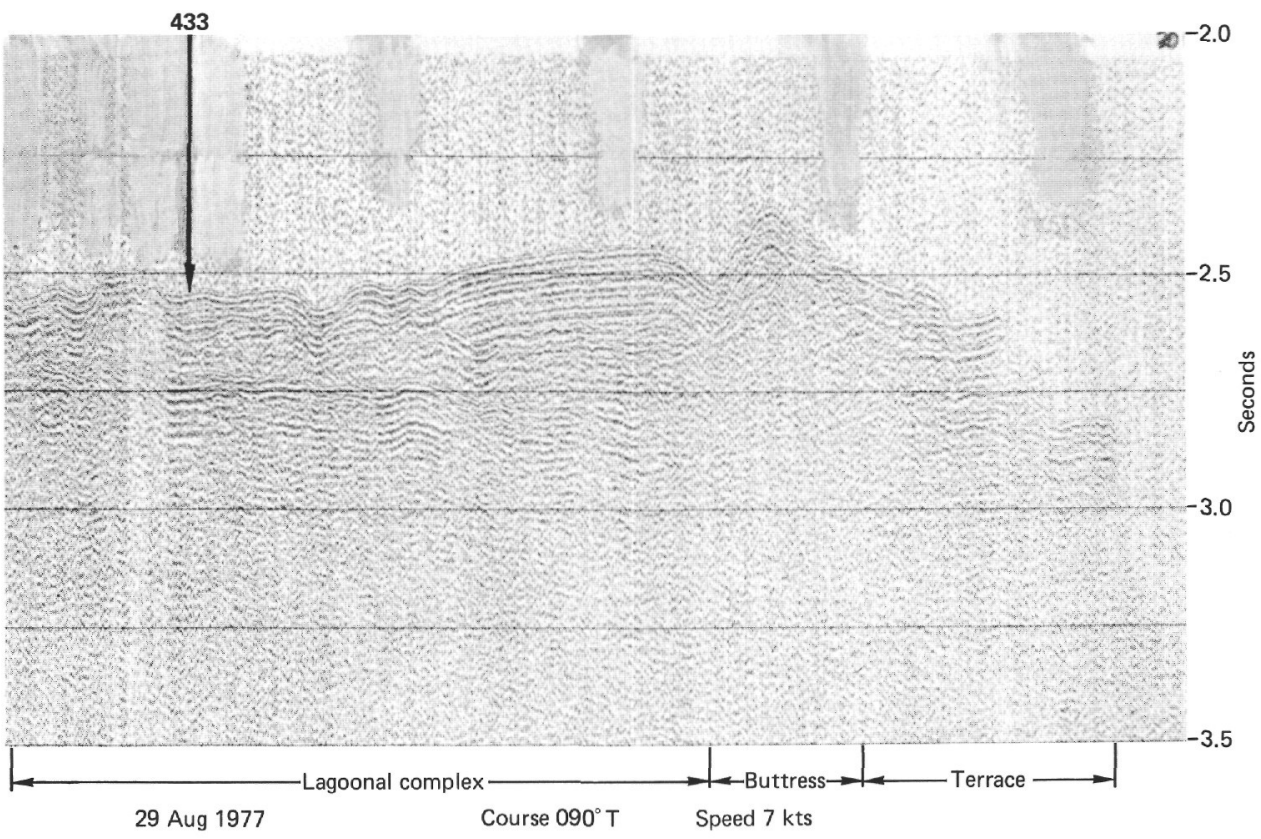

Figure 16. Glomar Challenger 2.5-s seismic reflection profile on departure from Site 433, showing lagoonal complex thickening to the east.

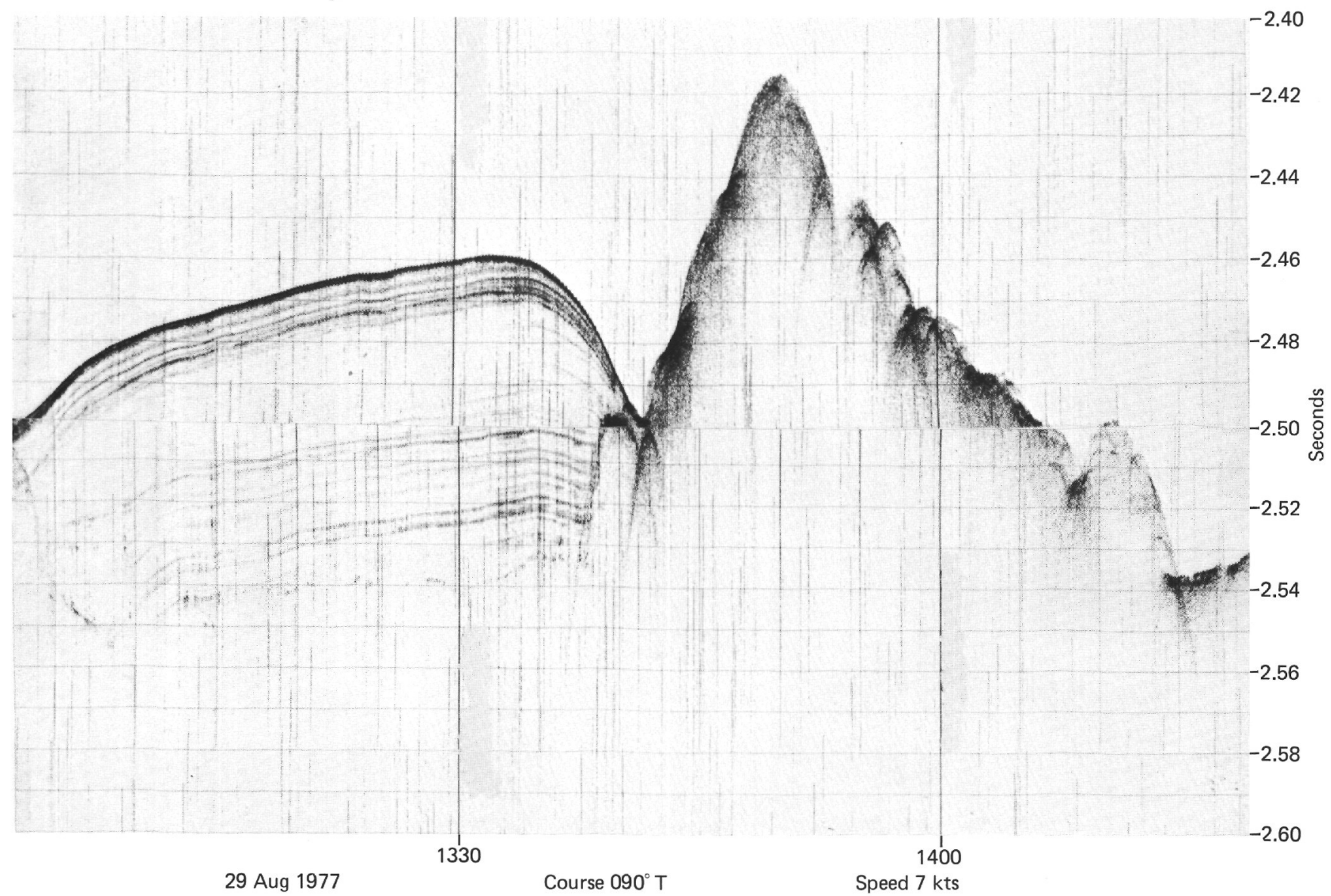

Figure 17. Glomar Challenger 3.5-kHz profile on departure from Site 433, showing thickening of pelagic sediments to the east. 


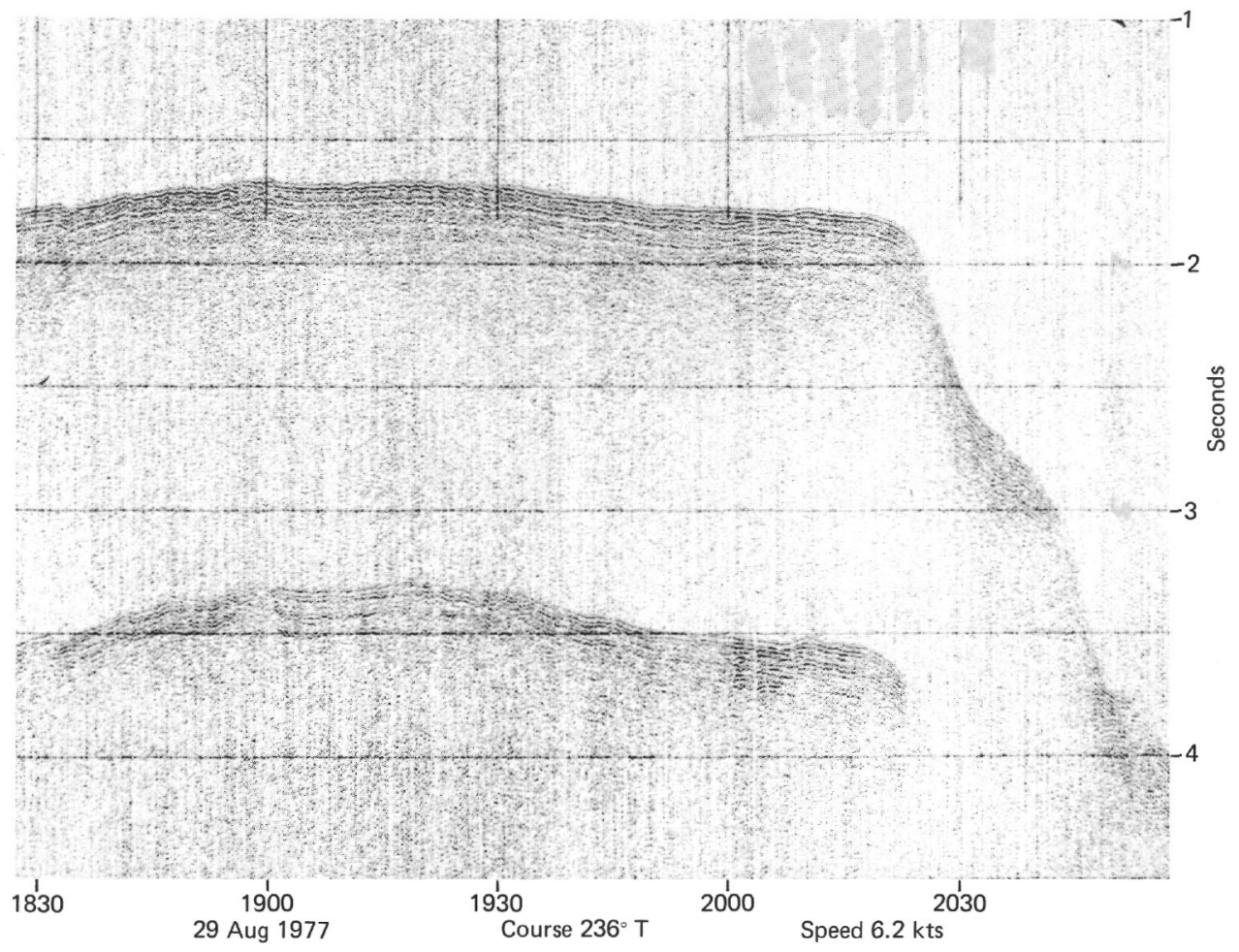

Figure 18. Glomar Challenger 5-s seismic reflection profile across central part of Suiko Seamount enroute to Yokohama, Japan.

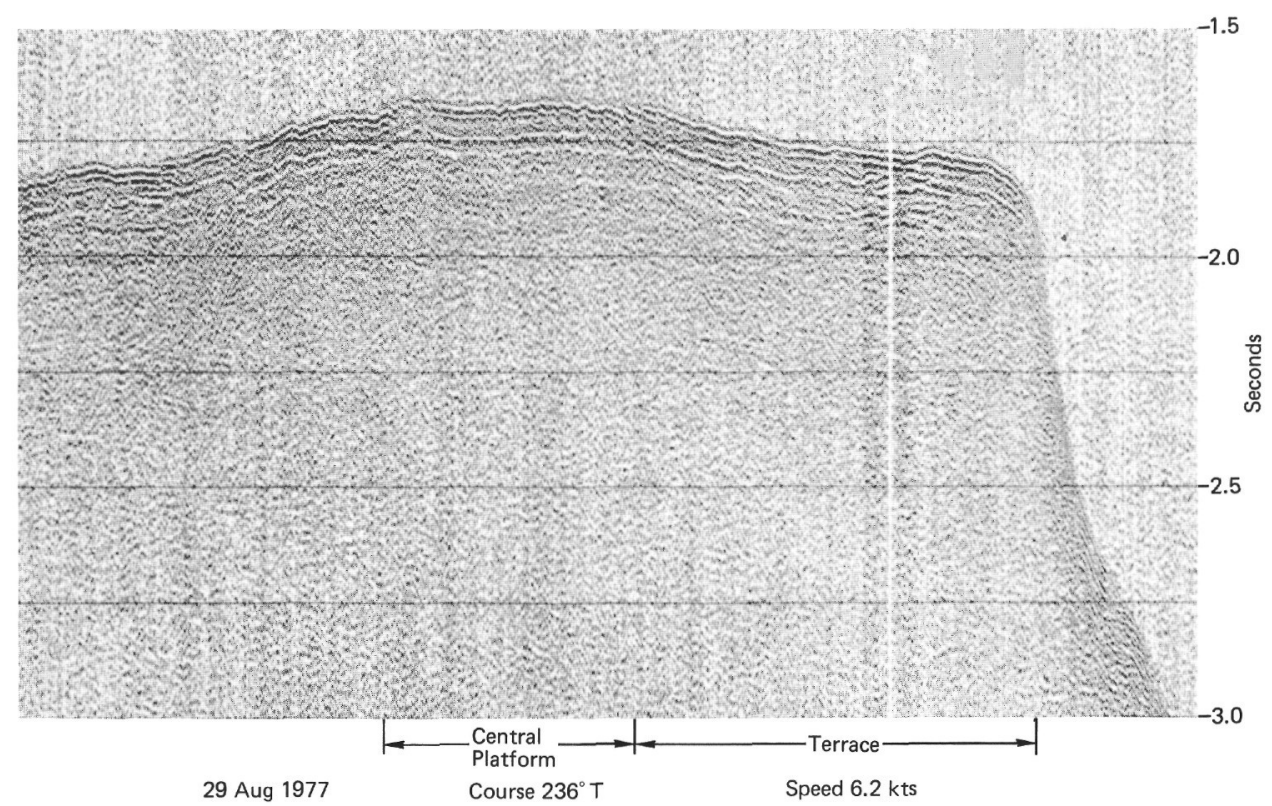

Figure 19. Glomar Challenger 2.5-s seismic reflection profile across the central part of Suiko Seamount, showing absence of lagoonal complexes. 

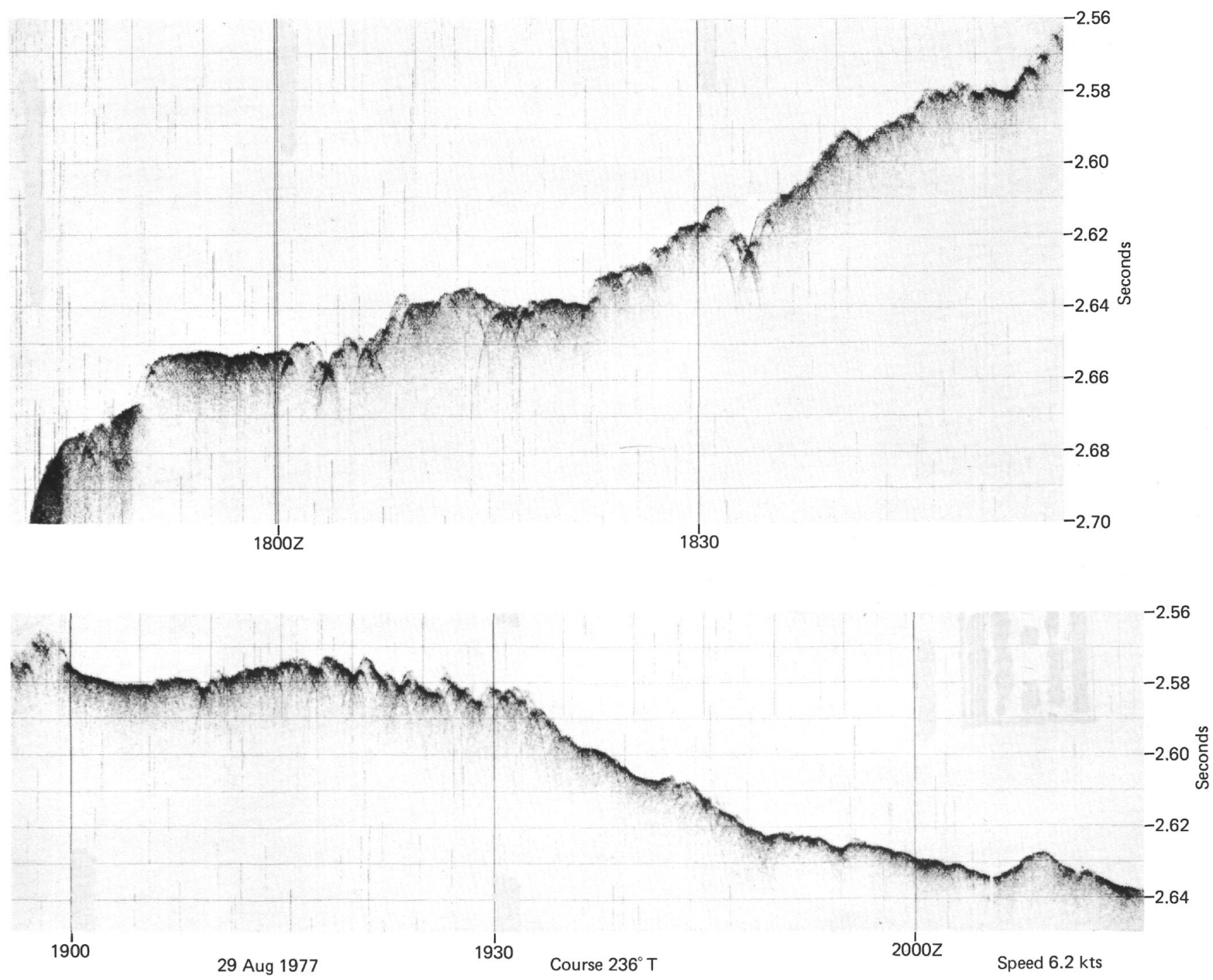

Figure 20. Glomar Challenger 5-kHz profile across the central part of Suiko Seamount, showing the lack of pelagic sediments.

constant throughout, and consists of diatoms (15 to $20 \%$ ), radiolarians ( 5 to $10 \%$ ), sponge spicules (trace to $5 \%$ ), and silicoflagellates (trace).

Unit 3, calcareous ooze to calcareous chalk, is confined entirely to Core 6 ( 0 to $9.15 \mathrm{~m})$. The calcareous ooze is light gray $(5 \mathrm{Y} 7 / 1)$, and consists of unspecified carbonate particles $(50 \%)$, calcareous nannofossils $(35 \%)$, diatoms $(10 \%)$ and radiolarians, sponge spicules, and silicoflagellates (5\%). A dense, well-crystallized pyrite concretion (olive-gray $5 \mathrm{Y} 1 / 2,3 \times 4 \times 1$ $\mathrm{cm})$ at 8.41 to 8.42 meters separates the ooze from the chalk. The white $(7.5 \mathrm{YR} 8 / 1)$ calcareous chalk, although somewhat deformed below its upper boundary, is very firm and compact. It splits apart along parallel planes, which attests to its degree of induration. Viewed microscopically, it contains unspecified carbonate particles $(40 \%)$, calcareous nannofossils $(45 \%)$, diatoms $(10 \%)$, and clay $(5 \%)$, along with traces of sponge spicules.
Unit 4, a tuffaceous sandy mud in Core 6 (9.15 to $9.50 \mathrm{~m}$ plus the core-catcher sample), was very highly deformed during drilling. It can be divided into two subunits: siliceous and volcanic. The stratigraphic relationship between the two sub-units was obscured during coring. The gray (5Y 5/1) marly siliceous ooze contains diatoms $(30 \%)$, radiolarians $(30 \%)$, sponge spicules $(15 \%)$, carbonate particles $(10 \%)$, volcanic glass $(10 \%)$, and clay $(5 \%)$. The dark gray (5Y 4/1) sandy, volcanic calcareous mud contains calcareous nannofossils $(20 \%)$, discoasters $(10 \%)$, diatoms $(5 \%)$, radiolarians $(5 \%)$, sponge spicules $(5 \%)$, clay $(20 \%)$, volcanic glass $(10 \%)$, quartz $(10 \%)$, heavy minerals $(10 \%)$, and feldspars $(5 \%)$. This tuffaceous sandy mud probably represents an unaltered volcanic ash layer.

Unit 5, Cores 7 through 19 , is a reef carbonate sand and sandy mud containing randomly dispersed algal nodules, often called rhodoliths. Calcarenites containing the same reef detritus occur at the base of the 


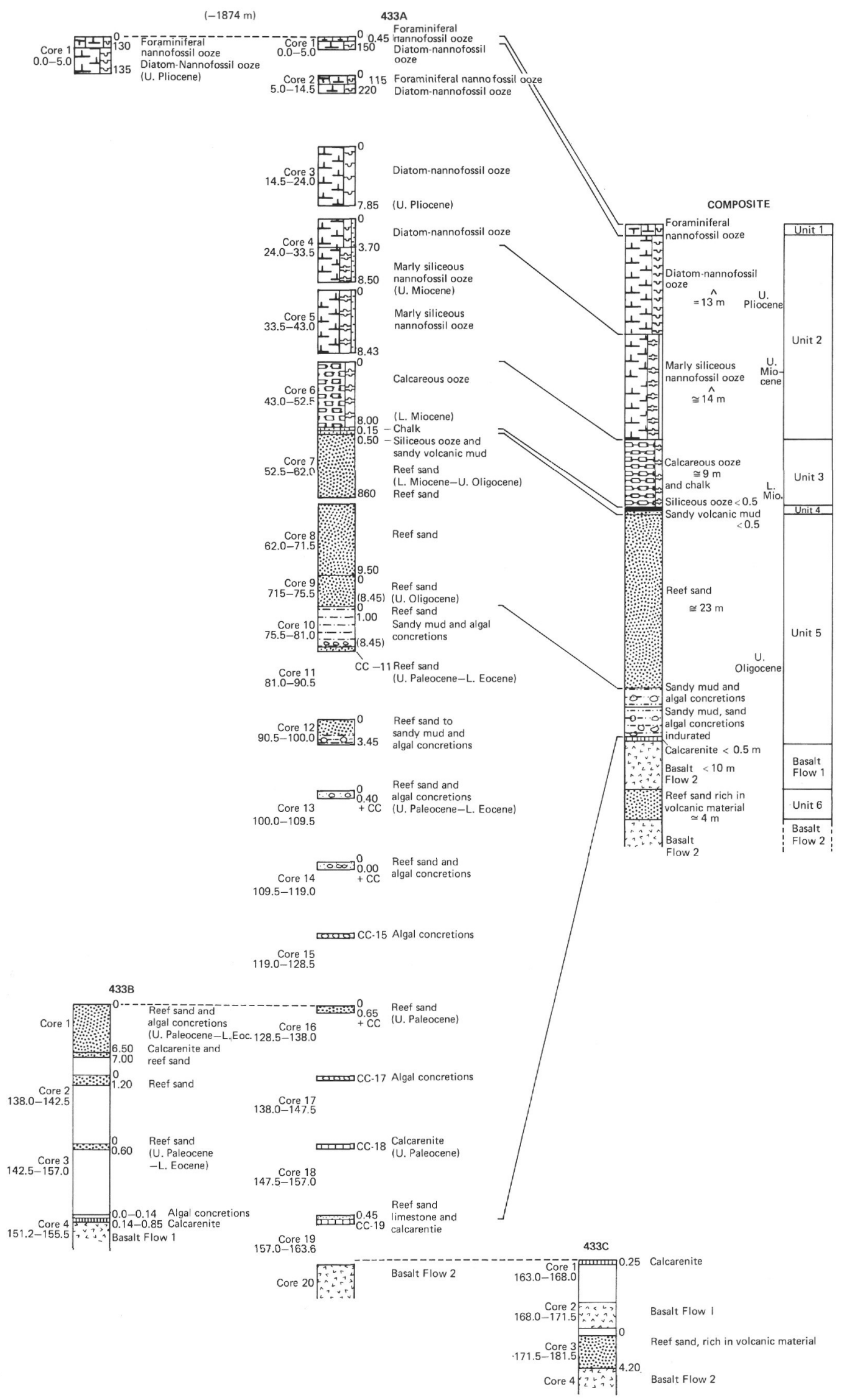

Figure 21. Composite of sedimentary lithologic units from Site 433. 
lithologic unit. The sand is composed of clastic fragments from a typical reef assemblage. Bryozoans, coralline algae, mollusk shells, sand-size algal nodules, fish teeth, and large foraminifers are represented. The sand is particularly rich in bryozoans. The fine fraction is in general 100 per cent unspecified carbonate.

Size sorting within the sands and muds varies from core to core. In general, sands are poorly to moderately well sorted. The carbonate clasts are usually subangular to rounded, indicating that they have been worked in a high-energy environment. The sand-size range spans the entire classification scale from very fine sand to very coarse sand, and even includes granule-size clasts. On the average, the sand is coarse- to medium-grained. Graded bedding in these cores is an artifact of drilling and settling. The color of the carbonate and mud changes gradually from pale yellow (5Y 8/3) and white $(5 Y 8 / 2)$ to light gray $(2.5 Y 7 / 1)$ to gray $(2.5 Y$ N6/1) with increasing depth in the hole. This color change is related to an increase in the percentage of gray reef carbonate clasts. With depth, the contribution of the gray clasts increases to 50 per cent of the total. The contribution of volcanic clasts to the sand particles varies randomly from 0 to 15 per cent.

The sandy carbonate mud (pale yellow, 5 Y 8/3) predominates in Core 10. This sediment is a mixture of clay to very fine grained sand particles, and contains algal nodules. It alternates with poorly sorted sand layers rich in nodules. The algal nodules found throughout Unit 5 are round, white to light gray balls frequently retaining smaller nobs on their surface. These nobs may indicate that no long-distance transport has occurred. In crosssection, the algae forming the nodule appears to have grown around a central nucleus, often dark gray. From the nucleus, growth continued outward with production of sequential crinkled laminae over the surface of the semispherical nodule, as shown in Figure 22. The diameter of the nodules varies between 1 and $6 \mathrm{~cm}$, and averages 2 to $3 \mathrm{~cm}$.

Two calcarenites were recovered at the base of Unit 5. In Core 18 , the specimen is a gray, poorly cemented, friable calcarenite composed of carbonate sand, small (1 to $3 \mathrm{~mm}$ diameter) algal nodules, shells, bryozoans, and coralline algal fragments. A light gray, porous but hard calcarenite composed of similar components was found in Core 19 (Figure 23). In both cases the cement is calcite, but the degree of lithification is more extreme in Core 19. In thin section, the detrital particles of the Core 19 calcarenite are cemented together with micritic calcite. Shell fragments of pelecypods, gastropods, and ostracodes have been partially dissolved, and their molds incompletely filled with recrystallized calcite; micrite along their edges gives way to drusy calcite in their interiors. The cells of the coralline algae are, in particular, filled completely with calcite in a drusy mosaic pattern.

\section{Hole 433B}

Gray $(2.5 \mathrm{Y} 6 / 0)$ and white $(2.5 \mathrm{Y} 8 / 0)$ reefal carbonate sand of Unit 5 occurs in the first three cores from Hole 433B. Its components are the same as those

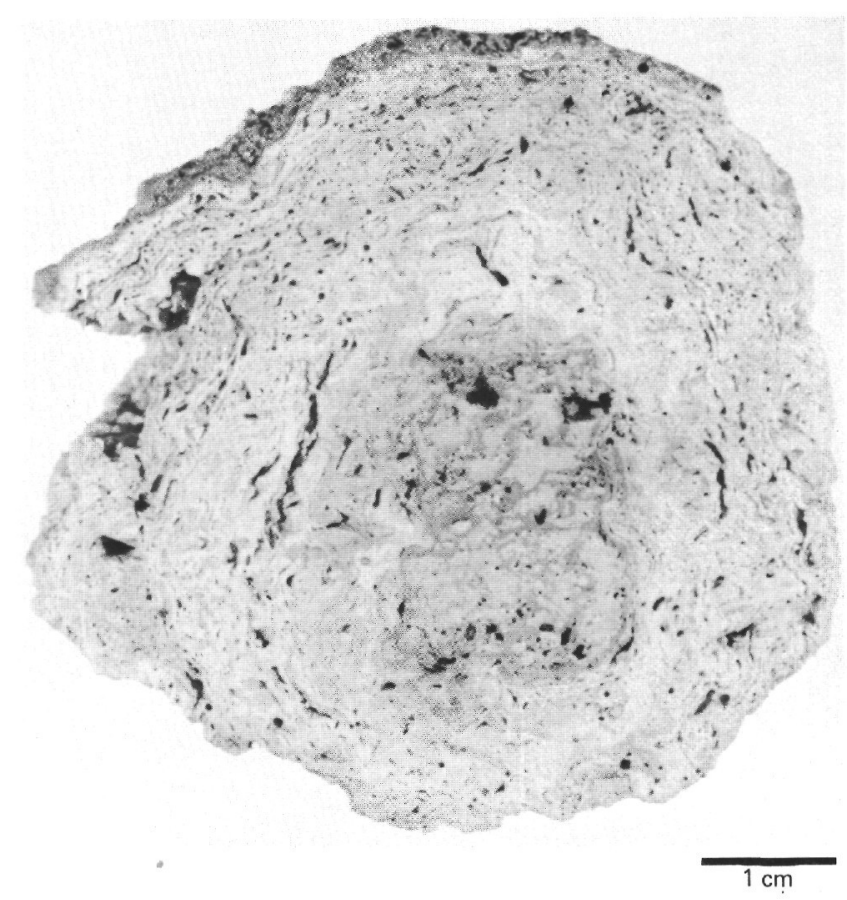

Figure 22. Cross-sectional view of an algal nodule from Hole 433A, Sample 14, CC.

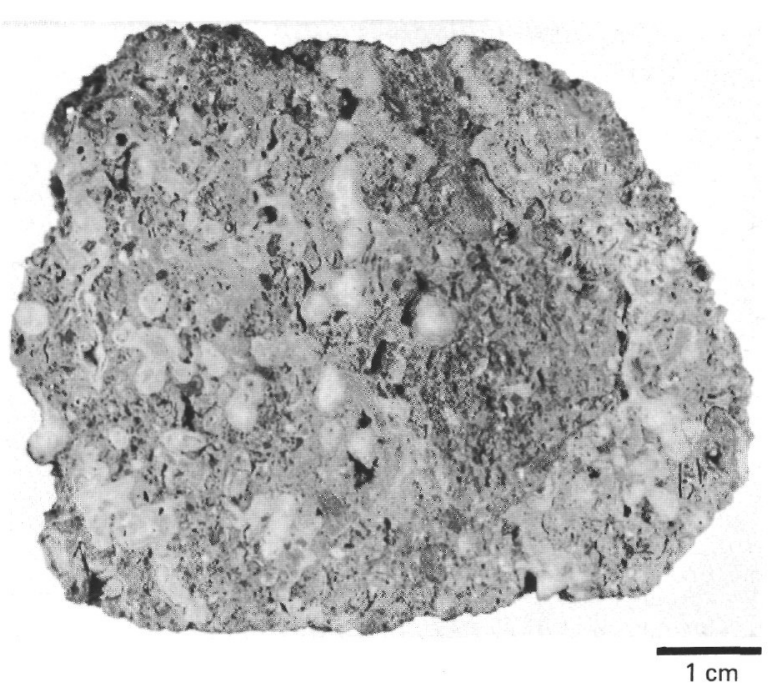

Figure 23. Light gray porous calcarenite, composed of biogenic carbonate sand, Hole 433A, Sample 19,CC.

in Hole 433A, given above. The sand is poorly to moderately well sorted. The percentage of volcanic clasts varies from 0 to 15 . Glauconite and pyrite crystals occur growing inside the openings of the lattice-like structure of the bryozoans. Pyrite is also present in the fine fraction of the sand. A gray (7.5YR N5), very friable calcarenite occurs in Core 3. Also, the ubiquitous algal nodules of Unit 5 are distributed thoughout the sand. The amount of turning the nodules received during the growth of their progressively accumulated layers is in- 
dicated by their shapes, which vary from round to oval to polygonal.

The contact between the basalt and the calcarenites of the lower part of Unit 5 was recovered in Core 4. Above the contact is a $35-\mathrm{cm}$ sequence of calcarenites that become progressively more lithified down-section, approaching the basalt. At the top of the core, broken fragments of the calcarenite occur, along with algal nodules; these are succeeded down the section by a continuously cored section of calcarenite, terminating at the basalt. The calcarenite contains clasts of coralline algae, bryozoans, algal nodules, and basalt. In the upper 20 $\mathrm{cm}$, the clasts range from coarse sand to pebbles. At about $20 \mathrm{~cm}$, a marked change to finer sand components occurs. The sands in this finer fraction are well sorted, and the particles are sub-angular to rounded. Overall, elongated particles tend to be aligned parallel to the plane of bedding. Some reverse size grading seems to occur between 15 and $30 \mathrm{~cm}$ : finer clasts grade up into coarse clasts. The sediment directly above the basalt is well rounded, well-sorted sand; the sorting undoubtedly contributes to denser packing of the grains.

Diagenetic changes in the calcarenite are notable. Porosity decreases with depth, as a result of cementation. Euhedral crystals are visible in the pores. At 28 $\mathrm{cm}$, the overall color of the rock changes from light gray $(5 Y 7 / 2)$ to pale yellow $(2.5 Y 8 / 4)$. In thin section, the particles are rimmed with rhombohedral micrite. Gastropods, pelecypods, and foraminifers have been dissolved and their molds filled with micrite and drusy calcite. Near the contact, the coralline algae has dissolved and recrystallized. With increasing depth, the calcite cement changes from predominantly micrite to a drusy mosaic calcite to a recrystallized matrix of microspar calcite at the sediment/basalt boundary.

Directly at the boundary, detrital carbonate sand fills the eroded surface of the basalt and extends into what might have been a large vesicle or fissure. Two generations of cement filling occur in the basalt: the first is a calcite vein filling of cemented basalt clasts and clay, and the second is the calcite-cemented reef carbonate sand.

\section{Hole 433C}

Unit 5 is represented by four calcarenite rocks found above the basalt in Core 1. The first two are gray (4.5YR N6) and porous. In thin section, the carbonate reef sand is rimmed and cemented with micrite. The second two calcarenite rocks are dark gray (7.5YR N4) and denser because of almost complete calcite cementation of the pores. In thin section, the cementation has progressed from micrite rims to drusy mosaic calcite to recrystallized microspar. The sand components are fragments of bryozoans and coralline algae, and algal nodules.

Unit 6 was cored only in Hole 433C, below the first basalt flow. The sediment in Core 3 is a well-sorted, coarse to very coarse reef carbonate sand rich in volcanic material. The grains are sub-rounded to rounded fragments of white and gray coralline algae and bryozoans $(70 \%)$, and basalt and quartz $(30 \%)$. A second basalt flow underlies the sand.

\section{Discussion}

Shallow-water sediments and fauna of coral reef origin have been identified on Kōkō Seamount, the southernmost seamount in the Emperor Seamount chain (Larson, Moberly, et al., 1975). With the recovery of reef carbonate sand and mud at Site 433, the existence of reefs in the Emperor Seamount chain has been extended approximately $10^{\circ}$ northward. The coralline algae and bryozoan detritus in the sediments cored on Suiko Seamount indicate that the drilling site is close to the site of an ancient bryozoan-algal reef. The sedimentological evidence, along with geophysical and biostratigraphical data, indicates that the Site 433 drilling was into shore and lagoonal zones on the back-reef region of a reef complex.

An unlithified, well-sorted, reef carbonate beach sand rich in volcanic material occurs sandwiched between the two uppermost basalt flows. This certainly suggests that volcanic activity and reef growth were contemporaneous processes on Suiko. Directly above and in contact with the basalt, a calcarenite composed of reef sand was cored. The calcarenite shows reverse grading, which could be explained as a result of wave grading of sand in a shore zone. The overall tendency of elongated grains to be aligned parallel to the bedding plane also suggests shoreline processes. Offshore, this orientation can result from wave action rolling the grains to and fro, or from longshore currents. Near shore, on the beach face, grain orientation is parallel to the backwash (Blatt et al., 1972).

In the calcarenite, the extent and degree of lithification rapidly decreases up the sedimentary column and ends in unconsolidated sand. The lithification appears to be associated with early-stage diagenesis, such as beach rock formation in the intertidal zone, or cementation in a shallow-water, restricted marine environment. Subtidal cementation of carbonate sands in back reef regions has been reported for the modern reefs of Bermuda (Ginsburg et al., 1971) and Jamaica (Land and Goreau, 1970). A study of the diagenesis of the Suiko shallow-water carbonates has been completed (McKenzie and Bernoulli, this volume).

The reef carbonates in Unit 6 and the lower part of Unit 5 are light gray to gray, and become white to pale yellow in the upper part of Unit 5. Crystals of pyrite and glauconite occur in the pore spaces of the gray bryozoans. These minerals, along with the darker color, can be indicators of reducing conditions. Perhaps these gray sands were deposited in what was, or was to become, an anaerobic environment. Subsequent changes in the circulation pattern within the basin produced oxidizing conditions, and the lighter color of the carbonate sediments resulted. Algal nodules occur randomly spaced throughout Unit 5. We cannot say whether they grew in place or were also part of the detrital input; either is possible.

The reef carbonate sediments are separated stratigraphically from the pelagic sediments by an altered volcanic sand. This layer is the stratigraphically highest evidence of the deposition of volcanic debris at Site 433. The fossil components mixed with the volcanic sand in- 
dicate the beginning of pelagic sedimentation. The onset of pelagic sedimentation and the end to the growth of the bryozoan-algae reef fauna on Suiko is marked by a hiatus. The cessation of reef production resulted from a subsidence rate of the seamount greater than the upward growth rate of the reefs, or from a decrease in sea water temperature that inhibited continued reefal growth - or from a combination of both.

\section{BIOSTRATIGRAPHY}

\section{Foraminifers and Other Microfossils}

\section{Hole 433}

\section{Pleistocene-Pliocene}

At Hole 433, Core 1 consists of foraminifer-rich sandy ooze and diatom-rich nannofossil ooze. Study of foraminifers in the samples from Section 1 and the upper part of Section $2(1-1,40-45 \mathrm{~cm}$ and 1-2, 1-3 cm) indicates a Pleistocene date. The assemblage includes very abundant Neogloboquadrina pachyderma (dominant left-coiled) and Globigerina bulloides. Other members of the assemblage include Globorotalia inflata and rare specimens of $G$. ronda, G. crassaformis, and G. scitula. Absence of Globorotalia truncatulinoides makes separation of Pleistocene from Pliocene sediment difficult, but data from diatom stratigraphy (see Koizumi, this volume) apparently place Samples 1-2, $9 \mathrm{~cm}$ through 1-1, $74 \mathrm{~cm}$ in the upper Pleistocene. Furthermore, the predominance of left-coiled $N$. pachyderma and the abundance of ice-rafted material in several samples of the section (heterogeneous sand and pebble) suggest a cold Pleistocene climate. The samples from the lower sections of Core $1(1-2,49-51 \mathrm{~cm}$ and $1, \mathrm{CC})$, however, contain Globorotalia puncticulata, G. inflata, G. crassaformis, Globigerinoides extremus, Neogloboquadrina humerosa, $N$. pachyderma (right-coiled), Orbulina universa, $O$. bilobata, and rare specimens of Globorotalia ronda, all indicating the upper Pliocene.

In contrast to the Pleistocene assemblage (see above), this assemblage indicates a relatively warm, subtropical watermass during the Pliocene (for benthic foraminiferal assemblage, see Hole 433A).

\section{Hole 433A}

\section{Pleistocene-Pliocene}

A foraminiferal assemblage almost identical to that at Hole 433 occurs in Hole 433A. Sample 1, 4-13 cm contains a low-diversity assemblage of small planktonic foraminifers, together with abundant ice-rafted material, indicating a cool Pleistocene environment. Typical species include abundant Globigerina bulloilides and Neogloboquadrina pachyderma (dominant left-coiled), and fairly abundant Globorotalia inflata and G. crassaformis. Scarce specimens of $G$. ronda and a single specimen of G. truncatulinoides are also present in the assemblage, indicating a Pleistocene date for Sample 1-1, $13 \mathrm{~cm}$. Diatoms (Koizumi, this volume) place Sample $1-1,1-19 \mathrm{~cm}$ in the upper Pleistocene.
In contrast to the underlying Pliocene sediment (Cores 1 through 3), the upper Pleistocene sediment (Sample 1-1, 13 cm) contains lower middle bathyal benthic foraminifers such as Planulina wuellerstorfi, Melonis pompiloides, Pyrgo murrhina, Oridorsalis umbonatus, Gyroidina neosoldanii, Cassidulina translucens, and $C$. lomitensis. Uvigerinids are abundant, and include bathyal species such as Uvigerina peregrina, $U$. hispida, and $U$. proboscidea. Scattered specimens belonging to the genera Siphonodosaria, Nodosaria, Lage$n a$, and Martinottiella also occur. This assemblage resembles other Quaternary benthic foraminiferal assemblages reported for Sites 430, 431, and 432, and may also indicate a change in bottom temperature, related to bottom currents, since the Pleistocene (see Butt, this volume).

In Hole 433A, Samples 1-1, 59-61 cm through 3, CC contain Pliocene nannofossil ooze. The lower Pliocene assemblage in the samples includes Globorotalia puncticulata, G. crassaformis, G. conoidea, G. scitula, Neogloboquadrina humerosa, N. pachyderma (right-coiled), Globigerina bulloides, G. glutinata, and Orbulina universa. The upper Pliocene assemblage in Samples 3-3, $44-46 \mathrm{~cm}$ through 1-1, 59-61 cm includes Globorotalia inflata, G. puncticulata, G. crassaformis, Globigerina bulloides, G. glutinata, Neogloboquadrina humerosa, N. pachyderma (right-coiled), Globigerinoides cf. ruber, Orbulina universa, and $O$. bilobata.

Important benthic species include Melonis affinis, Oridorsalis umbonatus, Pullenia bulloides, Gyroidina neosaldanii, Pyrgo murrhina, $P$. depressa, $P$. serrata, Rectoglandulina rotundata, and Laticarinina pauperata. Other benthic species present but scarce include Uvigerina peregrina, U. hispida, Cassidulina subglobosa, specimens of the genera Dentalina, Nodosaria, and Fissurina; Praeglobobulimina siphonodosaria, and species of Pleurostomella. Species of Stilostomella are abundant in Miocene through Pliocene sediments.

\section{Miocene}

Compared with Pliocene sediments, the Miocene sediments in Hole 433A, Cores 4 through 6, yield scarce to common planktonic foraminifers, but siliceous fossils such as radiolarians are the major constituents of the sand fraction. Detailed study of several samples from Cores 4 through 6 reveals that the lower part of the lower Miocene and some of the middle Miocene are absent. The upper part of the lower Miocene (Zone 6, Blow, 1969) occurs in the lower part of Core 6 (Samples 6 , CC; 6-7, 33-35 cm; and 6-6, 144-146 cm). The assemblage includes Globorotalia peripheroronda, G. scitula, G. continuosa, Globoquadrina praedehiscens, Catapsydrax unicavus, Globigerina venezuelana, Globigerinita incrusta, and Globigerinoides cf. trilobus. The upper Miocene occurs in Cores 4 through 6 (Samples 6-6, $49-51 \mathrm{~cm} ; 6-5,100-102 \mathrm{~cm} ; 6-4,110-112 \mathrm{~cm} ; 6-2$, $141-143 \mathrm{~cm} ; 5-4,51-53 \mathrm{~cm}$; 5-2, 121-123 cm; 4-6, 2-4 cm; $4-3,39-41 \mathrm{~cm} ; 4-1,54-56 \mathrm{~cm})$. Important species include 
Globorotalia continuosa, G. scitula, Neogloboquadrina pachyderma (dominant left-coiled), Globigerina bulloides, G. apertura, G. nepenthes, Orbulina universa, and Sphaeroidinellopsis subdehiscens. Globorotalia cf. crassaformis first occurs in Sample 4-1, 2-4 cm, suggesting uppermost Miocene or perhaps the Miocene/Pliocene boundary. The Miocene benthic foraminifers (see below) apparently indicate that Suiko Seamount had subsided to an upper middle bathyal depth (Butt, this volume) during this period. Typical upper Miocene benthic species in Cores 4 through 6 include Oridorsalis umbonatus, Pullenia bulloides, Gyroidina soldanii, Melonis affinis, Planulina kellenbergi, Laticarinina pauperata, Uvigerina proboscidea, and Pyrgo depressa. Stilostomellas and nodosariids are very abundant in all samples studied. Occasionally, species of the following genera are also present: Lagena, Fissurina, Pleurostomella, Rectoglandulina, and Bolivina. The lower Miocene benthic species include Laticarinina pauperata (small size), Anomalina globosa, Uvigerina holliki, Planulina bradyi, and species belonging to the genera Osangularia, Gyroidina, Valvulineria, Pullenia, Bulimina, and Bolivina.

\section{Paleogene}

In Hole 433A, planktonic foraminifers are very rare in Cores 7 through 19 (Unit 5), and fine biostratigraphic subdivision of the Paleogene is extremely difficult. No typical middle Eocene-Oligocene through lower Miocene species are present. Thus, this interval is represented in Hole 433A by a major erosional hiatus, perhaps related to vertical motion of Suiko Seamount. Two to three samples per section of Cores 7 through 19 were examined, but most of the samples are barren of planktonic species, although benthic fossils are abundant in nearly all samples. On the basis of some diagnostic species, it is plausible to suggest that the Paleogene reef sedimentary unit is middle Paleocene to lower Eocene. Because of the soupy nature of the Paleogene sediments at Hole 433A, the samples from Cores 7 through 19 are commonly contaminated with Neogene and Quaternary foraminifers, mixed through downhole contamination. These younger contaminated forms (such as N. pachyderma and species of Oridorsalis, Uvigerina, Cassidulina) can be easily distinguished from the Paleogene forms by their good preservation. Cores 16 (Sample 16-1, 7-14 cm) and 14 (Sample 14-1, 40-56 cm) contain Globorotalia angulata, G. aequa, $G$. cf. conicotruncata, $G$. aragonensis, and small specimens belonging to the genus Acarinina. Cores 13 (Sample 13, CC and Section 1), 11 (Sample 11, CC), 10 (Sections 7 and 5), and 8 (Sample 8, CC) contain some diagnostic species such as Globorotalia aragonensis, G. cf. lensiformis, and G. cf. pseudobulloides.

The samples from Core 7 yield some interesting lower Paleogene globorotaliids and two poorly preserved Maestrichtian species of Globotruncana. In addition, the samples also contain some lower Miocene species identical to those in Core 6, such as Catapsydrax unicavus and Globorotalia peripheroronda, and upper Neogene-Quaternary species such as Neogloboquadrina pachyderma and Globigerina bulloides and several benthic species of the same age. These fossils are more abundant in the upper portion of Core 7. The occurrence of these fossils here is considered to be a result of downhole contamination. The following Paleogene species seem to indicate that Core 7 is middle to upper Paleocene: Globorotalia aragonensis, G. cf. angulata, G. cf. pseudobulloides (Sample 7, CC); G. cf. compressa, G. aragonensis, G. aequa, Globigerina linaperta (Sample 7-2, 110-112 cm); Globorotalia cf. caucasica, G. aragonensis, Globigerina cf. linaperta (Sample 7-1, $40-42 \mathrm{~cm})$. The occurrence of two poorly preserved Globotruncana species (one of them identified as Globotruncana contusa) in Section 7-1 may indicate that these Cretaceous forms were reworked into Paleogene sediments, and that Suiko as a volcano was built near a time corresponding to the Cretaceous/Tertiary boundary.

In contrast to the planktonic foraminifers described above, shelf benthic foraminifers are frequent in all the studied samples from Cores 7 through 19. The assemblage includes species of Lenticulina, Vaginulina, Cibicides, and Ammodiscoides. Their joint occurrence with abundant bryozoans, calcareous algae, ostracodes, echinoids, serpulids, and gastropods indicates a Paleogene shelf reef environment at Suiko Seamount (see Butt, this volume).

\section{Hole 433B}

In Hole 433B, Cores 1 through 3, bryozoan-rich calcareous algae sand, are equivalent to Cores 16 through 19 from Hole 433A. Planktonic foraminifers are very rare and poorly preserved. Samples $1, \mathrm{CC}$ and 1-1, 3-6 $\mathrm{cm}$ contain Paleocene species such as Globigerina linaperta and Globorotalia aequa. As at Hole 433A, samples of the Paleogene sediments at Hole 433B are also contaminated by Quaternary planktonic foraminifers. Benthic foraminifers present include only shallow-water shelf forms such as Lenticulina, Vaginulina, and Cibicides; they are associated with ostracodes and bryozoans. The coarse-grained sandstone is made up chiefly of calcareous algae (Lithothamnium), stromatolites, and bryozoan fragments. The thin section of Sample 4-1, $28-32 \mathrm{~cm}$ contains scattered fragments of a Paleocene algae called Elianella elegans (see Hagn and Butt, this volume). Other biogenic constituents include gastropods, pelecypods, echinoids, and ostracodes. A few calcareous rotaliids occur in the thin section.

\section{Hole 433C}

Section 1-1, Hole 433C, contains a sediment/basalt contact similar to that in Hole 433B. The coarsegrained, well-sorted sandstone at the contact consists mainly of calcareous algal and bryozoan fragments, and a few stromatolites. Loose calcareous sand containing abundant volcanic fragments was recovered from Core 3 , between the lava Flow Units 1 and 2. The corecatcher sample contains bryozoans and benthic foraminifers (Lenticulina); planktonic forms are absent. This biogenic component provides no age information. But the occurrence of the algal fragments, Elianella ele- 
gans in Sample 1-1, 20-25 cm, suggests the Paleocene (See Hagn et al., this volume).

\section{Calcareous Nannofossils}

\section{Hole 433}

Only one sample $(1, \mathrm{CC})$ from this hole was examined on shipboard. It contains very abundant and wellpreserved calcareous nannofossils, but species diversity is low. Gephyrocapsa doronicoides and small undiagnostic placoliths dominate the assemblage. Coccolithus pelagicus, Cyclococcolithus leptoporus, and C. macintyrei are frequent; Pseudoemiliania lacunosa, Helicopontosphaera kamptneri, and $H$. sellii are extremely rare. The occurrence of Pseudoemiliania lacunosa together with Cyclococcolithus macintyrei and Helicopontosphaera sellii, and the absence of Gephyrocapsa specimens and Reticulofenestra pseudoumbilica, strongly indicate that this sample is upper Pliocene (NN 16 Discoaster surculus Zone to NN 18 Discoaster brouweri Zone). Discoasters are unexpectedly rare; only some fragments are recognizable. Because of this general absence of discoasters in the material examined, the precise age of this sample within the upper Pliocene interval is still uncertain.

\section{Hole 433A}

On the basis of the calcareous nannofossil assemblages, the sedimentary sequence recovered from Hole 433A can be divided into three microfloral units: assemblage 1 (Cores 1 through 5), assemblage 2 (Cores 6 through 7), and assemblage 3 (Cores 8 through 19). The abundance and state of preservation of the calcareous nannofossils change markedly between assemblages 1 and 2 and between assemblages 2 and 3 .

\section{Assemblage 1 (Cores 1 through 5)}

Assemblage 1 is characterized by very abundant, well-preserved but comparatively less species-diversified nannofossils, and is represented by six samples. Cores 1 through 3 are quite similar to the material in Hole 433. The coexistence of Cyclococcolithus macintyrei and Pseudoemiliania lacunosa indicates that Sample 1-1, 4-13 cm, the youngest sample of Hole 433A examined, is upper Pliocene or lower Pleistocene. In particular, a few occurrences of Gephyrocapsa caribbeanica strongly indicate that this sample is lowermost Pleistocene. It is therefore likely that most of the Quaternary sediments at this site are either too thin to recover or were eroded away by bottom currents. On similar evidence, we assign Samples 1, CC; 2, CC; and 3, CC to calcareous nannoplankton Zones NN 16 (Discoaster surculus Zone) to NN 18 (Discoaster brouweri Zone) (upper Pliocene). Sample 4, CC is also characterized by fairly abundant calcareous nannofossils. Though the species diversity is also comparatively low, the preservation is slightly poorer than in previous samples. In this sample, Discoaster intercalcaris and Cyclicargolithus floridanus occur together. This is significant because in previous studies the extinction of Cyclicargolithus floridanus defines the top of the Coccolithus miopelagicus Subzone of the Discoaster exilis Zone (middle Miocene), while the initial appearance of Discoaster intercalaris marks the base of the Discoaster hamatus Zone, and the Catinaster coalitus Zone is between them. Therefore, the joint occurrence of the two species observed here should be investigated further to determine whether the initial appearance of Discoaster intercalaris should be extended or whether the extinction of Cyclicargolithus floridanus could have occurred later in time than previously documented. Among the calcareous nannofossil species recovered from Sample 5, CC, the most important species is Discoaster quinqueramus, which can be used to assign the sample to NN 11 Discoaster quinqueramus Zone (upper Miocene).

\section{Assemblage 2 (Cores 6 through 7)}

Calcareous nannofossils in assemblage 2 include common lower Miocene species, moderately well preserved, together with a few Paleocene specimens, and Samples 6, CC and 7, CC are considered to be Paleocene.

\section{Assemblage 3 (Cores 8 through 19)}

In assemblage 3, calcareous nannofossils are extremely rare and poorly preserved. The assemblage is marked by very low species diversity. Sample $8, C C$ is barren, and Sample 10, CC contains no age-diagnostic specimens.

Samples 11, CC through 13, CC contain several lower Paleogene nannofossil species, the combined occurrence ranges of which provide evidence for an upper $\mathrm{Pa}$ leocene assignment. It is remarkable that in Sample 433A-16, CC, a typical Paleocene species, Cruciplacolithus tenuis, was found for the first time during this cruise, together with Neochiastozygus distentus, Toweius eminens, and $T$. craticulus. Generally, $C$. tenuis occurs abundantly in the sequence ranging from the lower Paleocene NN 2 Cruciplacolithus tenuis Zone to the upper Paleocene NN 6 Heliolithus kleinpellii Zone. The presence of this species therefore dictates that the sediments above the basalt can be no younger than upper Paleocene. Although Samples 17, CC and 18, CC contain no Cruciplacolithus tenuis, their age is considered the same as that of Sample 16, CC, because of the presence of such species as Neochiastozygus chiastus, $N$. distentus, and Toweius eminens. In Sample 19, CC, these species are completely absent. The upper half of this floral unit - Samples 10, CC; 11, CC; and 13, CC - contain a small number of moderately well preserved coccoliths and discoasters such as Gephyrocapsa doronicoides, Cyclococcolithus leptoporus, C. macintyrei, Discoaster intercalaris, Helicopontosphaera sellii, Pseudoemiliania lacunosa, and Reticulofenestra pseudoumbilica. There appears to be uphole contamination of Neogene nannofossils.

\section{Hole 433B}

Among three core-catcher samples recovered from this hole, 1, CC and 3, CC contain calcareous nannofossils. The assemblage of Sample 1, CC consists of poorly preserved Coccolithus pelagicus, Neochiastozygus chiastus, and Toweius eminens. Sample 3, CC con- 
tains $N$. distentus in addition to the above species, but in a state of poor preservation. These two samples are therefore probably upper Paleocene. Sample 3, CC contains also several moderately well preserved Neogene specimens; they include Gephyrocapsa doronicoides, Coccolithus pelagicus, Cyclicargolithus floridanus, $C y$ clococcolithus macintyrei, and Reticulofenestra pseudoumbilica. They are interpreted as resulting from uphole contamination.

\section{Hole 433C}

In the well-sorted reef carbonate and volcanic material intercalated between basaltic Flow Units 1 and 2 (Sample 3, CC), only two poorly preserved coccoliths were found: Coccolithus pelagicus and another which may belong to genus Zygodiscus - it is somewhat similar to Zygodiscus sigmoides. If this identification is correct, the sample may be Paleocene.

\section{Radiolarians}

Deep-sea sediments containing common to abundant and well-preserved radiolarians were recovered for the first time during Leg 55 at Site 433. Occurrences of radiolarian taxa and their relative abundances are shown in Table 7.

\section{Hole 433}

Core 1 from this hole contains Lamprocyclas heteroporos, but lacks some typical Quaternary forms expected at this latitude, including Eucyrtidium matuyamai, so the sediments in this core would appear to be middle to upper Pliocene. Subsequent shore-based study reveals, however, that approximately the uppermost 2 meters of sediments are upper lower to upper Pleistocene.

\section{Hole 433A}

Radiolarians occur continuously in the siliceous and calcareous ooze of the upper 62 meters and among the upper part of the reef carbonate sands of this hole. The topmost $20 \mathrm{~cm}$ (approx.) of sediments contains a few specimens of Lamprocyrtis heteroporos, but, like the previous hole, lacks Eucyrtidium matuyamai. Similar assemblages also occur in Cores 2 and 3 . In Cores 4 and 5, Stichocorys peregrina and $S$. delmontensis occur together, along with Theocorys redondoensis, but without Lamprocyrtis heteroporos. Cores 4 and 5 are assigned to the upper Miocene Stichocorys peregrina Zone.

In Cores 6 and 7, the assemblage consists of Cannartus tubarius, Cyrtocapsella japonica, C. tetrapera, and Lychnocanoma bipes, suggesting that the sediments are lower middle to lower Miocene. Apparently there is a hiatus between Cores 5 and 6 encompassing a part of the upper Miocene and at least a major part of middle Miocene. In Core 8 through Core 19 (the deepest core), radiolarians are either rare and poorly preserved or completely absent. Thus, for stratigraphic purposes, this section is considered barren of these siliceous microfossils.

\section{Holes 433B and 433C}

Radiolarians are completely absent in samples from Cores 1 to 3 of Hole 433B, and from the reef sands between basalt flows in Core 3 of Hole 433C.

TABLE 7

Occurrence of Radiolarians at Site 433

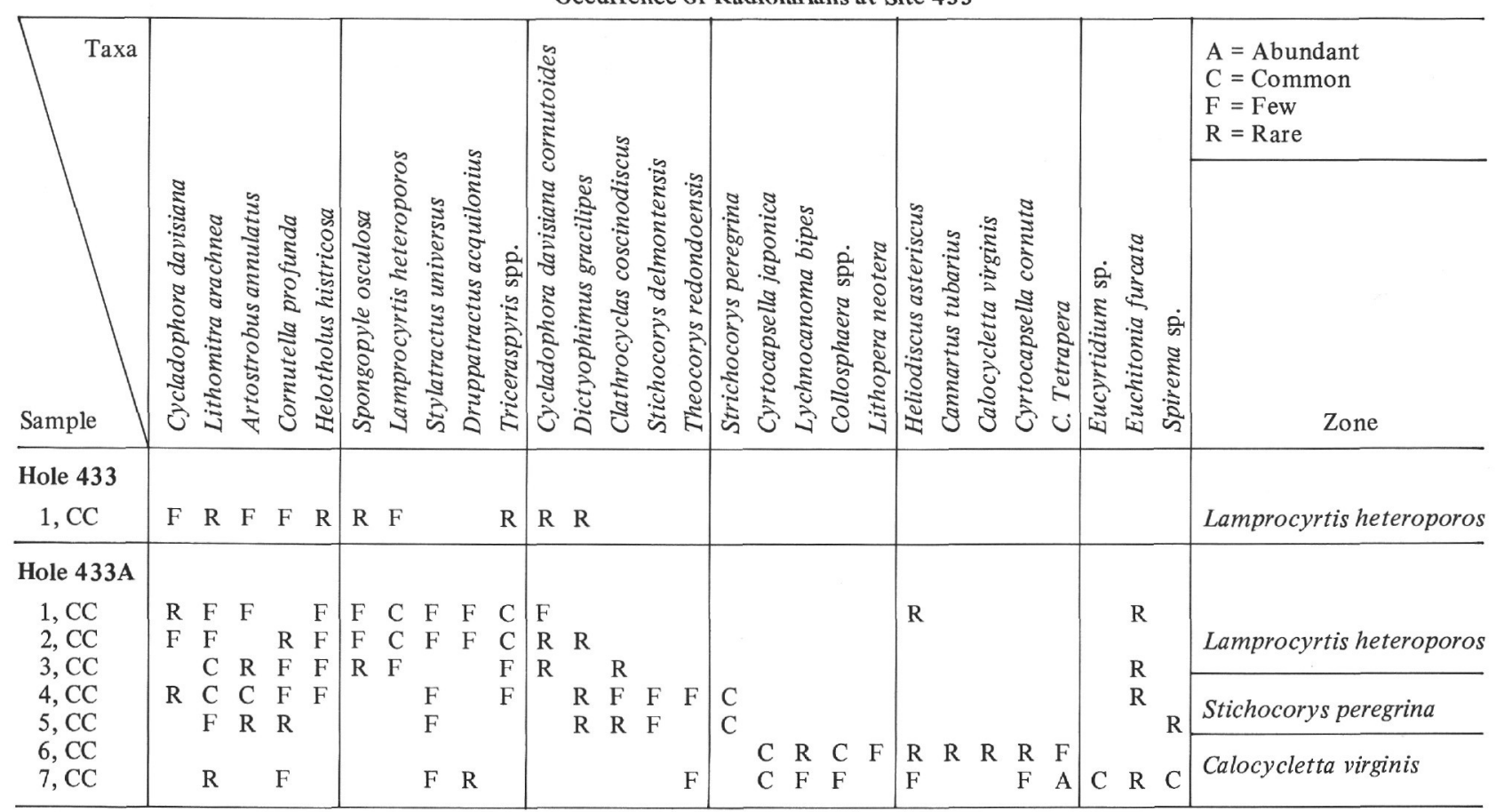




\section{Silicoflagellates}

\section{Hole 433}

The uppermost 2.5 meters of Pleistocene sediments, according to diatom and radiolarian data, contain no silicoflagellates. Sample 1-2, 113-115 cm belongs to the Ebriopsis antiqua antiqua Zone, whereas Sample 1-3, 94-99 $\mathrm{cm}$ belongs to the Distephanus boliviensis jimlingii Zone.

\section{Hole 433A}

Generally common to abundant, well-preserved silicoflagellates (and ebridians) are continuous in the upper 62 meters of the sediment column (Cores 1 through 7). In Cores 7 to 19, this group of microfossils is completely absent.

\section{Holes 433B and 433C}

No silicoflagellate specimens were found in Cores 1 through 3 of Hole 433B, or in Core 3 of Hole 433C. The uppermost $70 \mathrm{~cm}$ of sediment from Hole $433 \mathrm{C}$ does not contain this group of microfossils. A sediment sample, 433B-1-1, 70-73 cm, belongs to the Pliocene Ebriopsis antiqua Zone, but Sample 433B-1-1, 133-135 cm belongs to the lower Pliocene Distephanus boliviensis jimlingii Zone. The top of the Distephanus quinquangellus Zone occurs between Cores 3 and 4 (Miocene/Pliocene boundary). Silicoflagellates and ebridians are rare in the lower part of Core 6 (lower middle Miocene to lower Miocene section).

\section{SEDIMENT CHEMISTRY}

Three water samples from Site 433 were analyzed for $\mathrm{pH}$, alkalinity, salinity, $\mathrm{Ca}^{++}, \mathrm{Mg}^{++}$, and $\mathrm{Cl}^{-}$; a surface sea-water sample was analyzed for a standard, and two samples from Hole 433A (in Cores 4 and 8) were analyzed. These data are presented in Table 8 .

A total of 18 samples from Site 433 were analyzed by the carbonate bomb method: 2 from Hole 433, 13 from Hole 433A, 2 from Hole 433B, and 1 from Hole 433C. The data are presented in Tables 9 through 12. Values range from 26 to 100 per cent $\mathrm{CaCO}_{3}$.

A total of 11 samples, all from Hole 433A, were analyzed for water content, porosity, and wet-bulk density using the syringe technique. Ten of these yielded useful results. The data are presented in Table 13. Water contents range from 39.5 to 61.4 per cent, porosities from 64.7 to 83.5 per cent, and wet-bulk densities from 1.29 to $1.64 \mathrm{~g} / \mathrm{cm}^{3}$.

\section{PALEOENVIRONMENT}

During the middle Paleocene, at the end of its main shield-building stage, Suiko Seamount submerged and shallow-water sediments began to accumulate. These sediments were carbonate sands containing coralline algae, bryozoans, benthic foraminifers, and ostracodes, and indicate the nearby presence of a bryozoan-algal reef complex. Sedimentation at Site 433 occurred in a small graben basin located within one of the lateral lagoons on the seamount. Subsidence was continuous throughout most of the depositional history. The reef sands grade upward into carbonate muds which are occasionally interbedded with sand layers and algal nodules.

A major hiatus occurred between the end of this Paleocene shallow-water sedimentation and the onset of pelagic sedimentation in the late early Miocene. This hiatus can be interpreted in two ways: (1) continuous sedimentation, then emergence with erosion and subsequent submergence; or (2) a period of non-sedimentation during the interval in which the seamount subsided from a reef environment into the pelagic realm. A second hiatus occurred in the middle Miocene.

The fossils in the pelagic sediments of the lower upper Miocene indicate relatively warm (transitional) waters. From the late Miocene to the present, there was gradual cooling, culminating in modern (sub-arctic) conditions.

\section{LITHOSTRATIGRAPHY OF VOLCANIC ROCKS}

Hole $433 \mathrm{C}$ penetrated a total of 67 positively identified (numbered) lava flows, from a depth of 165.5 meters sub-bottom (where the driller first felt hard rock) to 550.5 meters sub-bottom. Of these flows, 21 contain one or more sub-units which may be separate lava flows or flow lobes of single lava flows. There are at least 113 possible lava flows. In addition, there appear to be a well-sorted carbonate and basalt beach sand below Flow Unit 1 in Core 3 (see above) and pumice lapilli tuff intervals in Cores 21 and 31. Hole 433A penetrated only the top lava flow in this sequence; Hole 433B penetrated only the top two. Figure 24 shows the positions of the flows in recovered core, the positions of thin sections, XRF analyses, and samples taken for paleomagnetic analyses.

We used several criteria for determining flow unit boundaries: major lithologic changes, the presence of an oxidized flow top, abrupt changes in vesicularity,

TABLE 8

Summary of Shipboard Geochemical Data, Hole 433A

\begin{tabular}{ccccccccc}
\hline $\begin{array}{c}\text { Sample } \\
\text { Number }\end{array}$ & Core-Section, Interval $(\mathrm{cm})$ & $\begin{array}{c}\text { Sub-Depth } \\
(\mathrm{m})\end{array}$ & $p \mathrm{H}$ & $\begin{array}{c}\text { Alkalinity } \\
(\mathrm{meq} / \mathrm{kg})\end{array}$ & $\begin{array}{c}\text { Salinity } \\
(\% \circ)\end{array}$ & $\begin{array}{c}\mathrm{Ca}^{++} \\
(\mathrm{mmol} / \mathrm{l})\end{array}$ & $\begin{array}{c}\mathrm{Mg}^{++} \\
(\mathrm{mmol} / 1)\end{array}$ & $\begin{array}{c}\mathrm{CL}^{-} \\
(\%)\end{array}$ \\
\hline A & Surface sea water & & 7.91 & 2.50 & 33.3 & 9.74 & 49.66 & 17.797 \\
1 & $4-4,144-150$ & 29.9 & 7.34 & 2.36 & 35.3 & 11.20 & 54.05 & 19.375 \\
2 & $8-6,140-150$ & 70.9 & 7.39 & 1.92 & 35.2 & 11.22 & 53.75 & 19.644 \\
\hline
\end{tabular}


TABLE 9

$\mathrm{CaCO}_{3}$ Content - Carbonate

Bomb Method, Holes 433 and $433 \mathrm{~A}$

\begin{tabular}{lr}
\hline $\begin{array}{l}\text { Core-Section, } \\
\text { Interval }(\mathrm{cm})\end{array}$ & $\mathrm{CaCO}_{3}(\%)$ \\
\hline Hole 433 & \\
1-1, 101 & 28 \\
$1-3,91$ & 73 \\
\hline Hole 433A & \\
2-1, 56 & \\
2-1, 136 & 26 \\
$3-2,80$ & 60 \\
$3-4,43$ & 82 \\
$4-2,60-61$ & 87 \\
$4-3,62-63$ & 15 \\
$5-1,70-71$ & 34 \\
$5-5,114-116$ & 59 \\
$8-1,52-53$ & 60 \\
\hline
\end{tabular}

TABLE 10

$\mathrm{CaCO}_{3}$ Content - Carbonate Bomb Method, Hole 433A

Core-Section,

Interval $(\mathrm{cm}) \quad \mathrm{CaCO}_{3}(\%)$

\begin{tabular}{ll}
\hline $5-2,145-147$ & 69 \\
$5-4,42-44$ & 82 \\
$10-6,80-81$ & 92 \\
$13-1,14-15$ & 97 \\
\hline
\end{tabular}

TABLE 11

$\mathrm{CaCO}_{3}$ Content - Carbonate Bomb Method, Hole 433B

Core-Section,

\begin{tabular}{lc} 
Interval $(\mathrm{cm})$ & $\mathrm{CaCO}_{3}(\%)$ \\
\hline $1-1,41-42$ & 97 \\
$1-4,128-129$ & 94
\end{tabular}

TABLE 12

$\mathrm{CaCO}_{3}$ Content - Carbonate Bomb Method, Hole 433C

\begin{tabular}{lc}
\hline $\begin{array}{l}\text { Core-Section, } \\
\text { Interval }(\mathrm{cm})\end{array}$ & $\mathrm{CaCO}_{3}(\%)$ \\
\hline $3-1,89-90$ & 82
\end{tabular}

brecciated flow tops (probably the most common criteria; see Figures $25 \mathrm{a}$ and $25 \mathrm{~b}$ ), vitrophyric zones (Figure 26), and a concentration of (presumably settled) olivine phenocrysts above vitrophyre. In general, subunit boundaries were drawn where there is no major lithologic change but one or more of the other criteria are present but not well developed.

The thickness and vesicularity of the flows, the absence of pillow structure, and the oxidized flow tops indicate that they erupted subaerially. The only evidence for advancement of flows into water is the sand-sized
TABLE 13

Water Content/Bulk Density/Porosity of Sediment, Hole 433A

\begin{tabular}{cccc}
\hline $\begin{array}{c}\text { Core-Section, } \\
\text { Interval }(\mathrm{cm})\end{array}$ & $\begin{array}{c}\text { Water } \\
\text { Content }(\%)\end{array}$ & Porosity $(\%)$ & $\begin{array}{c}\text { Wet-Bulk } \\
\text { Density }\left(\mathrm{g} / \mathrm{cm}^{3}\right)\end{array}$ \\
\hline $1-3,39$ & 48.4 & 70.7 & 1.46 \\
$1-4,30$ & 52.2 & 73.1 & 1.40 \\
$2-1,40$ & 48.4 & 71.9 & 1.48 \\
$3-2,10$ & 51.4 & 72.0 & 1.40 \\
$3-6,20$ & 39.7 & 64.8 & 1.63 \\
$4-6,60$ & 58.1 & & \\
$4-4,144$ & 61.4 & 83.5 & 1.36 \\
$5-1,10$ & 56.2 & 72.5 & 1.29 \\
$5-4,40$ & 43.1 & 67.2 & 1.56 \\
$6-2,80$ & 45.9 & 72.5 & 1.58 \\
$7-1,90$ & 39.5 & 64.7 & 1.64 \\
\hline
\end{tabular}

grains of basalt in the beach sand below Flow Unit 2; these may have been produced by phreatic activity as flows entered the sea.

\section{IGNEOUS PETROGRAPHY}

\section{Introduction}

Hole 433A, 433B, and 433C penetrated a nearly continuous section of subaerial basalt flows, starting at a sub-bottom depth of 165.5 meters and ending at 550.5 meters.

The basalt section starts in a thick $(>8.5-\mathrm{m})$ alkalic basalt flow (Flow Unit 1) overlying a beach sand. The beach sand in turn overlies alkalic basalts (Flow Units 2 and 3), which overlie a sequence of tholeiitic picrites and basalts (Flow Units 5 through 18). From Flow Unit 19 downward the flows are all tholeiitic basalts.

In all, 80 thin sections from 58 flow units, or possible flow units, were examined and described on board ship. The results are summarized in Table 14 and the Visual Core Descriptions at the end of this chapter. More detailed petrography is presented in the petrology chapter (Kirkpatrick et al., this volume).

\section{General Descriptions}

Flow Unit 1: Flow Unit 1 is a thick $(>8.5-\mathrm{m})$, massive, porphyritic alkalic basalt with moderately abundant (5 to $10 \%$ ) phenocrysts of plagioclase and microphenocrysts of olivine and sector-zoned clinopyroxene. The groundmass texture is intergranular to subtrachytic and medium grained. Groundmass olivine is relatively abundant, and the rock contains 10 to 15 per cent opaque Fe-Ti oxides. Apatite is common (1 to 2\%) and occurs as both stubby prisms and acicular needles. Groundmass plagioclase is generally more than twice as abundant as groundmass pyroxene.

Flow Unit 2: Flow Unit 2 is also an alkalic basalt, and contains phenocrysts of olivine (5\%, mostly fresh), clinopyroxene $(3 \%)$, and plagioclase $(2 \%)$. Some of the olivine phenocrysts contain subgrain boundaries; these probably represent mantle xenocrysts. The groundmass texture is intersertal, and plagioclase is more abundant than clinopyroxene. Apatite content is about 1 per cent.

Flow Units 4 through 66: All analyzed flows in this interval are tholeiitic basalts or tholeiitic picrites. 
The picrites all contain abundant (up to 55\%) olivine phenocrysts. In many flows the olivine is still fresh. Only a few flows contain clinopyroxene or plagioclase phenocrysts.

The groundmass of the picrites is usually intergranular or subophitic. Groundmass plagioclase is generally more abundant than groundmass clinopyroxene. Groundmass olivine and $\mathrm{Fe}-\mathrm{Ti}$ oxides are ubiquitous. Apatite is not present.

The tholeiitic basalts contain phenocrysts of either olivine alone, or of olivine, clinopyroxene, and plagioclase, or are aphyric. About one fourth of the flows contain more than 10 per cent olivine phenocrysts. In general, the older flows are less porphyritic, especially below Flow Unit 41. Groundmass textures in flow interiors are intersertal, intergranular, or diabasic. Groundmass olivine (or former groundmass olivine now altered to iddingsite or clay) is common. Groundmass plagioclase is generally more abundant than groundmass clinopyroxene.

\section{ALTERATION OF VOLCANIC ROCKS}

\section{Introduction}

This alteration summary is based upon the Visual Core Descriptions and thin-section examinations. Each flow unit was generally sampled in a relatively fresh part for XRF analysis and thin-section study.

All basalts recovered at Site 433 are at least moderately fresh, especially in their massive flow interiors. Olivine has been taken as the major mineralogical indicator of alteration, because plagioclase and clinopyroxene in most rocks are fresh. All basalts have been divided into four groups according to degree of alteration:

1) Slightly altered: olivine, plagioclase, and clinopyroxene fresh; glass devitrified and altered.

2) Moderately altered: olivine mostly altered, with some fresh cores; plagioclase and clinopyroxene fresh; glass altered.

3) Badly altered: olivine totally altered; plagioclase and clinopyroxene slightly (up to 5 to $10 \%$ ) altered.

4) Badly altered: olivine totally altered; plagioclase and clinopyroxene partially altered (up to 50 to $70 \%$ ). This division is more detailed and explicit than those in the Visual Core Descriptions.

As discussed in the Petrography section, we have described alteration products as clays (after glass, olivine, vesicles, and fracture filling) iddingsite (after olivine), and zeolites, without accurate sub-classification of these mineral species.

\section{Hole 433A}

The single lava flow unit of Hole 433A (Flow Unit 1) can be divided into three parts.

1) A moderately altered massive flow interior (Sections 20-1 and 20-2; Section 21-1, 0-109 cm) that contains a calcareous sandstone vein (Section 20-2, 31-33 $\mathrm{cm}$ ) with more altered vesicular layers upward and downward from the vein (Section 20-2, 0-54 cm).
2) A moderately to badly altered flow interior (Section 21-1, $109 \mathrm{~cm}$ to Section 21-2, $122 \mathrm{~cm}$ ) with subhorizontal thin zones altered to clay.

3) A moderately altered massive flow interior (Section $21-2,124 \mathrm{~cm}$ to Section $21-5,47 \mathrm{~cm}$ ) with small, badly altered sub-horizontal layers like those of part 2 .

\section{Hole 433B}

The upper flow unit of this hole (Flow Unit 1) is texturally and mineralogically similar to Flow Unit 1 in Hole 433A, and is thought to be the same lava flow. The alteration is also similar to that in Hole 433A. The unit consists of a moderately altered flow interior with some fresh olivine. More altered and oxidized parts occur near small fractures (Section 5-1, 0-95 cm).

\section{Hole 433C}

Flow Unit 1: Very similar to Flow Unit 1 in Holes 433A and 433B, and is thought to be the same lava flow. It consists of a moderately altered flow interior with fresh plagioclase, pyroxene, olivine altered to iddingsite and clays but with some fresh cores, and glass altered to clays (Section 1-1, $26 \mathrm{~cm}$ to Section 1-2, $30 \mathrm{~cm}$ ), and a badly altered part with sub-horizontal streaks of alteration (Section 1-2, $30 \mathrm{~cm}$ to Section 2-1) like part 2 of Hole 433A.

Flow Unit 2: A slightly altered massive porphyritic basalt containing fresh plagioclase, pyroxene, mostly fresh olivine phenocrysts and xenocrysts, and in the groundmass 3 to 5 per cent green to brown clays after interstitial glass and olivine grains (?).

Flow Unit 3: This is represented by a single piece from the bit (Section 2). It is a very sparsely phyric, moderately altered basalt with 1 per cent fresh plagioclase phenocrysts and 1 per cent fresh pyroxene phenocrysts. The glass in the groundmass (5 to $10 \%$ ) is altered to clays and the olivine grains to iddingsite.

Flow Units 4 (a through f): A very badly altered olivine phyric basalt, mostly oxidized (reddish color). Tops and bottoms of each unit are even more altered and more oxidized than the interiors.

Olivine: Phenocrysts are completely altered to iddingsite and clays; iddingsite is more abundant in the oxidized sub-unit tops and bottoms. Groundmass olivine grains are completely altered, usually to iddingsite, but some clays present.

Plagioclase: Laths and microlites partially altered (up to 60 to $70 \%$ ), especially in vesicular parts and near the sub-unit tops and bottoms.

Clinopyroxene: Partly altered but mostly fresh in the central parts of sub-units.

Glass: Altered to clays and zeolites(?).

Vesicles: Filled and lined by clays and zeolites, sometimes with carbonate in the central parts.

Flow Units 5 through 8: Sparsely olivine phyric basalts, badly altered. The phenocrysts and groundmass olivine are completely altered to iddingsite and clays, glass is altered to clays and zeolites, whereas plagioclase and clinopyroxene are fresh in the flow tops and bottoms and near fractures and vesicles. Alteration de- 

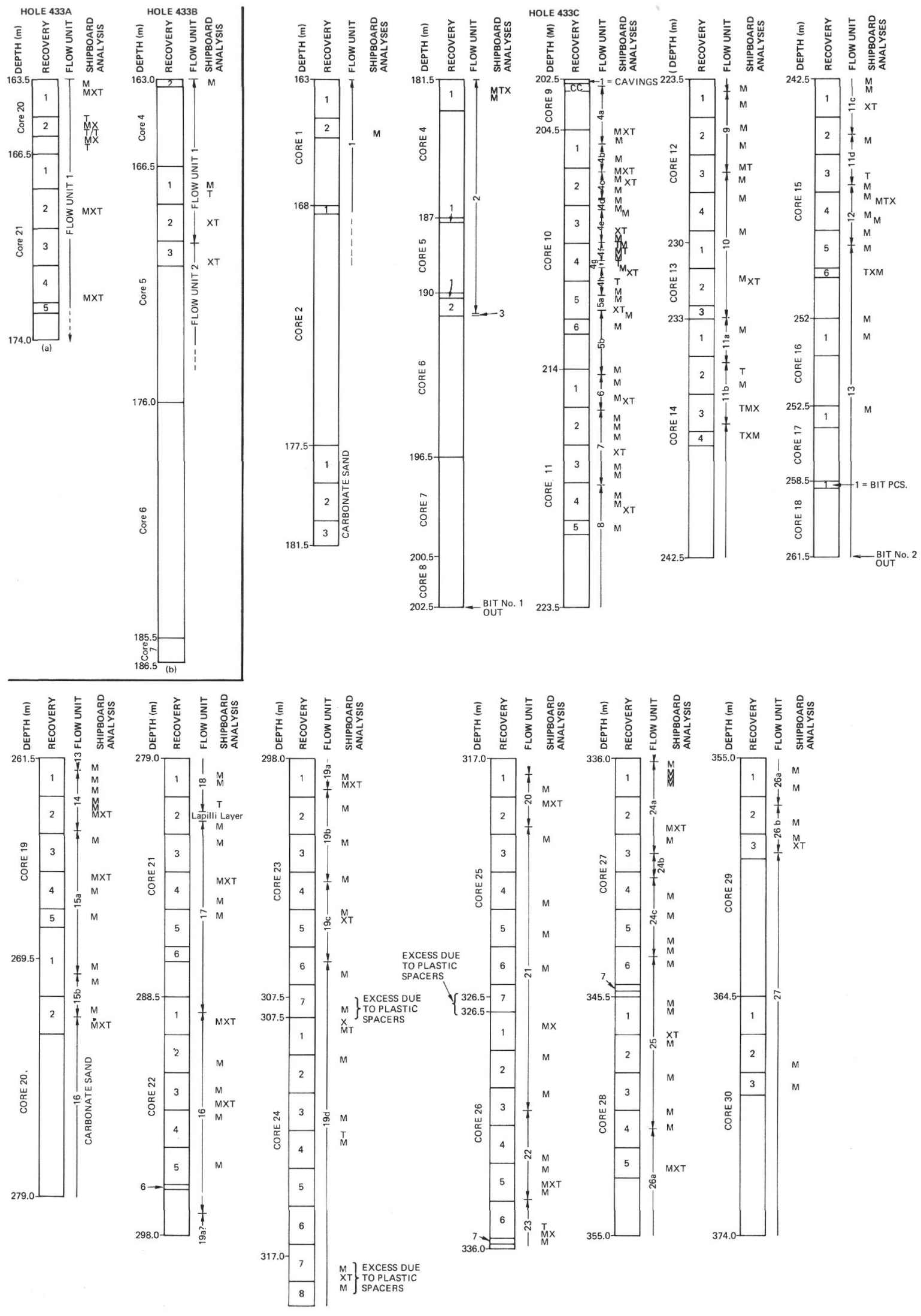

Figure 24. Coring, recovery, and stratigraphic column for basement rocks of (a) Hole 433A, (b) Hole $433 B$, (c) Hole 433C, respectively, also showing positions of XRF analyses, thin sections, and paleomagnetic samples. 

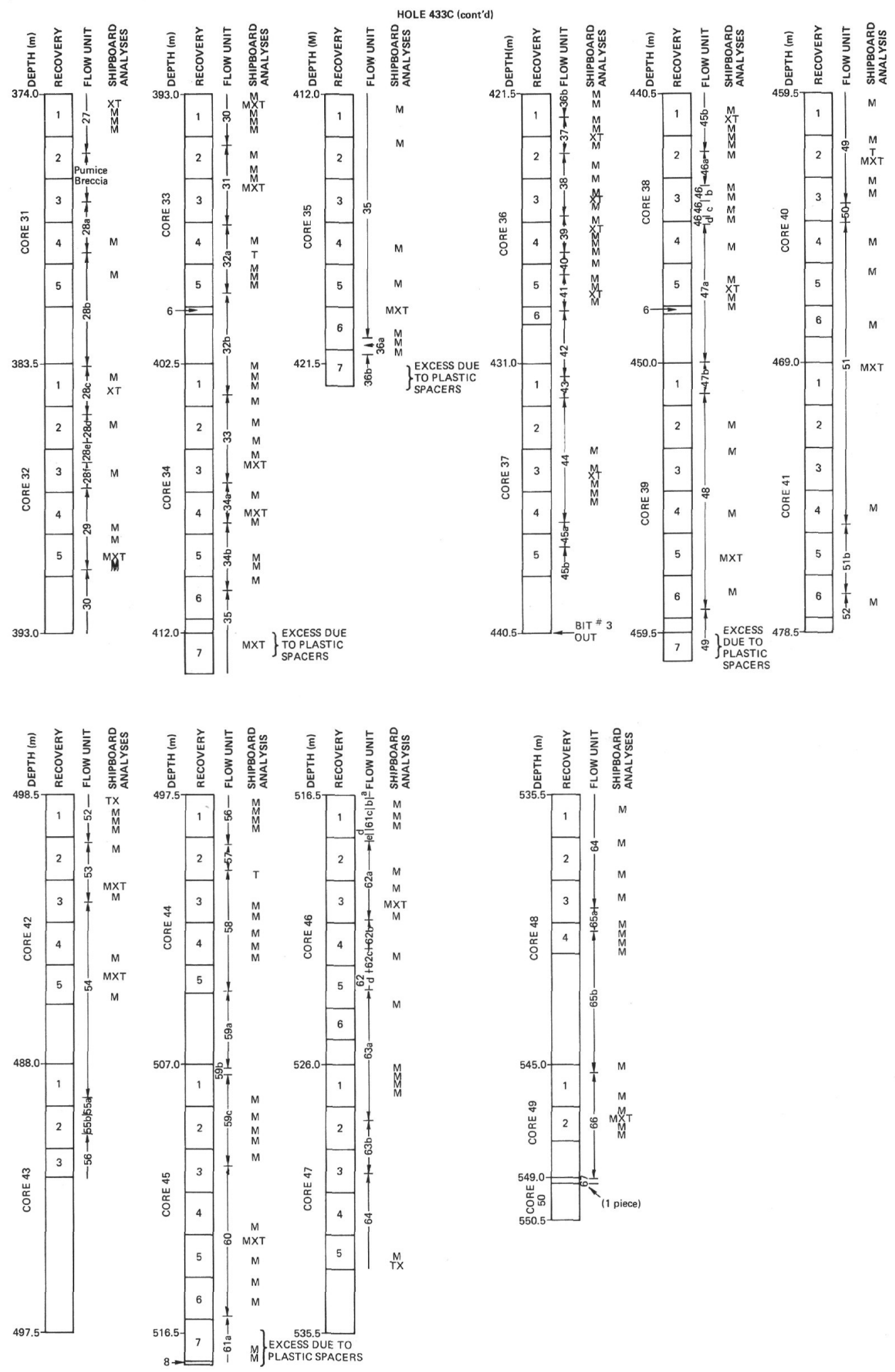

Figure 24. (Continued).

creases somewhat down the section. The flow interior of Flow Unit 5 is more altered than the interiors of Flow Units 7 and 8.

Flow Units 9 through 18: The sparsely phyric and aphyric basalts of these flow units are usually badly to moderately altered, and contain fresh plagioclase and clinopyroxene phenocrysts, microphenocrysts, and groundmass grains.

Olivine: Mostly altered to clays with iddingsite rims. In the slightly oxidized flow unit tops and in some flow unit bottoms, iddingsite is more abundant than clay. 

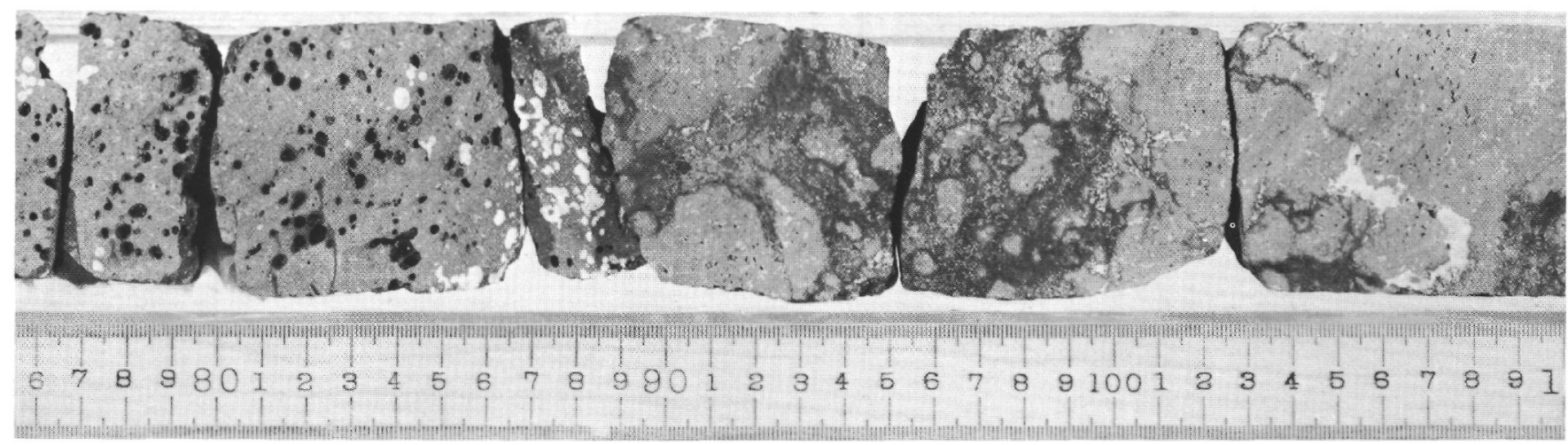

Figure 25a. Photograph of core, illustrating contact of Flow Sub-unit 63 b and Flow Unit 64 in Hole 433C, Section 473 , at $88 \mathrm{~cm}$. The upper part of Flow Unit 64 is an oxidized autobreccia similar to those found at the tops of many subaerial flows on the Hawaiian Islands.

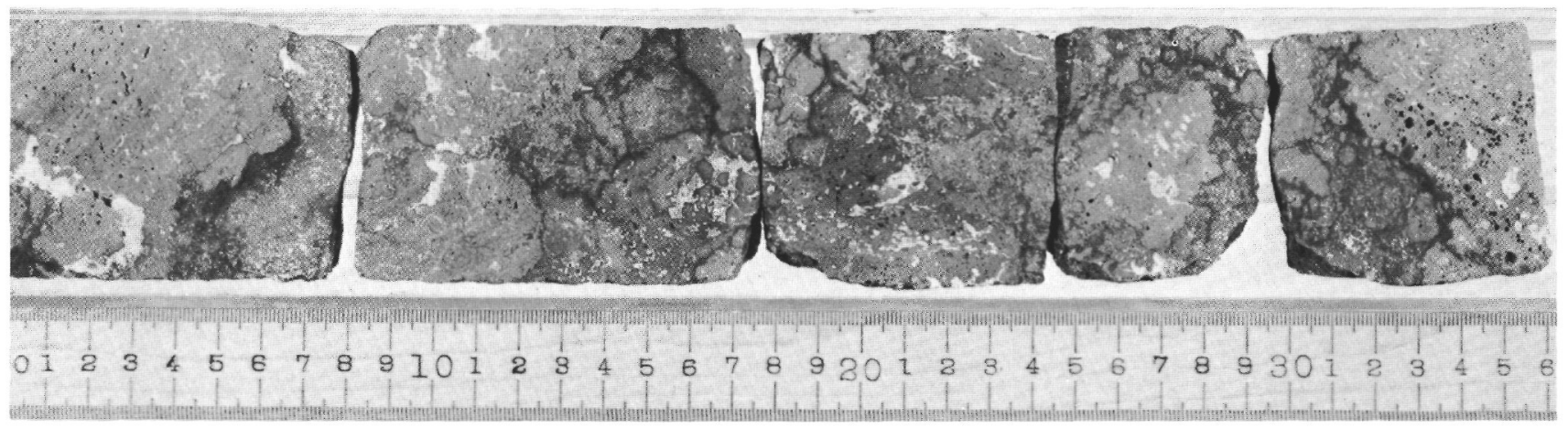

Figure 25b. Downward continuation of the photograph in Figure 25 .

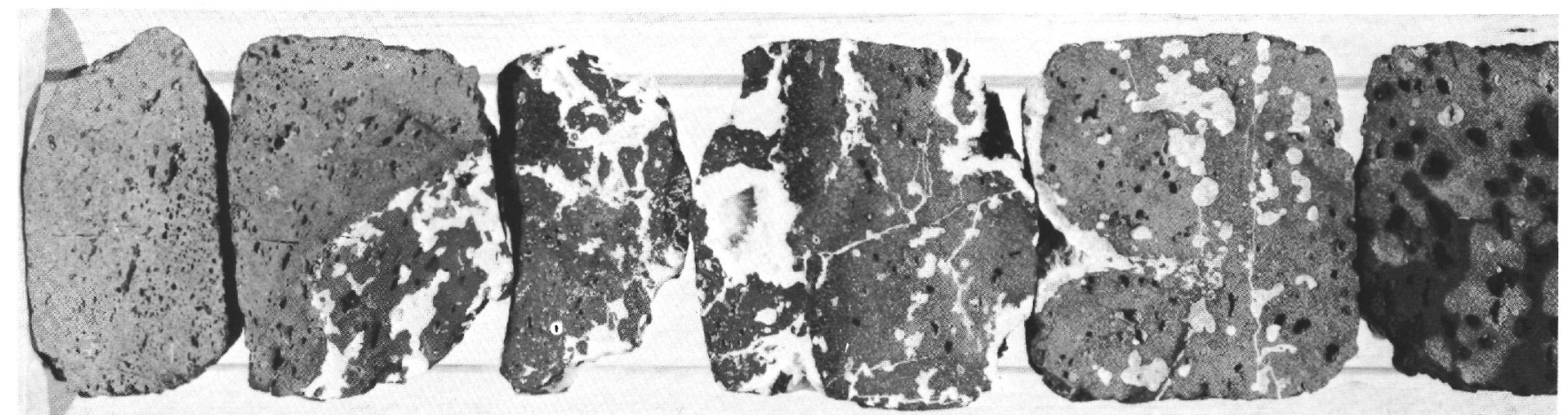

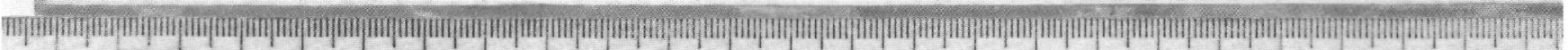

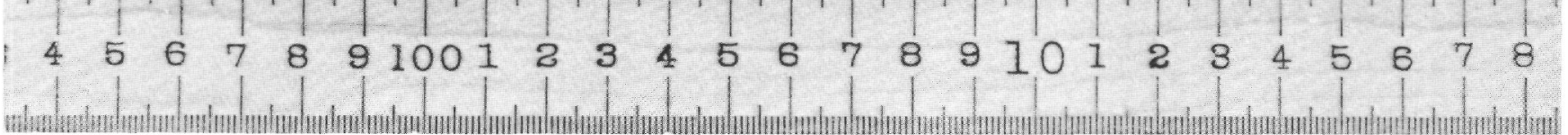

Figure 26. Photograph of core, illustrating the contact between Flow Unit 64 and 65 b in Hole 433C, Section 48-8, at $98 \mathrm{~cm}$. The bottom of Flow Unit 64 has a devitrified glassy contact, and shows elongation of vesicles resulting from flow. Note the change in vesicularity and calcite vug filling across the contact.

There are some fresh olivine phenocryst cores in Flow Unit 9 (Sections 12-2 and 12-3). Clay mineral content is usually not more than 10 per cent (after glass and olivine), but Sub-unit $11 \mathrm{~b}$ and Flow Units 14 and 15 have dark gray and green spots of almost totally altered groundmass, perhaps near pores (for example, thin sections prepared from Samples $15-3,92-93 \mathrm{~cm} ; 19-4$, $19-22 \mathrm{~cm} ; 20-2,120-132 \mathrm{~cm}$ ). 
TABLE 14

Petrographic Summary, Site 433

\begin{tabular}{|c|c|c|c|c|c|c|c|c|c|c|c|c|c|c|}
\hline \multirow{2}{*}{$\begin{array}{c}\text { Flow } \\
\text { Unit/ } \\
\text { Sub-Unit }\end{array}$} & \multirow[b]{2}{*}{$\begin{array}{l}\text { Core- } \\
\text { Section }\end{array}$} & \multirow[b]{2}{*}{$\begin{array}{l}\text { Interval } \\
(\mathrm{cm})\end{array}$} & \multirow[b]{2}{*}{$\begin{array}{l}\text { Rock Type } \\
(\mathrm{XRF})^{\mathrm{a}}\end{array}$} & \multicolumn{3}{|c|}{ Phenocrysts ${ }^{b}$} & \multicolumn{5}{|c|}{ Groundmass } & \multicolumn{3}{|c|}{ Alteration } \\
\hline & & & & OL & PX & PC & Texture & $\begin{array}{c}\text { Grain } \\
\text { Size }\end{array}$ & $\mathrm{OL}$ & $\mathrm{PC}, \mathrm{PX}^{\mathrm{C}}$ & $\begin{array}{l}\mathrm{Fe}-\mathrm{Ti} \\
\text { Oxides }\end{array}$ & $\begin{array}{l}\text { Vesi- } \\
\text { cles }^{b}\end{array}$ & $\begin{array}{l}\text { Pheno- } \\
\text { crysts }\end{array}$ & $\begin{array}{c}\text { Ground- } \\
\text { mass }\end{array}$ \\
\hline Hole 433A & & & & & & & & & & & & & & \\
\hline 1 & $20-1$ & $38-40$ & Alkalic basalt & M.6 & M.5 & M.2 & IG & $\mathbf{M}$ & M & $\mathrm{PC} \gg \mathrm{PX}$ & A & - & $\begin{array}{l}\text { BA } \\
\text { CL, ID }\end{array}$ & $\begin{array}{l}\text { MA } \\
\text { CL, ID }\end{array}$ \\
\hline 1 & $20-2$ & $7-10$ & Alkalic basalt & M.6 & A. 5 & M.2 & IG & M & $\mathbf{M}$ & $\mathrm{PC} \gg \mathrm{PX}$ & A & - & BA & $\begin{array}{l}\text { MA } \\
\text { CL, ID }\end{array}$ \\
\hline 1 & $20-2$ & $24-32$ & - & S.3 & S. 3 & M.2 & ST & $\mathrm{F}$ & A & $\mathrm{PC} \gg \mathrm{PX}$ & A & - & & $\begin{array}{l}\mathrm{MA} \\
\mathrm{CL}\end{array}$ \\
\hline 1 & $20-2$ & $32-36$ & - & VS.3 & M.3 & S.1 & ST & $\mathrm{F}$ & VS & $\mathrm{PC} \gg \mathrm{PX}$ & A & - & BA & $\begin{array}{l}\mathrm{MF} \\
\mathrm{CL}\end{array}$ \\
\hline 1 & $20-2$ & $60-63$ & Alkalic basalt & M.4 & M. 8 & M.2 & IG & M & M & $\mathrm{PC} \gg \mathrm{PX}$ & A & M.2 & $\begin{array}{l}\text { BA } \\
\text { CL, ID }\end{array}$ & $\begin{array}{l}\text { MA } \\
\text { CL, ID }\end{array}$ \\
\hline 1 & $21-2$ & $84-86$ & Alkalic basalt & S.1 & - & A. 3 & ST & M & M & $\mathrm{PC} \gg \mathrm{PX}$ & M & - & & $\begin{array}{l}\mathrm{MF} \\
\mathrm{CL}\end{array}$ \\
\hline 1 & $21-4$ & $138-140$ & Alkalic basalt & S.1 & VS.1 & M.2 & ST & $\mathrm{F}$ & $\mathrm{M}$ & $\mathrm{PC} \gg \mathrm{PX}$ & M & - & $\mathrm{F}$ & $\mathrm{F}$ \\
\hline Hole 433B & & & & & & & & & & & & & & \\
\hline 1 & $5-1$ & $124-128$ & - & M.2 & S.3 & M.2 & IG & M & $\mathrm{S}$ & $\mathrm{PC} \gg \mathrm{PX}$ & M & - & $\begin{array}{l}\text { BA } \\
\text { CL, ID }\end{array}$ & $\begin{array}{l}\text { MA } \\
\text { CL }\end{array}$ \\
\hline 1 & $5-2$ & $83-85$ & Alkalic basalt & - & M.5 & M.1 & IG & $\mathrm{F}$ & $\mathrm{S}$ & $\mathrm{PC} \gg \mathrm{PX}$ & M & - & & $\begin{array}{l}\mathrm{F} \\
\mathrm{CL}\end{array}$ \\
\hline 2 & $5-3$ & $86-88$ & - & A. 2 & M.1 & M.2 & ST & $\mathbf{M}$ & $\mathbf{M}$ & $\mathrm{PC} \gg \mathrm{PX}$ & A & - & $\begin{array}{l}\mathrm{F} \\
\mathrm{ID} \\
\end{array}$ & $\begin{array}{l}\text { MF } \\
\mathrm{CL}, \mathrm{ID}\end{array}$ \\
\hline Hole 433C & & & & & & & & & & & & & & \\
\hline 2 & 4-1 & $39-41$ & Alkalic basalt & M.2 & S.1 & S.1 & IG & M & $\mathrm{S}$ & $\mathrm{PC} \gg \mathrm{PX}$ & M & - & $\begin{array}{l}\text { BA } \\
\text { CL }\end{array}$ & $\begin{array}{l}\mathrm{MF} \\
\mathrm{CL}\end{array}$ \\
\hline $4 a$ & $10-1$ & $7-9$ & Picrite & M.1 & - & - & D & M & M & $\mathrm{PC} \gg \mathrm{PX}$ & A & A. 1 & $\begin{array}{l}\text { BA } \\
\text { CL }\end{array}$ & $\begin{array}{l}\text { BA } \\
\text { CL, ID }\end{array}$ \\
\hline $4 b$ & $10-2$ & $15-18$ & Picrite & M.1 & - & - & D & M & M & $\mathrm{PC}=\mathrm{PX}$ & A & VA. 2 & $\begin{array}{l}\text { BA } \\
\text { CL, ID }\end{array}$ & $\begin{array}{l}\text { BA } \\
\text { CL, ID }\end{array}$ \\
\hline $4 c$ & $10-2$ & $56-59$ & Picrite & M.1 & - & - & D & M & M & $\mathrm{PC}>\mathrm{PX}$ & A & VA. 4 & $\begin{array}{l}\text { BA } \\
\text { CL, ID }\end{array}$ & $\begin{array}{l}\text { BA } \\
\text { CL, ID }\end{array}$ \\
\hline $4 \mathrm{e}$ & $10-3$ & $103-106$ & Picrite & M.1 & - & - & D & M & M & $\mathrm{PC}>\mathrm{PX}$ & M & VA. 2 & $\begin{array}{l}\text { BA } \\
\text { CL, ID }\end{array}$ & $\begin{array}{l}\mathrm{BA} \\
\mathrm{CL}, \mathrm{ID}\end{array}$ \\
\hline $4 f$ & $10-4$ & 4-6 & - & S.1 & - & - & IG & $\mathrm{M}$ & M & $\mathrm{PC} \gg \mathrm{PX}$ & A & VA. 5 & $\begin{array}{l}\text { BA } \\
\text { ID }\end{array}$ & $\begin{array}{l}\text { BA } \\
\text { CL, ID }\end{array}$ \\
\hline $4 f$ & $10-4$ & $44-46$ & - & VA. 2 & - & - & D & M & M & $\mathrm{PC}>\mathrm{PX}$ & M & A. 3 & $\begin{array}{l}\text { BA } \\
\text { CL, ID }\end{array}$ & $\begin{array}{l}\text { BA } \\
\text { CL, ID }\end{array}$ \\
\hline $4 \mathrm{~g}$ & $10-4$ & 93-95 & - & VA. 2 & - & - & IS & M & VS & $\mathrm{PX}>\mathrm{PC}$ & A & VA. 2 & BA & $\begin{array}{l}\mathrm{BA} \\
\mathrm{CL}, \mathrm{ID}, \mathrm{ZL}\end{array}$ \\
\hline $4 \mathrm{~h}$ & $10-4$ & $118-120$ & Picrite & VA. 2 & - & VS.1 & D & M & $\mathrm{S}$ & $\mathrm{PC}>\mathrm{PX}$ & M & A. 3 & BA & CL, ID, ZL \\
\hline $4 \mathrm{~h}$ & $10-5$ & $11-13$ & - & A. 2 & - & - & IG & M & M & $\mathrm{PC} \gg \mathrm{PX}$ & A & VA. 2 & $\begin{array}{l}\text { BA } \\
\text { CL, ID, CC }\end{array}$ & $\begin{array}{l}\text { BA } \\
\text { CL, CC }\end{array}$ \\
\hline $5 a$ & $10-5$ & $119-121$ & Tholeiite & VS. 5 & - & - & IG & F & M & $\mathrm{PC} \gg \mathrm{PX}$ & A & VA.1 & $\begin{array}{l}\text { BA } \\
\text { CL, ID }\end{array}$ & $\begin{array}{l}\text { BA. } \\
\text { CL, ID }\end{array}$ \\
\hline 6 & $11-1$ & $135-137$ & Tholeiite & S.1 & - & - & D & A & M & $\mathrm{PC} \gg \mathrm{PX}$ & A & S.2 & $\begin{array}{l}\mathrm{BA} \\
\mathrm{CL}, \mathrm{ID}, \mathrm{CC}\end{array}$ & $\begin{array}{l}\mathrm{MF} \\
\mathrm{CL}, \text { ID }\end{array}$ \\
\hline 7 & $11-3$ & $31-34$ & Tholeiite & S.5 & - & - & IG & F & M & $\mathrm{PC}>\mathrm{PX}$ & $\mathrm{s}$ & VS.6 & $\begin{array}{l}\text { BA } \\
\text { CL, ID }\end{array}$ & $\begin{array}{l}\text { MA } \\
\text { CL, ID }\end{array}$ \\
\hline 8 & $11-4$ & 106-109 & Tholeiite & M.7 & S.2 & S.4 & IG & M & M & $\mathrm{PC}>\mathrm{PX}$ & M & A. 2 & $\begin{array}{l}\text { BA } \\
\text { CL, ID, CC }\end{array}$ & $\begin{array}{l}\text { MA } \\
\text { CL, ID }\end{array}$ \\
\hline 9 & $12-3$ & $50-53$ & Tholeiite & S.3 & M.3 & M. 3 & IG & M & VS & $\mathrm{PC}>\mathrm{PX}$ & A & - & $\begin{array}{l}\mathrm{BA} \\
\mathrm{CL}, \mathrm{ID}\end{array}$ & $\begin{array}{l}\text { BA } \\
\text { CL, ID, CC, } \mathrm{Zl}\end{array}$ \\
\hline 10 & $13-2$ & $47-49$ & Tholeiite & S.4 & S. 4 & S.4 & IG & C & VS & $\mathrm{PC}>\mathrm{PX}$ & $\mathrm{S}$ & - & & $\begin{array}{l}\text { MF } \\
\text { CL, ID }\end{array}$ \\
\hline $11 \mathrm{~b}$ & $14-2$ & $65-67$ & - & S.15 & VS.4 & VS.4 & D & M & $\mathrm{S}$ & $\mathrm{PC} \gg \mathrm{PX}$ & A & A. 1 & $\begin{array}{l}\text { MA } \\
\text { CL }\end{array}$ & $\begin{array}{l}\mathrm{MA} \\
\mathrm{CL}, \mathrm{ID}\end{array}$ \\
\hline $11 \mathrm{~b}$ & $14-3$ & $57-59$ & Tholeiite & S.15 & VS.4 & S.5 & D & M & M & $\mathrm{PC} \gg \mathrm{PX}$ & A & M.2 & $\begin{array}{l}\text { MA } \\
\text { CL }\end{array}$ & $\begin{array}{l}\text { MA } \\
\text { CL, ID }\end{array}$ \\
\hline $11 \mathrm{c}$ & $14-4$ & $21-23$ & Tholeiite & - & S.1 & S.6 & D & M & - & $\mathrm{PC} \gg \mathrm{PX}$ & VA & - & $\begin{array}{l}\mathrm{MF} \\
\mathrm{CL}\end{array}$ & \\
\hline $11 \mathrm{c}$ & $15-1$ & $118-122$ & Tholeiite & VS.8 & S.6 & VS.1 & D & M & M & $\mathrm{PC} \gg \mathrm{PX}$ & VA & M. 2 & $\begin{array}{l}\text { BA } \\
\text { CL, ID }\end{array}$ & $\begin{array}{l}\mathrm{MA} \\
\mathrm{CL}, \mathrm{ID}\end{array}$ \\
\hline $11 \mathrm{~d}$ & $15-3$ & $92-93$ & - & - & S.1 & VS.5 & ST & $\mathrm{M}$ & M & $\mathrm{PC} \gg \mathrm{PX}$ & VA & A. 3 & $\begin{array}{l}\text { BA } \\
\text { CL, ID }\end{array}$ & $\begin{array}{l}\text { BA } \\
\text { CL, ID }\end{array}$ \\
\hline 12 & $15-4$ & $43-46$ & Tholeiite & VS.3 & VS. 4 & VS.5 & ST & M & $\mathrm{S}$ & $\mathrm{PC}>\mathrm{PX}$ & A & M.2 & $\mathrm{F}$ & $\begin{array}{l}\text { MA } \\
\text { CL, ID }\end{array}$ \\
\hline 13 & $15-6$ & $32-35$ & Tholeiite & VS.7 & S.5 & VS.4 & ST & $\mathrm{F}$ & VS & $\mathrm{PC}=\mathrm{PX}$ & A & - & $\mathrm{F}$ & $\begin{array}{l}\mathrm{F} \\
\mathrm{CL}\end{array}$ \\
\hline 14 & $19-2$ & $53-56$ & Tholeiite & VS.1 & S.1 & VS.7 & D & M & A & $\mathrm{PC} \gg \mathrm{PX}$ & A & - & $\begin{array}{l}\text { BA } \\
\text { CL, ID }\end{array}$ & $\begin{array}{l}\text { MA } \\
\text { CL, ID }\end{array}$ \\
\hline $15 \mathrm{a}$ & $19-4$ & $19-22$ & Tholeiite & A. 1 & VS.6 & VS.1 & D & C & M & $\mathrm{PC}>\mathrm{PX}$ & M & - & $\begin{array}{l}\text { BA } \\
\text { CL, ID }\end{array}$ & $\begin{array}{l}\mathrm{MA} \\
\mathrm{CL}, \mathrm{ID}, \mathrm{ZL}\end{array}$ \\
\hline 16 & $20-2$ & $129-132$ & Tholeiite & VS.1 & - & VS.5 & D & $\mathrm{M}$ & A & $\mathrm{PC} \gg \mathrm{PX}$ & A & M.2 & & $\begin{array}{l}\text { MA } \\
\text { CL, ID, ZL }\end{array}$ \\
\hline
\end{tabular}


TABLE 14 - Continued

\begin{tabular}{|c|c|c|c|c|c|c|c|c|c|c|c|c|c|c|}
\hline \multirow{2}{*}{$\begin{array}{c}\text { Flow } \\
\text { Unit/ } \\
\text { Sub-Unit } \\
\end{array}$} & \multirow[b]{2}{*}{$\begin{array}{l}\text { Core- } \\
\text { Section }\end{array}$} & \multirow[b]{2}{*}{$\begin{array}{l}\text { Interval } \\
(\mathrm{cm})\end{array}$} & \multirow[b]{2}{*}{$\begin{array}{l}\text { Rock Type } \\
\text { (XRF)a }\end{array}$} & \multicolumn{3}{|c|}{ Phenocrysts ${ }^{b}$} & \multicolumn{5}{|c|}{ Groundmass } & \multicolumn{3}{|c|}{ Alteration } \\
\hline & & & & OL & PX & PC & Texture & $\begin{array}{c}\text { Grain } \\
\text { Size }\end{array}$ & $\mathrm{OL}$ & $\mathrm{PC}, \mathrm{PX}^{\mathrm{C}}$ & $\begin{array}{l}\text { Fe-Ti } \\
\text { Oxides }\end{array}$ & $\begin{array}{l}\text { Vesi- } \\
\text { cles }^{b}\end{array}$ & $\begin{array}{l}\text { Pheno- } \\
\text { crysts }\end{array}$ & $\begin{array}{c}\text { Ground- } \\
\text { mass }\end{array}$ \\
\hline 17 & $21-4$ & $40-42$ & Tholeiite & VS.5 & VS.7 & S.7 & IG & M & M & $\mathrm{PC} \gg \mathrm{PX}$ & A & M.2 & $\begin{array}{l}\text { BA } \\
\text { CL, ID }\end{array}$ & $\begin{array}{l}\text { BA } \\
\text { CL, ID }\end{array}$ \\
\hline 18 & $22-1$ & $96-98$ & Tholeiite & S.1 & - & S.7 & IG & $\mathbf{M}$ & $\mathbf{M}$ & $\mathrm{PC} \gg \mathrm{PX}$ & A & M.1 & $\begin{array}{l}\text { BA } \\
\text { CL, ID }\end{array}$ & $\begin{array}{l}\text { BA } \\
\text { CL, ID }\end{array}$ \\
\hline 18 & $22-3$ & $133-136$ & - & S.8 & - & S.1 & IG & M & M & $\mathrm{PC} \gg \mathrm{PX}$ & M & VA. 3 & $\begin{array}{l}\text { BA } \\
\text { CL, ID }\end{array}$ & $\begin{array}{l}\mathrm{MA} \\
\mathrm{CL}, \mathrm{ID}\end{array}$ \\
\hline $19 a$ & 23-1 & $4-6$ & - & M.1 & VS.6 & - & IS & $\mathrm{F}$ & M & $\mathrm{PC} \gg \mathrm{PX}$ & $\mathbf{M}$ & A. 5 & $\begin{array}{l}\text { BA } \\
\text { CL, ID, ZL }\end{array}$ & $\begin{array}{l}\mathrm{BA} \\
\mathrm{CL}, \mathrm{ZL}, \mathrm{ID}\end{array}$ \\
\hline $19 a$ & 23-1 & $100-103$ & Tholeiite & M.1 & VS. 6 & - & IS & $\mathrm{F}$ & A & $\mathrm{PC} \gg \mathrm{PX}$ & $\mathbf{M}$ & A.1 & $\begin{array}{l}\text { BA } \\
\text { CL, ZL, ID }\end{array}$ & $\begin{array}{l}\mathrm{BA} \\
\mathrm{CL}, \mathrm{ZL}, \mathrm{ID}\end{array}$ \\
\hline $19 c$ & $23-5$ & $5-8$ & Picrite & A. 2 & - & - & D & M & M & $\mathrm{PC}>\mathrm{PX}$ & A & M.2 & $\begin{array}{l}\text { BA } \\
\text { CL, ID }\end{array}$ & $\begin{array}{l}\mathrm{MF} \\
\mathrm{CL}, \mathrm{ID}\end{array}$ \\
\hline $19 d$ & 24-1 & $25-28$ & Picrite & VA.2 & VS. 6 & VS.1 & D & M & $\mathrm{S}$ & $\mathrm{PC}=\mathrm{PX}$ & M & M.1 & $\begin{array}{l}\text { VA } \\
\text { CL, ID }\end{array}$ & $\begin{array}{l}\mathrm{MF} \\
\mathrm{CL}, \mathrm{ID}, \mathrm{ZL}\end{array}$ \\
\hline $19 d$ & 24-7 & $142-143$ & Picrite & VA. 2 & - & - & D & M & VS & $\mathrm{PC}=\mathrm{PX}$ & M & - & & $\begin{array}{l}\mathrm{MF} \\
\mathrm{CL}, \mathrm{ZL}, \mathrm{ID}\end{array}$ \\
\hline 20 & $25-2$ & $20-23$ & Tholeiite & S.5 & - & - & D & M & A & $\mathrm{PC} \gg \mathrm{PX}$ & A & - & $\begin{array}{l}\text { BA } \\
\text { CL, ID }\end{array}$ & $\begin{array}{l}\text { BA } \\
\text { CL, ID }\end{array}$ \\
\hline 21 & 26-1 & $48-51$ & Tholeiite & S.1 & - & VS. 4 & D & M & M & $\mathrm{PC}>\mathrm{PX}$ & A & - & $\begin{array}{l}\text { BA } \\
\text { CL, ID }\end{array}$ & $\begin{array}{l}\text { BA } \\
\text { CL, ID }\end{array}$ \\
\hline 22 & $26-5$ & $85-88$ & Tholeiite & A.1 & - & - & D & M & $\mathrm{S}$ & $\mathrm{PC}=\mathrm{PX}$ & M & - & $\begin{array}{l}\text { BA } \\
\text { CL, ID }\end{array}$ & $\begin{array}{l}\mathrm{BA} \\
\mathrm{CL}, \mathrm{ID}, \mathrm{ZL}\end{array}$ \\
\hline 23 & $26-6$ & $109-111$ & Tholeiite & M.6 & - & - & ST & M & A & $\mathrm{PC}>\mathrm{PX}$ & M & - & $\begin{array}{l}\text { BA } \\
\text { CL, ID }\end{array}$ & $\begin{array}{l}\text { BA } \\
\text { CL, ID }\end{array}$ \\
\hline $24 a$ & $27-2$ & $135-138$ & Picrite & VA. 2 & - & - & IG & M & A & $\mathrm{PC} \gg \mathrm{PX}$ & A & - & $\begin{array}{l}\text { MA } \\
\text { CL, ID }\end{array}$ & $\begin{array}{l}\mathrm{MA} \\
\mathrm{CL}\end{array}$ \\
\hline 25 & $28-2$ & $21-24$ & Tholeiite & S.1 & M.1 & A. 2 & IG & $\mathrm{F}$ & - & $\mathrm{PC}=\mathrm{PX}$ & M & S.6 & & $\begin{array}{l}\mathrm{F} \\
\mathrm{CL}\end{array}$ \\
\hline $26 a$ & $28-5$ & $108-110$ & Tholeiite & M.5 & M.5 & M.1 & ST & M & M & $\mathrm{PC}>\mathrm{PX}$ & M & - & $\begin{array}{l}\text { BA } \\
\text { CL, ID }\end{array}$ & $\begin{array}{l}\text { MA } \\
\mathrm{CL}, \mathrm{ID}\end{array}$ \\
\hline $26 \mathrm{~b}$ & $29-3$ & $25-27$ & Tholeiite & VS.1 & M.1 & M.6 & IG & M & - & $\mathrm{PC}>\mathrm{PX}$ & M & A. 1 & $\begin{array}{l}\text { BA } \\
\text { CL, ID }\end{array}$ & $\begin{array}{l}\text { MA } \\
\text { CL }\end{array}$ \\
\hline 27 & $31-1$ & $14-17$ & Tholeiite & M.6 & VS.2 & S.6 & IG & $\mathrm{F}$ & $\mathrm{S}$ & $\mathrm{PC}=\mathrm{PX}$ & M & - & & $\begin{array}{l}\mathrm{F} \\
\mathrm{CL}\end{array}$ \\
\hline $28 \mathrm{c}$ & $32-1$ & $95-98$ & Picrite & VA. 3 & - & - & IG & M & M & $\mathrm{PX}>\mathrm{PC}$ & M & - & $\begin{array}{l}\text { BA } \\
\text { CL }\end{array}$ & $\begin{array}{l}\text { MA } \\
\text { CL, ID }\end{array}$ \\
\hline 29 & $32-5$ & $78-81$ & Picrite & M.5 & - & - & D & M & $\mathrm{S}$ & $\mathrm{PC}=\mathrm{PX}$ & S & - & $\begin{array}{l}\text { BA } \\
\text { CL }\end{array}$ & $\begin{array}{l}\text { BA } \\
\text { CL }\end{array}$ \\
\hline 30 & $33-1$ & $34-36$ & - & A. 2 & - & S. 3 & D & M & $\mathrm{S}$ & $\mathrm{PC}=\mathrm{PX}$ & S & - & $\begin{array}{l}\text { BA } \\
\text { CL, ID }\end{array}$ & $\begin{array}{l}\text { MA } \\
\text { CL, ID }\end{array}$ \\
\hline 31 & $33-3$ & $12-14$ & - & A. 1 & - & - & D & M & $\mathrm{S}$ & $\mathrm{PC}=\mathrm{PX}$ & M & - & $\begin{array}{l}\text { BA } \\
\text { CL, ID }\end{array}$ & $\begin{array}{l}\text { BA } \\
\text { CL, ID }\end{array}$ \\
\hline $32 a$ & 33-4 & $120-122$ & - & VA.1 & - & - & IS & M & M & $\mathrm{PC} \gg \mathrm{PX}$ & M & A. 3 & $\begin{array}{l}\text { BA } \\
\text { CL, ID }\end{array}$ & $\begin{array}{l}\text { BA } \\
\text { CL, ID }\end{array}$ \\
\hline 33 & $34-3$ & 41-43 & - & M.1 & - & - & D & M & $\mathrm{S}$ & $\mathrm{PC}=\mathrm{PX}$ & $\mathrm{s}$ & - & $\begin{array}{l}\text { BA } \\
\text { CL, ID }\end{array}$ & $\begin{array}{l}\mathrm{MA} \\
\mathrm{CL}, \mathrm{ID}\end{array}$ \\
\hline $34 a$ & $34-4$ & $68-70$ & - & A. 1 & - & - & D & M & $\mathrm{s}$ & $\mathrm{PX}>\mathrm{PC}$ & M & M.1 & $\begin{array}{l}\text { BA } \\
\text { CL, ID }\end{array}$ & $\begin{array}{l}\mathrm{MA} \\
\mathrm{CL}, \mathrm{ID}\end{array}$ \\
\hline 35 & $34-7$ & 96-98 & Tholeiite & M.1 & VS.1 & S.6 & IG & $\mathrm{F}$ & $\mathrm{S}$ & $\mathrm{PX}>\mathrm{PC}$ & A & - & & $\begin{array}{l}\mathrm{MF} \\
\mathrm{CL}, \mathrm{ID}\end{array}$ \\
\hline 35 & $35-6$ & $27-29$ & Tholeiite & M.6 & S. 5 & S.6 & ST & M & $\mathrm{S}$ & $\mathrm{PX}>\mathrm{PC}$ & M & - & $\begin{array}{l}\text { BA } \\
\text { CL, ID }\end{array}$ & $\begin{array}{l}\text { MF } \\
\text { CL, ID }\end{array}$ \\
\hline 37 & $36-2$ & $14-16$ & Tholeiite & M.1 & - & - & D & M & $\mathrm{S}$ & $P C=P X$ & M & VA. 2 & $\begin{array}{l}\text { BA } \\
\text { CL, ID }\end{array}$ & $\begin{array}{l}\mathrm{MA} \\
\mathrm{CL}, \mathrm{ID}\end{array}$ \\
\hline 38 & $36-3$ & $81-83$ & Tholeiite & A. 2 & - & - & D & M & M & $\mathrm{PC}>\mathrm{PX}$ & M & - & $\begin{array}{l}\text { BA } \\
\text { CL, ID }\end{array}$ & $\begin{array}{l}\mathrm{MA} \\
\mathrm{CL}, \mathrm{CC}, \mathrm{ID}\end{array}$ \\
\hline 39 & $36-4$ & $52-54$ & Tholeiite & A. 1 & - & - & D & M & $\mathrm{S}$ & $\mathrm{PC}>\mathrm{PX}$ & M & - & & $\begin{array}{l}\text { BA } \\
\text { CL, ID }\end{array}$ \\
\hline 41 & $36-5$ & $122-125$ & Tholeiite & M.1 & - & - & D & M & $\mathrm{S}$ & $\mathrm{PC}=\mathrm{PX}$ & M & VA.1 & $\begin{array}{l}\text { BA } \\
\text { CL, ID }\end{array}$ & $\begin{array}{l}\text { MA } \\
\text { CL, ID }\end{array}$ \\
\hline 44 & $37-3$ & 103-105 & Tholeiite & VS.7 & - & - & IG & M & M & $\mathrm{PC}=\mathrm{PX}$ & M & - & $\begin{array}{l}\text { BA } \\
\text { CL, ID }\end{array}$ & $\begin{array}{l}\text { MA } \\
\mathrm{CL}\end{array}$ \\
\hline $45 \mathrm{~b}$ & $38-1$ & $77-80$ & Tholeiite & M.2 & - & - & D & M & A & $\mathrm{PX}>\mathrm{PC}$ & $\mathrm{M}$ & - & $\begin{array}{l}\mathrm{MF} \\
\mathrm{CL}\end{array}$ & $\begin{array}{l}\text { MA } \\
\text { CL }\end{array}$ \\
\hline $47 a$ & $38-5$ & $95-100$ & Tholeiite & - & - & - & D & M & - & $\mathrm{PC}=\mathrm{PX}$ & A & - & & $\begin{array}{l}\mathrm{MA} \\
\mathrm{CL}\end{array}$ \\
\hline 48 & $39-5$ & $102-104$ & Tholeiite & M.7 & - & VS. 6 & IG & $\mathrm{F}$ & $S$ & $\mathrm{PC}=\mathrm{PX}$ & M & - & $\begin{array}{l}\text { BA } \\
\text { CL, ID }\end{array}$ & $\begin{array}{l}\text { MA } \\
\text { CL, ID }\end{array}$ \\
\hline 49 & $40-2$ & $92-97$ & Tholeiite & M.2 & - & - & IG & $\mathrm{F}$ & VS & $\mathrm{PC}=\mathrm{PX}$ & A & - & $\begin{array}{l}\text { BA } \\
\text { CL, ID }\end{array}$ & $\begin{array}{l}\text { MA } \\
\text { CL, ID }\end{array}$ \\
\hline $51 \mathrm{a}$ & $41-1$ & $15-19$ & Tholeiite & - & - & - & IG & M & vS & $\mathrm{PC}>\mathrm{PX}$ & A & - & & $\begin{array}{l}\mathrm{MA} \\
\mathrm{CL}, \mathrm{ID}\end{array}$ \\
\hline 52 & $42-1$ & $2-6$ & Tholeiite & - & - & - & IG & M & vS & $\mathrm{PC}=\mathrm{PX}$ & M & - & - & $\begin{array}{l}\text { MA } \\
\text { CL, ID }\end{array}$ \\
\hline
\end{tabular}


TABLE 14 - Continued

\begin{tabular}{|c|c|c|c|c|c|c|c|c|c|c|c|c|c|c|}
\hline \multirow{2}{*}{$\begin{array}{c}\text { Flow } \\
\text { Unit/ } \\
\text { Sub-Unit }\end{array}$} & \multirow[b]{2}{*}{$\begin{array}{l}\text { Core- } \\
\text { Section }\end{array}$} & \multirow[b]{2}{*}{$\begin{array}{l}\text { Interval } \\
(\mathrm{cm})\end{array}$} & \multirow[b]{2}{*}{$\begin{array}{l}\text { Rock Type } \\
(\text { XRF) }\end{array}$} & \multicolumn{3}{|c|}{ Phenocrysts ${ }^{b}$} & \multicolumn{5}{|c|}{ Groundmass } & \multicolumn{3}{|c|}{ Alteration } \\
\hline & & & & $\mathrm{OL}$ & PX & $\mathrm{PC}$ & Texture & $\begin{array}{c}\text { Grain } \\
\text { Size }\end{array}$ & $\mathrm{OL}$ & $\mathrm{PC}, \mathrm{PX}^{\mathrm{c}}$ & $\begin{array}{c}\text { Fe-Ti } \\
\text { Oxides }\end{array}$ & $\begin{array}{l}\text { Vesi- } \\
\text { cles b }\end{array}$ & $\begin{array}{l}\text { Pheno- } \\
\text { crysts }\end{array}$ & $\begin{array}{l}\text { Ground- } \\
\text { mass }\end{array}$ \\
\hline 53 & $42-3$ & $11-15$ & Tholeiite & - & - & - & IG & M & VS & $\mathrm{PC}>\mathrm{PX}$ & M & VA.7 & - & $\begin{array}{l}\text { MA } \\
C L, \text { ID }\end{array}$ \\
\hline 54 & $42-5$ & $35-38$ & Tholeiite & - & S.1 & M.1 & IG & M & vs & $P C=P X$ & M & VS.1 & $\mathrm{F}$ & $\begin{array}{l}\text { MA } \\
\text { CL, ID }\end{array}$ \\
\hline 58 & $44-2$ & $117-119$ & - & S.8 & VS.8 & VS. 8 & IS & M & MA & $\mathrm{PC} \gg \mathrm{PX}$ & $S ?$ & - & $\begin{array}{l}\text { BA } \\
\text { CL, ID }\end{array}$ & $\begin{array}{l}\text { MA } \\
\text { CL, ID }\end{array}$ \\
\hline 60 & $45-5$ & $2-4$ & Tholeiite & S.6 & - & MA.1 & IG & M & $\mathrm{S}$ & $\mathrm{PC}=\mathrm{PX}$ & M & - & $\mathrm{F}$ & $\begin{array}{l}\text { MF } \\
C L, I D\end{array}$ \\
\hline $62 \mathrm{a}$ & $46-3$ & $72-74$ & - & VS.8 & S.8 & S.1 & IG & M & M & $\mathbf{P X}>$ PC & M & - & $\begin{array}{l}\mathrm{MF} \\
\mathrm{ID}, \mathrm{CL}\end{array}$ & $\begin{array}{l}\text { MA } \\
\text { CL, ID }\end{array}$ \\
\hline 64 & $47-5$ & $\begin{array}{c}87-89 \\
?\end{array}$ & Tholeiite & S.7 & VS.3 & S.3 & IG & $\mathrm{F}$ & $\mathrm{S}$ & $\mathrm{PC}>\mathrm{PX}$ & A & M.7 & $\begin{array}{l}\mathrm{BA} \\
\text { ID }\end{array}$ & $\begin{array}{l}\text { MA } \\
\text { CL, ID }\end{array}$ \\
\hline 66 & $49-2$ & $31-36$ & - & - & - & - & $\mathrm{D}$ & $\mathrm{C}$ & A & $\mathrm{PC}>\mathrm{PX}$ & $\mathrm{M}$ & M.5 & - & $\begin{array}{l}\mathrm{MA} \\
\mathrm{ID}, \mathrm{CL}\end{array}$ \\
\hline
\end{tabular}

Notes:

Minerals

$$
\begin{aligned}
& \mathrm{OL}=\text { olivine } \\
& \mathrm{PX}=\text { pyroxene } \\
& \mathrm{PC}=\text { plagioclase } \\
& \mathrm{CL}=\text { clays } \\
& \mathrm{ID}=\text { iddingsite } \\
& \mathrm{CC}=\text { calcite } \\
& \mathrm{ZL}=\text { zeolite }
\end{aligned}
$$

\section{Alteration}

$\mathrm{F} \quad=$ fresh $(<5 \%$ altered $)$

$\mathrm{MF}=$ moderately fresh $(5-10 \%$ altered $)$

$\mathrm{MA}=$ moderately altered $(10-25 \%$ altered $)$

$\mathrm{BA}=$ badly altered $(>25 \%$ altered $)$
Textures

IG = intergranular

IS = intersertal (includes hayalopilitic and vitrophyric)

$\mathrm{D}=$ diabasic

$\mathrm{T}=$ trachytic

$\mathrm{ST}=$ sub-trachytic
Abundances

$$
\begin{aligned}
\mathrm{VA} & =\text { very abundant }(20-50 \%) \\
\mathrm{A} & =\text { abundant }(10-20 \%) \\
\mathrm{M} & =\text { moderately abundant }(5-10 \%) \\
\mathrm{S} & =\text { sparse }(2-5 \%) \\
\mathrm{VS} & =\text { very sparse }(<2 \%) \\
-- & =\text { none observed }
\end{aligned}
$$

aNA = no XRF analysis of flow unit. Where rock types are given, they are based on XRF analyses, and are placed opposite the nearest thin section.

bAverage grain size, in mm, follows abundance (e.g., VA.8 means very abundant, a verage $0.8 \mathrm{~mm}$ ).

CRelative abundance: PC $\gg$ PX means that $\mathrm{PC}$ is twice as abundant as PX. PC=PX indicates subequal amounts (within 5\%).

dPrimarily olivine. Plagioclase and pyroxene phenocrysts are usually fresh even when olivine is totally altered. Alteration products listed in relative order of abundance.

Flow Unit 19 (a through d): Olivine phyric basalts, usually badly altered in the vesicular intervals and near the unit tops and bottoms. The massive interior of Subunit $19 \mathrm{~b}$ is only moderately altered (Section 23-2, 50 $\mathrm{cm}$ ), as are the interiors of Sub-units 19c (Section 24-5, $60 \mathrm{~cm}$ ) and 19d (Section 24-8, $100 \mathrm{~cm}$ ). Flow Sub-unit $19 \mathrm{~d}$ has a slightly altered part from Section $24-7,70 \mathrm{~cm}$ to Section 24-8, $37 \mathrm{~cm}$.

Flow Units 20 through 24: The sparsely olivine phyric basalts of Flow Units 20 and 21, the olivine phyric basalts of Flow Units 22 and 23, and the picrite basalt of Flow Unit 24 are all altered in a similar way. The massive flow interiors, which usually occur in lower parts of flow units, are moderately altered and sometimes contain some fresh olivine. Vesicular intervals near flow tops and bottoms are badly altered. There are 1- to $2-\mathrm{mm}$ diameter dark green spots in Flow Units 20 through 22 in which the groundmass is nearly totally altered.

Flow Units 25 through 27: These porphyritic basalts are moderately to badly altered, and contain fresh plagioclase and clinopyroxene, and olivine altered to clays and iddingsite. Massive, fresher basalt usually occurs in the lower one half to one third of each flow unit. For example, Flow Unit 27 can be divided into 6 parts, as follows:

1) A badly altered oxidized top containing olivine phenocrysts altered to iddingsite and less extensively to clays, and plagioclase and pyroxene phenocrysts that are mostly fresh (Section 29-3, 72-102 cm). Vesicles (up to $25 \%$ ) are mostly lined by clays, but sometimes by quartz crystals.

2) A badly altered flow interior with 5 to 10 per cent clay-lined vesicles. Olivine phenocrysts altered to clays and iddingsite. (Section 30-1 to Section 30-2, $95 \mathrm{~cm}$.)

3) A moderately altered non-vesicular flow interior with some fresh olivine cores (Section $30-2,95 \mathrm{~cm}$ to Section $30-3,80 \mathrm{~cm}$ ).

4) A slightly altered massive flow interior with mostly fresh olivine (Section 31-1, 2-30 cm).

5) A moderately to badly altered flow interior in which alteration and vesicles increase (from 1 to $10 \%$ ) down-section (Section 31-1, 30-110 cm).

6) A badly altered oxidized flow bottom with 25 to 40 per cent vesicles and olivine altered to iddingsite (Section $31-1,110 \mathrm{~cm}$ to Section $31-2,60 \mathrm{~cm}$ ).

Flow Units 28 through 39: These olivine phyric basalts (Flow Units 35 and 36 have some plagioclase phenocrysts) are altered, and contain some fresh olivine in the massive flow interiors. In the upper and lower vesicular parts, the olivine is altered to clays with iddingsite rims. Alteration is more extensive in the flow tops and bottoms, where the olivine is altered mostly to iddingsite, and in lesser extent to clays; plagioclase and clinopyroxene are slightly altered to clays. 
Flow and Cooling Units 40 through 46: Olivine phyric and sparsely olivine phyric basalts. Most of these units are thin (usually less than $1 \mathrm{~m}$ ) and badly altered and oxidized, except the thick Flow Unit 44 and Subunit $45 \mathrm{~b}$, which are moderately to slightly altered, with fresh olivine in the massive flow interiors. Flow Subunit 45 b contains common phillipsite.

Flow Unit 47 (a and b): Aphyric basalt, moderately to badly altered in the flow interiors, containing 20 to 25 per cent clays glass and olivine(?) in the groundmass. The tops and bottoms are more altered and oxidized.

Flow Units 48 through 50: Olivine phyric basalts. The alteration is similar to that of Flow Units 40 through 46. Flow Unit 50 is badly altered; the interiors of Flow Units 48 and 49 are slightly to moderately altered.

Flow Units 51 through 53: Aphyric basalts; the massive flow interiors moderately altered (up to $10 \%$ clays in the groundmass). More altered vesicular parts and oxidized tops and bottoms.

Flow Units 54 through 64: These porphyritic basalts all show similar alteration. The thin cooling units (55a, $55 \mathrm{~b}, 61 \mathrm{~b}$ through $61 \mathrm{e}, 62 \mathrm{~b}$ through $62 \mathrm{~d}$ ) and the tops and bottoms of the thicker flow units are usually badly altered and oxidized. Glass is altered to clays, and olivine is mostly altered to iddingsite, less extensively to clays. Plagioclase and clinopyroxene are slightly altered. In the massive interiors of Flow Units 54, 56 through 60, Subunits 62a and 63a, and Flow Unit 64, glass is completely altered to clays, and the olivine is partially altered to iddingsite. The freshest massive flow interiors are always near the flow bottoms.

Flow Units 65 and 66: Aphyric basalts. The thin Flow Sub-units $65 \mathrm{a}$ and $65 \mathrm{~b}$ and the top of Flow Unit 66 are badly altered and slightly oxidized. Flow Unit 67 is fresher (moderately to slightly altered) and contains some fresh olivine grains.

\section{Discussion}

1) Alteration decreases visibly downward from the top and upward from the bottom of each flow unit.

2) The thin flow units are usually more altered than the thick ones.

3) The freshest part of each flow unit is situated in a massive flow interior, which as a rule is nearer the bottom than the top. The upper altered zones are commonly 3 to 5 times thicker than the bottom ones.

4) Many flow units have reddish oxidized tops and bottoms; the top oxidized zones are thicker than the bottom zones. The top zone is sometimes up to 2 meters thick; the bottom oxidized zones are usually not more than 0.1 meter thick.

The volcanic sequence of Site 433 can be divided into four groups according to degree of alteration.

1) Slightly to moderately altered: Flow Units 1 through 3.

2) Very badly altered: Flow Sub-units $4 a$ through $4 \mathrm{f}$.

3) Moderately altered: Flow Units 5 through 8, in which the alteration of the massive flow interiors decreases somewhat down-section.

4) Slightly and moderately altered: Flow Units 9 through 66 (in massive flow interiors), where no particular difference in degree of alteration is visible.
Some preliminary conclusions can be drawn from this examination.

1) The comparatively thick upper oxidized zone of each flow unit (up to $2 \mathrm{~m}$ ) is a result of volcanic eruption under subaerial conditions.

2) All the alteration probably took place after the lava flows cooled, except for the iddingsitization. The fresher part of each flow unit is in the coarse-grained, massive part of flows, which would have been the last to cool.

\section{BASALT CHEMISTRY}

Sixty-two basalt samples from Holes 433A, 433B, and $433 \mathrm{C}$ were subjected to chemical analysis aboard ship. Table 15 presents the reduced data with all the iron as $\mathrm{Fe}_{2} \mathrm{O}_{3}$, the dry and reduced normalized analyses and CIPW norms calculated with $\mathrm{Fe}^{+3} / \mathrm{Fe}_{\mathrm{T}}=0.15$. The basalts analyzed are alkalic basalts, oceanites (tholeiitic picrites), and fractionated tholeiites.

\section{Effects of Alteration}

All the basalts recovered at Site 433 are altered to some extent and have uniformly moderate to high $\mathrm{H}_{2} \mathrm{O}^{+}$and $\mathrm{CO}_{2}$ contents. The relatively rapid drilling rate in these basalts $(3.7 \mathrm{~m} / \mathrm{hr})$ and the high recovery rate $(>50 \%)$ necessitated sampling for onboard XRF analyses and for thin sections at the same time, so that there was no opportunity to study such effects as groundmass alteration before selecting samples for chemical analysis. In general, what appeared to be the least altered portion of each flow unit was sampled, and, since most vesicles were filled with clays or carbonates, most of the analyzed samples were selected from the nonvesicular, more massive centers of flows. One consequence of such sampling is that it selectively biases the olivine content to high values, because many flows contain concentrations of that mineral in their massive interiors. $\mathrm{Mg} /(\mathrm{Mg}+\mathrm{Fe})$ ratios in rocks with high $\mathrm{H}_{2} \mathrm{O}^{+}$values tend to be higher than in fresher basalts with the same $\mathrm{SiO}_{2}$ content. Thus, we suspect that much of the vesicle-filling and groundmass clays are nontronitic members of the smectite group. On the other hand, rocks rich in olivine phenocrysts that have been partly or completely altered to clays tend to have higher $\mathrm{SiO}_{2}$ contents than would be expected from olivine control, and we suspect these clays to be saponitic. Certain samples (particularly from Flow Sub-unit 4a and Flow Units 10 and 12) show $\mathrm{K}_{2} \mathrm{O}$ contents considerably in excess of those expected from the $\mathrm{TiO}_{2}, \mathrm{CaO}$, $\mathrm{P}_{2} \mathrm{O}_{5}, \mathrm{Sr}$, and $\mathrm{Zr}$ contents in the same samples. Re-examination of thin sections of these samples shows them to contain olive-green fibrous clays. We suspect that these olive-green "clays" contain $\mathrm{K}_{2} \mathrm{O}$, like those reported by Dalrymple and Clague (1976). Several analyzed rocks also contain colorless to pale green fibrous clay minerals, and in two analyzed flow sub-units (19a and $19 \mathrm{~d}$ ) they are abundant. Again, the $\mathrm{K}_{2} \mathrm{O}$ values reported for some samples of these two sub-units are far in excess of those expected from the abundance of their other distinctive oxides and elements. Some other analyzed flow units, however, contain much smaller amounts of clays (Flow Units/ Sub-units 4f, 9, 15, 16, 
and 22), and do not have suspiciously high $\mathrm{K}_{2} \mathrm{O}$ contents. Rocks with appreciable $\mathrm{CO}_{2}$ contents were observed to contain carbonate minerals, presumably calcite, and, indeed the $\mathrm{CaO}$ contents of analyzed basalts that contain $\mathrm{CO}_{2}$ appear somewhat high.

\section{Classification}

All three holes penetrated Flow Unit 1, and 6 chemical analyses, all very similar, were made from samples of it. The unit is at least 8.5 meters thick, and may be as much as 14.5 meters thick. Chemically the rock is a typical Hawaiian alkalic basalt. Its major-element contents are very close to those of average Hawaiian alkalic basalt (MacDonald and Katsura, 1964; MacDonald, 1968), and it falls well within the alkalic basalt field in the $\mathrm{Na}_{2} \mathrm{O}+\mathrm{K}_{2} \mathrm{O}$ versus $\mathrm{SiO}_{2}$ plot (Figure 27). It is different only in its low $\mathrm{Ba}$ and $\mathrm{Sr}$ contents and high $\mathrm{P}$ and Zr contents (Jackson et al., 1976; see Table 16). Flow Unit 2 is also a typical alkalic basalt, except, again, for its very low $\mathrm{Ba}$ and $\mathrm{Sr}$ contents. Flow Unit 3 was not sampled for analysis, but it has a trachytic texture and is probably alkalic as well.

Sub-units $4 \mathrm{a}$ through $4 \mathrm{f}$ are picritic (olivine-rich) rocks which appear to be related to the tholeiitic basalts. They plot (except for 4d, which contains abundant zeolites) in the tholeiitic field on the alkalis-silica plot, and have tholeiite trace-element ratios. All contain phenocrysts of olivine, but no pyroxene phenocrysts.

Flow Unit 5 has the chemical abundances expected of a tholeiite, except for $\mathrm{K}_{2} \mathrm{O}$, which is that of an alkalic basalt. Indeed, its $\mathrm{TiO}_{2}, \mathrm{P}_{2} \mathrm{O}_{5}, \mathrm{Sr}$, and $\mathrm{Zr}$ values are much too low for any known oceanic island rock with a $\mathrm{K}_{2} \mathrm{O}$ content of nearly 1 per cent. Olive-green fibrous clay minerals occur as vesicle fillings in this rock, and we attribute the excess potassium to a K-rich clay. This flow unit is probably an altered tholeiite.

Proceeding from Flow Unit 5 to the bottom of the hole at 550.5 meters, all the rocks are tholeiitic basalts. Most of the tholeiitic basalts fall well within the tholeiitic field on the total alkalis-silica plot (Figure 27), and all have incompatible-element abundances and ratios similar to Hawaiian tholeiitic basalts. Those analyses that do not fall in the tholeiitic field (Flow Units/Subunits $5,11 \mathrm{~b}, 12,17,18,19 \mathrm{~d}$, and 66 ) have all apparently gained $\mathrm{K}_{2} \mathrm{O}$ or lost silica during alteration.

The interval beginning with Flow Sub-unit 4a appears to represent the upper part of the tholeiitic, shieldbuilding suite which forms the underpinning of all subareally exposed volcanoes in the Hawaiian chain. The tholeiites at Suiko, like those of all southeastern Hawaiian volcanoes (MacDonald and Katsura 1964, table 9) have their own chemical peculiarities, which appear to include lower than average $\mathrm{TiO}_{2}, \mathrm{P}_{2} \mathrm{O}_{5}$, Sr values, but most fall within the range reported for Hawaiian tholeiitic basalts (Figures 28, 29, and 30).

\section{PALEOMAGNETISM}

\section{Introduction}

At Site 433 (Suiko Seamount), basalts were obtained from Holes 433A, 433B, and 433C. Holes 433A and
433B were single-bit holes, and only one flow unit was drilled. Paleomagnetism was studied in nine samples from Hole 433A and three samples from Hole 433B. Reentry Hole $433 \mathrm{C}$ penetrated nearly 400 meters of the basement, and at least 67 flow units were recovered. In total, 302 samples from this hole were measured between 20 and 31 August. In order to complete paleomagnetic experiments in such a short time, some simplification of the experimental procedures was inevitable; but to keep the standard of data as high as possible, we took care to satisfy, as far as possible, all the minimum conditions listed below.

1) The number of samples from each unit was four or more, preferably five or more.

2) At least two pilot samples each from Flow Units 1 through 22 (one each from Flow Units 23 through 66) were demagnetized progressively at peak fields of 25 , $50,100,150,200,300,400$, and 500 Oe (the step of 25 Oe was eliminated after Flow Unit 21). If more than half the original remanence remained at the 500 Oe step, additional AF demagnetization was carried out at 100Oe steps thereafter, until the median demagnetizing field (MDF) was reached.

3) After measurement of the NRM, other samples were demagnetized at a minimum of two different peak fields, the higher of which was 300 Oe or greater.

4) Near the MDF of each sample, the demagnetizing step did not exceed 100 Oe if the estimated MDF was less than $400 \mathrm{Oe}$, or $200 \mathrm{Oe}$ if it was between 400 and 800 Oe.

5) Measurement of susceptibility was as described in the summary for Site 430 .

For some of the flow units, it was impossible to satisfy condition 1 above, because the recovered flow units were too thin or too brecciated or in small pieces. When a substantial difference occurred in the inclinations of what were thought to be sub-units within a single flow unit (26a and $26 \mathrm{~b}$, etc.), or when such a difference occurred at some previously unnoticed place in a single flow unit (28a and $28 \mathrm{~b}$, etc.), an additional sample was measured to establish the reality of the difference and to satisfy condition 1. But this again was by no means possible in all cases, because of the limitation of available time.

Condition 3 was included to make sure that in $\mathrm{AF}$ demagnetization of a sample we were really picking out the stable component from the NRM, and not some spurious effect caused by the demagnetization experiment. It also served to show that the demagnetization was sufficient to obtain the primary component, since the effects of secondary components are negligibly small in the higher demagnetizing fields.

Because of condition 4, the MDF was determined for most of the present samples with estimated error of less than 10 Oe. In any case, the error in MDF does not exceed 25 Oe.

Because the data thus far accumulated are rather voluminous, thorough discussion of the results will be presented elsewhere (Kono, this volume). As shown by the high MDF and $Q_{n}^{\prime}$ ratios, most of the samples have very stable remanences, and there is no doubt that their 
TABLE 15

Shipboard Chemical Analyses of Basalts, Site 433

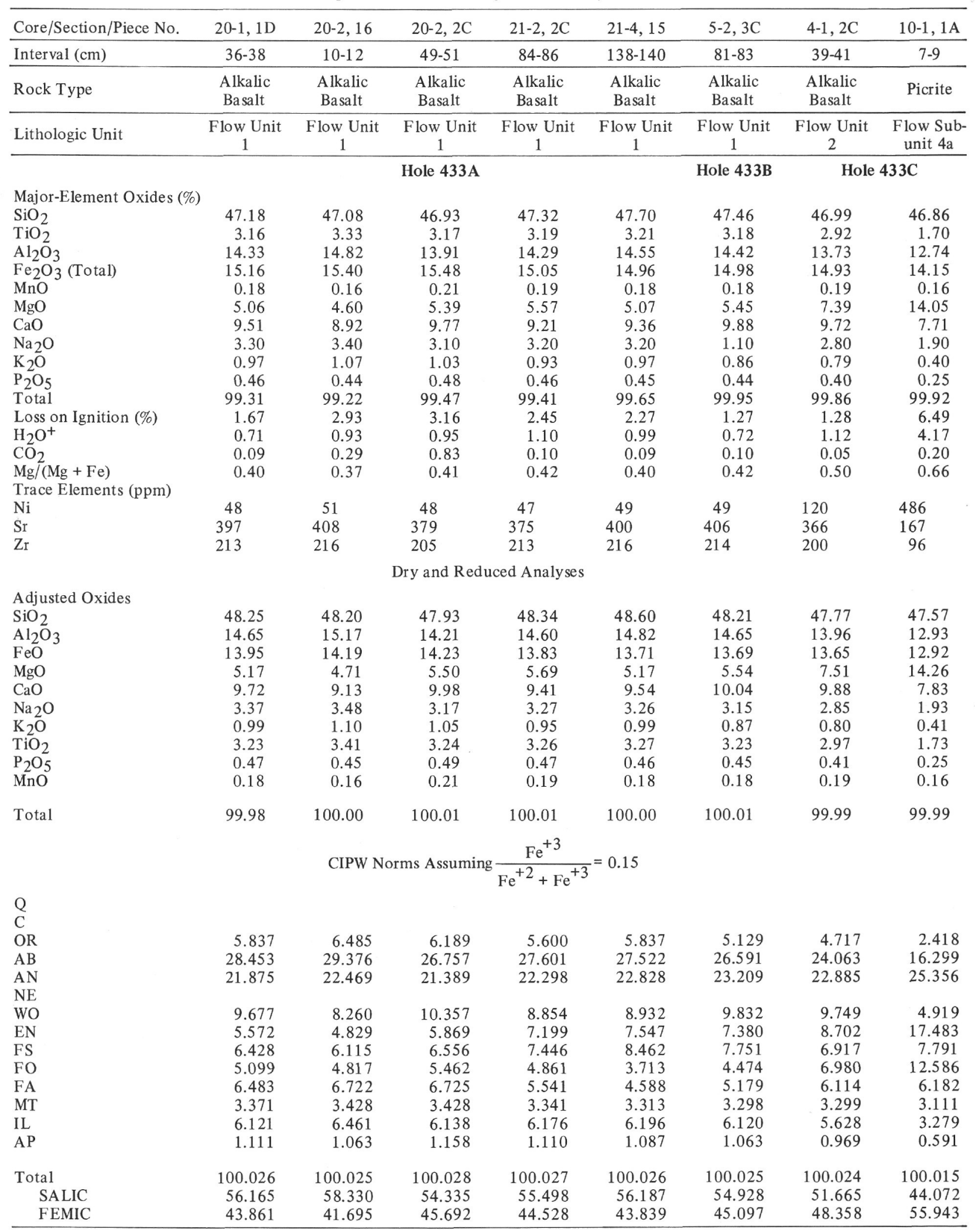


TABLE 15 - Continued

\begin{tabular}{|c|c|c|c|c|c|c|c|c|c|}
\hline $10-2,3 \mathrm{~A}$ & $10-2,7$ & $10-3,10 \mathrm{~A}$ & $10-4,8 \mathrm{~B}$ & $10-5,13 \mathrm{~A}$ & $11-1,9 \mathrm{C}$ & $11-3,2 \mathrm{~A}$ & $11-4,14$ & $12-3,1 \mathrm{E}$ & $13-2,1 \mathrm{H}$ \\
\hline $16-18$ & $58-60$ & $105-107$ & $118-121$ & $118-120$ & $135-137$ & $29-31$ & $110-112$ & $51-53$ & $53-55$ \\
\hline Picrite & Picrite & Picrite & Picrite & Tholeiite & Tholeiite & Tholeiite & Tholeiite & Tholeiite & Tholeiite \\
\hline $\begin{array}{l}\text { Flow Sub- } \\
\text { unit } 4 \mathrm{~b}\end{array}$ & $\begin{array}{c}\text { Flow Sub- } \\
\text { unit } 4 \mathrm{c}\end{array}$ & $\begin{array}{c}\text { Flow Sub- } \\
\text { unit } 4 \mathrm{e}\end{array}$ & $\begin{array}{l}\text { Flow Sub- } \\
\text { unit } 4 \mathrm{~h}\end{array}$ & $\begin{array}{c}\text { Flow Unit } \\
5\end{array}$ & $\begin{array}{c}\text { Flow Sub- } \\
\text { unit } 6 a\end{array}$ & $\begin{array}{c}\text { Flow Unit } \\
7\end{array}$ & $\begin{array}{c}\text { Flow Unit } \\
9\end{array}$ & $\begin{array}{c}\text { Flow Unit } \\
9\end{array}$ & $\begin{array}{c}\text { Flow Unit } \\
10 \\
\end{array}$ \\
\hline \multicolumn{10}{|c|}{ Hole 433C } \\
\hline 46.70 & 46.16 & 45.96 & 45.94 & 47.78 & 47.00 & 48.00 & 48.73 & 48.91 & 48.00 \\
\hline 1.85 & 1.91 & 1.97 & 1.15 & 1.89 & 1.89 & 1.92 & 2.40 & 2.35 & 2.26 \\
\hline 13.09 & 14.10 & 14.76 & 8.81 & 14.14 & 14.86 & 15.00 & 15.33 & 14.36 & 14.22 \\
\hline 14.16 & 14.63 & 14.95 & 14.10 & 15.70 & 13.35 & 13.03 & 12.71 & 12.30 & 13.16 \\
\hline 0.15 & 0.13 & 0.15 & 0.19 & 0.07 & 0.18 & 0.12 & 0.11 & 0.14 & 0.17 \\
\hline 14.09 & 11.34 & 9.23 & 20.39 & 10.81 & 8.02 & 8.25 & 6.95 & 7.43 & 7.90 \\
\hline 6.54 & 7.84 & 8.95 & 6.70 & 4.82 & 10.95 & 10.54 & 10.25 & 11.30 & 11.16 \\
\hline 2.00 & 2.30 & 2.20 & 1.40 & 2.80 & 2.50 & 2.50 & 2.50 & 2.50 & 2.30 \\
\hline 0.47 & 0.44 & 0.11 & 0.28 & 0.83 & 0.32 & 0.23 & 0.63 & 0.20 & 0.47 \\
\hline 0.21 & 0.24 & 0.25 & 0.15 & 0.23 & 0.24 & 0.22 & 0.28 & 0.28 & 0.28 \\
\hline 99.26 & 99.09 & 99.13 & 99.11 & 99.07 & 99.31 & 99.81 & 99.89 & 99.77 & 99.92 \\
\hline 10.4 & 6.59 & 7.83 & 14.00 & 8.74 & 7.24 & 5.41 & 5.66 & 3.38 & 2.47 \\
\hline 4.62 & 3.56 & 2.98 & 5.52 & 3.26 & 2.28 & 2.19 & 1.72 & 1.12 & 1.42 \\
\hline 0.20 & 0.17 & 0.37 & 1.76 & 0.17 & 1.31 & 0.51 & 0.56 & 0.47 & 0.14 \\
\hline 0.66 & 0.61 & 0.55 & 0.74 & 0.57 & 0.54 & 0.56 & 0.52 & 0.55 & 0.54 \\
\hline 462 & 375 & 303 & 1196 & 246 & 156 & 174 & 117 & 103 & 98 \\
\hline 145 & 202 & 217 & 88 & 151 & 248 & 273 & 288 & 294 & 297 \\
\hline 102 & 110 & 111 & 60 & 107 & 114 & 115 & 137 & 142 & 139 \\
\hline \multicolumn{10}{|c|}{ Dry and Reduced Analyses } \\
\hline 47.73 & 47.29 & 47.08 & 47.02 & 49.01 & 47.97 & 48.73 & 49.41 & 49.63 & 48.68 \\
\hline 13.38 & 14.44 & 15.12 & 9.02 & 14.50 & 15.17 & 15.23 & 15.54 & 14.57 & 14.42 \\
\hline 13.02 & 13.48 & 13.78 & 12.99 & 14.49 & 12.26 & 11.90 & 11.60 & 11.23 & 12.01 \\
\hline 14.40 & 11.62 & 9.45 & 20.87 & 11.09 & 8.19 & 8.38 & 7.05 & 7.54 & 8.01 \\
\hline 6.68 & 8.03 & 9.17 & 6.86 & 4.94 & 11.18 & 10.70 & 10.39 & 11.47 & 11.32 \\
\hline 2.04 & 2.36 & 2.25 & 1.43 & 2.87 & 2.55 & 2.54 & 2.53 & 2.54 & 2.33 \\
\hline 0.48 & 0.45 & 0.73 & 0.29 & 0.85 & 0.33 & 0.23 & 0.64 & 0.20 & 0.48 \\
\hline 1.89 & 1.96 & 2.02 & 1.18 & 1.94 & 1.93 & 1.95 & 2.43 & 2.38 & 2.29 \\
\hline 0.21 & 0.25 & 0.26 & 0.15 & 0.24 & 0.24 & 0.22 & 0.28 & 0.28 & 0.28 \\
\hline 0.15 & 0.13 & 0.15 & 0.19 & 0.07 & 0.18 & 0.12 & 0.11 & 0.14 & 0.17 \\
\hline 99.98 & 100.01 & 100.02 & 100.00 & 100.00 & 100.00 & 100.00 & 99.98 & 99.98 & 99.99 \\
\hline \multicolumn{10}{|c|}{ CIPW Norms Assuming $\frac{\mathrm{Fe}^{+3}}{\mathrm{Fe}^{+2}+\mathrm{Fe}^{+3}}=0.15$} \\
\hline & & & & 0.450 & & & & & \\
\hline 2.831 & 2.653 & 4.303 & 1.710 & 5.010 & 1.946 & 1.356 & 3.776 & 1.180 & 2.831 \\
\hline 17.227 & 19.922 & 18.993 & 12.074 & 24.225 & 21.534 & 21.450 & 21.372 & 21.456 & 19.678 \\
\hline 25.882 & 27.413 & 28.931 & 17.298 & 22.882 & 28.914 & 29.417 & 29.106 & 27.716 & 27.418 \\
\hline 2.431 & 4.468 & 6.162 & 6.548 & & 10.386 & 9.238 & 8.570 & 11.384 & 11.194 \\
\hline 18.165 & 12.413 & 10.136 & 19.548 & 15.490 & 9.825 & 13.560 & 15.199 & 17.300 & 14.375 \\
\hline 7.949 & 6.945 & 7.126 & 6.350 & 9.843 & 7.031 & 9.064 & 10.997 & 11.352 & 9.823 \\
\hline 12.352 & 11.532 & 9.350 & 22.645 & 8.452 & 7.380 & 5.094 & 1.632 & 1.014 & 3.879 \\
\hline 5.957 & 7.110 & 7.244 & 8.107 & 5.919 & 5.820 & 3.752 & 1.302 & 0.733 & 2.921 \\
\hline 3.140 & 3.254 & 3.327 & 3.139 & 3.500 & 2.952 & 2.865 & 2.794 & 2.707 & 2.894 \\
\hline 3.582 & 3.714 & 3.827 & 2.236 & 3.675 & 3.658 & 3.696 & 4.607 & 4.512 & 4.341 \\
\hline 0.496 & 0.591 & 0.614 & 0.355 & 0.567 & 0.567 & 0.520 & 0.662 & 0.662 & 0.662 \\
\hline 100.013 & 100.015 & 100.015 & 100.010 & 100.013 & 100.015 & 100.013 & 100.016 & 100.016 & 100.017 \\
\hline 45.940 & 49.987 & 52.228 & 31.082 & 52.568 & 52.394 & 52.223 & 54.253 & 50.352 & 49.927 \\
\hline 54.072 & 50.027 & 47.787 & 68.928 & 47.446 & 47.620 & 47.790 & 45.762 & 49.664 & 50.089 \\
\hline
\end{tabular}


TABLE 15 - Continued

\begin{tabular}{lcccccccc}
\hline Core/Section/Piece No. & $14-3,4 \mathrm{~A}$ & $14-4,1 \mathrm{~B}$ & $15-1,13$ & $15-4,4$ & $15-6,1 \mathrm{C}$ & $19-2,2 \mathrm{~F}$ & $19-4,1 \mathrm{~B}$ & $20-2,13$ \\
\hline Interval (cm) & $55-57$ & $21-23$ & $115-118$ & $46-48$ & $31-32$ & $56-58$ & $17-19$ & $132-134$ \\
\hline Rock Type & Tholeiite & Tholeiite & Tholeiite & Tholeiite & Tholeiite & Tholeiite & Tholeiite & Tholeiite \\
\hline Lithologic Unit & $\begin{array}{c}\text { Flow Sub- } \\
\text { unit 11b }\end{array}$ & $\begin{array}{c}\text { Flow Sub- } \\
\text { unit 11c }\end{array}$ & $\begin{array}{c}\text { Flow Sub- } \\
\text { unit 11c }\end{array}$ & $\begin{array}{c}\text { Flow Unit } \\
12\end{array}$ & $\begin{array}{c}\text { Flow Unit } \\
13\end{array}$ & $\begin{array}{c}\text { Flow Unit } \\
14\end{array}$ & $\begin{array}{c}\text { Flow Sub- } \\
\text { unit 15a }\end{array}$ & $\begin{array}{c}\text { Flow Unit } \\
16\end{array}$ \\
\hline
\end{tabular}

\section{Hole 433C}

Major-Element Oxides (\%)

$\begin{array}{lrr}\mathrm{SiO}_{2} & 48.26 & 48.6 \\ \mathrm{TiO}_{2} & 2.68 & 2.5 \\ \mathrm{Al}_{2} \mathrm{O}_{3} & 15.50 & 15.2 \\ \mathrm{Fe}_{2} \mathrm{O}_{3} \text { (Total) } & 13.97 & 13.5 \\ \mathrm{MnO} & 0.09 & 0.1 \\ \mathrm{MgO} & 7.20 & 7.00 \\ \mathrm{CaO} & 7.39 & 9.63 \\ \mathrm{Na}_{2} \mathrm{O} & 3.20 & 2.9 \\ \mathrm{~K}_{2} \mathrm{O} & 0.80 & 0.2 \\ \mathrm{P}_{2} \mathrm{O}_{5} & 0.31 & 0.3 \\ \mathrm{Total}_{\text {Loss on Ignition (\%) }} & 99.40 & 99.1 \\ \mathrm{H}_{2} \mathrm{O}^{+} & 4.64 & 3.3 \\ \mathrm{CO}_{2} & 1.93 & 1.1 \\ \mathrm{Mg} /(\mathrm{Mg}+\mathrm{Fe}) & 0.26 & 0.1 \\ \mathrm{Trace} \mathrm{Elements} \mathrm{(ppm)} & 0.51 & 0.5 \\ \mathrm{Ni} & & \\ \mathrm{Sr} & 51 & 46 \\ \mathrm{Zr} & 293 & 298 \\ \mathrm{Zr} & 157 & 153\end{array}$

Adjusted Oxides

$\mathrm{SiO}_{2}$
$\mathrm{Al}_{2} \mathrm{O}_{3}$
$\mathrm{FeO}$
$\mathrm{MgO}$
$\mathrm{CaO}$
$\mathrm{Na}_{2} \mathrm{O}$
$\mathrm{K}_{2} \mathrm{O}$
$\mathrm{TiO}_{2}$
$\mathrm{P}_{2} \mathrm{O}_{5}$
$\mathrm{MnO}$

Total
49.24 15.82

12.83

7.35

7.54

3.27

0.82

2.73

0.32

0.09

100.01

$$
\begin{array}{r}
47.78 \\
2.65 \\
14.75 \\
14.32 \\
0.12 \\
7.35 \\
8.84 \\
2.90 \\
0.46 \\
0.33 \\
99.50 \\
3.28 \\
1.37 \\
0.17 \\
0.50
\end{array}
$$

47.62
2.54
13.39
16.88
0.11
8.30
6.59
2.80
1.24
0.24
99.71
6.56
1.97
0.12
0.49

47.91
2.57
13.87
14.50
0.18
6.50
10.77
2.50
0.24
0.28
99.32
1.33
0.42
0.09
0.47

\section{4}

286
155

47
226
149

53

304

166

Dry and Reduced Analyses

$\begin{array}{rrr}49.23 & 49.24 & 48.58 \\ 15.42 & 14.89 & 13.66 \\ 12.34 & 13.01 & 15.50 \\ 7.09 & 7.42 & 8.47 \\ 9.75 & 8.92 & 6.72 \\ 2.94 & 2.93 & 2.86 \\ 0.22 & 0.46 & 1.27 \\ 2.56 & 2.67 & 2.59 \\ 0.30 & 0.33 & 0.24\end{array}$

48.95
14.17
13.33
6.64
11.00
2.55
0.25
2.63
0.29
0.18

49.01

15.15

12.10

7.44

10.37

2.74

0.30

2.49

0.27

0.13

99.99

100.00

99.99

99.99

100.00

CIPW Norms Assuming $\frac{\mathrm{Fe}^{+3}}{\mathrm{Fe}^{+2}+\mathrm{Fe}^{+3}}=0.15$

Q

OR

AB

$\mathrm{AN}$

WO

EN

FO

FA

MT

IL

AP

Total SALIC

FEMIC

\begin{tabular}{rrrrrrr}
1.297 & 2.713 & 7.485 & 1.474 & 1.769 & 1.416 & 1.829 \\
24.828 & 24.741 & 24.138 & 21.532 & 23.137 & 23.146 & 24.917 \\
28.172 & 26.063 & 20.630 & 26.424 & 28.094 & 28.827 & 29.638 \\
7.576 & 6.658 & 4.617 & 10.915 & 8.970 & 9.734 & 6.809 \\
14.276 & 14.495 & 10.802 & 15.227 & 14.059 & 14.741 & 14.136 \\
10.991 & 11.241 & 9.217 & 13.777 & 10.134 & 9.307 & 8.861 \\
2.345 & 2.765 & 7.174 & 0.894 & 3.106 & 3.278 & 2.934 \\
1.990 & 2.363 & 6.746 & 0.892 & 2.467 & 2.280 & 2.027 \\
2.981 & 3.140 & 3.731 & 3.212 & 2.923 & 2.634 & 2.721 \\
4.852 & 5.060 & 4.906 & 4.984 & 4.719 & 4.038 & 5.460 \\
0.709 & 0.780 & 0.567 & 0.685 & 0.638 & 0.615 & 0.686 \\
& & & & & & \\
100.017 & 100.019 & 100.014 & 100.017 & 100.016 & 100.015 & 100.016 \\
54.297 & 53.517 & 52.253 & 49.430 & 52.999 & 53.388 & 56.383 \\
45.720 & 46.502 & 47.760 & 50.587 & 47.016 & 46.627 & 43.633 \\
\hline
\end{tabular}


TABLE 15 - Continued

\begin{tabular}{|c|c|c|c|c|c|c|c|c|c|}
\hline $21-4$ & $22-1,10$ & $23-1,5 \mathrm{D}$ & $23-5,1 \mathrm{~B}$ & $24-1,2$ & $24-7,3 \mathrm{G}$ & $25-2,1 \mathrm{~B}$ & $26-1,2 \mathrm{~A}$ & $26-5,1 \mathrm{H}$ & $26-6,7 \mathrm{~A}$ \\
\hline $40-42$ & $94-96$ & $102-104$ & $16-19$ & $12-15$ & $141-144$ & $22-25$ & $42-45$ & $82-85$ & $114-117$ \\
\hline $\begin{array}{c}\text { Tholeiite } \\
\text { (plag. } \\
\text { phyric) }\end{array}$ & Tholeiite & Tholeiite & Tholeiite & Picrite & Picrite & Tholeiite & Tholeiite & Tholeiite & Tholeiite \\
\hline $\begin{array}{c}\text { Flow Unit } \\
17\end{array}$ & $\begin{array}{c}\text { Flow Unit } \\
18\end{array}$ & $\begin{array}{c}\text { Flow Sub- } \\
\text { unit } 19 a\end{array}$ & $\begin{array}{c}\text { Flow Sub- } \\
\text { unit } 19 c\end{array}$ & $\begin{array}{c}\text { Flow Sub- } \\
\text { unit 19d }\end{array}$ & $\begin{array}{c}\text { Flow Sub- } \\
\text { unit 19d }\end{array}$ & $\begin{array}{c}\text { Flow Unit } \\
20\end{array}$ & $\begin{array}{c}\text { Flow Unit } \\
21\end{array}$ & $\begin{array}{c}\text { Flow Unit } \\
22\end{array}$ & $\begin{array}{c}\text { Flow Unit } \\
23\end{array}$ \\
\hline
\end{tabular}

Hole 433C

$\begin{array}{rrrrrrrrrr}47.26 & 47.47 & 48.45 & 49.11 & 46.10 & 44.73 & 47.40 & 47.88 & 46.94 & 46.65 \\ 2.71 & 2.77 & 2.32 & 1.69 & 1.33 & 1.24 & 2.10 & 2.10 & 2.10 & 2.37 \\ 15.73 & 15.24 & 13.27 & 12.84 & 9.76 & 8.88 & 14.71 & 14.70 & 13.04 & 14.75 \\ 12.92 & 13.31 & 16.00 & 12.31 & 14.24 & 14.04 & 12.98 & 12.98 & 13.67 & 13.32 \\ 0.11 & 0.16 & 0.08 & 0.15 & 0.18 & 0.17 & 0.14 & 0.14 & 0.16 & 0.15 \\ 7.58 & 6.96 & 9.61 & 12.54 & 19.60 & 22.00 & 9.56 & 8.29 & 12.66 & 10.88 \\ 9.16 & 9.21 & 5.01 & 8.03 & 6.25 & 5.33 & 9.67 & 10.30 & 8.98 & 8.47 \\ 3.00 & 2.90 & 2.60 & 2.20 & 2.60 & 1.60 & 2.40 & 2.50 & 2.00 & 2.50 \\ 0.45 & 0.64 & 1.08 & 0.27 & 0.13 & 1.08 & 0.16 & 0.22 & 0.14 & 0.14 \\ 0.29 & 0.31 & 0.06 & 0.18 & 0.13 & 0.14 & 0.21 & 0.23 & 0.23 & 0.24 \\ 99.21 & 98.97 & 98.48 & 99.32 & 98.48 & 99.11 & 99.33 & 99.34 & 99.92 & 99.47 \\ 3.67 & 3.52 & 8.54 & 6.33 & 6.10 & 4.31 & 4.12 & 3.09 & 4.82 & 3.14 \\ 1.41 & 1.70 & 3.28 & 2.86 & 4.89 & 3.36 & 2.27 & 1.48 & 3.47 & 3.11 \\ 0.27 & 0.30 & 0.25 & 0.47 & 0.52 & 0.24 & 0.20 & 0.18 & 0.36 & 0.38 \\ 0.54 & 0.51 & 0.56 & 0.67 & 0.74 & 0.76 & 0.59 & 0.56 & 0.65 & 0.62 \\ & & & & & & & & 110 & \\ 121 & 106 & 252 & 458 & 985 & 1022 & 150 & 110 & 417 & 225 \\ 340 & 338 & 179 & 172 & 107 & 125 & 255 & 260 & 251 & 261 \\ 164 & 170 & 126 & 89 & 74 & 66 & 123 & 117 & 119 & 140\end{array}$

Dry and Reduced Analyses

$\begin{array}{rrrrrrrrrr}48.26 & 48.62 & 50.01 & 50.07 & 47.29 & 45.74 & 48.35 & 48.84 & 47.63 & 47.53 \\ 16.06 & 15.61 & 13.70 & 13.09 & 10.01 & 9.08 & 15.01 & 14.99 & 13.23 & 15.03 \\ 11.88 & 12.27 & 14.86 & 11.30 & 13.14 & 12.91 & 11.91 & 11.91 & 12.48 & 12.22 \\ 7.74 & 7.13 & 9.92 & 12.78 & 20.10 & 22.49 & 9.75 & 8.46 & 12.85 & 11.09 \\ 9.35 & 9.43 & 5.17 & 8.19 & 6.41 & 5.45 & 9.86 & 10.51 & 9.11 & 8.63 \\ 3.06 & 2.97 & 2.68 & 2.24 & 1.23 & 1.64 & 2.45 & 2.55 & 2.03 & 2.55 \\ 0.46 & 0.66 & 1.11 & 0.28 & 0.13 & 1.10 & 0.16 & 0.22 & 0.14 & 0.14 \\ 2.77 & 2.84 & 2.39 & 1.72 & 1.36 & 1.27 & 2.14 & 2.14 & 2.13 & 2.41 \\ 0.30 & 0.32 & 0.06 & 0.18 & 0.13 & 0.14 & 0.21 & 0.23 & 0.23 & 0.24 \\ 0.11 & 0.16 & 0.08 & 0.15 & 0.18 & 0.17 & 0.14 & 0.14 & 0.16 & 0.15\end{array}$

$\begin{array}{lllllllll}99.99 & 100.01 & 99.98 & 100.00 & 99.98 & 99.99 & 99.98 & 99.99 & 99.99\end{array}$

CIPW Norms Assuming $\frac{\mathrm{Fe}^{+3}}{\mathrm{Fe}^{+2}+\mathrm{Fe}^{+3}}=0.15$

\begin{tabular}{rrrrrrrrrr}
2.713 & 3.892 & 6.544 & 1.651 & 0.767 & 6.487 & 0.944 & 1.298 & 0.826 & 0.826 \\
25.844 & 25.076 & 22.625 & 18.918 & 10.387 & 13.850 & 20.694 & 21.536 & 17.143 & 21.534 \\
28.672 & 27.252 & 22.023 & 24.788 & 21.365 & 14.137 & 29.433 & 28.751 & 26.521 & 29.093 \\
& & & & & & & & & \\
6.542 & 7.241 & 1.326 & 6.093 & 3.977 & 4.983 & 7.526 & 9.099 & 7.133 & 5.040 \\
9.544 & 10.643 & 18.708 & 23.887 & 25.313 & 7.491 & 15.117 & 14.721 & 17.898 & 13.501 \\
6.209 & 7.832 & 13.135 & 10.156 & 8.490 & 2.218 & 8.508 & 9.548 & 8.135 & 6.693 \\
6.795 & 4.958 & 4.163 & 5.523 & 17.272 & 33.923 & 6.392 & 4.421 & 9.839 & 9.855 \\
4.872 & 4.021 & 3.221 & 2.588 & 6.385 & 11.071 & 3.964 & 3.160 & 4.928 & 5.385 \\
2.865 & 2.966 & 3.588 & 2.721 & 3.169 & 3.111 & 2.880 & 2.880 & 3.010 & 2.952 \\
5.251 & 5.382 & 4.529 & 3.260 & 2.578 & 2.407 & 4.057 & 4.057 & 4.037 & 4.568 \\
0.709 & 0.756 & 0.142 & 0.426 & 0.307 & 0.331 & 0.497 & 0.544 & 0.544 & 0.567 \\
& & & & & & & & & \\
100.017 & 100.019 & 100.004 & 100.011 & 100.009 & 100.009 & 100.013 & 100.014 & 100.014 & 100.014 \\
57.229 & 56.220 & 51.193 & 45.358 & 32.519 & 34.474 & 51.071 & 51.585 & 44.489 & 51.453 \\
42.787 & 43.798 & 48.812 & 54.653 & 67.490 & 65.536 & 48.942 & 48.429 & 55.525 & 48.562 \\
\hline
\end{tabular}


TABLE 15 - Continued

\begin{tabular}{lcccccccc}
\hline Core/Section/Piece No. & $27-2,6 \mathrm{~B}$ & $28.2,1 \mathrm{D}$ & $28-5,6 \mathrm{E}$ & $29-3,2 \mathrm{C}$ & $31-1,1 \mathrm{D}$ & $32-1,3 \mathrm{D}$ & $32-5,1 \mathrm{C}$ & $34-7$ \\
\hline Interval $(\mathrm{cm})$ & $131-134$ & $19-21$ & $107-109$ & $25-27$ & $15-18$ & $98-101$ & $72-75$ & $95-98$ \\
\hline Rock Type & Picrite & Tholeite & Tholeite & Tholeiite & Tholeiite & Picrite & Picrite & Tholeiite \\
\hline Lithologic Unit & Flow Unit & Flow Unit & $\begin{array}{c}\text { Flow Sub- } \\
\text { unit 26a }\end{array}$ & $\begin{array}{c}\text { Flow Sub- } \\
\text { unit 26b }\end{array}$ & $\begin{array}{c}\text { Flow Unit } \\
27\end{array}$ & $\begin{array}{c}\text { Flow Unit } \\
28\end{array}$ & $\begin{array}{c}\text { Flow Unit } \\
29\end{array}$ & $\begin{array}{c}\text { Flow Unit } \\
35\end{array}$ \\
\hline
\end{tabular}

Hole 433C

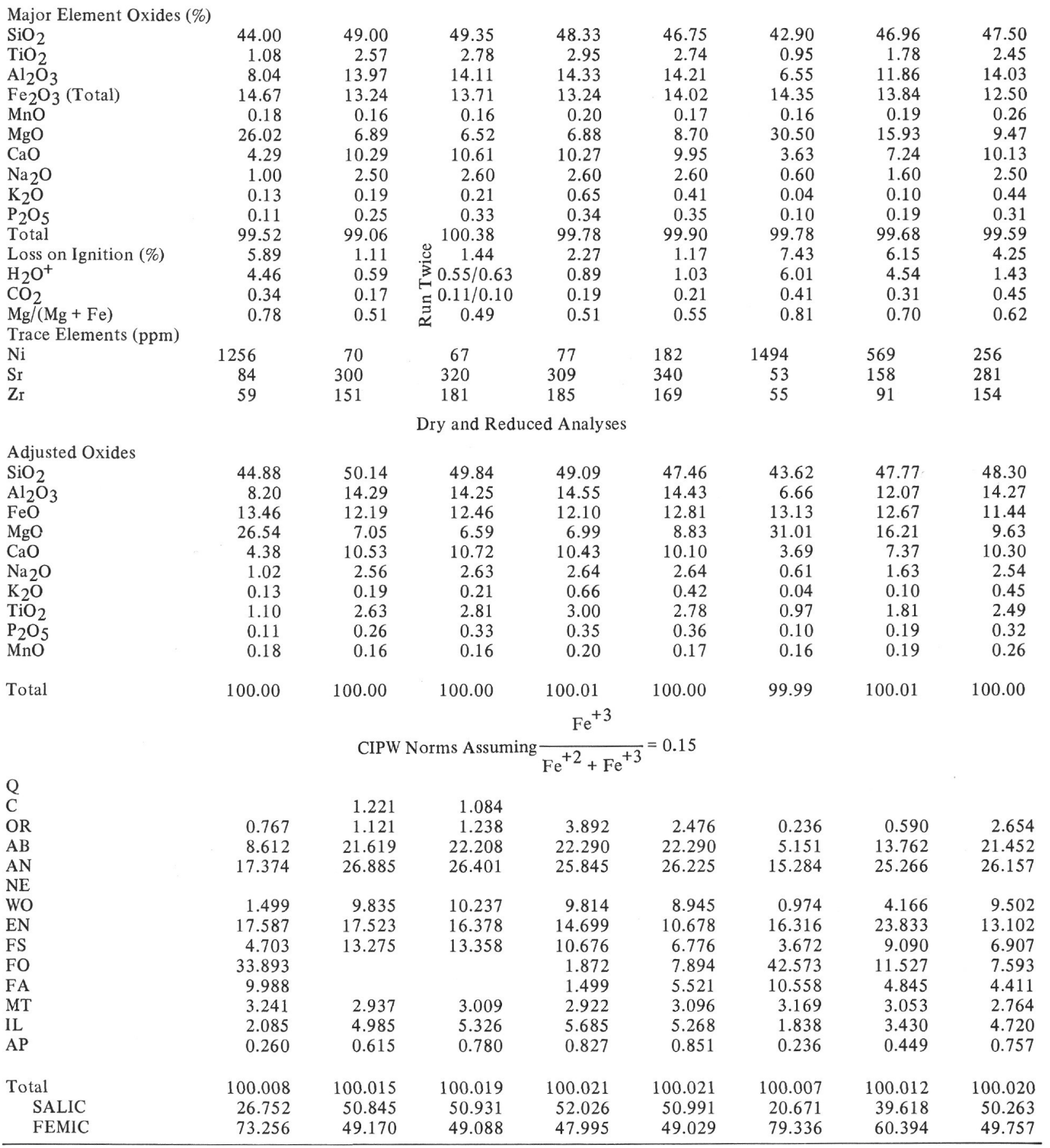


TABLE 15 - Continued

\begin{tabular}{cccccccccc}
\hline 35-6, 1D & $36-2,1 \mathrm{D}$ & $36-3,1 \mathrm{~J}$ & $36-4,1 \mathrm{~F}$ & $36-5,4 \mathrm{M}$ & $37-3,1 \mathrm{~F}$ & $38-1,1 \mathrm{G}$ & $38-5$ & $39-5,1 \mathrm{C}$ & $40-2,1 \mathrm{G}$ \\
\hline $27-29$ & $16-19$ & $79-82$ & $49-52$ & $119-122$ & $101-103$ & $76-79$ & $97-100$ & $102-104$ & $111-113$ \\
\hline Tholeiite & Tholeiite & Tholeiite & Tholeiite & Tholeiite & Tholeiite & Tholeiite & Tholeiite & Tholeiite & Tholeiite \\
\hline $\begin{array}{c}\text { Flow Unit } \\
35\end{array}$ & $\begin{array}{c}\text { Flow Unit } \\
37\end{array}$ & $\begin{array}{c}\text { Flow Unit } \\
38\end{array}$ & $\begin{array}{c}\text { Flow Unit } \\
39\end{array}$ & $\begin{array}{c}\text { Flow Unit } \\
41\end{array}$ & $\begin{array}{c}\text { Flow Sub- } \\
\text { unit 44b }\end{array}$ & $\begin{array}{c}\text { Flow Sub- } \\
\text { unit 45b }\end{array}$ & $\begin{array}{c}\text { Flow Unit } \\
47\end{array}$ & $\begin{array}{c}\text { Flow Unit } \\
48\end{array}$ & $\begin{array}{c}\text { Flow Unit } \\
49\end{array}$ \\
\hline
\end{tabular}

\section{Hole 433C}

$\begin{array}{rrrrrrrrrr}48.46 & 48.45 & 48.17 & 48.23 & 48.33 & 49.50 & 46.60 & 47.56 & 48.16 & 47.80 \\ 2.39 & 2.31 & 2.24 & 2.25 & 2.34 & 2.24 & 2.18 & 2.37 & 2.22 & 2.12 \\ 13.48 & 13.34 & 12.89 & 12.92 & 13.71 & 13.88 & 13.13 & 14.85 & 13.20 & 12.76 \\ 13.31 & 13.38 & 13.20 & 12.94 & 13.15 & 12.52 & 13.88 & 13.10 & 13.15 & 13.13 \\ 0.17 & 0.14 & 0.16 & 0.17 & 0.14 & 0.15 & 0.17 & 0.15 & 0.16 & 0.16 \\ 8.65 & 9.55 & 11.20 & 11.31 & 10.15 & 7.30 & 12.55 & 8.82 & 10.50 & 11.77 \\ 9.98 & 8.82 & 8.58 & 8.32 & 8.88 & 10.69 & 8.50 & 9.97 & 9.71 & 9.29 \\ 2.40 & 2.50 & 2.40 & 2.30 & 2.50 & 2.40 & 2.30 & 2.40 & 2.10 & 2.10 \\ 0.33 & 0.51 & 0.35 & 0.32 & 0.22 & 0.42 & 0.45 & 0.18 & 0.22 & 0.20 \\ 0.32 & 0.26 & 0.22 & 0.24 & 0.27 & 0.26 & 0.23 & 0.27 & 0.25 & 0.24 \\ 99.49 & 99.26 & 99.41 & 99.00 & 99.69 & 99.36 & 99.99 & 99.67 & 99.67 & 99.57 \\ 2.22 & 10.18 & 5.25 & 4.23 & 5.21 & 3.14 & 3.44 & 4.05 & 2.16 & 2.36 \\ 1.11 & 1.91 & 2.47 & 2.54 & 2.09 & 0.76 & 2.49 & 2.21 & 1.58 & 2.09 \\ 0.12 & 0.26 & 0.26 & 0.30 & 0.24 & 0.21 & 0.27 & 0.24 & 0.18 & 0.13 \\ 0.56 & 0.59 & 0.63 & 0.63 & 0.60 & 0.54 & 0.64 & 0.57 & 0.61 & 0.64 \\ & & & & & & & & & \\ 212 & 258 & 348 & 324 & 260 & 162 & 433 & 156 & 308 & 399 \\ 277 & 225 & 218 & 214 & 245 & 274 & 259 & 281 & 257 & 237 \\ 165 & 130 & 139 & 141 & 143 & 129 & 132 & 139 & 132 & 131\end{array}$

Dry and Reduced Analysis

\begin{tabular}{|c|c|c|c|c|c|c|c|c|c|}
\hline 49.37 & 49.48 & 49.11 & 49.37 & 49.13 & 50.45 & 47.26 & 48.35 & 48.97 & 48.65 \\
\hline 13.73 & 13.62 & 13.14 & 13.22 & 13.94 & 14.15 & 13.32 & 15.10 & 13.42 & 12.99 \\
\hline 12.20 & 12.30 & 12.11 & 11.91 & 12.03 & 11.49 & 12.67 & 11.99 & 12.03 & 12.02 \\
\hline 8.81 & 9.75 & 11.42 & 11.58 & 10.32 & 7.44 & 12.73 & 8.97 & 10.68 & 11.98 \\
\hline 10.17 & 9.01 & 8.75 & 8.52 & 9.03 & 10.90 & 8.62 & 10.14 & 9.87 & 9.46 \\
\hline 2.44 & 2.55 & 2.45 & 2.35 & 2.54 & 2.45 & 2.33 & 2.44 & 2.14 & 2.14 \\
\hline 0.34 & 0.52 & 0.36 & 0.33 & 0.22 & 0.43 & 0.46 & 0.18 & 0.22 & 0.20 \\
\hline 2.43 & 2.36 & 2.28 & 2.30 & 2.38 & 2.28 & 2.21 & 2.41 & 2.26 & 2.16 \\
\hline 0.33 & 0.27 & 0.22 & 0.25 & 0.27 & 0.27 & 0.23 & 0.27 & 0.25 & 0.24 \\
\hline 0.17 & 0.14 & 0.16 & 0.17 & 0.14 & 0.15 & 0.17 & 0.15 & 0.16 & 0.16 \\
\hline 99.99 & 100.00 & 100.00 & 100.00 & 100.00 & 100.01 & 100.00 & 100.00 & 100.00 & 100.00 \\
\hline \multicolumn{10}{|c|}{ CIPW Norms Assuming $\frac{\mathrm{Fe}^{+3}}{\mathrm{Fe}^{+2}+\mathrm{Fe}^{+3}}=0.15$} \\
\hline 2.005 & 3.066 & 2.123 & 1946 & 1297 & $\begin{array}{l}0.616 \\
2536\end{array}$ & 2713 & 1062 & 1207 & 1170 \\
\hline 20.607 & 21.532 & 20.690 & 19.845 & 21.448 & 20.688 & 19.674 & 20.605 & $\begin{array}{r}1.297 \\
18.070\end{array}$ & $\begin{array}{l}1.1 / 9 \\
18.072\end{array}$ \\
\hline 25.458 & 24.131 & 23.745 & 24.500 & 25.931 & 26.287 & 24.476 & 29.658 & 26.307 & 25.197 \\
\hline 9.498 & 7.814 & 7.575 & 6.703 & 7.104 & 10.820 & 6.972 & 7.844 & 8.737 & 8.382 \\
\hline 18.687 & 17.980 & 18.611 & 21.329 & 18.727 & 18.491 & 12.088 & 15.679 & 20.819 & 19.980 \\
\hline 11.642 & 10.275 & 9.003 & 9.952 & 9.804 & 12.842 & 5.605 & 9.376 & 10.716 & 9.272 \\
\hline 2.251 & 4.381 & 6.849 & 5.224 & 4.850 & & 13.700 & 4.637 & 4.011 & 6.865 \\
\hline 1.546 & 2.759 & 3.652 & 2.686 & 2.798 & & 7.001 & 3.056 & 2.275 & 3.511 \\
\hline 2.938 & 2.966 & 2.923 & 2.880 & 2.908 & 2.778 & 3.053 & 2.894 & 2.908 & 2.894 \\
\hline 4.606 & 4.473 & 4.322 & 4.359 & 4.511 & 4.321 & 4.188 & 4.568 & 4.283 & 4.094 \\
\hline 0.780 & 0.638 & 0.520 & 0.591 & 0.638 & 0.638 & 0.544 & 0.638 & 0.591 & 0.567 \\
\hline 100.019 & 100.016 & 100.013 & 100.015 & 100.016 & 100.016 & 100.014 & 100.016 & 100.015 & 100.014 \\
\hline 48.071 & 18.729 & 46.558 & 46.291 & 48.676 & 50.126 & 46.863 & 51.325 & 45.674 & 44.449 \\
\hline 51.948 & 51.287 & 53.455 & 53.724 & 51.340 & 49.890 & 53.151 & 48.691 & 54.341 & 55.566 \\
\hline
\end{tabular}


TABLE 15 - Continued

\begin{tabular}{lcccccccc}
\hline Core/Section/Piece No. & $41-1,1 \mathrm{C}$ & $42-1,1 \mathrm{G}$ & $42-3,1 \mathrm{~B}$ & $42-5,1 \mathrm{~F}$ & $45-5,1 \mathrm{~A}$ & $46-3$ & $47-5,6 \mathrm{~B}$ & $49-2,1 \mathrm{D}$ \\
\hline Interval $(\mathrm{cm})$ & $19-21$ & $2-6$ & $14-16$ & $37-39$ & $6-8$ & $72-74$ & $87-89$ & $31-36$ \\
\hline Rock Type & Tholeiite & Tholeiite & Tholeiite & Tholeiite & Tholeiite & Tholeiite & Tholeiite & Tholeiite \\
\hline Lithologic Unit & Flow Unit & Flow Unit & $\begin{array}{c}\text { Flow Unit } \\
51\end{array}$ & $\begin{array}{c}\text { Flow Unit } \\
52\end{array}$ & $\begin{array}{c}\text { Flow Unit } \\
60\end{array}$ & $\begin{array}{c}\text { Flow Sub- } \\
\text { unit 62a }\end{array}$ & $\begin{array}{c}\text { Flow Unit } \\
64\end{array}$ & $\begin{array}{c}\text { Flow Unit } \\
66\end{array}$ \\
\hline
\end{tabular}

Hole 433C

Major-Element Oxides (\%)

$\mathrm{SiO}_{2}$

$\mathrm{TiO}_{2}$

$\mathrm{Al}_{2} \mathrm{O}_{3}$

$\mathrm{Fe}_{2} \mathrm{O}_{3}$ (Total)

$\mathrm{MnO}$

$\mathrm{MgO}$

$\mathrm{CaO}$

$\mathrm{Na}_{2} \mathrm{O}$

$\mathrm{K}_{2} \mathrm{O}$

$\mathrm{P}_{2} \mathrm{O}_{5}$

Total

Loss on Ignition (\%)

$\mathrm{H}_{2} \mathrm{O}^{+}$

$\mathrm{CO}_{2}$

$\mathrm{Mg} /(\mathrm{Mg}+\mathrm{Fe})$

Trace Elements (ppm)

$\mathrm{Ni}$

$\mathrm{Sr}$

$\mathrm{Zr}$

Adjusted Oxides

$\mathrm{SiO}_{2}$

$\mathrm{Al}_{2} \mathrm{O}_{3}$

$\mathrm{FeO}$

$\mathrm{MgO}$

$\mathrm{CaO}$

$\mathrm{Na}_{2} \mathrm{O}$

$\mathrm{K}_{2} \mathrm{O}$

$\mathrm{TiO}_{2}$

$\mathrm{P}_{2} \mathrm{O}_{5}$

$\mathrm{MnO}$

Total

Q

OR

$\mathrm{AB}$

AN

$\mathrm{NE}$

WO

FS

FO

FA

MT

IL

AP

Total

SALIC

FEMIC

$\begin{array}{rr}48.96 & 49.26 \\ 2.39 & 2.37 \\ 14.00 & 13.89 \\ 13.28 & 12.91 \\ 0.12 & 0.13 \\ 7.68 & 7.68 \\ 10.07 & 10.14 \\ 2.60 & 2.70 \\ 0.24 & 0.25 \\ 0.26 & 0.26 \\ 99.60 & 99.59 \\ 3.08 & 2.89 \\ 1.08 & 1.02 \\ 0.20 & 0.22 \\ 0.53 & 0.54\end{array}$
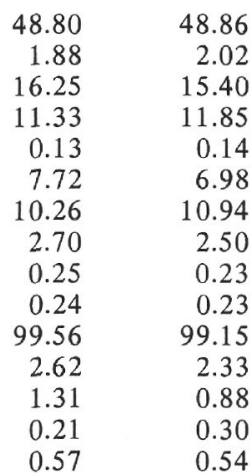

$$
\begin{array}{r}
48.72 \\
2.16 \\
14.47 \\
12.90 \\
0.21 \\
6.69 \\
11.15 \\
2.60 \\
0.18 \\
0.21 \\
99.29 \\
2.26 \\
0.81 \\
0.32 \\
0.51
\end{array}
$$

83
268
132

84
267
143

143

132
88

$\begin{array}{rr}85 & 84 \\ 270 & 272 \\ 115 & 118\end{array}$

105

$$
\begin{array}{r}
48.96 \\
2.19 \\
14.72 \\
13.17 \\
0.13 \\
6.75 \\
9.58 \\
2.80 \\
0.65 \\
0.26 \\
99.21 \\
3.60 \\
1.24 \\
0.19 \\
0.50
\end{array}
$$

80
259

259
140

$\begin{array}{rr}45.45 & 46.70 \\ 3.12 & 2.84 \\ 14.00 & 15.44 \\ 14.80 & 14.40 \\ 0.19 & 0.16 \\ 6.76 & 6.19 \\ 10.92 & 9.77 \\ 2.60 & 2.90 \\ 0.89 & 0.52 \\ 0.33 & 0.32 \\ 99.06 & 99.24 \\ 4.65 & 3.97 \\ 1.74 & 1.84 \\ 1.06 & 0.22 \\ 0.48 & 0.46 \\ & \\ 186 & 133 \\ 294 & 325 \\ 184 & 168\end{array}$

Dry and Reduced Analyses

$\begin{array}{rrrrrrrr}49.82 & 50.11 & 49.58 & 49.88 & 49.71 & 50.02 & 46.58 & 47.75 \\ 14.25 & 14.13 & 16.51 & 15.72 & 14.77 & 15.04 & 14.35 & 15.79 \\ 12.16 & 11.82 & 10.35 & 10.88 & 11.85 & 12.11 & 13.65 & 13.25 \\ 7.82 & 7.81 & 7.84 & 7.13 & 6.83 & 6.90 & 6.93 & 6.33 \\ 10.25 & 10.32 & 10.42 & 11.17 & 11.38 & 9.79 & 11.19 & 0.99 \\ 2.65 & 2.75 & 2.74 & 2.55 & 2.65 & 2.86 & 2.66 & 2.97 \\ 0.24 & 0.25 & 0.25 & 0.23 & 0.18 & 0.66 & 0.91 & 0.53 \\ 2.43 & 2.41 & 1.91 & 2.06 & 2.20 & 2.24 & 3.20 & 2.90 \\ 0.26 & 0.26 & 0.24 & 0.23 & 0.21 & 0.27 & 0.34 & 0.33 \\ 0.12 & 0.13 & 0.13 & 0.14 & 0.21 & 0.13 & 0.19 & 0.16\end{array}$

100.00 $\begin{array}{lll}99.97 & 99.99 & 99.99\end{array}$

$$
\text { CIPW Norms Assuming } \frac{\mathrm{Fe}^{+3}}{\mathrm{Fe}^{+2}+\mathrm{Fe}^{+3}}=0.15
$$

\begin{tabular}{rrrrrrrr}
1.415 & 1.475 & 1.475 & 1.357 & 1.062 & 3.892 & 5.365 & 3.125 \\
22.377 & 23.226 & 23.150 & 21.541 & 22.381 & 24.147 & 20.821 & 25.076 \\
26.223 & 25.424 & 31.963 & 30.716 & 27.822 & 26.193 & 24.471 & 28.126 \\
& & & & & & 0.886 & \\
9.531 & 10.013 & 7.552 & 9.647 & 11.340 & 8.563 & 11.983 & 8.006 \\
18.089 & 18.011 & 14.650 & 16.915 & 15.548 & 14.092 & 6.320 & 8.140 \\
12.558 & 12.120 & 8.867 & 11.763 & 12.444 & 11.292 & 5.305 & 7.415 \\
0.943 & 0.983 & 3.396 & 0.569 & 1.002 & 2.140 & 7.638 & 5.319 \\
0.721 & 0.729 & 2.265 & 0.436 & 0.884 & 1.890 & 7.066 & 5.339 \\
2.937 & 2.851 & 2.505 & 2.620 & 2.865 & 2.922 & 3.298 & 3.197 \\
4.605 & 4.568 & 3.622 & 3.906 & 4.170 & 4.245 & 6.064 & 5.496 \\
0.615 & 0.615 & 0.568 & 0.544 & 0.496 & 0.638 & 0.803 & 0.780 \\
& & & & & & & \\
100.015 & 100.015 & 100.014 & 100.014 & 100.013 & 100.016 & 100.020 & 100.019 \\
50.015 & 50.124 & 56.589 & 53.613 & 51.264 & 54.232 & 51.544 & 56.327 \\
50.000 & 49.891 & 43.425 & 46.400 & 48.749 & 45.783 & 48.476 & 43.692 \\
\hline
\end{tabular}




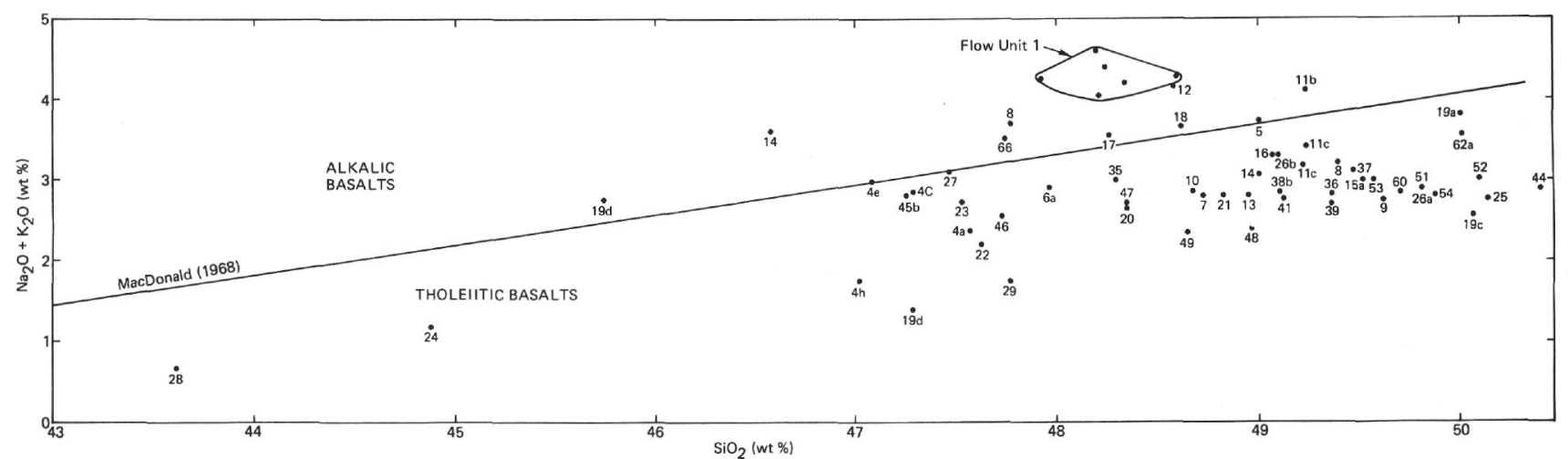

Figure 27. Total alkalis versus silica for volcanic rocks from Site 433 (dry and reduced analyses).

TABLE 16

Range and Average Abundance (ppm) of Selected Minor Elements in Basalts of Hole 315A, Compared with Those of Hawaiian Tholeiites and Alkalic Olivine Basalts (after Jackson et al., 1976)

\begin{tabular}{|c|c|c|c|c|c|c|c|}
\hline \multirow[b]{2}{*}{ Element } & \multicolumn{2}{|c|}{ Hole 315A } & \multicolumn{2}{|c|}{$\begin{array}{l}\text { Hawaiian } \\
\text { Tholeiites }\end{array}$} & \multicolumn{2}{|c|}{$\begin{array}{c}\text { Hawaiian Alkalic } \\
\text { Olivine Basalts }\end{array}$} & \multirow[b]{2}{*}{ Source } \\
\hline & Range & Average & Range & Average & Range & Average & \\
\hline $\mathrm{Ba}$ & $92-144$ & $117^{\mathrm{a}}$ & $50-300$ & 120 & $200-1000$ & 420 & $\mathrm{e}, \mathrm{f}, \mathrm{g}, \mathrm{h}, \mathrm{i}, \mathrm{j}$ \\
\hline $\mathrm{Sr}$ & $237-275$ & $249^{a}$ & $100-1000$ & 383 & $262-1000$ & 607 & $\mathrm{e}, \mathrm{f}, \mathrm{g}, \mathrm{h}, \mathrm{i}, \mathrm{j}, \mathrm{k}$ \\
\hline Co & $43.5-55.9$ & $49.3^{b}$ & $20-71$ & 48 & $30-100$ & 66 & $\mathrm{e}, \mathrm{f}, \mathrm{g}, \mathrm{h}, \mathrm{i}, \mathrm{j}$ \\
\hline $\mathrm{Cr}$ & $\begin{array}{l}75-174 \\
61-145\end{array}$ & $\begin{array}{l}121^{\mathrm{b}} \\
108^{\mathrm{c}}\end{array}$ & $150-1500$ & 567 & $20-1000$ & 433 & $\mathrm{e}, \mathrm{f}, \mathrm{g}, \mathrm{h}, \mathrm{i}, \mathrm{j}$ \\
\hline $\mathrm{Cu}$ & $70-100$ & $87^{d}$ & $50-200$ & 139 & $30-300$ & 105 & $e, f, g, h, i, j$ \\
\hline $\mathrm{Nb}$ & $32-44$ & $38 \mathrm{c}$ & $>10$ & $>10$ & $10-40$ & 20 & $\mathrm{e}, \mathrm{f}, \mathrm{g}, \mathrm{h}, \mathrm{i}, \mathrm{j}$ \\
\hline $\mathrm{Ni}$ & $38-92$ & $66^{\mathrm{c}}$ & $50-1240$ & 235 & $15-972$ & 219 & $\mathrm{e}, \mathrm{f}, \mathrm{g}, \mathrm{h}, \mathrm{i}, \mathrm{j}$ \\
\hline $\mathrm{P}$ & 1091-1397 & $1314^{a}$ & $524-2095$ & 1135 & $873-3317$ & 1615 & $1, \mathrm{~m}$ \\
\hline $\mathrm{Sc}$ & $25.9-34.4$ & $29.9 \mathrm{~b}$ & $20-70$ & 32 & $20-50$ & 30 & $e, f, g, h, i, j$ \\
\hline $\mathrm{Ti}$ & $13309-17505$ & $15527^{a}$ & $10971-22122$ & 14988 & $11091-24100$ & 18045 & $1, \mathrm{~m}$ \\
\hline V & $170-280$ & 235 & $150-500$ & 289 & $30-500$ & 323 & $e, f, g, h, i, j$ \\
\hline $\mathrm{Y}$ & $39-60$ & $50^{\mathrm{c}}$ & $15-50$ & 26 & $19-50$ & 27 & $\mathrm{e}, \mathrm{f}, \mathrm{g}, \mathrm{h}, \mathrm{i}, \mathrm{j}, \mathrm{k}$ \\
\hline $\mathrm{Zr}$ & $165-230$ & $192^{\mathrm{c}}$ & $70-247$ & 131 & $70-348$ & 149 & $\mathrm{e}, \mathrm{f}, \mathrm{g}, \mathrm{h}, \mathrm{i}, \mathrm{j}$ \\
\hline
\end{tabular}

${ }_{\mathrm{b}}^{\mathrm{a}} \mathrm{X}$-ray fluorescence analyses.

$\mathrm{b}_{\mathrm{C}}$ Radioactivation and radiochemistry analyses.

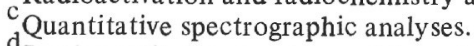

$\mathrm{d}_{\text {Semiquantitative spectrographic analyses. }}$.

e Unpublished semiquantitative spectrographic analy ses of E. D. Jackson.

f Unpublished semiquantitative spectrographic analyses of R. L. Christiansen.

${ }^{g}$ Unpublished semiquantitative spectrographic analyses of D. A. Swanson.

${ }_{i}$ Unpublished semiquantitative spectrographic analyses of R. I. Tilling.

${ }_{j}^{1}$ Unpublished semiquantitative spectrographic analyses of T. L. Wright.

$\mathrm{j}_{\text {Hubbard (1967). }}$

${ }^{\mathrm{k}}$ Schilling (1966)

${ }_{\mathrm{m}} \mathrm{MacDonald}$ and Katsura (1964).

$\mathrm{m}_{\text {MacDonald (1968). }}$

directions represent the ambient magnetic field when these basalts erupted and cooled. Results of paleomagnetic measurements on individual samples are summarized in Table 17. This table follows the format used in the site summary chapters for Sites 430 and $\mathbf{4 3 2}$.

The basalts from Suiko Seamount are characterized by unimodal, nearly Gaussian distribution of $\mathrm{J}_{\mathrm{NRM}}$, high median demagnetizing field, and moderate to high $\mathrm{Q}_{\mathrm{n}}^{\prime}$ ratio. Shipboard observations using the reflecting microscope showed that the ferromagnetic minerals in these rocks are fresh titanomagnetites with sharp crystal boundaries. Most titanomagnetite grains range from homogeneous and unoxidized to moderately oxidized with exsolution lamellae of ilmenite, but some show higher stages of oxidation with pseudobrookite and hematite (Wilson and Haggarty, 1966). They therefore represent different stages of high-temperature oxidation commonly observed in subaerially erupted volcanic rocks (Buddington and Lindsley, 1964; Ozima and Larson, 1970), but with little trace of low-temperature oxidation resulting in formation of titanomaghemite (Readman and O'Reilley, 1972). These observations have been confirmed by shore-based studies (Kono et al., this volume). In typical mid-oceanic ridge basalts, the effect of low-temperature oxidation becomes apparent at an age of about $1 \mathrm{~m} . \mathrm{y}$. (Johnson and Atwater, 1977). By this effect, Curie temperature and MDF are increased, and $J_{N R M}$, susceptibility, and $Q_{n}^{\prime}$ are de- 


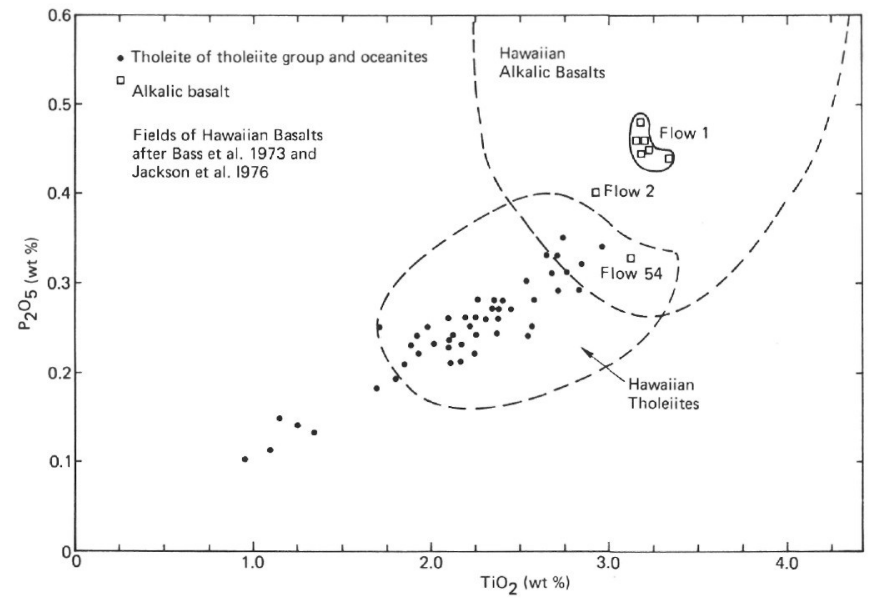

Figure 28. $\mathrm{P}_{2} \mathrm{O}_{5}-\mathrm{TiO}_{2}$ plots for basalts from Site 433.

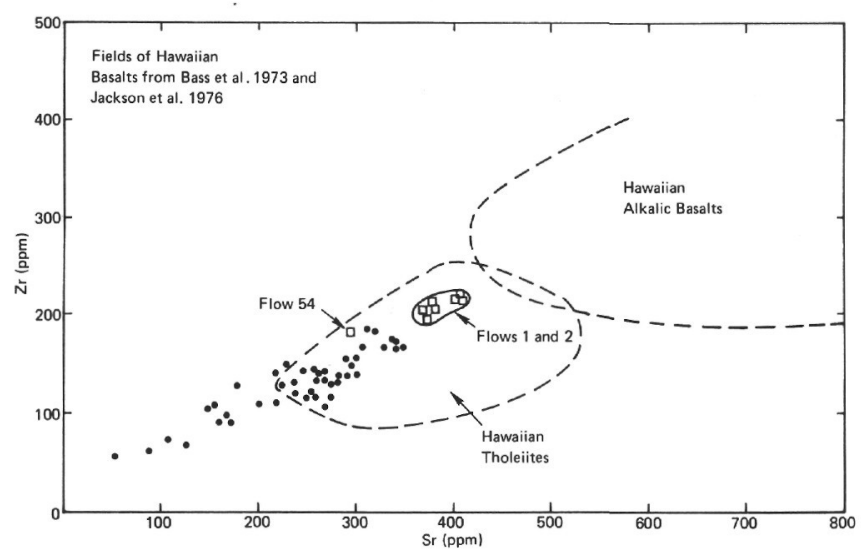

Figure 29. Zr-Sr plots of basalts from Site 433.

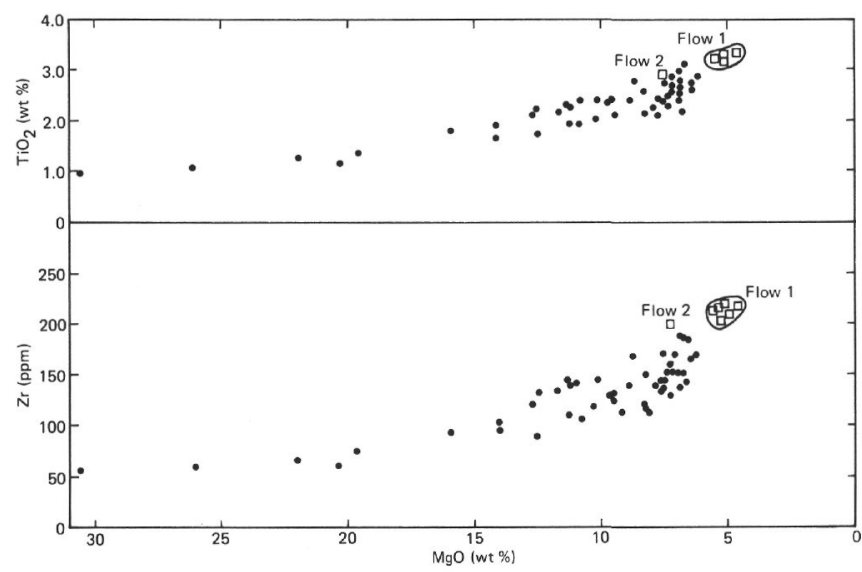

Figure 30. $\mathrm{MgO}$ variation diagrams for $\mathrm{Zr}$ and $\mathrm{TiO}_{2}$ in the basalts cored at Site 433. Symbols are the same as those of Figures 28 and 29.

creased. Shipboard and shore-based studies have shown, however, that the basalts from Suiko Seamount are similar in magnetic properties to those found on oceanic islands and not similar to mid-oceanic ridge basalts.

\section{Magnetic Stability and Flow Boundaries}

Samples from Site 433 were, on the whole, stable to $\mathrm{AF}$ demagnetization, and changes of more than about $10^{\circ}$ between the original NRM and the stable component were observed in only six flow units: $1,2,10,13$, 25 , and 27. Directions of stable remanence could be determined for these flows by AF demagnetization between 200 and 300 Oe.

Magnetic stability of most of the other samples was quite high; direction of magnetization changed only a few degrees throughout the AF demagnetization steps. We clearly did obtain the directions of primary magnetic moments representing the true field directions when the rocks formed.

The flow-mean values of inclination, $\mathrm{J}_{\mathrm{NRM}}, \mathrm{MDF}$, susceptibility, and $Q_{n}^{\prime}$ are listed in Table 18 . Because the magnetic stability was very high and groupings of inclination were good in most of the flows, it was sometimes possible to detect flow boundaries on the basis of inclination differences at places where the Initial Core Description failed to do so. Two such flow units (28 and 51 ) were studied closely by taking additional samples, and the existence of boundaries within them was confirmed by magnetic measurements as well as by subsequent visual observations of the core. Some of the units suspected of being sub-flow members (designated as a, b, etc.) also showed distinctly different inclinations. Examples of this kind are Flow Sub-units 26a, 46a, and $62 \mathrm{c}$. In the case of Flow Unit 26, enough samples were measured to warrant separation of the flow unit into Sub-units 26a and 26b, but in other cases (46a and 62c) the samples were omitted from the inclination analyses because the number of samples was only one.

Some samples taken from places too close to the upper flow unit boundaries show inclinations very similar to those of the upper flows, and very different from the mean inclination of the flows to which they belong. This probably represents the effect of reheating, so such samples were excluded from inclination analysis, as indicated in the footnotes of Table 18.

\section{Magnetic Inclination, Secular Variation, and Paleolatitude}

Figure 31 shows the change of inclination with depth. The dots and horizontal bars represent the individual flow mean and standard deviations, and the vertical bars represent the vertical extent of flow units with different magnetic inclinations. Although this figure is based only on shipboard data, inclusion of shore-based data does not change the figure except in a few small details (Kono, this volume).

In this figure, we can see that some of the consecutive flow units have very similar inclinations; e.g., Flow Units 4 to 7 and 35 to 38 . This may indicate that these units erupted in a short time, say, a few hundred years. At other places, most notably between Flow Units 51-2 and 63 , the inclination data define a smooth curve against depth. This certainly reflects the change in the earth's magnetic field, i.e., secular variation. If the characteristics of the geomagnetic secular variation at 
TABLE 17

Paleomagnetism, Site 433

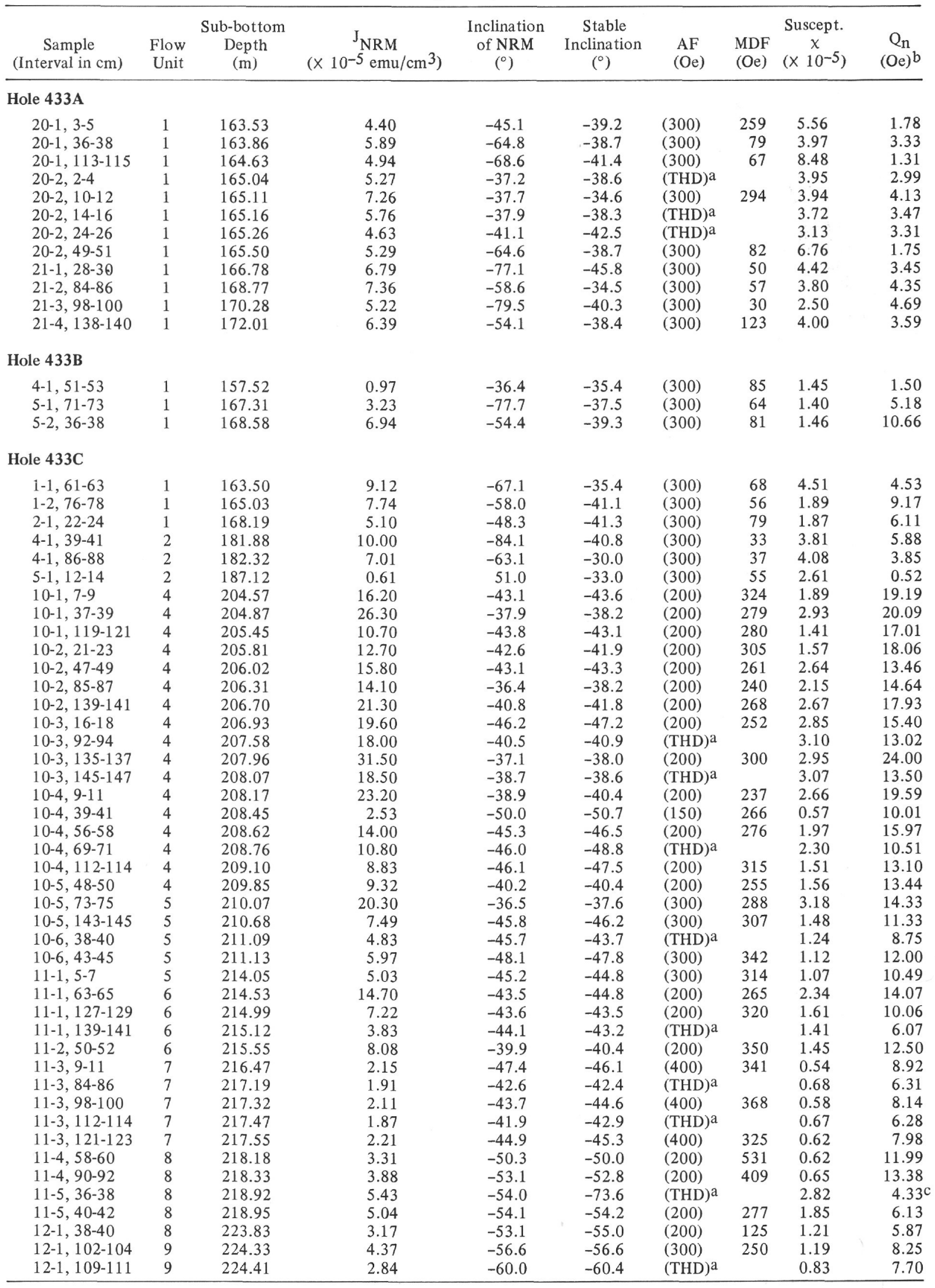


TABLE 17 - Continued

\begin{tabular}{|c|c|c|c|c|c|c|c|c|c|}
\hline $\begin{array}{c}\text { Sample } \\
\text { (Interval in } \mathrm{cm} \text { ) }\end{array}$ & $\begin{array}{l}\text { Flow } \\
\text { Unit }\end{array}$ & $\begin{array}{l}\text { Sub-bottom } \\
\text { Depth } \\
\text { (m) }\end{array}$ & $\begin{array}{c}\mathrm{J}_{\mathrm{NRM}} \\
\left(\times 10^{-5} \mathrm{emu} / \mathrm{cm}^{3}\right)\end{array}$ & $\begin{array}{l}\text { Inclination } \\
\text { of NRM } \\
\left({ }^{\circ}\right)\end{array}$ & $\begin{array}{c}\text { Stable } \\
\text { Inclination } \\
\left({ }^{\circ}\right)\end{array}$ & $\begin{array}{l}\mathrm{AF} \\
(\mathrm{Oe})\end{array}$ & $\begin{array}{l}\text { MDF } \\
(\mathrm{Oe})\end{array}$ & $\begin{array}{c}\text { Suscept. } \\
\times \\
\left(\times 10^{-5}\right)\end{array}$ & $\begin{array}{c}\mathrm{Q}_{\mathrm{n}} \\
(\mathrm{Oe})^{\mathrm{b}}\end{array}$ \\
\hline \multicolumn{10}{|l|}{ Hole 433C } \\
\hline $12-2,49-51$ & 9 & 225.19 & 2.78 & -56.1 & -55.8 & $(300)$ & 217 & 0.79 & 7.91 \\
\hline $12-2,115-117$ & 9 & 225.85 & 2.48 & -55.3 & -57.1 & $(300)$ & 156 & 0.66 & 8.45 \\
\hline $12-3,5-7$ & 9 & 226.21 & 1.67 & -43.1 & -42.2 & (THD) $)^{\mathrm{a}}$ & & 1.12 & $3.34^{\mathrm{C}}$ \\
\hline $12-3,48-50$ & 9 & 226.63 & 4.22 & -54.4 & -56.3 & $(300)$ & 110 & 1.22 & 7.74 \\
\hline $12-3,100-102$ & 10 & 227.08 & 4.50 & -20.8 & -23.0 & $(300)$ & 90 & 1.67 & 6.06 \\
\hline $12-4,22-24$ & 10 & 227.62 & 3.99 & -18.6 & -25.4 & $(300)$ & 160 & 0.82 & 10.90 \\
\hline $13-1,6-8$ & 10 & 230.03 & 4.60 & -40.6 & -30.4 & $(300)$ & 83 & 1.55 & 6.65 \\
\hline $13-1,125-127$ & 10 & 231.18 & 2.30 & -64.9 & -62.1 & (THD) $)^{\mathrm{a}}$ & & 1.31 & $3.95^{\mathrm{d}}$ \\
\hline $13-2,53-55$ & 10 & 231.93 & 3.75 & -52.2 & -35.0 & $(300)$ & 44 & 1.00 & 8.43 \\
\hline $13-2,103-105$ & 10 & 232.44 & 0.72 & -79.4 & -71.4 & (THD) $)^{\mathrm{a}}$ & & 0.88 & $1.85^{\mathrm{c}}$ \\
\hline $14-1,47-49$ & $11 \mathrm{~A}$ & 233.47 & 2.21 & -34.6 & -31.7 & $(200)$ & 372 & 1.58 & 3.12 \\
\hline $14-2,37-39$ & $11 \mathrm{~A}$ & 234.84 & 2.66 & -32.9 & -32.6 & (THD) $)^{\mathrm{a}}$ & & 0.96 & 6.24 \\
\hline $14-2,128-130$ & $11 \mathrm{~A}$ & 235.73 & 1.17 & -36.1 & -35.8 & $(200)$ & 569 & 0.57 & 4.60 \\
\hline $14-3,56-58$ & $11 \mathrm{~B}$ & 236.47 & 4.13 & -52.3 & -51.5 & $(400)$ & 367 & 1.62 & 5.71 \\
\hline $14-4,21-23$ & $11 \mathrm{~B}$ & 237.56 & 2.47 & -60.1 & -47.7 & $(400)$ & 61 & 1.52 & 3.64 \\
\hline $15-1,17-19$ & $11 \mathrm{~B}$ & 242.65 & 2.68 & -57.9 & -54.2 & $(\mathrm{THD})^{\mathrm{a}}$ & & 1.41 & 4.26 \\
\hline $15-1,47-49$ & $11 \mathrm{~B}$ & 242.94 & 4.92 & -52.7 & -53.3 & $(400)$ & 253 & 1.14 & 9.68 \\
\hline $15-1,10-12$ & $11 \mathrm{~B}$ & 242.57 & 2.40 & -53.0 & -53.4 & $(400)$ & 118 & 1.31 & 4.12 \\
\hline $15-2,103-105$ & $11 \mathrm{~B}$ & 244.40 & 4.00 & -43.1 & -51.7 & $(400)$ & 313 & 2.82 & 3.19 \\
\hline $15-3,127-129$ & 12 & 245.67 & 5.02 & -16.7 & -16.3 & $(300)$ & 369 & 1.82 & 6.19 \\
\hline $15-4,21-23$ & 12 & 246.00 & 3.58 & -22.5 & -18.5 & $(300)$ & 303 & 3.73 & 2.15 \\
\hline $15-4,46-48$ & 12 & 246.19 & 2.18 & -25.6 & -19.3 & $(300)$ & 301 & 3.90 & 1.25 \\
\hline $15-4,48-50$ & 12 & 246.22 & 1.63 & -28.8 & -32.9 & $(\mathrm{THD})^{\mathrm{a}}$ & & 5.90 & $0.62^{\mathrm{d}}$ \\
\hline $15-4,84-86$ & 12 & 246.50 & 1.26 & -25.6 & -28.0 & (THD) & & 4.79 & $0.59 \mathrm{c}$ \\
\hline $15-4,99-101$ & 12 & 246.61 & 2.17 & -30.2 & -23.2 & $(300)$ & 267 & 3.55 & 1.37 \\
\hline $15-4,115-117$ & 12 & 246.75 & 2.23 & -25.8 & -20.1 & $(300)$ & 298 & 2.94 & 1.70 \\
\hline $15-5,14-16$ & 12 & 247.13 & 2.58 & -24.5 & -19.6 & $(300)$ & 436 & 2.45 & 2.36 \\
\hline $15-5,72-74$ & 13 & 247.66 & 1.50 & -21.2 & -22.1 & $(\mathrm{THD})^{\mathrm{a}}$ & & 1.53 & 2.20 \\
\hline $15-5,79-81$ & 13 & 247.72 & 1.78 & -23.7 & -20.8 & $(300)$ & 446 & 1.93 & 2.06 \\
\hline $15-6,31-33$ & 13 & 248.69 & 4.94 & -37.0 & -23.7 & $(300)$ & 191 & 2.92 & 3.79 \\
\hline $16-1,11-13$ & 13 & 252.10 & 7.80 & -83.3 & -23.5 & $(300)$ & 46 & 3.90 & 4.48 \\
\hline $16-1,75-77$ & 13 & 252.68 & 4.08 & -59.4 & -24.0 & $(300)$ & 79 & 2.73 & 3.35 \\
\hline $16-1,80-82$ & 13 & 252.74 & 3.24 & -55.5 & -46.6 & $(\mathrm{THD})^{\mathrm{a}}$ & & 3.16 & $2.30^{\mathrm{c}}$ \\
\hline $17-1,17-19$ & 13 & 255.65 & 8.93 & -72.7 & -21.7 & $(300)$ & 61 & 2.11 & 9.51 \\
\hline $19-1,14-16$ & 13 & 261.62 & 5.13 & -59.8 & -17.7 & $(300)$ & 69 & 2.88 & 3.99 \\
\hline $19-1,87-89$ & 14 & 262.26 & 1.47 & -24.4 & -24.9 & $(300)$ & 825 & 0.42 & 7.92 \\
\hline $19-1,112-114$ & 14 & 262.51 & 1.22 & -24.6 & -24.9 & $(300)$ & 657 & 0.31 & 8.81 \\
\hline $19-2,9-11$ & 14 & 262.95 & 0.95 & -25.8 & -24.6 & (THD) $)^{\mathrm{a}}$ & & 0.43 & 4.92 \\
\hline $19-2,12-14$ & 14 & 262.98 & 0.94 & -22.2 & -21.9 & $(300)$ & 497 & 0.30 & 7.06 \\
\hline $19-2,23-25$ & 14 & 263.07 & 1.04 & -25.6 & -24.8 & $(300)$ & 474 & 0.28 & 8.36 \\
\hline $19-2,40-42$ & 14 & 263.25 & 0.79 & -29.9 & -27.6 & $(\mathrm{THD})^{\mathrm{a}}$ & & 0.28 & 6.40 \\
\hline $19-2,56-58$ & 14 & 263.40 & 0.59 & -25.9 & -25.7 & $(300)$ & 598 & 0.22 & 5.94 \\
\hline $19-2,64-66$ & 14 & 263.49 & 0.43 & -25.3 & -27.8 & $(\mathrm{THD})^{\mathrm{a}}$ & & 0.19 & 4.96 \\
\hline $19-3,15-17$ & $15 \mathrm{~A}$ & 264.28 & 1.63 & -39.2 & -38.9 & $(300)$ & 757 & 0.42 & 8.70 \\
\hline $19-3,74-76$ & $15 \mathrm{~A}$ & 264.88 & 2.48 & -35.9 & -38.6 & (THD) $)^{\mathrm{a}}$ & & 0.74 & 7.51 \\
\hline $19-4,17-19$ & $15 \mathrm{~A}$ & 265.78 & 1.69 & -52.4 & -44.0 & $(300)$ & 144 & 1.30 & 2.93 \\
\hline $19-4,68-70$ & $15 \mathrm{~A}$ & 266.28 & 4.41 & -45.9 & -45.5 & $(300)$ & 307 & 0.79 & 12.48 \\
\hline $19-5,25-27$ & $15 \mathrm{~A}$ & 267.32 & 1.71 & -53.6 & -48.3 & $(300)$ & 153 & 0.90 & 4.24 \\
\hline $20-1,24-26$ & $15 \mathrm{~A}$ & 269.72 & 3.54 & -49.1 & -49.4 & $(300)$ & 395 & 0.37 & 21.46 \\
\hline $20-1,81-83$ & $15 B$ & 270.19 & 7.18 & -55.6 & -57.7 & $(200)$ & 173 & 1.05 & 15.34 \\
\hline $20-1,103-105$ & $15 B$ & 270.39 & 5.56 & -61.3 & -59.5 & $(\mathrm{THD})^{\mathrm{a}}$ & & 0.83 & 15.01 \\
\hline $20-2,20-22$ & $15 \mathrm{~B}$ & 270.90 & 5.41 & -58.3 & -30.3 & $(\mathrm{THD})^{\mathrm{a}}$ & & 0.72 & $16.85^{\mathrm{C}}$ \\
\hline $20-2,35-37$ & $15 \mathrm{~B}$ & 271.03 & 4.42 & -57.0 & -57.1 & $(\mathrm{THD})^{\mathrm{a}}$ & & 0.83 & 12.00 \\
\hline $20-2,48-50$ & $15 \mathrm{~B}$ & 271.13 & 6.01 & -56.1 & -59.7 & $(200)$ & 157 & 0.75 & 17.92 \\
\hline $20-2,132-134$ & 16 & 271.84 & 2.60 & -58.6 & -60.6 & $(300)$ & 114 & 1.88 & 3.11 \\
\hline $21-1,73-75$ & 16 & 279.55 & 1.85 & -55.2 & -58.2 & $(300)$ & 208 & 0.93 & 4.46 \\
\hline $21-1,107-109$ & 16 & 279.89 & 2.40 & -60.1 & -58.3 & $(300)$ & 183 & 1.14 & 4.72 \\
\hline $21-1,128-130$ & 16 & 280.06 & 6.77 & -60.5 & -57.6 & $(\mathrm{THD})^{\mathrm{a}}$ & & 4.57 & 3.32 \\
\hline $21-2,27-29$ & 16 & 280.45 & 16.70 & -56.6 & -56.8 & $(300)$ & 288 & 1.83 & 20.50 \\
\hline $21-2,104-106$ & 17 & 280.92 & 6.70 & -60.7 & -60.8 & $(200)$ & 312 & 2.16 & 6.96 \\
\hline $21-3,7-9$ & 17 & 281.35 & 2.54 & -63.5 & -61.0 & $(\mathrm{THD})^{\mathrm{a}}$ & & 1.46 & 3.91 \\
\hline $21-3,32-34$ & 17 & 281.53 & 3.69 & -52.8 & -61.5 & $(200)$ & 246 & 2.19 & 3.78 \\
\hline $21-4,40-42$ & 17 & 282.82 & 2.89 & -68.0 & -63.8 & $(200)$ & 241 & 3.69 & 1.76 \\
\hline $21-4,64-66$ & 17 & 283.01 & 4.28 & -66.2 & -66.5 & (THD) ${ }^{a}$ & & 3.78 & 2.54 \\
\hline
\end{tabular}


TABLE 17 - Continued

\begin{tabular}{|c|c|c|c|c|c|c|c|c|c|}
\hline $\begin{array}{c}\text { Sample } \\
\text { (Interval in } \mathrm{cm} \text { ) }\end{array}$ & $\begin{array}{l}\text { Flow } \\
\text { Unit }\end{array}$ & $\begin{array}{l}\text { Sub-bottom } \\
\text { Depth } \\
\text { (m) }\end{array}$ & $\begin{array}{c}\mathrm{J}_{\mathrm{NRM}} \\
\left(\times 10^{-5} \mathrm{emu} / \mathrm{cm}^{3}\right)\end{array}$ & $\begin{array}{c}\text { Inclination } \\
\text { of NRM } \\
\left({ }^{\circ}\right)\end{array}$ & $\begin{array}{l}\text { Stable } \\
\text { Inclination } \\
\left(^{\circ}\right)\end{array}$ & $\begin{array}{l}\mathrm{AF} \\
(\mathrm{Oe})\end{array}$ & $\begin{array}{l}\text { MDF } \\
(\mathrm{Oe})\end{array}$ & $\begin{array}{c}\text { Suscept. } \\
\times \\
\left(\times 10^{-5}\right)\end{array}$ & $\begin{array}{l}\mathrm{Q}_{\mathrm{n}} \\
(\mathrm{Oe})^{\mathrm{b}}\end{array}$ \\
\hline \multicolumn{10}{|l|}{ Hole 433C } \\
\hline $21-4,101-103$ & 17 & 283.29 & 3.97 & -52.1 & -55.8 & $(\mathrm{THD})^{\mathrm{a}}$ & & 2.90 & 3.07 \\
\hline $21-4,120-122$ & 17 & 283.41 & 1.65 & -43.0 & -58.6 & $(200)$ & 89 & 3.15 & 1.17 \\
\hline $21-5,9-11$ & 17 & 283.74 & 4.45 & -59.6 & -60.6 & $(200)$ & 384 & 0.99 & 10.09 \\
\hline $22-1,94-96$ & 18 & 289.18 & 4.37 & -43.4 & -43.6 & (200) & 278 & 2.97 & 3.30 \\
\hline $22-1,104-106$ & 18 & 289.26 & 1.78 & -32.6 & -37.9 & (THD) $)^{a}$ & & 2.69 & $1.48^{\mathrm{c}}$ \\
\hline $22-2,113-115$ & 18 & 290.54 & 4.20 & -41.8 & -41.7 & $(200)$ & 248 & 1.37 & 6.87 \\
\hline $22-3,64-66$ & 18 & 291.35 & 2.83 & -42.1 & -41.5 & $(200)$ & 93 & 1.56 & 4.06 \\
\hline $22-3,130-132$ & 18 & 291.89 & 1.64 & -50.1 & -41.5 & $(200)$ & 116 & 0.92 & 4.00 \\
\hline $22-4,23-25$ & 18 & 292.24 & 1.91 & -52.9 & -42.1 & $(200)$ & 89 & 0.97 & 4.41 \\
\hline $22-5,58-60$ & 18 & 293.82 & 2.49 & -48.7 & -38.6 & $(200)$ & 92 & 1.31 & 4.26 \\
\hline $23-1,86-88$ & 19 & 298.77 & 10.30 & -33.5 & -33.7 & $(300)$ & 263 & 1.60 & 14.42 \\
\hline $23-1,102-104$ & 19 & 298.93 & 6.97 & -37.0 & -37.2 & $(300)$ & 204 & 1.64 & 9.54 \\
\hline $23-2,55-57$ & 19 & 299.70 & 2.73 & -39.2 & -38.7 & $(300)$ & 415 & 0.97 & 6.29 \\
\hline $23-3,33-35$ & 19 & 300.80 & 1.63 & -43.6 & -42.2 & $(300)$ & 323 & 0.52 & 7.04 \\
\hline $23-4,99-101$ & 19 & 302.75 & 1.99 & -42.1 & -45.1 & (THD) $)^{\mathrm{a}}$ & & 1.17 & 3.81 \\
\hline $23-7,102-104$ & 19 & 306.92 & 0.91 & -38.3 & -36.6 & $(300)$ & 359 & 0.35 & 5.87 \\
\hline $24-2,17-19$ & 19 & 308.75 & 4.53 & -38.7 & -38.5 & (300) & 364 & 1.10 & 9.20 \\
\hline $24-3,81-83$ & 19 & 309.42 & 2.69 & -41.0 & -40.6 & $(300)$ & 408 & 0.40 & 14.99 \\
\hline $25-1,131-133$ & 20 & 317.43 & 0.48 & -43.3 & -42.4 & $(200)$ & 617 & 0.27 & 3.97 \\
\hline $25-2,7-9$ & 20 & 318.49 & 0.67 & -41.7 & -40.4 & (THD) $)^{a}$ & & 0.32 & 4.64 \\
\hline $25-2,10-12$ & 20 & 318.51 & 0.84 & -40.2 & -40.4 & $(200)$ & 684 & 0.34 & 5.49 \\
\hline $25-2,22-24$ & 20 & 318.63 & 1.22 & -40.4 & -40.2 & $(200)$ & 631 & 0.36 & 7.63 \\
\hline $25-2,27-29$ & 20 & 318.69 & 1.12 & -39.8 & -39.7 & $(\mathrm{THD})^{\mathrm{a}}$ & & 0.38 & 6.62 \\
\hline $25-2,45-47$ & 20 & 318.86 & 1.65 & -40.6 & -39.6 & $(200)$ & 554 & 0.44 & 8.31 \\
\hline $25-2,54-56$ & 20 & 318.96 & 1.50 & -39.6 & -38.2 & (THD) $)^{\mathrm{a}}$ & & 0.48 & 7.00 \\
\hline $25-2,89-91$ & 20 & 319.30 & 2.10 & -41.0 & -39.6 & (200) & 209 & 0.78 & 6.05 \\
\hline $25-3,18-20$ & 21 & 320.04 & 3.25 & -19.3 & -19.8 & $(200)$ & 236 & 2.27 & $3.21^{\mathrm{d}}$ \\
\hline $25-5,77-79$ & 21 & 323.31 & 4.37 & -42.3 & -40.1 & $(200)$ & 273 & 1.26 & 7.76 \\
\hline $25-5,103-105$ & 21 & 323.58 & 3.58 & -40.7 & -39.1 & (THD) ${ }^{\mathrm{a}}$ & & 1.23 & 6.51 \\
\hline $25-6,56-58$ & 21 & 324.55 & 4.70 & -39.7 & -39.8 & $(200)$ & 297 & 1.23 & 8.57 \\
\hline $26-1,42-44$ & 21 & 326.88 & 1.47 & -37.6 & -36.4 & $(200)$ & 448 & 0.41 & 8.13 \\
\hline $26-2,29-31$ & 21 & 328.18 & 2.01 & -35.6 & -34.8 & $(200)$ & 357 & 0.58 & 7.73 \\
\hline $26-3,20-22$ & 21 & 329.51 & 3.78 & -41.3 & -38.4 & (200) & 270 & 1.09 & 7.74 \\
\hline $26-4,138-140$ & 22 & 331.96 & 0.74 & -44.7 & -43.3 & $(600)$ & 690 & 0.27 & 6.03 \\
\hline $26-5,35-37$ & 22 & 332.47 & 1.41 & -42.6 & -42.4 & $(600)$ & 863 & 0.29 & 10.81 \\
\hline $26-5,82-84$ & 22 & 332.94 & 3.59 & -42.1 & -41.9 & $(600)$ & 554 & 0.39 & 20.46 \\
\hline $26-5,94-96$ & 22 & 333.07 & 3.08 & -44.7 & -44.0 & (THD) $)^{a}$ & & 0.38 & 18.02 \\
\hline $26-5,123-125$ & 22 & 333.35 & 2.78 & -43.9 & -43.3 & $(600)$ & 428 & 0.74 & 8.41 \\
\hline $26-6,114-116$ & 23 & 334.50 & 1.93 & -40.7 & -39.9 & $(300)$ & 180 & 0.82 & 5.26 \\
\hline $26-6,129-131$ & 23 & 334.66 & 1.79 & -41.4 & -42.6 & $(\mathrm{THD})^{\mathrm{a}}$ & & 0.77 & 5.25 \\
\hline $26-7,7-9$ & 23 & 334.89 & 1.94 & -40.4 & -42.0 & (300) & 344 & 0.42 & 10.46 \\
\hline $27-1,17-19$ & 24 & 336.14 & 0.80 & -39.3 & -41.5 & $(200)$ & 405 & 0.21 & 8.46 \\
\hline $27-1,56-58$ & 24 & 336.53 & 1.10 & -42.3 & -36.7 & $(200)$ & 157 & 0.56 & 4.43 \\
\hline $27-1,69-71$ & 24 & 336.66 & 1.04 & -38.3 & -35.7 & $(200)$ & 123 & 0.38 & 6.09 \\
\hline $27-1,88-90$ & 24 & 336.85 & 2.22 & -41.7 & -40.4 & $(200)$ & 240 & 0.32 & 15.38 \\
\hline $27-2,131-133$ & 24 & 338.55 & 1.68 & -43.4 & -34.9 & (200) & 133 & 0.28 & 13.55 \\
\hline $27-3,12-14$ & 24 & 338.83 & 1.23 & -37.0 & -32.8 & $(200)$ & 248 & 0.31 & 8.91 \\
\hline $27-5,18-20$ & 24 & 341.47 & 2.38 & -33.2 & -31.9 & $(200)$ & 277 & 1.01 & 5.26 \\
\hline $27-5,125-127$ & 24 & 342.48 & 0.14 & -43.8 & -35.8 & $(200)$ & 225 & 0.21 & 1.52 \\
\hline $27-6,13-15$ & 24 & 342.82 & 0.68 & -41.7 & -35.5 & $(200)$ & 91 & 0.48 & 3.17 \\
\hline $27-6,58-60$ & 25 & 343.24 & 3.58 & -28.0 & -23.3 & (300) & 178 & 5.74 & $1.40^{\mathrm{d}}$ \\
\hline $28-1,82-84$ & 25 & 346.29 & 2.66 & -84.9 & -69.4 & $(300)$ & 72 & 1.88 & 3.17 \\
\hline $28-2,34-36$ & 25 & 347.20 & 2.18 & -69.0 & -70.7 & $(300)$ & 85 & 2.75 & 1.78 \\
\hline $28-3,38-40$ & 25 & 348.63 & 1.97 & -71.6 & -63.6 & $(300)$ & 74 & 1.72 & 2.56 \\
\hline $28-4,26-28$ & 25 & 349.87 & 1.63 & -66.7 & -69.5 & $(300)$ & 227 & 1.60 & 2.28 \\
\hline $28-4,87-89$ & $26 \mathrm{~A}$ & 350.37 & 2.46 & -71.6 & -69.5 & $(200)$ & 516 & 0.56 & 9.86 \\
\hline $28-4,121-123$ & $26 \mathrm{~A}$ & 350.66 & 1.47 & -69.1 & -69.3 & (THD) $)^{\mathrm{a}}$ & & 0.61 & 5.40 \\
\hline $28-5,113-115$ & $26 \mathrm{~A}$ & 351.88 & 1.55 & -73.2 & -68.3 & $(200)$ & 130 & 1.29 & 2.68 \\
\hline $29-1,48-50$ & $26 \mathrm{~A}$ & 355.43 & 1.37 & -70.8 & -67.8 & (200) & 132 & 0.99 & 3.10 \\
\hline $29-1,115-117$ & $26 \mathrm{~A}$ & 356.05 & 2.93 & -65.8 & -69.4 & $(200)$ & 236 & 0.88 & 7.42 \\
\hline $29-2,96-98$ & $26 \mathrm{~B}$ & 357.00 & 2.25 & -35.5 & -22.8 & $(300)$ & 261 & 1.56 & 3.24 \\
\hline $29-2,108-110$ & $26 \mathrm{~B}$ & 357.06 & 6.21 & -21.3 & -17.7 & $(300)$ & 298 & 2.70 & 5.16 \\
\hline $29-2,115-117$ & $26 \mathrm{~B}$ & 357.14 & 2.56 & -20.0 & 25.9 & $(\mathrm{THD})^{\mathrm{a}}$ & & 2.44 & $2.35^{\mathrm{c}}$ \\
\hline $29-2,138-140$ & $26 B$ & 357.29 & 13.70 & -22.1 & -21.2 & $(300)$ & 371 & 2.39 & 12.91 \\
\hline
\end{tabular}


TABLE 17 - Continued

\begin{tabular}{|c|c|c|c|c|c|c|c|c|c|}
\hline $\begin{array}{c}\text { Sample } \\
\text { (Interval in } \mathrm{cm} \text { ) }\end{array}$ & $\begin{array}{l}\text { Flow } \\
\text { Unit }\end{array}$ & $\begin{array}{l}\text { Sub-bottom } \\
\text { Depth } \\
\text { (m) }\end{array}$ & $\begin{array}{c}{ }^{\mathrm{J}_{\mathrm{NRM}}} \\
\left(\times 10^{-5} \mathrm{emu} / \mathrm{cm}^{3}\right)\end{array}$ & $\begin{array}{l}\text { Inclination } \\
\text { of NRM } \\
\left({ }^{\circ}\right)\end{array}$ & $\begin{array}{c}\text { Stable } \\
\text { Inclination } \\
\left({ }^{\circ}\right)\end{array}$ & $\begin{array}{c}\mathrm{AF} \\
(\mathrm{Oe})\end{array}$ & $\begin{array}{l}\text { MDF } \\
\text { (Oe) }\end{array}$ & $\begin{array}{l}\text { Suscept. } \\
x \\
\left(\times 10^{-5}\right)\end{array}$ & $\begin{array}{c}\mathrm{Qn}_{\mathrm{n}} \\
(\mathrm{Oe})^{\mathrm{b}}\end{array}$ \\
\hline \multicolumn{10}{|l|}{ Hole 433C } \\
\hline $29-3,17-19$ & $26 \mathrm{~B}$ & 357.50 & 4.41 & -26.9 & -22.2 & $(300)$ & 358 & 2.02 & 4.90 \\
\hline $30-2,134-136$ & 27 & 366.54 & 7.79 & -74.3 & -62.9 & $(200)$ & 96 & 4.63 & 3.78 \\
\hline $30-3,57-59$ & 27 & 367.15 & 5.29 & -80.1 & -64.3 & $(200)$ & 85 & 3.95 & 3.01 \\
\hline $31-1,37-39$ & 27 & 374.37 & 6.08 & -77.2 & -60.6 & $(200)$ & 51 & 2.14 & 6.37 \\
\hline $31-1,79-81$ & 27 & 374.79 & 3.72 & -70.2 & -59.9 & $(200)$ & 65 & 2.17 & 3.85 \\
\hline $31-1,120-122$ & 27 & 375.20 & 5.71 & -63.6 & -64.3 & $(200)$ & 277 & 1.48 & 8.65 \\
\hline $31-3,88-90$ & $28 \mathrm{~A}$ & 377.25 & 3.67 & -64.4 & -65.0 & $(200)$ & 347 & 1.03 & 8.01 \\
\hline $31-4,49-51$ & $28 \mathrm{~A}$ & 378.07 & 3.09 & -53.0 & -52.7 & $(200)$ & 451 & 0.61 & 11.45 \\
\hline $31-4,73-75$ & $28 \mathrm{~A}$ & 378.31 & 1.85 & -54.3 & -52.9 & $(200)$ & 303 & 0.44 & 9.34 \\
\hline $31-4,83-85$ & $28 \mathrm{~A}$ & 378.42 & 1.18 & -55.7 & -56.3 & $(\mathrm{THD})^{\mathrm{a}}$ & & 0.71 & 3.73 \\
\hline $31-5,29-31$ & $28 \mathrm{~B}$ & 379.23 & 1.58 & -46.2 & -45.4 & $(300)$ & 269 & 0.28 & 12.49 \\
\hline $32-1,30-32$ & $28 \mathrm{~B}$ & 383.72 & 2.61 & -43.3 & -43.0 & $(300)$ & 447 & 0.41 & 14.13 \\
\hline $32-1,38-40$ & $28 \mathrm{~B}$ & 383.81 & 2.43 & -44.6 & -43.3 & $(\mathrm{THD})^{\mathrm{a}}$ & & 0.41 & 13.28 \\
\hline $32-2,43-45$ & $28 \mathrm{~B}$ & 385.23 & 6.79 & -43.1 & -42.4 & $(300)$ & 369 & 0.82 & 18.56 \\
\hline $32-3,100-102$ & $28 \mathrm{~B}$ & 387.19 & 1.85 & -41.8 & -41.0 & $(200)$ & 278 & 0.25 & 16.84 \\
\hline $32-4,138-140$ & 29 & 388.52 & 5.45 & -40.0 & -39.9 & $(200)$ & 275 & 0.61 & 20.10 \\
\hline $32-5,13-1.5$ & 29 & 388.73 & 4.91 & -39.7 & -39.7 & $(200)$ & 274 & 0.43 & 25.87 \\
\hline $32-5,72-74$ & 29 & 389.32 & 4.11 & -41.1 & -40.5 & $(200)$ & 325 & 0.36 & 25.40 \\
\hline $32-5,84-86$ & 29 & 389.44 & 4.48 & -40.0 & -39.5 & $(200)$ & 313 & 0.36 & 27.59 \\
\hline $32-5,115-117$ & 29 & 389.75 & 4.27 & -42.4 & -42.6 & (200) & 316 & 0.45 & 21.33 \\
\hline $33-1,23-25$ & 30 & 393.18 & 6.18 & -43.0 & -42.2 & $(200)$ & 416 & 0.39 & 35.26 \\
\hline $33-1,34-36$ & 30 & 393.29 & 5.27 & -42.9 & -42.4 & $(200)$ & 380 & 0.39 & 30.50 \\
\hline $33-1,62-64$ & 30 & 393.57 & 5.79 & -44.5 & -43.8 & $(200)$ & 352 & 0.50 & 26.17 \\
\hline $33-1,87-89$ & 30 & 393.82 & 3.02 & -41.6 & -41.8 & $(200)$ & 278 & 0.49 & 13.76 \\
\hline $33-2,21-23$ & 30 & 394.64 & 18.70 & -40.9 & -41.1 & $(200)$ & 503 & 1.23 & 34.21 \\
\hline $33-2,72-74$ & 31 & 395.10 & 11.10 & -40.2 & -40.3 & $(200)$ & 366 & 1.56 & 16.01 \\
\hline $33-2,138-140$ & 31 & 395.76 & 13.40 & -41.0 & -41.1 & $(200)$ & 596 & 0.83 & 36.08 \\
\hline $33-3,12-14$ & 31 & 395.98 & 4.85 & -41.8 & -41.5 & $(200)$ & 545 & 0.46 & 23.51 \\
\hline $33-3,88-90$ & 31 & 396.72 & 19.00 & -40.3 & -40.3 & $(200)$ & 330 & 1.67 & 25.46 \\
\hline $33-5,10-12$ & 32 & 398.70 & 27.40 & -38.4 & -38.9 & (200) & 294 & 2.04 & 30.03 \\
\hline $33-5,37-39$ & 32 & 398.97 & 25.70 & -38.7 & -39.0 & (200) & 378 & 1.61 & 35.78 \\
\hline $33-5,63-65$ & 32 & 399.23 & 10.60 & -43.6 & -44.2 & $(200)$ & 337 & 1.21 & 19.65 \\
\hline $34-1,3-5$ & 32 & 402.53 & 9.23 & -38.2 & -38.9 & $(200)$ & 337 & 1.30 & 15.98 \\
\hline $34-1,56-58$ & 32 & 403.06 & 16.60 & -40.6 & -40.3 & $(200)$ & 352 & 1.29 & 28.79 \\
\hline $34-1,140-142$ & 33 & 403.90 & 1.69 & -42.5 & -42.1 & $(200)$ & 636 & 0.51 & 7.44 \\
\hline $34-2,59-61$ & 33 & 404.57 & 2.82 & -43.2 & -43.0 & (200) & 566 & 0.29 & 22.19 \\
\hline $34-2,124-126$ & 33 & 405.22 & 3.11 & -41.7 & -41.8 & $(200)$ & 520 & 0.22 & 31.96 \\
\hline $34-3,8-10$ & 33 & 405.53 & 4.70 & -41.9 & -42.0 & $(200)$ & 432 & 0.28 & 37.78 \\
\hline $34-3,41-43$ & 33 & 405.86 & 4.33 & -42.6 & -42.6 & $(200)$ & 432 & 0.29 & 34.09 \\
\hline $34-4,14-16$ & 34 & 407.05 & 5.69 & -39.3 & -39.8 & (200) & 333 & 1.07 & 11.89 \\
\hline $34-4,50-52$ & 34 & 407.34 & 4.60 & -40.4 & -40.3 & (200) & 376 & 0.50 & 20.68 \\
\hline $34-4,95-97$ & 34 & 407.79 & 2.73 & -42.4 & -42.2 & $(200)$ & 358 & 0.38 & 16.35 \\
\hline $34-5,76-78$ & 34 & 408.94 & 2.28 & -42.8 & -43.0 & $(200)$ & 445 & 0.43 & 11.98 \\
\hline $34-5,113-115$ & 34 & 409.29 & 1.93 & -41.5 & -41.8 & (200) & 456 & 0.40 & 10.73 \\
\hline $34-7,95-97$ & 35 & 412.02 & 4.04 & -51.9 & -50.4 & (200) & 254 & 3.53 & 2.57 \\
\hline $35-1,112-114$ & 35 & 413.13 & 3.29 & -48.1 & -55.2 & $(\mathrm{THD})^{\mathrm{a}}$ & & 1.78 & $4.14^{\mathrm{c}}$ \\
\hline $35-2,21-23$ & 35 & 413.67 & 5.20 & -49.6 & -49.8 & $(200)$ & 375 & 1.48 & 7.85 \\
\hline $35-4,115-117$ & 35 & 417.52 & 11.80 & -49.1 & -48.9 & $(200)$ & 358 & 1.63 & 16.33 \\
\hline $35-5,97-99$ & 35 & 418.80 & 5.96 & -52.2 & -50.4 & $(200)$ & 360 & 1.04 & 12.80 \\
\hline $35-6,27-29$ & 35 & 419.56 & 8.42 & -52.0 & -50.1 & (200) & 461 & 1.26 & 15.01 \\
\hline $35-6,48-50$ & 35 & 419.78 & 7.86 & -47.4 & -48.0 & $(\mathrm{THD})^{\mathrm{a}}$ & & 1.53 & 11.52 \\
\hline $35-6,114-116$ & 36 & 420.43 & 2.90 & -47.3 & -47.8 & $(500)$ & 760 & 0.95 & 6.83 \\
\hline $35-6,121-123$ & 36 & 420.12 & 2.57 & -50.2 & -49.4 & $(\mathrm{THD})^{\mathrm{a}}$ & & 0.81 & 7.11 \\
\hline $35-6,134-136$ & 36 & 420.63 & 3.14 & -50.9 & -51.4 & $(500)$ & 906 & 0.47 & 14.80 \\
\hline $35-7,116-118$ & 36 & 421.74 & 1.65 & -52.8 & -53.0 & (THD) $)^{\mathrm{a}}$ & & 0.42 & 8.72 \\
\hline $36-1,24-26$ & 36 & 421.74 & 3.29 & -52.0 & -51.2 & $(500)$ & 1269 & 0.28 & 26.36 \\
\hline $36-1,45-47$ & 36 & 421.96 & 3.38 & -51.6 & -51.9 & $(\mathrm{THD})^{\mathrm{a}}$ & & 0.39 & 19.21 \\
\hline $36-1,50-52$ & 36 & 422.00 & 4.81 & -52.3 & -51.7 & $(500)$ & 990 & 0.44 & 24.79 \\
\hline $36-1,105-107$ & 37 & 422.50 & 5.52 & -51.3 & -51.7 & $(\mathrm{THD})^{\mathrm{a}}$ & & 1.30 & 9.51 \\
\hline $36-1,114-116$ & 37 & 422.58 & 5.28 & -51.7 & -51.0 & $(200)$ & 380 & 1.16 & 10.20 \\
\hline $36-1,125-127$ & 37 & 422.70 & 6.67 & -50.9 & -51.0 & (200) & 391 & 1.25 & 11.93 \\
\hline $36-2,27-29$ & 37 & 423.19 & 9.92 & -51.0 & -51.3 & $(200)$ & 335 & 1.52 & 14.63 \\
\hline $36-2,124-126$ & 38 & 423.97 & 8.67 & -51.3 & -51.0 & $(300)$ & 277 & 1.36 & 14.28 \\
\hline $36-3,22-24$ & 38 & 424.42 & 7.59 & -51.5 & -51.1 & $(300)$ & 284 & 1.31 & 13.03 \\
\hline
\end{tabular}


TABLE 17 - Continued

\begin{tabular}{|c|c|c|c|c|c|c|c|c|c|}
\hline $\begin{array}{c}\text { Sample } \\
\text { (Interval in } \mathrm{cm} \text { ) }\end{array}$ & $\begin{array}{l}\text { Flow } \\
\text { Unit }\end{array}$ & $\begin{array}{l}\text { Sub-bottom } \\
\text { Depth } \\
\text { (m) }\end{array}$ & $\begin{array}{c}\mathrm{J}_{\mathrm{NRM}} \\
\left(\times 10^{-5} \mathrm{emu} / \mathrm{cm}^{3}\right)\end{array}$ & $\begin{array}{c}\text { Inclination } \\
\text { of NRM } \\
\left(^{\circ}\right)\end{array}$ & $\begin{array}{c}\text { Stable } \\
\text { Inclination } \\
\left(^{\circ}\right)\end{array}$ & $\begin{array}{l}\mathrm{AF} \\
(\mathrm{Oe})\end{array}$ & $\begin{array}{l}\text { MDF } \\
(\mathrm{Oe})\end{array}$ & $\begin{array}{c}\text { Suscept. } \\
\quad x \\
\left(\times 10^{-5}\right)\end{array}$ & $\begin{array}{c}\mathrm{Q}_{\mathrm{n}} \\
(\mathrm{Oe})^{\mathrm{b}}\end{array}$ \\
\hline \multicolumn{10}{|l|}{ Hole 433C } \\
\hline $36-3,35-37$ & 38 & 424.55 & 10.90 & -51.7 & -51.8 & $(300)$ & 328 & 1.46 & 16.70 \\
\hline $36-3,60-62$ & 38 & 424.81 & 5.56 & -46.3 & -45.5 & (THD) ${ }^{\mathrm{a}}$ & & 1.91 & 6.53 \\
\hline $36-3,76-78$ & 38 & 424.96 & 7.75 & -50.0 & -50.0 & $(300)$ & 285 & 0.93 & 18.77 \\
\hline $36-3,101-103$ & 38 & 425.21 & 6.67 & -52.4 & -51.9 & $(300)$ & 298 & 0.79 & 18.88 \\
\hline $36-4,20-22$ & 39 & 425.87 & 2.78 & -52.6 & -55.0 & $(300)$ & 134 & 0.78 & 7.96 \\
\hline $36-4,56-58$ & 39 & 426.24 & 2.50 & -54.9 & -57.9 & $(\mathrm{THD})^{\mathrm{a}}$ & & 0.84 & 6.63 \\
\hline $36-4,72-74$ & 39 & 426.39 & 2.90 & -58.2 & -53.4 & $(300)$ & 182 & 0.84 & 7.78 \\
\hline $36-4,84-86$ & 39 & 426.51 & 4.78 & -56.0 & -54.7 & $(300)$ & 193 & 0.84 & 12.84 \\
\hline $36-4,113-115$ & 40 & 426.80 & 14.00 & -53.4 & -52.9 & $(400)$ & 335 & 1.70 & 18.53 \\
\hline $36-5,12-14$ & 40 & 427.26 & 24.10 & -51.0 & -50.6 & $(400)$ & 338 & 2.38 & 22.71 \\
\hline $36-5,29-31$ & 40 & 427.44 & 2.29 & -53.1 & -47.5 & (THD) $)^{\mathrm{a}}$ & & 0.58 & 8.81 \\
\hline $36-5,79-81$ & 41 & 427.85 & 4.02 & -53.1 & -53.6 & (300) & 268 & 0.76 & 11.92 \\
\hline $36-5,103-105$ & 41 & 428.09 & 8.94 & -54.9 & -54.6 & $(300)$ & 304 & 1.19 & 16.81 \\
\hline $36-5,126-128$ & 41 & 428.32 & 6.08 & -53.1 & -53.6 & $(300)$ & 311 & 0.86 & 15.89 \\
\hline $37-3,32-34$ & 44 & 433.78 & 4.18 & -51.1 & -50.6 & $(200)$ & 308 & 1.06 & 8.86 \\
\hline $37-3,74-76$ & 44 & 434.21 & 3.68 & -54.9 & -54.3 & $(\mathrm{THD})^{\mathrm{a}}$ & & 1.43 & 5.77 \\
\hline $37-3,87-89$ & 44 & 434.33 & 4.12 & -52.3 & -49.2 & $(200)$ & 164 & 1.36 & 6.80 \\
\hline $37-3,139-141$ & 44 & 434.83 & 2.84 & -53.6 & -47.5 & $(200)$ & 149 & 1.19 & 5.35 \\
\hline $37-4,7-9$ & 44 & 434.99 & 2.43 & -51.0 & -49.7 & (200) & 115 & 1.12 & 4.85 \\
\hline $37-4,52-54$ & 44 & 435.44 & 2.02 & -58.2 & -50.3 & (200) & 140 & 1.40 & 3.25 \\
\hline $38-1,29-31$ & 45 & 440.79 & 2.82 & -48.5 & -47.3 & $(200)$ & 482 & 0.33 & 19.18 \\
\hline $38-1,57-59$ & 45 & 441.08 & 2.22 & -46.9 & -45.7 & $(\mathrm{THD})^{\mathrm{a}}$ & & 0.36 & 13.76 \\
\hline $38-1,70-72$ & 45 & 441.20 & 2.02 & -49.1 & -47.5 & (200) & 560 & 0.26 & 17.67 \\
\hline $38-1,121-123$ & 45 & 441.70 & 2.08 & -46.7 & -46.7 & $(200)$ & 519 & 0.28 & 16.80 \\
\hline $38-2,16-18$ & 45 & 442.13 & 6.00 & -49.3 & -49.1 & $(200)$ & 368 & 0.96 & 14.02 \\
\hline $38-2,41-43$ & 45 & 442.38 & 4.61 & -48.7 & -47.7 & (200) & 257 & 0.96 & 10.81 \\
\hline $38-2,62-64$ & 46 & 442.58 & 1.99 & -53.0 & -52.2 & (200) & 383 & 0.38 & $11.65^{\mathrm{d}}$ \\
\hline $38-3,46-48$ & 46 & 443.75 & 3.11 & -7.6 & -6.6 & $(200)$ & 432 & 0.75 & 9.35 \\
\hline $38-3,46-48$ & 46 & 443.74 & 1.82 & -17.8 & -15.0 & $(200)$ & 282 & 0.78 & 5.24 \\
\hline $38-3,118-120$ & 46 & 444.46 & 1.78 & -16.0 & -9.9 & $(200)$ & 297 & 0.71 & 5.66 \\
\hline $38-3,139-141$ & 46 & 444.66 & 3.07 & -7.0 & -5.5 & (200) & 349 & 0.77 & 8.97 \\
\hline $38-4,98-100$ & 47 & 445.72 & 1.33 & -12.4 & -7.7 & $(300)$ & 264 & 0.42 & 7.13 \\
\hline $38-5,63-65$ & 47 & 446.83 & 1.22 & -7.0 & -2.2 & $(300)$ & 246 & 0.40 & 6.85 \\
\hline $38-5,103-105$ & 47 & 447.23 & 1.52 & -24.9 & -8.9 & $(300)$ & 168 & 0.53 & 6.45 \\
\hline $38-5,119-121$ & 47 & 447.40 & 0.97 & -18.4 & -24.3 & $(\mathrm{THD})^{\mathrm{a}}$ & & 0.57 & $3.85^{\mathrm{c}}$ \\
\hline $38-5,139-141$ & 47 & 447.59 & 1.46 & -6.3 & -2.3 & $(300)$ & 278 & 0.53 & 6.13 \\
\hline $38-6,11-13$ & 47 & 447.79 & 1.53 & -8.6 & -5.9 & $(300)$ & 300 & 0.50 & 6.88 \\
\hline $39-2,58-60$ & 48 & 451.59 & 2.93 & -42.8 & -43.3 & $(200)$ & 330 & 0.74 & 8.94 \\
\hline $39-3,25-27$ & 48 & 452.74 & 0.97 & -48.1 & -45.4 & $(200)$ & 332 & 0.43 & 5.08 \\
\hline $39-4,91-93$ & 48 & 454.89 & 1.61 & -47.2 & -45.0 & (200) & 331 & 0.43 & 8.44 \\
\hline $39-5,96-98$ & 48 & 456.44 & 1.08 & -42.8 & -43.1 & (THD) $)^{\mathrm{a}}$ & & 0.30 & 7.98 \\
\hline $39-5,102-104$ & 48 & 456.49 & 1.26 & -45.6 & -42.0 & $(200)$ & 527 & 0.31 & 9.26 \\
\hline $39-6,56-58$ & 48 & 457.52 & 1.37 & -43.0 & -41.7 & (200) & 524 & 0.44 & 7.00 \\
\hline $39-6,78-80$ & 48 & 457.75 & 1.30 & -47.6 & -48.1 & (THD) $)^{\mathrm{a}}$ & & 0.54 & 5.38 \\
\hline $40-1,37-39$ & 49 & 459.84 & 11.80 & -42.9 & -42.4 & $(200)$ & 252 & 3.80 & 6.96 \\
\hline $40-2,24-26$ & 49 & 461.19 & 9.44 & -45.3 & -44.5 & $(200)$ & 332 & 1.30 & 16.31 \\
\hline $40-2,111-113$ & 49 & 462.06 & 9.55 & -46.8 & -45.8 & (200) & 403 & 1.14 & 18.79 \\
\hline $40-3,8-10$ & 49 & 462.50 & 6.79 & -46.7 & -45.9 & (200) & 408 & 1.08 & 14.05 \\
\hline $40-3,80-82$ & 49 & 463.22 & 8.44 & -46.6 & -46.3 & $(200)$ & 318 & 1.47 & 12.85 \\
\hline $40-4,94-96$ & $51 \mathrm{~A}$ & 464.73 & 0.68 & -48.7 & -48.0 & $(400)$ & 480 & 0.25 & 6.03 \\
\hline $40-4,111-113$ & $51 \mathrm{~A}$ & 464.90 & 1.32 & -33.4 & -32.7 & $(400)$ & 502 & 0.88 & $3.34^{\mathrm{d}}$ \\
\hline $40-5,18-20$ & $51 \mathrm{~A}$ & 465.44 & 3.78 & -54.5 & -53.5 & $(400)$ & 459 & 1.31 & 6.48 \\
\hline $40-5,39-41$ & $51 \mathrm{~A}$ & 465.65 & 1.18 & -52.0 & -50.6 & $(400)$ & 475 & 1.18 & 2.24 \\
\hline $40-6,71-73$ & $51 \mathrm{~B}$ & 467.31 & 5.12 & -15.4 & -12.8 & (200) & 297 & 0.98 & 11.76 \\
\hline $40-6,94-96$ & $51 \mathrm{~B}$ & 467.54 & 4.68 & -18.4 & -12.5 & $(200)$ & 307 & 0.95 & 11.09 \\
\hline $41-1,51-53$ & $51 \mathrm{~B}$ & 469.52 & 4.22 & -9.9 & -13.7 & (THD) ${ }^{a}$ & & 1.22 & 7.73 \\
\hline $41-4,91-93$ & $51 \mathrm{~B}$ & 474.18 & 4.13 & -13.0 & -11.1 & $(200)$ & 303 & 1.00 & 9.27 \\
\hline $41-4,74-76$ & $51 \mathrm{~B}$ & 473.96 & 5.81 & -11.4 & -10.0 & (200) & 286 & 1.31 & 9.94 \\
\hline $41-6,110-112$ & 52 & 476.97 & 3.80 & -14.4 & -13.0 & $(200)$ & 320 & 1.15 & 7.44 \\
\hline $41-6,138-140$ & 52 & 477.25 & 4.22 & -18.4 & -15.7 & $(200)$ & 322 & 0.82 & 11.57 \\
\hline $42-1,45-47$ & 52 & 478.95 & 4.49 & -16.0 & -13.8 & $(200)$ & 307 & 1.16 & 8.71 \\
\hline $42-1,68-70$ & 52 & 479.19 & 3.26 & -14.5 & -15.9 & (THD) ${ }^{\mathrm{a}}$ & & 1.18 & 6.22 \\
\hline $42-1,79-81$ & 52 & 479.29 & 3.77 & -14.1 & -11.2 & $(200)$ & 338 & 1.02 & 8.26 \\
\hline $42-1,106-108$ & 52 & 479.56 & 4.12 & -13.0 & -11.7 & $(200)$ & 338 & 0.96 & 9.58 \\
\hline
\end{tabular}


TABLE 17 - Continued

\begin{tabular}{|c|c|c|c|c|c|c|c|c|c|}
\hline $\begin{array}{c}\text { Sample } \\
\text { (Interval in } \mathrm{cm} \text { ) }\end{array}$ & $\begin{array}{l}\text { Flow } \\
\text { Unit }\end{array}$ & $\begin{array}{l}\text { Sub-bottom } \\
\text { Depth } \\
\text { (m) }\end{array}$ & $\begin{array}{c}\mathrm{J}_{\mathrm{NRM}} \\
\left(\times 10^{-5} \mathrm{emu} / \mathrm{cm}^{3}\right)\end{array}$ & $\begin{array}{l}\text { Inclination } \\
\text { of NRM } \\
\left({ }^{\circ}\right)\end{array}$ & $\begin{array}{c}\text { Stable } \\
\text { Inclination } \\
\left({ }^{\circ}\right)\end{array}$ & $\begin{array}{l}\mathrm{AF} \\
(\mathrm{Oe})\end{array}$ & $\begin{array}{l}\text { MDF } \\
(\mathrm{Oe})\end{array}$ & $\begin{array}{c}\text { Suscept. } \\
\quad x \\
\left(\times 10^{-5}\right)\end{array}$ & $\begin{array}{l}\mathrm{Qn}_{\mathrm{n}} \\
(\mathrm{Oe})^{\mathrm{b}}\end{array}$ \\
\hline \multicolumn{10}{|l|}{ Hole 433C } \\
\hline $42-2,35-37$ & 53 & 480.19 & 2.93 & -13.6 & -13.9 & $(200)$ & 474 & 0.56 & $11.72^{\mathrm{d}}$ \\
\hline $42-2,126-128$ & 53 & 481.01 & 2.61 & -22.4 & -22.8 & $(200)$ & 513 & 0.93 & 6.31 \\
\hline $42-2,136-138$ & 53 & 481.12 & 2.11 & -25.8 & -28.8 & $(\mathrm{THD})^{\mathrm{a}}$ & & 1.09 & 4.32 \\
\hline $42-3,14-16$ & 53 & 481.36 & 3.12 & -28.4 & -25.3 & $(200)$ & 399 & 1.16 & 6.01 \\
\hline $42-3,25-27$ & 53 & 481.47 & 2.73 & -31.6 & -26.1 & $(200)$ & 350 & 1.15 & 5.32 \\
\hline $42-4,137-139$ & 54 & 483.56 & 5.35 & -33.1 & -31.8 & $(200)$ & 307 & 1.02 & 11.81 \\
\hline $42-5,37-39$ & 54 & 484.03 & 4.12 & -36.4 & -34.1 & (200) & 307 & 0.91 & 10.15 \\
\hline $42-5,110-112$ & 54 & 484.76 & 5.15 & -36.1 & -34.5 & $(200)$ & 295 & 1.15 & 10.04 \\
\hline $42-5,134-136$ & 54 & 485.01 & 4.63 & -36.7 & -34.8 & (THD) $)^{\mathrm{a}}$ & & 1.15 & 8.99 \\
\hline $43-1,7-9$ & 54 & 488.07 & 4.77 & -37.1 & -34.7 & $(200)$ & 298 & 1.05 & 10.24 \\
\hline $43-1,33-35$ & 54 & 488.34 & 3.64 & -37.6 & -36.0 & $(\mathrm{THD})^{\mathrm{a}}$ & & 1.11 & 7.36 \\
\hline $43-1,52-54$ & 54 & 488.48 & 4.35 & -33.8 & -31.5 & $(200)$ & 301 & 0.97 & 10.02 \\
\hline $44-1,23-25$ & 56 & 497.73 & 2.51 & -49.0 & -43.6 & $(300)$ & 265 & 1.42 & 3.95 \\
\hline $44-1,41-43$ & 56 & 497.92 & 2.82 & -49.8 & -47.6 & (THD) $)^{\mathrm{a}}$ & & 1.94 & 3.25 \\
\hline $44-1,46-48$ & 56 & 497.96 & 3.99 & -56.6 & -43.1 & $(300)$ & 172 & 1.71 & 5.24 \\
\hline $44-1,84-86$ & 56 & 498.34 & 2.97 & -38.7 & -37.9 & $(300)$ & 284 & 1.01 & 6.60 \\
\hline $44-1,107-109$ & 56 & 498.57 & 1.82 & -40.0 & -40.0 & $(300)$ & 173 & 1.12 & 3.63 \\
\hline $44-3,89-91$ & 58 & 501.12 & 9.46 & -45.2 & -43.7 & (200) & 250 & 0.96 & 22.00 \\
\hline $44-3,131-133$ & 58 & 501.48 & 3.55 & -51.3 & -48.9 & $(200)$ & 244 & 0.97 & 8.25 \\
\hline $44-4,38-40$ & 58 & 502.00 & 3.47 & -50.9 & -50.8 & (200) & 313 & 1.16 & 6.72 \\
\hline $44-4,81-83$ & 58 & 502.43 & 8.99 & -47.4 & -47.6 & $(200)$ & 335 & 1.03 & 19.51 \\
\hline $44-4,108-110$ & 58 & 502.68 & 6.30 & -45.3 & -45.7 & $(\mathrm{THD})^{\mathrm{a}}$ & & 1.15 & 12.34 \\
\hline $44-4,126-128$ & 58 & 502.83 & 5.95 & -46.8 & -46.2 & $(200)$ & 307 & 1.09 & 12.25 \\
\hline $45-1,127-129$ & 59 & 508.24 & 8.50 & -48.2 & -46.1 & $(300)$ & 293 & 1.30 & 14.69 \\
\hline $45-2,31-33$ & 59 & 508.76 & 3.62 & -44.8 & -43.8 & $(300)$ & 216 & 1.06 & 7.64 \\
\hline $45-2,45-47$ & 59 & 508.91 & 5.78 & -46.8 & -46.6 & (THD) $)^{\mathrm{a}}$ & & 1.08 & 12.03 \\
\hline $45-2,59-61$ & 59 & 509.04 & 7.09 & -45.1 & -45.1 & $(300)$ & 357 & 0.94 & 16.87 \\
\hline $45-2,104-106$ & 59 & 509.49 & 5.03 & -47.2 & -46.1 & $(300)$ & 304 & 1.08 & 10.47 \\
\hline $45-3,22-24$ & 59 & 510.15 & 4.38 & -42.8 & -42.4 & $(300)$ & 375 & 0.65 & 15.19 \\
\hline $45-4,124-126$ & 60 & 512.57 & 4.20 & -49.7 & -43.9 & $(300)$ & 295 & 1.54 & 6.14 \\
\hline $45-4,6-8$ & 60 & 511.39 & 4.61 & -47.0 & -42.5 & $(300)$ & 257 & 1.55 & 6.67 \\
\hline $45-5,51-53$ & 60 & 513.25 & 4.10 & -54.5 & -49.9 & $(\mathrm{THD})^{\mathrm{a}}$ & & 2.33 & 3.95 \\
\hline $45-5,84-86$ & 60 & 513.57 & 6.21 & -47.7 & -41.4 & $(300)$ & 231 & 1.49 & 9.37 \\
\hline $45-6,16-18$ & 60 & 514.31 & 4.10 & -69.7 & -44.2 & $(300)$ & 121 & 1.80 & 5.10 \\
\hline $45-6,43-45$ & 60 & 514.59 & 2.37 & -49.5 & -56.5 & $(\mathrm{THD})^{\mathrm{a}}$ & & 1.71 & $3.10^{\mathrm{c}}$ \\
\hline $45-6,73-75$ & 60 & 514.88 & 2.03 & -58.5 & -42.7 & $(300)$ & 155 & 1.84 & 2.48 \\
\hline $45-7,121-123$ & 61 & 516.74 & 4.75 & -45.2 & -43.3 & $(200)$ & 297 & 1.41 & 7.57 \\
\hline $45-7,144-146$ & 61 & 516.97 & 4.55 & -45.9 & -44.0 & $(200)$ & 332 & 1.21 & 8.41 \\
\hline $46-1,11-13$ & 61 & 516.61 & 2.94 & -43.2 & -41.2 & $(200)$ & 270 & 1.56 & 4.24 \\
\hline $46-1,48-50$ & 61 & 516.98 & 1.75 & -44.2 & -44.1 & $(200)$ & 261 & 1.39 & 2.81 \\
\hline $46-1,83-85$ & 61 & 517.33 & 2.13 & -44.1 & -43.7 & (200) & 396 & 0.83 & 5.73 \\
\hline $46-2,120-122$ & 62 & 519.17 & 8.59 & -41.5 & -40.3 & $(400)$ & 393 & 1.51 & 12.80 \\
\hline $46-3,14-16$ & 62 & 519.57 & 5.04 & -41.2 & -40.4 & $(400)$ & 377 & 1.28 & 8.83 \\
\hline $46-3,54-56$ & 62 & 519.95 & 3.49 & -42.3 & -44.8 & $(\mathrm{THD})^{\mathrm{a}}$ & & 1.27 & 6.17 \\
\hline $46-3,72-74$ & 62 & 520.12 & 4.05 & -43.9 & -42.0 & $(400)$ & 384 & 1.20 & 7.55 \\
\hline $46-3,120-122$ & 62 & 520.60 & 2.52 & -45.0 & -41.3 & $(400)$ & 351 & 1.14 & 4.98 \\
\hline $46-4,109-111$ & 62 & 521.92 & 8.95 & -34.7 & -34.4 & $(400)$ & 336 & 1.72 & 11.69 \\
\hline $46-5,142-144$ & 63 & 523.54 & 3.85 & -42.3 & -40.9 & $(200)$ & 373 & 1.57 & 5.50 \\
\hline $47-1,20-22$ & 63 & 526.17 & 3.57 & -41.2 & -38.9 & (200) & 318 & 1.09 & 7.34 \\
\hline $47-1,26-28$ & 63 & 526.24 & 3.13 & -39.7 & -40.2 & (THD) $)^{\mathrm{a}}$ & & 1.17 & 6.01 \\
\hline $47-1,42-44$ & 63 & 526.39 & 3.79 & -45.1 & -40.4 & $(200)$ & 302 & 1.07 & 7.93 \\
\hline $47-1,60-62$ & 63 & 526.57 & 4.00 & -44.5 & -40.7 & $(200)$ & 311 & 1.13 & 7.97 \\
\hline $47-1,93-95$ & 63 & 526.90 & 3.15 & -41.0 & -39.1 & (200) & 339 & 1.07 & 6.62 \\
\hline $47-5,25-27$ & 64 & 531.94 & 10.40 & -71.3 & -79.1 & (THD) $)^{\mathrm{a}}$ & & 1.22 & $19.04 \mathrm{C}$ \\
\hline $47-5,80-82$ & 64 & 532.39 & 2.89 & -78.3 & -77.0 & $(400)$ & 177 & 1.02 & 6.32 \\
\hline $48-1,44-46$ & 64 & 535.94 & 7.54 & -65.1 & -62.2 & $(400)$ & 318 & 1.11 & 15.18 \\
\hline $48-2,15-17$ & 64 & 537.13 & 30.30 & -71.7 & -71.2 & $(400)$ & 351 & 2.60 & 26.12 \\
\hline $48-2,138-140$ & 64 & 538.34 & 6.11 & -68.5 & -67.3 & $(400)$ & 388 & 1.22 & 11.28 \\
\hline $48-3,30-32$ & 64 & 538.76 & 5.72 & -64.3 & -62.6 & (THD) $)^{\mathrm{a}}$ & & 1.03 & 12.47 \\
\hline $48-3,55-57$ & 64 & 539.00 & 6.50 & -69.6 & -65.7 & $(400)$ & 379 & 1.11 & 13.14 \\
\hline $48-4,12-14$ & 65 & 540.03 & 7.98 & -65.8 & -65.6 & $(400)$ & 480 & 0.71 & 25.35 \\
\hline $48-4,47-49$ & 65 & 540.35 & 7.10 & -67.3 & -68.0 & $(400)$ & 574 & 0.60 & 26.78 \\
\hline $48-4,61-63$ & 65 & 540.49 & 3.85 & -65.2 & -65.1 & $(400)$ & 513 & 0.45 & 19.31 \\
\hline $48-4,93-95$ & 65 & 540.77 & 4.15 & -66.3 & -66.4 & $(400)$ & 504 & 0.71 & 13.19 \\
\hline
\end{tabular}


TABLE 17 - Continued

\begin{tabular}{|c|c|c|c|c|c|c|c|c|c|}
\hline $\begin{array}{c}\text { Sample } \\
\text { (Interval in } \mathrm{cm} \text { ) }\end{array}$ & $\begin{array}{l}\text { Flow } \\
\text { Unit }\end{array}$ & $\begin{array}{l}\text { Sub-bottom } \\
\text { Depth } \\
\text { (m) }\end{array}$ & $\begin{array}{c}\mathrm{J}_{\mathrm{NRM}} \\
\left(\times 10^{-5} \mathrm{emu} / \mathrm{cm}^{3}\right)\end{array}$ & $\begin{array}{c}\text { Inclination } \\
\text { of NRM } \\
\left(^{\circ}\right)\end{array}$ & $\begin{array}{c}\text { Stable } \\
\text { Inclination } \\
\left(^{\circ}\right)\end{array}$ & $\begin{array}{l}\mathrm{AF} \\
(\mathrm{Oe})\end{array}$ & $\begin{array}{l}\text { MDF } \\
(\mathrm{Oe})\end{array}$ & $\begin{array}{l}\text { Suscept. } \\
x \\
\left(\times 10^{-5}\right)\end{array}$ & $\begin{array}{c}\mathrm{Q}_{\mathrm{n}} \\
(\mathrm{Oe})^{\mathrm{b}}\end{array}$ \\
\hline \multicolumn{10}{|l|}{ Hole $433 \mathrm{C}$} \\
\hline $\begin{array}{l}49-1,6-8 \\
49-1,122-124 \\
49-1,142-144 \\
49-2,10-12 \\
49-2,31-33 \\
49-2,50-52 \\
49-2,58-60 \\
49-2,72-74 \\
49-2,111-113\end{array}$ & $\begin{array}{l}65 \\
66 \\
66 \\
66 \\
66 \\
66 \\
66 \\
66 \\
66\end{array}$ & $\begin{array}{l}545.06 \\
546.18 \\
546.38 \\
546.54 \\
546.75 \\
546.95 \\
547.02 \\
547.16 \\
547.56\end{array}$ & $\begin{array}{l}6.25 \\
3.92 \\
3.06 \\
4.24 \\
4.96 \\
4.29 \\
4.41 \\
3.55 \\
9.62\end{array}$ & $\begin{array}{l}-64.9 \\
-65.6 \\
-64.1 \\
-67.0 \\
-64.7 \\
-64.8 \\
-64.6 \\
-67.7 \\
-65.1\end{array}$ & $\begin{array}{l}-65.4 \\
-66.0 \\
-64.8 \\
-66.9 \\
-64.6 \\
-63.9 \\
-65.1 \\
-67.2 \\
-64.3\end{array}$ & $\begin{array}{l}(400) \\
(400) \\
(\mathrm{THD}) \mathrm{a} \\
(400) \\
(400) \\
(\mathrm{THD})^{\mathrm{a}} \\
(400) \\
(400) \\
(400)\end{array}$ & $\begin{array}{l}373 \\
502 \\
\\
514 \\
545 \\
\\
401 \\
394 \\
367\end{array}$ & $\begin{array}{l}1.05 \\
0.61 \\
0.59 \\
0.61 \\
0.59 \\
0.74 \\
0.67 \\
0.78 \\
1.35\end{array}$ & $\begin{array}{l}13.39 \\
14.40 \\
11.71 \\
15.58 \\
18.96 \\
13.07 \\
14.76 \\
10.16 \\
15.86\end{array}$ \\
\hline
\end{tabular}

$\mathrm{a}_{\mathrm{b}} \mathrm{THD}=$ Thermal demagnetization.

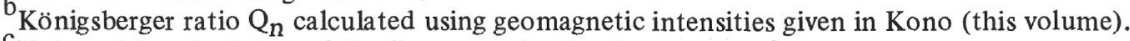

${ }_{d}$ Not used in calculation of the flow mean inclination.

Baked by the overlying lava flow. Not used in calculation of the flow mean inclination.

the time Suiko Seamount was formed were similar to those of the present magnetic field, such curves may represent an interval of several hundred to a few thousand years. Jumps in inclination trends also occur at many places. These may correspond to time gaps of any length, but certainly longer than several hundred years.

At least twelve such inclination jumps are apparent in Figure 31. From the rough estimates of time discussed above, we can conclude that the flow units collected in Hole $433 \mathrm{C}$ cover a time span of at least $10^{4}$ years, probably considerably longer than that. On the other hand, all the flow units are reversely magnetized. According to the normal-reversed time scale of Heirtzler et al. (1968), the longest single polarity interval in the period 50 to 70 m.y. ago was about $2 \mathrm{~m}$.y. long, and most of the others were less than $1 \mathrm{~m} . \mathrm{y}$. long. Since their time scale may neglect polarity intervals of short duration, the true length of a polarity interval may have been even shorter. It is therefore very unlikely that these flow units cover a time span of more than about $10^{6}$ years. As discussed in the site summary chapter for Site 430 (this volume), a time interval of more than $10^{4}$ years but less than $10^{6}$ years is a very convenient one for sampling the paleosecular variation of the geomagnetic field; $10^{4}$ to $10^{6}$ years is regarded as sufficient to average out the secular variation, and in an interval less than $10^{6}$ years we do not have to deal with the disturbing effects of plate motions, geomagnetic polarity reversals, and excursion.

To discuss the secular variation, we need to know how many of the inclination values can be regarded as independent data. In fact, as mentioned earlier, some flow units may have erupted in too short a time to be treated as independent samples. Proper treatment of this problem is a difficult matter, however. Instead, we show here that the statistical characteristics of inclination data from Suiko Seamount are essentially the same when analyzed at different sampling levels, implying that they represent the real properties of secular variation.

If we have two groups of $n_{1}$ and $n_{2}$ samples with mean $\bar{x}_{1}$ and $\bar{x}_{2}$ and standard deviation $s_{1}$ and $s_{2}$, and if the covariance

$$
\text { C.V. }=1.960 \sqrt{\frac{s_{1}^{2}}{n_{1}}+\frac{s_{2}^{2}}{n_{2}}}
$$

is smaller than the difference $\bar{x}_{1}-\bar{x}_{2}$, we can say that true means of the two groups $\mu_{1}$ and $\mu_{2}$ are different at the 95 per cent confidence level. This analysis was carried out on the flow mean inclination data in Table 18. When the statistical test showed a true difference in the means of adjacent flow units, a group boundary was drawn. Group means were calculated from inclinations of individual samples, and are listed in Table 19. In this table, $\mathrm{N}$ is the number of samples, $I$ the mean inclination, $s_{1}$ the standard deviation, $\theta$ the magnetic latitude corresponding to $I$, and $\Delta \theta$ a measure of uncertainty in $\theta$ calculated by

$$
\Delta \theta=2\left(1+3 \cos ^{2}\right) I^{-1 / 2} d I
$$

Figure 32 shows the distributions of inclination data at different levels. A striking similarity is apparent among the figures for different statistical levels. All have very similar modes, means, and median values (marked in arrows). This suggests that the sampling is adequate in our case and that the data represent true properties of inclination changes. Statistical data of inclination analyses are given in Table 20.

We conclude that the inclination changed with standard deviation of $14^{\circ}$ about a mean of $42^{\circ}$ during the time the Hole $433 \mathrm{C}$ lavas were erupted. The mean value is accurate to within $\pm 4^{\circ}$ at the 95 per cent confidence level. If this mean inclination is assumed to represent the axial dipole field of the earth, the estimated paleolatitude of Suiko Seamount is about $25^{\circ}$.

Another way to estimate the paleolatitude is to use magnetic latitude data of individual flow units or groups. Figure 33 shows distributions of such data, and corresponding statistics are given in Table 21. Again, there are no significant differences between these two levels. The mean and standard error shown in Table 21 suggest that the paleolatitude of Suiko Seamount was $26.3^{\circ} \pm 2.8^{\circ}$ if flow units are taken as data base, or 
TABLE 18

Statistics of Paleomagnetic Data, Leg 55, Site 433 (mean value with standard deviation in parentheses)

\begin{tabular}{|c|c|c|c|c|c|c|c|c|c|c|}
\hline \multirow{2}{*}{$\begin{array}{c}\begin{array}{c}\text { Flow } \\
\text { Unit/ } \\
\text { Sub-unit }\end{array} \\
1\end{array}$} & \multirow{2}{*}{$\begin{array}{c}\begin{array}{c}\text { Number } \\
\text { of } \\
\text { Samples }\end{array} \\
15\end{array}$} & \multirow{2}{*}{$\begin{array}{c}\begin{array}{c}\text { Inclination } \\
\left({ }^{\circ}\right)\end{array} \\
-39.1(3.5)\end{array}$} & \multirow{2}{*}{$\begin{array}{c}\begin{array}{c}\text { Magnetic } \\
\text { Latitude } \\
\left({ }^{\circ}\right)\end{array} \\
22.1\end{array}$} & \multirow{2}{*}{$\begin{array}{c}\begin{array}{c}\text { Intensity of } \\
\mathrm{NRM}\end{array} \\
\left(10^{-5} \mathrm{emu} / \mathrm{cm}^{3}\right)\end{array}$} & \multirow{2}{*}{$\begin{array}{c}\begin{array}{c}\text { Median Demagne- } \\
\text { tizing Field } \\
(\mathrm{MDF})(\mathrm{Oe})\end{array} \\
100(75)\end{array}$} & \multicolumn{2}{|c|}{$\begin{array}{c}\text { Susceptibility } \\
\left(10^{-5} \mathrm{emu} / \mathrm{cm}^{3} \mathrm{Oe}\right)\end{array}$} & \multicolumn{2}{|c|}{$\begin{array}{l}\mathrm{Q}_{\mathrm{n}} \\
(\mathrm{Oe})\end{array}$} & \multirow{2}{*}{$\frac{\text { Remarks }}{\mathrm{a}}$} \\
\hline & & & & & & 370 & (206) & 1.94 & $(1.19)$ & \\
\hline 2 & 3 & $-36.3(5.6)$ & 20.2 & $585(476)$ & $25(20)$ & 347 & $(77)$ & 1.52 & $(1.20)$ & \\
\hline 4 & 14 & $-43.2(3.9)$ & 25.1 & $1600(760)$ & $280(25)$ & 208 & (71) & 7.38 & $(1.60)$ & b \\
\hline 5 & 4 & $-44.1(4.5)$ & 25.9 & $964(711)$ & $315(20)$ & 170 & (98) & 5.44 & $(0.71)$ & \\
\hline 6 & 3 & $-43.3(2.5)$ & 25.2 & $989(401)$ & $315(40)$ & 179 & (47) & 5.44 & $(0.90)$ & \\
\hline 7 & 3 & $-45.2(1.3)$ & 26.7 & $214(5)$ & $345(20)$ & 57.6 & $(4.0)$ & 3.72 & $(0.23)$ & \\
\hline 8 & 4 & $-52.9(2.3)$ & 33.5 & $382(84)$ & $335(175)$ & 107 & (57) & 4.17 & $(1.75)$ & \\
\hline 9 & 4 & $-56.0(1.2)$ & 36.5 & $344(96)$ & $185(65)$ & 88.1 & $(29.2)$ & 3.61 & $(0.14)$ & \\
\hline 10 & 4 & $-28.3(6.1)$ & 15.1 & $418(40)$ & $95(50)$ & 125 & (41) & 3.57 & $(0.97)$ & c \\
\hline 11 & 8 & $-42.8(13.7)$ & 24.9 & $326(140)$ & $300(160)$ & 153 & (63) & 2.24 & $(0.97)$ & d \\
\hline 12 & 5 & $-20.2(1.7)$ & 10.4 & $261(77)$ & $320(65)$ & 328 & $(60)$ & 0.788 & $(0.214)$ & \\
\hline 13 & 6 & $-21.9(2.4)$ & 11.4 & $540(256)$ & $190(180)$ & 272 & (70) & 2.02 & $(1.15)$ & \\
\hline 14 & 5 & $-24.4(1.5)$ & 12.8 & $105(32)$ & $610(140)$ & 30.3 & $(7.0)$ & 3.40 & $(0.51)$ & \\
\hline 15 & 7 & $-49.2(7.6)$ & 30.1 & $371(222)$ & $300(225)$ & 79.0 & $(32.5)$ & 5.29 & $(3.10)$ & $\mathrm{e}$ \\
\hline 16 & 4 & $-58.5(1.6)$ & 39.2 & $585(716)$ & $200(70)$ & 143 & (48) & 3.65 & $(3.67)$ & \\
\hline 17 & 5 & $-61.0(2.3)$ & 42.1 & 384 (187) & $255(110)$ & 241 & (103) & 2.12 & $(1.67)$ & \\
\hline 18 & 6 & $-42.0(1.8)$ & 24.2 & $290(117)$ & $150(90)$ & 150 & (74) & 2.00 & $(0.55)$ & \\
\hline 19 & 7 & $-38.2(2.8)$ & 21.5 & $421(330)$ & $335(75)$ & 93.5 & (54.0) & 4.29 & (1.67) & \\
\hline 20 & 5 & $-40.3(1.2)$ & 23.0 & $125(64)$ & 540 (185) & 43.6 & (19.9) & 2.80 & $(0.77)$ & \\
\hline 21 & 6 & $-37.5(2.3)$ & 21.0 & $324(128)$ & $320(70)$ & 113 & $(65.3)$ & 3.20 & $(0.88)$ & $\mathrm{f}$ \\
\hline 22 & 6 & $-42.0(1.2)$ & 24.2 & $205(100)$ & $510(245)$ & 48.7 & (23.3) & 4.57 & $(2.45)$ & \\
\hline 23 & 4 & $-39.2(3.3)$ & 22.2 & $128(63)$ & $230(125)$ & 36.6 & (14.3) & 3.83 & (2.15) & \\
\hline 24 & 5 & $-34.2(1.7)$ & 18.8 & $121(86)$ & $215(60)$ & 45.6 & (32.5) & 2.89 & (2.15) & \\
\hline 25 & 5 & $-68.3(3.2)$ & 51.5 & $239(75)$ & $125(75)$ & 272 & (172) & 0.998 & $(0.305)$ & $\mathrm{g}$ \\
\hline $26 a$ & 4 & $-68.1(1.5)$ & 51.2 & $206(74)$ & $245(190)$ & 92.5 & (29.9) & 2.57 & (1.54) & \\
\hline $26 b$ & 4 & $-21.0(2.3)$ & 10.9 & $659(494)$ & $330(40)$ & 215 & (49) & 2.92 & $(1.93)$ & \\
\hline 27 & 5 & $-62.7(1.9)$ & 44.1 & 567 (146) & $110(95)$ & 285 & (133) & 2.29 & (1.05) & \\
\hline $28-1$ & 3 & $-57.3(6.8)$ & 37.9 & 285 (93) & $360(80)$ & 68.7 & (29.9) & 4.28 & $(0.77)$ & $\mathrm{h}$ \\
\hline $28-2$ & 4 & $-43.0(1.8)$ & 25.0 & $318(241)$ & $350(80)$ & 43.7 & (25.9) & 7.15 & $(0.92)$ & $\mathrm{h}$ \\
\hline 29 & 5 & $-40.3(1.3)$ & 22.9 & $461(54)$ & $310(30)$ & 43.8 & (9.9) & 10.7 & (1.4) & \\
\hline 30 & 5 & $-42.2(0.7)$ & 24.4 & 774 (619) & $385(80)$ & 59.5 & (35.3) & 12.5 & $(3.9)$ & \\
\hline 31 & 4 & $-40.8(0.9)$ & 23.3 & $1200(580)$ & $460(135)$ & 112 & (58) & 11.3 & (3.7) & \\
\hline 32 & 5 & $-40.6(2.4)$ & 23.2 & $1770(827)$ & $330(40)$ & 148 & (34) & 11.6 & $(3.6)$ & \\
\hline 33 & 5 & $-42.3(0.5)$ & 24.5 & $330(120)$ & $515(85)$ & 31.3 & (11.2) & 11.9 & $(5.4)$ & \\
\hline 34 & 5 & $-41.4(1.3)$ & 23.8 & $342(161)$ & $390(55)$ & 55.2 & (29.3) & 6.39 & (1.9) & \\
\hline 35 & 5 & $-49.7(0.7)$ & 30.6 & $703(306)$ & $360(75)$ & 177 & (99) & 4.87 & $(2.52)$ & \\
\hline 36 & 4 & $-50.4(2.0)$ & 31.2 & $351(86)$ & $990(225)$ & 53.1 & (28.8) & 8.11 & $(4.08)$ & \\
\hline 37 & 3 & $-50.7(1.0)$ & 31.4 & $723(236)$ & $370(25)$ & 130 & (19) & 5.46 & $(1.00)$ & \\
\hline 38 & 5 & $-51.0(0.9)$ & 31.7 & 825 (159) & 295 (15) & 116 & (29) & 7.28 & $(1.17)$ & \\
\hline 39 & 3 & $-54.4(0.9)$ & 34.9 & 346 (111) & $170(30)$ & 81.2 & (3.0) & 4.25 & $(1.28)$ & \\
\hline 40 & 2 & $-51.8(1.6)$ & 32.4 & $1900(715)$ & $340(5)$ & 203 & (49) & 9.18 & $(1.30)$ & \\
\hline 41 & 3 & $-53.9(0.6)$ & 34.5 & $630(245)$ & $295(20)$ & 92.8 & (22.4) & 6.63 & $(1.16)$ & \\
\hline 44 & 4 & $-49.3(1.5)$ & 30.2 & $310(98)$ & $175(80)$ & 121 & (15) & 2.60 & $(0.94)$ & \\
\hline 45 & 5 & $-47.2(0.9)$ & 28.4 & $348(173)$ & 435 (120) & 55.1 & (36.4) & 7.00 & (1.48) & \\
\hline 46 & 5 & $-8.9(3.8)$ & 4.5 & $233(67)$ & $350(60)$ & 67.1 & (16.6) & 3.64 & (1.20) & $\mathrm{i}$ \\
\hline 47 & 5 & $-5.4(3.1)$ & 2.7 & $140(14)$ & $250(50)$ & 47.1 & $(6.3)$ & 2.98 & $(0.18)$ & \\
\hline 48 & 5 & $-43.0(1.6)$ & 25.0 & $162(76)$ & $410(105)$ & 46.3 & (15.8) & 3.45 & $(0.76)$ & \\
\hline 49 & 5 & $-44.8(2.0)$ & 26.4 & $913(181)$ & 385 (115) & 175 & (114) & 6.15 & (1.98) & \\
\hline $51 \mathrm{a} 1$ & 4 & $-46.2(9.3)$ & 27.5 & $173(138)$ & 480 (15) & 90.0 & (46.7) & 2.02 & $(0.92)$ & j \\
\hline $51 \mathrm{~b} 2$ & 4 & $-11.6(1.3)$ & 5.9 & $490(71)$ & $300(10)$ & 105 & (17) & 4.69 & $(0.50)$ & $\mathrm{j}$ \\
\hline 52 & 5 & $-12.8(1.8)$ & 6.5 & $405(30)$ & $325(10)$ & 101 & (14) & 4.06 & $(0.70)$ & \\
\hline 53 & 3 & $-25.0(2.0)$ & 13.1 & $283(22)$ & $435(70)$ & 94.2 & $(27.8)$ & 3.27 & (1.32) & $\mathrm{k}$ \\
\hline 54 & 5 & $-32.9(1.4)$ & 18.0 & $471(51)$ & $300(5)$ & 101 & (9) & 4.66 & $(0.34)$ & \\
\hline 56 & 4 & $-41.2(2.7)$ & 23.6 & $280(91)$ & $220(60)$ & 130 & (31) & 2.17 & $(0.60)$ & \\
\hline 58 & 5 & $-47.5(2.7)$ & 28.6 & $623(285)$ & $290(45)$ & 104 & (8) & 6.13 & $(3.02)$ & \\
\hline
\end{tabular}


TABLE 18 - Continued

\begin{tabular}{|c|c|c|c|c|c|c|c|c|}
\hline $\begin{array}{l}\text { Flow } \\
\text { Unit/ } \\
\text { Sub-unit }\end{array}$ & $\begin{array}{l}\text { Number } \\
\text { of } \\
\text { Samples }\end{array}$ & $\begin{array}{l}\text { Inclination } \\
\left(^{\circ}\right)\end{array}$ & $\begin{array}{l}\text { Magnetic } \\
\text { Latitude } \\
\quad\left({ }^{\circ}\right)\end{array}$ & $\begin{array}{c}\text { Intensity of } \\
\mathrm{NRM} \\
\left(10^{-5} \mathrm{emu} / \mathrm{cm}^{3}\right)\end{array}$ & $\begin{array}{c}\text { Median Demagne- } \\
\text { tizing Field } \\
(\mathrm{MDF})(\mathrm{Oe})\end{array}$ & $\begin{array}{c}\text { Susceptibility } \\
\left(10^{-5} \mathrm{emu} / \mathrm{cm}^{3} \mathrm{Oe}\right)\end{array}$ & $\begin{array}{l}\mathrm{Q}_{\mathrm{n}} \\
(\mathrm{Oe})\end{array}$ & Remarks \\
\hline 59 & 5 & $-44.7(1.6)$ & 26.3 & $568(200)$ & $310(60)$ & 99.7 (23.7) & 5.78 (1.69) & \\
\hline 60 & 5 & -42.9 (1.1) & 25.0 & $420(148)$ & $210(70)$ & 163 (17) & $2.65 \quad(1.12)$ & \\
\hline 61 & 5 & $-43.1(1.0)$ & 25.1 & $320(136)$ & $310(55)$ & $127 \quad$ (27) & $2.56(1.03)$ & \\
\hline 62 & 5 & $-41.0(0.8)$ & 23.5 & $578(281)$ & $350(65)$ & $136 \quad(24)$ & 4.09 (1.41) & $\ell$ \\
\hline 63 & 5 & $-40.3(0.8)$ & 22.9 & 364 (33) & $330(30)$ & $118 \quad(22)$ & $3.15(0.46)$ & \\
\hline 64 & 5 & $-69.0(5.3)$ & 52.4 & $1060(1100)$ & $360(120)$ & $140 \quad(66)$ & $6.41 \quad(3.25)$ & \\
\hline 65 & 5 & $-66.1(1.2)$ & 48.5 & $582(180)$ & $490(75)$ & $69.5(22.0)$ & $8.73(2.85)$ & \\
\hline 66 & 6 & $-65.7(1.2)$ & 47.9 & $506(221)$ & $455(75)$ & $76.2(29.2)$ & $6.67 \quad(1.27)$ & \\
\hline
\end{tabular}

${ }_{\mathrm{b}}^{\mathrm{a}}$ Three samples from Hole 433B showed unstable behavior in AF demagnetization. They were excluded from inclination analysis.

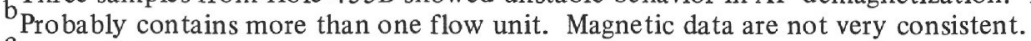

${ }^{c}$ Probable flow boundary between Section $13-1,8 \mathrm{~cm}$ and Section $13-2,53 \mathrm{~cm}$.

Two probable flow boundaries are indicated by magnetic data: (1) between Section 14-2, $130 \mathrm{~cm}$ and Section 13-3, 55 cm; and (2) between Section 15-2, $105 \mathrm{~cm}$ and Section 15-3, $127 \mathrm{~cm}$.

e Probable flow boundary within Section $20-1$, in the interval $26-80 \mathrm{~cm}$. Also a flow boundary is possible between Section $19-3,17 \mathrm{~cm}$ and Section 19-4, $17 \mathrm{~cm}$.

${ }^{\mathrm{f}}$ Possible flow boundary between Section 25-3, $20 \mathrm{~cm}$ and Section 25-5, $77 \mathrm{~cm}$. A sample from Section 25-3, interval 18-20 cm, was excluded from inclination analysis.

${ }^{\mathrm{g}}$ Section $27-6,58-60 \mathrm{~cm}$ was probably reheated by Unit 24 , and so is excluded from inclination analysis.

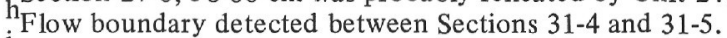

${ }_{j}^{i}$ Flow 46a excluded from inclination analysis.

$\mathrm{j}$ Flow boundary detected at approximately $130 \mathrm{~cm}$ in Section 40-5.

$\mathrm{k}_{\text {Section }} 42-2,35-37 \mathrm{~cm}$ was probably reheated by Unit 52 , and so is excluded from inclination analysis.

${ }^{\ell}$ Flow $62 \mathrm{c}$ excluded from inclination analysis.

$25.1^{\circ} \pm 3.4^{\circ}$ if groups are taken as the data base, at the 95 per cent confidence level.

\section{Conclusions}

We draw several conclusions from this study.

1) The paleolatitude of Suiko Seamount is about $25^{\circ}$, with uncertainty of $4^{\circ}$ at 95 per cent confidence level.

2) The 400-meters-thick basaltic cored top of Suiko Seamount apparently accumulated in a period greater than $10^{4}$ years but less than $10^{6}$ years. Some flow units seem to have erupted in quick succession, but a time gap is represented at other flow boundaries, suggesting that the volcanism was intermittent and episodic, just as is observed on volcanoes of the Island of Hawaii. The interval estimated above also suggests that a substantial part of a seamount may have been formed in a relatively short time, within a polarity interval, say, giving some support to paleomagnetism of seamount magnetic anomalies.

3) A good record of secular variation in inclination about $60 \mathrm{~m}$.y. ago was obtained. It contains some portions where almost continuous change is recorded, 12 or more time gaps, and about 15 extreme (maximum and minimum) values. It seems sufficiently long to cover the entire range of secular variation. The standard deviation of inclination data is about $14^{\circ}$, and if we assume an isotropic variation, this corresponds to a standard deviation of about $20^{\circ}$ in angle. This is somewhat larger than the value obtained from the present-day field at $25^{\circ}$ latitude (about $15^{\circ}$ ).

4) The drilled basalts have magnetic properties similar to those of oceanic island basalts, and different from those of mid-ocean ridge basalts. Most rocks have
NRM's stable to AF demagnetization, representing the direction of the ambient field when these rocks formed.

\section{PHYSICAL PROPERTIES}

Sonic velocity and density were measured with the Hamilton Frame and the GRAPE apparatus. For soft sediments, the sonic measurements were made through the plastic liner; for basalts, they were made on "splits" within a few hours after they were sawed, and on paleomagnetic "minicores" after paleomagnetic studies had been completed (one or two days, no thermal treatment). All the velocity measurements are listed in Tables 22 and 23. Continuous GRAPE measurements were made on the sediments and on all basalt pieces larger than about $10 \mathrm{~cm}$, but because of time restrictions these data have not been reduced. The minicores were placed in a holder for " 2 -minute GRAPE" counts; these have been reduced, tabulated and plotted here.

There is no completely satisfactory way to assign subbottom depths to each sample. (The best would be to log the hole and match the samples to the log's signature.) We computed sub-bottom depth on the following assumptions: the top of the core is where coring began, and any void is at the bottom of the interval (i.e., we "push" the core "up"); each previous section of a core is exactly $150 \mathrm{~cm}$ long (even though there may be only 90 or $120 \mathrm{~cm}$ of rock in a section because of gaps and styrofoam spacers); the distance down in a section is the "centimeter" position of the sample (again we include the gaps and spacers). This method of assigning subbottom depths was derived before drilling in seamounts; when recovery is more than 90 per cent the interesting situation develops where samples from the bottom of 


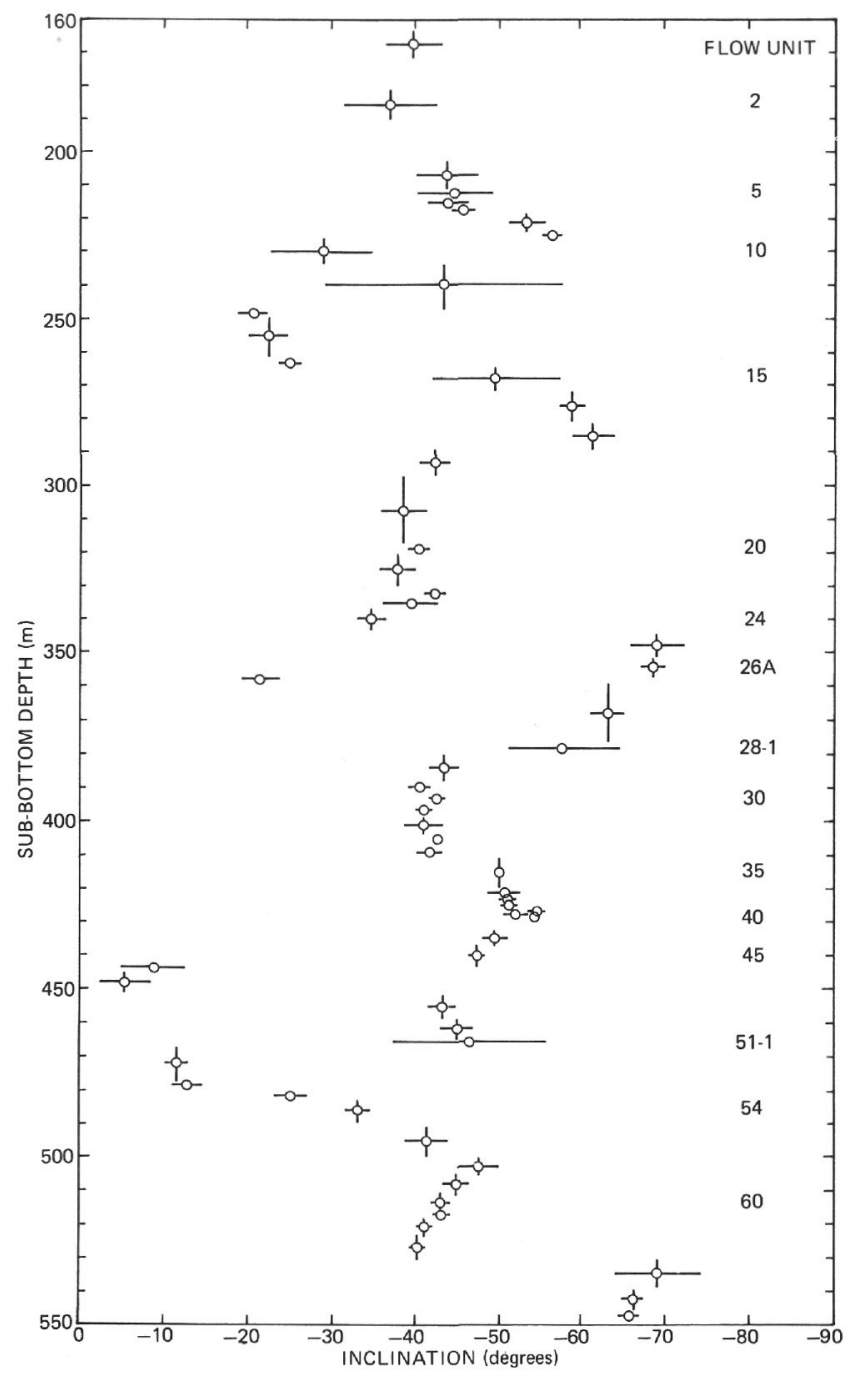

Figure 31. Magnetic inclinations, Hole 433C.

one core are deeper than those at the top of the next! Since the error is never more than about a meter, and since knowing the depths more accurately than this is not important to any of our studies, we adopted this simple, unambiguous method of calculating depth.

Four units in the sediments may be defined on the basis of velocities (densities will be processed later).

1) The top 1 meter in both Hole 433 and Hole $433 \mathrm{~A}$ had a velocity of $1.60 \mathrm{~km} / \mathrm{s}$, higher than that below.

2) From 1 meter to 52 meters, the velocity was a very smooth $1.54 \mathrm{~km} / \mathrm{s}$, occasionally varying to 1.52 to 1.56 $\mathrm{km} / \mathrm{s}$.

3) Abruptly at 52 meters the signal disappeared. Whereas above the signal was very strong, the ultrasonic pulse could not propagate through the sample between 52 meters and about 62 meters.

4) Between 62 meters and $80+$ meters, the velocity was about $2.00 \mathrm{~km} / \mathrm{s}$, perhaps decreasing slightly (to about $1.90 \mathrm{~km} / \mathrm{s}$ ) toward the bottom of this interval. Although the signal was weak (and in some parts of this interval the ultrasonic pulse could not propagate through the coarse, lumpy sediments), a velocity could be measured, and it was significantly higher than that of the unit above.
TABLE 19

Statistics of Grouped Magnetic Inclination Data, Site 433

\begin{tabular}{clrrrrr}
\hline & Flow Units/ & & & & & \\
Group & Sub-units & N & I & SI & $\theta$ & $\Delta \theta$ \\
\hline 1 & 1,2 & 15 & -38.5 & 3.9 & 21.7 & 2.8 \\
2 & $4,5,6,7$ & 24 & -43.6 & 3.5 & 25.4 & 2.7 \\
3 & 8 & 4 & -52.9 & 2.3 & 33.5 & 2.2 \\
4 & 9 & 4 & -56.0 & 1.2 & 36.5 & 1.3 \\
5 & 10 & 4 & -28.3 & 6.1 & 15.1 & 3.7 \\
6 & 11 & 8 & -42.8 & 13.7 & 24.9 & 10.4 \\
7 & 12,13 & 11 & -21.2 & 2.2 & 11.0 & 1.2 \\
8 & 14 & 5 & -24.4 & 1.5 & 12.8 & 0.8 \\
9 & 15 & 7 & -49.2 & 7.6 & 30.1 & 6.7 \\
10 & 16,17 & 9 & -59.9 & 2.4 & 40.8 & 2.8 \\
11 & 18 & 6 & -42.0 & 1.8 & 24.2 & 1.4 \\
12 & 19,20 & 12 & -39.1 & 2.4 & 22.1 & 1.7 \\
13 & 21 & 5 & -37.5 & 2.3 & 21.0 & 1.6 \\
14 & 22,23 & 10 & -40.9 & 2.6 & 23.4 & 1.9 \\
15 & 24 & 5 & -34.2 & 1.7 & 18.8 & 1.1 \\
16 & $25,26 \mathrm{a}$ & 9 & -63.2 & 1.5 & 44.7 & 1.9 \\
17 & $26 \mathrm{~b}$ & 4 & -21.0 & 2.3 & 10.9 & 1.3 \\
18 & $27,28 \mathrm{a} 1$ & 8 & -60.7 & 4.8 & 41.7 & 5.6 \\
19 & $28 \mathrm{c} 2$ & 4 & -43.0 & 1.8 & 25.0 & 1.4 \\
20 & 29 & 5 & -40.3 & 1.3 & 22.9 & 1.0 \\
21 & 30 & 5 & -42.2 & 0.7 & 24.4 & 0.5 \\
22 & $31,32,33,34$ & 19 & -41.3 & 1.5 & 23.7 & 1.1 \\
23 & $35,36,37,38$ & 17 & -50.4 & 1.2 & 31.2 & 1.1 \\
24 & 39 & 3 & -54.4 & 0.9 & 34.9 & 0.8 \\
25 & 40,41 & 5 & -53.1 & 1.5 & 33.6 & 1.4 \\
26 & 44 & 5 & -49.3 & 1.5 & 30.2 & 1.3 \\
27 & 45 & 5 & -47.3 & 0.8 & 28.4 & 0.7 \\
28 & 46,47 & 9 & -7.0 & 3.7 & 3.5 & 1.8 \\
29 & $48,49,51 \mathrm{a} 1$ & 14 & -44.6 & 4.9 & 26.2 & 3.9 \\
30 & $51 \mathrm{~b} 2,52$ & 9 & -12.3 & 1.6 & 6.2 & 0.8 \\
31 & 53 & 3 & -25.0 & 2.0 & 13.1 & 1.2 \\
32 & 54 & 5 & -32.9 & 1.4 & 18.0 & 0.9 \\
33 & 56 & 4 & -41.2 & 2.7 & 23.6 & 2.0 \\
34 & 58,59 & 10 & -46.1 & 2.5 & 27.5 & 2.1 \\
35 & 60,61 & 10 & -43.0 & 1.0 & 25.0 & 0.8 \\
36 & 62,63 & 10 & -40.0 & 2.1 & 22.7 & 1.5 \\
37 & $64,65,66$ & 16 & -66.8 & 3.2 & 49.4 & 4.4 \\
\hline & & & & & &
\end{tabular}

5) From 80 meters to 160 meters the core recovery was so incomplete that a meaningful velocity study could not be made.

In the basalts the physical properties vary widely. Velocity varies repeatedly from less than $3 \mathrm{~km} / \mathrm{s}$ to more than $6 \mathrm{~km} / \mathrm{s}$ in about a 5 -meter or 10 -meter interval. (The densities shown are for minicores only; presumably the less selective continuous GRAPE data will show equally sharp swings.) These variations correlate with the flow unit boundaries.

Because of the very high core recovery, we have here velocity and density data for a very continuous section. These data may be useful in two ways. First, they provide a good sample of what a well log of a large seamount would give, with large variations in velocity/ density which correlate with flow boundaries. Thus, the feasibility of logging can be evaluated. Second, these properties correlate strongly with the flow boundaries as cored. If, however, petrologists and paleomagneticists cannot find among these data any information about units that is not better found by petrologic examination of the core itself, then the whole program of measuring 


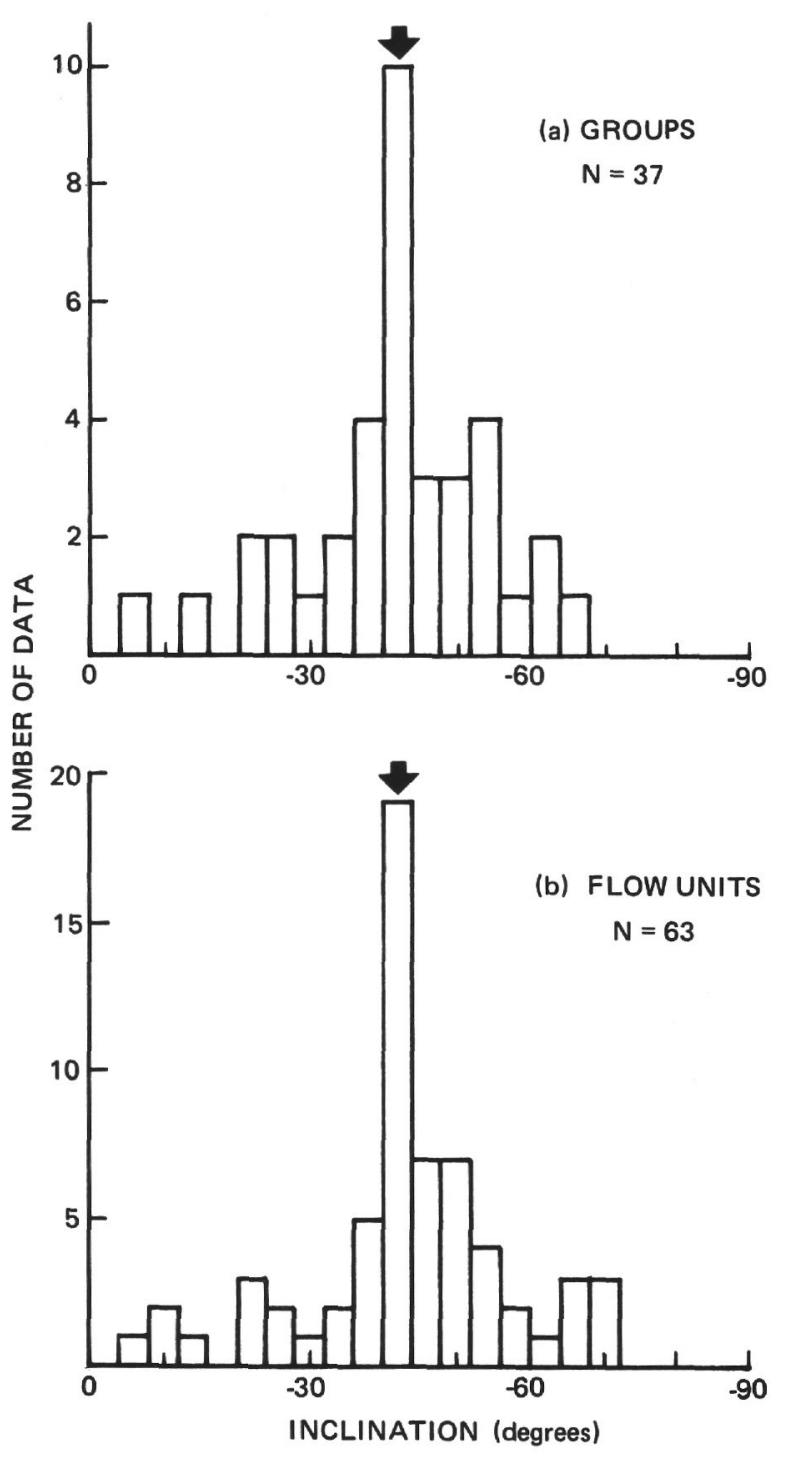

Figure 32. Histograms of magnetic inclination (a) by groups and (b) by flow units, Site 433. The means are shown by the arrows.

TABLE 20

Magnetic Inclination Statistics, Site 433

\begin{tabular}{lcccc}
\hline \multicolumn{1}{c}{ Sample } & $\mathrm{n}$ & $\overline{\mathrm{x}}$ & $\mathrm{Sx}$ & $\mathrm{S} \overline{\mathrm{x}}$ \\
\hline Flow Units & 63 & 42.8 & 14.1 & 1.8 \\
Groups & 37 & 41.5 & 13.4 & 2.2 \\
\hline
\end{tabular}

physical properties in basalts should be re-evaluated to allow for more effort in other areas.

\section{CORRELATION OF SEISMIC PROFILES WITH DRILLED SEQUENCE}

Suiko Seamount is the largest and most morphologically complex seamount drilled on the Emperor chain during Leg 55. The seismic reflection profiles across Suiko Seamount indicate that it has an extensive, flattopped or slightly domed, northeast-southwest, elongated, central platform that probably is a drowned table
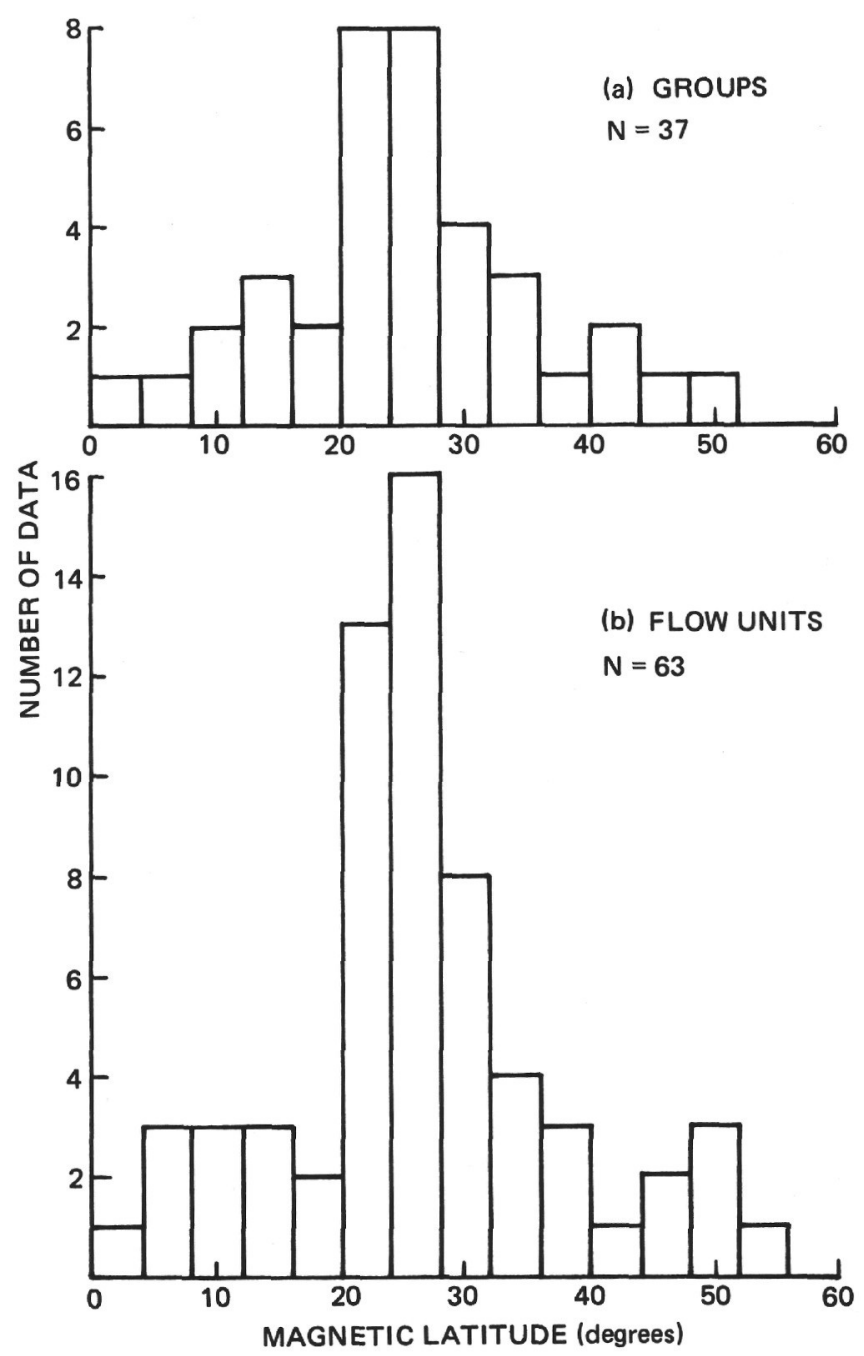

Figure 33. Histograms of magnetic latitude (a) by groups and (b) by flow units, Site 433.

TABLE 21

Paleolatitude Statistics, Site 433

\begin{tabular}{lcccc}
\hline \multicolumn{1}{c}{ Sample } & $\mathrm{n}$ & $\overline{\mathrm{x}}$ & $\mathrm{Sx}$ & $\mathrm{S} \overline{\mathrm{x}}$ \\
\hline Flow Units & 63 & 26.3 & 11.1 & 1.4 \\
Groups & 37 & 25.1 & 10.2 & 1.7
\end{tabular}

reef, reef flat, or reef bank. These platform deposits appear to overlie unconformably an irregular acoustic basement of volcanic rock which may be locally exposed at the surface and which stands above the platform as rounded knobs or hills. Flanking this central platform on the north is a fairly extensive (approx. 300-sq.-mi.) ancestral lagoon filled with over 160 meters of wellstratified, unconsolidated sediments. This lagoon does not completely surround the central platform, as we first thought from interpretation of the Lee and Kana Keoke profiles, but appears to be restricted to the northern fringe of the seamount; another, smaller lagoon appears to be restricted to the southern fringe (Figure 2). The Challenger profiles show lagoonal features crossing 
TABLE 22

Sonic Velocity for Site 433

\begin{tabular}{|c|c|c|c|}
\hline Core-Section, Interval $(\mathrm{cm})$ & $\begin{array}{c}\text { Piece } \\
\text { Number }\end{array}$ & $\begin{array}{l}\text { Velocity } \\
(\mathrm{km} / \mathrm{s})\end{array}$ & $\begin{array}{l}\text { Sub-bottom } \\
\text { Depth (m) }\end{array}$ \\
\hline \multicolumn{4}{|l|}{ Hole 433} \\
\hline $\begin{array}{l}1-1,9 \\
1-1,35 \\
1-1,70 \\
1-1,102 \\
1-1,133 \\
1-2,15 \\
1-2,76 \\
1-2,90 \\
1-2,137 \\
1-3,40\end{array}$ & & $\begin{array}{l}1.65 \\
1.57 \\
1.57 \\
(1.61)^{\mathrm{a}} \\
1.60 \\
(1.61)^{\mathrm{a}} \\
1.52 \\
1.57 \\
1.53 \\
1.54\end{array}$ & $\begin{array}{l}0.09 \\
0.35 \\
0.70 \\
1.02 \\
1.33 \\
1.65 \\
2.26 \\
2.40 \\
2.87 \\
3.40\end{array}$ \\
\hline $\begin{array}{l}1-3,95 \\
1-3,132 \\
1-4,25\end{array}$ & & $\begin{array}{l}1.54 \\
1.53 \\
1.53\end{array}$ & $\begin{array}{l}3.95 \\
4.32 \\
4.75\end{array}$ \\
\hline \multicolumn{4}{|l|}{ Hole 433A } \\
\hline $\begin{array}{l}1-1,7 \\
1-1,36 \\
1-1,38 \\
1-1,85 \\
1-1,96\end{array}$ & & $\begin{array}{c}1.60 \\
(1.59)^{\mathrm{a}} \\
1.61 \\
1.52 \\
1.52\end{array}$ & $\begin{array}{l}0.07 \\
0.36 \\
0.38 \\
0.85 \\
0.96\end{array}$ \\
\hline $\begin{array}{l}1-1,130 \\
2-1,13 \\
2-1,59 \\
2-1,96 \\
2-1,134\end{array}$ & & $\begin{array}{l}1.52 \\
1.58 \\
1.60 \\
1.61 \\
1.52\end{array}$ & $\begin{array}{l}1.30 \\
5.13 \\
5.59 \\
5.96 \\
6.34\end{array}$ \\
\hline $\begin{array}{l}2-2,8 \\
2-2,37 \\
2-2,61 \\
3-1,8 \\
3-1,73\end{array}$ & & $\begin{array}{l}1.52 \\
1.53 \\
1.53 \\
1.53 \\
1.51\end{array}$ & $\begin{array}{r}6.58 \\
6.87 \\
7.11 \\
14.58 \\
15.23\end{array}$ \\
\hline $\begin{array}{l}3-1,129 \\
3-2,27 \\
3-2,120 \\
3-4,43 \\
3-4,127\end{array}$ & & $\begin{array}{l}1.52 \\
1.52 \\
1.52 \\
1.53 \\
1.52\end{array}$ & $\begin{array}{l}15.79 \\
16.27 \\
17.20 \\
19.43 \\
20.27\end{array}$ \\
\hline $\begin{array}{l}3-6,27 \\
4-1,13 \\
4-1,75 \\
4-1,128 \\
4-2,12\end{array}$ & & $\begin{array}{l}1.54 \\
1.53 \\
1.53 \\
1.54 \\
1.55\end{array}$ & $\begin{array}{l}22.27 \\
24.13 \\
24.75 \\
25.28 \\
25.62\end{array}$ \\
\hline $\begin{array}{l}4-2,31 \\
4-2,74 \\
4-2,94 \\
4-2,121 \\
4-2,137\end{array}$ & & $\begin{array}{l}1.55 \\
1.56 \\
1.54 \\
1.55 \\
1.55\end{array}$ & $\begin{array}{l}25.81 \\
26.24 \\
26.44 \\
26.77 \\
26.87\end{array}$ \\
\hline $\begin{array}{l}4-3,11 \\
4-3,38 \\
4-3,63 \\
4-3,105 \\
4-3,136\end{array}$ & & $\begin{array}{l}1.54 \\
1.54 \\
1.53 \\
1.54 \\
1.54\end{array}$ & $\begin{array}{l}27.11 \\
27.38 \\
27.63 \\
28.05 \\
28.36\end{array}$ \\
\hline $\begin{array}{l}4-4,32 \\
4-4,86 \\
4-4,128 \\
4-5,33 \\
4-5,85\end{array}$ & & $\begin{array}{l}1.54 \\
1.54 \\
1.54 \\
1.54 \\
1.54\end{array}$ & $\begin{array}{l}28.82 \\
29.36 \\
29.78 \\
30.33 \\
30.85\end{array}$ \\
\hline $\begin{array}{l}4-5,141 \\
4-6,26 \\
4-6,28 \\
4-6,42 \\
4-6,81\end{array}$ & & $\begin{array}{l}1.54 \\
(1.54)^{\mathrm{a}} \\
1.54 \\
1.54 \\
1.53\end{array}$ & $\begin{array}{l}31.41 \\
31.76 \\
31.78 \\
31.92 \\
32.31\end{array}$ \\
\hline
\end{tabular}

TABLE 22 - Continued

\begin{tabular}{lccc}
\hline Core-Section, Interval $(\mathrm{cm})$ & $\begin{array}{c}\text { Piece } \\
\text { Number }\end{array}$ & $\begin{array}{c}\text { Velocity } \\
(\mathrm{km} / \mathrm{s})\end{array}$ & $\begin{array}{c}\text { Sub-bottom } \\
\text { Depth }(\mathrm{m})\end{array}$ \\
\hline
\end{tabular}

\section{Hole 433A}

$5-1,34$

5-1, 101

$5-2,18$

$5-2,60$

$5-2,94$

$5-2,116$

5-2, 133

$5-2,142$

$5-3,13$

$5-3,53$

$5-3,123$

$5-4,13$

$5-4,54$

$5-4,116$

$5-5,40$

$5-6,58$

$5-6,87$

$6-1,36$

$6-1,63$

6-1, 109

6-2, 61

6-2, 126

$6-2,136$

6-3, 47

$6-3,111$

6-4, 34

6-4, 76

$6-4,135$

$6-4,141$

$6-5,47$

$6-5,127$

6-6, 15

$6-6,50$

6-6, 82

6-6, 102

6-6, 132

6-6, 143

$6-7,12$

6-7, 27

6-7, 33

$1.52 \quad 33.84$

$1.53 \quad 34.51$

$1.53 \quad 35.18$

$1.53 \quad 35.60$

$1.54 \quad 35.94$

$1.54 \quad 36.16$

$1.54 \quad 36.33$

$1.54 \quad 36.42$

$\begin{array}{ll}1.53 & 36.63\end{array}$

$1.54 \quad 37.03$

$\begin{array}{ll}1.53 & 37.73\end{array}$

$\begin{array}{ll}1.53 & 38.13\end{array}$

$1.54 \quad 38.54$

$\begin{array}{ll}1.53 & 39.16\end{array}$

$1.52 \quad 39.90$

$\begin{array}{ll}1.56 & 41.58\end{array}$

$\begin{array}{ll}1.58 & 41.87\end{array}$

$1.54 \quad 43.36$

$\begin{array}{ll}1.53 & 43.63\end{array}$

$1.54 \quad 44.09$

$1.54 \quad 45.11$

$1.54 \quad 45.76$

$1.53 \quad 45.86$

$1.54 \quad 46.47$

$1.53 \quad 47.11$

$1.53 \quad 47.84$

$1.55 \quad 48.26$

$1.53 \quad 48.85$

$1.54 \quad 48.91$

$\begin{array}{ll}1.54 & 48.91 \\ 1.54 & 49.47\end{array}$

$\begin{array}{ll}1.53 & 50.27\end{array}$

$1.53 \quad 50.65$

$\begin{array}{ll}1.53 & 51.00\end{array}$

$1.53 \quad 51.32$

$\begin{array}{ll}1.55 & 51.52\end{array}$

$\begin{array}{ll}1.56 & 51.82\end{array}$

$1.54 \quad 51.93$

$\begin{array}{ll}1.56 & 52.12\end{array}$

$(1.58)^{\mathrm{a}} \quad 52.27$

7 attenuated

8-1, 85

8-1, 136

$8-2,52$

8-3, 69

$8-3,130$

$8-5,63$

8-6, 88

$8-6,106$

$8-6,131$

$(1.56)^{\mathrm{a}}$

52.33

$8-7,21$

$8-7,25$

9 attenuated

$10-1,112$

$10-1,122$

$(2.02)^{\mathrm{a}}$

$(2.08)^{\mathrm{a}}$

$(2.01)^{\mathrm{a}}$

$(1.97)^{\mathrm{a}}$

62.85

63.36

64.02

64.19

$(2.08)^{\mathrm{a}}$

$(1.88)^{\mathrm{a}}$

$(2.58)^{\mathrm{a}}$

64.80

68.63

$\begin{array}{ll}1.91 & 70.38 \\ 1.95 & 70.56\end{array}$

$1.95 \quad 70.81$

$1.86 \quad 71.21$

$\begin{array}{ll}1.88 & 71.25\end{array}$

10-1, 144

10-2, 37

$10-2,95$

$10-3,40$

10-3, 112

$(1.88)^{\mathrm{a}} \quad 76.62$

$(1.90)^{\mathrm{a}} \quad 76.72$

$2.21 \quad 76.94$

$\begin{array}{ll}(1.89)^{\mathrm{a}} & 77.37\end{array}$

$\begin{array}{ll}1.86 & 77.95\end{array}$

atten. $\quad 78.90$

$\begin{array}{ll}1.87 & 79.62\end{array}$ 
TABLE 22 - Continued

\begin{tabular}{|c|c|c|c|}
\hline Core-Section, Interval $(\mathrm{cm})$ & $\begin{array}{l}\text { Piece } \\
\text { Number }\end{array}$ & $\begin{array}{l}\text { Velocity } \\
(\mathrm{km} / \mathrm{s})\end{array}$ & $\begin{array}{l}\text { Sub-botton } \\
\text { Depth }(\mathrm{m})\end{array}$ \\
\hline \multicolumn{4}{|l|}{ Hole 433A } \\
\hline $\begin{array}{l}10-3,121 \\
20-1,3 \\
20-1,4 \\
20-1,37 \\
20-1,64\end{array}$ & & $\begin{array}{l}(1.82)^{\mathrm{a}} \\
4.73 \\
4.73^{\mathrm{b}} \\
5.66^{\mathrm{b}} \\
5.49\end{array}$ & $\begin{array}{r}79.71 \\
163.53 \\
163.54 \\
163.87 \\
164.14\end{array}$ \\
\hline $\begin{array}{l}20-1,114 \\
20-1,115 \\
20-1,126 \\
20-2,11 \\
20-2,21\end{array}$ & & $\begin{array}{l}5.12^{\mathrm{b}} \\
(4.83) \\
4.95 \\
5.23 \mathrm{~b} \\
4.83\end{array}$ & $\begin{array}{l}164.64 \\
164.65 \\
164.76 \\
165.11 \\
165.21\end{array}$ \\
\hline $\begin{array}{l}20-2,50 \\
20-2,74 \\
21-1,6 \\
21-1,29 \\
21-1,31\end{array}$ & & $\begin{array}{l}5.40^{b} \\
4.78 \\
5.52 \\
5.76^{b} \\
5.61\end{array}$ & $\begin{array}{l}165.50 \\
165.74 \\
166.56 \\
166.79 \\
166.81\end{array}$ \\
\hline $\begin{array}{l}21-1,83 \\
21-2,20 \\
21-2,80 \\
21-2,85 \\
21-2,128\end{array}$ & & $\begin{array}{l}5.63 \\
5.27 \\
5.40 \\
5.80^{b} \\
5.20\end{array}$ & $\begin{array}{l}167.33 \\
168.20 \\
168.80 \\
168.85 \\
169.28\end{array}$ \\
\hline $\begin{array}{l}21-3,14 \\
21-3,99 \\
21-4,139\end{array}$ & & $\begin{array}{l}5.56 \\
5.67 \mathrm{~b} \\
5.77 \mathrm{~b}\end{array}$ & $\begin{array}{l}169.64 \\
170.49 \\
172.39\end{array}$ \\
\hline
\end{tabular}

Hole 433B

$\begin{array}{llll}4-1,30 & 1 \mathrm{c} & 4.75 & 157.30 \\ 4-1,52 & 3 \mathrm{c} & 4.86^{\mathrm{b}} & 157.52 \\ 4-1,62 & 2 \mathrm{c} & 4.83 & 157.62 \\ 5-1,72 & 6 \mathrm{a} & 4.33^{\mathrm{b}} & 166.72 \\ 5-1,93 & 8 & 4.59 & 166.93 \\ 5-2,37 & 2 \mathrm{a} & 5.41^{\mathrm{b}} & 167.87 \\ 5-2,81 & 3 \mathrm{c} & 5.99 & 168.31 \\ 5-2,106 & 5 & 5.83 & 168.56 \\ 5-3,90 & 9 & 6.06 & 169.90\end{array}$

Hole 433C

$1-1,11$

$1-1,22$

$1-1,60$

$1-1,62$

$1-2,73$

2-1, 5

$2-1,23$

$2-3,30$

$4-1,29$

$4-1,40$

$4-1,61$

$4-1,95$ ?

$4-1,87$

$5-1,13$

10-1, 8

$10-1,15$

$10-1,38$

$10-1,75$

$10-1,118$

$10-2,22$

$10-2,22$

$10-2,48$

$10-2,88$

$10-2,140$

$10-2,140$

TABLE 22 - Continued

\begin{tabular}{lccc}
\hline Core-Section, Interval (cm) & $\begin{array}{c}\text { Piece } \\
\text { Number }\end{array}$ & $\begin{array}{c}\text { Velocity } \\
(\mathrm{km} / \mathrm{s})\end{array}$ & $\begin{array}{c}\text { Sub-bottom } \\
\text { Depth }(\mathrm{m})\end{array}$ \\
\hline
\end{tabular}

Hole 433C

10-3, 18

$10-3,35$

$10-3,86$

10-3, 135

$10-3,136$

10-3, 146

$10-4,6$

$10-4,10$

$10-4,40$

$10-4,49$

10-4, 57

$10-4,113$

$10-4,122$

$10-5,49$

$10-5,58$

10-5, 98

$10-5,119$

10-5, 144

$10-6,12$

$10-6,44$

$10-6,58$

$11-1,7$

$11-1,60$

$11-1,64$

11-1, 92

11-2, 51

$11-2,125$

$11-3,10$

11-3, 123

$11-4,59$

11-5, 41

$12-1,93$

$12-1,101$

$12-1,134$

$12-2,19$

$12-2,35$

$12-2,53$

$12-2,126$

$12-3,45$

$12-3,49$

$12-3,84$

$12-3,101$

$12-3,125$

$12-4,20$

$12-4,23$

$12-4,75$

$12-4,128$

13-1, 19

13-1, 95

13-1, 128

13-2, 34

$13-2,54$

13-2, 89

$13-2,130$

13-3, 4

14-1, 5

$14-1,35$

14-1, 48

14-1, 106

14-1, 133

\begin{tabular}{|c|c|c|}
\hline $\begin{array}{l}2 b \\
5 a \\
9 c \\
11 \\
11\end{array}$ & $\begin{array}{l}3.15 \\
2.81^{b} \\
2.76 \\
3.61 \\
3.47 b\end{array}$ & $\begin{array}{l}207.68 \\
207.85 \\
208.36 \\
208.85 \\
208.86\end{array}$ \\
\hline $\begin{array}{c}11 \\
2 \\
2 \\
3 a \\
3 b\end{array}$ & $\begin{array}{l}3.62 \\
3.17 \\
3.39 \mathrm{~b} \\
3.32^{\mathrm{b}} \\
3.47\end{array}$ & $\begin{array}{l}208.96 \\
209.06 \\
209.10 \\
209.40 \\
209.49\end{array}$ \\
\hline $\begin{array}{l}3 c \\
8 a \\
8 b \\
6 a \\
6 b\end{array}$ & $\begin{array}{l}4.40^{b} \\
3.60^{b} \\
3.62 \\
4.03^{b} \\
3.32\end{array}$ & $\begin{array}{l}209.57 \\
210.13 \\
210.22 \\
210.99 \\
211.08\end{array}$ \\
\hline $\begin{array}{c}9 \\
13 \mathrm{a} \\
13 \mathrm{c} \\
1 \mathrm{c} \\
3 \mathrm{c}\end{array}$ & $\begin{array}{l}4.17 \\
3.16 \\
3.65 b \\
4.75 \\
4.94 b\end{array}$ & $\begin{array}{l}211.48 \\
211.69 \\
211.94 \\
212.12 \\
212.44\end{array}$ \\
\hline $\begin{array}{l}4 \\
1 \mathrm{a} \\
4 \\
4 \\
1 \mathrm{~g}\end{array}$ & $\begin{array}{l}4.78 \\
4.26 \\
3.51 \\
3.74 b \\
4.52 b\end{array}$ & $\begin{array}{l}212.58 \\
214.07 \\
214.60 \\
214.64 \\
214.92\end{array}$ \\
\hline $\begin{array}{l}5 \\
9 \mathrm{~b} \\
1 \mathrm{~b} \\
2 \mathrm{~g} \\
6\end{array}$ & $\begin{array}{l}3.50^{b} \\
4.18^{b} \\
5.25^{b} \\
4.59 b \\
3.99 b\end{array}$ & $\begin{array}{l}216.01 \\
216.75 \\
217.10 \\
218.23 \\
219.09\end{array}$ \\
\hline $\begin{array}{c}4 \\
9 \mathrm{a} \\
9 \mathrm{~b} \\
11 \\
2 \mathrm{~b}\end{array}$ & $\begin{array}{l}4.61 \mathrm{~b} \\
3.09 \\
2.99 \mathrm{~b} \\
3.93 \\
3.41\end{array}$ & $\begin{array}{l}220.41 \\
224.43 \\
224.51 \\
224.84 \\
225.19\end{array}$ \\
\hline $\begin{array}{l}2 \mathrm{e} \\
2 \mathrm{~h} \\
3 \mathrm{a} \\
1 \mathrm{~d} \\
1 \mathrm{~d}\end{array}$ & $\begin{array}{l}3.96 \\
3.90 \\
4.28 \\
4.37 \\
4.34 \mathrm{~b}\end{array}$ & $\begin{array}{l}225.35 \\
225.53 \\
226.26 \\
226.95 \\
226.99\end{array}$ \\
\hline $\begin{array}{l}3 \mathrm{~b} \\
4 \\
7 \\
3 \\
3\end{array}$ & $\begin{array}{l}3.21 \\
4.69 \mathrm{~b} \\
4.88 \\
5.09 \\
5.26^{b}\end{array}$ & $\begin{array}{l}227.34 \\
227.51 \\
227.75 \\
228.20 \\
228.23\end{array}$ \\
\hline $\begin{array}{c}9 \\
16 \mathrm{a} \\
3 \mathrm{a} \\
4 \mathrm{~b} \\
6 \mathrm{c}\end{array}$ & $\begin{array}{l}5.09 \\
5.14 \\
5.34 \\
4.93 \\
5.29\end{array}$ & $\begin{array}{l}228.75 \\
229.28 \\
230.19 \\
230.95 \\
231.28\end{array}$ \\
\hline $\begin{array}{l}1 \mathrm{e} \\
1 \mathrm{~h} \\
1 \mathrm{~L} \\
3 \\
1 \mathrm{a}\end{array}$ & $\begin{array}{l}5.75 \\
5.40^{\mathrm{b}} \\
6.19 \\
5.29 \\
5.08\end{array}$ & $\begin{array}{l}231.84 \\
232.04 \\
232.39 \\
232.80 \\
233.04\end{array}$ \\
\hline $\begin{array}{l}1 \mathrm{a} \\
1 \mathrm{~g} \\
1 \mathrm{~h} \\
1 \mathrm{r} \\
4 \mathrm{a}\end{array}$ & $\begin{array}{l}3.08 \\
4.00 \\
3.97 \mathrm{~b} \\
4.57 \\
4.23\end{array}$ & $\begin{array}{l}233.05 \\
233.35 \\
233.48 \\
234.06 \\
234.33\end{array}$ \\
\hline
\end{tabular}


TABLE 22 - Continued

\begin{tabular}{|c|c|c|c|}
\hline Core-Section, Interval (cm) & $\begin{array}{l}\text { Piece } \\
\text { Number }\end{array}$ & $\begin{array}{l}\text { Velocity } \\
(\mathrm{km} / \mathrm{s})\end{array}$ & $\begin{array}{l}\text { Sub-bottom } \\
\text { Depth }(\mathrm{m})\end{array}$ \\
\hline \multicolumn{4}{|l|}{ Hole 433C } \\
\hline $\begin{array}{l}14-2,16 \\
14-2,69 \\
14-2,129 \\
14-3,24 \\
14-3,56\end{array}$ & $\begin{array}{l}1 \mathrm{c} \\
2 \mathrm{a} \\
3 \mathrm{e} \\
1 \mathrm{~d} \\
4 \mathrm{a}\end{array}$ & $\begin{array}{l}3.85 \\
4.06 \\
4.25 \mathrm{~b} \\
3.79 \\
4.11^{b}\end{array}$ & $\begin{array}{l}234.66 \\
235.19 \\
235.79 \\
236.24 \\
236.56\end{array}$ \\
\hline $\begin{array}{l}14-3,128 \\
14-4,18 \\
14-4,22 \\
14-4,48 \\
15-1,12\end{array}$ & $\begin{array}{r}11 \mathrm{a} \\
1 \mathrm{~b} \\
1 \mathrm{~b} \\
2 \mathrm{~b} \\
2 \mathrm{a}\end{array}$ & $\begin{array}{l}4.57 \\
4.85 \\
4.77 \mathrm{~b} \\
4.74 \\
4.10^{\mathrm{b}}\end{array}$ & $\begin{array}{l}237.28 \\
237.68 \\
237.72 \\
237.98 \\
242.62\end{array}$ \\
\hline $\begin{array}{l}15-1,48 \\
15-1,48 \\
15-1,87 \\
15-1,129 \\
15-2,29\end{array}$ & $\begin{array}{c}2 \mathrm{e} \\
2 \mathrm{e} \\
8 \\
12 \\
4\end{array}$ & $\begin{array}{l}4.07 \\
4.08 \mathrm{~b} \\
4.04 \\
4.49 \\
3.69\end{array}$ & $\begin{array}{l}242.98 \\
242.98 \\
243.37 \\
243.79 \\
244.29\end{array}$ \\
\hline $\begin{array}{l}15-2,95 \\
15-2,104 \\
15-3,21 \\
15-3,79 \\
15-3,128\end{array}$ & $\begin{array}{r}16 \\
11 \\
2 \\
8 \\
15\end{array}$ & $\begin{array}{l}3.71 \\
2.72^{b} \\
3.66 \\
4.56 \\
3.13^{b}\end{array}$ & $\begin{array}{l}244.95 \\
245.04 \\
245.71 \\
246.29 \\
246.78\end{array}$ \\
\hline $\begin{array}{l}15-3,131 \\
15-4,11 \\
15-4,22 \\
15-4,23 \\
15-4,47\end{array}$ & $\begin{array}{l}15 \\
1 \mathrm{a} \\
2 \\
2 \\
4\end{array}$ & $\begin{array}{l}3.30 \\
3.71 \\
3.74 \mathrm{~b} \\
3.83 \\
3.61^{\mathrm{b}}\end{array}$ & $\begin{array}{l}246.81 \\
247.11 \\
247.22 \\
247.23 \\
247.47\end{array}$ \\
\hline $\begin{array}{l}15-4,68 \\
15-4,100 \\
15-4,116 \\
15-4,128 \\
15-5,15\end{array}$ & $\begin{array}{l}5 \\
8 \\
9 \mathrm{~b} \\
9 \mathrm{~d} \\
2\end{array}$ & $\begin{array}{l}3.81 \\
3.85^{b} \\
3.56^{b} \\
4.11 \\
3.79 \mathrm{~b}\end{array}$ & $\begin{array}{l}247.68 \\
248.00 \\
248.16 \\
248.28 \\
248.65\end{array}$ \\
\hline $\begin{array}{l}15-5,80 \\
15-5,90 \\
15-5,116 \\
15-6,10 \\
15-6, ?\end{array}$ & $\begin{array}{l}4 a \\
4 b \\
5 b \\
1 a \\
1 c\end{array}$ & $\begin{array}{l}4.39 \mathrm{~b} \\
5.06 \\
5.51 \\
5.38 \\
5.98 \mathrm{~b}\end{array}$ & $\begin{array}{c}249.30 \\
249.40 \\
249.66 \\
250.10 \\
?\end{array}$ \\
\hline $\begin{array}{l}16-1,12 \\
16-1,43 \\
16-1,76 \\
16-1,105 \\
16-1,131\end{array}$ & $\begin{array}{l}2 \\
4 b \\
6 b \\
8 a \\
9\end{array}$ & $\begin{array}{l}5.98 \mathrm{~b} \\
5.93 \\
6.09 \mathrm{~b} \\
6.23 \\
5.86\end{array}$ & $\begin{array}{l}252.12 \\
252.43 \\
252.76 \\
253.05 \\
254.31\end{array}$ \\
\hline $\begin{array}{l}17-1,18 \\
17-1,34 \\
17-1,82 \\
18-1,5 \\
19-1,15\end{array}$ & $\begin{array}{l}2 \\
3 \mathrm{a} \\
6 \\
2 \mathrm{a}\end{array}$ & $\begin{array}{l}6.21^{b} \\
5.88 \\
6.22 \\
6.07 \\
6.03^{b}\end{array}$ & $\begin{array}{l}255.68 \\
255.84 \\
256.32 \\
258.55 \\
261.65\end{array}$ \\
\hline $\begin{array}{l}19-1,21 \\
19-1,46 \\
19-1,113 \\
19-2,13 \\
19-2,50\end{array}$ & $\begin{array}{l}2 b \\
4 b \\
8 d \\
1 b \\
2 e\end{array}$ & $\begin{array}{l}5.76 \\
4.89 \\
4.94 \mathrm{~b} \\
5.26^{\mathrm{b}} \\
5.23\end{array}$ & $\begin{array}{l}261.71 \\
261.96 \\
262.63 \\
263.13 \\
263.50\end{array}$ \\
\hline $\begin{array}{l}19-2,113 \\
19-2,148 \\
19-3,16 \\
19-3,47 \\
19-3,91\end{array}$ & $\begin{array}{c}8 \mathrm{a} \\
14 \\
1 \mathrm{c} \\
1 \mathrm{i} \\
1 \mathrm{p}\end{array}$ & $\begin{array}{l}4.50 \\
3.78 \\
4.16^{b} \\
4.71 \\
4.92\end{array}$ & $\begin{array}{l}264.13 \\
264.48 \\
264.66 \\
264.97 \\
265.41\end{array}$ \\
\hline $\begin{array}{l}19-3,136 \\
19-4,36 \\
19-4,69 \\
19-4,102 \\
19-4,146\end{array}$ & $\begin{array}{l}1 \mathrm{x} \\
2 \mathrm{a} \\
2 \mathrm{f} \\
3 \mathrm{a} \\
3 \mathrm{f}\end{array}$ & $\begin{array}{l}5.04 \\
5.16 \\
5.17 \mathrm{~b} \\
5.19 \\
5.01\end{array}$ & $\begin{array}{l}265.86 \\
266.36 \\
266.69 \\
267.02 \\
267.46\end{array}$ \\
\hline
\end{tabular}

TABLE 22 - Continued

\begin{tabular}{cccc}
\hline & $\begin{array}{c}\text { Piece } \\
\text { Number }\end{array}$ & $\begin{array}{c}\text { Velocity } \\
(\mathrm{km} / \mathrm{s})\end{array}$ & $\begin{array}{c}\text { Sub-bottom } \\
\text { Depth }(\mathrm{m})\end{array}$
\end{tabular}

\section{Hole 433C}

$19-5,16$

$19-5,26$

$19-5,68$

20-1, 18

20-1, 25

20-1, 80

20-1, 82

20-1, 127

$20-2,37$

$20-2,49$

20-2, 79

20-2, 141

21-1, 44

21-1, 89

21-1, 106

21-1, 108

$21-1,129$

$21-2,20$

21-2, 85

$21-2,105$

$21-2,105$

21-2, 139

21-3, 23

21-3, 60

21-3, 120

21-4, 46

21-4, 103

$21-5,36$

22-1, 14

22-1, 90

22-2, 24

22-2, 80

22-2, 114

22-3, 38

22-3, 65

22-3, 120

22-3, 131

22-4, 44

$22-4,135$

22-5, 91

22-6, 13

23-1, 19

23-1, 46

23-2, 33

23-2, 56

23-2, 73

23-2, 140

23-3, 34

23-3, 59

23-3, 130

$23-4,46$

23-4, 98

$23-5,37$

23-5, 115

$23-6,34$

23-6, 119

23-7, 31

$23-7,103$

23-7, 108

24-1, 20

$\begin{array}{cll}1 \mathrm{~b} & 5.12 & 267.66 \\ 1 \mathrm{c} & 4.95 \mathrm{~b} & 267.76 \\ 1 \mathrm{~h} & 5.23 & 268.18 \\ 2 \mathrm{a} & 5.21 & 269.68 \\ 2 & 5.23 \mathrm{~b} & 269.75 \\ 8 & 4.58 & 270.30 \\ 8 & 4.61 \mathrm{~b} & 270.32 \\ 13 & 4.82 & 270.77 \\ 4 \mathrm{~b} & 4.82 & 271.37\end{array}$

$\begin{array}{lll}5 & 4.70^{\mathrm{b}} & 271.49\end{array}$

$\begin{array}{lll}9 & 3.76 & 271.79\end{array}$

$4.44 \quad 272.41$

$4.98 \quad 279.44$

$\begin{array}{ll}4.70 & 279.89\end{array}$

$5.21 \quad 280.06$

$5.25^{\mathrm{b}} \quad 280.08$

$4.59 \quad 280.29$

$\begin{array}{lll}9 \mathrm{~b} & 4.59 & 280.29 \\ 2 \mathrm{a} & 4.55 & 280.70\end{array}$

$\begin{array}{lll}10 & 3.91 & 281.35\end{array}$

$12 \quad 4.92 \quad 281.55$

$4.76^{\mathrm{b}} \quad 281.55$

$\begin{array}{lll}15 \mathrm{a} & 4.60 & 281.89\end{array}$

$\begin{array}{lll}2 & 5.34 & 282.23\end{array}$

$\begin{array}{lll}6 \mathrm{a} & 4.88 & 282.60\end{array}$

$8 \mathrm{~b} \quad 4.93 \quad 283.20$

$\begin{array}{lll}6 & 4.91 & 283.96\end{array}$

$\begin{array}{lll}10 & 4.93 & 284.53\end{array}$

$\begin{array}{lll}4 & 5.09 & 285.36\end{array}$

$\begin{array}{lll}2 \mathrm{a} & 5.12 & 288.64\end{array}$

$\begin{array}{lll}10 & 4.36 & 289.40\end{array}$

$\begin{array}{lll}3 & 4.36 & 290.24\end{array}$

$5 \mathrm{~d} \quad 4.13 \quad 290.80$

$5 \mathrm{~h} \quad 4.78 \mathrm{~b} \quad 291.14$

$\begin{array}{lll}4 & 4.90 & 291.88\end{array}$

$\begin{array}{lll}5 c & 4.81^{b} & 292.15\end{array}$

$8 \quad 4.64 \quad 292.70$

$9 \quad 4.83 \mathrm{~b} \quad 292.81$

$\begin{array}{lll}2 b & 4.77 & 293.44\end{array}$

$\begin{array}{lll}7 & 5.01 & 293.44 \\ 2 b & 5.30\end{array}$

$\begin{array}{lll}7 \mathrm{a} & 5.30 & 295.41\end{array}$

1b $\quad 4.84 \quad 296.13$

$\begin{array}{lll}2 \mathrm{c} & 3.89 & 298.19\end{array}$

$\begin{array}{lll}4 \mathrm{a} & 4.52 & 298.46\end{array}$

$\begin{array}{lll}3 & 2.77 & 299.83\end{array}$

$\begin{array}{lll}4 \mathrm{~d} & 3.32^{\mathrm{b}} & 300.06\end{array}$

$\begin{array}{lll}5 \mathrm{a} & 3.68 & 300.23\end{array}$

$\begin{array}{lll}9 \mathrm{a} & 4.30 & 300.90\end{array}$

$1 \mathrm{~b} \quad 3.76^{\mathrm{b}} \quad 301.34$

le $\quad 4.94 \quad 301.59$

$1 \mathrm{j} \quad 4.97 \quad 302.30$

$\begin{array}{lll}1 \mathrm{c} & 3.09 & 302.96\end{array}$

$\begin{array}{lll}7 \mathrm{a} & 3.66 & 302.46 \\ & 4.55 & 304.37\end{array}$

$1 \mathrm{e} \quad 4.55 \quad 304.37$

$\begin{array}{lll}1 \mathrm{n} & 4.30 & 305.15 \\ 2 \mathrm{a} & 3.63 & 305.84\end{array}$

$\begin{array}{lll}4 \mathrm{k} & 4.27 & 306.69\end{array}$

$3 \quad 4.25 \quad 307.31$

$\begin{array}{lll}5 \mathrm{a} & 5.48^{\mathrm{b}} & 308.03\end{array}$

$\begin{array}{lll}5 \mathrm{a} & 5.31 & 308.08\end{array}$

$\begin{array}{lll}5 \mathrm{a} & 5.31 \mathrm{~b} & 308.08 \\ 2 & 5.06^{\mathrm{b}} & 307.70\end{array}$ 
TABLE 22 - Continued

\begin{tabular}{|c|c|c|c|}
\hline Core-Section, Interval $(\mathrm{cm})$ & $\begin{array}{c}\text { Piece } \\
\text { Number }\end{array}$ & $\begin{array}{l}\text { Velocity } \\
(\mathrm{km} / \mathrm{s})\end{array}$ & $\begin{array}{l}\text { Sub-bottom } \\
\text { Depth }(\mathrm{m})\end{array}$ \\
\hline \multicolumn{4}{|l|}{ Hole 433C } \\
\hline $\begin{array}{l}24-1,54 \\
24-1,134 \\
24-2,18 \\
24-2,28 \\
24-2,96\end{array}$ & $\begin{array}{l}3 \mathrm{~b} \\
6 \mathrm{~g} \\
1 \mathrm{a} \\
1 \mathrm{c} \\
8\end{array}$ & $\begin{array}{l}3.21 \\
3.99 \\
3.25^{b} \\
3.57 \\
4.03\end{array}$ & $\begin{array}{l}308.04 \\
308.84 \\
309.18 \\
309.28 \\
309.96\end{array}$ \\
\hline $\begin{array}{l}24-3,12 \\
24-3,82 \\
24-3,106 \\
24-4,13 \\
24-4,42\end{array}$ & $\begin{array}{r}2 \\
9 \mathrm{c} \\
10 \mathrm{~b} \\
2 \mathrm{a} \\
2 \mathrm{c}\end{array}$ & $\begin{array}{l}3.65 \\
3.99 \mathrm{~b} \\
4.19 \\
4.22 \\
3.12\end{array}$ & $\begin{array}{l}310.62 \\
311.32 \\
311.56 \\
312.13 \\
312.42\end{array}$ \\
\hline $\begin{array}{l}24-4,103 \\
24-5,56 \\
24-7,30 \\
24-7,75 \\
24-7,87\end{array}$ & $\begin{array}{l}2 \mathrm{e}^{\prime} \\
1 \mathrm{~b} \\
1 \mathrm{f} \\
2\end{array}$ & $\begin{array}{c}4.29 \\
\text { atten. } \\
3.28 \\
5.08 \\
5.45\end{array}$ & $\begin{array}{l}313.03 \\
314.06 \\
315.30 \\
315.75 \\
315.87\end{array}$ \\
\hline $\begin{array}{l}24-7,113 \\
24-8,23 \\
24-8,96 \\
25-1,9 \\
25-1,54\end{array}$ & $\begin{array}{l}3 \mathrm{c} \\
1 \mathrm{c} \\
3 \mathrm{a} \\
1 \mathrm{~b} \\
1 \mathrm{i}\end{array}$ & $\begin{array}{l}6.05 \\
4.97 \\
(3.54)^{a} \\
3.97 \\
3.58\end{array}$ & $\begin{array}{l}316.13 \\
316.73 \\
317.46 \\
317.09 \\
317.54\end{array}$ \\
\hline $\begin{array}{l}25-1,75 \\
25-1,105 \\
25-1,128 \\
25-1,132 \\
25-2,11\end{array}$ & $\begin{array}{l}2 \mathrm{a} \\
2 \mathrm{~g} \\
2 \mathrm{~m} \\
2 \mathrm{o} \\
1 \mathrm{a}\end{array}$ & $\begin{array}{l}3.61 \\
4.22 \\
4.86 \\
4.84 \mathrm{~b} \\
5.18^{\mathrm{b}}\end{array}$ & $\begin{array}{l}317.75 \\
318.05 \\
318.28 \\
318.32 \\
318.61\end{array}$ \\
\hline $\begin{array}{l}25-2,26 \\
25-2,90 \\
25-2,134 \\
25-3,19 \\
25-3,33\end{array}$ & $\begin{array}{l}1 \mathrm{~b} \\
1 \mathrm{~m} \\
1 \mathrm{u} \\
1 \mathrm{c} \\
1 \mathrm{e}\end{array}$ & $\begin{array}{l}5.03 \\
3.88^{b} \\
3.06 \\
2.39 \mathrm{~b} \\
2.81\end{array}$ & $\begin{array}{l}318.76 \\
319.40 \\
319.84 \\
320.19 \\
320.33\end{array}$ \\
\hline $\begin{array}{l}25-3,72 \\
25-4,19 \\
25-4,83 \\
25-4,135 \\
25-5,33 \\
25-5,120 \\
25-6,24 \\
25-6,100 \\
25-7,14 \\
25-7,78\end{array}$ & $\begin{array}{l}1 \mathrm{k} \\
1 \mathrm{c} \\
3 \mathrm{~b} \\
6 \mathrm{a} \\
1 \mathrm{~b} \\
1 \mathrm{j} \\
1 \mathrm{c} \\
1 \mathrm{~L} \\
1 \mathrm{~b} \\
1 \mathrm{j}\end{array}$ & $\begin{array}{l}3.12 \\
4.20 \\
4.42 \\
5.00^{\mathrm{b}} \\
4.92 \\
4.87 \\
5.42 \\
5.60 \\
5.55 \\
5.62\end{array}$ & $\begin{array}{l}320.72 \\
321.69 \\
322.33 \\
322.85 \\
323.33 \\
324.20 \\
324.74 \\
325.50 \\
326.14 \\
326.78\end{array}$ \\
\hline $\begin{array}{l}26-1,36 \\
26-1,115 \\
26-2,30 \\
26-2,60 \\
26-3,21\end{array}$ & $\begin{array}{l}2 \mathrm{a} \\
2 \mathrm{~g} \\
2 \mathrm{c} \\
1 \mathrm{~g} \\
1 \mathrm{~b}\end{array}$ & $\begin{array}{l}5.58 \\
5.83 \\
5.71 \mathrm{~b} \\
5.75 \\
5.65\end{array}$ & $\begin{array}{l}326.86 \\
327.65 \\
328.30 \\
328.60 \\
329.71\end{array}$ \\
\hline $\begin{array}{l}26-3,81 \\
26-4,50 \\
26-4,135 \\
26-4,139 \\
26-5,60\end{array}$ & $\begin{array}{l}2 \mathrm{c} \\
1 \mathrm{i} \\
4 \mathrm{j} \\
4 \mathrm{j} \\
1 \mathrm{f}\end{array}$ & $\begin{array}{l}5.42 \\
4.42 \\
4.60 \\
4.32 \mathrm{~b} \\
5.00\end{array}$ & $\begin{array}{l}330.31 \\
331.50 \\
332.35 \\
332.39 \\
333.10\end{array}$ \\
\hline $\begin{array}{l}26-5,124 \\
26-6,79 \\
26-6,139 \\
26-7,6 \\
26-7,8\end{array}$ & $\begin{array}{l}1 \mathrm{k} \\
3 \mathrm{f} \\
7 \mathrm{~b} \\
1 \mathrm{a} \\
1 \mathrm{a}\end{array}$ & $\begin{array}{l}4.47 \mathrm{~b} \\
4.22 \\
4.74 \\
4.22 \\
3.88^{\mathrm{b}}\end{array}$ & $\begin{array}{l}333.74 \\
334.79 \\
335.39 \\
335.56 \\
335.58\end{array}$ \\
\hline $\begin{array}{l}27-1,52 \\
27-2,66 \\
27-3,97 \\
27-4,15 \\
27-4,112\end{array}$ & $\begin{array}{l}2 \mathrm{~m} \\
2 \mathrm{~g} \\
4 \\
1 \mathrm{c} \\
7 \mathrm{~g}\end{array}$ & $\begin{array}{l}3.38 \\
4.22 \\
3.50 \\
3.55 \\
3.67\end{array}$ & $\begin{array}{l}336.52 \\
338.16 \\
339.97 \\
340.65 \\
341.62\end{array}$ \\
\hline
\end{tabular}

TABLE 22 - Continued

\begin{tabular}{cccc}
\hline & Piece & Velocity & Sub-bottom \\
Core-Section, Interval $(\mathrm{cm})$ & Number & $(\mathrm{km} / \mathrm{s})$ & Depth $(\mathrm{m})$
\end{tabular}

Hole 433C

\begin{tabular}{|c|}
\hline $\begin{array}{l}27-5,102 \\
27-5,126 \\
27-6,14 \\
27-6,29 \\
27-6,110\end{array}$ \\
\hline $\begin{array}{l}27-6,137 \\
28-1,42 \\
28-2,70 \\
28-3,102 \\
28-4,23\end{array}$ \\
\hline $\begin{array}{l}28-4,66 \\
28-4,58 \\
28-4,95 \\
28-5,95 \\
29-1,13\end{array}$ \\
\hline $\begin{array}{l}29-1,49 \\
29-1,90 \\
29-2,97 \\
29-2,97 \\
29-2,109\end{array}$ \\
\hline $\begin{array}{l}29-2,139 \\
29-2,139 \\
30-2,20 \\
30-2,51 \\
30-2,135\end{array}$ \\
\hline $\begin{array}{l}30-2,146 \\
30-3,50 \\
31-1,37 \\
31-1,38 \\
31-1,72\end{array}$ \\
\hline $\begin{array}{l}31-1,80 \\
31-2,74 \\
31-3,34 \\
31-3,89 \\
31-4,10\end{array}$ \\
\hline $\begin{array}{l}31-4,50 \\
31-4,50 \\
31-4,74 \\
31-5,30 \\
31-5,46\end{array}$ \\
\hline $\begin{array}{l}31-5,97 \\
32-1,22 \\
32-2,17 \\
32-2,55 \\
32-2,126\end{array}$ \\
\hline $\begin{array}{l}32-2,145 \\
32-3,123 \\
32-4,15 \\
32-4,128 \\
32-4,139\end{array}$ \\
\hline $\begin{array}{l}32-5,95 \\
33-1,24 \\
33-1,35 \\
33-1,42 \\
33-1,63\end{array}$ \\
\hline $\begin{array}{l}33-1,133 \\
33-2,47 \\
33-2,109 \\
33-3,13 \\
33-3,101\end{array}$ \\
\hline
\end{tabular}

\begin{tabular}{|c|c|c|}
\hline $3 c$ & 3.50 & 343.02 \\
\hline $3 c$ & 3.21 & 343.26 \\
\hline $1 \mathrm{e}$ & 3.36 & 343.64 \\
\hline $1 \mathrm{e}$ & 3.60 & 343.79 \\
\hline $4 b$ & 3.18 & 344.60 \\
\hline 5 & 3.82 & 344.87 \\
\hline $2 d$ & 4.92 & 345.92 \\
\hline $4 b$ & 5.05 & 347.70 \\
\hline $5 b$ & 5.44 & 349.52 \\
\hline $2 a$ & 5.09 & 350.23 \\
\hline $5 b$ & 4.17 & 350.66 \\
\hline $0 \mathrm{C}$ & $4.42^{b}$ & 350.58 \\
\hline $6 \mathrm{~d}$ & 4.46 & 350.95 \\
\hline $7 d$ & 5.83 & 352.45 \\
\hline $2 a$ & 5.25 & 355.13 \\
\hline $3 \mathrm{c}$ & $5.13^{b}$ & 355.49 \\
\hline $3 \mathrm{i}$ & 5.38 & 355.90 \\
\hline 4 & 5.09 & 357.47 \\
\hline & $4.89 \mathrm{~b}$ & 357.47 \\
\hline & $4.73^{b}$ & 357.59 \\
\hline 9 & 3.63 & 357.89 \\
\hline 9 & $3.38^{\mathrm{b}}$ & 357.89 \\
\hline 2 & 4.42 & 366.20 \\
\hline 6 & 4.93 & 366.51 \\
\hline & $5.95^{\mathrm{b}}$ & 367.35 \\
\hline 3 & 5.94 & 367.46 \\
\hline $3 a$ & 6.15 & 368.00 \\
\hline 1f & 6.27 & 374.37 \\
\hline $1 \mathrm{e}$ & $6.35^{\mathrm{b}}$ & 374.38 \\
\hline $1 \mathrm{j}$ & 6.07 & 374.72 \\
\hline $1 \mathrm{k}$ & $6.03^{b}$ & 374.80 \\
\hline $3 d$ & 4.72 & 376.24 \\
\hline $1 \mathrm{f}$ & 4.50 & 377.34 \\
\hline $4 a$ & $3.87^{b}$ & 377.89 \\
\hline & 4.52 & 378.60 \\
\hline $3 a$ & 3.40 & 379.00 \\
\hline $3 a$ & $2.88^{\mathrm{b}}$ & 379.00 \\
\hline $3 b$ & $3.84^{b}$ & 379.24 \\
\hline $1 \mathrm{~b}$ & atten.b & 380.30 \\
\hline 2 & atten. $b$ & 380.46 \\
\hline 5 & 4.13 & 380.97 \\
\hline $3 a$ & 3.24 & 383.72 \\
\hline $1 \mathrm{i}$ & atten. & 385.17 \\
\hline $2 b$ & 3.13 & 385.55 \\
\hline $2 \mathrm{~g}$ & 3.79 & 386.26 \\
\hline $3 b$ & 2.87 & 386.45 \\
\hline $5 a$ & 2.43 & 387.73 \\
\hline $1 d$ & 3.33 & 388.15 \\
\hline $1 \mathrm{~b}$ & 4.37 & 389.28 \\
\hline $1 \mathrm{~b}$ & 4.34 & 389.39 \\
\hline $1 \mathrm{e}$ & 4.81 & 390.45 \\
\hline & $4.93 \mathrm{~b}$ & 393.24 \\
\hline & $5.06^{\mathrm{b}}$ & 393.35 \\
\hline $3 c$ & 5.22 & 393.42 \\
\hline & $5.36^{\mathrm{b}}$ & 393.63 \\
\hline $3 \mathrm{j}$ & 3.64 & 394.33 \\
\hline $3 d$ & 4.01 & 394.97 \\
\hline $3 j$ & 5.16 & 395.59 \\
\hline & $5.67 \mathrm{~b}$ & 396.13 \\
\hline 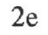 & 4.94 & 397.01 \\
\hline
\end{tabular}


TABLE $22-$ Continued

\begin{tabular}{|c|c|c|c|}
\hline Core-Section, Interval $(\mathrm{cm})$ & $\begin{array}{l}\text { Piece } \\
\text { Number }\end{array}$ & $\begin{array}{l}\text { Velocity } \\
(\mathrm{km} / \mathrm{s})\end{array}$ & $\begin{array}{l}\text { Sub-bottom } \\
\text { Depth (m) }\end{array}$ \\
\hline \multicolumn{4}{|l|}{ Hole 433C } \\
\hline $\begin{array}{l}33-4,13 \\
33-4,123 \\
33-5,29 \\
33-5,64 \\
33-5,93\end{array}$ & $\begin{array}{l}1 c \\
6 b \\
1 b \\
3 b\end{array}$ & $\begin{array}{c}3.83 \\
4.14 \\
4.55 \\
(3.6)^{\mathrm{a}, \mathrm{b}} \\
4.44\end{array}$ & $\begin{array}{l}397.63 \\
398.73 \\
399.29 \\
399.64 \\
399.93\end{array}$ \\
\hline $\begin{array}{l}34-1,4 \\
34-1,57 \\
34-1,70 \\
34-1,75 \\
34-1,127\end{array}$ & $\begin{array}{l}1 \mathrm{p} \\
1 \mathrm{aa}\end{array}$ & $\begin{array}{l}3.76^{\mathrm{b}} \\
3.92^{\mathrm{b}} \\
4.17 \\
4.01 \\
4.31\end{array}$ & $\begin{array}{l}402.54 \\
403.07 \\
403.20 \\
403.25 \\
403.77\end{array}$ \\
\hline $\begin{array}{l}34-2,80 \\
34-2,101 \\
34-2,125 \\
34-3,9 \\
34-3,42\end{array}$ & $\begin{array}{l}1 \mathrm{n} \\
1 \mathrm{p}\end{array}$ & $\begin{array}{l}5.05 \\
5.31 \\
5.24 \mathrm{~b} \\
5.27 \mathrm{~b} \\
5.17 \mathrm{~b}\end{array}$ & $\begin{array}{l}404.80 \\
405.01 \\
405.25 \\
405.59 \\
405.92\end{array}$ \\
\hline $\begin{array}{l}34-3,93 \\
34-3,140 \\
34-4,77 \\
34-4,96 \\
34-5,77\end{array}$ & $\begin{array}{l}1 \mathrm{~g} \\
2 \mathrm{e} \\
4 \mathrm{~b}\end{array}$ & $\begin{array}{l}4.96 \\
3.81 \\
4.74 \\
5.00 \\
3.53^{b}\end{array}$ & $\begin{array}{l}406.43 \\
406.90 \\
407.77 \\
407.96 \\
409.27\end{array}$ \\
\hline $\begin{array}{l}34-5,88 \\
34-5,114 \\
34-6,31 \\
34-6,133 \\
34-7,83\end{array}$ & $\begin{array}{l}4 \mathrm{~b} \\
1 \mathrm{~b} \\
1 \mathrm{~s} \\
3 \mathrm{j}\end{array}$ & $\begin{array}{l}4.30 \\
4.13^{b} \\
3.89 \\
4.24 \\
4.55\end{array}$ & $\begin{array}{l}409.38 \\
409.64 \\
410.31 \\
411.33 \\
412.33\end{array}$ \\
\hline $\begin{array}{l}34-7,131 \\
35-1,47 \\
35-1,121 \\
35-2,5 \\
35-2,126\end{array}$ & $\begin{array}{l}3 \mathrm{o} \\
1 \mathrm{f} \\
1 \mathrm{n} \\
1 \mathrm{a} \\
1 \mathrm{z}\end{array}$ & $\begin{array}{l}5.07 \\
5.37 \\
4.78 \\
4.55 \\
4.33\end{array}$ & $\begin{array}{l}412.81 \\
412.47 \\
413.21 \\
413.55 \\
414.76\end{array}$ \\
\hline $\begin{array}{l}35-3,45 \\
35-4,51 \\
35-4,111 \\
35-4,116 \\
35-5,32\end{array}$ & $\begin{array}{l}1 \mathrm{~h} \\
1 \mathrm{p} \\
1 \mathrm{dd} \\
1 \mathrm{dd} \\
1 \mathrm{~d}\end{array}$ & $\begin{array}{l}3.91 \\
4.83 \\
4.97 \\
4.96 \mathrm{~b} \\
5.89\end{array}$ & $\begin{array}{l}415.45 \\
417.01 \\
417.61 \\
417.66 \\
418.32\end{array}$ \\
\hline $\begin{array}{l}35-5,98 \\
35-5,132 \\
35-6,53 \\
35-6,113 \\
35-6,115\end{array}$ & $\begin{array}{l}1 \mathrm{~L} \\
1 \mathrm{q} \\
1 \mathrm{e} \\
1 \mathrm{n} \\
1 \mathrm{n}\end{array}$ & $\begin{array}{l}5.76^{b} \\
5.92 \\
5.78 \\
4.29 \\
4.01 \mathrm{~b}\end{array}$ & $\begin{array}{l}418.98 \\
419.32 \\
420.03 \\
420.63 \\
420.65\end{array}$ \\
\hline $\begin{array}{l}35-6,135 \\
35-7,5 \\
35-7,83 \\
35-7,118 \\
36-1,29\end{array}$ & $\begin{array}{l}1 \mathrm{q} \\
1 \mathrm{a} \\
4 \mathrm{a} \\
5 \mathrm{a} \\
\mathrm{od}\end{array}$ & $\begin{array}{l}4.43^{b} \\
4.81 \\
4.70 \\
4.92 \\
4.27\end{array}$ & $\begin{array}{l}420.85 \\
421.05 \\
421.83 \\
422.18 \\
421.79\end{array}$ \\
\hline $\begin{array}{l}36-1,51 \\
36-1,115 \\
36-1,117 \\
36-1,126 \\
36-2,28\end{array}$ & $\begin{array}{l}1 \mathrm{e} \\
3 \mathrm{~b} \\
3 \mathrm{~b} \\
3 \mathrm{c} \\
1 \mathrm{~g}\end{array}$ & $\begin{array}{l}4.79 \mathrm{~b} \\
3.92^{\mathrm{b}} \\
4.06 \\
4.12^{\mathrm{b}} \\
4.70\end{array}$ & $\begin{array}{l}422.01 \\
422.65 \\
422.67 \\
422.76 \\
423.28\end{array}$ \\
\hline $\begin{array}{l}36-2,28 \\
36-2,140 \\
36-3,23 \\
36-3,36 \\
36-3,61\end{array}$ & $\begin{array}{l}1 \mathrm{~g} \\
8 \mathrm{~g} \\
1 \mathrm{~d} \\
1 \mathrm{e} \\
1 \mathrm{~h}\end{array}$ & $\begin{array}{l}4.07 \mathrm{~b} \\
4.50 \\
4.15^{\mathrm{b}} \\
4.01 \mathrm{~b} \\
4.52\end{array}$ & $\begin{array}{l}423.28 \\
424.40 \\
424.73 \\
424.86 \\
425.11\end{array}$ \\
\hline $\begin{array}{l}36-3,77 \\
36-3,102 \\
36-3,124 \\
36-4,21 \\
36-4,39\end{array}$ & $\begin{array}{l}1 \mathrm{i} \\
1 \mathrm{~L} \\
1 \mathrm{n} \\
1 \mathrm{c} \\
1 \mathrm{e}\end{array}$ & $\begin{array}{l}4.04 \mathrm{~b} \\
4.28 \mathrm{~b} \\
4.85 \\
4.10 \\
4.76\end{array}$ & $\begin{array}{l}425.27 \\
425.52 \\
425.74 \\
426.21 \\
426.39\end{array}$ \\
\hline
\end{tabular}

TABLE 22 - Continued

\begin{tabular}{lccc}
\hline Core-Section, Interval $(\mathrm{cm})$ & $\begin{array}{c}\text { Piece } \\
\text { Number }\end{array}$ & $\begin{array}{c}\text { Velocity } \\
(\mathrm{km} / \mathrm{s})\end{array}$ & $\begin{array}{c}\text { Sub-bottom } \\
\text { Depth }(\mathrm{m})\end{array}$ \\
\hline
\end{tabular}

\section{Hole 433C}

$36-4,73$
$36-4,114$
$36-4,130$
$36-5,99$
$36-5,104$
$36-5,127$
$37-1,37$
$37-1,116$
$37-2,44$
$37-2,143$
$37-3,12$
$37-3,13$
$37-3,65$
$37-3,88$
$37-3,124$
$37-3,140$
$37-4,28$
$37-4,53$
$37-4,109$
$37-5,34$
$38-1,30$
$38-1,59$
$38-1,71$
$38-1,110$
$38-2,12$
$38-2,17$
$38-2,62$
$38-2,63$
$38-2,104$
$38-3,26$
$38-3,47$
$38-3,65$
$38-3,140$
$38-4,8$
$38-4,12$
$38-4,58$
$38-4,99$
$38-4,112$
$38-5,64$
$38-5,88$
$38-5,104$
$38-5,140$
$38-6,9$
$38-6,12$
$39-1,14$
$39-1,68$
$39-2,13$
$39-2,39$
$39-2,59$
$39-2,135$
$39-3,26$
$39-3,50$
$39-3,114$
$39-4,80$
$39-4,92$
$39-4,129$
$39-5,50$
$39-5,113$
$39-6,39$
$39-6,57$
-

$\begin{array}{rll}1 \mathrm{i} & 4.54 & 426.73 \\ 1 \mathrm{n} & 3.76 \mathrm{~b} & 427.14 \\ 1 \mathrm{q} & 4.20 & 427.30 \\ 4 \mathrm{~h} & 4.64 & 428.49 \\ 4 \mathrm{i} & 4.05 \mathrm{~b} & 428.54 \\ 4 \mathrm{k} & 4.28 \mathrm{~b} & 428.77 \\ 5 \mathrm{~b} & 4.00 & 431.37 \\ 12 \mathrm{c} & 4.41 & 432.16 \\ 5 \mathrm{a} & 3.57 & 432.94\end{array}$

$\begin{array}{ll}11 \mathrm{~d} & 4.74 \quad 433.93\end{array}$

lb $\quad 4.75 \quad 434.12$

le $\quad 4.40^{\mathrm{b}} \quad 434.33$

1i $\quad 4.90 \quad 434.65$

$\begin{array}{lll}1 \mathrm{k} & 5.12^{\mathrm{b}} & 434.88\end{array}$

$\begin{array}{lll}1 \mathrm{r} & 5.03 & 435.24\end{array}$

$\begin{array}{lll}2 & 4.25^{\mathrm{b}} & 435.40\end{array}$

$\begin{array}{lll}1 \mathrm{~b} & 4.68 & 435.78\end{array}$

ld $\quad 4.24 \mathrm{~b} \quad 436.03$

$\begin{array}{lll}3 b & 3.81 & 436.59\end{array}$

$\begin{array}{lll}3 \mathrm{a} & 4.52 & 437.34\end{array}$

1d $\quad 5.61 \quad 440.80$

1f $\quad 5.90 \quad 441.09$

$1 \mathrm{~g} \quad 5.88 \quad 441.21$

$\begin{array}{lll}2 \mathrm{c} & 4.48 & 441.60\end{array}$

$\begin{array}{lll}\text { 1b } & 5.04 & 442.12\end{array}$

$\begin{array}{lll}1 \mathrm{~b} & 5.29 \mathrm{~b} & 442.17\end{array}$

$\begin{array}{lll}2 \mathrm{~b} & 3.67 & 442.62\end{array}$

$2 \mathrm{~b} \quad 3.42^{\mathrm{b}} \quad 442.63$

$\begin{array}{lll}4 \mathrm{a} & 3.49 & 443.04\end{array}$

$\begin{array}{lll}3 & 3.57 & 443.76\end{array}$

$\begin{array}{lll}5 \mathrm{c} & 3.21 \mathrm{~b} & 443.97\end{array}$

6d $\quad 3.26^{\mathrm{b}} \quad 444.15$

$7 \mathrm{~d} \quad 3.00^{\mathrm{b}} \quad 444.90$

la $\quad 3.97 \mathrm{~b} \quad 445.08$

$\begin{array}{lll}1 \mathrm{~d} & 3.85 & 445.12\end{array}$

$\begin{array}{lll}2 \mathrm{~h} & 4.65 & 445.58\end{array}$

2o $\quad 3.58^{\mathrm{b}} \quad 445.99$

$2 \mathrm{q} \quad 4.24 \quad 446.12$

$1 \mathrm{k} \quad 4.66^{\mathrm{b}} \quad 447.14$

$\begin{array}{lll}\text { in } & 5.39 & 447.38\end{array}$

$1 \mathrm{r} \quad 5.33^{\mathrm{b}} \quad 447.54$

$1 \mathrm{u} \quad 4.94^{\mathrm{b}} \quad 447.90$

$\begin{array}{lll}1 \mathrm{a} & 4.47 & 448.09\end{array}$

$1 \mathrm{a} \quad 3.99 \mathrm{~b} \quad 448.12$

$\begin{array}{lll}4 & 3.63 & 450.14\end{array}$

$\begin{array}{lll}24 & 4.61 & 450.68\end{array}$

$1 \mathrm{~b} \quad 2.93 \quad 451.63$

$\begin{array}{lll}1 \mathrm{~h} & 3.60 & 451.89\end{array}$

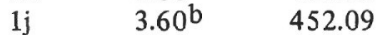

$1 \mathrm{t} \quad 4.49 \quad 452.85$

1a $\quad 4.21^{\mathrm{b}} \quad 453.26$

lb $\quad 4.78 \quad 453.50$

$\begin{array}{lll}1 \mathrm{i} & 5.05 & 454.14\end{array}$

$1 \mathrm{~g} \quad 5.40 \quad 455.30$

lh $\quad 5.57 \mathrm{~b} \quad 455.42$

$1 \mathrm{j} \quad 5.52 \quad 455.79$

$1 \mathrm{~b} \quad 5.94 \quad 456.50$

if $\quad 6.18 \quad 457.13$

$\begin{array}{lll}1 \mathrm{~b} & 5.71 & 457.89\end{array}$

$\begin{array}{ll}1 \mathrm{~d} & 5.50^{\mathrm{b}} \quad 458.07\end{array}$ 
TABLE 22 - Continued

\begin{tabular}{cccc}
\hline & Piece & Velocity & Sub-bottom \\
Core-Section, Interval (cm) & Number & $(\mathrm{km} / \mathrm{s})$ & Depth $(\mathrm{m})$
\end{tabular}

Hole 433C

\begin{tabular}{|c|c|c|c|}
\hline $39-6,132$ & 3 & 3.11 & 458.82 \\
\hline $39-7,27$ & $1 \mathrm{e}$ & 3.51 & 459.27 \\
\hline $39-7,84$ & 10 & 4.67 & 459.84 \\
\hline $39-7,131$ & $5 a$ & 3.96 & 460.31 \\
\hline $40-1,14$ & $2 a$ & 4.25 & 459.64 \\
\hline $40-1,10$ & $1 \mathrm{a}$ & 6.12 & 461.10 \\
\hline $40-1,25$ & $1 \mathrm{~b}$ & $5.79 \mathrm{~b}$ & 461.25 \\
\hline $40-1,105$ & $1 \mathrm{~g}$ & 5.78 & 462.05 \\
\hline $40-1,112$ & $1 \mathrm{~g}$ & $5.84 \mathrm{~b}$ & 462.12 \\
\hline $40-3,9$ & $1 \mathrm{a}$ & $5.64^{b}$ & 462.59 \\
\hline $40-3,18$ & $1 \mathrm{~b}$ & 6.14 & 462.68 \\
\hline $40-3,90$ & $1 \mathbf{j}$ & 4.39 & 463.40 \\
\hline $40-4,112$ & $1 v$ & $3.49 \mathrm{~b}$ & 465.12 \\
\hline $40-4,144$ & $1 \mathrm{aa}$ & 3.77 & 465.44 \\
\hline $40-5,27$ & 1e & 4.56 & 465.77 \\
\hline $40-5,40$ & $1 \mathrm{~g}$ & $3.26^{\mathrm{b}}$ & 465.90 \\
\hline $40-5,138$ & $5 \mathrm{~b}$ & 4.08 & 466.88 \\
\hline $40-6,72$ & $2 r$ & $4.42^{\mathrm{b}}$ & 467.72 \\
\hline $40-6,95$ & $2 \mathrm{t}$ & $4.32^{\mathrm{b}}$ & 467.95 \\
\hline $40-6,104$ & $2 u$ & 4.87 & 468.04 \\
\hline $41-1,26$ & $1 \mathrm{c}$ & 5.00 & 469.26 \\
\hline $41-1,114$ & $1 \mathrm{~h}$ & 4.74 & 470.14 \\
\hline $41-2,63$ & $1 \mathrm{k}$ & 4.45 & 471.13 \\
\hline $41-2,129$ & $3 \mathrm{~g}$ & 4.41 & 471.79 \\
\hline $41-3,78$ & 4 & 3.93 & 472.78 \\
\hline $41-4,53$ & $3 g$ & 4.90 & 474.03 \\
\hline $41-4,75$ & $3 \mathrm{k}$ & $4.59 \mathrm{~b}$ & 474.25 \\
\hline $41-4,106$ & $5 b$ & 4.00 & 474.56 \\
\hline $41-5,85$ & $5 a$ & 4.11 & 475.85 \\
\hline $41-6,65$ & $1 \mathrm{~m}$ & 4.33 & 477.15 \\
\hline $41-6,111$ & $3 c$ & $4.70^{\mathrm{b}}$ & 477.61 \\
\hline $41-6,139$ & $3 \mathrm{f}$ & 4.83 & 477.89 \\
\hline $41-6,139$ & $3 \mathrm{f}$ & $4.41^{b}$ & 477.89 \\
\hline $42-1,46$ & 1e & $4.71^{b}$ & 478.96 \\
\hline $42-1,60$ & $1 \mathrm{f}$ & 4.98 & 479.10 \\
\hline $42-1,80$ & $1 \mathrm{~h}$ & $4.71^{b}$ & 479.30 \\
\hline $42-2,22$ & $2 b$ & 3.92 & 480.22 \\
\hline $42-2,36$ & $3 b$ & $4.03^{b}$ & 480.36 \\
\hline $42-2,127$ & $6 \mathrm{~d}$ & $4.79 \mathrm{~b}$ & 481.27 \\
\hline $42-2,135$ & $6 e$ & 4.97 & 481.35 \\
\hline $42-3,26$ & $1 \mathrm{c}$ & 4.28 & 481.76 \\
\hline $42-3,127$ & $10 \mathrm{a}$ & 4.45 & 482.77 \\
\hline $42-4,49$ & $3 e$ & 4.71 & 483.49 \\
\hline $42-4,138$ & $8 \mathrm{e}$ & $4.86^{b}$ & 484.38 \\
\hline $42-4,141$ & $8 \mathrm{e}$ & 5.09 & 484.41 \\
\hline $42-5,57$ & $1 \mathrm{~g}$ & 4.94 & 485.07 \\
\hline $42-5,111$ & $1 \mathrm{~L}$ & $4.56^{\mathrm{b}}$ & 485.61 \\
\hline $43-1,8$ & $1 \mathrm{a}$ & $4.76^{b}$ & 488.08 \\
\hline $43-1,31$ & $1 \mathrm{~g}$ & 4.95 & 488.31 \\
\hline $43-1,53$ & $2 a$ & $4.81^{b}$ & 488.53 \\
\hline $43-1,126$ & $4 c$ & 3.92 & 489.26 \\
\hline $43-2,63$ & $4 \mathrm{~L}$ & 4.31 & 490.13 \\
\hline $43-2,111$ & $5 f$ & 3.86 & 490.61 \\
\hline $44-1,35$ & $1 d$ & 5.16 & 497.85 \\
\hline $44-1,85$ & $1 \mathrm{i}$ & $4.10^{b}$ & 498.35 \\
\hline $44-1,109$ & $1 \mathrm{~L}$ & 4.54 & 498.59 \\
\hline $44-2,4$ & $1 \mathrm{a}$ & 4.40 & 499.04 \\
\hline $44-2,99$ & $7 \mathrm{c}$ & 4.01 & 499.99 \\
\hline $44-3,85$ & $6 f$ & 4.29 & 501.35 \\
\hline $44-3,90$ & $6 f$ & $3.95^{b}$ & 501.40 \\
\hline
\end{tabular}

TABLE 22 - Continued

\begin{tabular}{|c|c|c|c|}
\hline Core-Section, Interval $(\mathrm{cm})$ & $\begin{array}{l}\text { Piece } \\
\text { Number }\end{array}$ & $\begin{array}{l}\text { Velocity } \\
(\mathrm{km} / \mathrm{s})\end{array}$ & $\begin{array}{l}\text { Sub-bottom } \\
\text { Depth }(m)\end{array}$ \\
\hline \multicolumn{4}{|l|}{ Hole 433C } \\
\hline $\begin{array}{l}44-3,142 \\
44-4,39 \\
44-4,53 \\
44-4,82 \\
44-4,127\end{array}$ & $\begin{array}{c}10 \mathrm{~b} \\
2 \mathrm{~g} \\
2 \mathrm{~h} \\
2 \mathrm{k} \\
5\end{array}$ & $\begin{array}{l}4.58 \\
4.47^{b} \\
5.11 \\
4.00^{b} \\
4.14^{b}\end{array}$ & $\begin{array}{l}501.92 \\
502.39 \\
502.53 \\
502.82 \\
503.27\end{array}$ \\
\hline $\begin{array}{l}44-5,11 \\
44-5,76 \\
45-1,10 \\
45-1,128 \\
45-2,32\end{array}$ & $\begin{array}{l}1 \mathrm{a} \\
1 \mathrm{e} \\
1 \mathrm{~b} \\
2 \mathrm{y} \\
1 \mathrm{c}\end{array}$ & $\begin{array}{l}4.91 \\
4.59 \\
4.16 \\
4.34 \mathrm{~b} \\
4.69 \mathrm{~b}\end{array}$ & $\begin{array}{l}503.61 \\
504.26 \\
507.10 \\
508.28 \\
508.82\end{array}$ \\
\hline $\begin{array}{l}45-2,47 \\
45-2,60 \\
45-2,105 \\
45-2,125 \\
45-3,70\end{array}$ & $\begin{array}{l}1 \mathrm{~d} \\
1 \mathrm{e} \\
1 \mathrm{i} \\
1 \mathrm{~L} \\
3 \mathrm{c}\end{array}$ & $\begin{array}{l}5.24 \\
4.71^{b} \\
4.24 \mathrm{~b} \\
4.56 \\
3.87\end{array}$ & $\begin{array}{l}508.97 \\
509.10 \\
509.55 \\
509.75 \\
510.70\end{array}$ \\
\hline $\begin{array}{l}45-3,142 \\
45-4,39 \\
45-4,111 \\
45-4,125 \\
45-5,31\end{array}$ & $\begin{array}{l}4 \mathrm{a} \\
3 \mathrm{f} \\
4 \mathrm{~d} \\
1 \mathrm{k} \\
1 \mathrm{~b}\end{array}$ & $\begin{array}{l}4.81 \\
4.85 \\
5.55 \\
4.76 \\
5.81\end{array}$ & $\begin{array}{l}511.42 \\
511.89 \\
512.61 \\
512.75 \\
513.31\end{array}$ \\
\hline $\begin{array}{l}45-5,109 \\
45-6,17 \\
45-6,46 \\
45-6,74 \\
45-7,51\end{array}$ & $\begin{array}{l}3 b \\
1 c \\
3 b\end{array}$ & $\begin{array}{l}6.07 \\
4.75 b \\
5.13 \\
4.99 b \\
4.15\end{array}$ & $\begin{array}{l}514.09 \\
514.67 \\
514.96 \\
515.24 \\
516.51\end{array}$ \\
\hline $\begin{array}{l}45-7,122 \\
45-7,133 \\
45-7,145 \\
46-1,12 \\
46-1,55\end{array}$ & $\begin{array}{l}5 \mathrm{~g} \\
5 \mathrm{k} \\
1 \mathrm{j}\end{array}$ & $\begin{array}{l}4.58^{\mathrm{b}} \\
5.21 \\
4.66^{\mathrm{b}} \\
3.55^{\mathrm{b}} \\
3.45\end{array}$ & $\begin{array}{l}517.22 \\
517.33 \\
517.45 \\
516.62 \\
517.05\end{array}$ \\
\hline $46-1,48-50$ & $(48-58)$ & $3.97 \mathrm{~b}$ & $\begin{array}{l}516.98- \\
517.08\end{array}$ \\
\hline $\begin{array}{l}46-1,127 \\
46-2,19 \\
46-2,121 \\
46-2,125\end{array}$ & $\begin{array}{l}1 \mathrm{x} \\
1 \mathrm{~d} \\
1 \mathrm{aa}\end{array}$ & $\begin{array}{l}3.80 \\
3.91 \\
4.64 \mathrm{~b} \\
5.15\end{array}$ & $\begin{array}{l}517.77 \\
518.19 \\
519.21 \\
519.25\end{array}$ \\
\hline $\begin{array}{l}46-3,15 \\
46-3,31 \\
46-3,108 \\
46-3,121 \\
46-4,23\end{array}$ & $\begin{array}{l}1 \mathrm{~b} \\
2 \mathrm{f} \\
1 \mathrm{e}\end{array}$ & $\begin{array}{l}4.71^{b} \\
5.05 \\
4.99 \\
4.65^{b} \\
4.13\end{array}$ & $\begin{array}{l}519.65 \\
519.81 \\
520.58 \\
520.71 \\
521.23\end{array}$ \\
\hline $\begin{array}{l}46-4,27 \\
46-4,110 \\
46-5,55 \\
46-5,97 \\
46-5,130\end{array}$ & $\begin{array}{l}2 \mathrm{o} \\
4 \mathrm{~b} \\
6 \mathrm{~b} \\
6 \mathrm{~h}\end{array}$ & $\begin{array}{l}4.74 \\
3.70^{\mathrm{b}} \\
4.32 \\
5.01 \\
4.61\end{array}$ & $\begin{array}{l}521.27 \\
522.10 \\
523.05 \\
523.47 \\
523.80\end{array}$ \\
\hline $\begin{array}{l}46-5,143 \\
46-6,30 \\
46-6,93 \\
47-1,21 \\
47-1,26\end{array}$ & $\begin{array}{l}1 \mathrm{e} \\
4 \mathrm{a} \\
2 \mathrm{a}\end{array}$ & $\begin{array}{l}4.39 \mathrm{~b} \\
4.89 \\
5.01 \\
4.44^{b} \\
5.11\end{array}$ & $\begin{array}{l}523.93 \\
524.30 \\
524.93 \\
526.21 \\
526.26\end{array}$ \\
\hline $\begin{array}{l}47-1,61 \\
47-1,94 \\
47-1,127 \\
47-2,37 \\
47-2,106\end{array}$ & $\begin{array}{l}2 \mathrm{~m} \\
1 \mathrm{f} \\
3 \mathrm{e}\end{array}$ & $\begin{array}{l}4.06^{\mathrm{b}} \\
3.98^{\mathrm{b}} \\
5.31^{\mathrm{b}} \\
4.18 \\
4.55\end{array}$ & $\begin{array}{l}526.61 \\
526.94 \\
527.27 \\
527.87 \\
528.56\end{array}$ \\
\hline $\begin{array}{l}47-2,135 \\
47-3,105 \\
47-4,45 \\
47-4,137 \\
47-5,17\end{array}$ & $\begin{array}{l}4 \mathrm{~b} \\
2 \mathrm{~m} \\
1 \mathrm{~h} \\
1 \mathrm{x} \\
2\end{array}$ & $\begin{array}{l}4.55 \\
3.83 \\
3.64 \\
4.32 \\
4.37\end{array}$ & $\begin{array}{l}528.85 \\
530.05 \\
530.95 \\
531.87 \\
532.17\end{array}$ \\
\hline
\end{tabular}


TABLE 22 - Continued

\begin{tabular}{cccc}
\hline Core-Section, Interval (cm) & $\begin{array}{c}\text { Piece } \\
\text { Number }\end{array}$ & $\begin{array}{c}\text { Velocity } \\
(\mathrm{km} / \mathrm{s})\end{array}$ & $\begin{array}{c}\text { Sub-bottom } \\
\text { Depth }(\mathrm{m})\end{array}$ \\
\hline Hole 433C & & & \\
$47-5,81$ & $6 \mathrm{a}$ & $5.26^{\mathrm{b}}$ & 532.81 \\
$47-5,95$ & 7 & 4.08 & 532.95 \\
$48-1,25$ & $1 \mathrm{~d}$ & 5.63 & 535.75 \\
$48-1,45$ & & $5.40^{\mathrm{b}}$ & 535.95 \\
$48-1,130$ & $2 \mathrm{f}$ & 5.76 & 536.80 \\
$48-2,122$ & $2 \mathrm{~b}$ & 5.87 & 538.22 \\
$48-3,7$ & $1 \mathrm{a}$ & 6.16 & 538.57 \\
$48-3,56$ & & $5.63 \mathrm{~b}$ & 539.06 \\
$48-3,135$ & $3 \mathrm{i}$ & 4.70 & 539.85 \\
$48-4,54$ & $4 \mathrm{~b}$ & 5.14 & 540.54 \\
$48-4,62$ & $4 \mathrm{c}$ & $4.80^{\mathrm{b}}$ & 540.62 \\
$48-4,94$ & $7 \mathrm{a}$ & $3.97 \mathrm{~b}$ & 540.94 \\
$49-1,69$ & $5 \mathrm{a}$ & 4.39 & 545.69 \\
$49-1,123$ & $7 \mathrm{e}$ & $4.05 \mathrm{~b}$ & 546.23 \\
$49-1,129$ & $7 \mathrm{f}$ & 4.68 & 546.29 \\
$49-2,21$ & $1 \mathrm{c}$ & 4.78 & 546.71 \\
$49-2,32$ & $1 \mathrm{~d}$ & 4.51 & 546.82 \\
$49-2,59$ & $1 \mathrm{i}$ & $4.74 \mathrm{~b}$ & 547.09 \\
$49-2,65$ & $1 \mathrm{j}$ & 4.80 & 547.15 \\
$49-2,112$ & $4 \mathrm{a}$ & $3.76^{\mathrm{b}}$ & 547.62 \\
\hline
\end{tabular}

a ( ) - lesser quality.

On minicore.

the central part of the seamount in a southwest direction (Figure 18). Locally, terrace deposits overlie a flat erosional acoustic basement surface along the outer edge of the seamount.

Site 433 is along the northeast margin of the lagoonal complex, and within what appears to be a graben that has formed along the southwest flank of the central ridge or platform (Figures 34 and 35 ). That ridge may originally have been constructed by a volcanic rift which probably trends northeast from the seamount crest. Faulting along the upper flanks of the ridge produced scarps upon which fringing reefs developed. To the southwest, the lagoon deepens, and about 16 nautical miles northwest of the graben, the lagoonal sediments thin and lap onto an acoustic basement ridge or cone of what is probably volcanic rock (Figures 2,34 , and 35 ).

The $3.5-\mathrm{kHz}$ Challenger profiles taken across Site 433 show a relatively thick section of well-stratified sediments filling the graben (Figure 11). Many strong, continuous, rhythmically bedded, flat-lying to gently folded reflectors are shown (Figures 36 and 37). The records taken on station at Site 433 (Figure 12) show the sea floor as a wide $(0.002 \mathrm{~s})$, strong reflector beneath which an acoustically semitransparent zone (Zone A) with many weak, discontinuous reflectors occurs at a subsurface depth corresponding to 0 to $0.015 \mathrm{~s}$. From $0.015 \mathrm{~s}$ to $0.019 \mathrm{~s}$, a thin, acoustically transparent zone (Zone B) occurs; its top is distinctly marked by the shallowest, most continuous strong reflector (reflector 1). Between 0.019 and $0.024 \mathrm{~s}$ is a layer (Zone C) of weak, discontinuous reflectors lying upon a very strong, continuous reflector (reflector 2) that apparently marks a disconformable contact. To the south, near the base of the acoustic basement buttress that bounds the southern part of the graben, this reflector marks an angular, unconformable
TABLE 23

Density Data for Site 433

\begin{tabular}{|c|c|c|c|}
\hline \multicolumn{4}{|c|}{ (2-minute GRAPE of minicores, $\sigma=0.100 \mathrm{~cm}^{2} / \mathrm{g}$ ) } \\
\hline Core-Section, Interval $(\mathrm{cm})$ & $\begin{array}{l}\text { Piece } \\
\text { Number }\end{array}$ & $\begin{array}{c}\rho \\
\left(\mathrm{g} / \mathrm{cm}^{3}\right)\end{array}$ & $\begin{array}{l}\text { Sub-bottom } \\
\text { Depth (m) }\end{array}$ \\
\hline \multicolumn{4}{|l|}{ Hole 433A } \\
\hline $\begin{array}{l}20-1,4 \\
20-1,37 \\
20-1,114 \\
20-2,11 \\
20-2,50 \\
21-1,29 \\
21-2,85 \\
21-3,99 \\
21-4,139\end{array}$ & & $\begin{array}{l}2.78 \\
2.92 \\
2.85 \\
2.91 \\
2.83 \\
2.59 \\
2.96 \\
2.94 \\
2.94\end{array}$ & $\begin{array}{l}163.54 \\
163.87 \\
164.64 \\
165.11 \\
165.50 \\
166.79 \\
168.85 \\
170.49 \\
172.39\end{array}$ \\
\hline \multicolumn{4}{|l|}{ Hole 433B } \\
\hline $\begin{array}{l}4-1,52 \\
5-1,72 \\
5-2,37\end{array}$ & $\begin{array}{l}3 \mathrm{c} \\
6 \mathrm{a} \\
2 \mathrm{a}\end{array}$ & $\begin{array}{l}2.54 \\
2.79 \\
2.92\end{array}$ & $\begin{array}{l}157.52 \\
166.72 \\
167.87\end{array}$ \\
\hline
\end{tabular}

Hole 433C

\begin{tabular}{|c|c|c|c|}
\hline $1-1,62$ & 9 & 2.92 & 163.62 \\
\hline $2-1,23$ & 3 & 2.86 & 168.23 \\
\hline $4-1,40$ & $2 c$ & 3.05 & 181.90 \\
\hline $4-1,87$ & 4 & 2.96 & 182.37 \\
\hline $5-1,13$ & 1 & 2.94 & 187.13 \\
\hline $6-1,5$ & 1 & 2.92 & \\
\hline $10-1,38$ & $1 d$ & 2.71 & 204.88 \\
\hline $10-1,120$ & 15 & 2.58 & 205.70 \\
\hline $10-2,22$ & 3 & 2.45 & 206.22 \\
\hline $10-2,48$ & $6 \mathrm{~b}$ & 2.35 & 206.48 \\
\hline $10-2,140$ & 20 & 1.89 & 207.40 \\
\hline $10-3,17$ & $2 b$ & 2.38 & 207.67 \\
\hline $10-3,136$ & 11 & 2.57 & 208.86 \\
\hline $10-4,10$ & 2 & 2.16 & 209.10 \\
\hline $10-4,113$ & $8 \mathrm{a}$ & 2.51 & 210.13 \\
\hline $10-5,49$ & $6 a$ & 2.51 & 210.99 \\
\hline $10-5,144$ & $13 \mathrm{c}$ & 2.36 & 211.94 \\
\hline $10-6,44$ & $3 c$ & 2.71 & 212.44 \\
\hline $11-1,6$ & $1 \mathrm{a}$ & 2.64 & 214.06 \\
\hline $11-1,64$ & 4 & 2.45 & 214.64 \\
\hline $11-1,92$ & $1 \mathrm{~g}$ & 2.81 & 214.92 \\
\hline $11-2,51$ & 5 & 2.13 & 216.01 \\
\hline $11-3,10$ & $1 b$ & 2.87 & 217.10 \\
\hline $11-3,99$ & & 2.79 & 217.99 \\
\hline $11-3,122$ & $2 \mathrm{~g}$ & 2.73 & 218.22 \\
\hline $11-4,59$ & 6 & 2.41 & 219.09 \\
\hline $11-4,91$ & 11 & 2.69 & 219.41 \\
\hline $11-5,41$ & 4 & 2.22 & 220.41 \\
\hline $12-1,39$ & $3 d$ & 2.60 & 223.89 \\
\hline $12-1,103$ & $9 b$ & 2.30 & 224.53 \\
\hline $12-3,49$ & $1 \mathrm{~d}$ & 2.71 & 226.99 \\
\hline $12-3,101$ & 4 & 2.52 & 227.51 \\
\hline $12-4,23$ & 3 & 2.82 & 228.23 \\
\hline $13-1,7$ & $3 a$ & 2.86 & 230.07 \\
\hline $14-1,48$ & $1 \mathrm{~h}$ & 2.08 & 233.48 \\
\hline $14-2,129$ & $3 e$ & 2.46 & 235.79 \\
\hline $15-1,11$ & $2 \mathrm{a}$ & 2.60 & 242.61 \\
\hline $15-1,48$ & $2 \mathrm{e}$ & 2.37 & 242.98 \\
\hline $15-2,104$ & 11 & 2.22 & 245.04 \\
\hline $15-3,128$ & 15 & 2.34 & 246.78 \\
\hline $15-4,22$ & 2 & 2.56 & 247.22 \\
\hline
\end{tabular}


TABLE 23 - Continued

\begin{tabular}{|c|c|c|c|}
\hline Core-Section, Interval (cm) & $\begin{array}{c}\text { Piece } \\
\text { Number }\end{array}$ & $\begin{array}{c}\rho \\
\left(\mathrm{g} / \mathrm{cm}^{3}\right)\end{array}$ & $\begin{array}{l}\text { Sub-bottom } \\
\text { Depth (m) }\end{array}$ \\
\hline \multicolumn{4}{|l|}{ Hole 433C } \\
\hline $\begin{array}{l}15-4,100 \\
15-4,116 \\
15-5,15 \\
15-5,80 \\
16-1,12\end{array}$ & $\begin{array}{l}8 \\
9 b \\
2 \\
4 a \\
2\end{array}$ & $\begin{array}{l}2.54 \\
2.43 \\
2.49 \\
2.68 \\
2.97\end{array}$ & $\begin{array}{l}248.00 \\
248.16 \\
248.65 \\
249.30 \\
252.12\end{array}$ \\
\hline $\begin{array}{l}16-1,76 \\
17-1,18 \\
19-1,15 \\
19-1,88 \\
19-2,13\end{array}$ & $\begin{array}{l}6 \mathrm{~b} \\
2 \\
2 \mathrm{a} \\
8 \mathrm{a} \\
1 \mathrm{~b}\end{array}$ & $\begin{array}{l}3.06 \\
3.06 \\
3.02 \\
2.50 \\
2.77\end{array}$ & $\begin{array}{l}252.76 \\
255.68 \\
261.65 \\
262.33 \\
263.13\end{array}$ \\
\hline $\begin{array}{l}19-2,24 \\
19-3,16 \\
19-4,69 \\
19-5,26 \\
20-1,25\end{array}$ & $\begin{array}{l}2 \mathrm{a} \\
1 \mathrm{c} \\
2 \mathrm{f} \\
1 \mathrm{c} \\
2\end{array}$ & $\begin{array}{l}2.68 \\
2.46 \\
2.91 \\
2.87 \\
2.83\end{array}$ & $\begin{array}{l}263.24 \\
264.66 \\
266.69 \\
267.76 \\
269.75\end{array}$ \\
\hline $\begin{array}{l}20-1,83 \\
20-2,49 \\
21-1,108 \\
21-2,28 \\
21-2,105\end{array}$ & $\begin{array}{l}8 \\
5\end{array}$ & $\begin{array}{l}2.73 \\
2.82 \\
2.86 \\
2.73 \\
2.78\end{array}$ & $\begin{array}{l}270.33 \\
271.49 \\
280.08 \\
280.78 \\
281.55\end{array}$ \\
\hline $\begin{array}{l}21-3,33 \\
21-4,121 \\
21-5,10 \\
22-2,114 \\
22-3,65\end{array}$ & $\begin{array}{l}5 \mathrm{~h} \\
5 \mathrm{c}\end{array}$ & $\begin{array}{l}2.85 \\
2.83 \\
2.78 \\
2.76 \\
2.75\end{array}$ & $\begin{array}{l}282.33 \\
284.71 \\
285.10 \\
291.14 \\
292.15\end{array}$ \\
\hline $\begin{array}{l}22-3,131 \\
22-4,24 \\
22-5,59 \\
23-1,87 \\
23-2,56\end{array}$ & $\begin{array}{l}9 \\
2 \mathrm{a} \\
4 \\
4 \mathrm{a} \\
4 \mathrm{~d}\end{array}$ & $\begin{array}{l}2.80 \\
2.77 \\
2.89 \\
2.63 \\
2.46\end{array}$ & $\begin{array}{l}292.80 \\
293.24 \\
295.09 \\
298.87 \\
300.06\end{array}$ \\
\hline $\begin{array}{l}23-3,34 \\
23-4,30 \\
23-5,6 \\
23-6,109 \\
23-7,103\end{array}$ & $\begin{array}{l}1 \mathrm{~b} \\
1 \mathrm{~b} \\
1 \mathrm{a} \\
4 \mathrm{j} \\
5 \mathrm{a}\end{array}$ & $\begin{array}{l}2.70 \\
2.45 \\
2.64 \\
2.61 \\
2.93\end{array}$ & $\begin{array}{l}301.34 \\
302.80 \\
304.06 \\
306.59 \\
308.03\end{array}$ \\
\hline $\begin{array}{l}24-2,18 \\
24-3,82 \\
24-8,13 \\
25-1,132 \\
25-2,11\end{array}$ & $\begin{array}{l}1 \mathrm{a} \\
9 \mathrm{c} \\
1 \mathrm{~b} \\
2 \mathrm{o} \\
1 \mathrm{a}\end{array}$ & $\begin{array}{l}2.48 \\
2.66 \\
2.99 \\
2.79 \\
2.81\end{array}$ & $\begin{array}{l}309.18 \\
311.32 \\
316.63 \\
318.32 \\
318.61\end{array}$ \\
\hline $\begin{array}{l}25-2,46 \\
25-2,90 \\
25-3,19 \\
25-4,135 \\
25-5,78\end{array}$ & $\begin{array}{l}1 \mathrm{~d} \\
1 \mathrm{~m} \\
1 \mathrm{c} \\
6 \mathrm{~d} \\
1 \mathrm{~g}\end{array}$ & $\begin{array}{l}2.79 \\
2.56 \\
2.13 \\
2.78 \\
2.86\end{array}$ & $\begin{array}{l}318.96 \\
319.40 \\
320.19 \\
322.85 \\
323.78\end{array}$ \\
\hline $\begin{array}{l}25-6,57 \\
26-2,30 \\
26-3,21 \\
26-4,139 \\
26-5,36\end{array}$ & $\begin{array}{l}1 \mathrm{~g} \\
2 \mathrm{c} \\
1 \mathrm{~b} \\
4 \mathrm{j} \\
1 \mathrm{~d}\end{array}$ & $\begin{array}{l}2.90 \\
2.95 \\
2.93 \\
2.59 \\
2.81\end{array}$ & $\begin{array}{l}325.07 \\
328.30 \\
329.71 \\
332.39 \\
332.86\end{array}$ \\
\hline $\begin{array}{l}26-5,124 \\
26-7,8 \\
27-1,18 \\
27-1,70 \\
27-3,13\end{array}$ & $\begin{array}{l}1 \mathrm{k} \\
1 \mathrm{a} \\
2 \mathrm{~b} \\
2 \mathrm{q} \\
1 \mathrm{a}\end{array}$ & $\begin{array}{l}2.80 \\
2.68 \\
2.42 \\
2.39 \\
2.76\end{array}$ & $\begin{array}{l}333.74 \\
335.58 \\
336.18 \\
336.70 \\
339.13\end{array}$ \\
\hline $\begin{array}{l}27-5,19 \\
27-5,126 \\
27-6,14 \\
28-1,83 \\
28-2,35\end{array}$ & $\begin{array}{l}1 \mathrm{c} \\
3 \mathrm{c} \\
1 \mathrm{c}\end{array}$ & $\begin{array}{l}2.43 \\
2.49 \\
2.57 \\
2.88 \\
2.72\end{array}$ & $\begin{array}{l}342.19 \\
343.26 \\
343.64 \\
346.33 \\
347.35\end{array}$ \\
\hline
\end{tabular}

TABLE 23 - Continued

\begin{tabular}{lccc}
\hline & Piece & $\rho$ & Sub-bottom \\
Core-Section, Interval $(\mathrm{cm})$ & Number & $\left(\mathrm{g} / \mathrm{cm}^{3}\right)$ & Depth $(\mathrm{m})$ \\
\hline
\end{tabular}

\section{Hole 433C}

28-3, 39

28-4, 27

28-4, (57-90)

28-5, 114

29-1, 49

29-1, 83

29-1, 116

29-2, 97

29-2, 109

29-2, 139

29-3, 18

$30-2,135$

30-3, 58

$31-1,38$

$31-1,80$

31-1, 121

$31-3,89$

$31-4,50$

$31-4,74$

$31-5,30$

$32-1,31$

32-3, 101

$32-4,139$

$32-5,14$

$32-5,85$

$32-5,116$

$33-1,24$

33-1, 35

$33-1,63$

$33-1,88$

33-1, 105

$33-2,22$

33- 2,73

$33-2,139$

33-3, 13

$33-5,11$

$33-5,38$

$33-5,64$

$34-1,4$

$34-1,57$

$34-1,70$

34-1, 141

$34-2,60$

$34-2,125$

34-3, 9

34-3, 42

34-4, 15

$34-4,96$

$34-5,51$

$34-5,77$

$34-5,114$

34-6, 13

$35-1,71$

$35-2,22$

35-4, 116

$35-5,98$

35-6, 115

35-6, 135

$36-1,25$

36-1, 51

36-1, 115

\begin{tabular}{|c|c|c|}
\hline & 2.68 & 348.89 \\
\hline \multirow[t]{3}{*}{$2 b$} & 2.84 & 350.27 \\
\hline & 2.42 & $(350.58)$ \\
\hline & 2.90 & 351.14 \\
\hline \multirow[t]{3}{*}{$3 c$} & 2.71 & 355.49 \\
\hline & 2.88 & 355.83 \\
\hline & 2.73 & 356.16 \\
\hline 14 & 2.89 & 357.47 \\
\hline 16 & 2.79 & 357.59 \\
\hline \multirow[t]{4}{*}{19} & 2.55 & 357.89 \\
\hline & 2.76 & 358.18 \\
\hline & 2.92 & 367.35 \\
\hline & 2.96 & 368.08 \\
\hline $1 \mathrm{e}$ & 3.04 & 374.38 \\
\hline $1 \mathrm{k}$ & 3.00 & 374.80 \\
\hline \multirow{4}{*}{$\begin{array}{l}4 a \\
3 a\end{array}$} & 2.88 & 375.21 \\
\hline & 2.64 & 376.39 \\
\hline & 2.41 & 379.00 \\
\hline & 2.68 & 379.24 \\
\hline \multirow[t]{35}{*}{$1 \mathrm{~b}$} & 2.66 & 380.30 \\
\hline & 2.53 & 383.81 \\
\hline & 2.49 & 387.51 \\
\hline & 2.70 & 389.39 \\
\hline & 2.72 & 389.64 \\
\hline & & \\
\hline & 2.79 & 390.66 \\
\hline & 2.87 & 393.24 \\
\hline & 2.96 & 393.35 \\
\hline & 2.93 & 393.63 \\
\hline & 2.53 & 393.88 \\
\hline & 2.60 & 394.05 \\
\hline & 2.81 & 394.77 \\
\hline & 2.61 & 395.23 \\
\hline & 2.86 & 395.89 \\
\hline & 2.99 & 396.13 \\
\hline & 2.66 & 399.11 \\
\hline & 2.72 & 399.38 \\
\hline & 2.48 & 399.64 \\
\hline & 2.65 & 402.54 \\
\hline & 2.41 & 403.07 \\
\hline & 2.60 & 403.20 \\
\hline & 2.51 & 403.91 \\
\hline & 2.76 & 404.60 \\
\hline & 2.76 & 405.25 \\
\hline & 2.84 & 405.59 \\
\hline & 2.82 & 405.92 \\
\hline & 2.51 & 407.15 \\
\hline & 2.79 & 407.96 \\
\hline & 2.74 & 409.01 \\
\hline & 2.59 & 409.27 \\
\hline & 2.90 & 409.64 \\
\hline & 2.49 & 410.13 \\
\hline & 2.92 & 412.71 \\
\hline & 2.64 & 413.72 \\
\hline 1dd & 2.82 & 417.66 \\
\hline $1 \mathrm{~L}$ & 2.98 & 418.98 \\
\hline $1 \mathrm{n}$ & 2.52 & 420.65 \\
\hline \multirow[t]{2}{*}{$1 \mathrm{q}$} & 2.47 & 420.85 \\
\hline & 2.61 & 421.75 \\
\hline $1 \mathrm{e}$ & 2.85 & 422.01 \\
\hline $3 b$ & 2.34 & 422.65 \\
\hline
\end{tabular}


TABLE 23 - Continued

\begin{tabular}{|c|c|c|c|}
\hline Core-Section, Interval $(\mathrm{cm})$ & $\begin{array}{l}\text { Piece } \\
\text { Number }\end{array}$ & $\begin{array}{c}\rho \\
\left(\mathrm{g} / \mathrm{cm}^{3}\right)\end{array}$ & $\begin{array}{c}\text { Sub-bottom } \\
\text { Depth }(\mathrm{m})\end{array}$ \\
\hline \multicolumn{4}{|l|}{ Hole 433C } \\
\hline $\begin{array}{l}36-1,126 \\
36-3,23 \\
36-3,36 \\
36-3,77 \\
36-3,102\end{array}$ & $\begin{array}{l}3 \mathrm{c} \\
1 \mathrm{~d} \\
1 \mathrm{e} \\
1 \mathrm{i} \\
1 \mathrm{~L}\end{array}$ & $\begin{array}{l}2.57 \\
2.68 \\
2.73 \\
2.76 \\
2.79\end{array}$ & $\begin{array}{l}422.76 \\
424.73 \\
424.86 \\
425.27 \\
425.52\end{array}$ \\
\hline $\begin{array}{l}36-4,21 \\
36-4,73 \\
36-4,85 \\
36-4,114 \\
36-5,13\end{array}$ & $\begin{array}{l}1 \mathrm{c} \\
1 \mathrm{i}\end{array}$ & $\begin{array}{l}2.65 \\
2.79 \\
2.78 \\
2.39 \\
2.55\end{array}$ & $\begin{array}{l}426.21 \\
426.73 \\
426.85 \\
427.14 \\
427.63\end{array}$ \\
\hline $\begin{array}{l}36-5,80 \\
36-5,104 \\
36-5,127 \\
37-3,33 \\
37-3,88\end{array}$ & $\begin{array}{c}\mathrm{i} \\
4 \mathrm{k} \\
1 \mathrm{e} \\
1 \mathrm{k}\end{array}$ & $\begin{array}{l}2.59 \\
2.70 \\
2.76 \\
2.77 \\
2.90\end{array}$ & $\begin{array}{l}428.30 \\
428.54 \\
428.77 \\
434.33 \\
434.88\end{array}$ \\
\hline $\begin{array}{l}37-3,140 \\
37-4,8 \\
37-4,53 \\
38-1,30 \\
38-1,71\end{array}$ & $\begin{array}{l}7 d \\
1 \mathrm{a} \\
1 \mathrm{~d} \\
1 \mathrm{~d} \\
1 \mathrm{~g}\end{array}$ & $\begin{array}{l}2.85 \\
2.85 \\
2.80 \\
2.87 \\
2.88\end{array}$ & $\begin{array}{l}435.40 \\
435.58 \\
436.03 \\
440.80 \\
441.21\end{array}$ \\
\hline $\begin{array}{l}38-2,17 \\
38-2,42 \\
38-2,63 \\
38-3,47 \\
38-3,65\end{array}$ & $\begin{array}{l}1 \mathrm{~b} \\
2 \mathrm{~b} \\
5 \mathrm{c} \\
6 \mathrm{~d}\end{array}$ & $\begin{array}{l}2.80 \\
2.59 \\
2.36 \\
2.16 \\
2.08\end{array}$ & $\begin{array}{l}442.17 \\
442.42 \\
442.63 \\
443.97 \\
444.15\end{array}$ \\
\hline $\begin{array}{l}38-3,140 \\
38-4,99 \\
38-5,64 \\
38-5,104 \\
38-5,140\end{array}$ & $\begin{array}{l}7 \mathrm{~d} \\
2 \mathrm{o} \\
1 \mathrm{k} \\
1 \mathrm{r} \\
1 \mathrm{u}\end{array}$ & $\begin{array}{l}2.37 \\
2.87 \\
2.72 \\
2.86 \\
2.82\end{array}$ & $\begin{array}{l}444.90 \\
445.99 \\
447.14 \\
447.54 \\
447.90\end{array}$ \\
\hline $\begin{array}{l}38-6,12 \\
39-2,59 \\
39-3,26 \\
39-4,92 \\
39-6,57\end{array}$ & $\begin{array}{l}1 \mathrm{a} \\
1 \mathrm{j} \\
1 \mathrm{a} \\
1 \mathrm{~h} \\
1 \mathrm{~d}\end{array}$ & $\begin{array}{l}2.66 \\
2.54 \\
2.75 \\
2.87 \\
2.87\end{array}$ & $\begin{array}{l}448.12 \\
452.09 \\
453.26 \\
455.42 \\
458.07\end{array}$ \\
\hline $\begin{array}{l}40-2,25 \\
40-2,112 \\
40-3,9 \\
40-3,81 \\
40-4,95\end{array}$ & $\begin{array}{l}1 \mathrm{~b} \\
1 \mathrm{~g} \\
1 \mathrm{a}\end{array}$ & $\begin{array}{l}2.95 \\
3.01 \\
2.92 \\
2.75 \\
1.82\end{array}$ & $\begin{array}{l}461.25 \\
462.12 \\
462.59 \\
463.31 \\
464.95\end{array}$ \\
\hline $\begin{array}{l}40-4,112 \\
40-5,19 \\
40-5,(34-41) \\
40-6,72 \\
40-6,95\end{array}$ & $\begin{array}{l}1 \mathrm{v} \\
1 \mathrm{c} \\
2 \mathrm{r} \\
2 \mathrm{t}\end{array}$ & $\begin{array}{l}2.45 \\
2.44 \\
2.28 \\
2.65 \\
2.78\end{array}$ & $\begin{array}{l}465.12 \\
465.69 \\
465.90 \\
467.72 \\
467.95\end{array}$ \\
\hline $\begin{array}{l}41-4,75 \\
41-6,111 \\
41-6,139 \\
42-1,46 \\
42-1,107\end{array}$ & $\begin{array}{l}3 \mathrm{k} \\
3 \mathrm{f} \\
1 \mathrm{e} \\
1 \mathrm{j}\end{array}$ & $\begin{array}{l}2.76 \\
2.77 \\
2.82 \\
2.79 \\
2.76\end{array}$ & $\begin{array}{l}474.25 \\
477.61 \\
477.89 \\
478.96 \\
479.57\end{array}$ \\
\hline $\begin{array}{l}42-2,36 \\
42-2,127 \\
42-3,26 \\
42-4,138 \\
42-5,111\end{array}$ & $\begin{array}{l}3 \mathrm{~b} \\
6 \mathrm{~d} \\
1 \mathrm{c} \\
8 \mathrm{e} \\
1 \mathrm{~L}\end{array}$ & $\begin{array}{l}2.31 \\
2.74 \\
2.68 \\
2.60 \\
2.87\end{array}$ & $\begin{array}{l}480.36 \\
481.27 \\
481.76 \\
484.38 \\
485.61\end{array}$ \\
\hline $\begin{array}{l}43-1,8 \\
43-1,53 \\
44-1,24 \\
44-1,47 \\
44-1,85\end{array}$ & $\begin{array}{l}1 \mathrm{a} \\
2 \mathrm{a} \\
1 \mathrm{c} \\
1 \mathrm{e} \\
1 \mathrm{~L}\end{array}$ & $\begin{array}{l}2.90 \\
2.80 \\
2.84 \\
2.98 \\
2.74\end{array}$ & $\begin{array}{l}488.08 \\
488.53 \\
497.74 \\
497.97 \\
498.35\end{array}$ \\
\hline
\end{tabular}

TABLE 23 - Continued

\begin{tabular}{lccc}
\hline & Piece & $\rho$ & Sub-bottom \\
Core-Section, Interval $(\mathrm{cm})$ & Number & $\left(\mathrm{g} / \mathrm{cm}^{3}\right)$ & Depth $(\mathrm{m})$ \\
\hline
\end{tabular}

\section{Hole 433C}

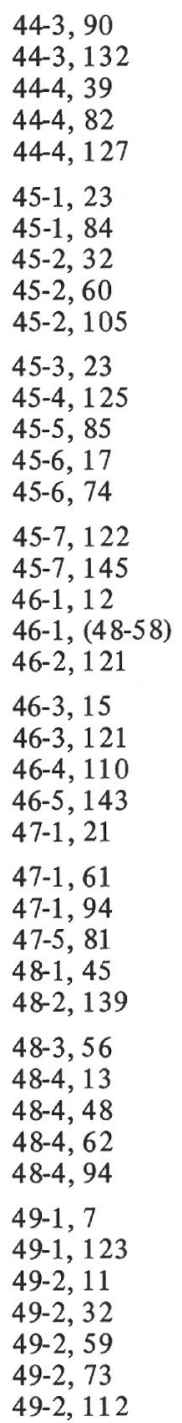

$\begin{array}{lll}6 \mathrm{f} & 2.52 & 501.40 \\ 9 \mathrm{~g} & 2.69 & 501.82 \\ 2 \mathrm{~g} & 2.79 & 502.39 \\ 2 \mathrm{k} & 2.76 & 502.82\end{array}$

$\begin{array}{lll}5 & 2.78 & 503.27\end{array}$

$1 \mathrm{~d} \quad 2.15 \quad 507.23$

$2.56 \quad 507.84$

$\begin{array}{ll}1 \mathrm{c} & 2.62 \\ 1 \mathrm{e} & 508.82\end{array}$

$1 \mathrm{e} \quad 2.86 \quad 509.10$

1i $\quad 2.75 \quad 509.55$

$\begin{array}{lll}\text { ii } & 2.75 & 509.55 \\ 1 \mathrm{~d} & 2.15 & 510.23\end{array}$

$\begin{array}{lll}1 \mathrm{k} & 2.89 & 512.75\end{array}$

lh $\quad 2.90 \quad 513.85$

513.85
514.67

514.67
515.24

517.22

517.45

516.62

(517.03)

519.21

519.65

520.71

522.10

523.93

526.21

526.61

526.94

$\begin{array}{lll}6 \mathrm{a} & 2.93 & 532.81 \\ & 2.91 & 535.95\end{array}$

538.39

539.06

540.13

540.48

540.62

540.94

545.07

546.23

546.61

546.82

548.59

548.73

549.12

contact between overlying, gently southerly-dipping beds and underlying, synclinally folded strata.

A relatively thick, acoustically semitransparent zone (Zone D) containing many weak, discontinuous reflectors occurs between 0.024 and $0.037 \mathrm{~s}$. The basal reflector (reflector 3 ) of this zone is the strongest and most continuous reflector in the $3.5-\mathrm{kHz}$ profile at Site 433 . Beneath reflector 3, from 0.037 to $0.041 \mathrm{~s}$, another thin, acoustically transparent zone (Zone E) occurs; and beneath this, a zone (Zone F) of three strong, continuous reflectors, equally spaced, occurs between 0.041 and $0.045 \mathrm{~s}$. An acoustically semitransparent zone (Zone G), 0.045 to $0.059 \mathrm{~s}$, contains a few, weak, discontinuous reflectors. Finally, the base of the sedimentary pile observed in the $3.5-\mathrm{kHz}$ profile consists of two to three 


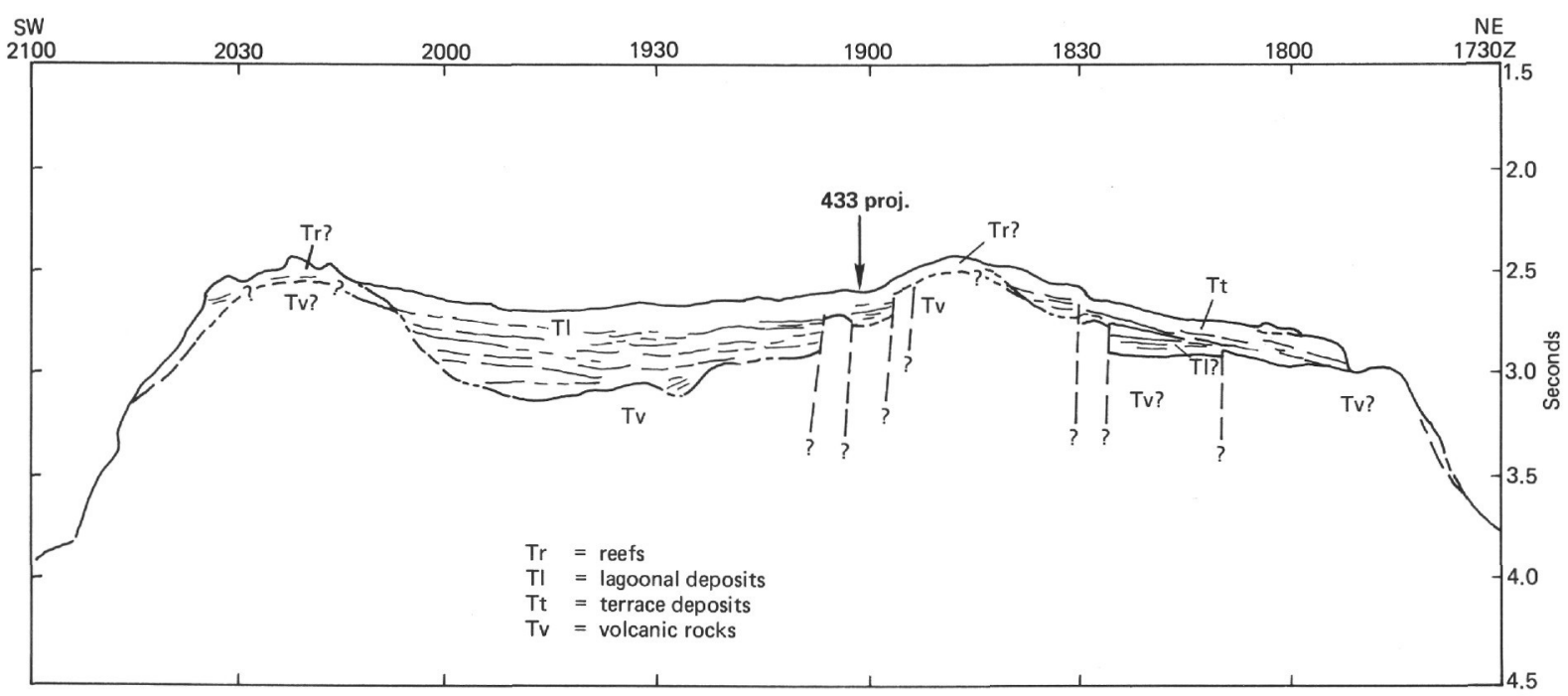

Figure 34. Line drawing of Kana Keoki seismic reflection profile across Suiko Seamount, showing the lagoonal complex drilled at Site 433.

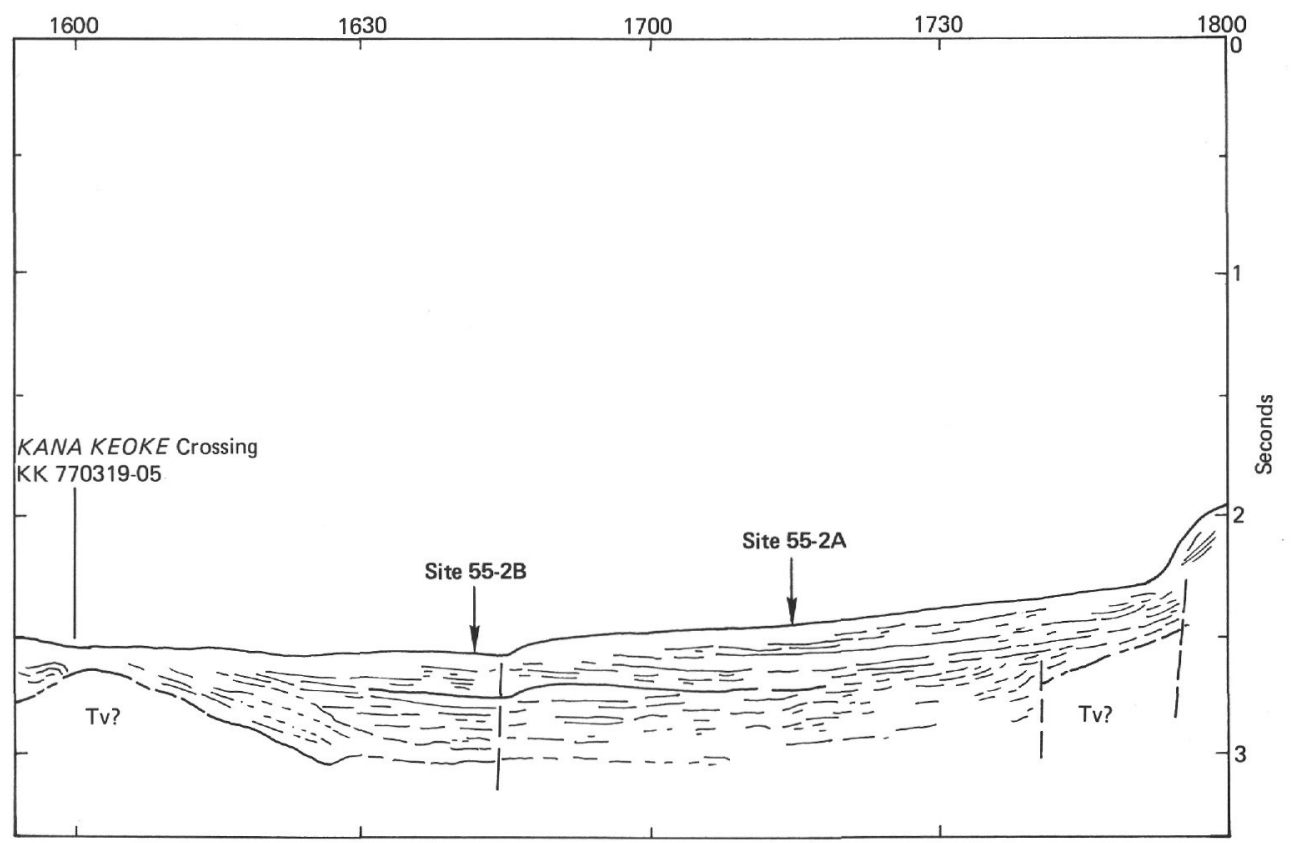

Figure 35. Line drawing of the northern part of S.P. Lee seismic reflection profile across Suiko Seamount, showing the lagoonal complex drilled at Site 433.

very strong, continuous reflectors (reflector 4) which range from 0.059 to $0.061 \mathrm{~s}$ and locally represent the surface of the acoustic basement for the $3.5-\mathrm{kHz}$ system.

Using sonic velocities from cores of Hole 433A (see Physical Properties section), we correlated these reflectors with the lithology of the hole (Figure 38). The depths and thicknesses of the various acoustic zones identified in the $3.5-\mathrm{kHz}$ and seismic reflection profiles are given in Tables 24 and 25. A relationship also exists between the defined acoustic zones and the drilling rate. Generally, the drilling rate decreases at every depth interval in which a strong, continuous reflector is identified in the seismic record. Therefore, the point of intersection of the drill bit with an acoustic zone can be determined by the decrease or increase of the drilling rate (see Table 26 ). The cores generally have homogeneous lithology and texture, however, with periodic layering of more consolidated material. Evidently, the density contrast that creates a seismic reflection boundary in the pelagic sediments results from better packing or from minor differences in diagenetic boundaries, rather than from a change in grain size.

The seismic reflection profiles obtained by the Glomar Challenger across Site 433 (Figures 9 and 10) show the drilled sedimentary basin to consist of three major acoustic units. The first (Unit 1) occurs between 0 and $0.08 \mathrm{~s}$ subsurface depth, and is masked in its upper part 


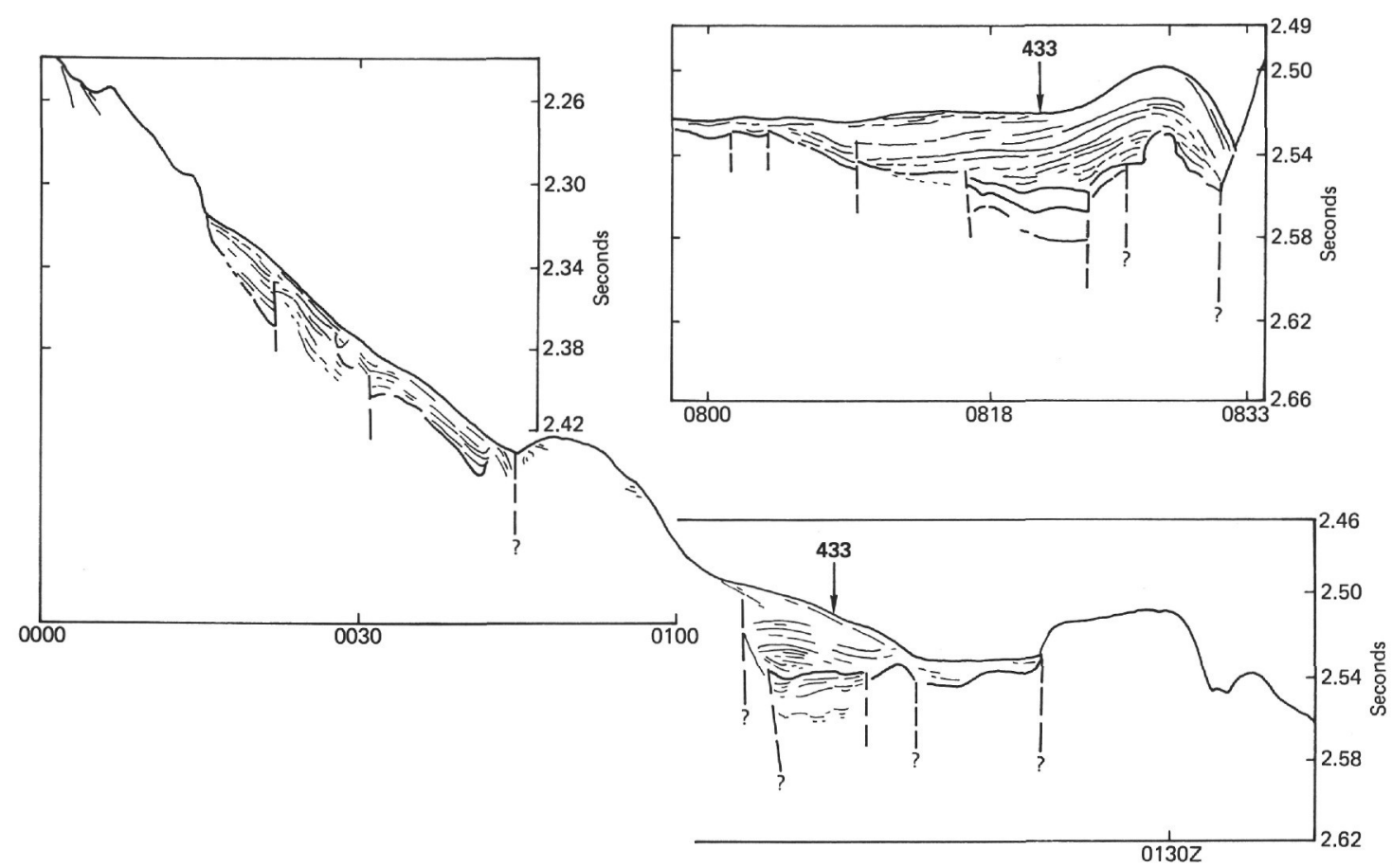

Figure 36. Line drawings of Glomar Challenger 3.5-kHz profiles across Site 433, showing the graben basin.

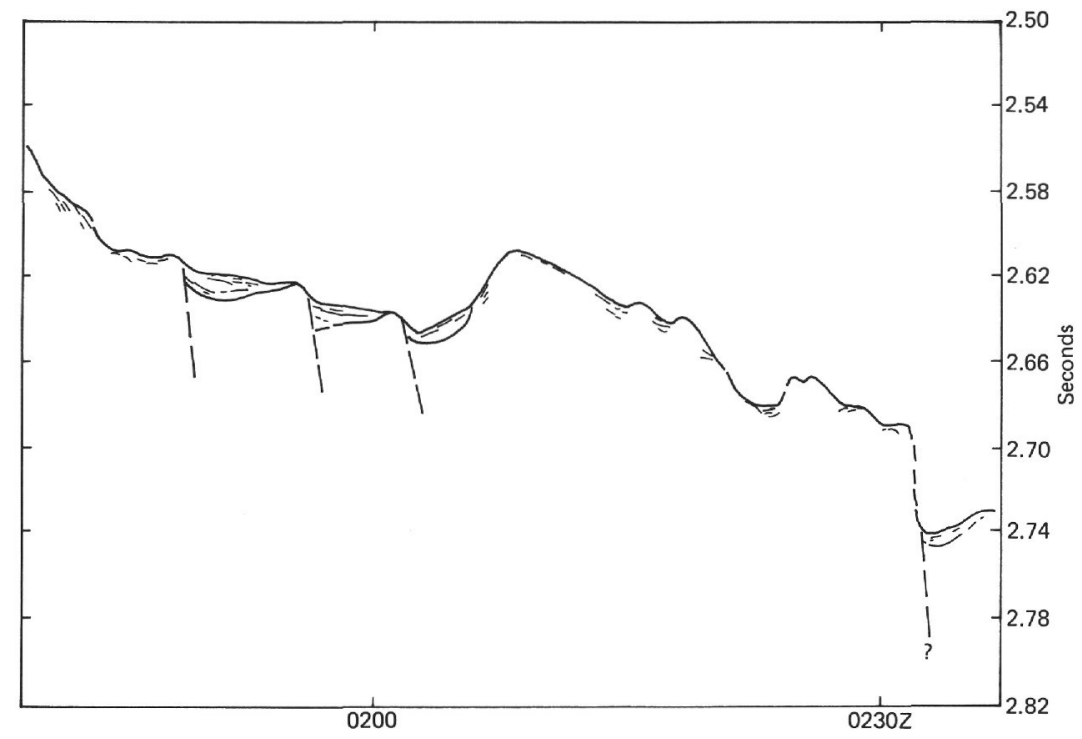

Figure 37. Line drawing of Glomar Challenger 3.5-kHz profile north of Site 433, showing faulting along the northern flank of the seamount.

by nearly $0.05 \mathrm{~s}$ of bubble pulse. This part of the seismic record is clearly defined, however, in the Challenger's $3.5-\mathrm{kHz}$ profile across the site (Figure 11). Beneath the bubble pulse, several strong, fairly continuous reflectors can be seen down to $0.08 \mathrm{~s}$ depth; they are flat-lying, except locally, where they are folded into a small, gentle syncline. Unit II consists of an acoustically semitransparent zone that extends from 0.08 to $0.18 \mathrm{~s}$ and contains few weak, discontinuous reflectors. Between 0.18 and $0.28 \mathrm{~s}$, a zone (Unit III) of very strong, continuous reflectors exists. These reflectors are rhythmically bedded, equally spaced, and suggest acoustic ringing. The upper reflector of this unit is the strongest, and may represent the surface of a relatively dense bed overlying less dense material in which the seismic signal is trapped.

All these acoustic units appear to thin and lap onto an acoustic basement buttress to the north (Figure 39). The southern flank of this buttress is terminated by a normal fault, down-dropped to the south, which truncates the reflectors of acoustic Unit C. A high-angle 

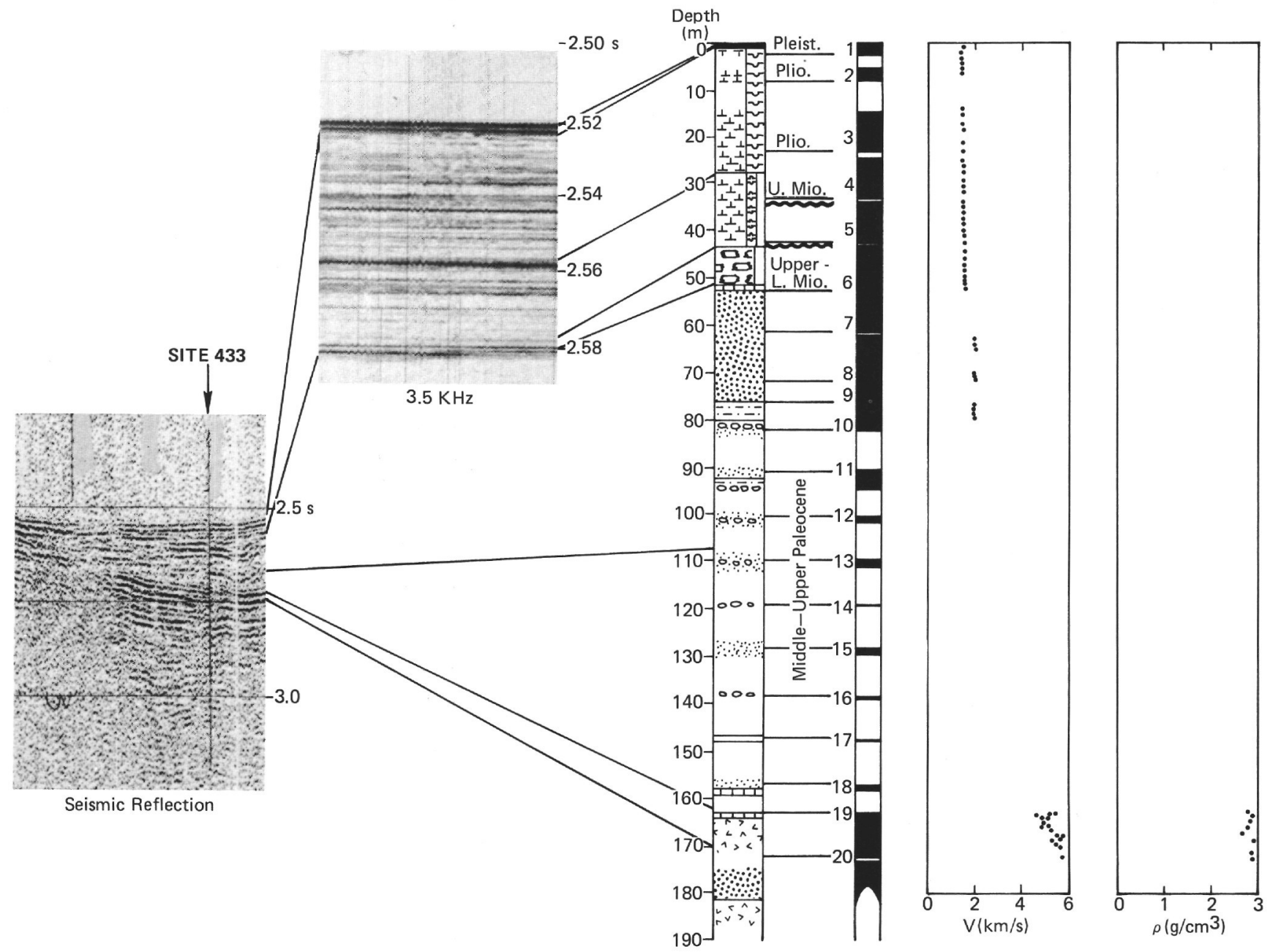

Figure 38. Correlation of seismic reflection and 3.5-kHz profiles with physical properties and lithologic column, Site 433.

reverse or thrust fault dipping to the north may have pushed the strata of acoustic Units C and B up toward the south and folded the beds of acoustic Unit A. Displacement appears to be small, however, and this fault probably has not significantly offset stratigraphy.

Figure 38 correlates the acoustic units with the lithostratigraphy established from the cores of Hole 433A. Acoustic Unit A is an unconsolidated Pliocene to Pleistocene foraminiferal-diatom-nannofossil ooze. Initial examination of the textural characteristics of the core did not indicate the presence of reflector 1 , which was observed in the $3.5-\mathrm{kHz}$ profile at a depth of 11.6 meters; but the drilling rate increased at a depth of about 10 meters. One would not expect to see all reflectors in the core, because drilling destroys consolidation of friable materials. Units B and C are Pliocene diatomnannofossil ooze. No indication of reflector 2 was evident in the cores, and the drilling rate did not chang (Table 26).

Acoustic Unit D is a diatom-nannofossil ooze that rests on reflector 3. Reflector 3 is not clearly apparent in the core, but at the general depth of 28 meters (the reflector is placed at $28.9 \mathrm{~m}$ in the profile), lithology changes from a diatom-nannofossil ooze to a marly, siliceous nannofossil ooze. The paleontologists believe an upper Miocene/lower Pliocene unconformity may possibly occur at this depth, and the drillers reported a decrease in the drilling rate at a subsurface depth of 30 meters (Table 26). Upper Miocene marly siliceous nannofossil ooze evidently makes up acoustic Units E and F. Acoustic Unit G consists of a pelagic calcareous ooze that rests on chalk, siliceous ooze, and volcanic fine sand layers. The drilling rate slowed slightly between depths of 41 and 43 meters (Table 26), within Unit G, but in the $3.5-\mathrm{kHz}$ profile only a few weak, discontinuous reflectors hint of any change in consolidation. At about 43 meters, a middle Miocene hiatus occurs (see Biostratigraphy chapter, this volume), and the core lithology changes from a marly siliceous nannofossil ooze to a calcareous ooze.

Reflector 4 appears at depths of 45.7 to 47.3 meters in the $3.5-\mathrm{kHz}$ profile, and probably represents the surface of the lower Miocene chalk layer which occurs at a depth of about 49 meters in the core. The drilling rate 
TABLE 24

Subsurface Depth Ranges for Acoustic Zones and Major Reflectors, Site 433

\begin{tabular}{|c|c|c|}
\hline Acoustic Zone & $\begin{array}{l}\text { Subsurface Depth Range } \\
\text { (two-way travel time } \\
\text { in seconds) }\end{array}$ & $\begin{array}{c}\text { Subsurface Depth } \\
\text { Range } \\
(\mathrm{m})\end{array}$ \\
\hline A & $0-0.015$ & $0-11.6$ \\
\hline B & $0.015-0.019$ & $11.6-14.7$ \\
\hline $\mathrm{C}$ & $0.019-0.024$ & $14.7-18.6$ \\
\hline D & $0.024-0.037$ & $18.6-28.7$ \\
\hline E & $0.037-0.041$ & $28.7-31.8$ \\
\hline F & $0.041-0.045$ & $31.8-34.9$ \\
\hline G & $0.045-0.059$ & $34.9-45.7$ \\
\hline Major Reflectors & $\begin{array}{l}\text { Subsurface Depth } \\
\text { (s) }\end{array}$ & $\begin{array}{c}\text { Subsurface Depth } \\
(\mathrm{m})\end{array}$ \\
\hline 1 & 0.015 & 11.6 \\
\hline 2 (discontinuity) & 0.024 & 18.6 \\
\hline 3 & 0.037 & 28.7 \\
\hline $\begin{array}{l}4 \text { (acoustic base- } \\
\text { ment surface) }\end{array}$ & $0.059-0.061$ & $45.7-47.3$ \\
\hline
\end{tabular}

${ }^{\mathrm{a}}$ Depth in meters calculated using an average velocity of 1.55 $\mathrm{km} / \mathrm{s}$, as determined from the sonic velocity measurements (see Physical Properties Chapter, this volume).

TABLE 25

Subsurface Depth Ranges for Acoustic Units, Site 433

\begin{tabular}{ccc}
\hline Acoustic Unit & $\begin{array}{c}\text { Subsurface Depth Range } \\
\text { (two-way travel time } \\
\text { in seconds) }\end{array}$ & $\begin{array}{c}\text { Subsurface Depth } \\
\text { Rangea } \\
\text { (m) }\end{array}$ \\
\hline I & $0-0.08$ & $0-62.0$ \\
II & $0.08-0.18$ & $62.0-150.3$ \\
III & $0.18-0.28$ & $150.3-420.0$ \\
$\begin{array}{l}\text { Major Reflector } \\
\text { (in Unit II) }\end{array}$ & 0.13 & 109.0 \\
\hline
\end{tabular}

${ }^{\mathrm{a}}$ Depth in meters calculated using an average velocity of $1.55 \mathrm{~km} / \mathrm{s}$ for Unit I, $1.78 \mathrm{~km} / \mathrm{s}$ for Unit II, and $5.7 \mathrm{~km} / \mathrm{s}$ for Unit III; mean velocity used in calculating depths at the base of Unit II and the top of Unit III is $1.67 \mathrm{~km} / \mathrm{s}$. These velocities are based on sonic velocity measurements from cores within the acoustic units (see Physical Properties Chapter, this volume).

TABLE 26

Comparison of Major Reflector Depths Defined in Challenger Profiles with Depths of Changes in Drilling Rate

\begin{tabular}{cc}
\hline $\begin{array}{c}\text { Depth to } \\
\begin{array}{c}\text { Major Reflectora } \\
(\mathrm{m})\end{array}\end{array}$ & $\begin{array}{c}\text { Depth at Which } \\
\text { Drilling Rate Decreased } \\
(\mathrm{m})\end{array}$ \\
\hline 11.6 & 9 \\
18.6 & 30 \\
28.7 & 41 \\
& 42 \\
& 43 \\
45.7 & 46 \\
47.3 & 49 \\
& 68 \\
\hline
\end{tabular}

${ }^{\mathrm{a}}$ See Table 24.

$\mathrm{b}$ Obtained from driller's geolograph. Depth at which rate of drilling decreased for a short duration,

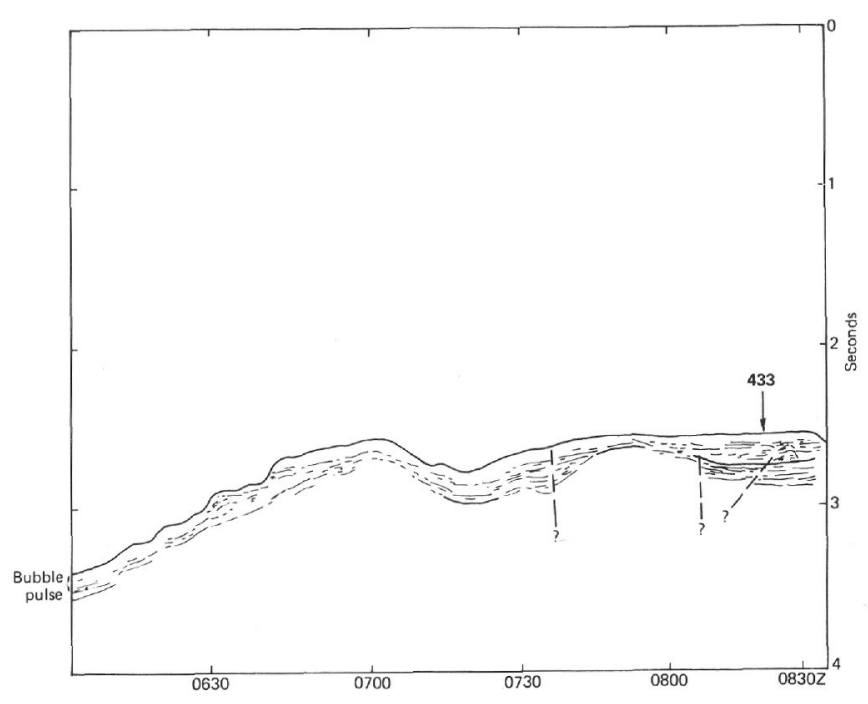

Figure 39. Line drawing of Glomar Challenger seismic reflection profile across Site 433, showing the nature of lagoonal sediments drilled.

decreased at 46 meters and again at 49 meters; this suggests that the bit encountered harder, more consolidated strata. The $3.5-\mathrm{kHz}$ signal did not penetrate a siliceous ooze and volcanic sand layer beneath this surface, but the surface is shown on the profile as several strong reflectors, and on the seismic reflection profiles as the first strong, continuous reflector (and also the first folded reflector) beneath the bubble pulse (Figure 10).

All the above acoustic units defined in the $3.5-\mathrm{kHz}$ profile make up the upper part of acoustic Unit I in the seismic reflection profiles. The lower part of Unit I is evidently composed of reef sand ranging from middle Paleocene to upper Paleocene. The base of acoustic Unit $I$ is at 52 meters, where a large Oligocene to Eocene hiatus occurs (see Biostratigraphy section). But since the paleontologic age determinations of all cores involved core-catcher samples only, the depth to any age boundary may vary from 0 to 9.5 meters. Also, velocities used in depth calculations are probably lower than in-situ velocities because of the disturbance, mixing, and destruction of consolidation by drilling. Differences between acoustic and cored boundaries could thus differ by as much as 10 meters. We suggest that Unit I unconformably overlies the chalk and volcanic sand layers marking the boundary between the overlying pelagic sediments and the underlying shallow-water reef sands.

Acoustic Unit II consists of middle to upper Paleocene reef sands and calcareous sandy mud with algal concretions. It rests at 157 meters $(150.3 \mathrm{~m}$ seismic depth) on a thin layer of well-lithified calcarenite. Only one strong, discontinuous reflector exists in Unit II - at a depth of 109 meters; it may represent a zone of high concentrations of algal concretions in the core.

Acoustic Unit III consists of interlayered basaltic lava flows and reef sands. At least two sand layers near the top of the unit appear to be interlayered with thin flows about 10 meters thick (see Operations section). Acoustic ringing and high attenuation of the seismic 
energy prevented us from distinguishing alteration zones and soil horizons that may be present between shallowly buried thin flows at deeper levels in the basaltic basement.

\section{Discussion}

On the basis of this correlation of the seismic reflection data with lithostratigraphy, we suggest a Tertiary tectonic and sedimentologic history for Suiko Seamount. Biostratigraphic data for Site 433 indicate that Suiko developed about 60 m.y. ago. Perhaps by early Paleocene time, several volcanic highs had been constructed and a well-developed northeast-trending rift lay near a structural basin developed by faulted, downdropped blocks. The island was beginning to sink, and the graben basin in which the Site $\mathbf{4 3 3}$ holes were drilled had been inundated by the sea. North of this basin a large lagoon was becoming increasingly isolated from the open ocean as fringing reefs and reef flats continued to widen. Fringing reefs grew along the nearby fault scarps of the rift and supplied coarse reef detritus to the graben basin. This debris was continually washed by waves in a shoreline environment, and was mixed with the volcanic detritus contemporaneously being eroded from the island.

Volcanism was probably still active during the early Paleocene, and several lava flows advanced across and buried beach deposits. Beach sands developed over the older flows, only to be covered later by further flows. The invasion of these flows across the shoreline of the lagoon probably ended during early Paleocene time, and the area experienced a long episode of shallowwater reef sedimentation.

Throughout the middle to late Paleocene, the reefs continued to grow, and kept pace with the subsidence that was by now well underway. The protective fringes of reefs essentially at sea level around the island produced a quiet-water environment for the lagoon and its marginal graben basin, where reef muds were deposited and algal mounds flourished. The island of Suiko submerged to become an atoll with the development of a table reef or reef flat on the central platform. The outer fringing reefs and lagoons, including the graben basin, were probably drowned at this time.

During the Eocene and Oligocene, sedimentation ceased, or all record of deposition was eroded. The reefed island could have emerged above sea level and been partially eroded, or it could have submerged deep enough to remove the seamount from clastic sediment sources and deep enough for currents to prevent accumulation of pelagic sediments. Continued subsidence removed the atoll from a reef environment. Deep-water pelagic sedimentation began in the early Miocene and is represented by a layer of volcanic fine sand mixed with siliceous ooze and chalk. Pelagic sedimentation of calcareous ooze continued through the early Miocene, but a middle Miocene hiatus exists at Site 433. In late Miocene time, pelagic sediments again began to rain upon the area of the lagoonal complex, and marly siliceous nannofossil oozes accumulated; these probably formed in a deeper water environment than did the calcareous oozes of the early Miocene. Accumulation of diatom-nannofossil ooze continued through PliocenePleistocene time.

The folding and growth faulting evident in the Challenger's $3.5-\mathrm{kHz}$ profile across Site 433 on Suiko Seamount indicate that tectonic activity within the graben basin continued at least through the late Pliocene. Most reef sediments have been down-dropped in the central part of the graben. The pelagic sediments are faulted only at their base, but their upper parts are folded in a manner that could only be caused by tectonic warping - not by sedimentary draping.

\section{SUMMARY AND CONCLUSIONS}

In the four holes drilled at Suiko Seamount we cored a continuous section from the surface to a depth of 550.5 meters. Sedimentary rocks were recovered between mudline and a sub-bottom depth of 163.0 meters. Below the contact of reef calcarenite with basalt, we penetrated 387.5 meters of basalt, and achieved the deepest penetration into basement to date in the Pacific basin.

Drilling of sediments on Suiko Seamount disclosed a lower Tertiary reef complex, as predicted by Green et al. (1978), although the reef developed in waters too cold for growth of reef corals. The sediments at Site $\mathbf{4 3 3}$ were divided into six lithologic units, in order of increasing age: (1) foraminiferal nannofossil ooze; (2) diatom-nannofossil ooze; (3) calcareous ooze; (4) tuffaceous sandy mud; (5) reef carbonate sand and mud; and (6) reef carbonate sand rich in volcanic material. Unit 6 occurs between the upper two basalt flows, indicating contemporaneous volcanic and reef activity. The reef detritus of Unit 5 grades from sand to a calcarenite at the base, which is in erosional contact with the basalt. A volcanic layer, Unit 4, separates the sediments laid down in warm shallow water from the overlying pelagic sediments, Units 1 through 3 . The abrupt change from shallow- to deep-water sedimentation marked the end of reef growth and the progressive subsidence of the seamount.

During deposition of lithologic Units 1 through 3 (upper part), representing Pleistocene through late Miocene time, Suiko seems to have remained in approximately the same environment. The lower part of Unit 3 contains lower Miocene pelagic fossils; this finding suggests a sedimentological hiatus or period of erosion that encompassed at least the entire middle Miocene. Upper Miocene submarine deposits are diatomaceous ooze and contain more siliceous fossils than the lower Miocene. Subsidence was not significant in terms of the CCD (carbonate compensation depth), however, so that planktonic foraminifers were preserved in the sediments. Lower Miocene microfossils of pelagic origin occur at the base of sedimentological Unit 3 and in the upper part of Unit 4. The lower part of Unit 4 and the upper part of Unit 5, however, contain Paleocene fossils.

Within the middle part of Unit 4, a major sedimentological hiatus occurs, indicating erosion through a major part of the Oligocene and the Eocene. During Paleocene time, the seamount remained at about the same level beneath the sea; subsidence, if any, was mini- 
mal. Calcarenite and reef sands of the lower part of Unit 5 were continuously deposited in a depression on the flat top of the seamount during this time. The occurrence of well-sorted sands and overlying poorly sorted sands, however, indicates that minor vertical fluctuations may have taken place (in the area) during this period. The end of the main shield-building stage of Suiko Seamount occurred in middle Paleocene time; the top of the seamount submerged to a shallow water depth, allowing well-sorted coarse-grained sands at the base of lithologic Unit 5 to accumulate. These sands contain biota of warm- and shallow-water habitat, such as benthic foraminifers, coralline algae, bryozoans, and ostracodes which also occur in Unit 6, interlayered between basalt Flow Units 1 and 2. The oldest sediments above basalt contain nannofossils and foraminifers that suggest cessation of volcanism and submergence of the volcano by the middle Paleocene.

Hole $433 \mathrm{C}$ penetrated a total of 67 positively identified (numbered) lava flows between 165.5 and 550.5 meters sub-bottom. Of these, 21 contain one or more sub-units which may be either separate lava flows or flow lobes of single lava flows. This gives a total of at least 113 possible lava flows. In addition, there is apparently well-sorted carbonate and basalt beach sand below Flow Unit 1 in Core 433C-3, and a pumice lapilli tuff interval in Core 433C-21. The basalts were subdivided into an alkalic group (Flow Units 1 through 3 ) and a tholeiitic group (Flow Units 4 through 67). Shipboard XRF analyses were performed on 62 basalt samples. Flow Unit 1 is chemically a typical Hawaiian alkalic basalt. Its major-element contents are very close to those of average Hawaiian alkalic basalt (Macdonald and Katsura, 1964; Macdonald, 1968), and it is chemically distinct only in its low contents of $\mathrm{Ba}$ and $\mathrm{Sr}$ and high contents of $\mathbf{P}$ and $\mathrm{Zr}$ (Jackson et al., 1976). Flow Unit 2 is also a typical alkalic basalt, except, again, for its very low $\mathrm{Ba}$ and $\mathrm{Sr}$ contents. Flow Unit 3 was not sampled for analysis on shipboard, but it has a trachytic texture, and subsequent analyses show that it is alkalic as well. Flow Units 4 through 67 are all tholeiitic basalts. Flow Units/Sub-units 4 a through $4 \mathrm{~h}, 19 \mathrm{a}$ to $19 \mathrm{~d}, 24,28$, and 29 are chemically and petrographically tholeiitic picrites (oceanites). The tholeiitic flows recovered from Suiko appear to represent the upper part of the tholeiitic, shield-building suite such as form the underpinnings of all subareally exposed volcanoes in the Hawaiian chain. The tholeiites at Suiko, like those of all southeastern Hawaiian volcanoes (Macdonald and Katsura, 1964, table 9), have their own chemical peculiarities, apparently including slightly lower than average $\mathrm{TiO}_{2}, \mathrm{P}_{2} \mathrm{O}_{5}$, and $\mathrm{Sr}$ values, but all fall within the range reported for Hawaiian tholeiitic basalts.

More than 300 samples of basalt from Site 433 were studied for paleomagnetism on board ship. Most have very stable remanences, and their directions do represent the ambient magnetic field when these basalts erupted and cooled. The basalts are characterized by high median demagnetizing field, and moderate to high $\mathrm{Q}_{\mathrm{n}}$ ratio. Examination under the reflection microscope shows that the ferromagnetic minerals in these rocks are fresh titanomagnetites with sharp crystal boundaries and with little trace of secondary alteration. Most titanomagnetite grains range from homogeneous and unoxidized to moderately oxidized (containing exsolution lamellae of ilmenite), but some show higher stages of oxidation (containing pseudobrookite and hematite) (Wilson and Haggarty, 1966). These results suggest that the basalts are similar in magnetic properties to those found on oceanic islands, and not similar to midoceanic ridge basalts.

With more than 60 successive lava flows, we have an adequate set of samples representing the geomagnetic field about $65 \mathrm{~m} . \mathrm{y}$. ago. In some sections, inclinations are almost identical among successive flows (e.g., Flow Units 4 to 7); at other places, inclination data define a smooth change with depth (e.g., Flow Units/Sub-units $51 \mathrm{~b}$ to 63 ), or show jumps of $20^{\circ}$ or more. They can be interpreted as representing secular variation of the geomagnetic field in which characteristic duration time varied from less than 100 years to $10^{4}$ years or more. On the other hand, all the flows recovered are reversely magnetized. Magnetic data therefore suggest that these flows erupted in a period longer than $10^{4}$ years but less than about $10^{6}$ years, which is an ideal period for averaging out secular variation. We conclude that the inclination fluctuated about a mean of $42^{\circ}$, with a standard deviation of $14^{\circ}$, about 65 m.y. ago. The mean value is accurate to within $\pm 4^{\circ}$ at the 95 per cent confidence level. Assuming this mean inclination to represent the axial dipole field of the earth, the estimated paleolatitude of Suiko Seamount is about $25^{\circ}$.

If the paleolatitude of formation of Suiko Seamount is taken as $25^{\circ} \pm 4^{\circ}$ at the 95 per cent confidence level, then the melting anomaly that formed the volcano in earliest Paleocene time lay $2^{\circ}$ to $10^{\circ}$ north of the present latitude of the present melting anomaly at Kilauea $\left(19^{\circ} \mathrm{N}\right)$. Other investigators (Molnar and Atwater, 1973) have, on other grounds, suggested small excursions of the hot spot in time. Still, when combined with data from Midway (Gromme and Vine, 1972), the Suiko data indicate that the Hawaiian-Emperor hot spot has remained fixed within five or ten degrees, and that reconstructions of the developmental history of the Pacific must take this into account.

\section{REFERENCES}

Benson, M. H., 1976. Petrology, mineralogy, and geochemistry of the East Molokai volcanic series, Hawaii, Geol. Survey Prof. Paper 961: Washington (U. S. Government Printing Office), p. 53.

Blatt, H., Middleton, G., and Murray, R., 1972. Origin of Sedimentary Rocks: New Jersey (Prentice-Hall, Inc.).

Buddington, A. F. and Lindsley, D. H., 1964. Iron-titanium oxides and synthetic equivalent, J. Petrol., v. 5, p. 310-357.

Creager, J. S., Scholl, D. W., et al., 1973. Initial Reports of the Deep Sea Drilling Project, v. 19: Washington (U.S. Government Printing Office).

Dalrymple, G. B. and Clague, D. A., 1976. Age of the Hawaiian-Emperor bend, Earth Planet. Sci. Lett., v. 31, p. 313-329.

Ginsburg, R. N., Murszalek, D. S., and Schneidermann, N., 1971. Ultra structure of carbonate cements in a Holocene 
algal reef of Bermuda, J. Sediment. Petrol., v. 41, p. 472-482.

Greene, H. G., Dalrymple, G. B., and Clague, D. A., 1978. Evidence for the northward movement of the Emperor Seamounts chain, Geology, v. 6, p. 70-74.

Gromme, S. and Vine, F. J., 1972. Paleomagnetism of Midway Atoll lavas and northward movement of the Pacific plate, Earth Planet. Sci. Lett., v. 17, p. 159-168.

Heirtzler, J. R., Dickson, G. O., Herron, E. J., Pitman, W. C., III, and Le Pichon, X., 1968. Marine magnetic anomalies, geomagnetic field reversals and motions of the ocean floor and continents, J. Geophys. Res., v. 73, p. 2119-2136.

Hubbard, N. J., 1967. Some trace elements in Hawaiian lavas, Unpublished Ph.D. thesis, University of Hawaii.

Jackson, E. D., Bargar, K. E., Fabbi, B. P., and Heropoulous, C., 1976. Petrology of the basaltic rocks drilled on Leg 33 of the Deep Sea Drilling Project. In Schlanger, S. O., Jackson, E. D., et al., Initial Reports of the Deep Sea Drilling Project, v. 33: Washington (U.S. Government Printing Office), p. 571-630.

Johnson, H. P. and Atwater, T., 1977. Magnetic study of basalts from the Mid-Atlantic Ridge, lat. 37N, Geol. Soc. Am. Bull., v. 88, p. 637-647.

Land, L. S. and Goreau, T. G., 1970. Submarine lithification of Jamaican reefs, J. Sediment. Petrol., v. 40, p. 457-462.
Larson, R. L., Moberly, R., et al., 1975. Initial Reports of the Deep Sea Drilling Project, v. 32: Washington (U.S. Government Printing Office).

Macdonald, G. A., 1968. Composition and origin of Hawaiian lavas. In Coats, R. R., Hay, L., and Anderson, C. A. (Eds.), Studies in Volcanology: Geol. Soc. Am. Mem. 116, p. 477-522.

Macdonald, G. A. and Katsura, T., 1964. Chemical composition of Hawaiian lavas, J. Petrol., v. 5, p. 82-133.

Molnar, P., and Atwater, T., 1973. Relative motion of hotspots in the mantle, Nature, v. 246, p. 288.

Ozima, M. and Larson, E. E., 1970. Low and high temperature oxidation of titanomagnetite in relation to irreversible changes in the magnetic properties of submarine basalts, $J$. Geophy. Res., v. 75, p. 1003-1017.

Readman, P. W. and O'Reilley, W. O., 1972. Magnetic properties of oxidized (cation-deficient) titanomagnetite (Fe, Ti, ) ${ }_{3} \mathrm{O}_{4}$, J. Geomag. Geoelectr., v. 24, p. 69-90.

Schilling, J. G., 1966. Rare earth fractionation in Hawaiian volcanic rocks, Unpublished Ph.D. thesis, Massachusetts Institute of Technology.

Wilson, R. L. and Haggarty, S. E., 1966. Reversals of the earth's magnetic field, Endeavour, v. 25, p. 104-109. 


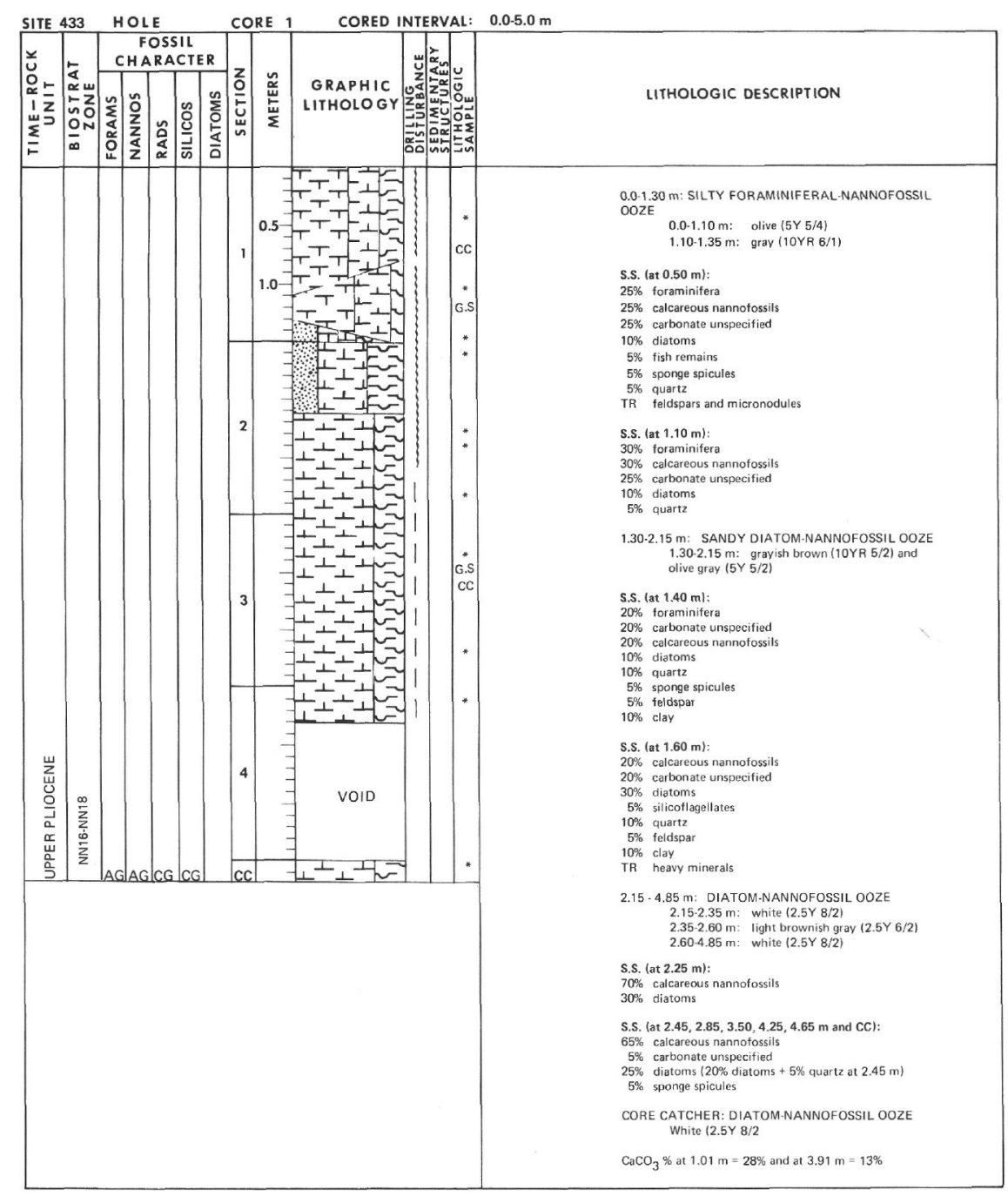




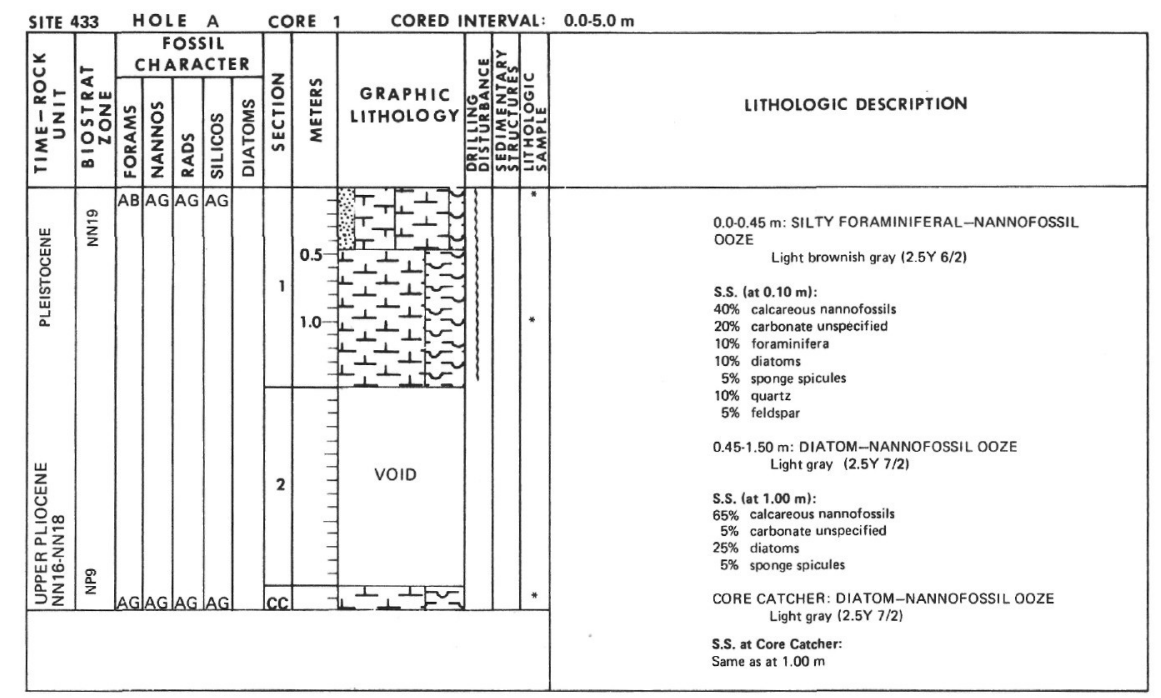

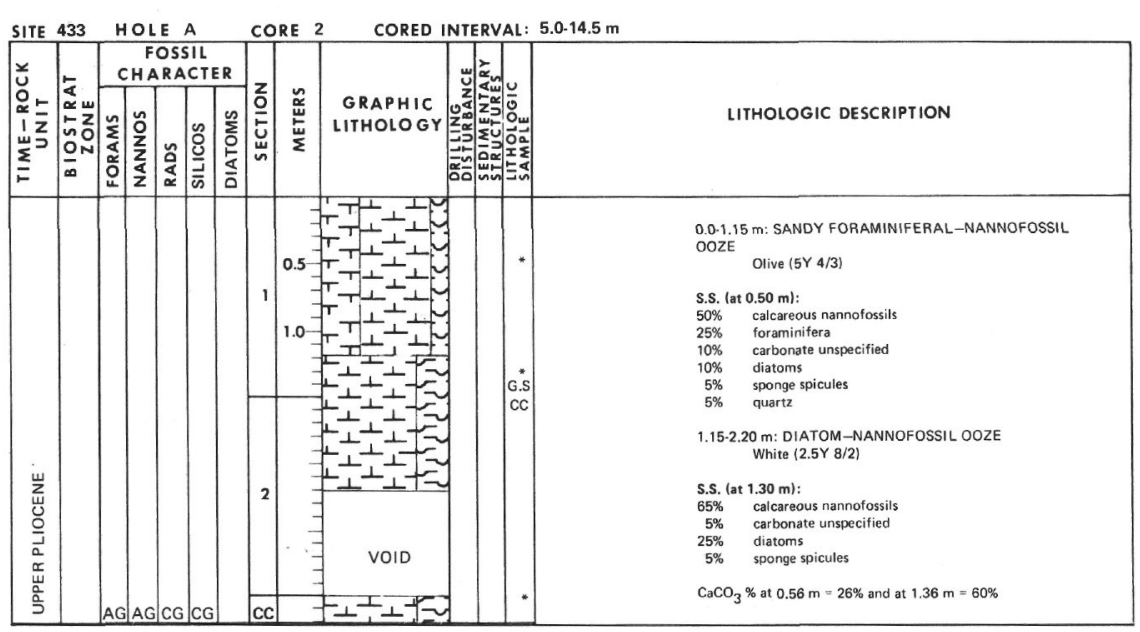

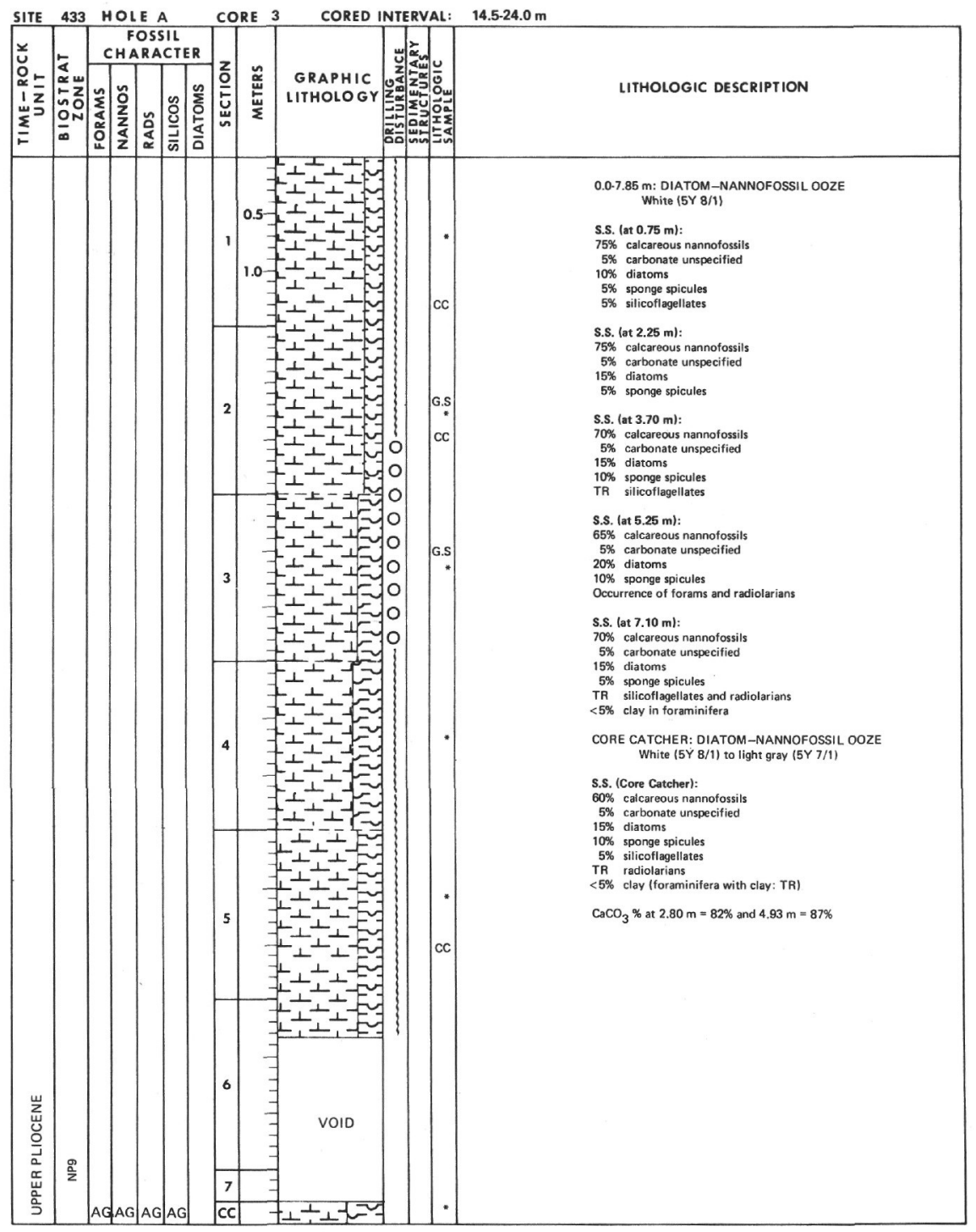



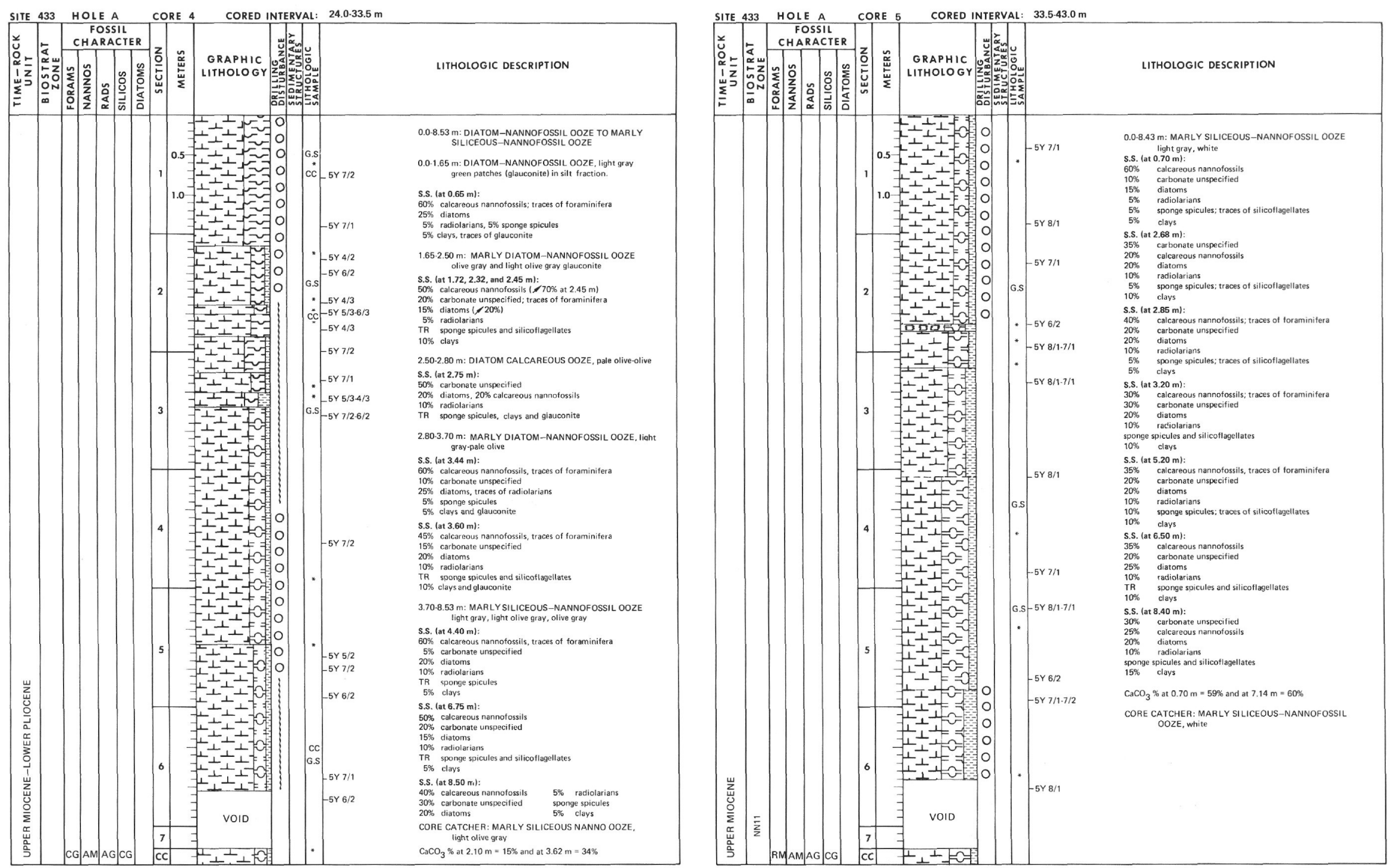


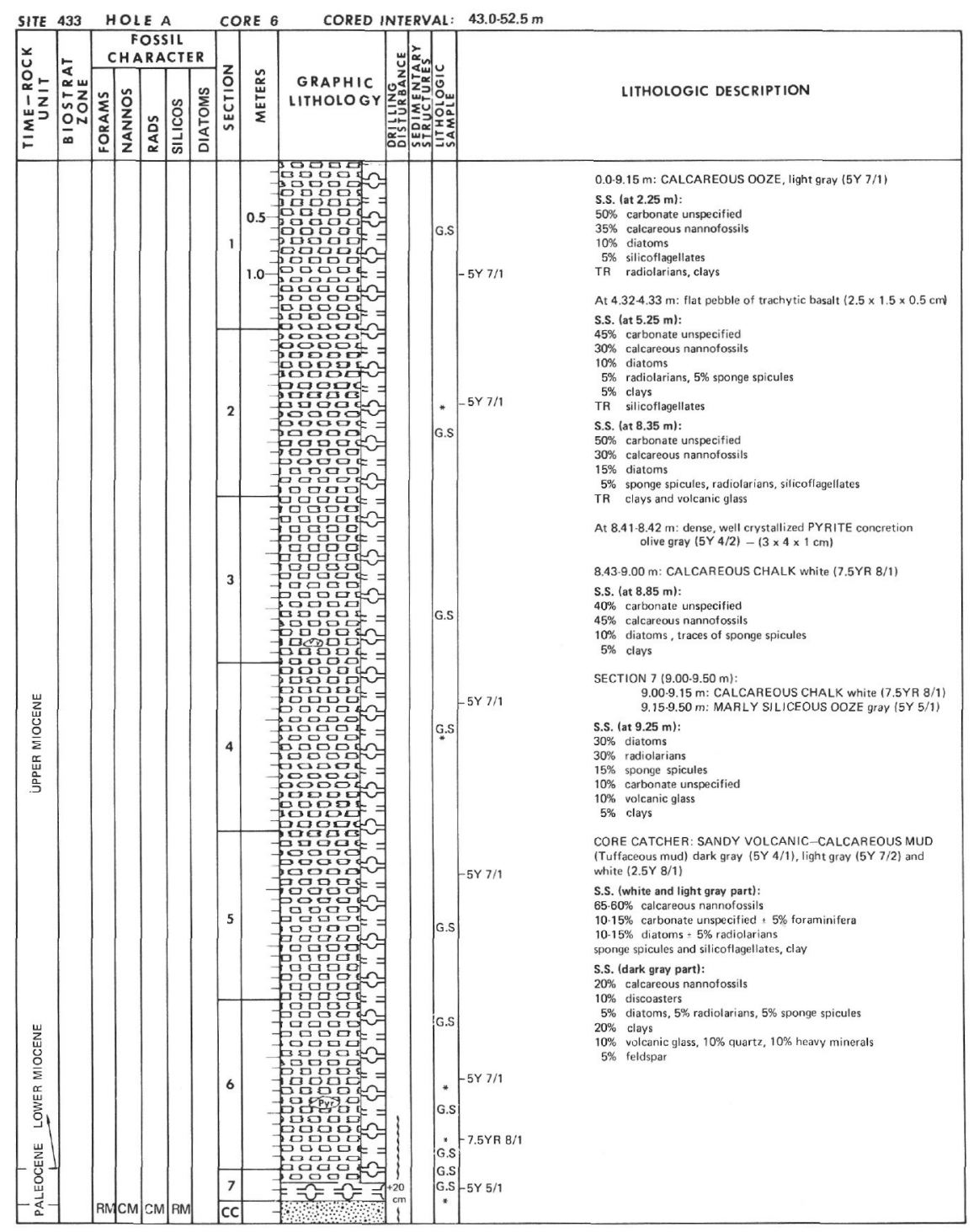

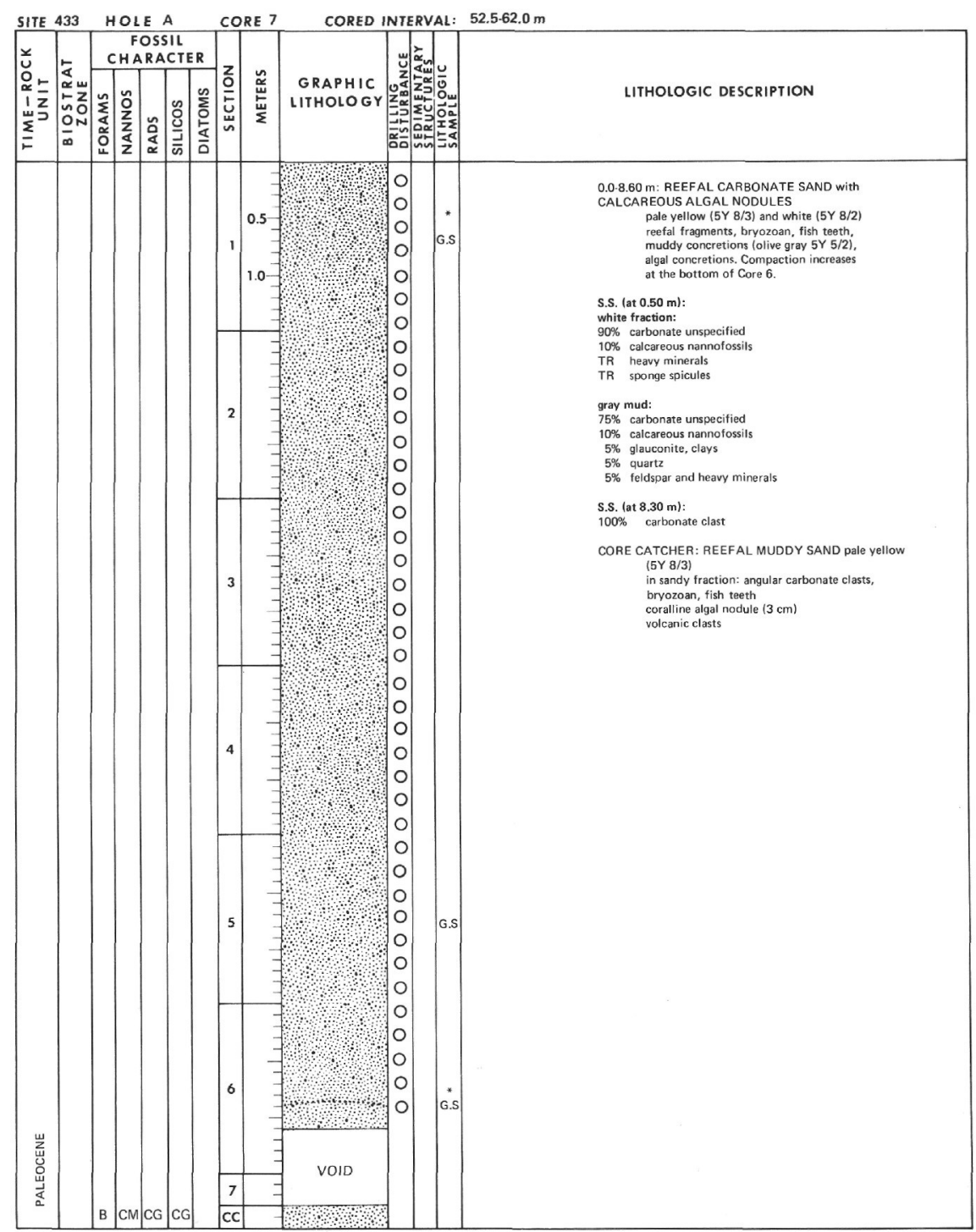



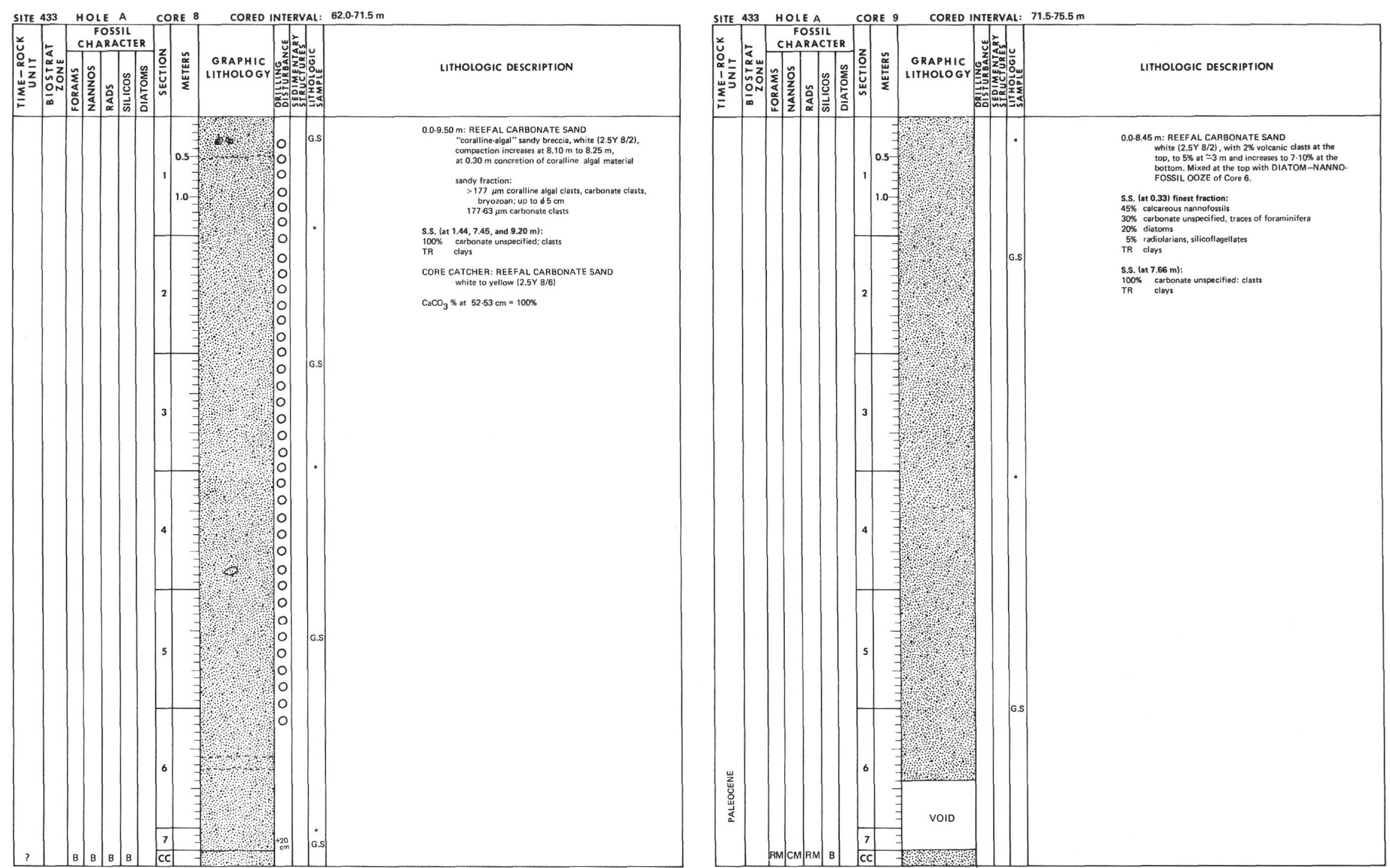


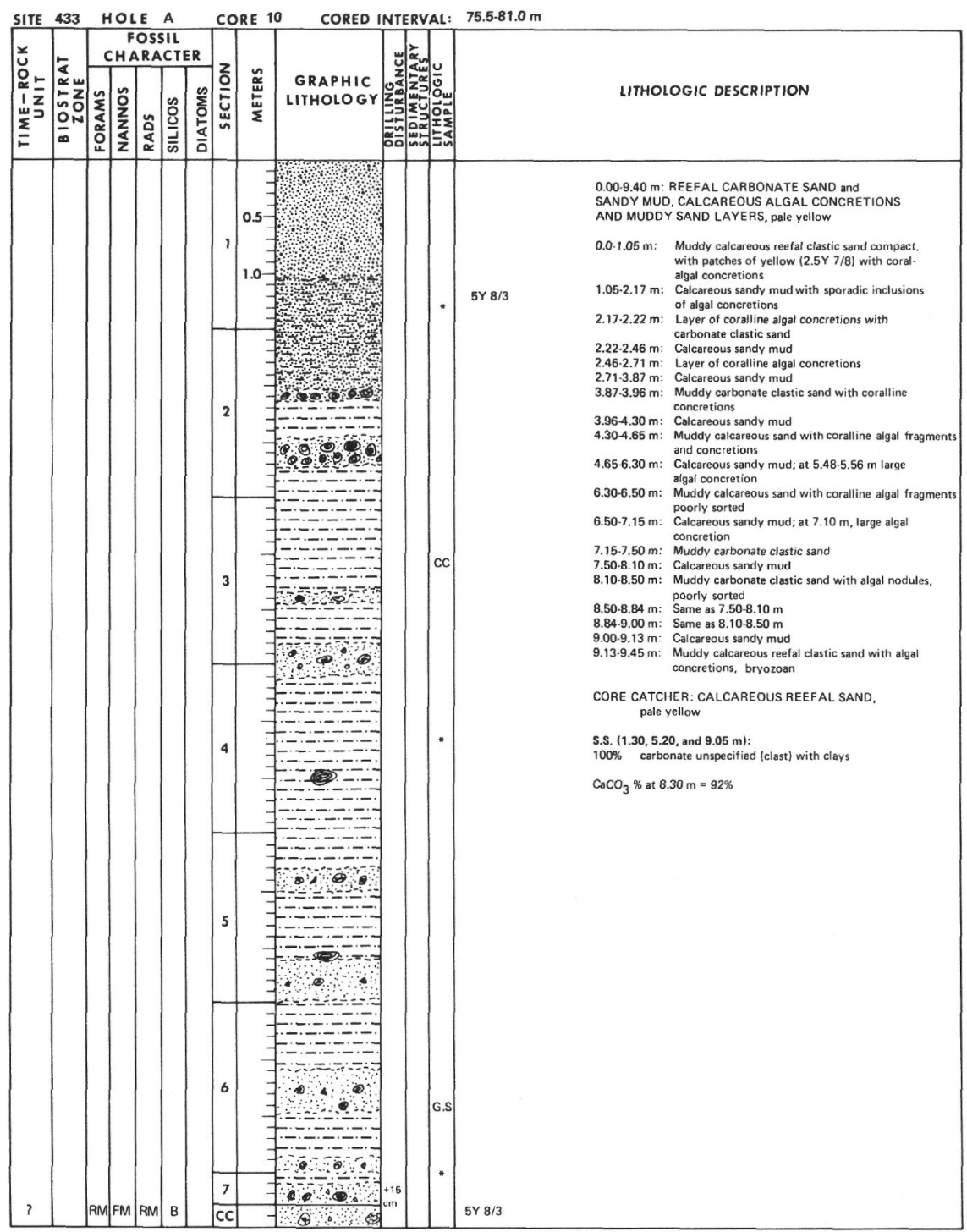

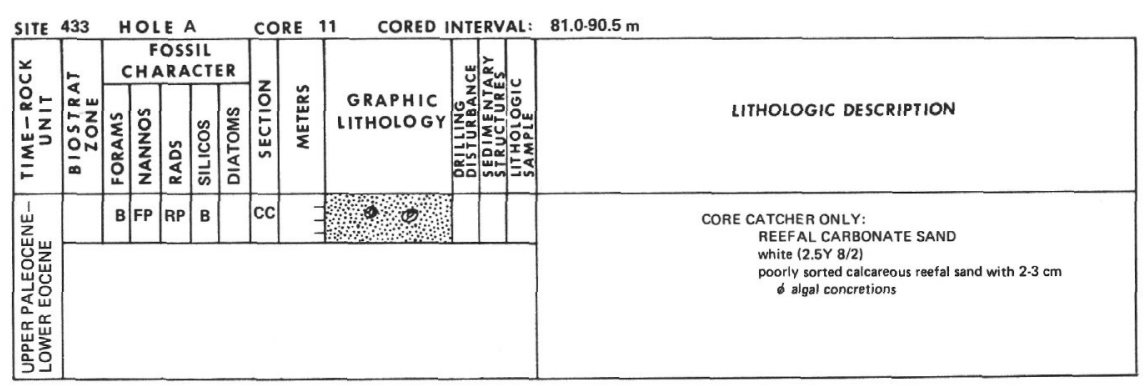

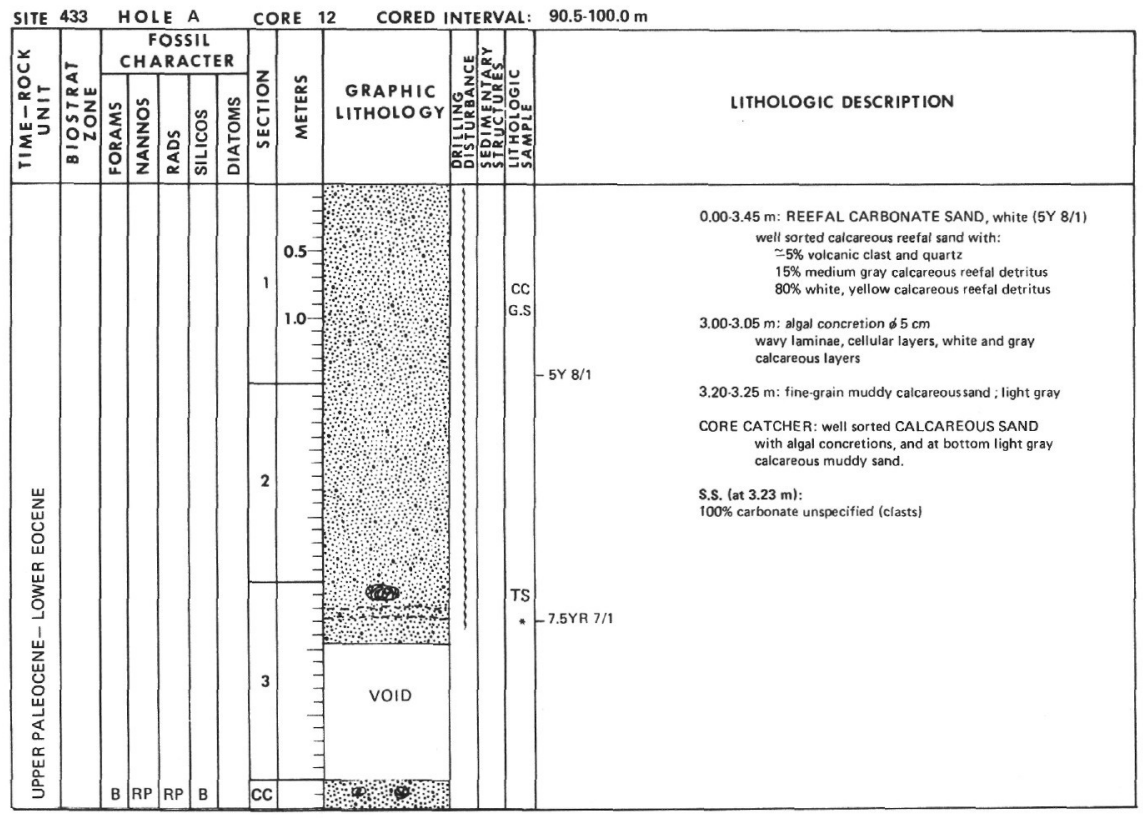

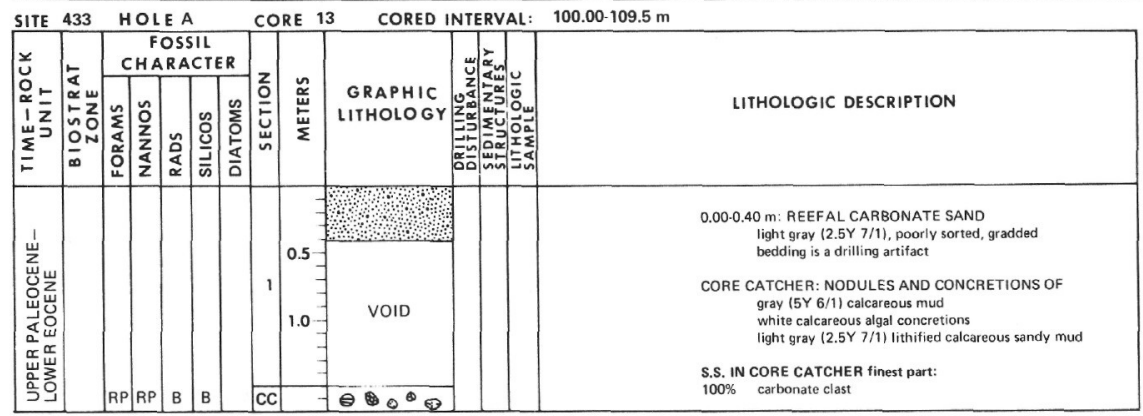




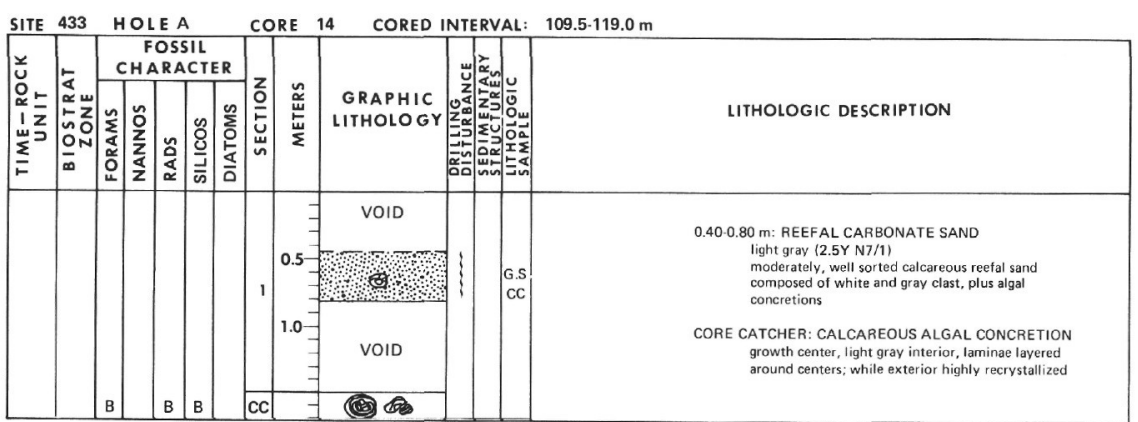
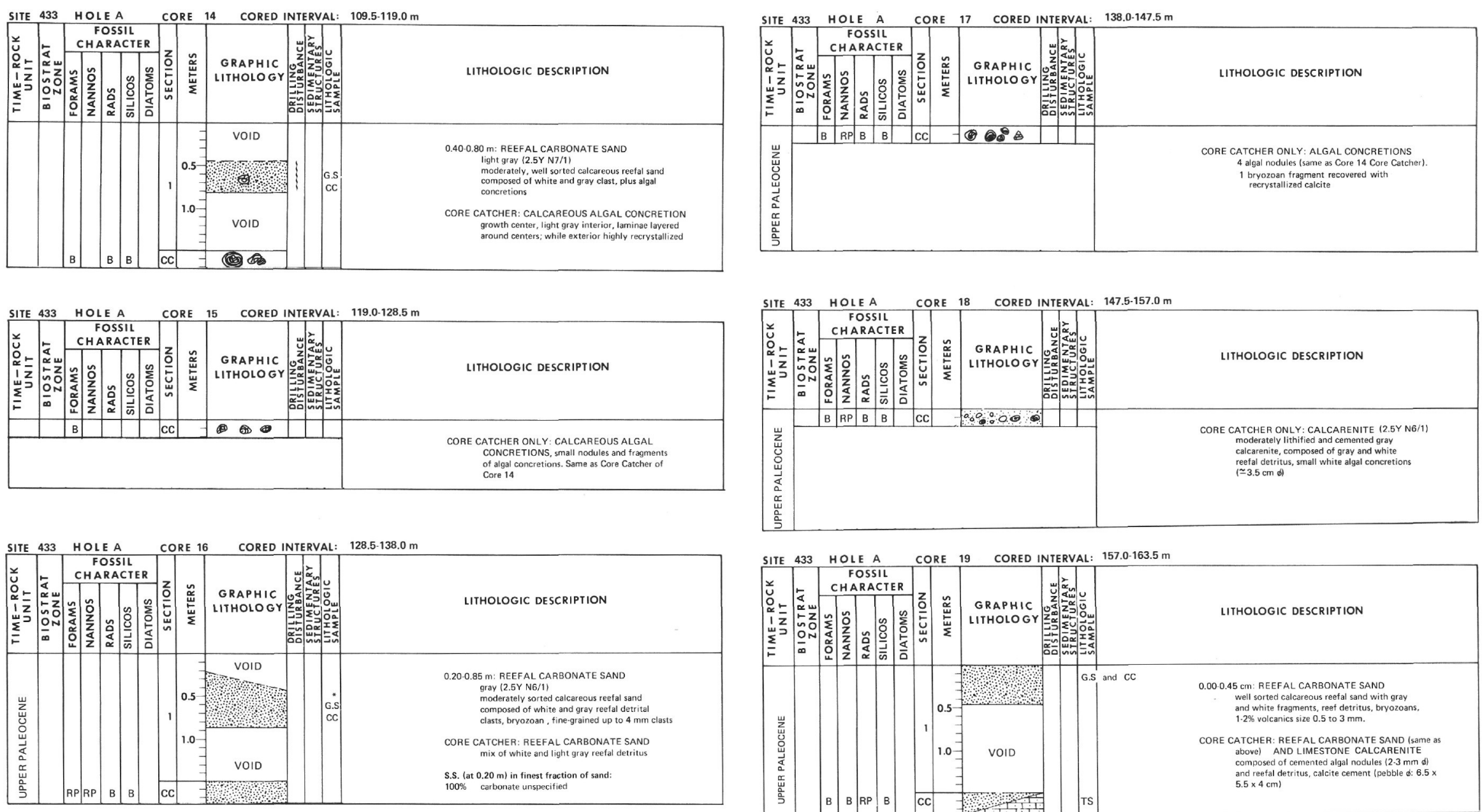

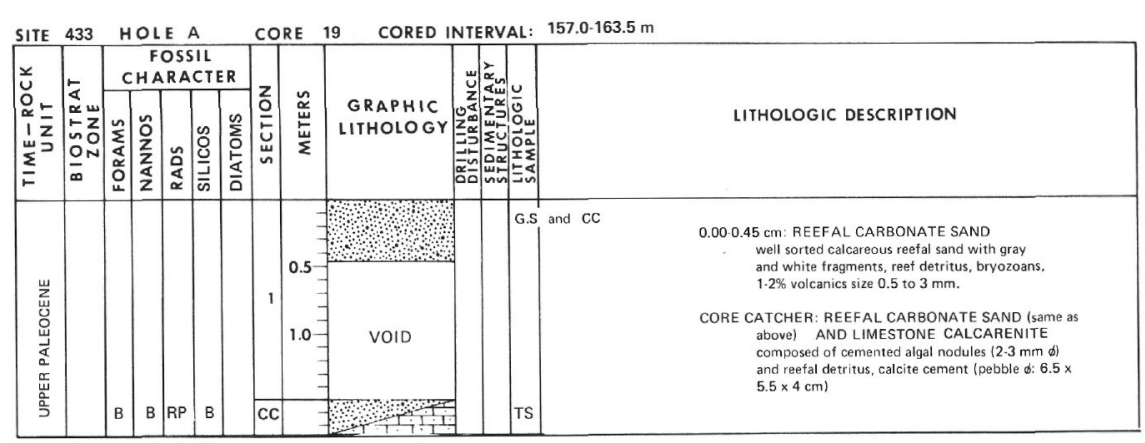




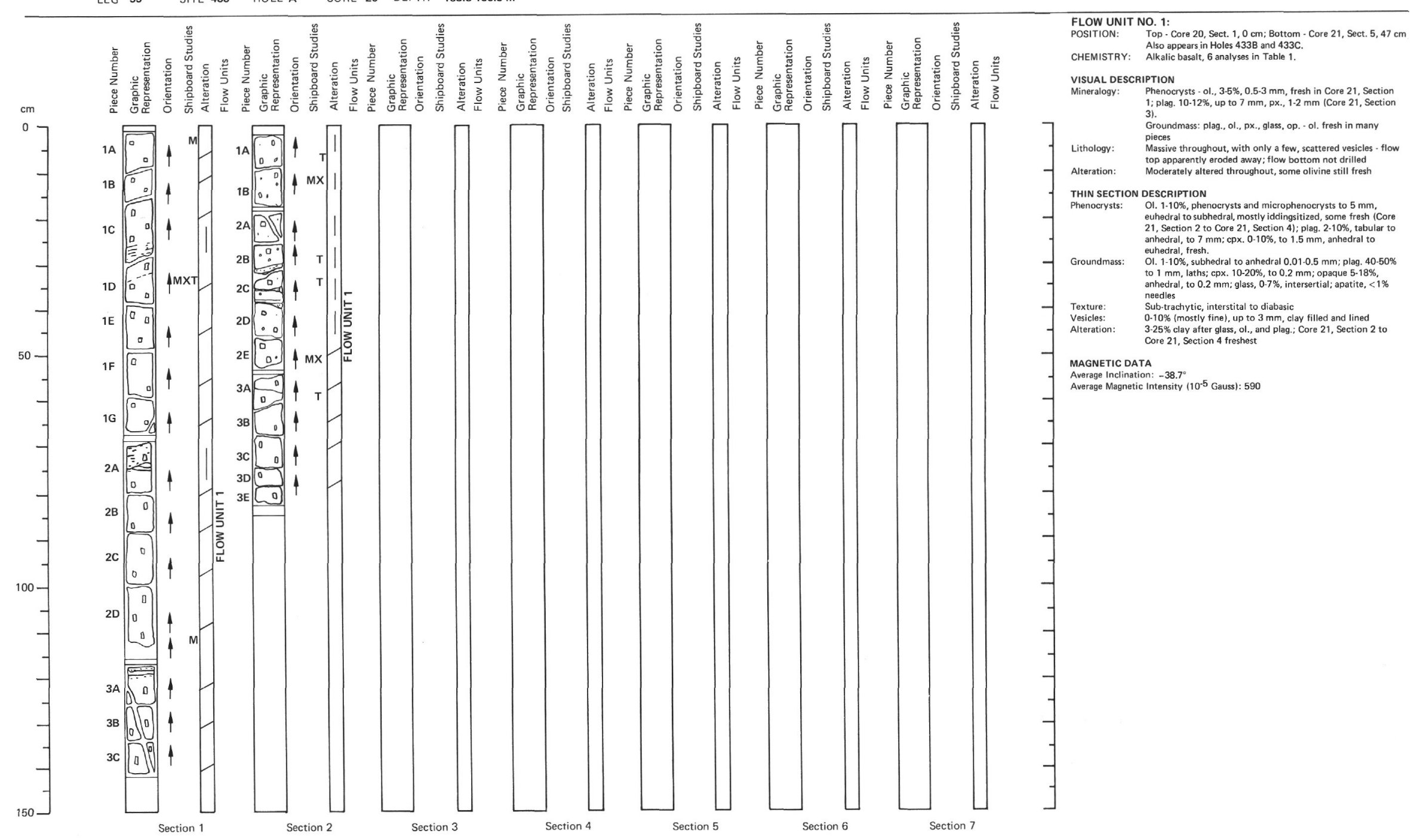


LEG 55 SITE 433 HOLE A CORE 21 DEPTH 166.5-174.0 m

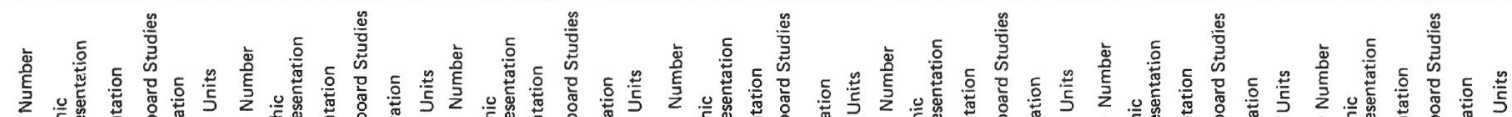

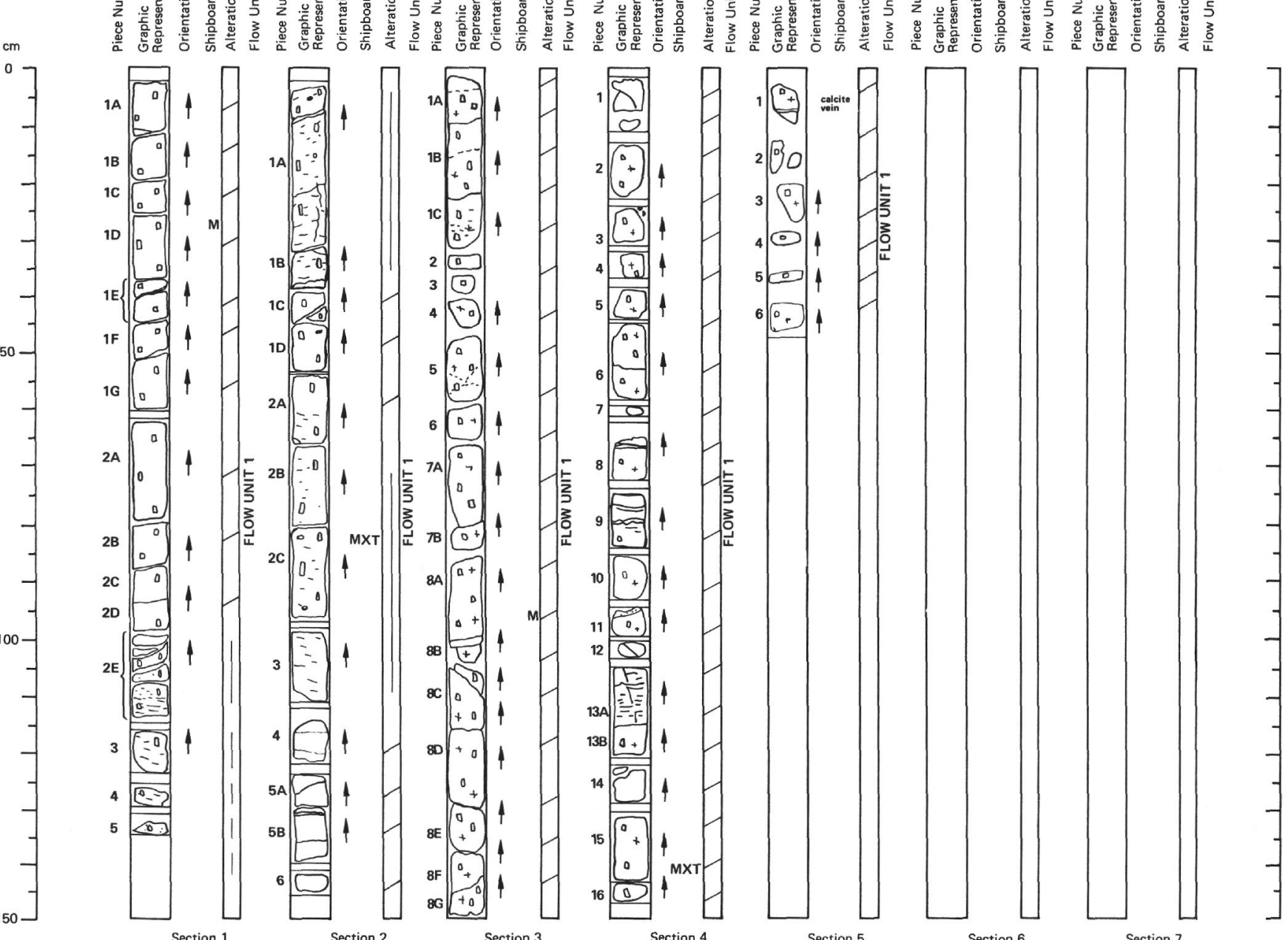




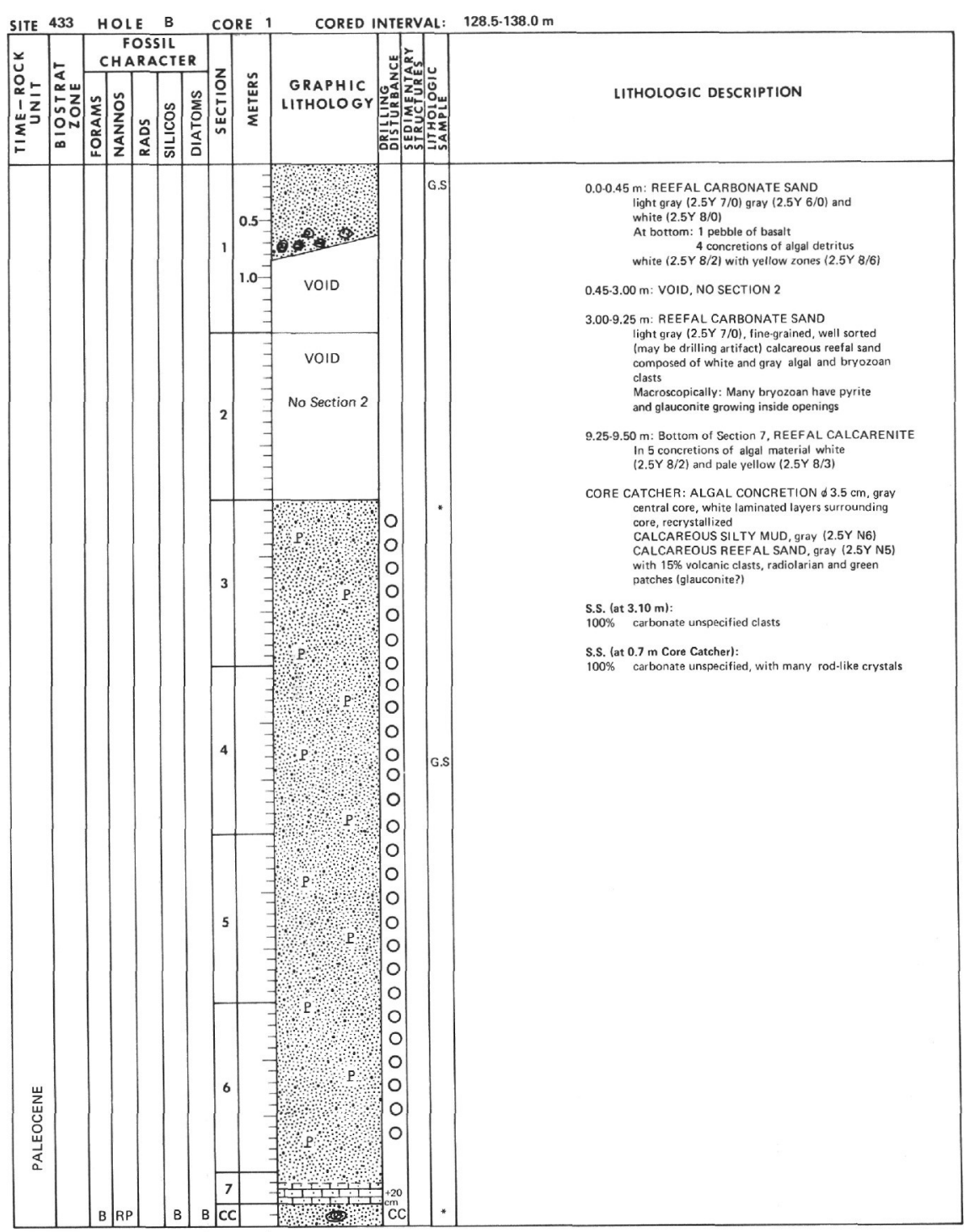

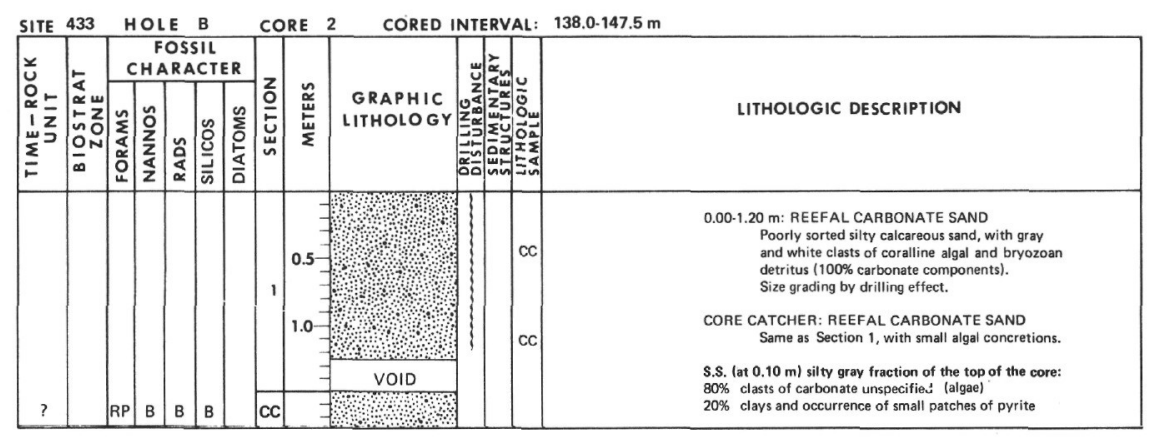

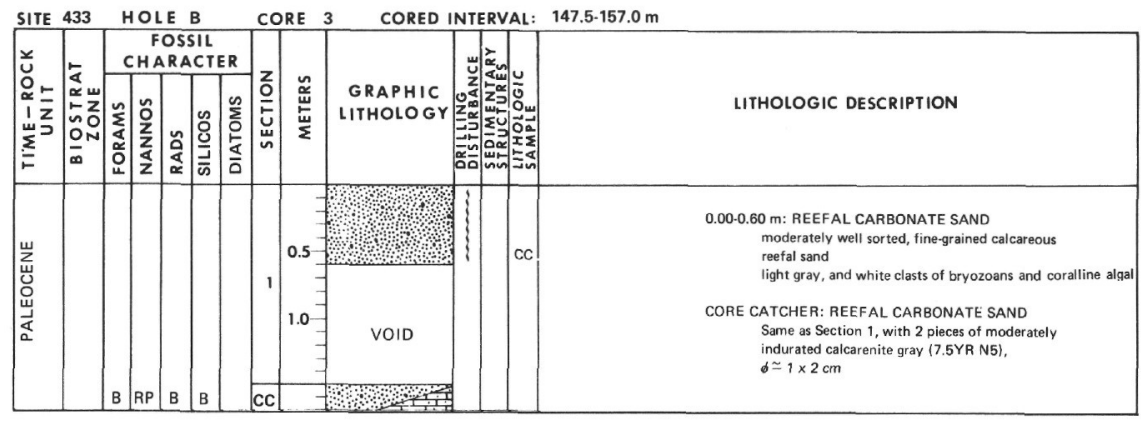

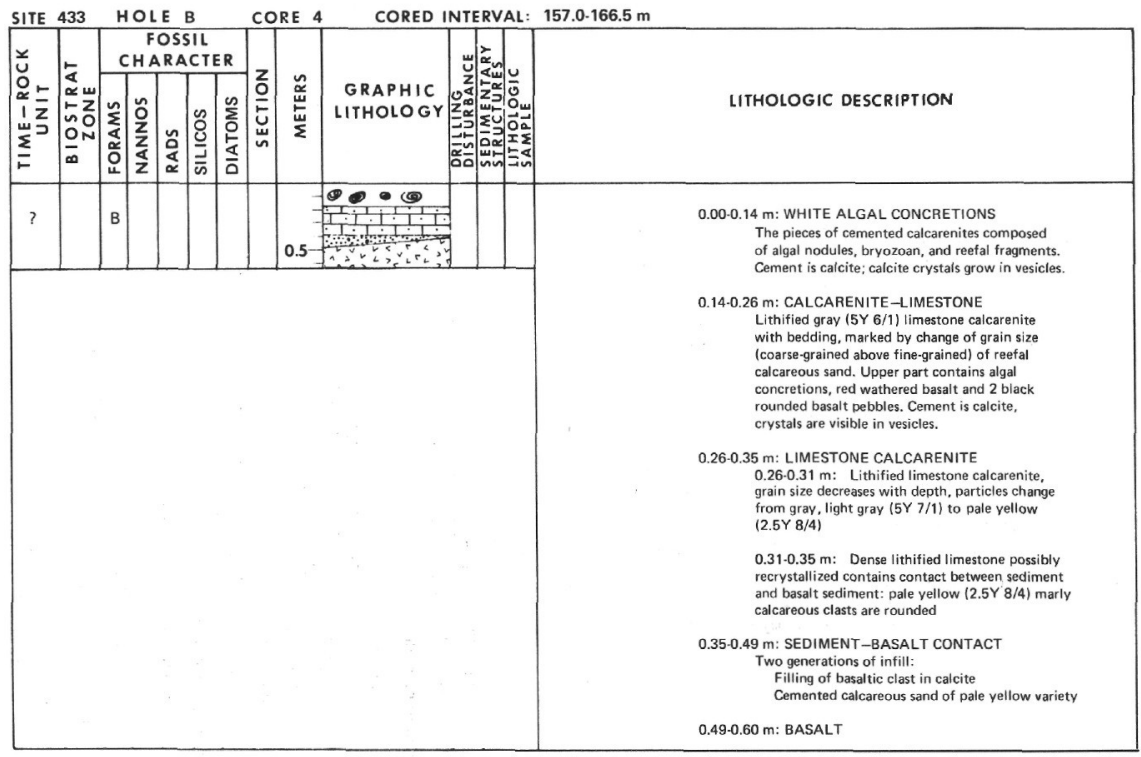




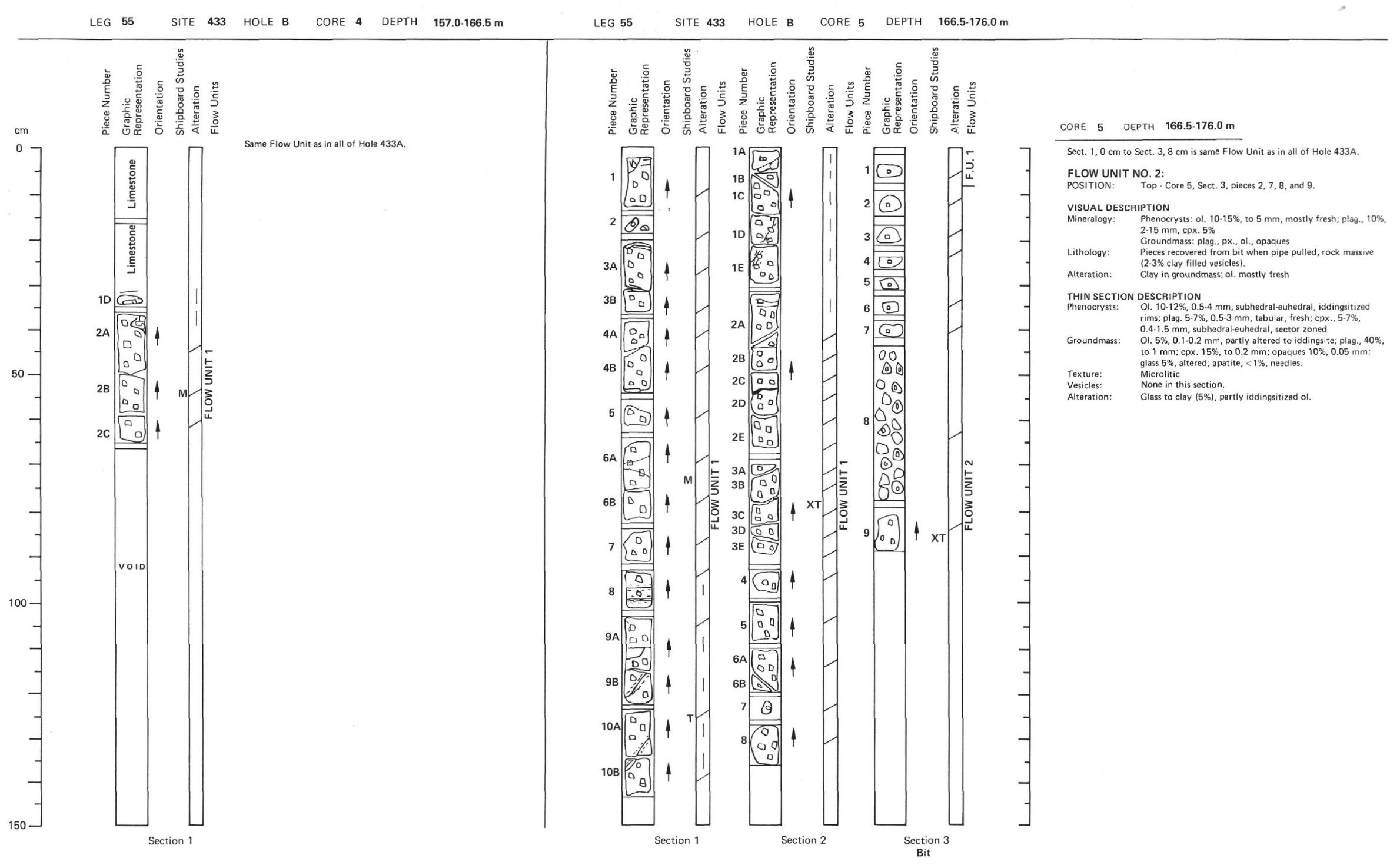

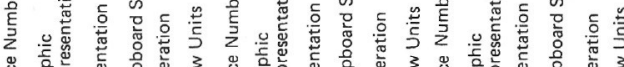

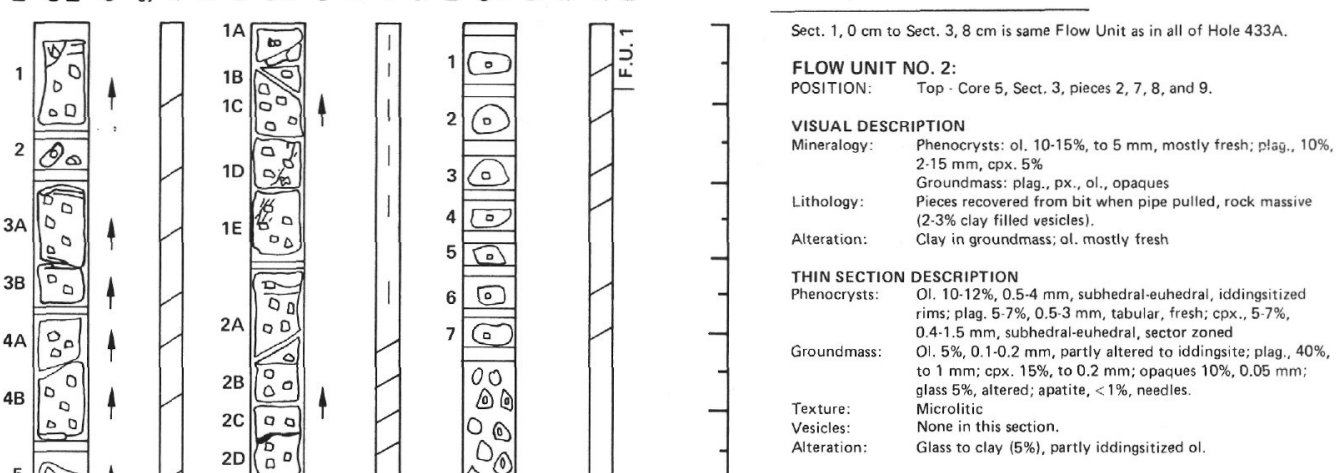




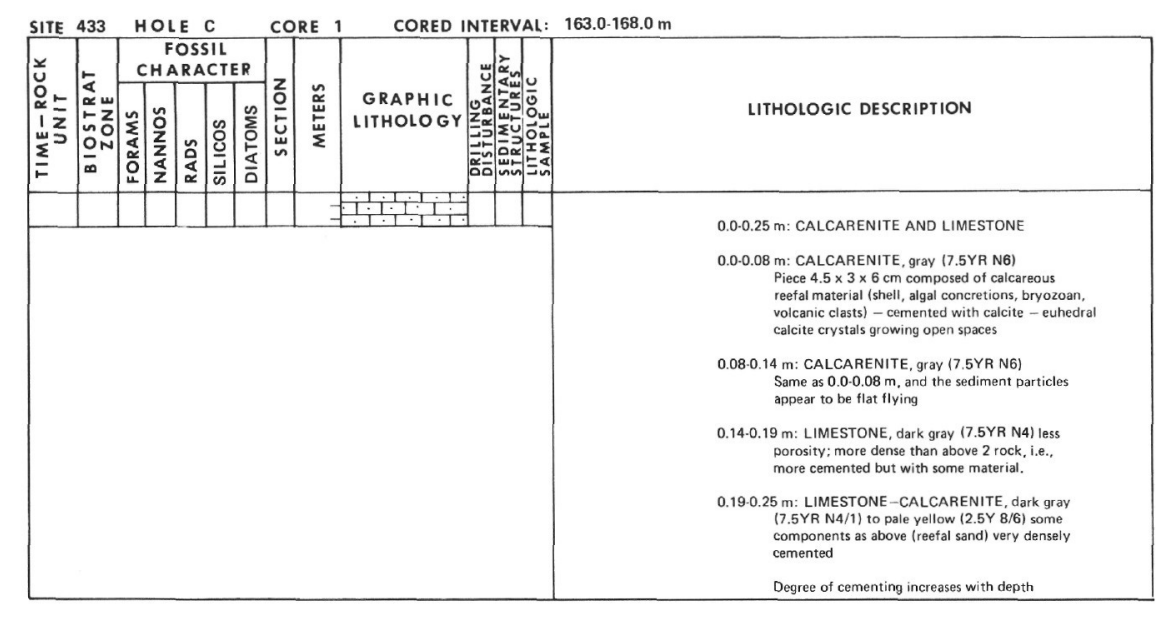




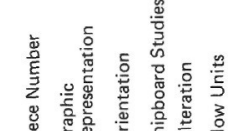

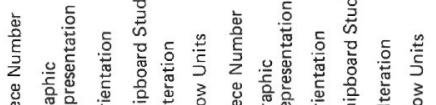

0

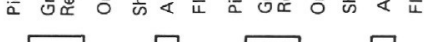

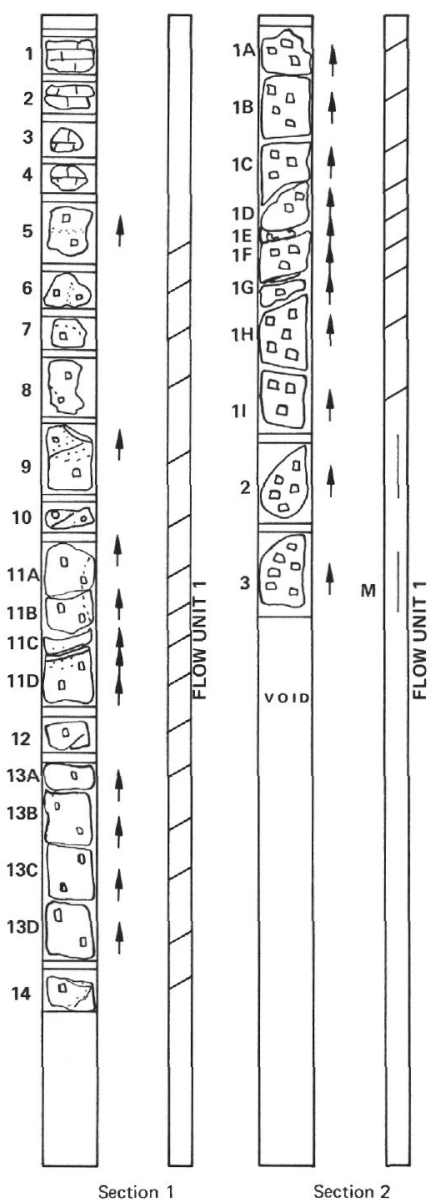

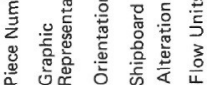

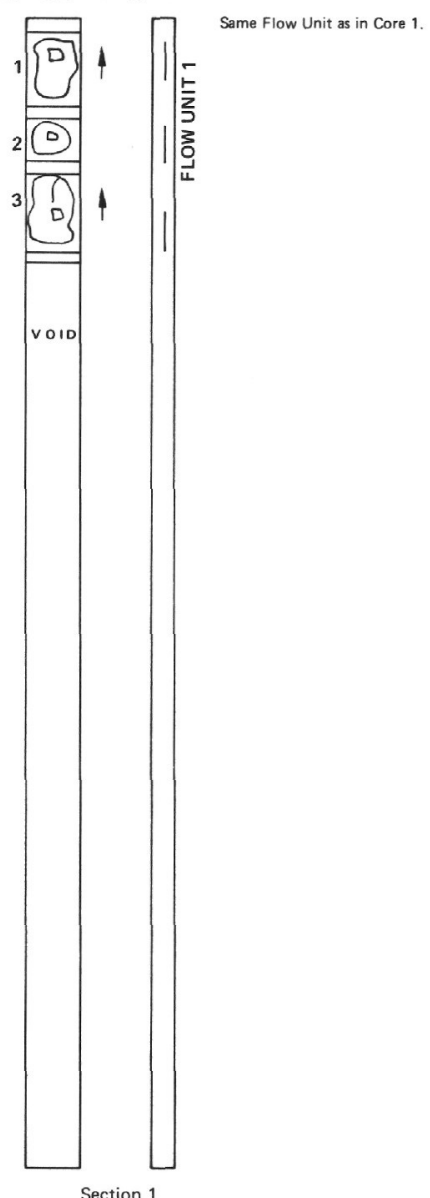

VISUAL DESCRIPTION

some fresh; plag., 10\%, up

Groundmass: plag, px., ol, opaques, clay

Mostly massive basalt (a few $1.3 \mathrm{~mm}$ vesicles) - flow top

Alteration: Patches of clay in groundmass, ol. partially to iddingsine

MAGNETIC DATA

Average Inclination: $-40.2^{\circ}$ 


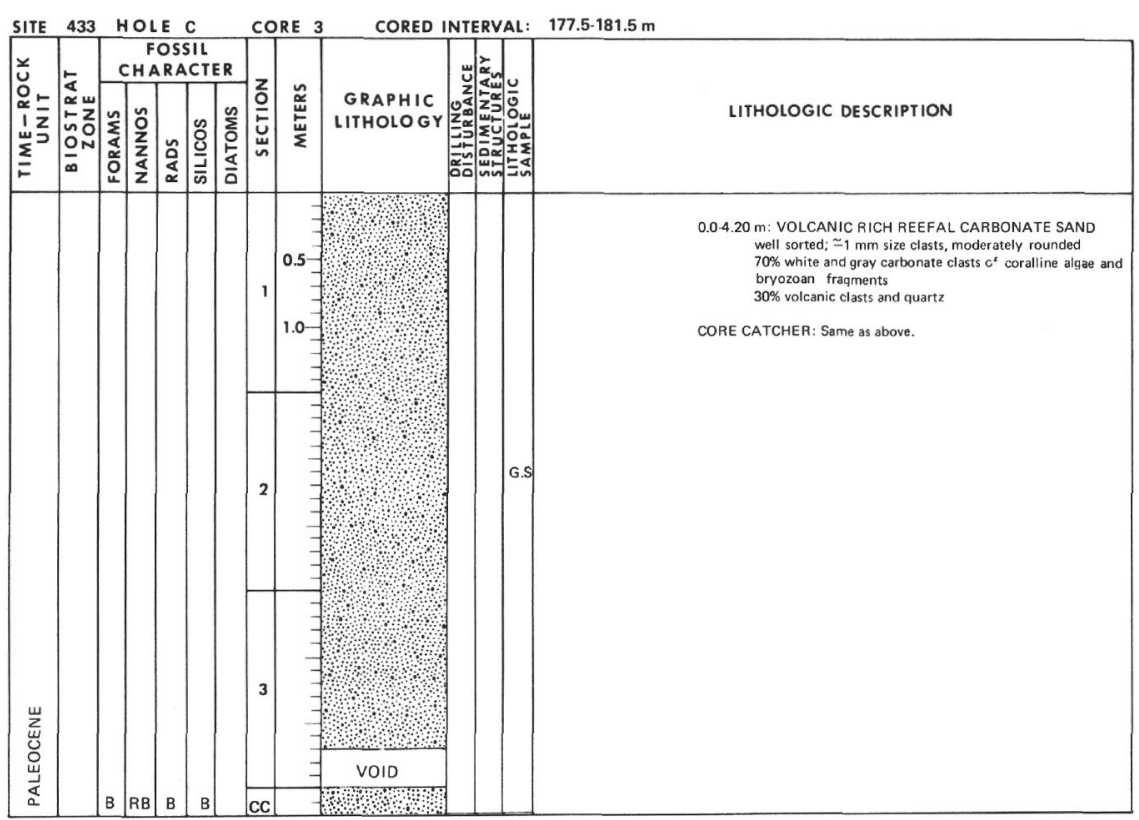


LEG 55 SITE 433 HOLE C CORE 4 DEPTH $\quad 181.5-187.0 \mathrm{~m}$

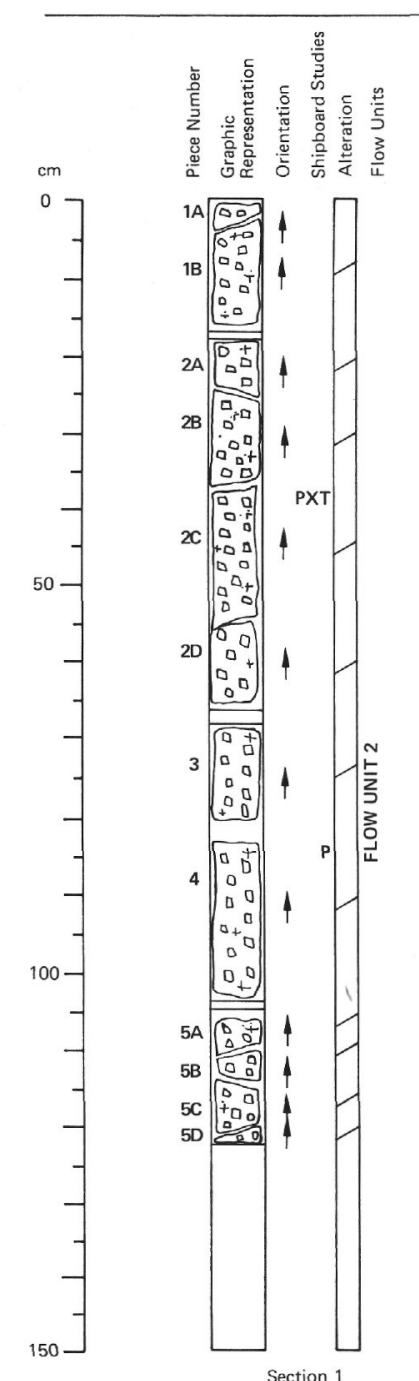

LEG $\quad 55$

SITE 433 HOLE C CORE 5 DEPTH $187.0-190.0 \mathrm{~m}$

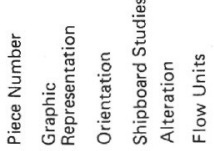

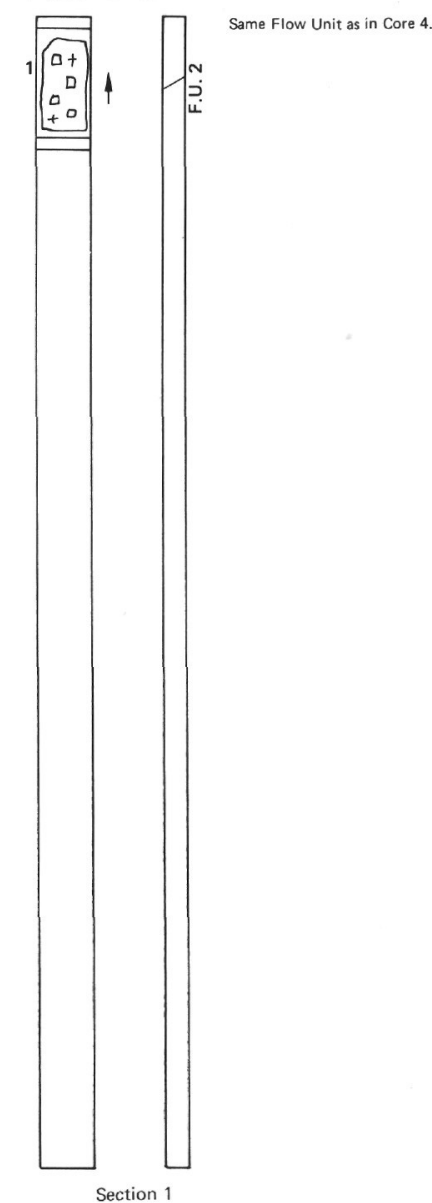

FLOW UNIT NO. 2:

POSITION:
CHEMISTRY: Core 4, Sect. $1,0 \mathrm{~cm}$
Alkalic basalt, a analysis in Table

VISUAL DESCRIPTION

.

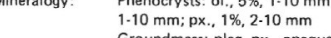

Lithology: Groundmass: plag, px., opaque $\quad$ Flow top probabaly eroded, massive throughout $11 \%$

$\begin{array}{ll} & 1.10 \mathrm{~mm} \text { clay filled vesicles) } \\ \text { Alteration: } & \text { Mostly fresh, some clay in vesicles and fractures }\end{array}$

THIN SECTION DESCRIPTION

1.., $5 \%, 13 \mathrm{~mm}$, subhedral, partially altered; plag., $3 \%$

$-0.2 .3 \mathrm{~mm}$, subhedral; c cpx., $2 \%, 0.2 \cdot 3 \mathrm{~mm}$, subhedral

Plagu, $50 \%$, to $0.2 \mathrm{~mm}$, laths; c c px., $15 \%$, to $0.2 \mathrm{~mm}$,
colorless: opaque , $7 \%$, to $0.1 \mathrm{~mm}$; apatite, $1 \%$, needles

Texture: Interstitial

$\begin{array}{ll}\text { Vesicles: } & \text { None in this section. } \\ \text { Alteration: } & 5 \% \text { clay after groundmass ol.tin }\end{array}$

MAGNETIC DATA

Average Inclination: - $36.33^{\circ}$
Average Magnetic Intensity (10.5 


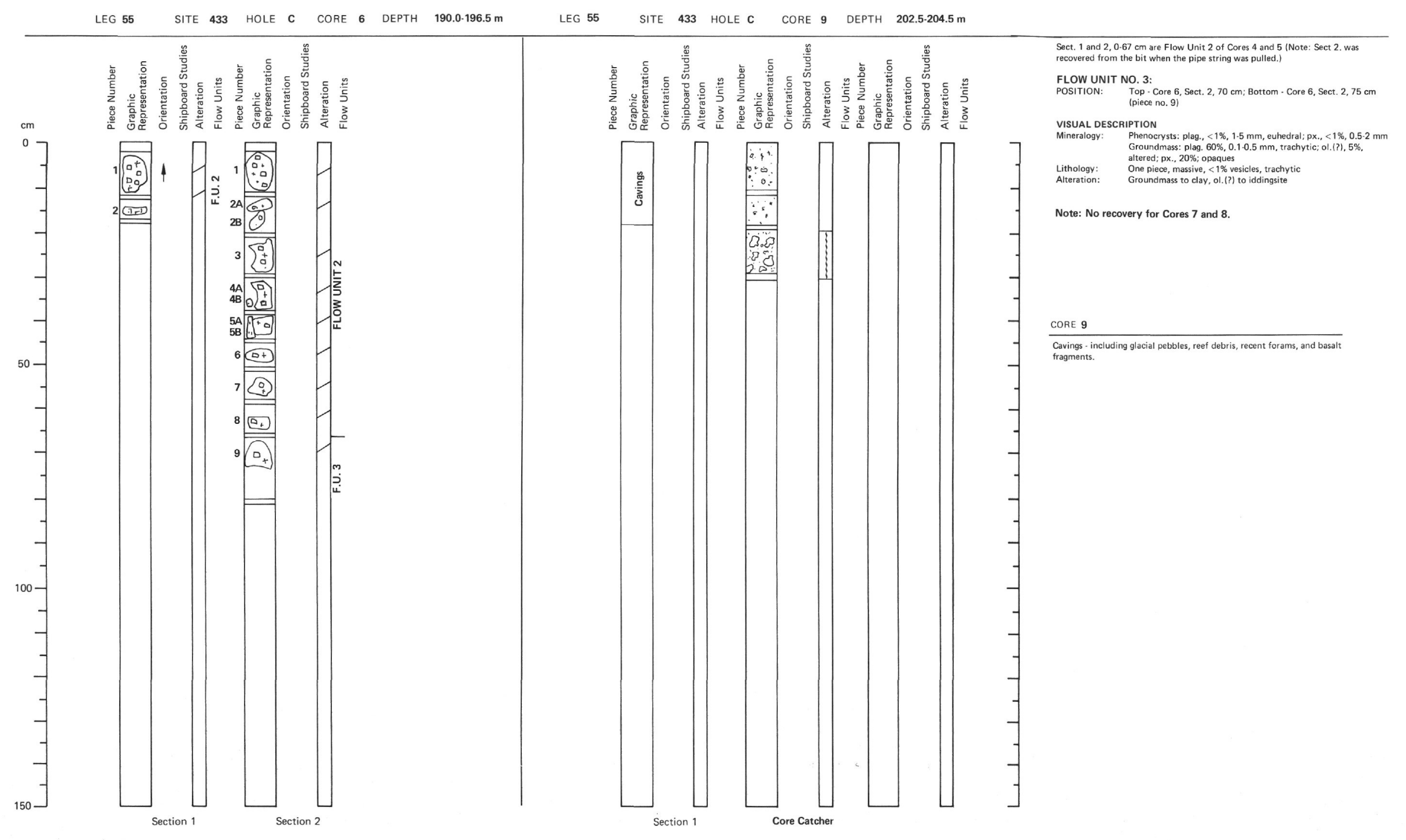




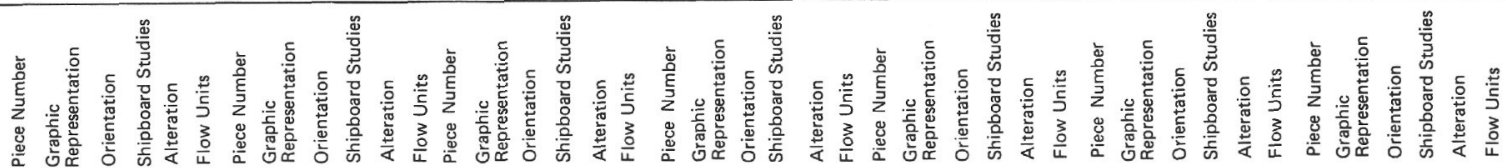
VISUAL DESCRIPTION

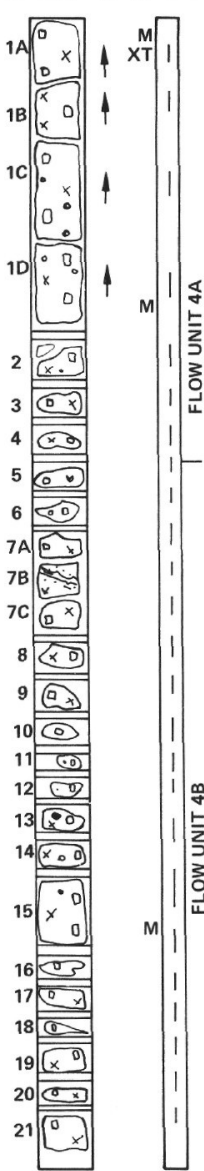

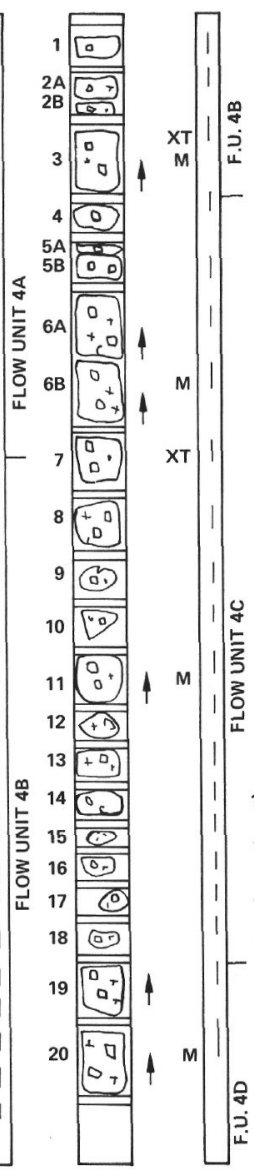

Section 2

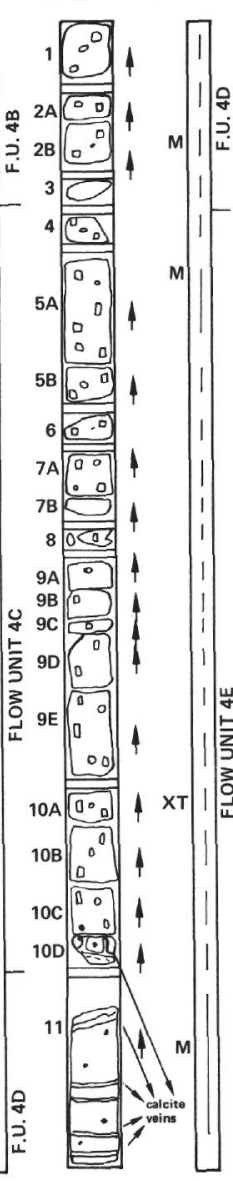

Section 3

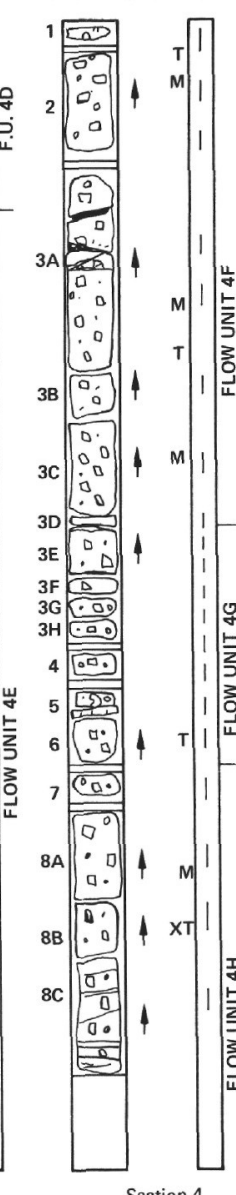

Section 4

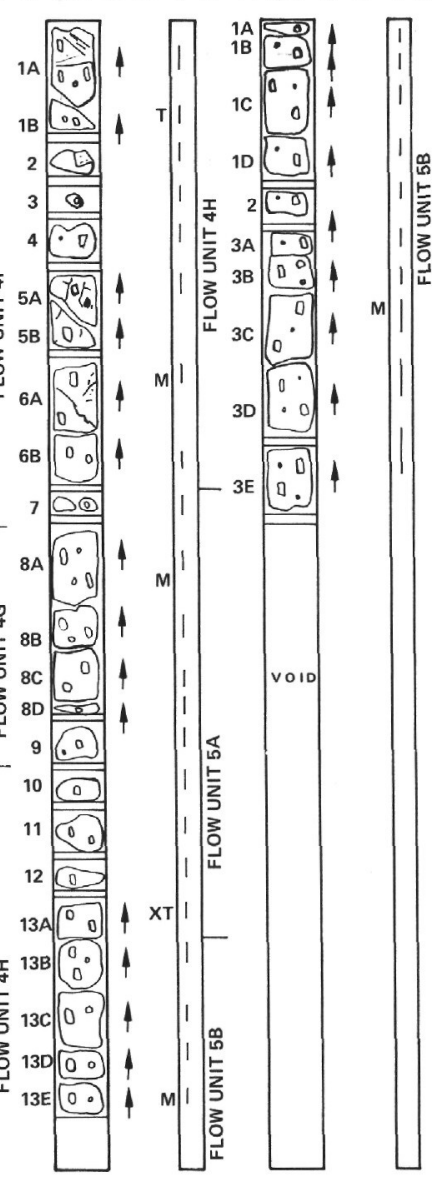

Section 5
Section 6

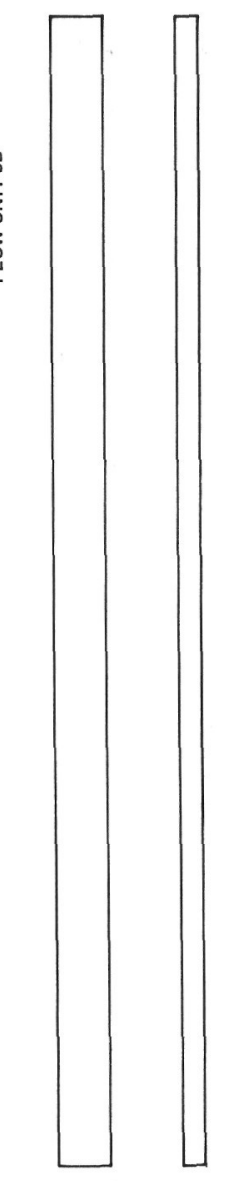

Section 7

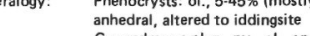

Groundmass: phas py., ol., opaques Alteration: $\quad \begin{aligned} & \text { zeolites } \\ & \text { Moderately to extensively altered; groundmass contain rich } \\ & \text { clyy }\end{aligned}$

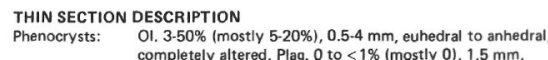

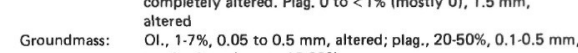

Texture: Vitrophyric, intergranular, sub-ophitic depending on position

Vesicles: $\quad 10.45 \%$ mostily 0.5 to $5 \mathrm{~mm}$, filled by clay, calcite, and

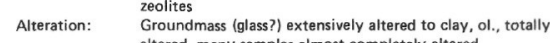

\section{MAGNETIC DATA}

Average Inclination: $-43.1^{\circ}$
Average Magnetic Intensity $\left(10^{-5}\right.$ Gauss): 1600

COMMENTS
8 sub-units based primarily on presence of intervals with many small vesicles flow center. Tips of $4 \mathrm{C}$ and $4 \mathrm{D}$ are oxidized, $4 \mathrm{H}$ is much more olivine richs.
fictive FLOW UNIT NO. 5:

Top.

CHEMISTRY: Tholeiitic basalt, 1 analyses in Table 1

VISUAL DESCRRPTION

Mineralogy: Phenocrysts: $01,<1 \%, 4 \mathrm{~mm}$, altered

Lithology: Two sub-units based on changes in number and size of

Alteration: $\quad \begin{aligned} & \text { vesicles. Vesicles } 5-20 \%,<1 \mathrm{~mm} \text { to } 8 \mathrm{~mm}, \mathrm{a} \text {, ife } \\ & \text { ol, to iddingsite; dark clay in groundmass, top oxidized red }\end{aligned}$

\section{THIN SECTION DESCRIPTION}

$7 \mathrm{~mm}$, subhedral, alteree

0.02 to $0.1 \mathrm{~mm}$, granular, altered; plag., $25 \%$, $<0.01$ Texture: $\quad 15 \%$

$\begin{array}{ll}\text { Texture: } & \text { Intergranular } \\ \text { Vesicles: } & 20 \%, 0.5 \text { to } 1 \mathrm{~mm} \text {, filled by calcite, clays, and zeolite } \\ \text { Alteration. } & 25 \% \text { in } 9 \text { roundmass, ol to iddingsite }\end{array}$

\section{MAGNETIC DATA}




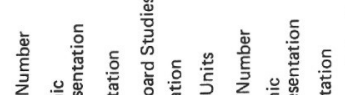

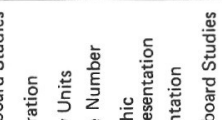

\section{噌}

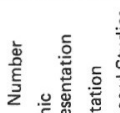

年-
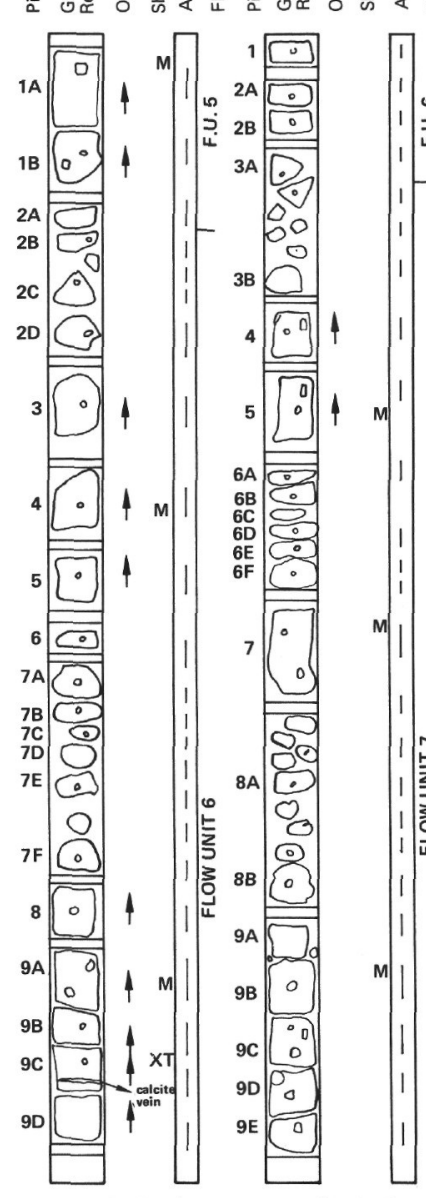

Section 2

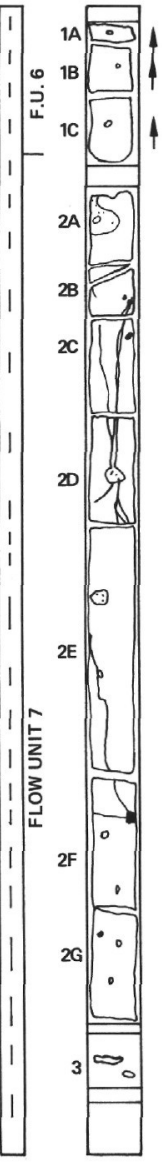

Section

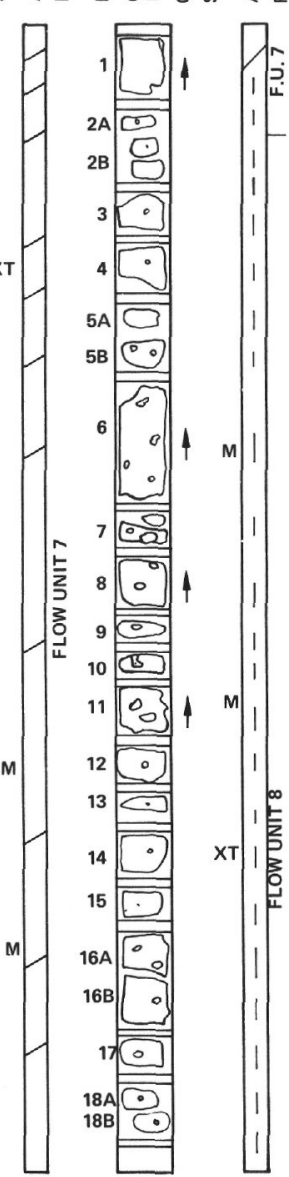

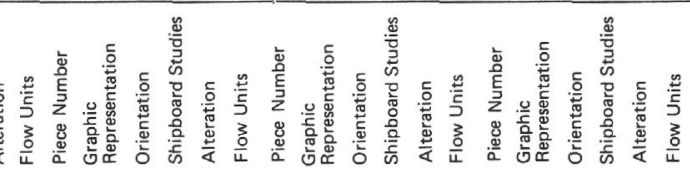

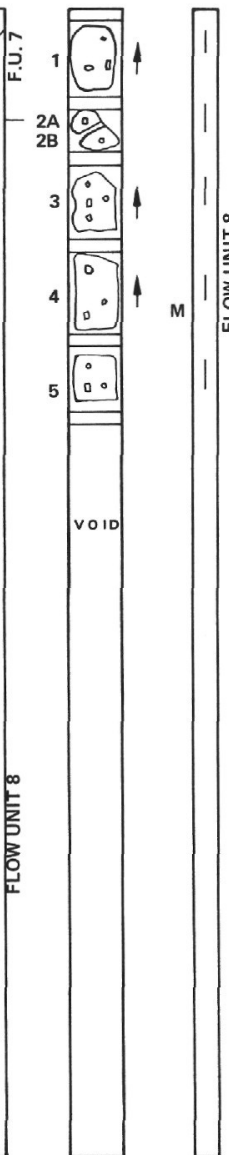

Section 5

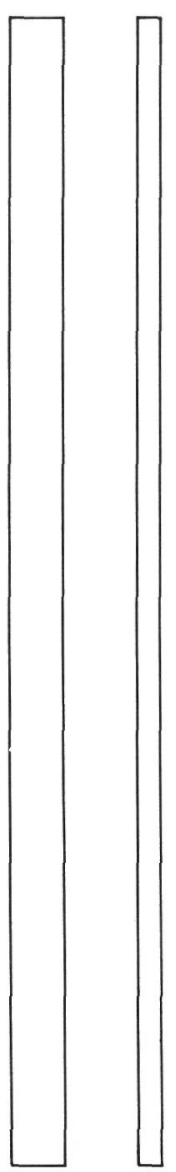

Section 6

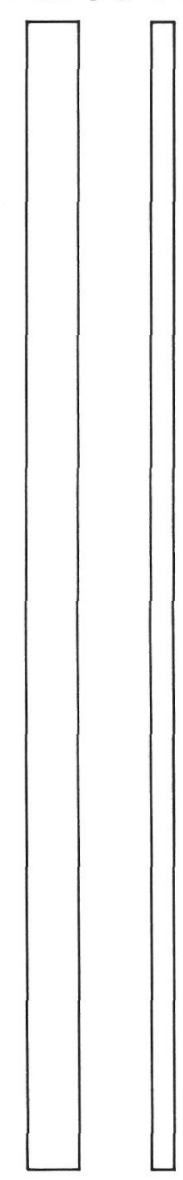

Section 7
FLOW UNIT NO. 6:
POSITION:

CHEMISTRY: $\quad \begin{aligned} & 19 \mathrm{~cm} \\ & \text { Tholeitic basalt, } 1 \text { analysis in Table } 1 .\end{aligned}$

VISUAL DESCRIPTION

Wineralogy: Phenocrysts: ol., \& $<1 \%, 1.2 \mathrm{~mm}$, altered

Lithology: Vesicular flow top (25.40\% vesiciles, $1.20 \mathrm{~mm}$ ) grading down-

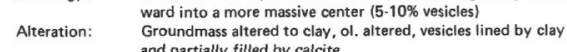
THIN SECTION DESCRIPTION

Pronocrysts:
Groundmass: 10-12\%; glass, $5 \%$, alte

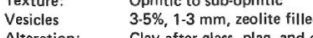

MAGNETIC DATA

Average Inclination: $-44.7^{\circ}$
Average Magnetic Intensity (10-5 Gauss): 1083

FLOW UNIT NO. 7:
POSITION:
Top - Core 11, Sect. 2, $19 \mathrm{~cm}$; Bottom - Core 11, Sect. 4

CHEMISTRY: $\begin{aligned} & 15 \mathrm{~cm} \\ & \text { Tholeitic basalt, } 1 \text { analysis in Table } 1 .\end{aligned}$

VISUAL DESCRIPTION

Mineralogy: Phenocrysts - ol., 1-2\%, 1-2 mm

Lithology: Vesicular flow top in Sect. 2, grading downward into a more

Alteration: Most vesicles partiblly filled by green clay and calcite ground

mass moderately to extensively altered to clay

THIN SECTION DESCRIPTION

$\begin{array}{ll}\text { Phenocrysts: } & \text { Ol., } 3 \%, 0.3-1.0 \mathrm{~mm}, \text { anhedral, altered } \\ \text { Groundmass: } & 0.1 .5 \%, 0.05 \text { to } 0.3 \mathrm{~mm} \text {, anhedral, altered; plag., } 40 \% \text {, }\end{array}$

0.02 to $0.1 \mathrm{~mm}$, laths; cpx.., $40 \%,<0.010 .1$
colorless; op., $3.5 \%, 0.01-0.1 \mathrm{~mm}$, equa

$\begin{array}{ll}\text { Texture: } & \text { Intergranular } \\ \text { Vesicles: } & \text { in this section, calcite filled }\end{array}$

MAGNETIC DATA
Average Inclination: -44 .

Average Magnetic Intensity $10^{-5}$ Gauss): 36

FLOW UNIT NO. 8

POSITION: Top - Core 11, Sect. $4,14 \mathrm{~cm}$; Bottom - Core 12, Sect. 1,

CHEMISTRY: Tholeititic basalt, 1 analysis in Table 1.

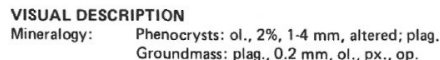

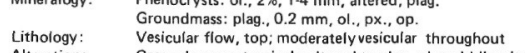

$\begin{array}{ll}\text { Lithology: } & \text { Vesicular flow, top; moderately yesicular throughout } \\ \text { Alteration: } & \text { Groundmass extensively altered to clay, ol, to iddingsite, } \\ \text { vesesides clay lined and partially calcice filled }\end{array}$

THIN SECTION DESCRIPTION

Phenocrysts: O.l.10\% (phenocrysts and microphenocrysts), $0.5-3 \mathrm{~mm}$

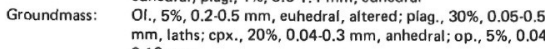

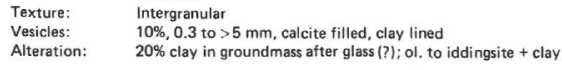

MAGNETIC DATA

Average Inclination: $-52.9^{\circ}$
Average Magnetic Intensity (10.5 Gauss): 382 
LEG 55 SITE 433 HOLE C CORE 12 DEPTH $\quad 223.5-230.0 \mathrm{~m}$

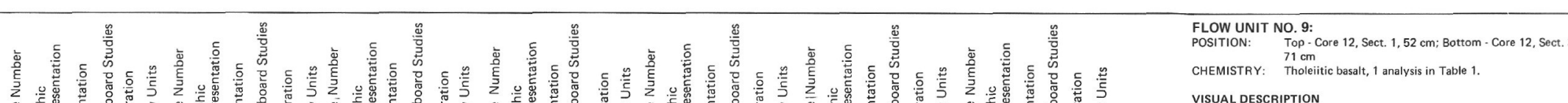

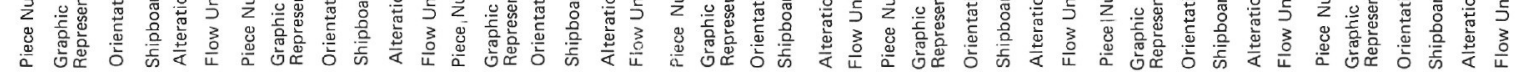

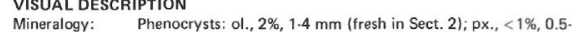

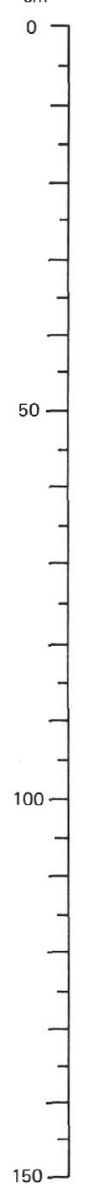
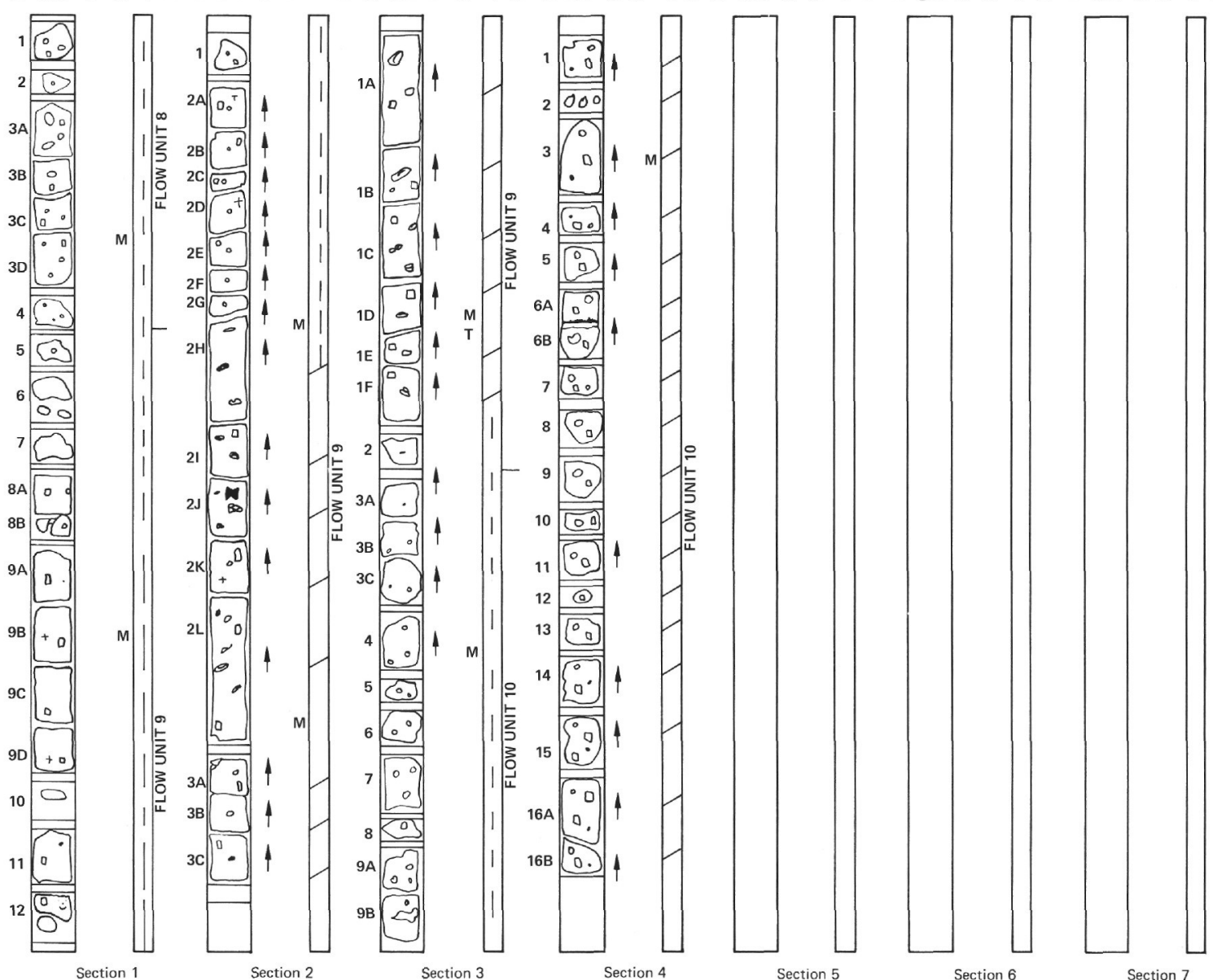

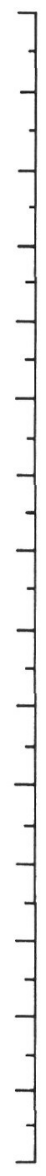
Vesicular and oxidized flow top $(25 \%, 0.5-2 \mathrm{~mm}$ vesicles $)$ in
Sect. 1 , grades down into center and bottom with fewer an Sect. 1, extensively altered (phenocrysts and groundmas)

THIN SECTION DESCRIPTION

Phenocrysts: $\quad$ OI., $2 \%, 0.5 \cdot 2 \mathrm{~mm}$, euhedral, altered; plag. $1 \%, 0.5 \cdot 1 \mathrm{~mm}$

$\begin{array}{ll}\text { Groundmass: } & 0.1,2 \%,<0.1 \mathrm{~mm} \text {, granular; ; plag. } 40 \%, 0.31 .0 \mathrm{~mm} \text {, micro- } \\ & \text { lites and laths; cpx., } 15-20 \%, 0.20 .5 \mathrm{~mm} \text {, anhedral to sub- }\end{array}$

zoned; 0 p. $10 \%$; glass, 3\%, altered

$25-30 \%$ clay after glass and ol., calcite after $01 ., 1-2 \%$

\section{MAGNETIC DATA}

Average Magnetic Intensity (10-5 Gauss): 344

$$
\text { . }
$$




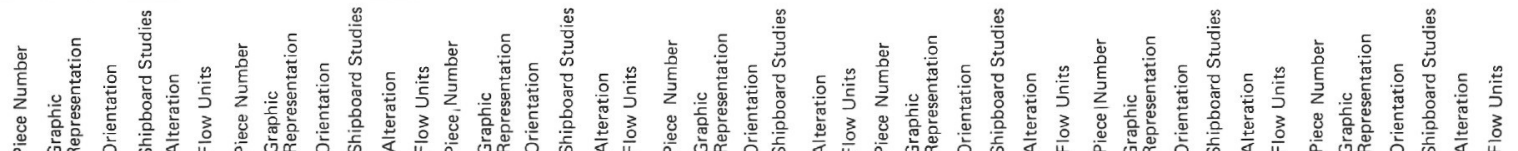

${ }^{0}$
-
-
-
-
-
-
-
-
-
-
-
-
-
-
-
-
-
-
-
-
-

150

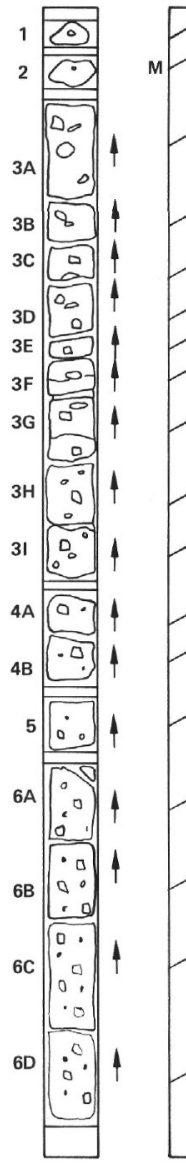

Section 1

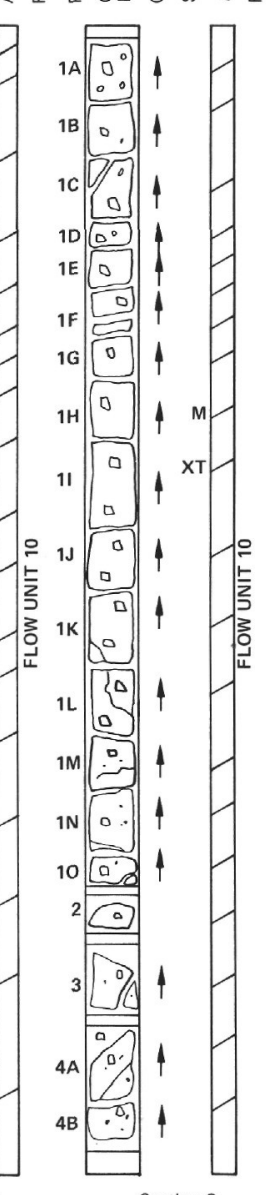

Section 2

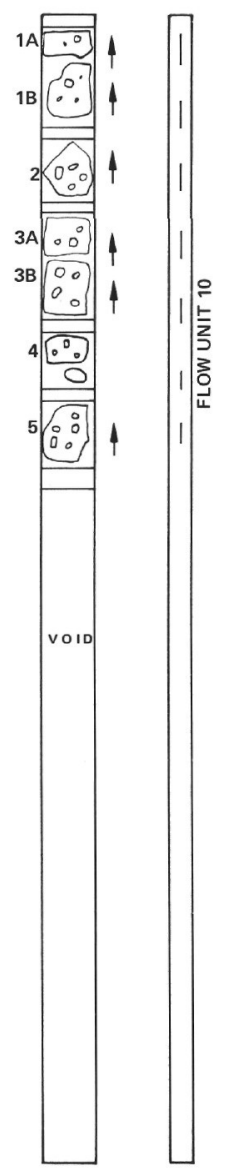

Section 3

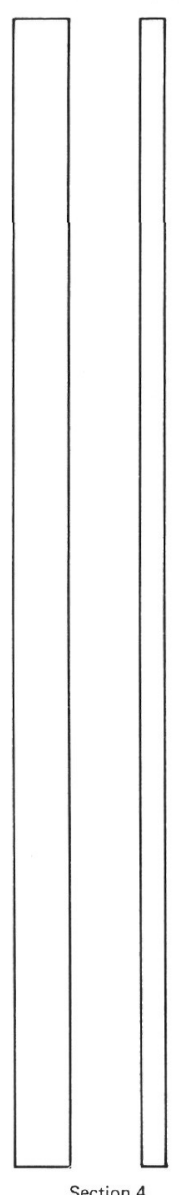

Section 4

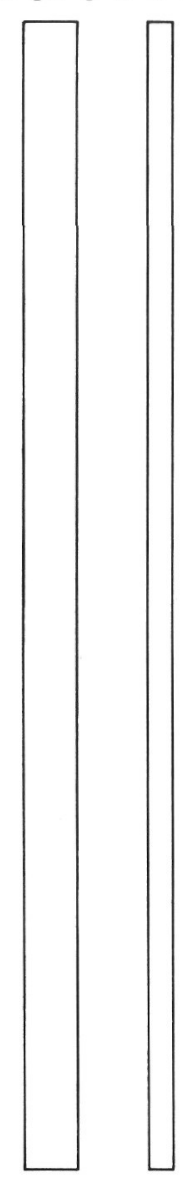

Section 5

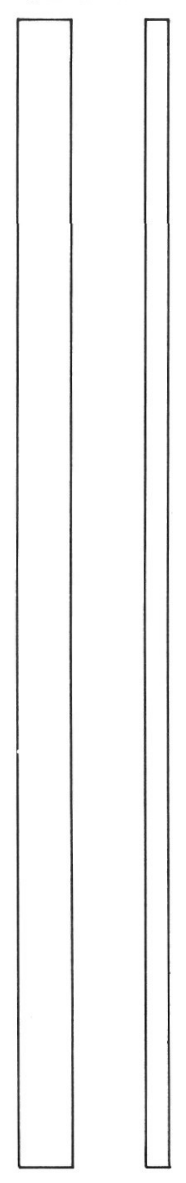

Section 6
FLOW UNIT NO. 10:

Top - Core 12, Sect. 3, $73 \mathrm{~cm}$; Bottom - Core 13, Sect. 3 . CHEMISTRY: $\begin{aligned} & 60 \mathrm{~cm} \\ & \text { Tholeititic basalt, } 1 \text { analysis in Table } 1 .\end{aligned}$

VISUAL DESCRIPTION

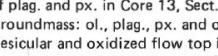

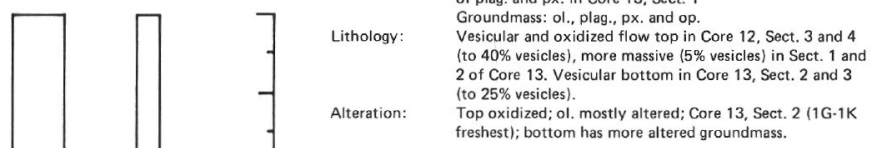

THIN SECTION DESCRIPTION

Phenocrysts: None in this section

作

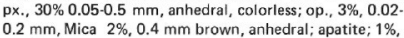

Texture: Intergranular to sub-ophitic

$\begin{array}{ll}\text { Vexture: } & \text { None in this section } \\ \text { Alteration: } & 7 \% \text { interstitial clays after ol. and glass ?? } \\ \text { Alteration } & \end{array}$

MAGNETIC DATA

Average Inclination:- $28.3^{\circ}$
Average Magnetic litensity $\left(10^{-5}\right.$ Gauss): 417 


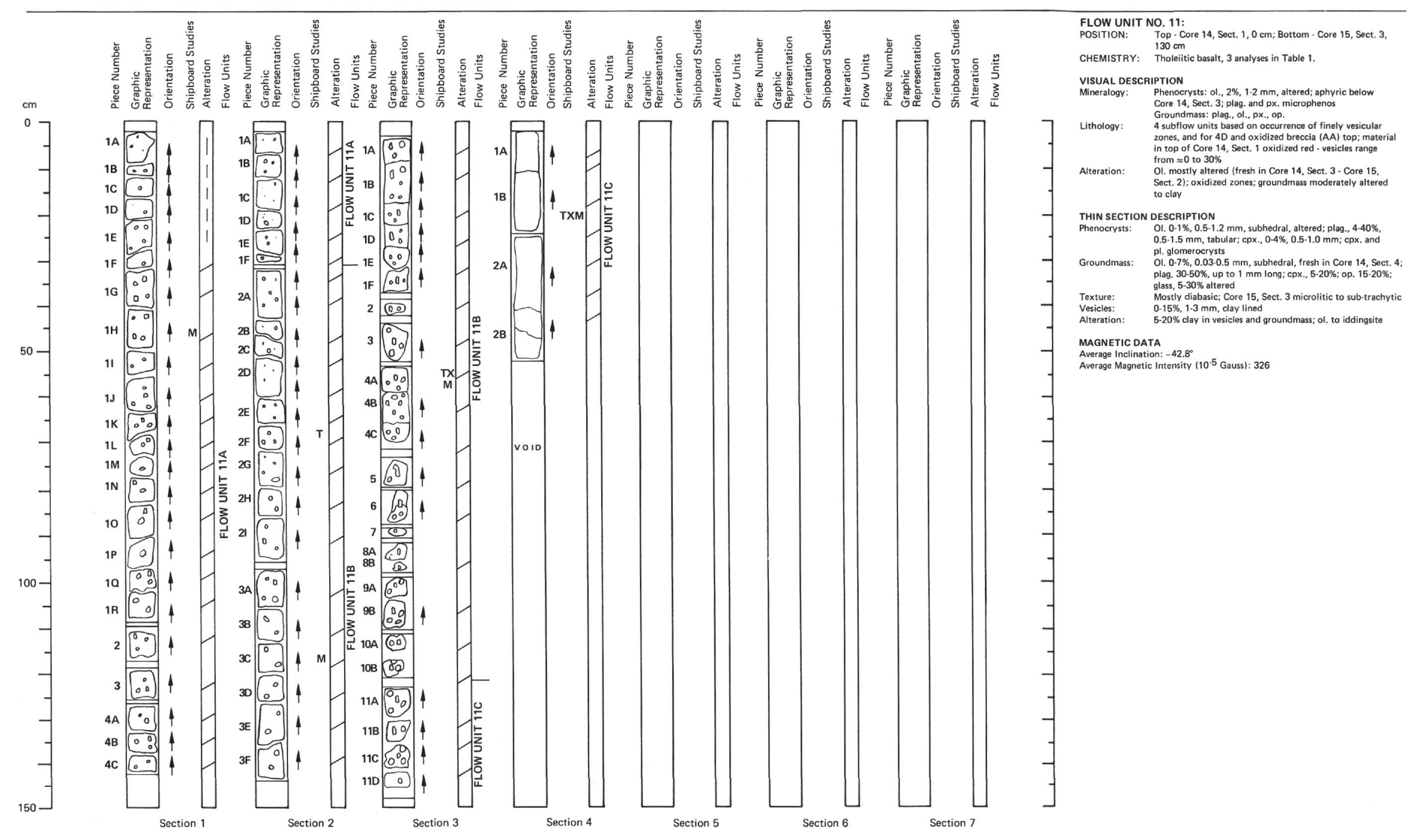




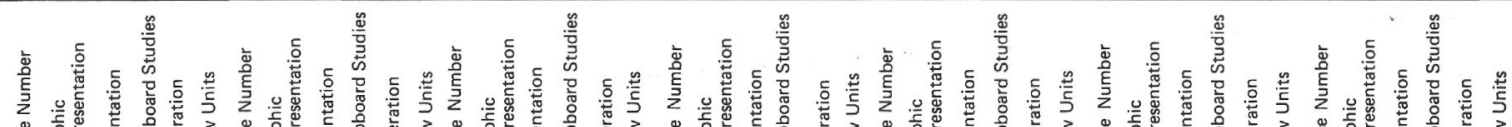

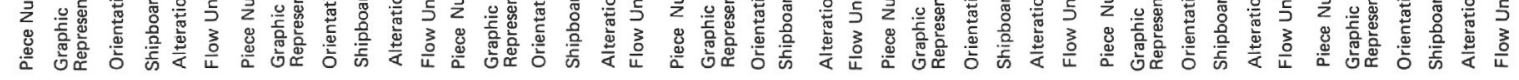

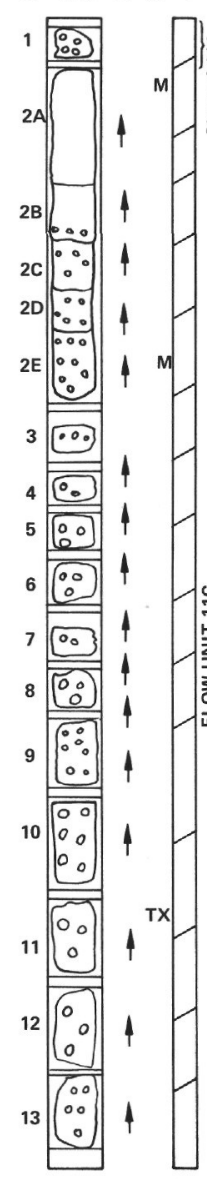

Section

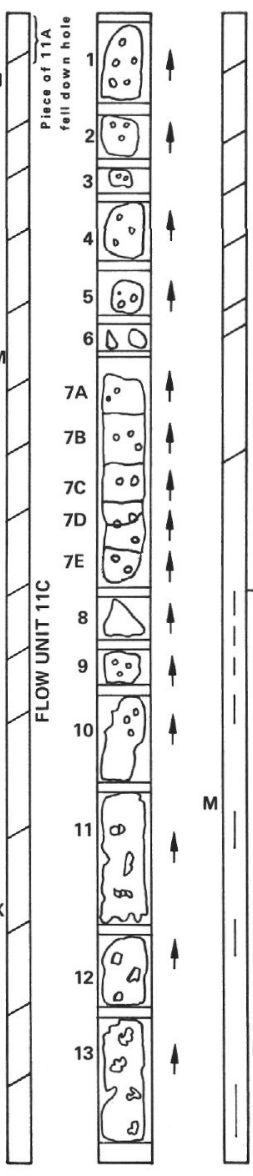

Section 2

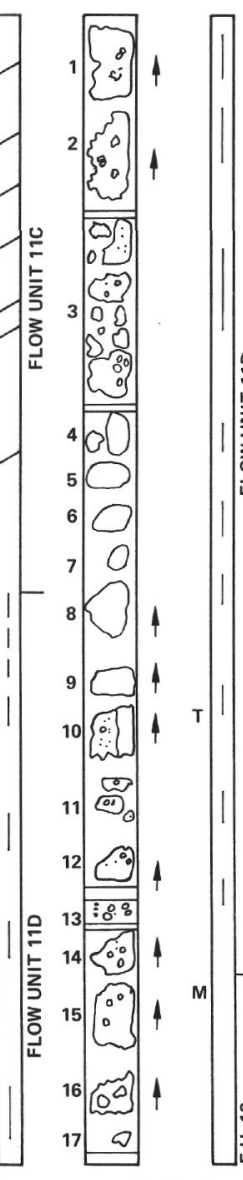

Section 3

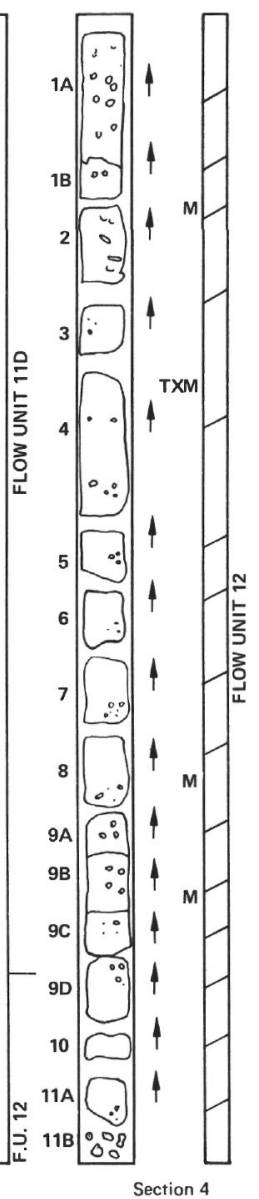

Section 4

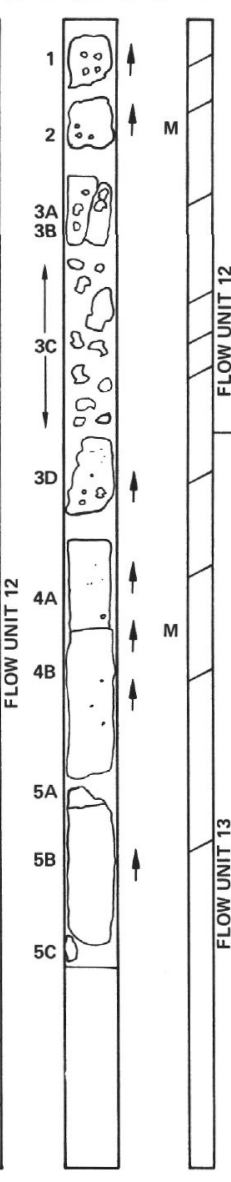

Section 5
FLOW UNIT NO. 12

Top - Core 15, Sect. 3, $130 \mathrm{~cm}$; Bottom - Core 15, Sect. 5,

CHEMISTRY: Tholeitic basalt, 1 analysis in Table 1

VIUSAL DESCRIPTION

Groundmass: plag., ol., px. op.

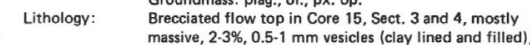

Alteration: $\quad \begin{aligned} & \text { trachytic texture locally } \\ & \text { Dark clay alteration more abundant in Core } 15, \text { Sect. } 5\end{aligned}$

THIN SECTION DESCRIPTION

Phenocrysts: cpx., 1\%, 0.3.0.7 mm, euhedral, colorless

$0.4 \mathrm{~mm}$. laths; cox., $25 \%,<0.010 .1 \mathrm{~mm}$, granular, colorles.

Texture: $\quad$ op., 10\%, 0.01-0.1 m

Vesicles: $\quad 5 \%, 1 \cdot 3 \mathrm{~mm}$, filled by green clay
$\quad 15 \%$ clay in wiscles and groundm

MAGNETIC DATA

Average Inclination: $-20.2^{\circ}$
Average Magnetic I 


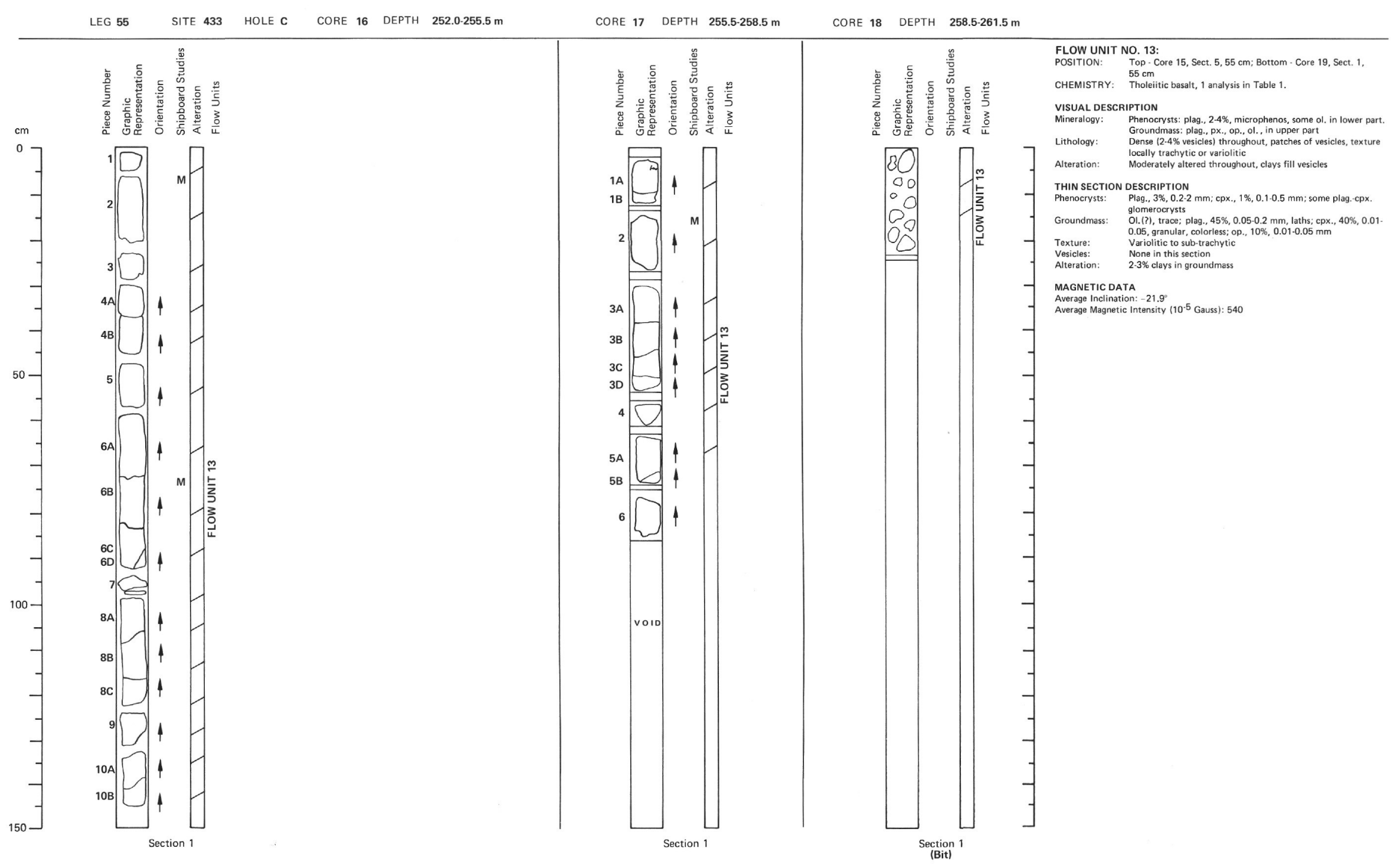




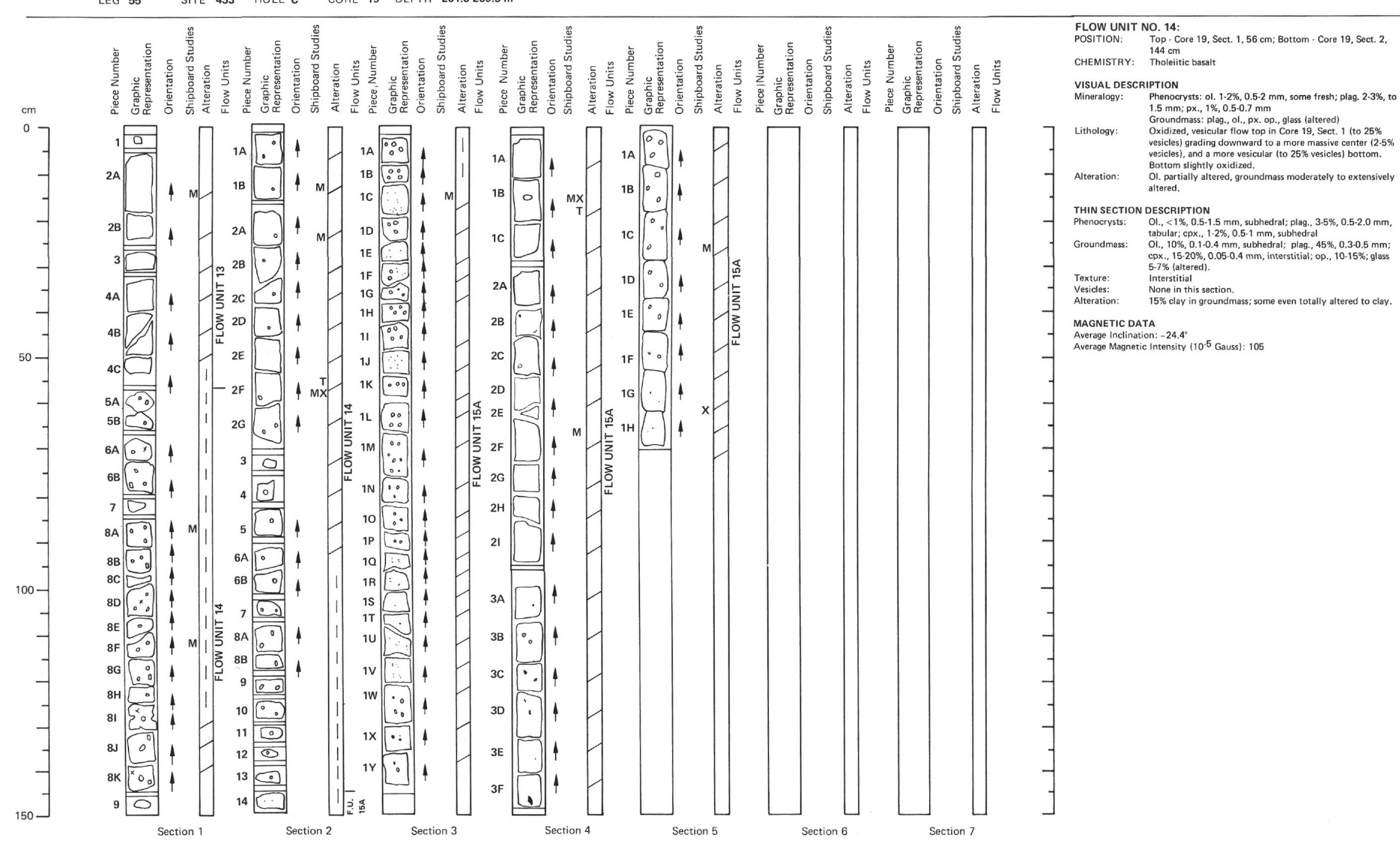




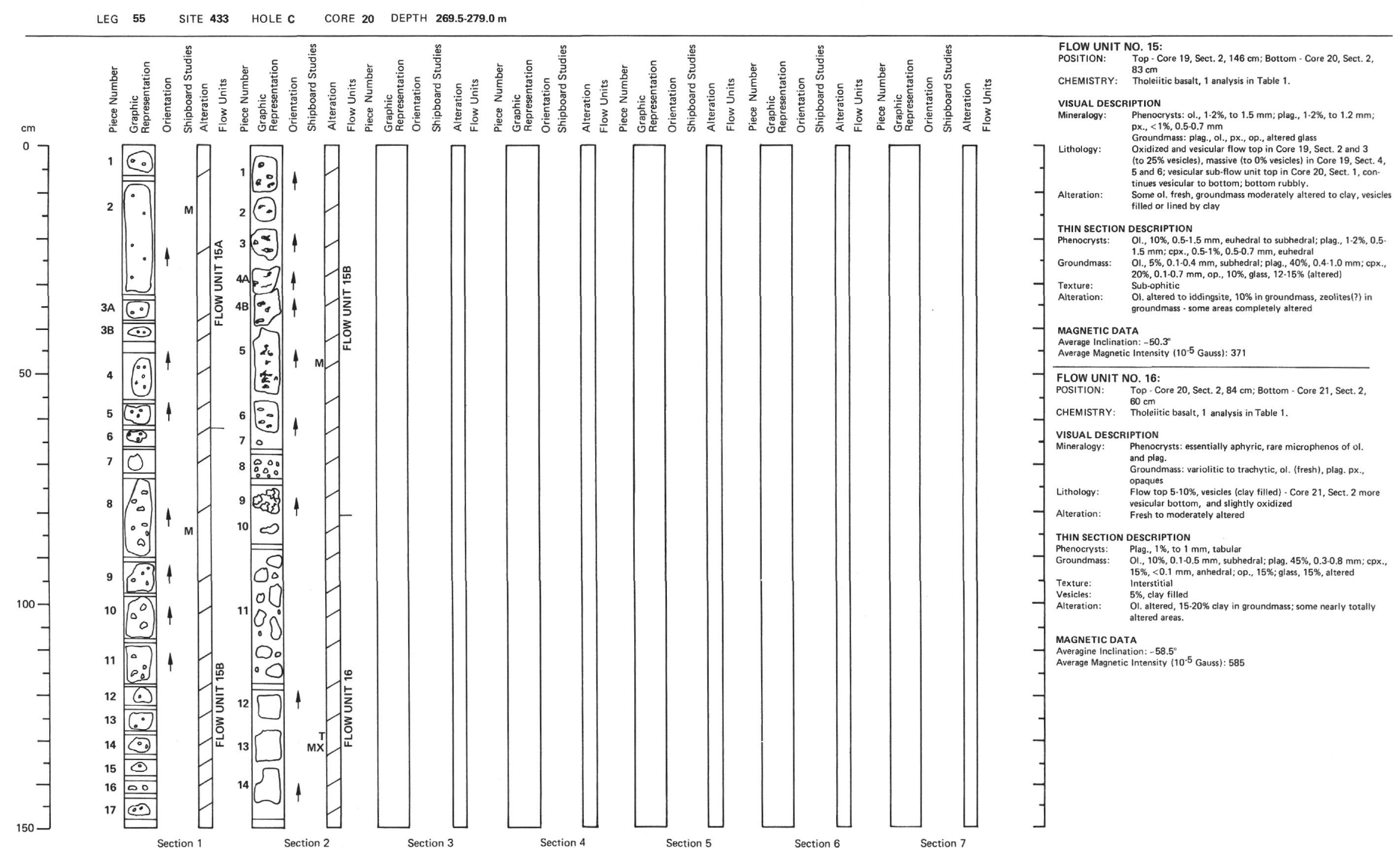




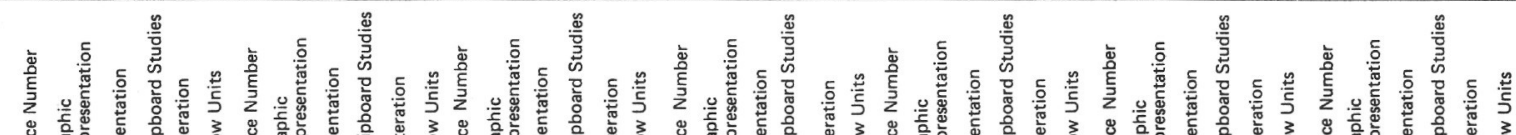

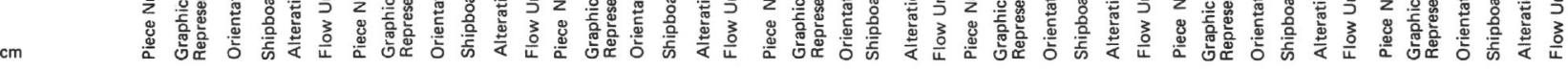

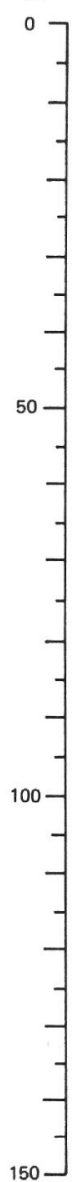
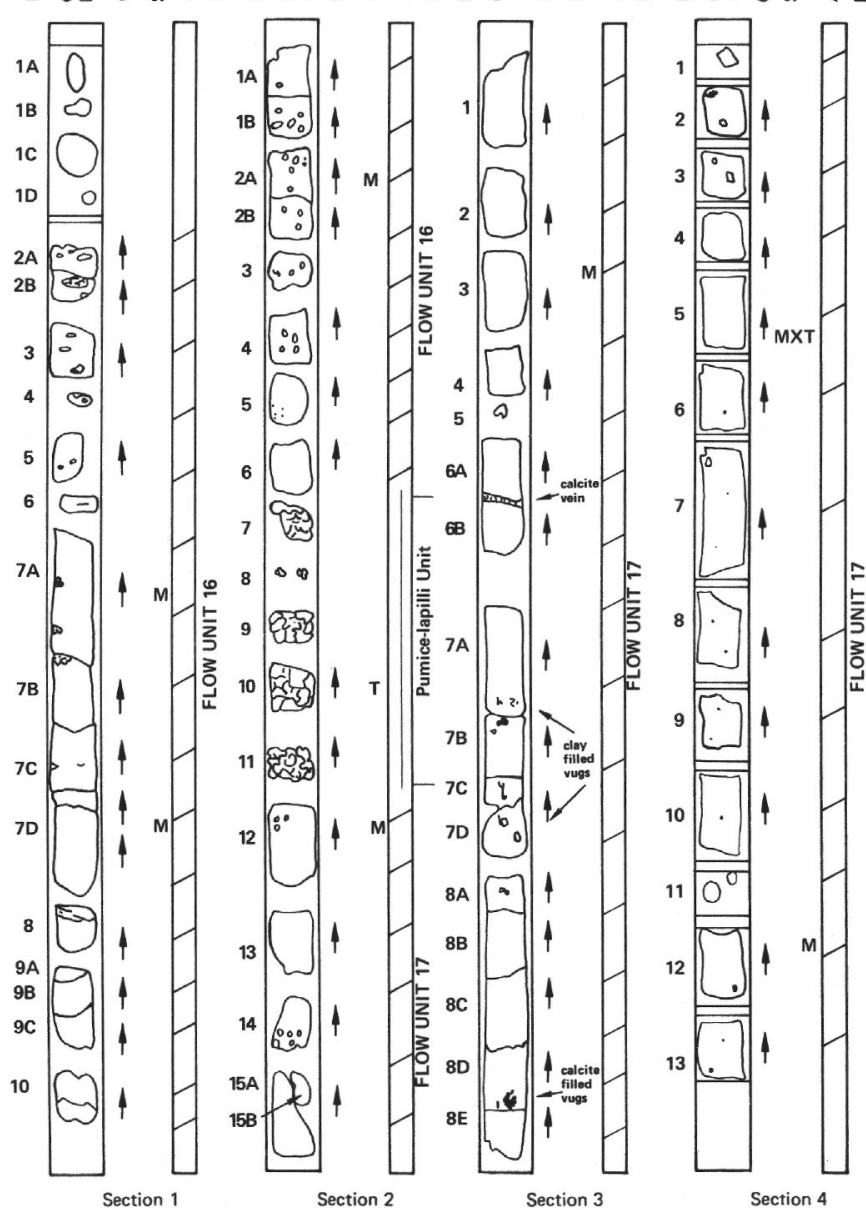

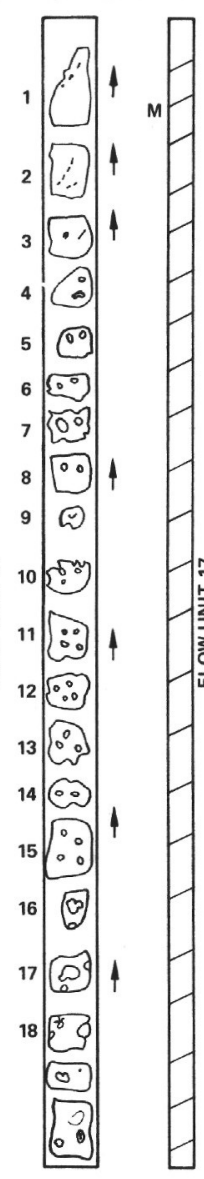

Section

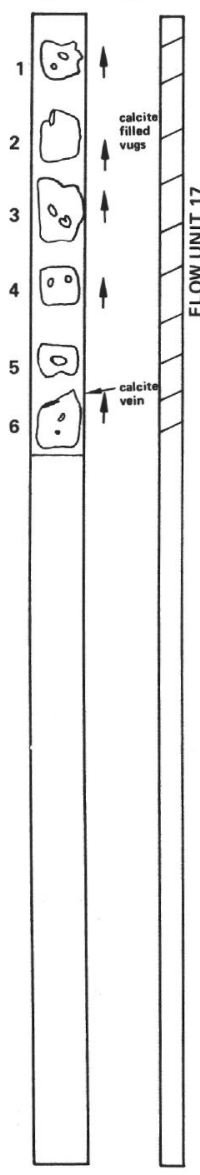

Section 6

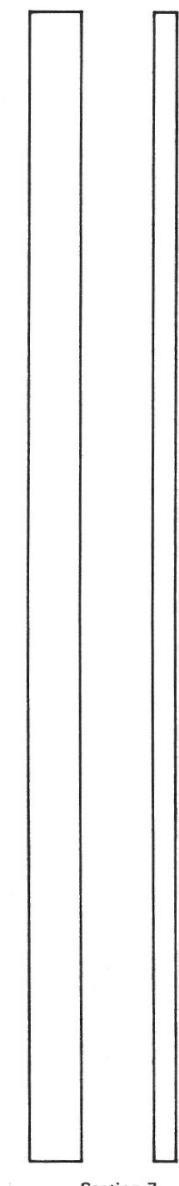

Core 21, Sect. $2,60.98 \mathrm{~cm}$, is a layer of pumice lapilli oxidized red

FLOW UNIT NO. 17:

POSITION: NOP. Core 21, Sect. 2, $100 \mathrm{~cm}$ : Bottom - Core 22, Sect. 1 ,

CHEMISTRY: Tholeiticic basalt, 1 analysis in Table 1.

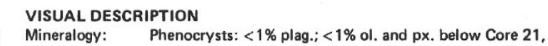

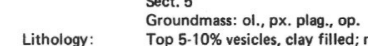

Alteration: $\quad \begin{aligned} & \text { vesicles) to bottom } \\ & 15 \text { to } 30 \% \text { clay in groundmass }\end{aligned}$

THIN SECTION DESCRIPTION

heñiocrysts. Ol., $1 \%, 0.40 .6 \mathrm{~mm}$, subhedral; plag., 2-3\%, anhedrat;

Groundmass $01,5 \%, 0103 \mathrm{~mm}: \mathrm{plog}^{2} 30 \%, 0205 \mathrm{~mm}$

Vesicles: $\quad 5.7 \%$, filled by dark dey

$50 \%$ clay in ground

MAGNETIC DATA
Average Inclination: - 6 -

Average Inclination: - $611^{\circ}$
Average Magnetic Intensity (10-5 Gauss): 384

$-$

$-$

$-$

$-$

$-$

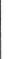

-

- 
LEG 55 SITE 433 HOLE C CORE 22 DEPTH 288.5-298.0 m

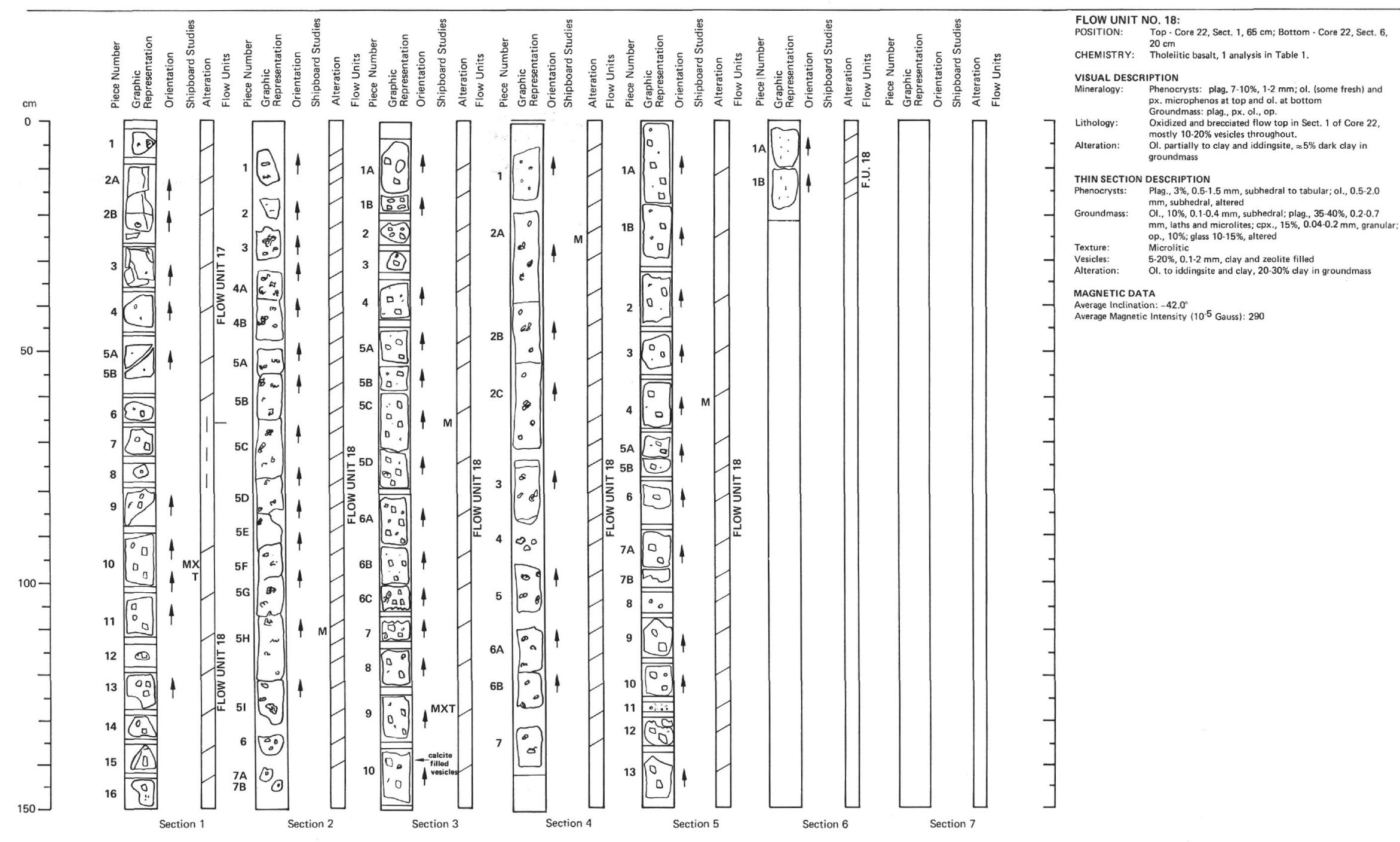




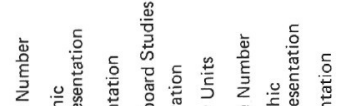
总

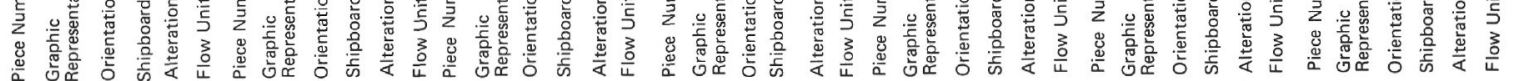

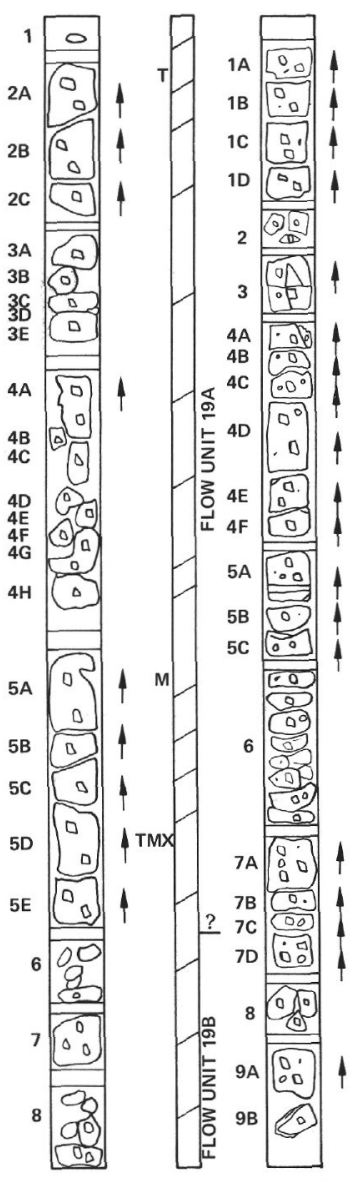

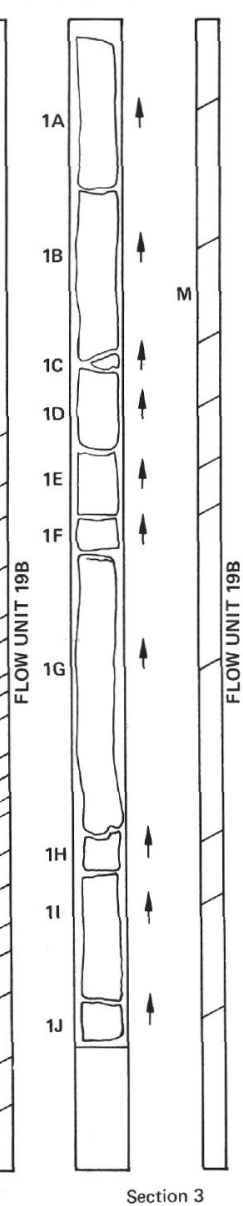

Section 3

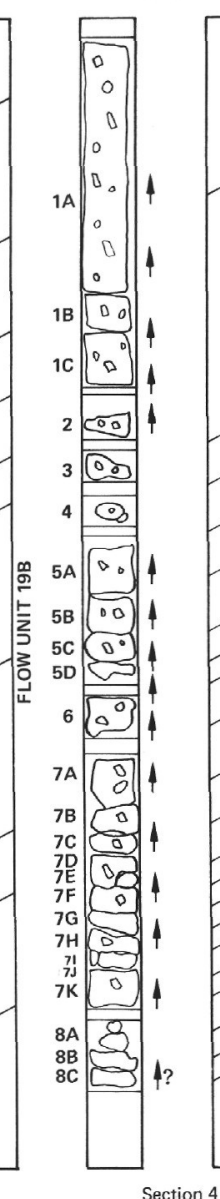

Section 4

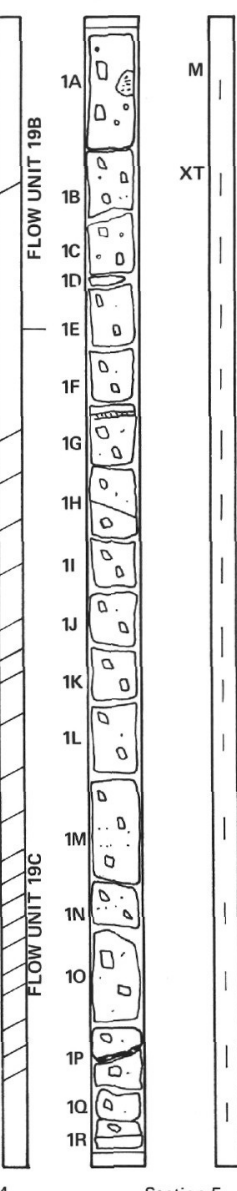

Section 5

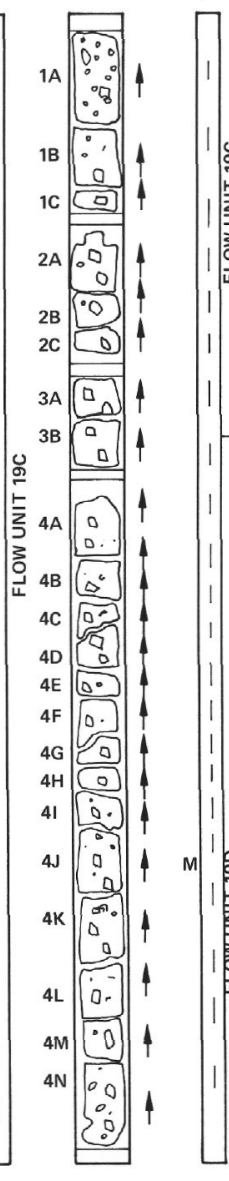

Section 6

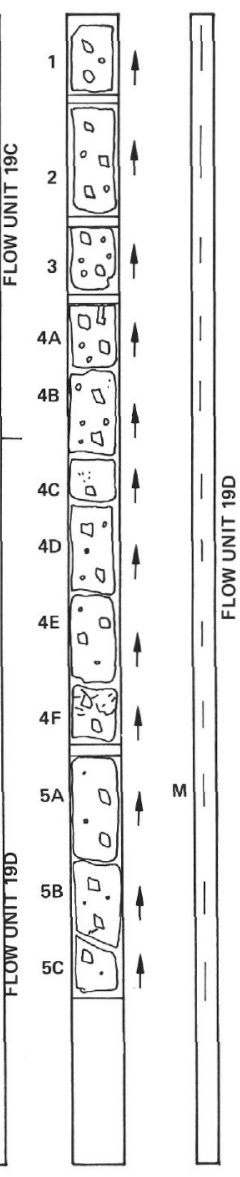

Section 7
FLOW UNIT NO. 19:

Tect. 1, $0 \mathrm{~cm}$; Bottom - Core 25, Sect. 1,

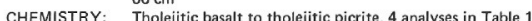

VISUAL DESCRIPTION
Mineralogy: Phenocrysts: $01 ., 7-15 \%, 1-2 \mathrm{~mm}$, some fresh

Groundmass: ol., plag., px., op., clay

Lithology: 4 sub-units based on changes in vesicularity, mineralogy.
and oxidation: $5.30 \%$ vesicles. $1-30$ man, mosty cley Alteration: Goroundmass moderately altered to clays; fresh ol. in Cor THIN SECTION DESCRIPTION

$0.5 .5 \mathrm{~mm}$, euhedral to subhedral, mostly

$\begin{array}{ll}\text { Groundmass: } & \begin{array}{l}0 \text { to } 11 \% \text {, anhedral, fresh } \\ 01 ., 1-10 \%, 0.05 \text { to } 0.5 \mathrm{~mm} \text {, subhedral, altered; plag. } 15\end{array}\end{array}$

$35 \%, 0.05 \cdot 1.0 \mathrm{~mm}$. cox. $5.25 \%, 0.02 .05 \mathrm{~mm}$, anhedral

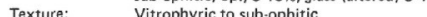

$\begin{array}{ll}\text { Vesicles: } & 0.15 \%, \text { to } 3 \mathrm{~mm} \text {, clay filled or lined } \\ \text { Alteration: } & 3 \text { to } 55 \% \text { clay in groundmass, ol. mostiv altered }\end{array}$

MAGNETIC DATA

Averagine Inclination:- $38.2^{\circ}$
Average Magnetic Intensity $410^{-5}$ Gauss): 421 
SITE 433 HOLE C CORE 24 DEPTH $307.5-317.0 \mathrm{~m}$

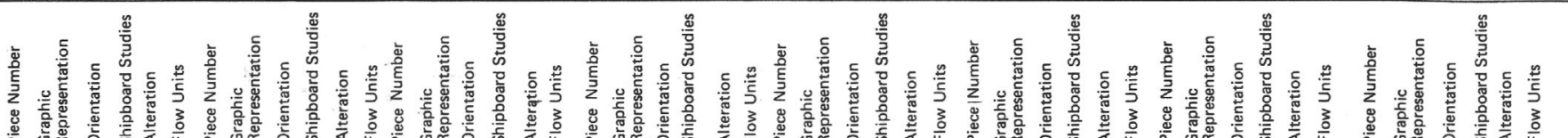

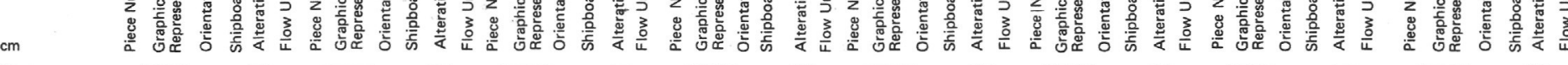

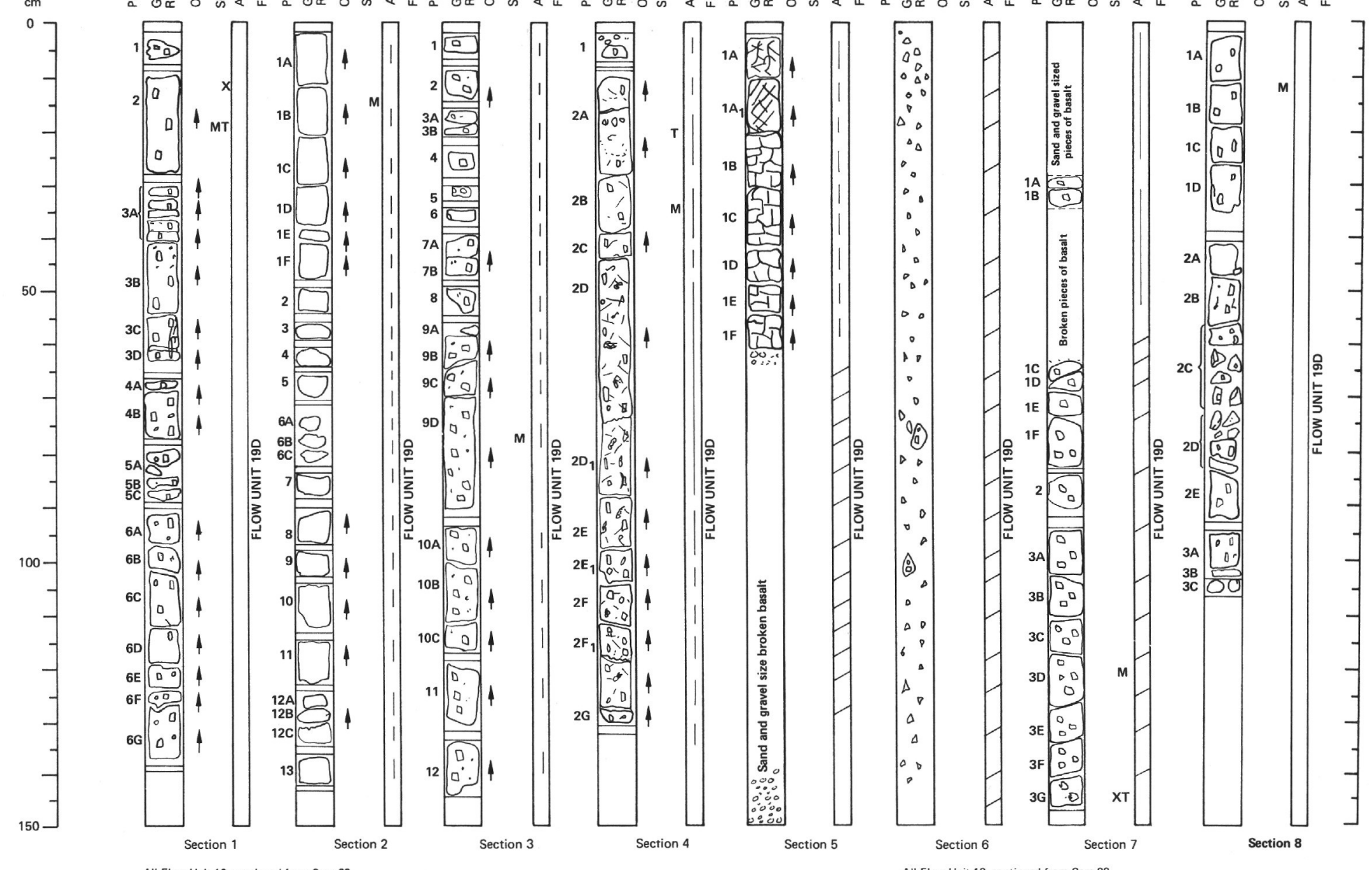




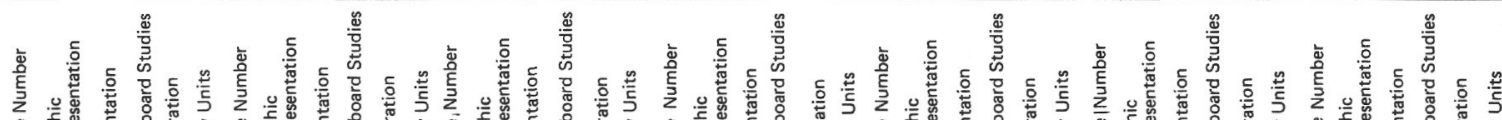

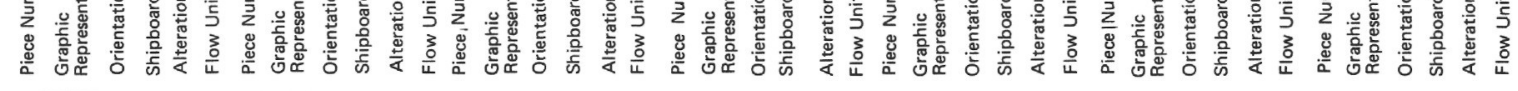
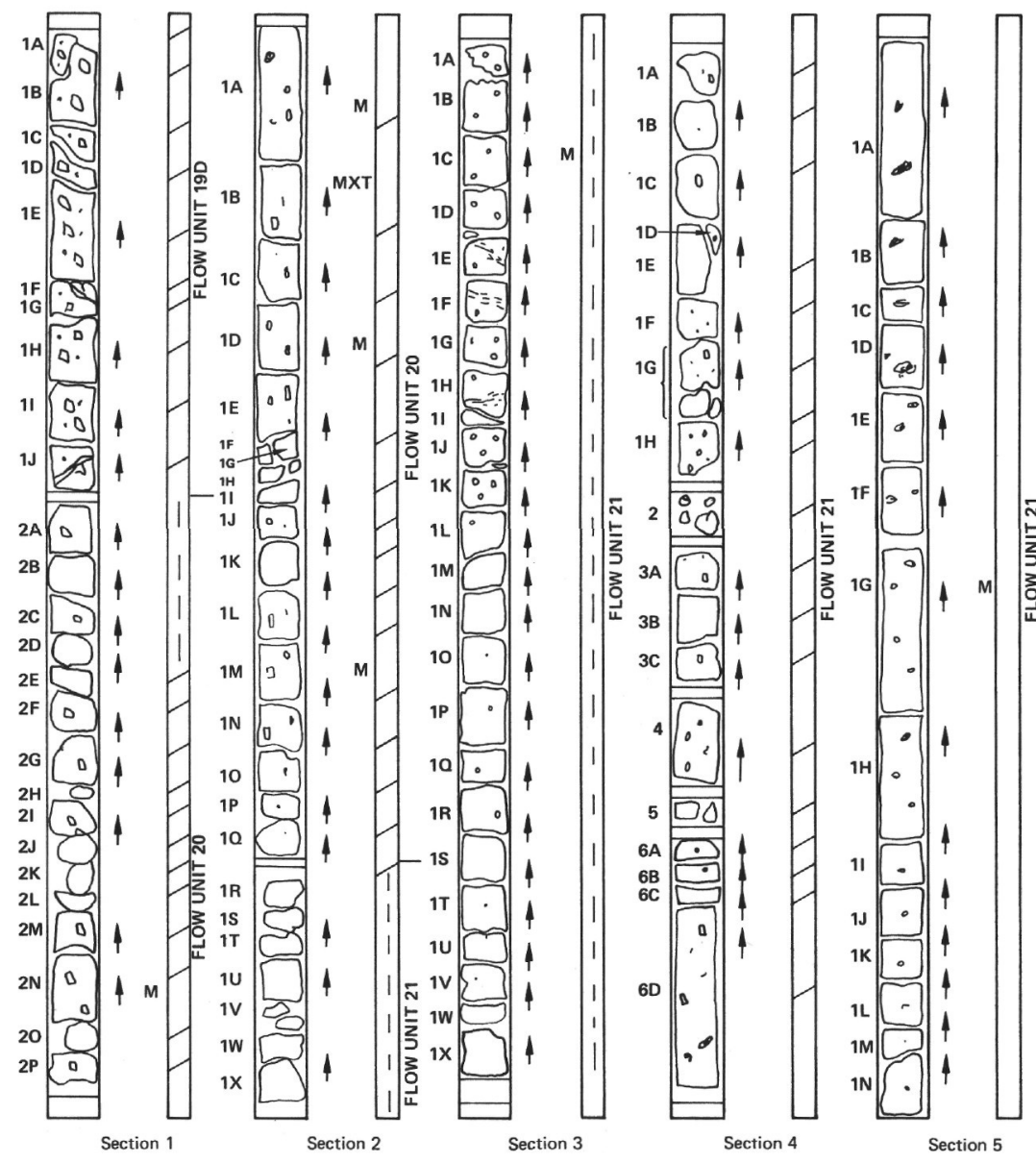

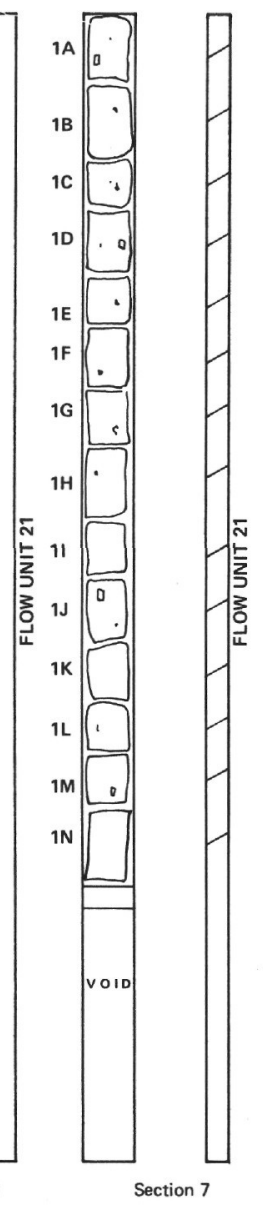

FLOW UNIT NO. 20:

CHEMISTRY: Tholeitic basalt, 1 analysis in Table 1.

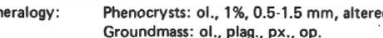

Groundmass: ol, plag., px., op.

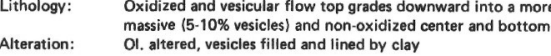

Phenocrysts: Ol., $1.2 \%, 0.4-0.6 \mathrm{~mm}$, subhedral, altered

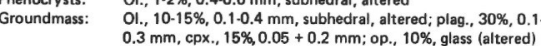

Texture: $\quad 30 \%$

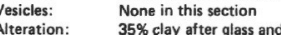

MAGNETIC DATA

Average Magnetic Intensity $\left(10^{-5}\right.$ Gauss): 124

FLOW UNIT NO. 21:

Top - Core 25, Sect. 2, $119 \mathrm{~cm}$; Bottom - Core 26, Sect. 3

CHEMISTRY: Tholelitic basalt, 1 analysis in Table 1.

VISUAL DESCRIPTION

Mineralogy: Phenocrysts: $01,0.5 \cdot 1.5 \mathrm{~mm}$. $3.5 \%$, some frest

Alteration: Moderately to extensively alt

THIN SECTION DESCRIPTION

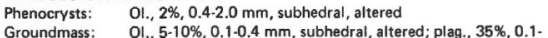

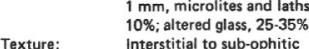

ol. to iddingsite and clay

MAGNETIC DATA

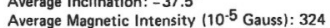


LEG 55 SITE 433 HOLE $C$ CORE 26 DEPTH $326.5-336.0 \mathrm{~m}$

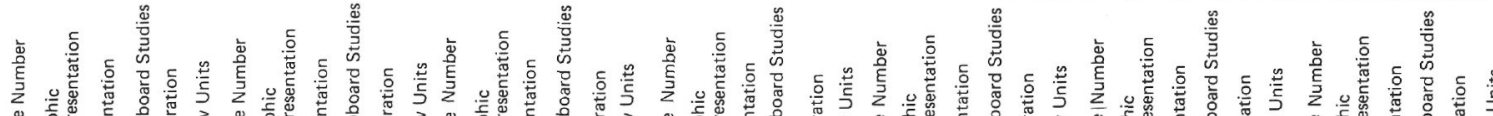

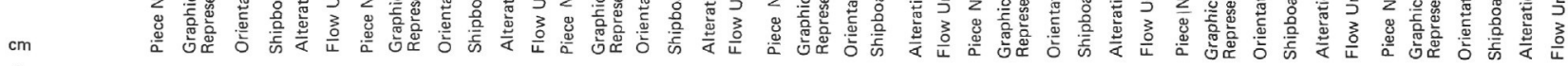

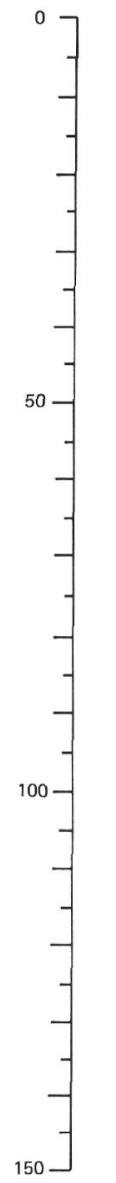

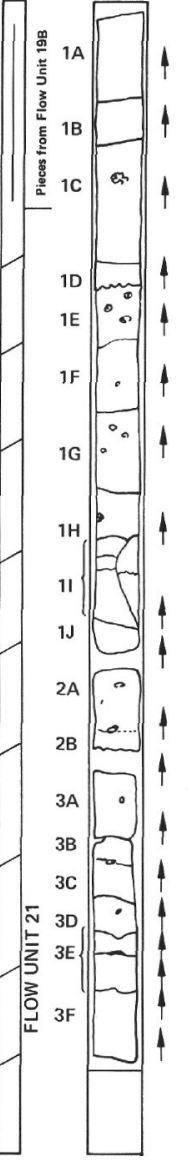

Section 2

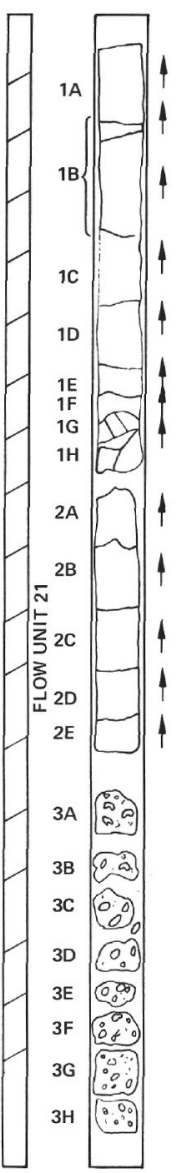

Section 3

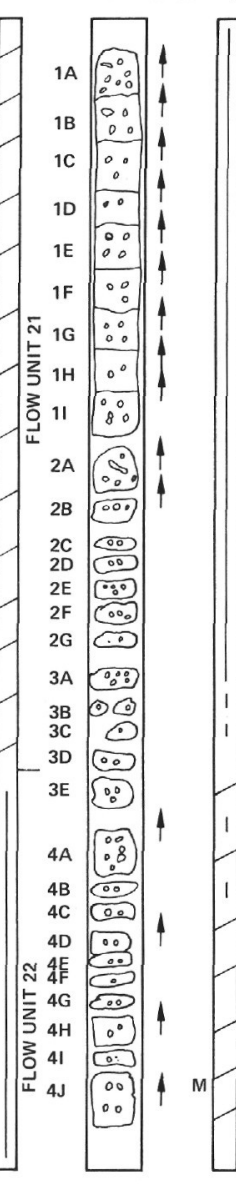

Section 4

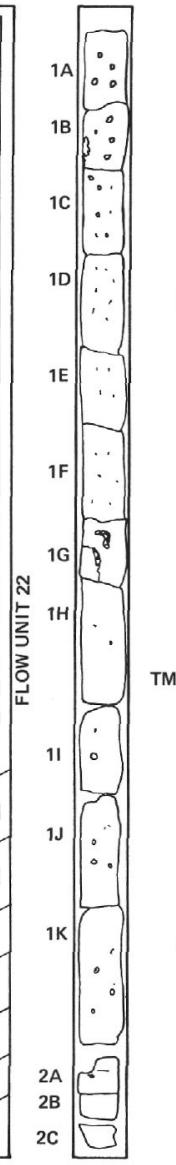

Section 5
FLOW UNIT NO. 22:

22.

CHEMISTRY: $\begin{aligned} & 145 \mathrm{~cm} \\ & \text { Tholeitic basalt, } 1 \text { analysis in Table } 1 .\end{aligned}$

Mineralogy:

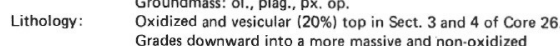
Grades down ward into a more massive and non-oxidized center and bottom.
Clay in rounundmass and filling vesicles; ol. to iddingsite; upper part extensively a

THIN SECTION DESCRIPTION

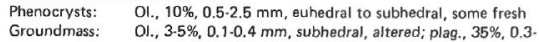

(1.

$\begin{array}{ll}\text { Texture: } & \text { Sub-ophitic } \\ \text { Alteration: } & 15 \% \text { clay atter glass, ol. iddingsitized and altered to clay }\end{array}$

MaGnetic DATA

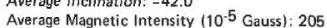

FLOW UNIT NO. 23:

.

CHEMISTRY: $\quad \begin{aligned} & 21 \mathrm{~cm} \\ & \text { Tholeititic basalt, } 1 \text { analysis in Table } 1 .\end{aligned}$

VISUAL DESCRIPTION

Mineralogy: Phenocrysts: ol. (microphenos), 0.25\%, $0.5 \mathrm{~mm}$, altered

Lithology: Vesicles 10-25\% throughout, ol. microphenos mostly at

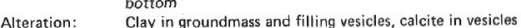

THIN SECTION DESCRIPTION

Phenocrysts:
Groundmass:

20\%, 0.2-1 mm, ophitic, op., 5\%, $0.05-0.15 \mathrm{~m}$

$\begin{array}{lll}\text { Texture: } & \text { Ophitic, sub-trachytic } \\ \text { Alteration: } & 20 \% \text { clay after glass }\end{array}$

MAGNETIC DATA

Average Inclination: $-39.2^{\circ}$
Average Magnetic Intensity
$\left(10^{-5}\right.$ Gauss): 128 
LEG 55 SITE 433 HOLE C CORE 27 DEPTH $336.0-345.5 \mathrm{~m}$

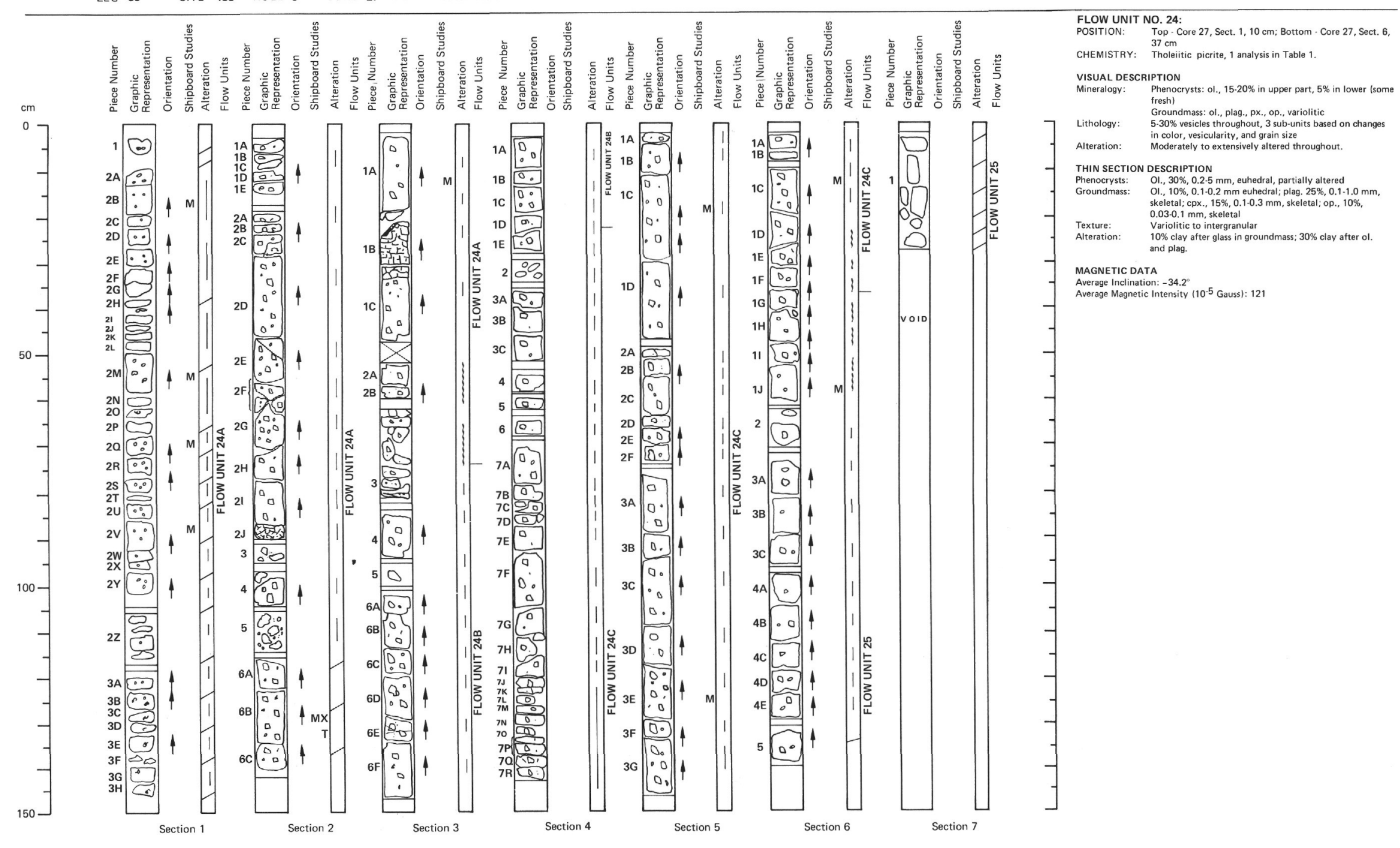




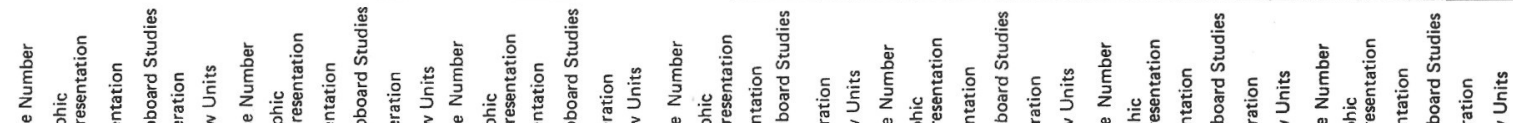
CHEMISTRY: Tholeitic basalt, 1 analysis in Table 1.

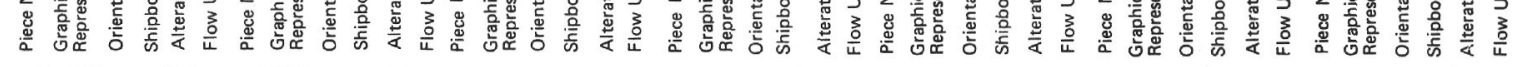

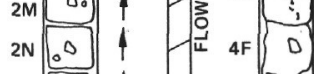

20

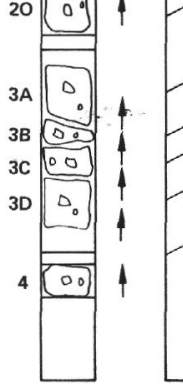

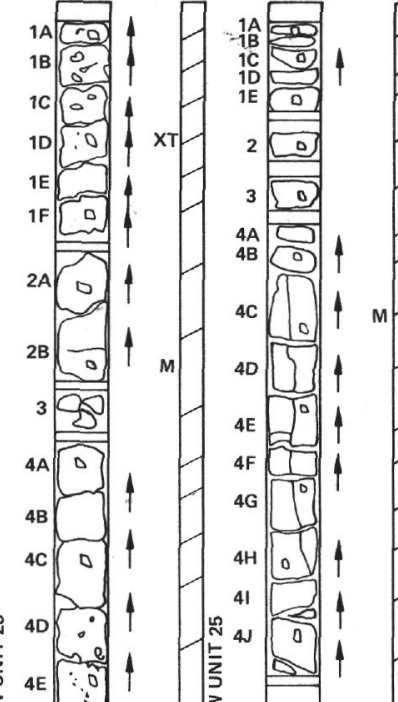

$2 \mathrm{~L}$ 1

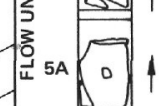

IA 5 A 1

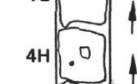

$4 \mathrm{H} .0$

1 Sc

4. 15

Section 1 Section 2

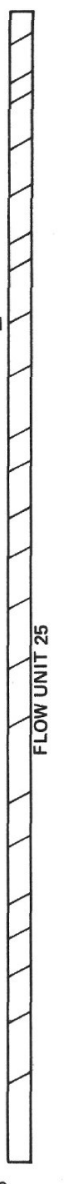

Section 3

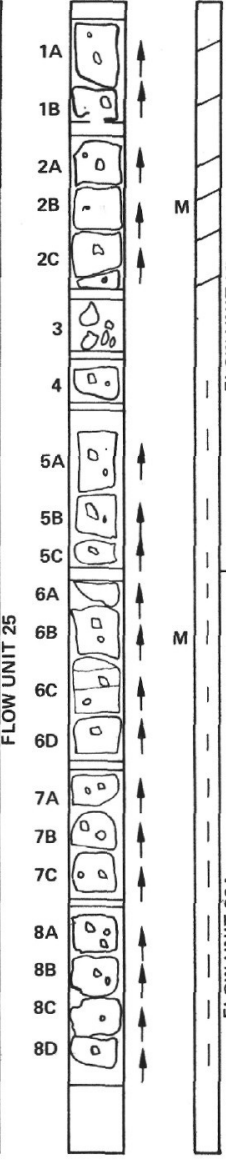

Section 4

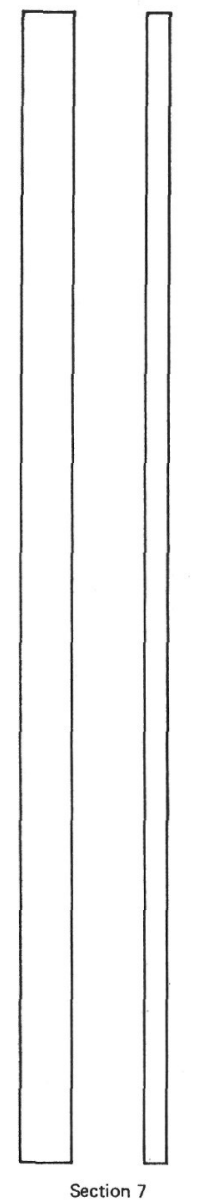

VISUAL DESCRIPTION

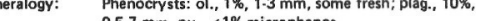

px., $21 \%$ microphenen

Core 27, Sect. 6 contains a brecciated, oxidized, and in abundance downward $/ \mathrm{s}$ oxidized.
in

Alte THIN SECTION DESCRIPTION O1. $2 \%, 0.22 .5 \mathrm{~mm}$, euhedral; plag. $18 \%, 0.2 .4 \mathrm{~mm}$ euhedral, cpx., $5 \%, 0.15-2.0 \mathrm{~mm}$, euhedral; some

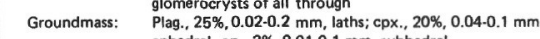
Texture: Intedral, op.., $3 \%, 0.01-0.1 \mathrm{~mm}$, subhedral $2 \%, 0.40 .8 \mathrm{~mm}$, clay filled MAGNETIC DATA
Average Inclination: Average Inclination: - $68.3^{\circ}$
Average Magnetic Intensity (10-5 Gauss): 239 


\section{.}

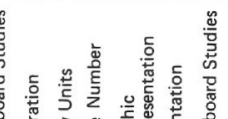

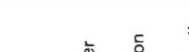
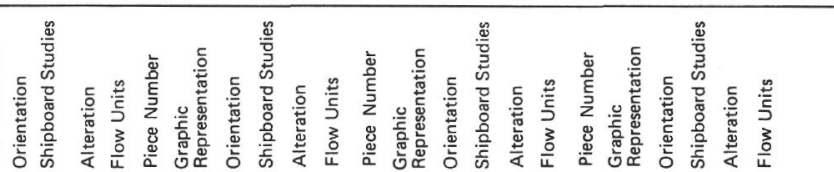

FLOW UNIT NO. 26

$28,5 e c, 4,75 \mathrm{~cm}$ : Bottom - Core 20, Sect.

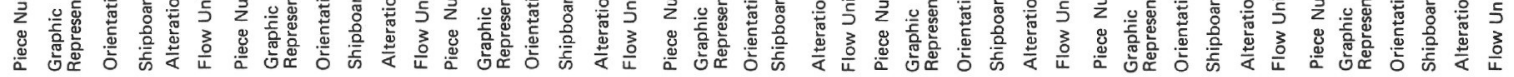

MISTRY: Tholeitic, 2 analyses in Table
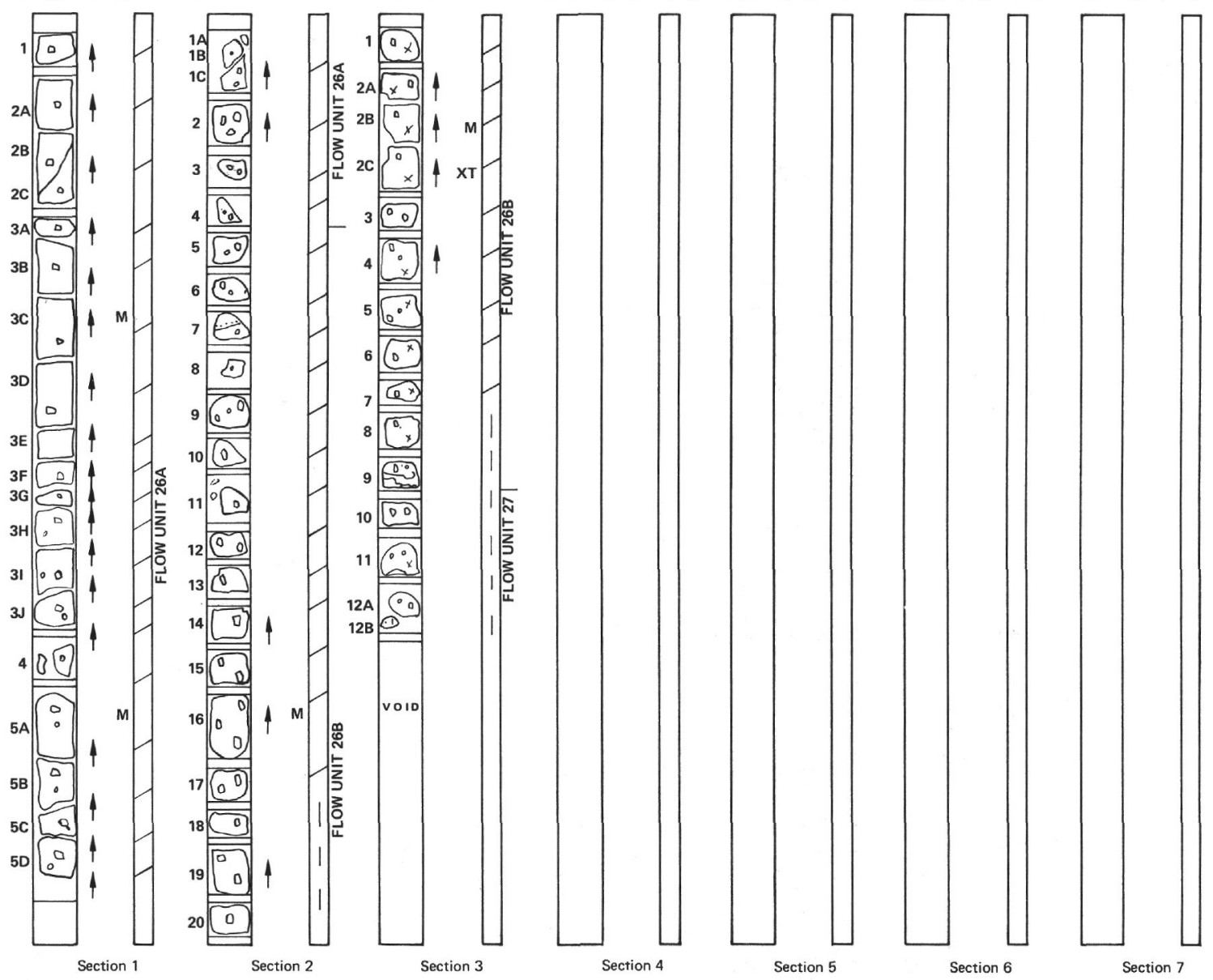

VISUAL DESCRIPTION

Phenocrysts: $01 .,<1 \%, 1-2 \mathrm{~mm}$; plag. $2 \%$ in 26A, $5 \%$ in

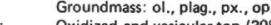

政, Sect. 4 and 5 and in Core 2 2, Sect. 2 . Two sub-units
based on changes in mineralog, vesicles, and oxidation

Alteration: $\quad \begin{aligned} & \text { should be two separate units. } \\ & \text { Clay in roundmass and filling vesicles }- \text { some ol. fresh }\end{aligned}$

THIN SECTION DE

Phenocrysts: Ol., $2.5 \%$, to $2.5 \mathrm{~mm}$ euhedral; plag., $5.7 \%$, to $2 \mathrm{~mm}$

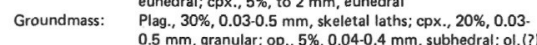

Texture: altered, $0.15 \%$ a 1 interstitial variolitic to sub-trachytic

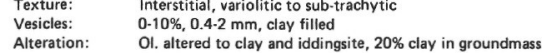

MAGNETIC DATA

Average Inclination: - $68.1^{\circ}(26 \mathrm{~A}),-20^{\circ}(26 \mathrm{~B})$
Average Magnetic intensity (10-5 Gauss): 206 (26A), 526 (268) 
LEG 55 SITE 433 HOLE C CORE 30 DEPTH $364.5-374.0 \mathrm{~m}$

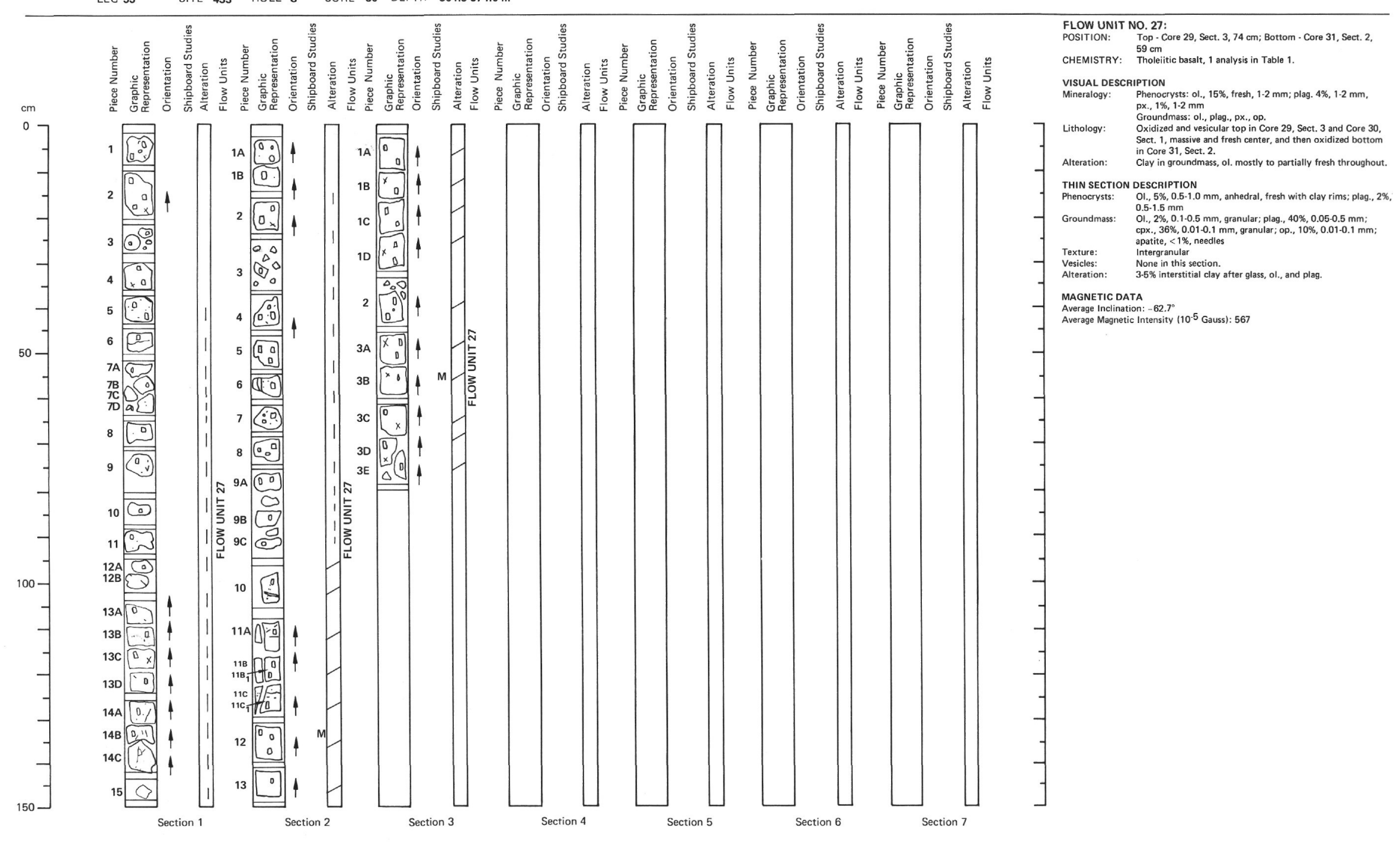


LEG 55 SITE 433 HOLE C CORE 31 DEPTH 374.0-383.5 m

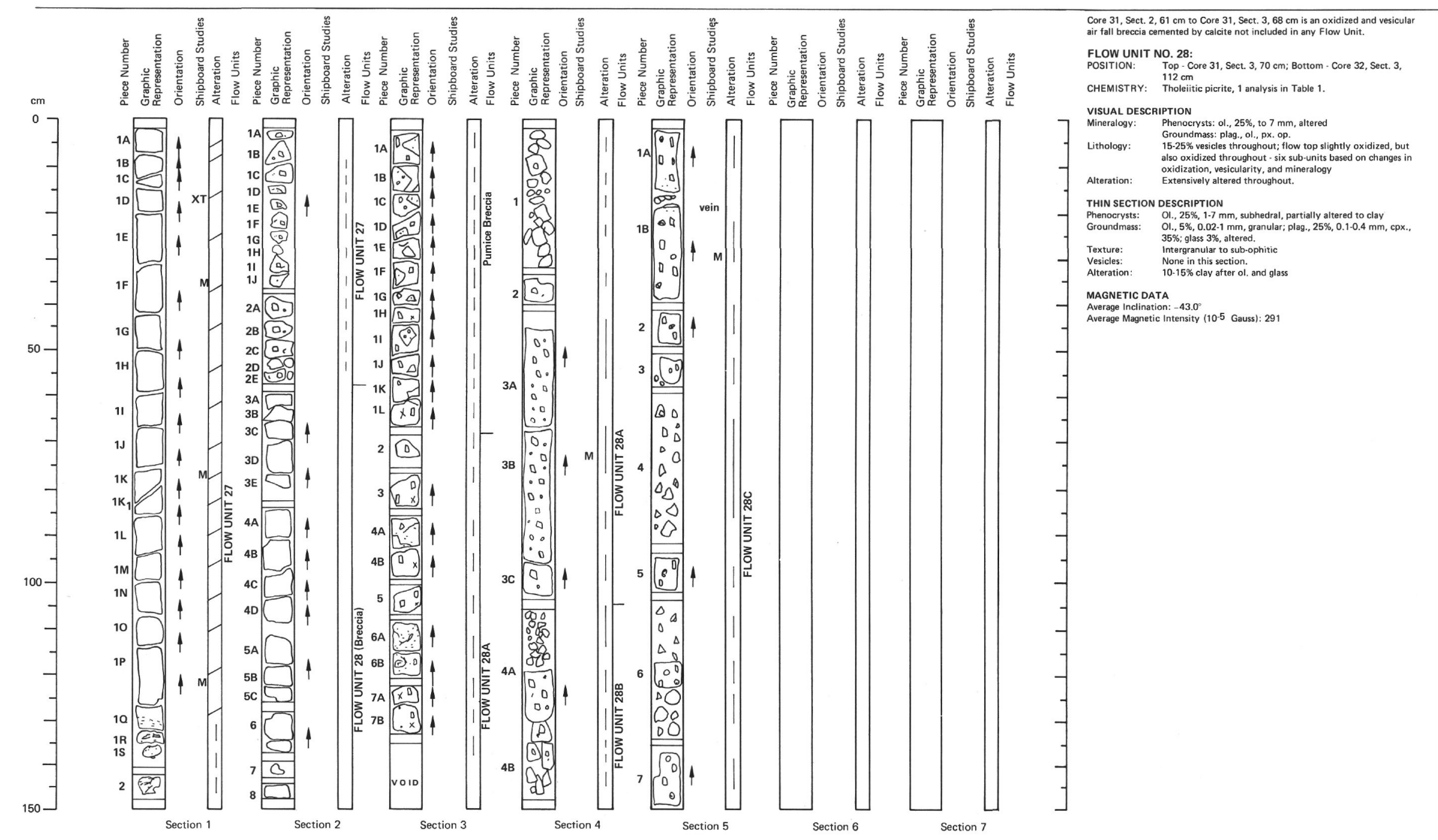


LEG 55 SITE 433 HOLE C CORE 32 DEPTH $383.5-393.0 \mathrm{~m}$

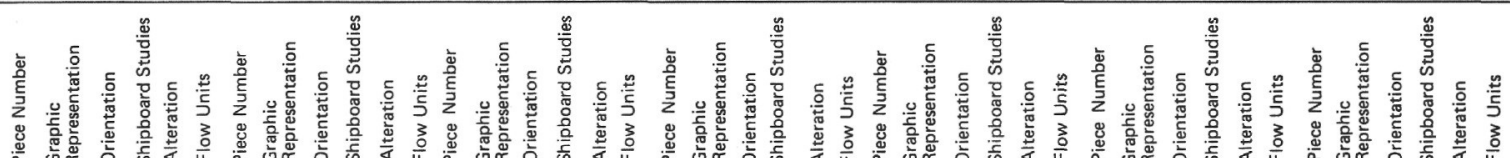

FLOW UNIT NO. 29:
POSITION:
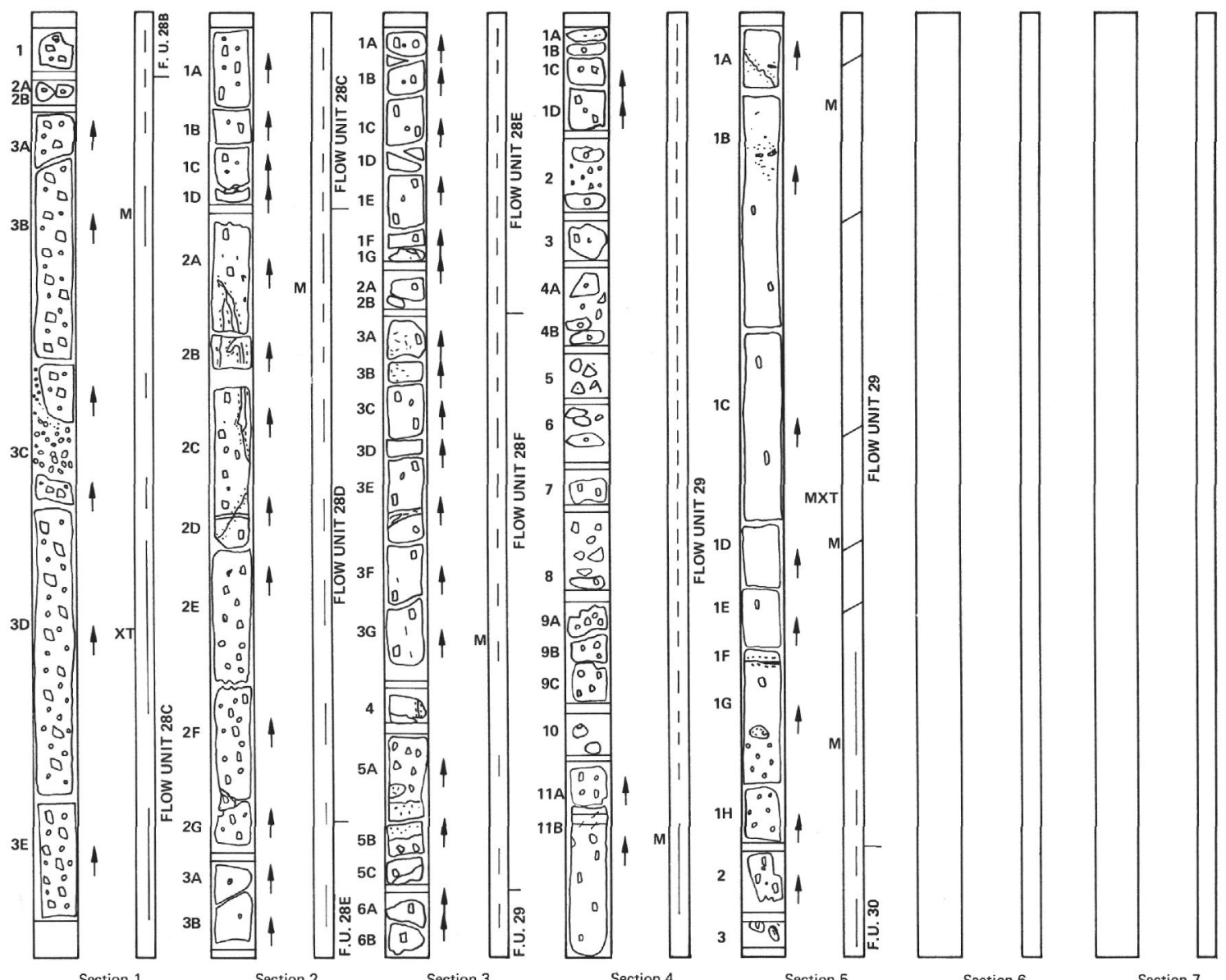

Lithologr: $\quad 0-15 \%$ vesicles throughout, breccia and sandstone above.

Alteration: Clay in groundmass and vesicles.

THIN SECTION DESCRIPTION

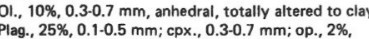

Texture: $\quad 0.05$ hitic

$\begin{array}{ll}\text { Vescicles: } & \text { Nonen in this section. } \\ \text { Alteration: } & 30 \% \text { clay after ol, glass, and plag. }\end{array}$

MAGNETIC DATA

Average Inclination: $-40.3^{\circ}$
Average Magnetic Intensity (10.5 Gauss): 461 


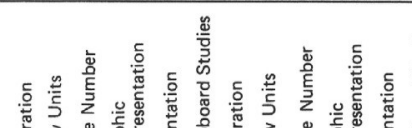

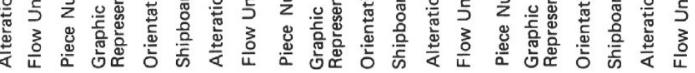
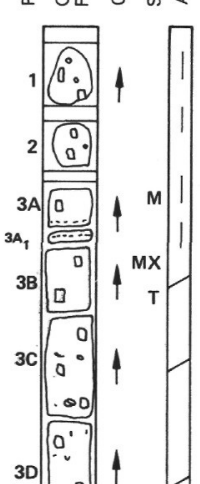

30 a

$$
\frac{0}{1,0}
$$

$3 E$.
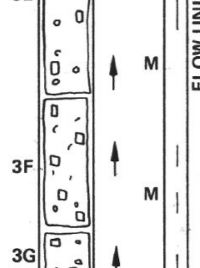

$3 \mathrm{G}\left[\begin{array}{cc}0 & 0 \\ 0 & 0 \\ 0\end{array}\right.$ $3 \mathrm{H}$

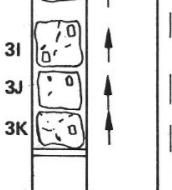

Section

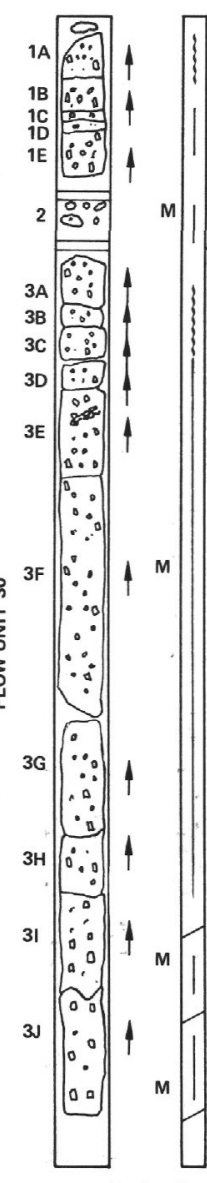

Section 2

Section 3

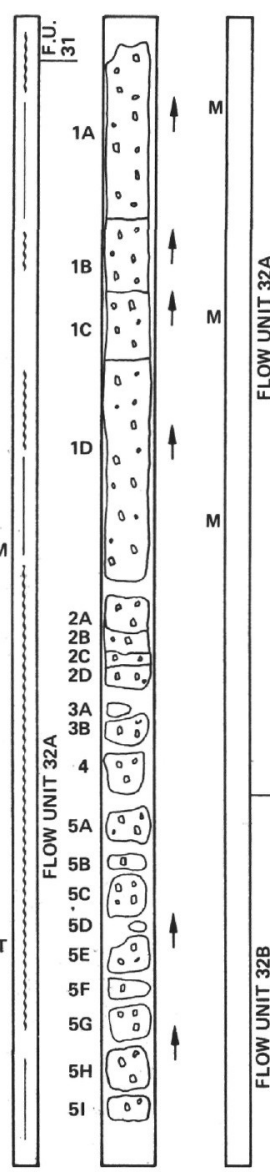

Section 5

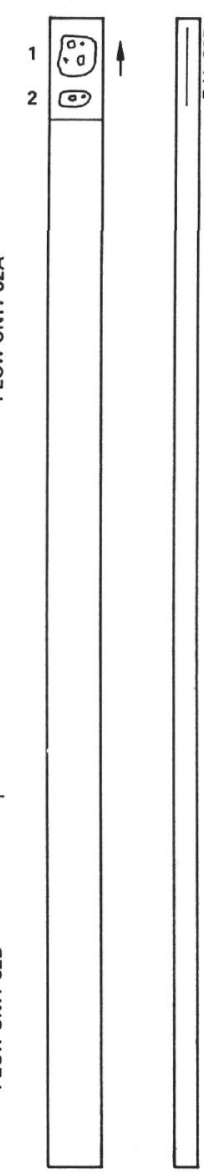

Section 6
FLOW UNIT NO. 30 CHEMISTRY: $\quad 28 \mathrm{~cm}$ Not analyzed.

VISUAL DESCRIPTION

Ple clay and iddingsite,

Ground

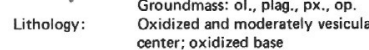

Phenocrysts: $\quad 01 ., 15 \%, 1.4 \mathrm{~mm}, 75 \%$ altered; plag., $2 \%, 24 \mathrm{~mm}$

Texture: $\quad 0.5 \mathrm{~mm} ;$ op. $3 \%, 0.010 .1 \mathrm{~mm}$

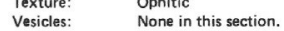

Alteration: Clay 20\% in groundmass, $1 \%$ intersitilabouse.

MAGNETIC DATA

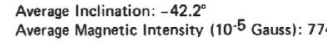

FLOW UNIT NO. 31:
POSITION:
TOp - Core 33 , Sect. 2, $30 \mathrm{~cm}$; Bottom - Core 33, Sect.

$\begin{array}{ll} & \\ \text { CHEMISTRY: } & \text { Not analyzed. }\end{array}$

VISUAL DEscription

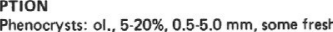

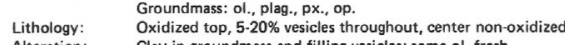

THIN SECTION DESCRIPTION

Groundmass: Ol., $3 \%, 0.02 .05 \mathrm{~mm}$, subhedral, some fresh

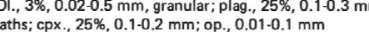

Texture: $\quad$ Ophitic

MAGNETIC DATA

Average Magnetic Intensitiv (10.5 Gusse) 1200

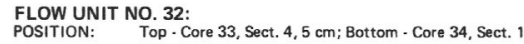

CHEMISTRY: $\quad 112 \mathrm{~cm}$ Not analyzed.

VISUAL DESCRIPTION

Phenocrysts: ol... 15.20\% (25.30\% in central parts of eact)

sub-unitit, averaga $2 \cdot 3 \mathrm{~mm}$, soma tresh

Lithology: Two sub-units (probabably lobes of the same flow), moderately

each sub-unit coarser grained

THIN SECTION DESCRIPTION

$0.5 .3 \mathrm{~mm}$, euhedral, altered

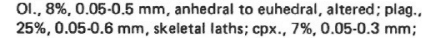

Texture: $\begin{gathered}\text { Op., } \\ \text { Intersertral }\end{gathered}$

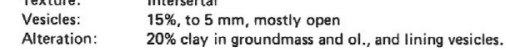

MAGNETTC DATA

Average Inclination: $-40.6^{\circ}$
Average Magnetic Intensity $\left(10^{-5}\right.$ Gauss): 1770 


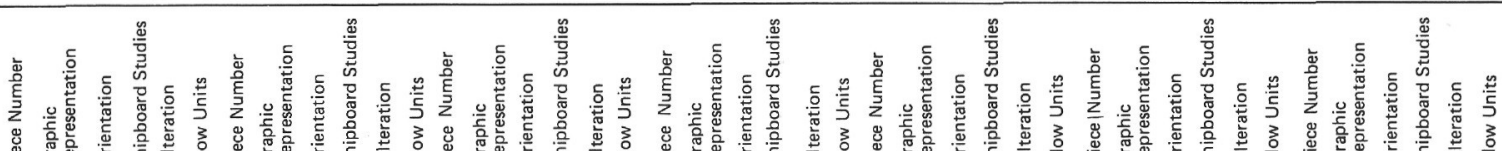

作 CHEMISTRY: $\quad 118 \mathrm{~cm}$ Not analyzed

THIN SECTION DESCRIPTION

$m$, subhedral, altered

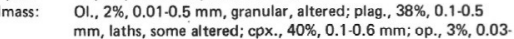

Texture: $\begin{array}{ll}0.1 \mathrm{~mm} \\ \text { Ophitic }\end{array}$

$\begin{array}{ll}\text { Vesicles: } & \text { None in this section. } \\ \text { Alteration: } & 10 \% \text { clay in groundm }\end{array}$

MAGNETIC DATA

Average Inclination: $-42.3^{\circ}$
Average Magnetic Intensity $\left(10^{-5} \mathrm{Gauss}\right): 330$

\section{Average Magnetic Intensity}

FLOW UNIT NO. 34:
POSITION:

CHEMISTRY: $\quad \begin{array}{ll}50 \mathrm{~cm} \\ \text { Not analyzed. }\end{array}$

VISUAL DESCRIPTION

Wheralogy. Thenocrysts: 0l., 10.15\%, average $1.2 \mathrm{~mm}$, some fres

\section{Lithology: Two sub-units based on textural changess slightly oxidized}

Alteration: Chroughout; vesicles $10.25 \%$ throughout.

Thin section

THIN SECTION DESCRIPTION

$\begin{array}{ll}\text { Phenocrysts: } & \text { Ol., } 10 \%, 0.5-2 \mathrm{~mm} \text {, subhedral, some fresh cores } \\ \text { Groundmass: } & \text { OI., } 3 \%, 0.05-0.5 \mathrm{~mm} \text {, granular, altered; plag. } 20 \%, 0.1 .\end{array}$

Texture: $\quad$ Ophitic

$\begin{array}{ll}\text { Texture: } & \text { Ophitic } \\ \text { Vesicles: } & 5 \% \text {, calcite filled } \\ \text { Alteration: } & \text { Clay in groundromas }\end{array}$

MAGNETIC DATA

Average Inclination:- $414^{\circ}$
Average Magnetic Intensity $\left(10^{-5}\right.$ Gauss): 342 
LEg 55 SITE 433 HOLE C CORE 35 DEPTH 412.0-421.5 m

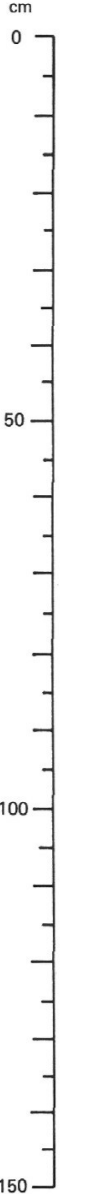

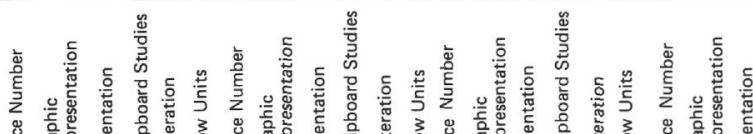

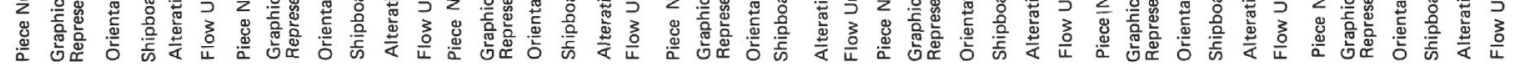

FLOW UNIT NO. 35:
POSITION: TOp - Core 34, Sect. 6, $50 \mathrm{~cm}$; Bottom - Core 35, Sect.

CHEMISTRY: Tholeitic basalt, 2 analyses in Table 1.

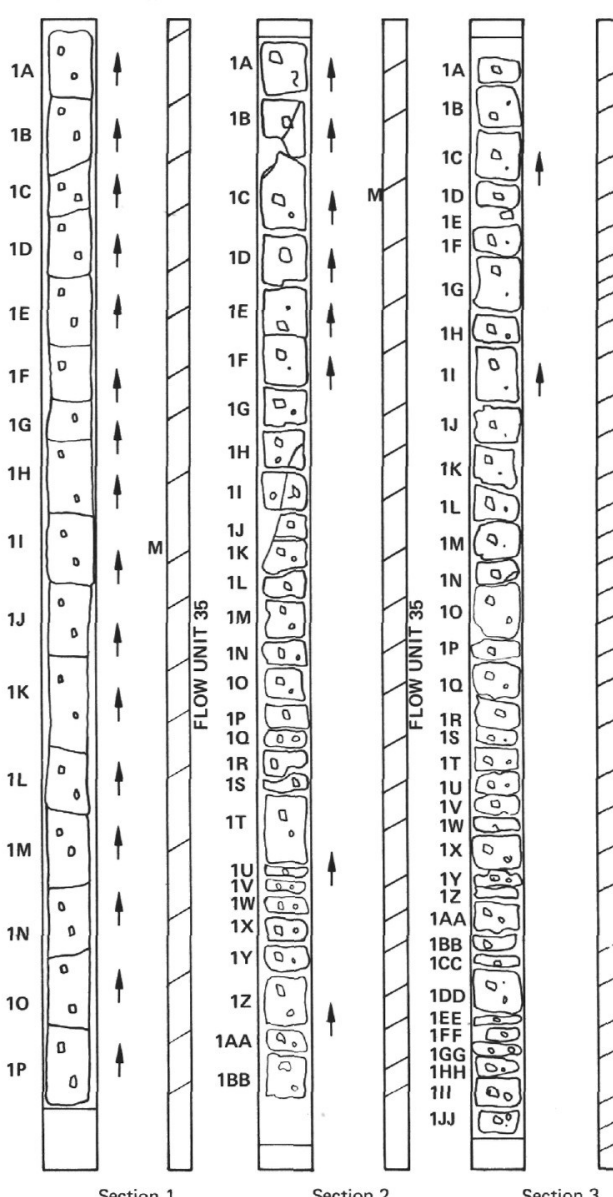

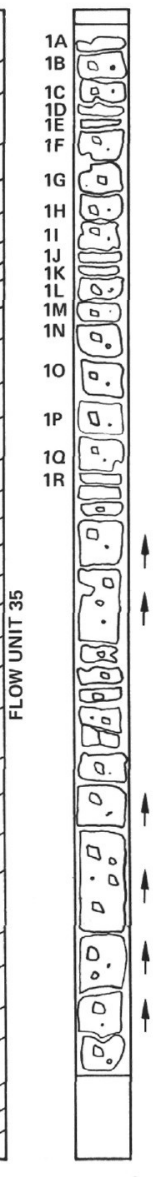

Section 3

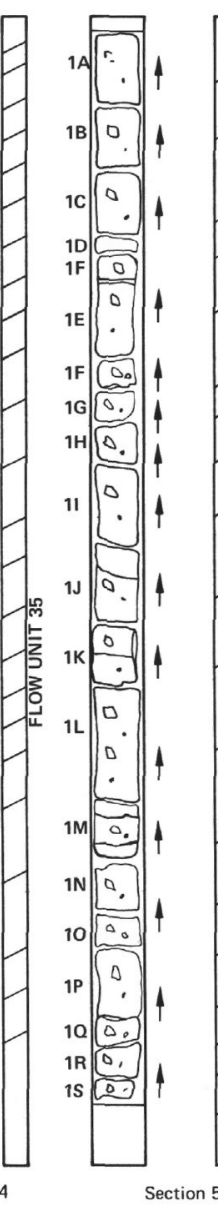

Section 5

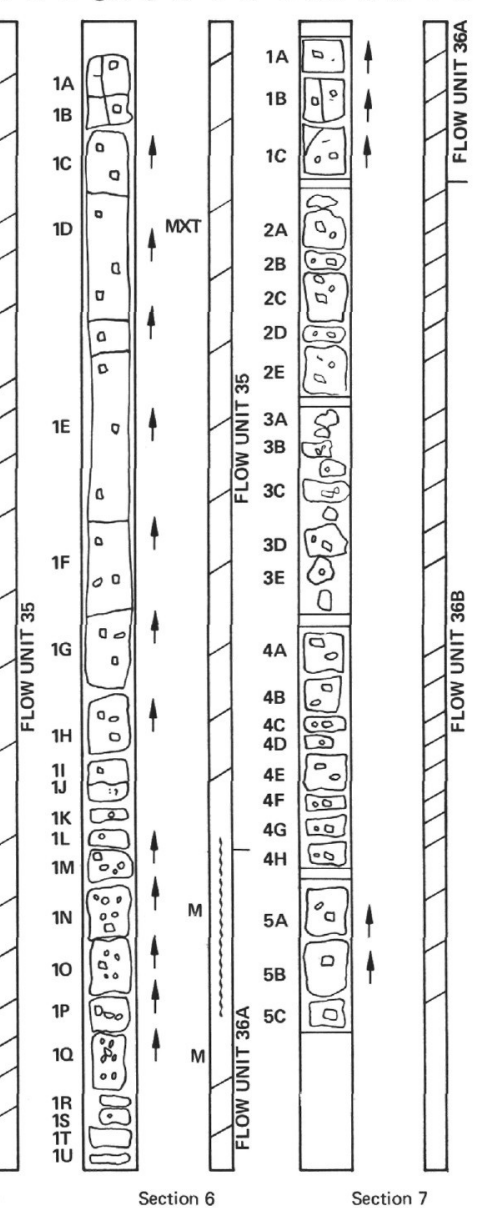

VISUAL DESCRIPTION

(more lower), $0.54 \mathrm{~mm}$, mostly altered, Gioundmass: ol., plag., px., op., clay

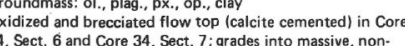
oxidized, center in Core 34, Sect. 7. Core 35, Section 1 , and oxidized Clay in groundmass; clay and calcite fill vesicles; 0 i. to idding

THIN SECTION DESCRIPTION

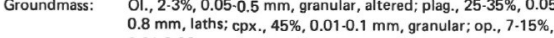

$\begin{array}{ll}\text { Texture: } & \text { Sub-trachytic, intergranular } \\ \text { Vesicles: } & \text { None in thi sectiogn }\end{array}$

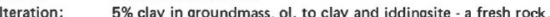
MAGNETIC DATA

Average Magnetic Intensity (10-5 Gauss): 703

FLOW UNIT NO. 36:
POSITION:
Top - Core 35, Sect. 6, $107 \mathrm{~cm}$; Bottom - Core 36, Sect. 1.

$\begin{array}{ll} & \\ \text { CHEMISTRY: } & 85 \mathrm{~cm} \\ \text { Not analyzed }\end{array}$

VISUAL DESCRIPTION
Mineralogy:
Phenocrysts: $01,10-12 \%, 0.5 .1 .5 \mathrm{~mm}$, altered; plag. $1 \%$,

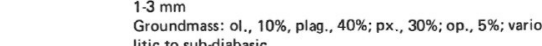

Lithology: mass: ol., 10\%, plag.. 40\%; px., 30\%; op., $5 \%$; var

Linogr: units based on ox oxidatida $20.40 \%$ vesicles throughout. two sub. Iddingsite and clly

Average Magnetic Intensity (10.5 Gauss): 351 
FLOW UNIT NO. 37:

POSITION: Top - Core 36, Sect. 1, $85 \mathrm{~cm}$; Bottom - Core 36, Sect. 2 , $60 \mathrm{~cm}$

CHEMISTRY: Tholeiitic basalt, 1 analysis in Table 1.

\section{VISUAL DESCRIPTION}

Mineralogy: Phenocrysts: ol., 10\%, 0.5-1.5 mm

Groundmass: ol., plag., px., op.

Lithology: Vitrophyric top and bottom, 10-25\% vesicles throughout

Alteration: Moderately oxidized throughout; vesicles clay lined,ol. to clay and iddingsite.

\section{THIN SECTION DESCRIPTION}

Phenocrysts: OI., $5 \%, 0.5-2.5 \mathrm{~mm}$, anhedral, altered

Groundmass: $\quad$ Ol., $3 \%, 0.1-0.5 \mathrm{~mm}$, granular; plag., $35 \%, 0.1-0.8 \mathrm{~mm}$, laths; cpx., 30\%, 0.1-0.3 mm; op., 7\%, 0.05-0.2 mm, altered glass, $10 \%$

Texture: Ophitic

Vesicles: $\quad 20 \%$, clay lined

Alteration: $\quad 10 \%$ clay after glass and ol.; ol. to iddingsite and clay

\section{MAGNETIC DATA}

Average Inclination: $-50.7^{\circ}$

Average Magnetic Intensity (10-5 Gauss): 723

FLOW UNIT NO. 38:

POSITION: Top - Core 36, Sect. 2, $60 \mathrm{~cm}$; Bottom - Core 36, Sect. 3 , $123 \mathrm{~cm}$

CHEMISTRY: Tholeiitic basalt, 1 analysis in Table 1.

\section{VISUAL DESCRIPTION}

Mineralogy: Phenocrysts: ol., 15\%, 0.5-1.0 mm, altered; plag., $<1 \%, 1 \mathrm{~mm}$

Groundmass: ol., plag., px., op.,; variolitic

Lithology: Vitrophyric top and bottom, top is vesicular $(30 \%)$, lower part more massive.

Alteration: Clay in groundmass; clay and calcite fill and line vesicles; ol. to iddingsite and clay.

Phenocrysts: Ol., $15 \%, 0.5-3 \mathrm{~mm}$, subhedral, $95 \%$ altered

Groundmass: OI., 5\%, 0.05-0.5 mm, granular; plag., 33\%, 0.1-0.7 mm some altered; cpx., $25 \%, 0.1-0.4 \mathrm{~mm}$; op. $5 \%, 0.05-0.2$ $\mathrm{mm}$; altered glass, $7 \%$

Texture: Ophitic

Alteration: $\quad 5 \%$ calcite patches in groundmass; clay in groundmass; ol. to clay and iddingsite.

\section{MAGNETIC DATA}

Average Inclination: $-51.0^{\circ}$

Average Magnetic Intensity (10-5 Gauss): 825

FLOW UNIT NO. 39:

POSITION: Top - Core 36, Sect. 3, $122 \mathrm{~cm}$; Bottom - Core 36, Sect. 4, $124 \mathrm{~cm}$

CHEMISTRY: Tholeiitic basalt, 1 analysis in Table 1.

\section{VISUAL DESCRIPTION}

Mineralogy: Phenocrysts: ol., $15-25 \%, 0.5-1.5 \mathrm{~mm}$, altered

$\begin{array}{ll} & \text { Groundmass: ol., plag., px., op. } \\ \text { Lithology: } & \text { Vitrophyric top and bottom }\end{array}$

SITE 433 HOLE C CORE 36 DEPTH $421.5-431.0 \mathrm{~m}$

Alteration:

Clay in groundmass; ol. to iddingsite and clay; clay and calcite fill vesicles

THIN SECTION DESCRIPTION

Phenocrysts: OI., $15 \%, 0.5-2 \mathrm{~mm}$, anhedral, altered

Groundmass: $\quad$ OI. $2 \%, 0.1-0.5 \mathrm{~mm}$, granular, altered; plag., $33 \%, 0.1$.

$0.5 \mathrm{~mm}$, laths, partly altered; cpx., $20 \%, 0.05-0.2 \mathrm{~mm}$;

op., $5 \%, 0.02-0.1 \mathrm{~mm}$, altered glass, $10 \%$

Texture: Ophitic

Alteration: $\quad 15 \%$ clay in groundmass; ol. to clay and iddingsite.

\section{MAGNETIC DATA}

Average Inclination: $-54.4^{\circ}$

Average Magnetic Intensity (10-5 Gauss): 346

FLOW UNIT NO. 40:

POSITION: $\quad$ Top - Core 36, Sect. 4, $124 \mathrm{~cm}$; Bottom - Core 36, Sect. 5 , $35 \mathrm{~cm}$

CHEMISTRY: Not analyzed.

\section{VISUAL DESCRIPTION}

Mineralogy: Phenocrysts: ol., 15\%, 0.5-1.5 mm, altered

Groundmass: ol., plag., px., op.; variolitic

Alteration: Clay in groundmass; clay and calcite lined and filled vesicles; ol. to iddingsite and clay.

MAGNETIC DATA

Average Inclination: $-51.8^{\circ}$

Average Magnetic Intensity (10-5 Gauss): 1900

\section{FLOW UNIT NO. 41:}

POSITION: Top - Core 36, Sect. 5, $36 \mathrm{~cm}$; Bottom - Core 36, Sect. 6 . $14 \mathrm{~cm}$

CHEMISTRY: Tholeiitic basalt, 1 analysis in Table 1.

\section{VISUAL DESCRIPTION}

Mineralogy: Phenocrysts: ol., $15 \%, 0.5-1.5 \mathrm{~mm}$, altered

Groundmass: ol., plag., px., op., clay

Lithology: $\quad$ Fine-grained top and bottom; vesicles decrease in size and abundance downward.

Alteration: $\quad$ Clay in groundmass; vesicles lined and filled by clay and calcite; ol. to iddingsite and clay.

\section{THIN SECTION DESCRIPTION}

Phenocrysts: $\quad$ OI., 7\%, 0.5-2 $\mathrm{mm}$, subhedral, altered

Groundmass: $\quad$ Ol., 3\%, 0.05-0.5 mm, granular; plag., 35\%, 0.1-0.5 mm, laths, partially altered; cpx., 35\%, 0.1-0.3 mm; op., 0.01$0.1 \mathrm{~mm}$; altered glass, $10 \%$

Texture:

Vesicles: Ophitic

$30 \%$

Alteration: $\quad 40 \%$ clay in vesicles and groundmass; ol. to iddingsite and clay.

MAGNETIC DATA

Average Inclination: $-53.9^{\circ}$

Average Magnetic Intensity (10-5 Gauss): 630 
LEG 55 SITE 433 HOLE $\mathrm{C}$ CORE 37 DEPTH $431.0440 .5 \mathrm{~m}$

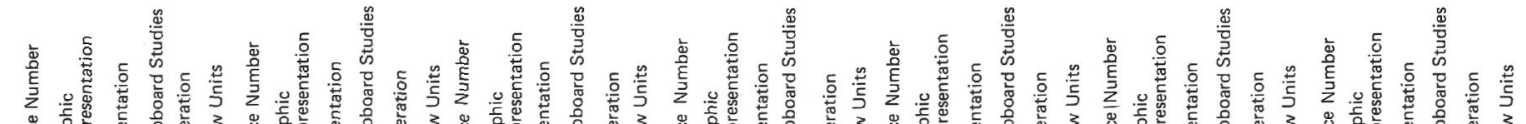

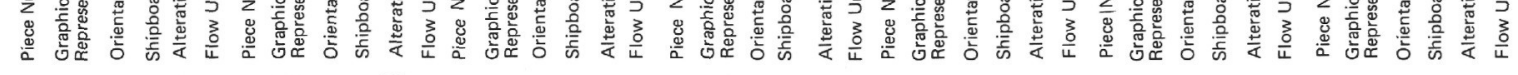

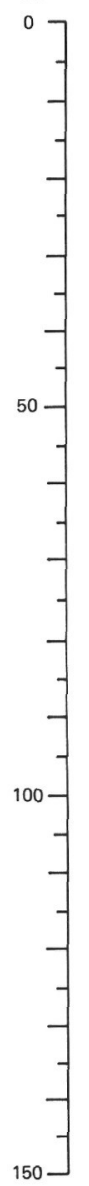

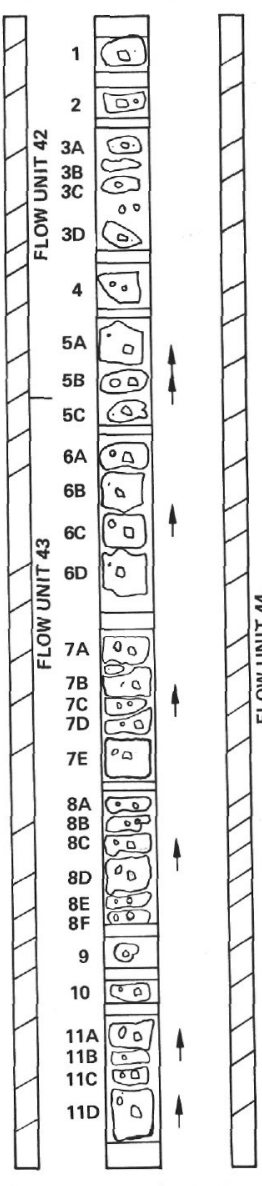

Section 2

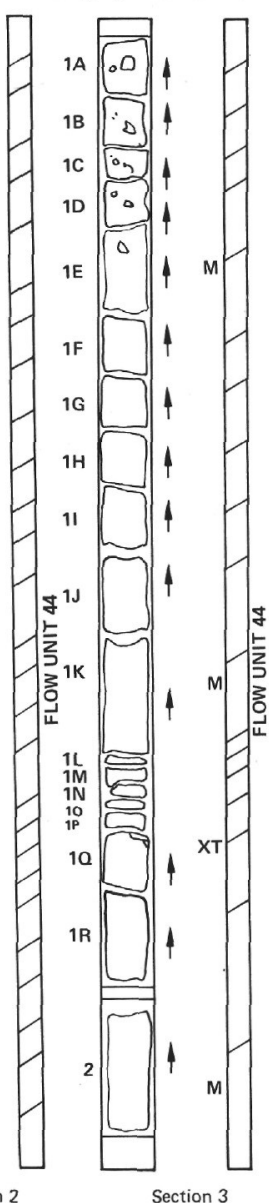

Section 3

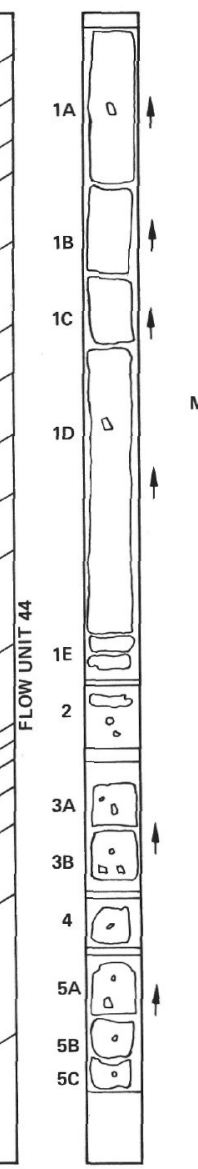

Section 4

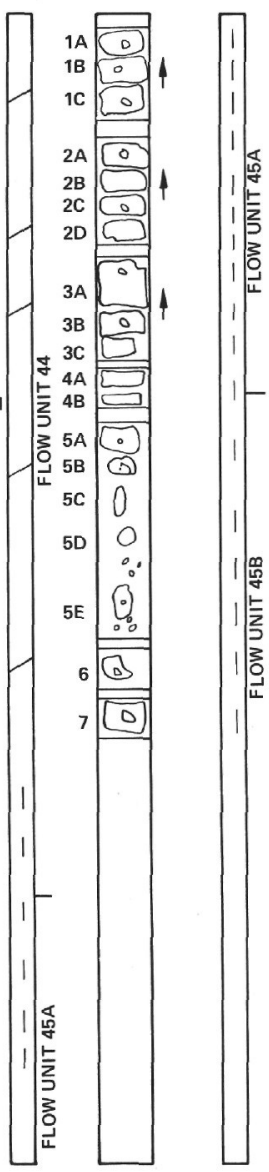

Section 5

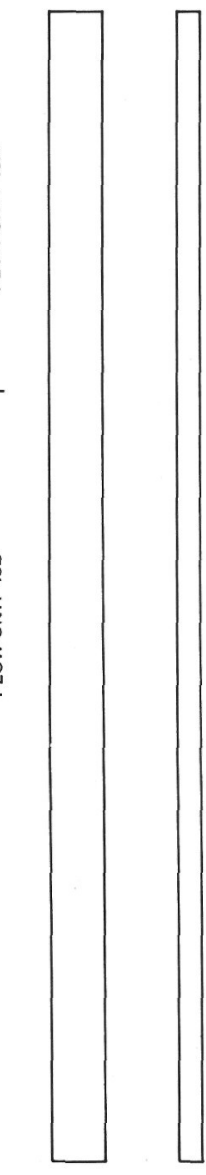

Section 6

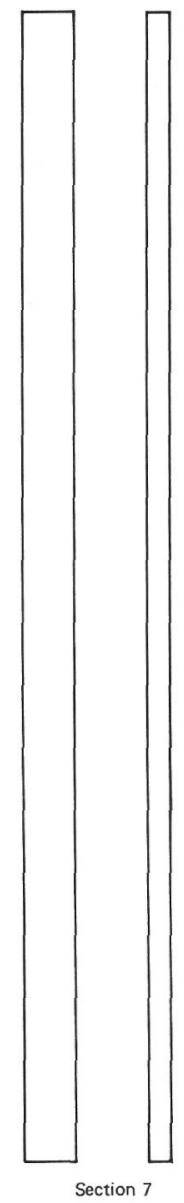

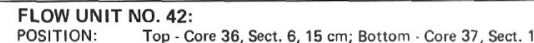
$\begin{array}{ll}\text { POSITION: } & \text { Top - Core } 36 \\ \text { CHEMISTRY: } & 50 \mathrm{~cm} \\ & \text { Not analyzed }\end{array}$

VISUAL DESCRIPTION

Mineralogy: Phenocrysts: $01 ., 15 \%, 0.5-3 \mathrm{~mm}$, altered

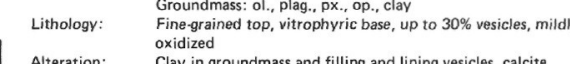

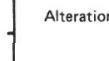
Clay in groundmas
filling vesicles.

- FLOW UNIT NO. 43:

POSITION: Top - Core 37, Sect. 1, $50 \mathrm{~cm}$; Bottom - Core 37, Sect. 2, CHEMISTRY: Not analyzed.

VISUAL DESCRIPTION

. $15 \%, 0.5 \cdot 2 \mathrm{~mm}$, altere

$\begin{array}{ll}\text { Lithology: } & \text { Groundmass: ol., plag., px., op., clay } \\ \text { Vitrophyric top and bottom tall glass altered). Vesicular }\end{array}$

top, down center and base

FLOW UNIT NO. 44:
POSITION:

CHEMISTRY: $\quad 113 \mathrm{~cm}$ Tholeitic basalt, 1 analysis in Table 1.

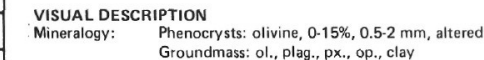

Lithology: Vitrophyric top and bottom; top vesicular (30\% vesicles)

Alteration: $\quad$ center massive, base 4 bex vesicl

THIN SECTION DESCRIPTION

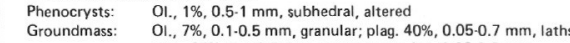

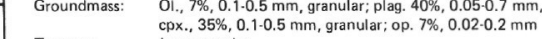

- Texture: Intergranular

Alleration: $\quad 10 \%$ clay in groundmass: ol to iddingsite and clay

MAGNETIC DATA

Average Inclination:- -49.3
Average Magnetic Intensity (10

FLOW UNIT NO. 45:

FLOW UNIT NO. 45:
POSITION: Top - Core 37, Sect. 4, $115 \mathrm{~cm}$; Bottom - Core 38 , Sect.

CHEMISTRY: Tholeitici basalt, 1 analysis in Table 1.

VISUAL DESCRIPTION

VISUAL DESCRIPTION
Mineralogy: Phenourst

Phenocrysts: 0.1.2.2.10\%, $0.5-2 \mathrm{~mm}$, mostly altered ffresh in

$\begin{array}{ll}\text { Groundmass: ol., plag., px., op., clay } \\ \text { Lithology: } & \text { Two subunits separated by. vitrophyre; vitrophyric top, }\end{array}$

Alteration: $\quad \begin{aligned} & \text { vesicles } 10.30 \% \text { throughout } \\ & \text { Clay in groundmass: } 1 \text {. mostly to clay and iddingsit. }\end{aligned}$

THIN SECTION DESCRIPTION

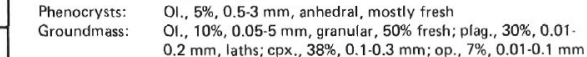

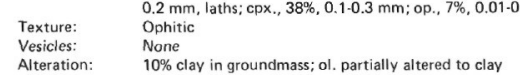

Alteration: $10 \%$

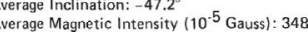


LEG 55 SITE 433 HOLE C CORE 38 DEPTH $440.5-450.0 \mathrm{~m}$

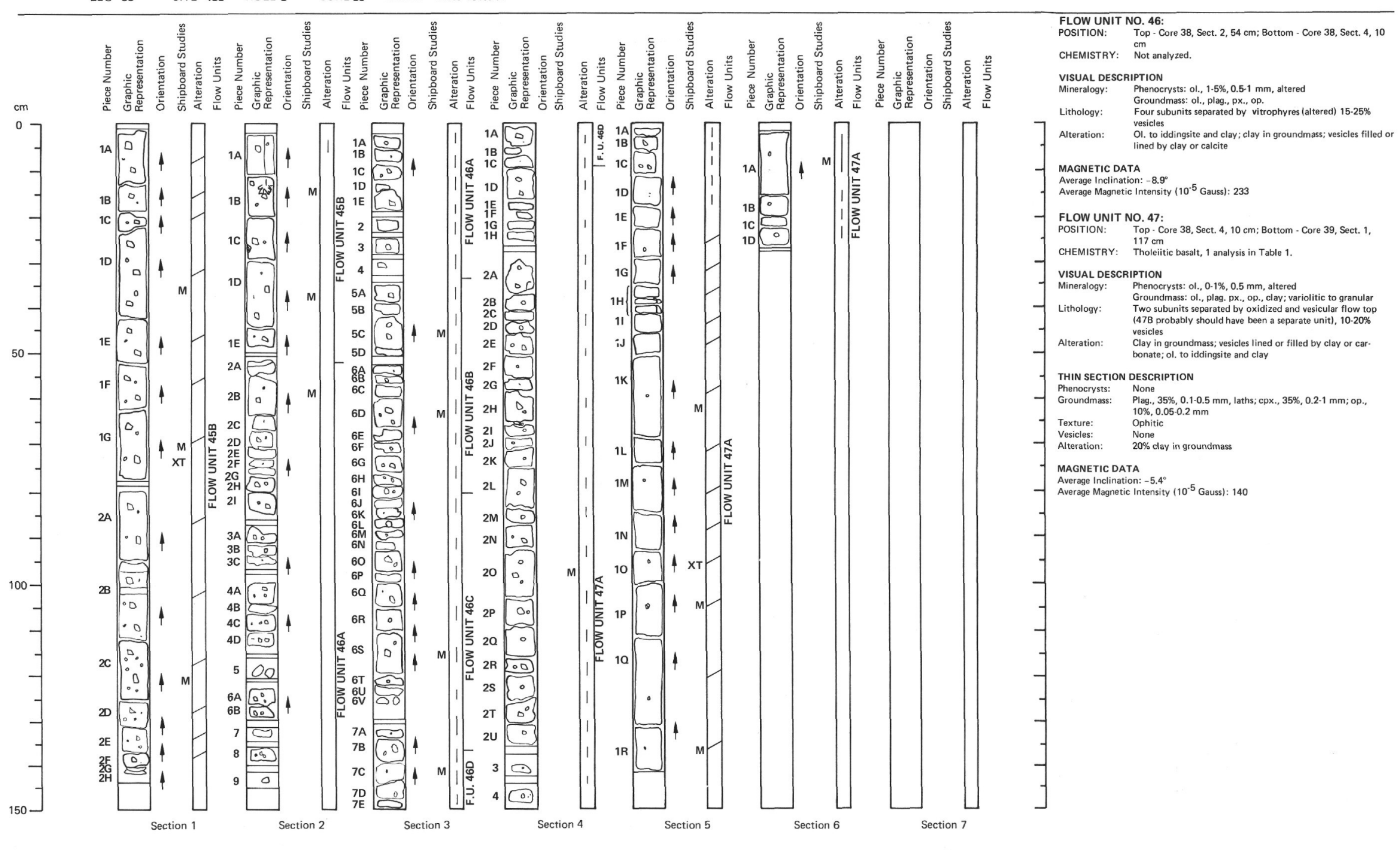


LEG 55 SITE 433 HOLE C CORE 39 DEPTH $450.0-459.5 \mathrm{~m}$

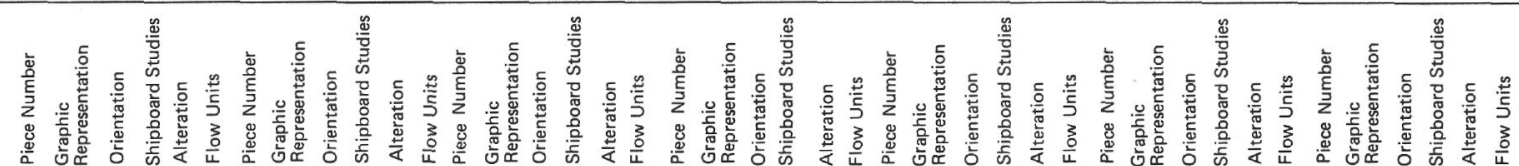

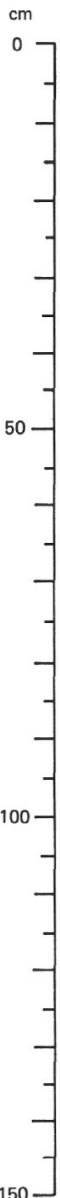
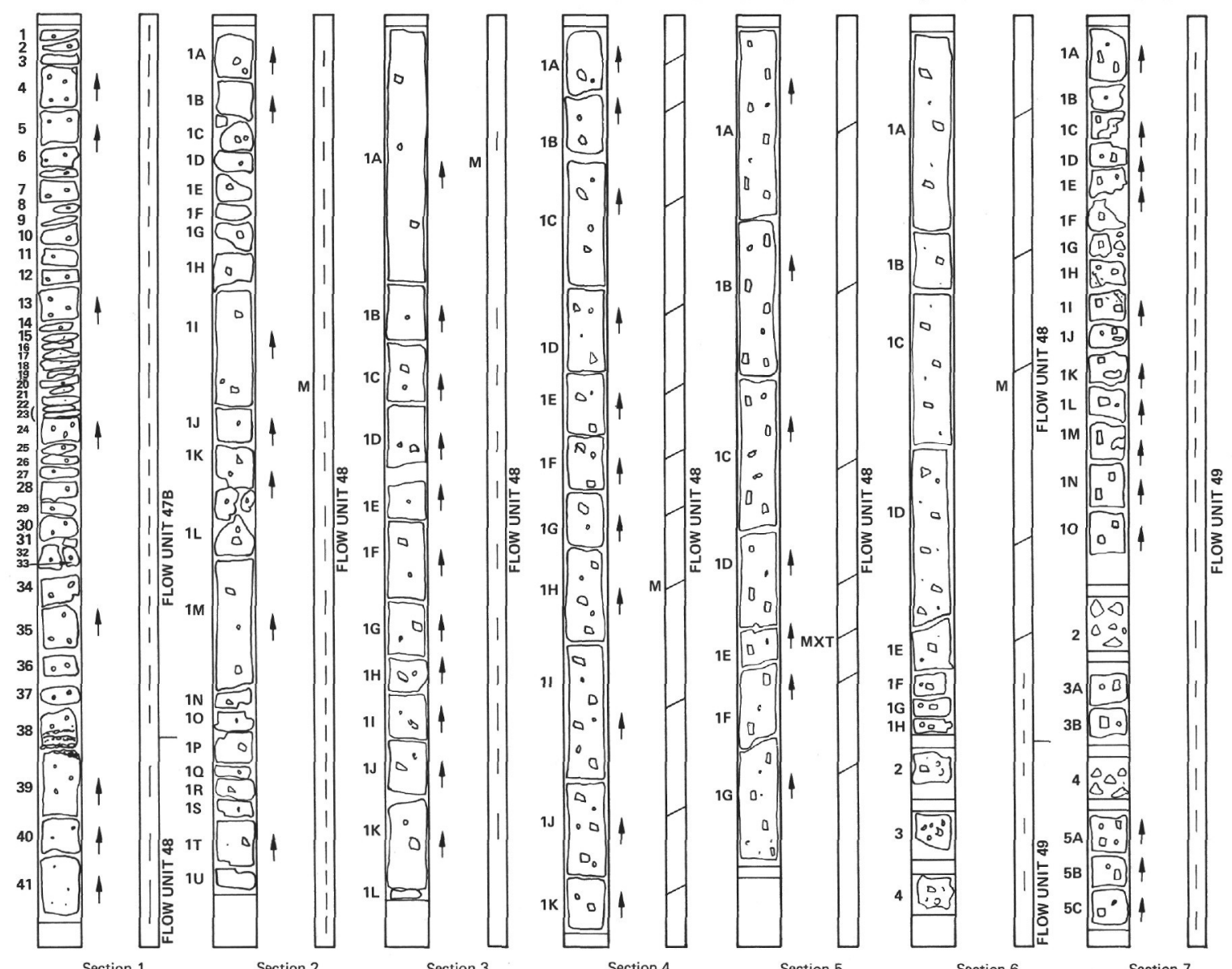

FLOW UNIT NO. 48

POSITION: Top - Core 39, Sect, 1, $117 \mathrm{~cm}$ : Botrom Core 39, Sect 6

CHEMISTRY: $\quad 117 \mathrm{~cm}$. Tholeitic basalt, 1 analysis in Table 1 .

Phenocrysts: $01 ., 5.10 \%, 0.5-1.5 \mathrm{~mm}$, some fresh in Sect. 5 of

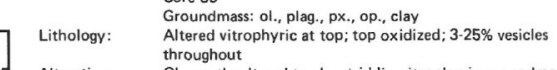

$\begin{array}{ll}\text { Alteration: } & \begin{array}{l}\text { throughout } \\ \text { Ol. mostly aterered to clay }+ \text { idd } \\ \text { vesicles filled or lined by clay }\end{array}\end{array}$

THIN SECTION DESCRIPTION

Ghenocrysts: $\quad 01 ., 5 \%, 0.5-1 \mathrm{~mm}$, subhedral, $50 \%$ altered

$35 \%, 0.02 \cdot 0.06 \mathrm{~mm}$, granular: op., $5 \%, 0.02-0.2 \mathrm{~mm}$

Vexture: Intes: $\quad$ Nengrant

Alteration: $\quad 15 \%$ clay in groundmass; ol. to iddingsite + clay

MAGNETIC DATA

Average Inclination: $-43.0^{\circ}$
Average Magnetic Intensity (10-5 Gauss): 162

FLOW UNIT NO. 49

.

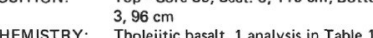

VISUAL DESCRIPTION

VISUAL DESCRIPTION
Mineralogy: Phenocrysts: $01 ., 10 \%, 1.4 \mathrm{~mm}$, mostly altered

Lithology: Oxidized and aldar flow top; glassy (altered) $6 \mathrm{~cm}$;

and lower part of flow massive and non-oxidized
Alteration:
Ol. mostly to iddingsite clay, some fresh in Core 40,

THIN SECTION DESCRIPTION

Phenocrysts:
Groundmass:

$\begin{array}{ll}\text { Texture: Intergranular } & \\ \text { Vesicles: } & \text { Not }\end{array}$

Alteration: $\quad 15$ to $20 \%$ clay in gro

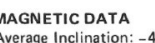

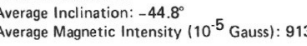




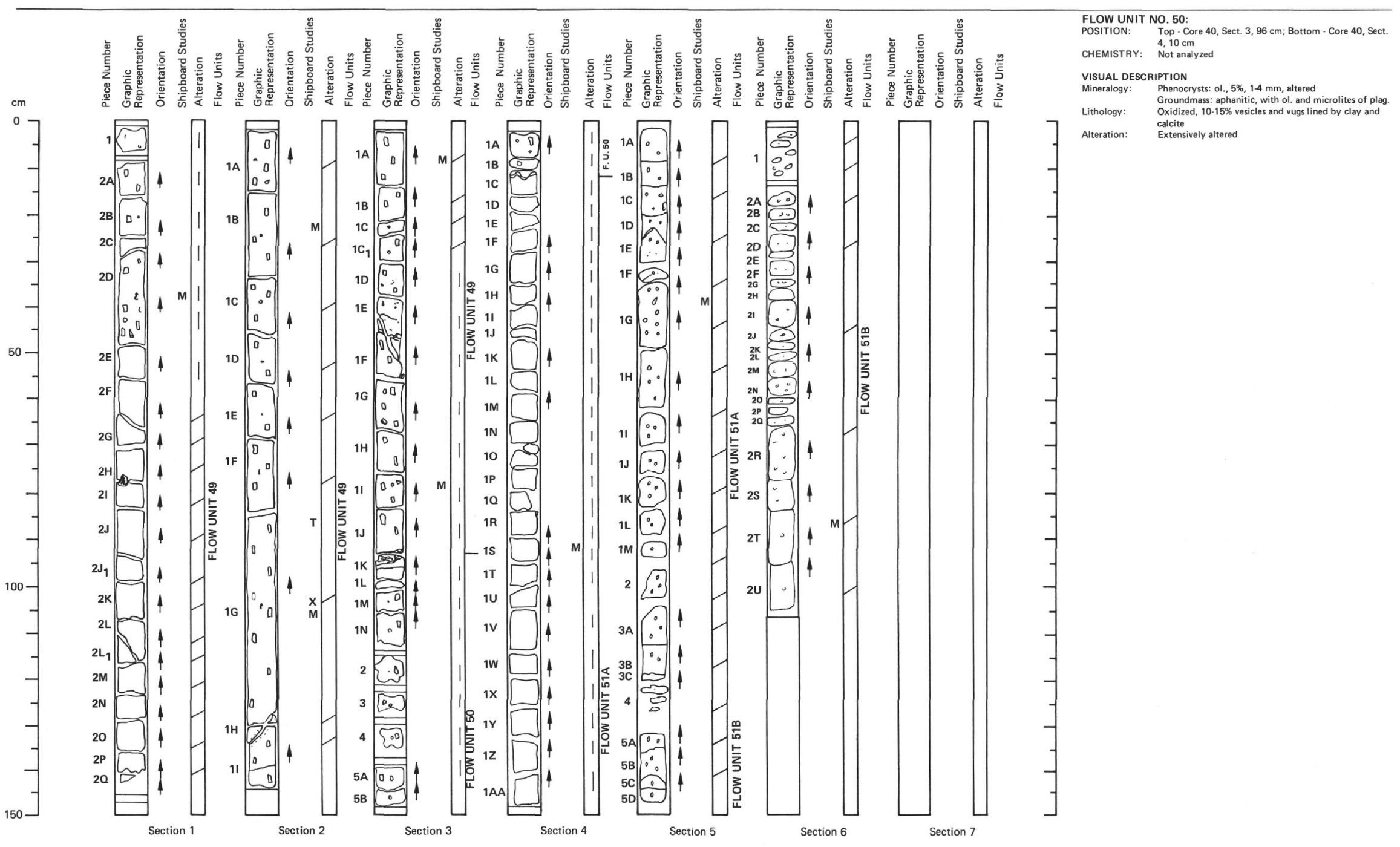


LEG 55 SITE 433 HOLE C CORE 41 DEPTH $\quad 469.0-478.5 \mathrm{~m}$

FLOW UNIT NO. 51: $\quad$ 40, Sect. $4,10 \mathrm{~cm}$; Bottom- Core 41, Sect. 6, 70

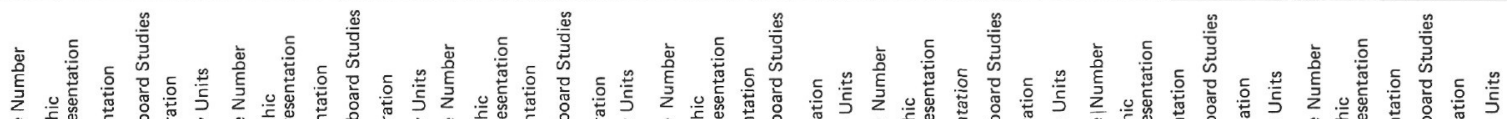

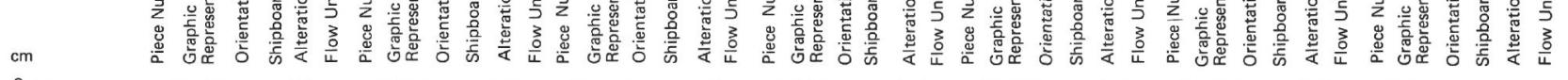




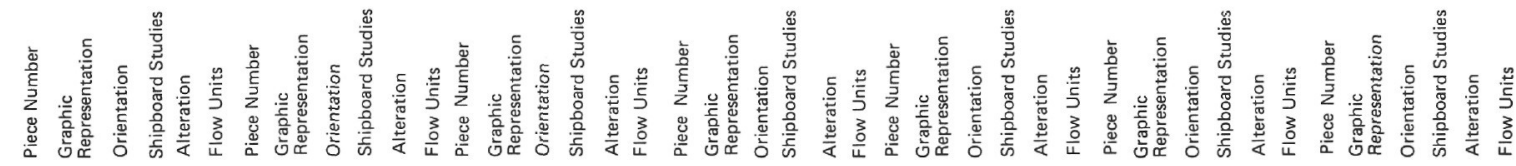

-
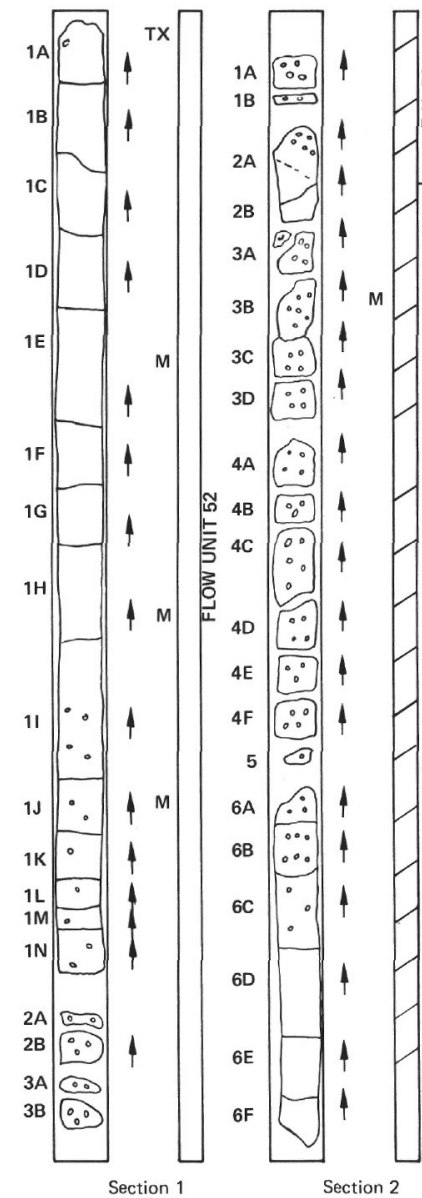

Section 2

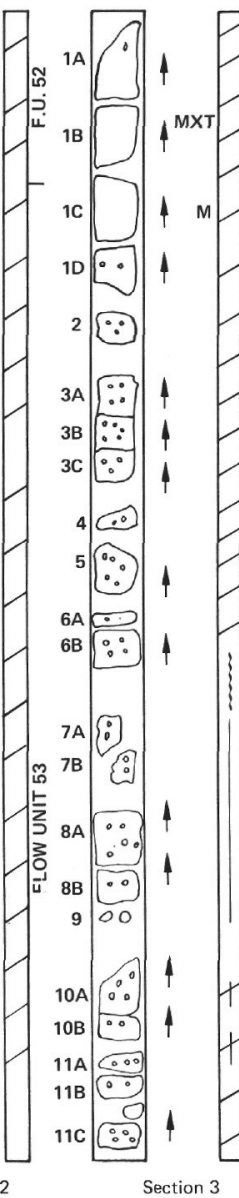

Section 3
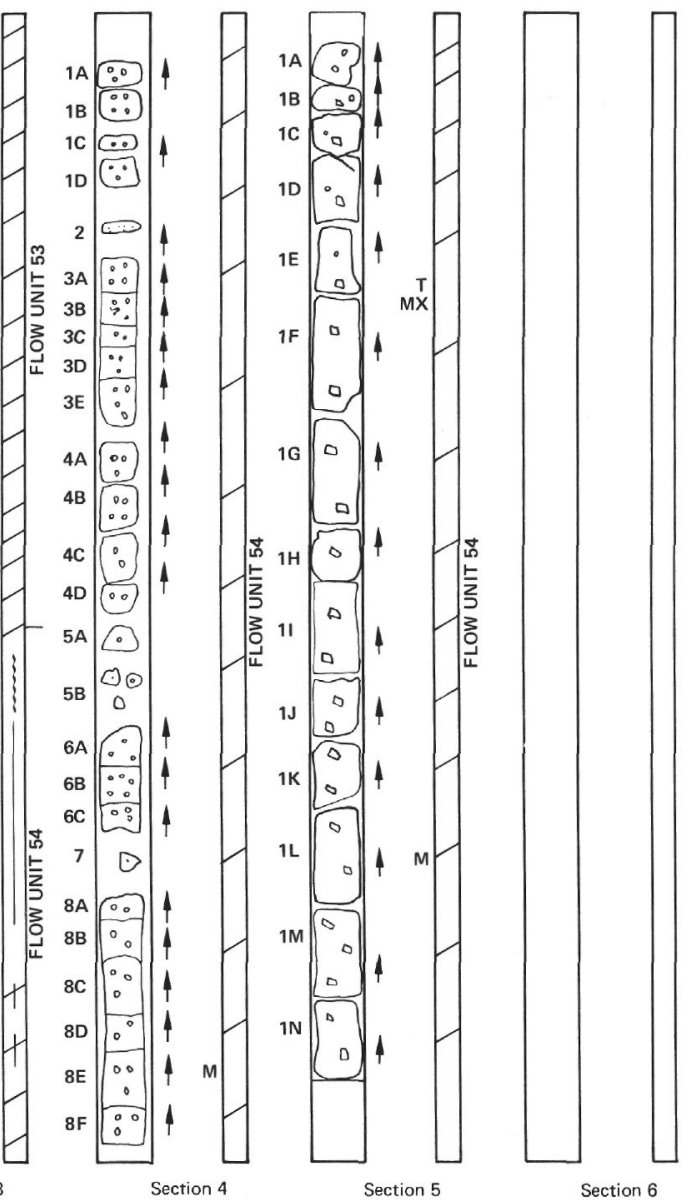

Section 6

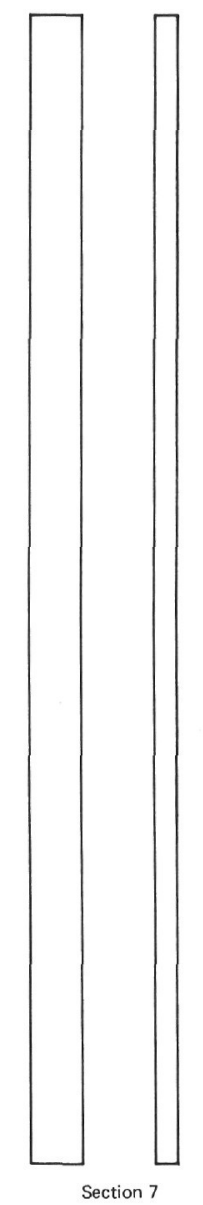

FLOW UNIT NO. 53:

POSTION: Top - Core 42, Sect. 2, $15 \mathrm{~cm}$; Bottom - Core 42, Sect. 3,

EMISTRY: Tholeititic basalt, 1 analysis in Table 1.

VISUAL DESCRIPTION

Lithology: Oxidized and vesicicular fllow to. too, massive center (30)

Alteration: vesiles, vesicular (15\%) lower part; base glass:

\section{CTION DESCRIPTION}

Groundmass: $\quad 01,2 \%, 0.05-1 \mathrm{~mm}$, altered; plag. $46 \%, 0.1 .1 \mathrm{~mm}$, laths,

mostly fresh; cpx., $35 \%, 0.1 \%$
altered glass, $10 \%$

Texture: Intergranular to intersertal

Vesicles:
Alteration:
$30 \%$, clay in vesicles and groundmass

MAGNETIC DATA

Average Inclination: $-25.0^{\circ}$
Average Magnetic Intensity $\left(10^{-5}\right.$ Gauss): 283

FLOW UNIT NO. 54:

(1) 81 mis

CHEMISTRY: Tholeiticic basalt, 1 analysis in Table 1.

VISUAL DESCRIPTION
Mineralogy:
Phenocrysts: $01 ., 1.5 \%, 0.5-1.5 \mathrm{~mm}$, some fresh throughout,
plag., $2.5 \%, 0.5-2 \mathrm{~mm}$

Groundmass: ol., plag., px., op., clay

Center fresher and

Aiteration: Clay in groundmass, ol. to iddingsite telay

THIN SECTION DESCRIPTION

Phenocrysts: Plag. 7\%, 0.5-1.5 mm; cpx., 4\%, 0.5-1.5 mm, anhedral

Groundmass: Ol., $1 \%, 0.1 \mathrm{~mm}$, altered; plag., $39 \%, 0.1 .0 .5 \mathrm{~mm} ;$; cpx.,

Texture: $\quad$ glass, $7 \%$

Inte' $r$ ranular to intersertac
$2 \%, 1 \mathrm{~mm}$, round, brown clay rims and green clay fillings

MAGNETIC DATA

Average Magnetic Intensity (10-5 Gauss): 47 


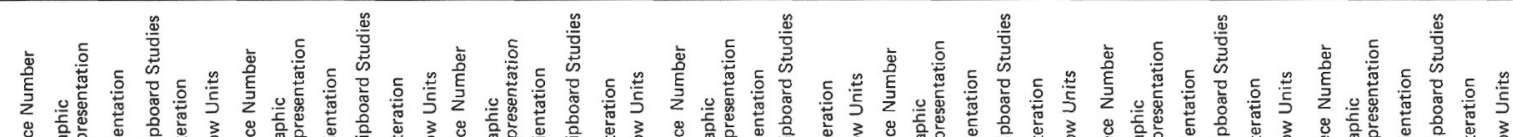

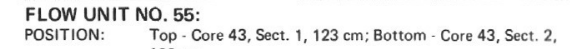

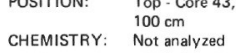

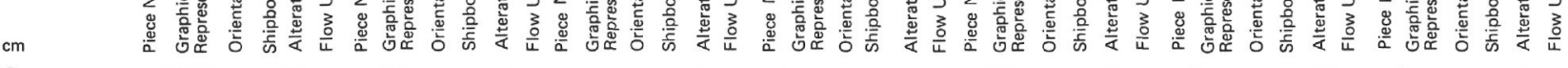

-
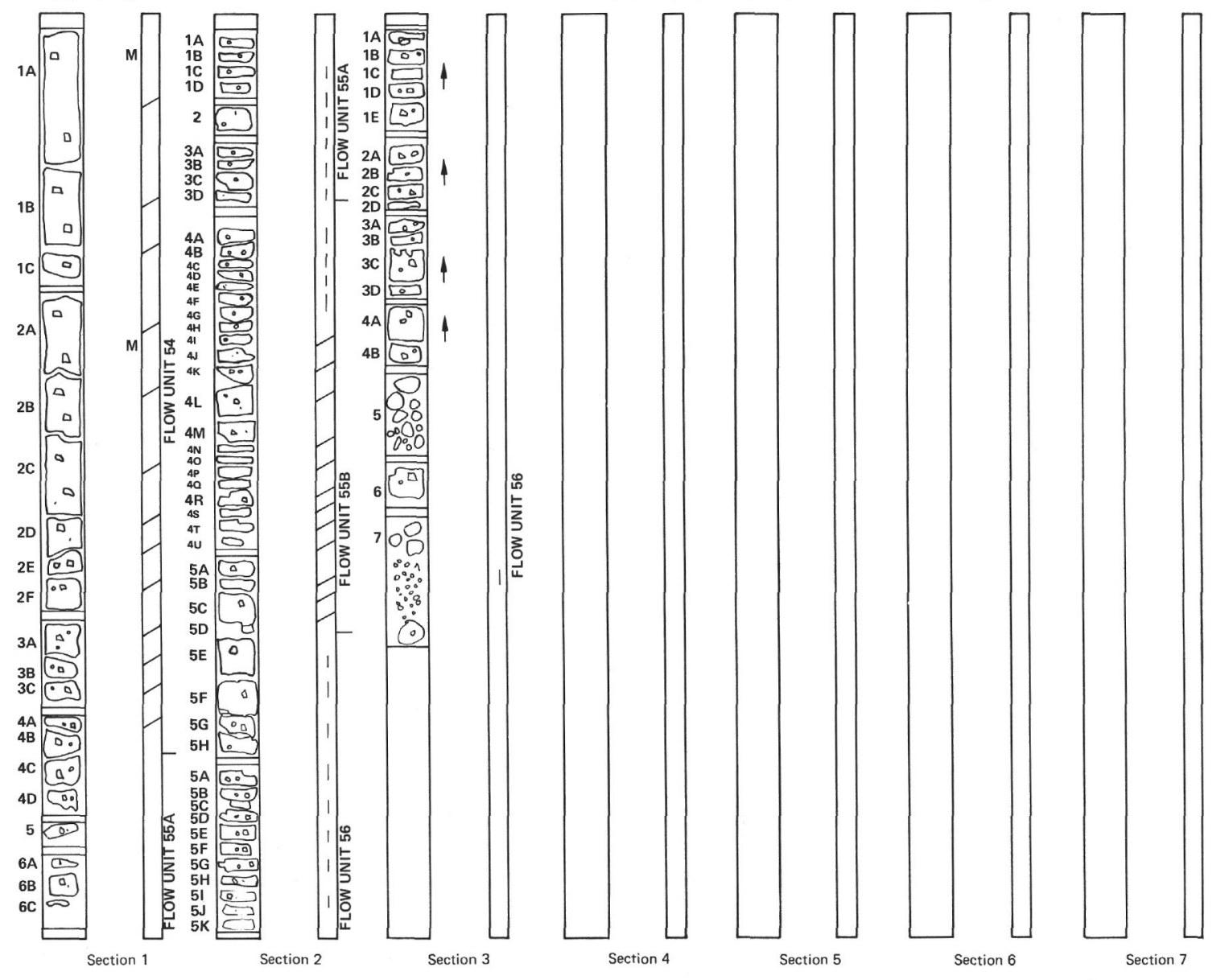

VISUAL DESCRIPTION

Groundmass: $01.10 \%$, plag. $40 \%$, px. $30 \%$, op. $5 \%$, clay $15 \%$
Lithology: Alteration: trayghout

FLOW UNIT NO. 56:

POSITION: Top - Core 43, Sect.2, $150 \mathrm{~cm}$;Bottom - Core 44, Sect. 2,

CHEMISTRY: Not analyzed

VISUAL DESCRIPTION

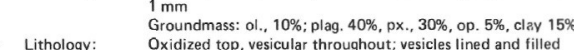

(1)

MAGNETIC DATA

Average Inclination: $-412^{\circ}$
Average Magnetic Intensity $\left(10^{-5}\right.$ Gauss): 280 
LEG 55 SITE 433 HOLE C CORE 44 DEPTH $\quad$ 497.5.507.0 m

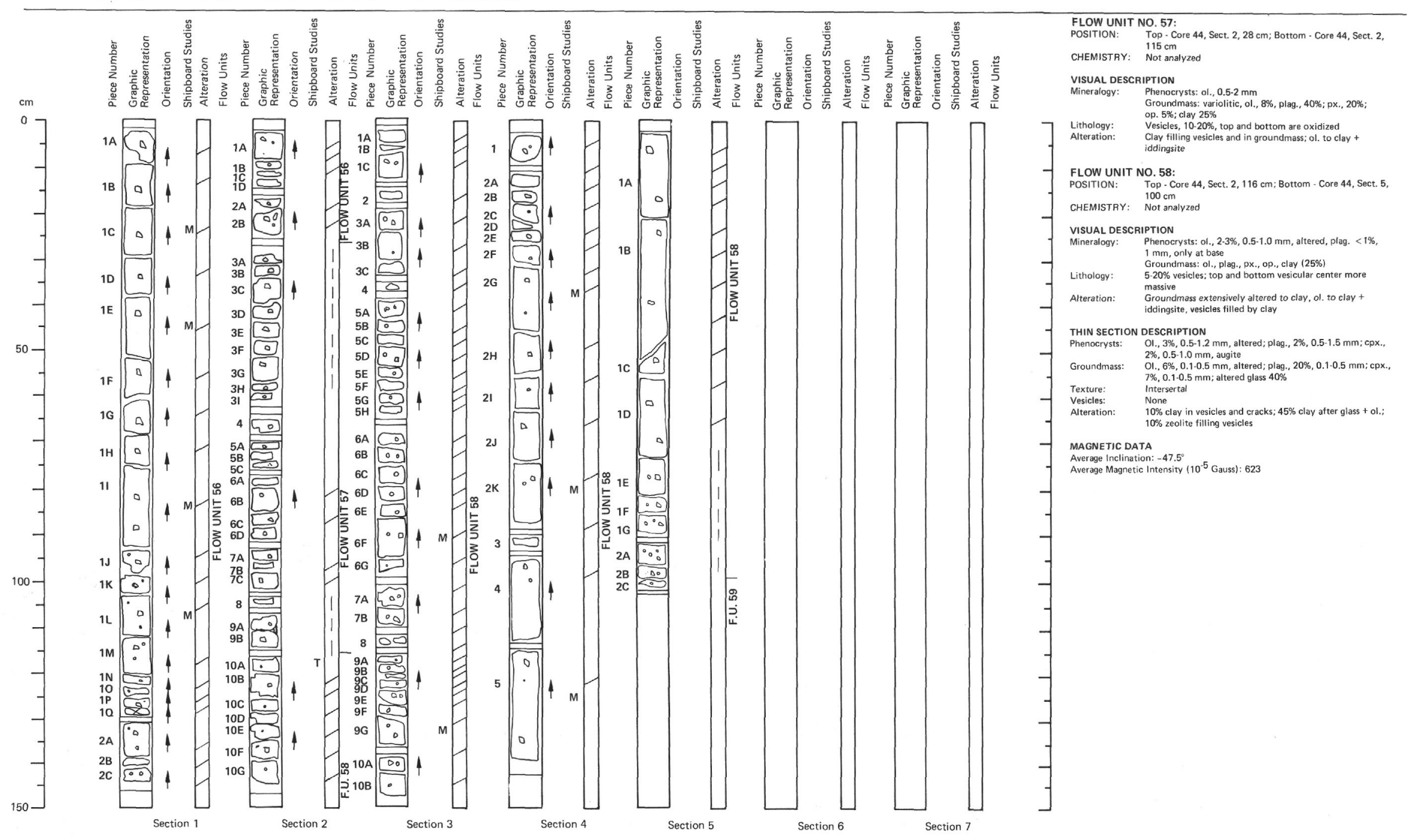


LEG 55 SITE 433 HOLE $C$ CORE 45 DEPTH $\quad 507.0-516.5 \mathrm{~m}$

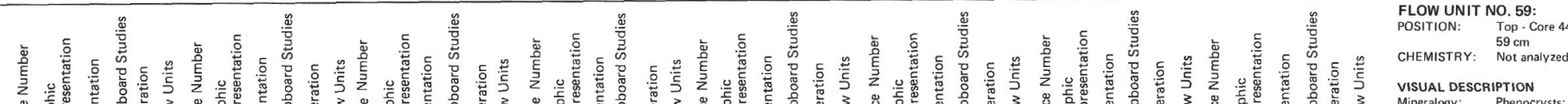

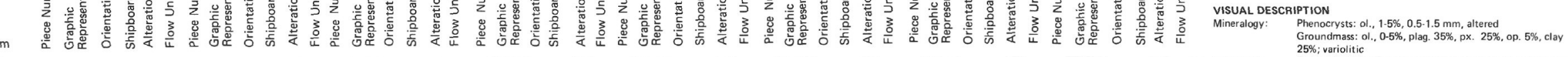

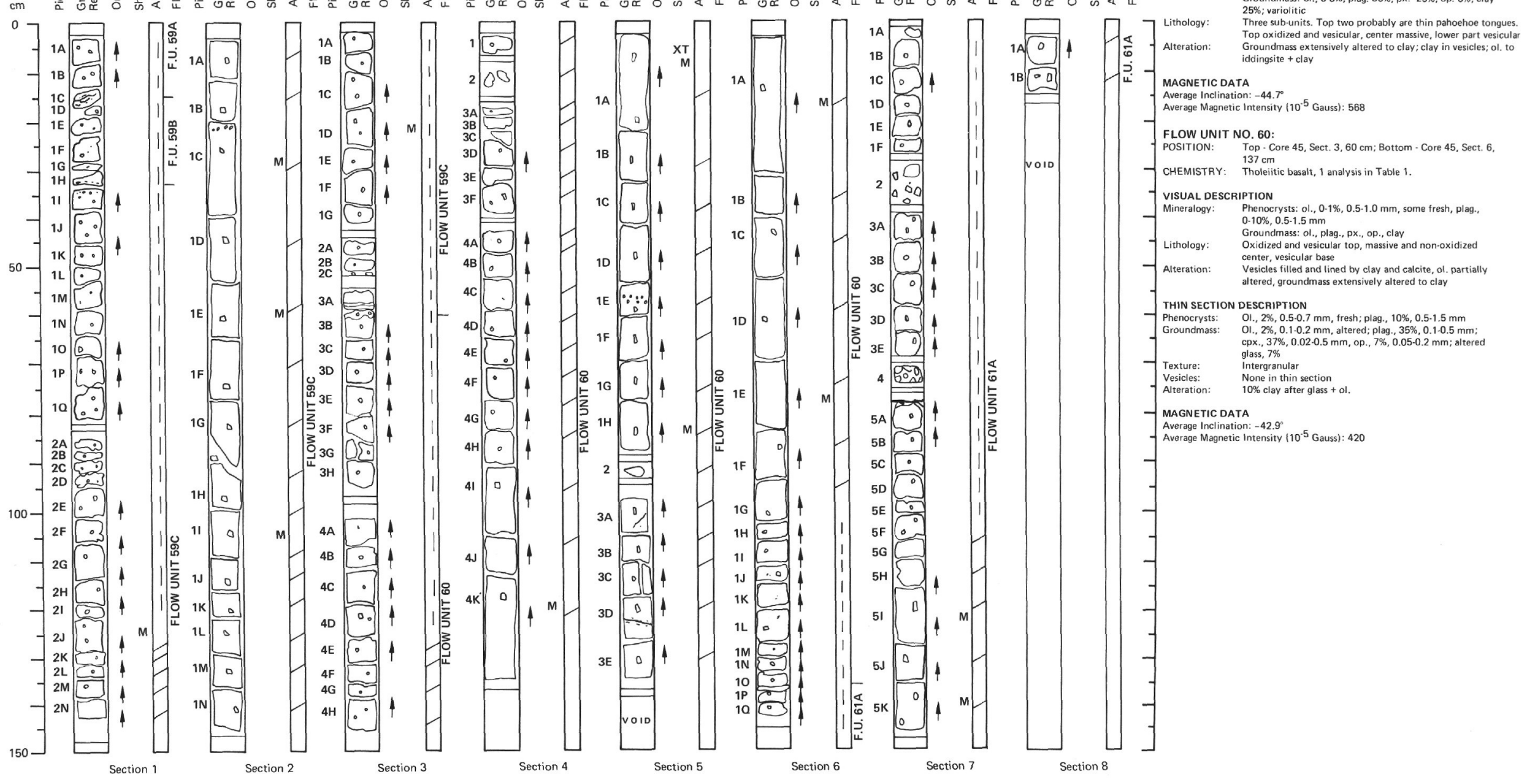




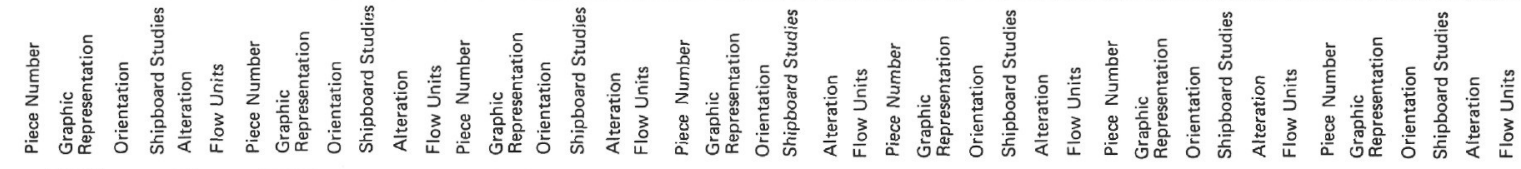

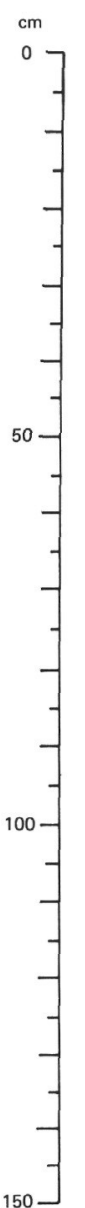

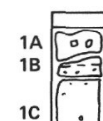

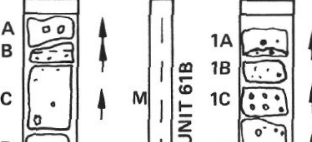

10

$1 F$

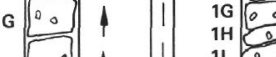

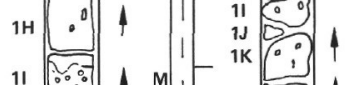

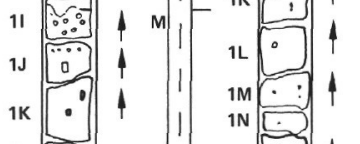

$1 \mathrm{IM}$

IN $10,10,10$

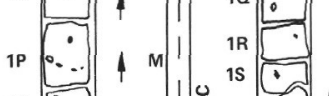

10 (

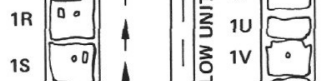

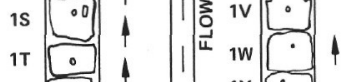

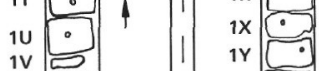

$1 \mathrm{x}$

$1 Y$

12

$1 \mathrm{AA} \because$

1CC

\begin{abstract}
Section 2
\end{abstract}

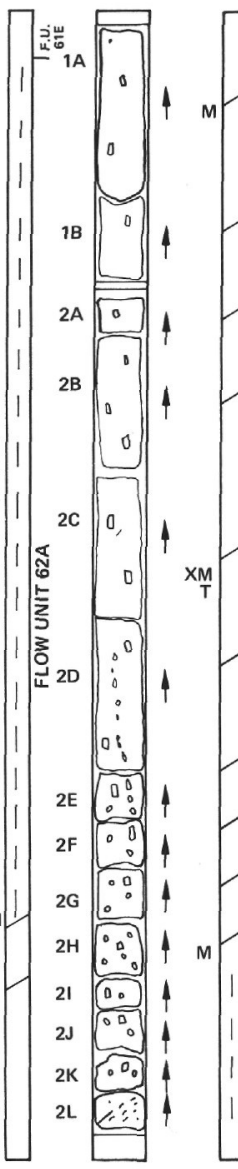

Section 3

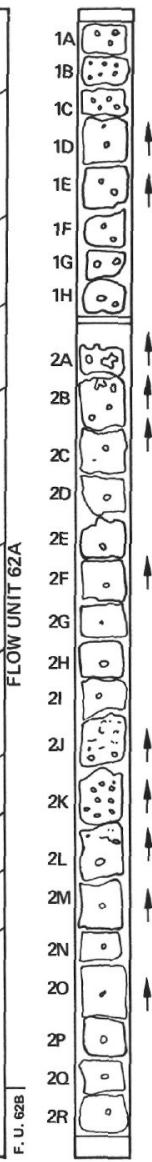

Section 4

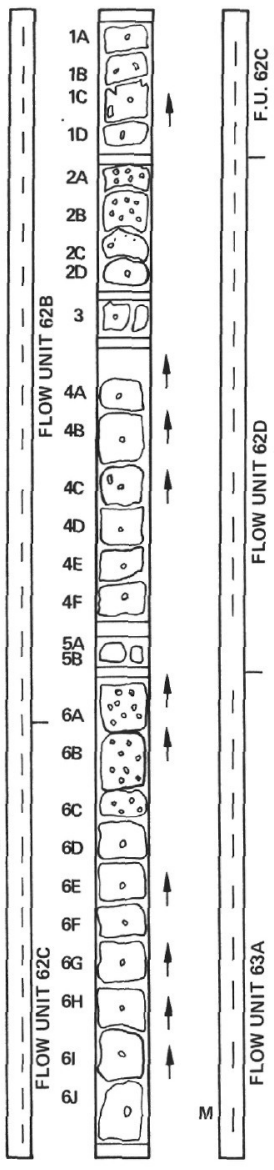

Section 5

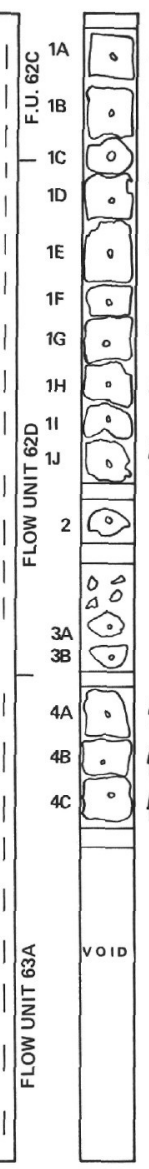

Section 6
FLOW UNIT NO. 61:
POSITIION: CHEMISTRY: $\begin{array}{ll}5 \mathrm{~cm} \\ \text { Not analyzed }\end{array}$

VISUAL DESCRIPTION

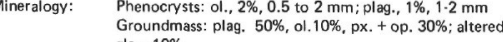

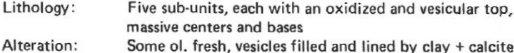

MAGNETIC DATA

Average Inclination: $-43.1^{\circ}$
Average Magnetic Intensity $\left(10^{-5}\right.$ Gauss): 320

FLOW UNIT NO. 62:

, 4 , Sect. 2, $5 \mathrm{~cm}$; Bottom - Core 46, Sect.

CHEMISTRY: $\quad \begin{aligned} & 85 \mathrm{~cm} \\ & \text { Tholeititic basalt, } 1 \text { analysis in Table } 1 .\end{aligned}$

VISUAL OESCRIPTION

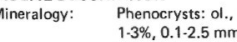

Litholo

Lithology:

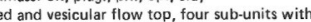

THIN SECTION DESCRIPTION

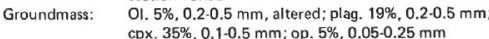

Texture: Interstitial
Vesicles:

Alteration: $\quad 30 \%$ clay after gro

MAGNETIC DATA

Average Inclination: $-41.0^{\circ}$
Average Magnetic Intensity $\left(10^{-5}\right.$ Gauss): 578 
LEG 55 SITE 433 HOLE $\mathrm{C}$ CORE 47 DEPTH $526.0 .535 .5 \mathrm{~m}$

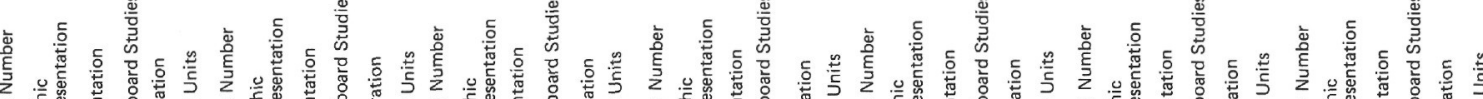

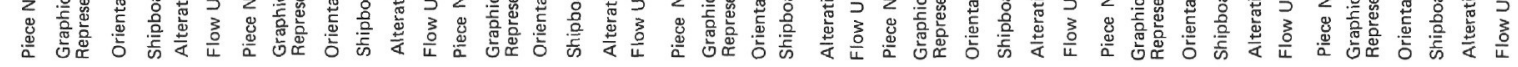

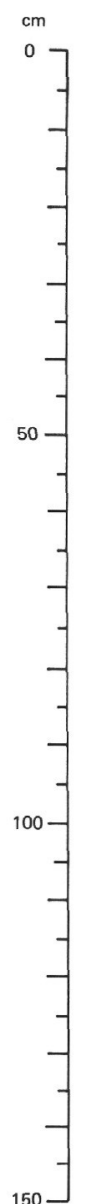

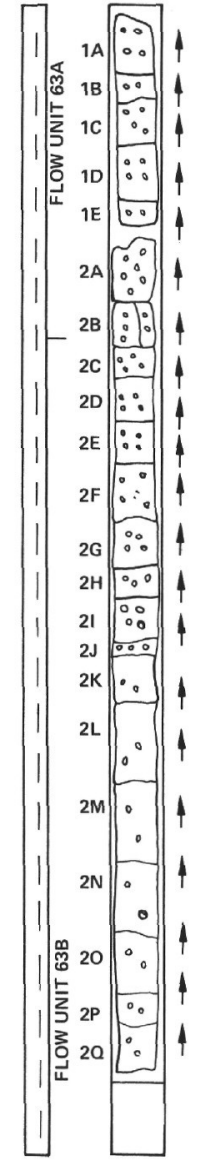

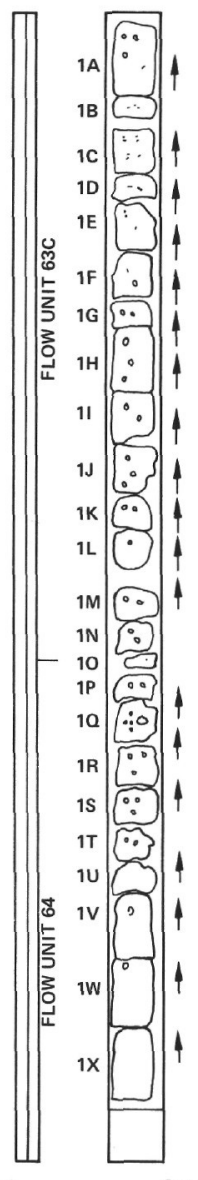

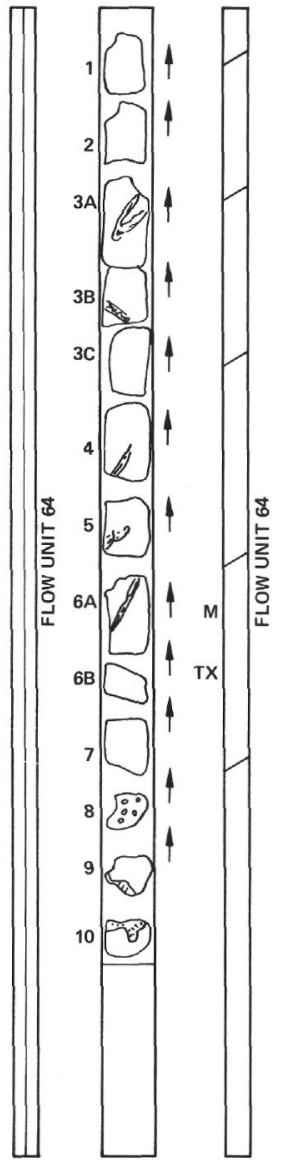

Section
FLOW UNIT NO. 63:

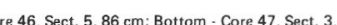
CHEMISTRY: $\begin{array}{ll}86 \mathrm{~cm} \\ \text { Not analyzed }\end{array}$

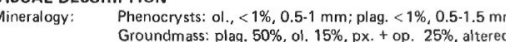

Alteration: Vesicles filled and lined by clay and calcite around

MAGNETIC DATA

Average Inclination: - $40.3^{\circ}{ }^{\circ}-5$ 


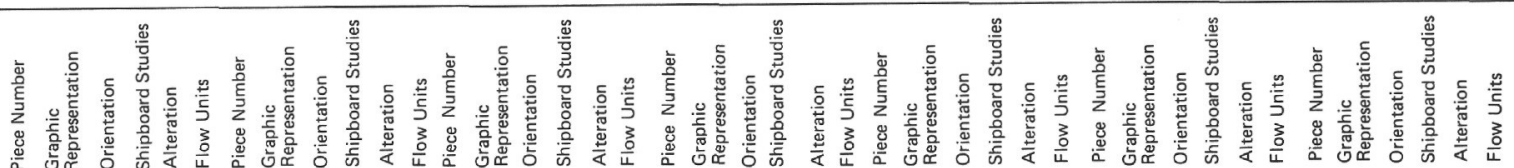

FLOW UNIT NO. 64:
POSITION:
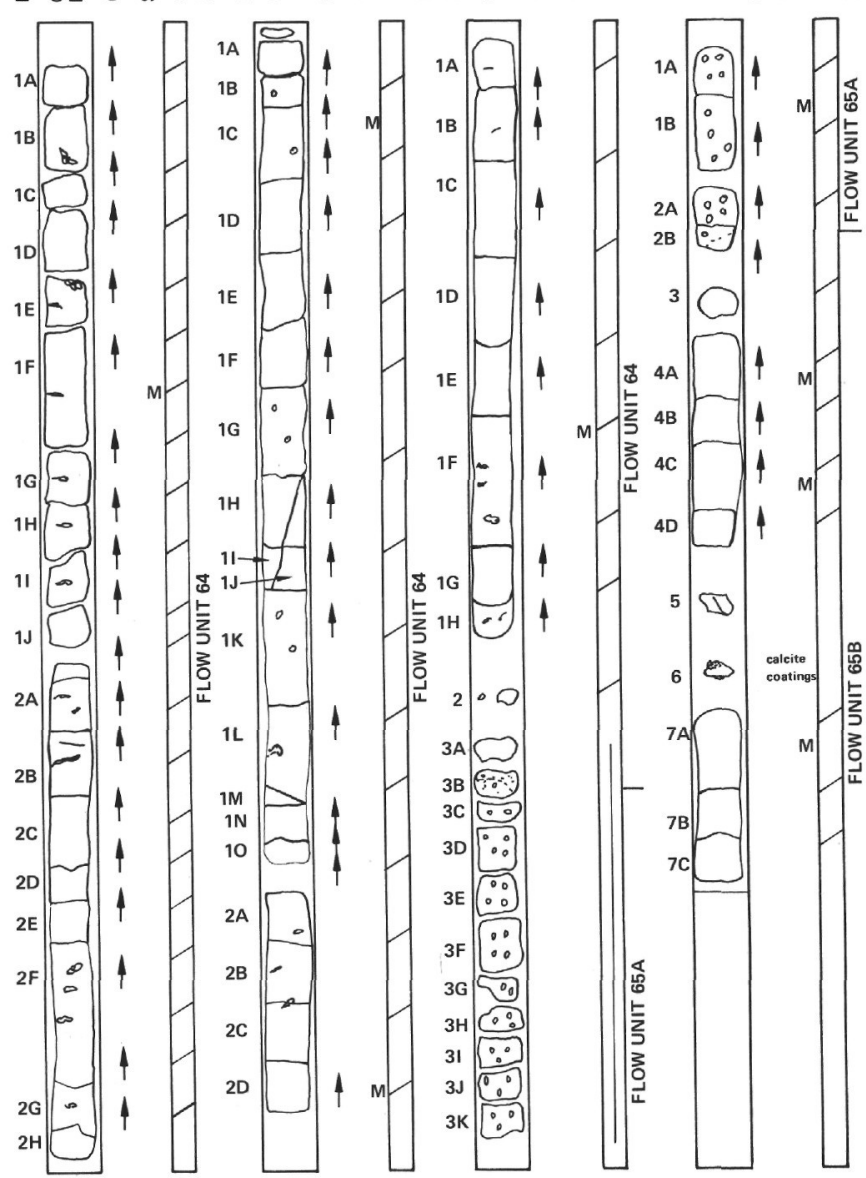

Section 1

Section 2

Section 3

Section 4
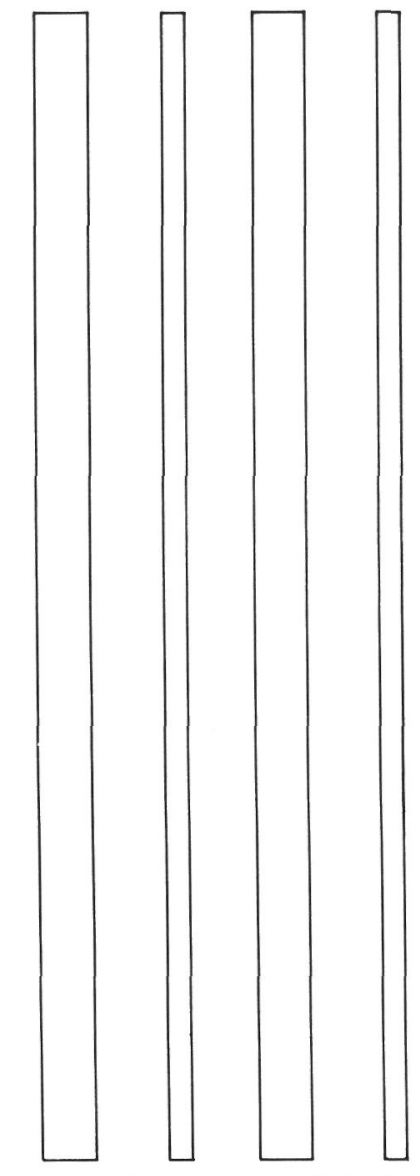

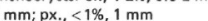

Groundmass: plag., px., op., ol.

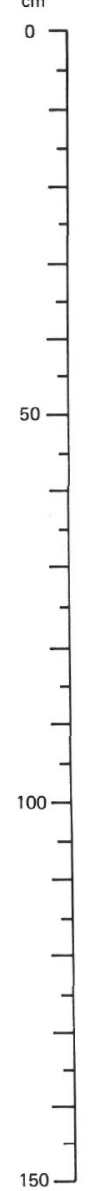

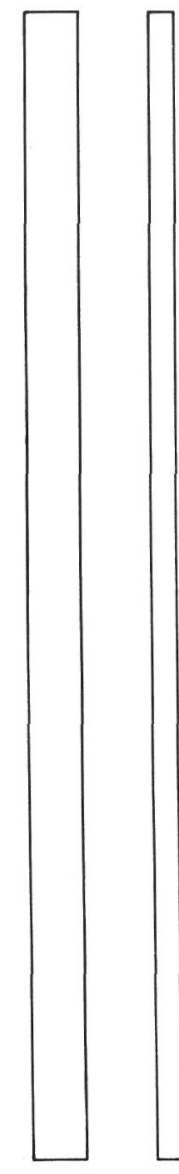

Alteration and very fresh

Phenocrysts: $\quad 01 ., 2 \%, 0.7 \mathrm{~mm}$, subhedral to anhedral, altered, plag., $2 \%$,

Groundmass: $\quad 01.2 \%, 0.05-0.2 \mathrm{~mm}$, altered; plag, $45 \%$, $0.01-0.1 \mathrm{c}$ cpx, $25 \%$

Texture: $\quad 0.01 \cdot 0.02$, colorless; op. $15 \%, 0.01-0.02 \mathrm{~mm}$

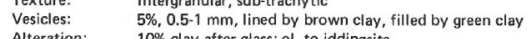
Alteration: $10 \%$ clay after glass; ol. to iddingsite

MAGNETIC DATA

Average Inclination: $-69.0^{\circ}$
Average Magnetic Intensity (10-5 Gauss): 1060

Average Magnetic Intensity

FLOW UNIT NO. 65:
POSITION:
TOp. Core

CHEMISTRY: Not analyzed

VISUAL DESCRIPTION

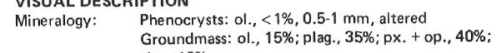

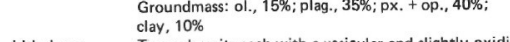

$\begin{array}{ll}\text { Lithology: } & \text { Two sub-units each with a vesicular and slightly oxidized } \\ \text { top, and a moderately vesicular center and bottom. Also }\end{array}$

Alteration: $\quad$ separated by a vitrophyre.

MAGNETIC DATA

Average Magnetic I

$-$

$-$

$-$

$-1$ 
SITE 433 HOLE $\mathrm{C}$ CORE 49 DEPTH $545.0-549.0 \mathrm{~m}$

SITE 433 HOLE C CORE 50 DEPTH $5499.0 .550 .5 \mathrm{~m}$

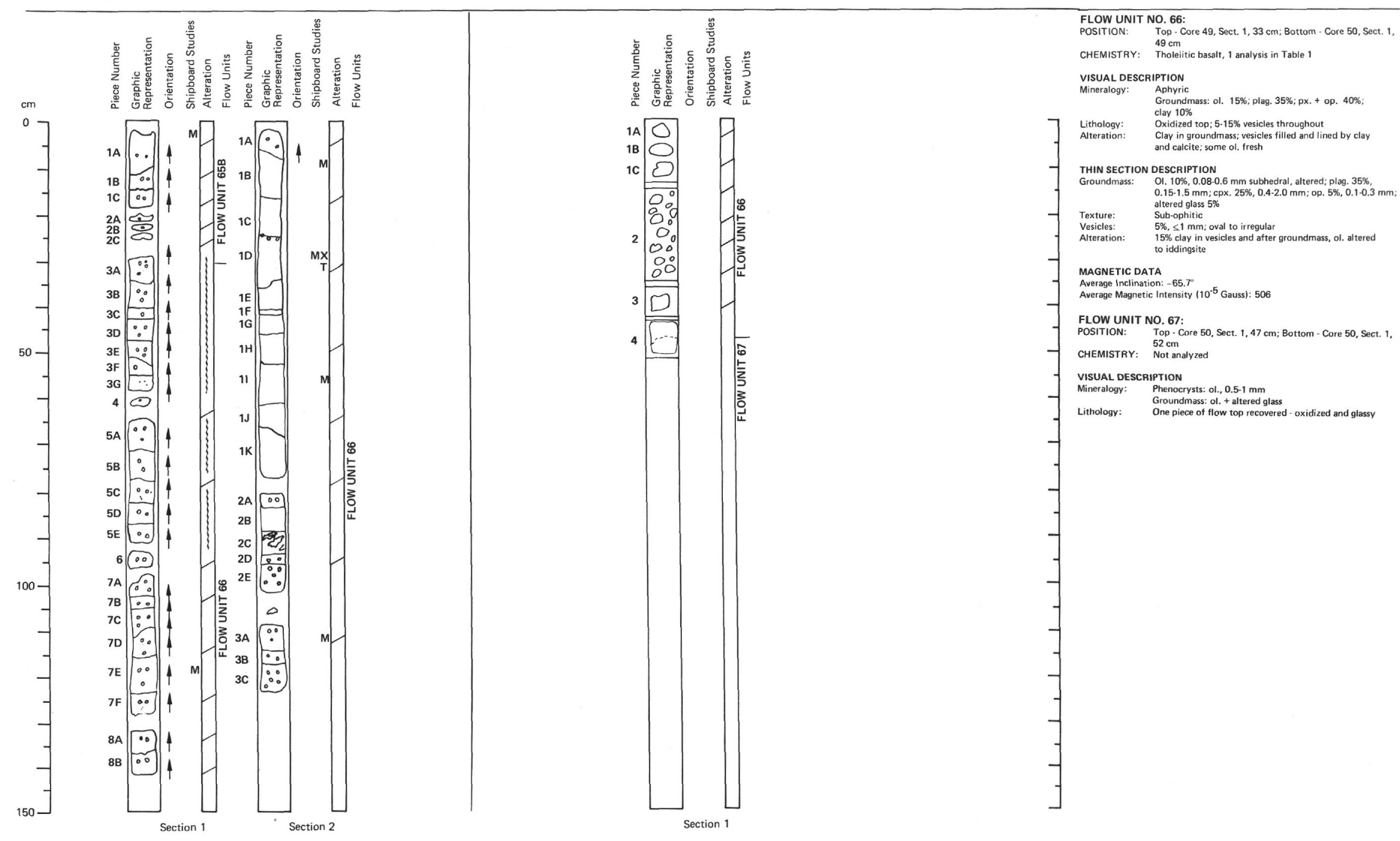


Site 433

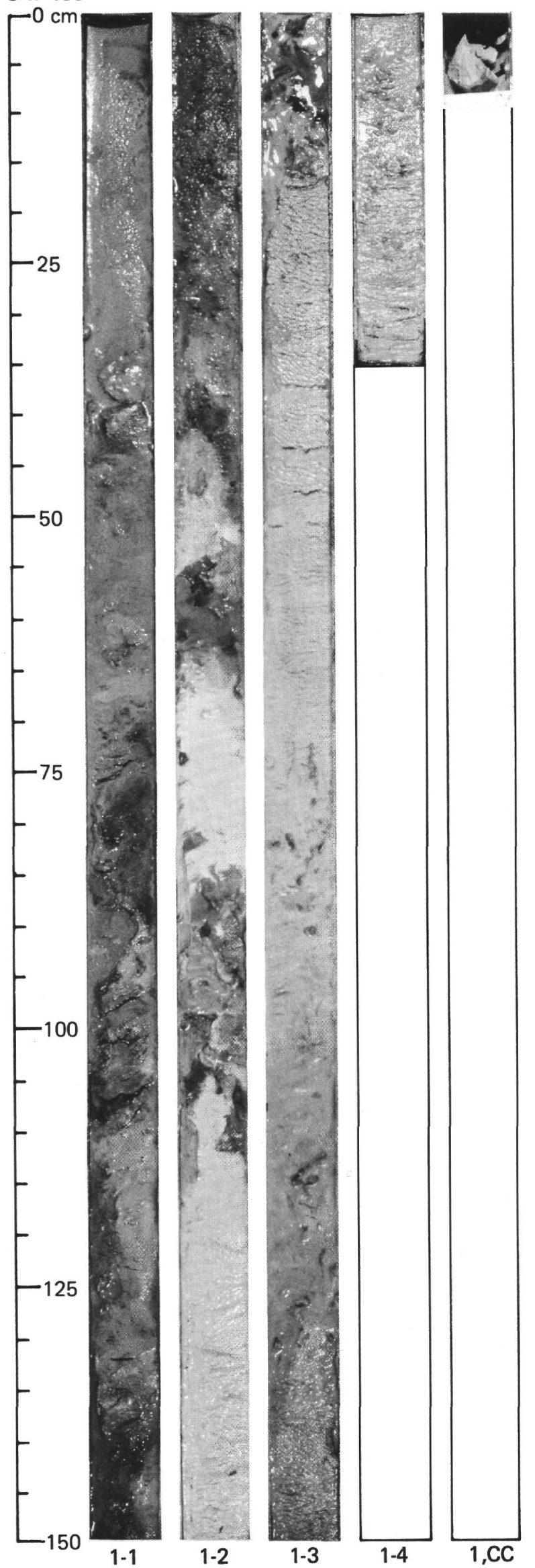




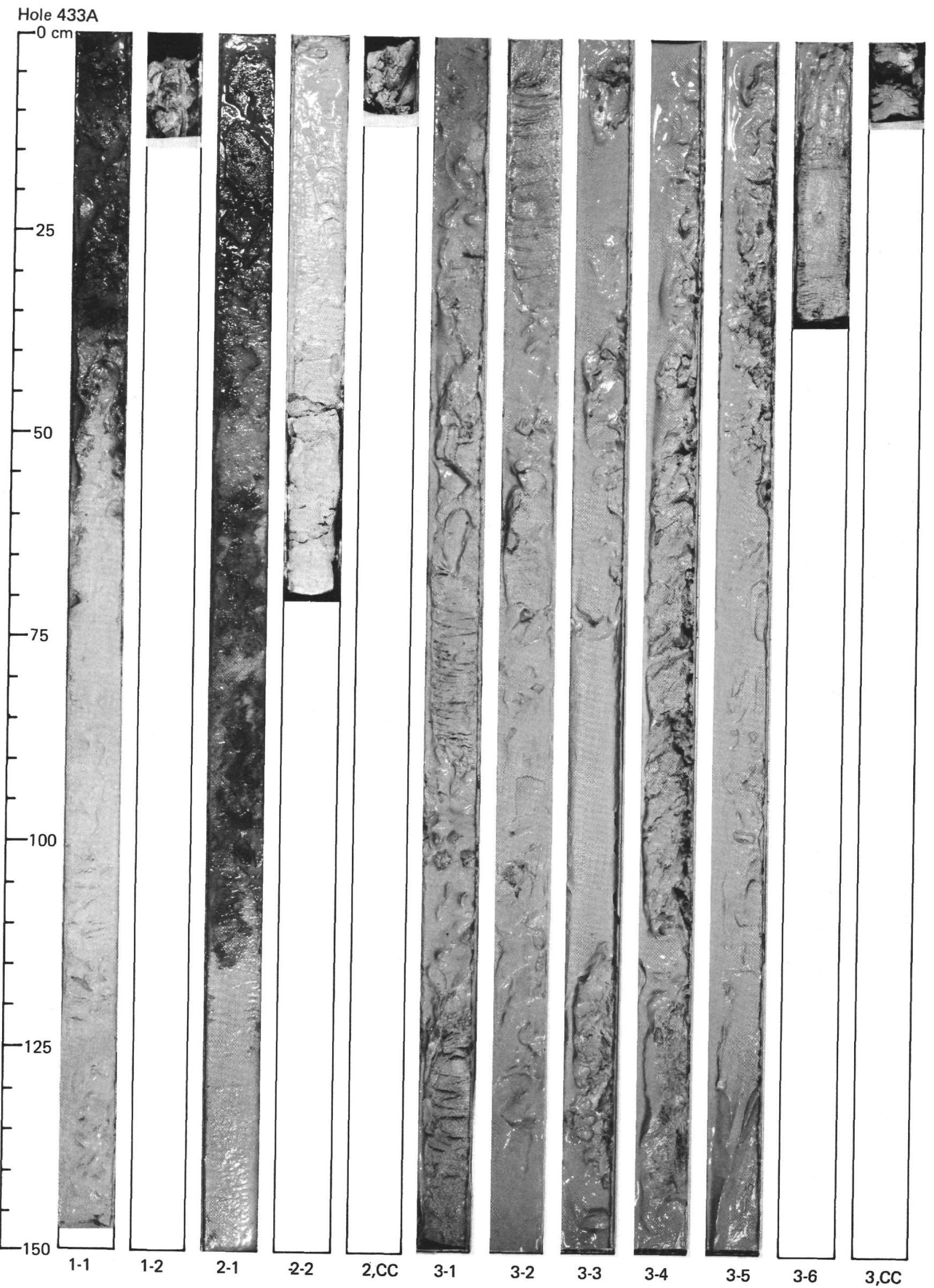


Hole 433A

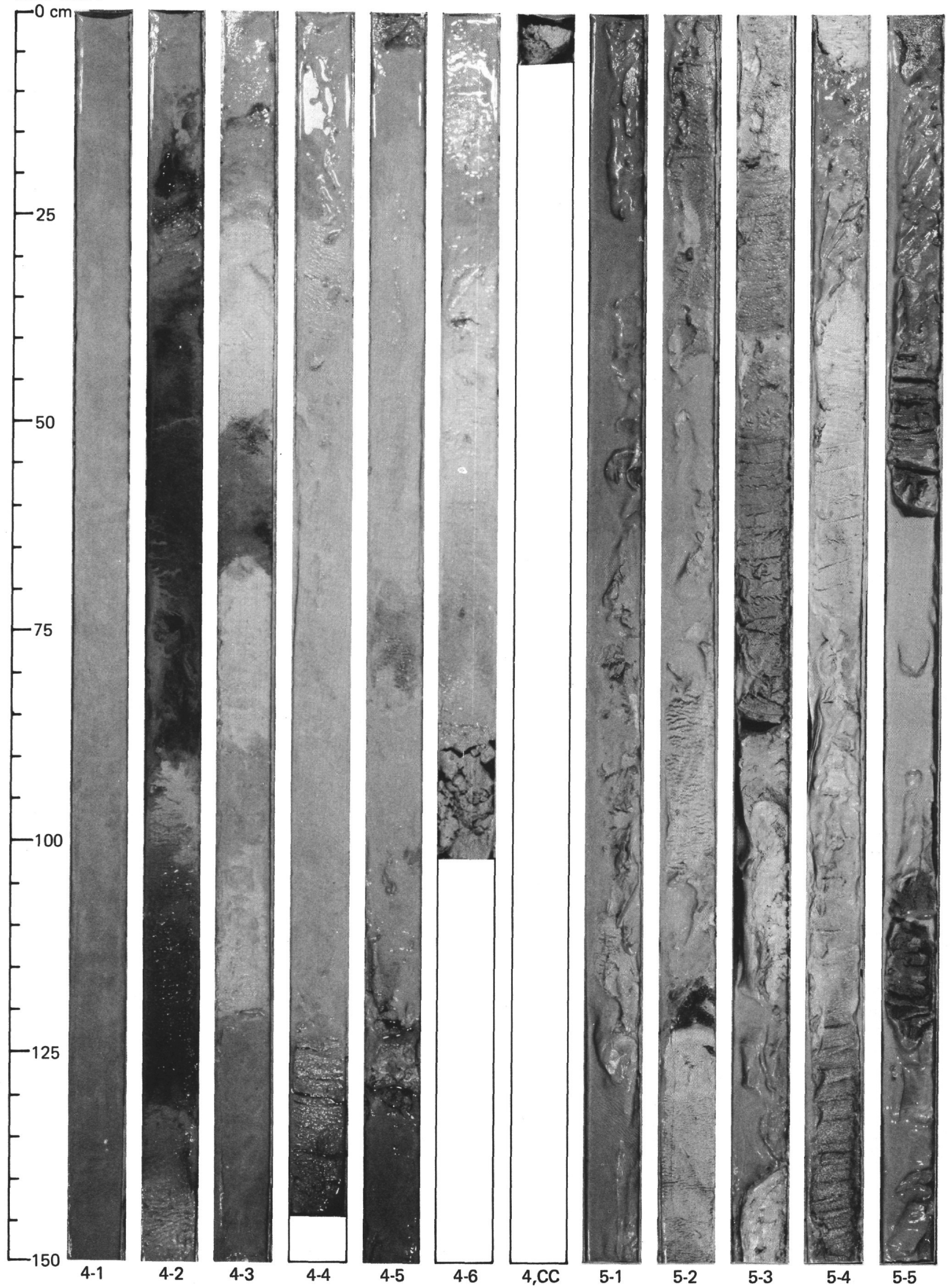


Hole 433A

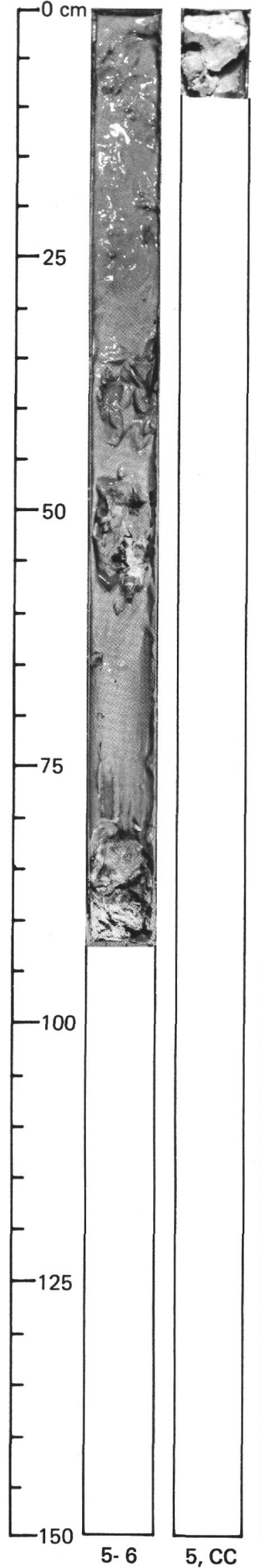

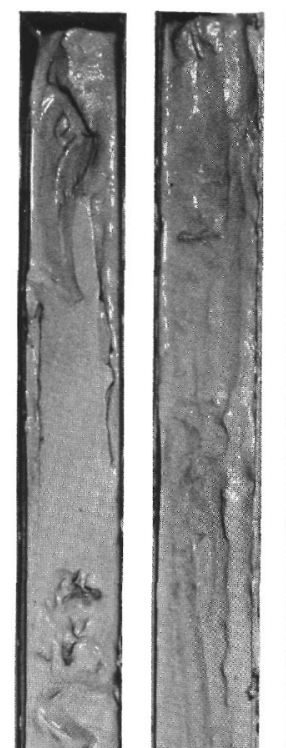
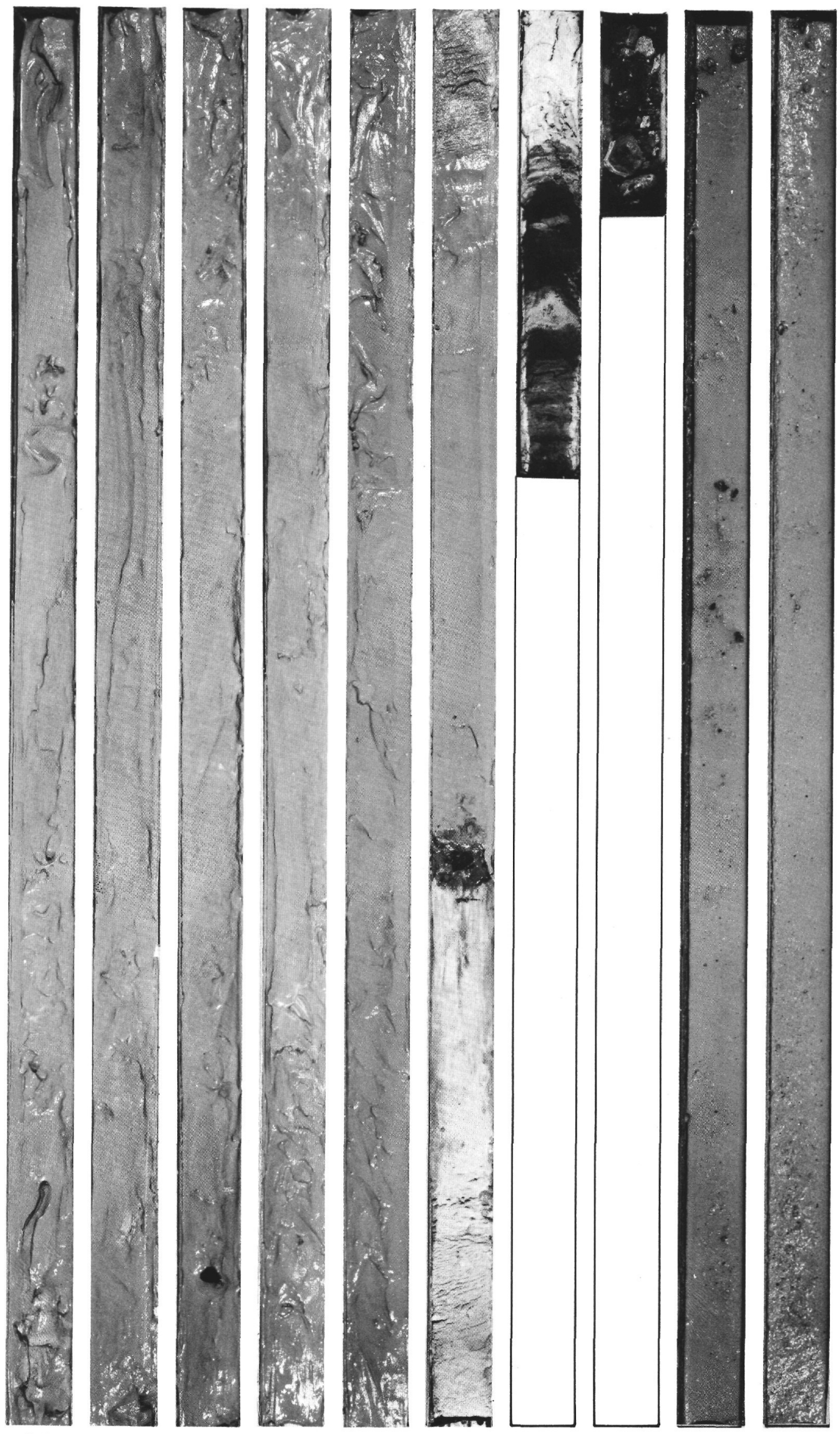
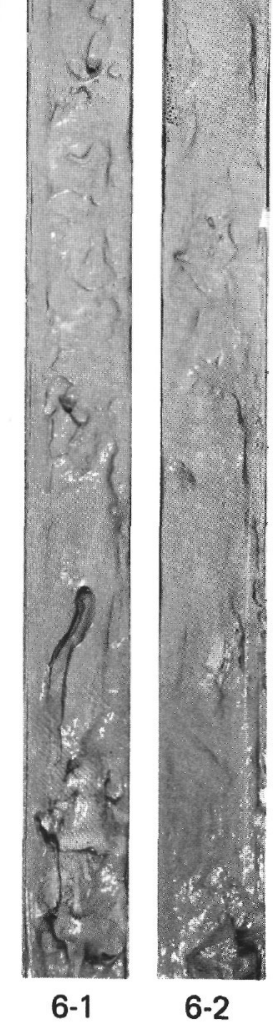

6-2
6-4
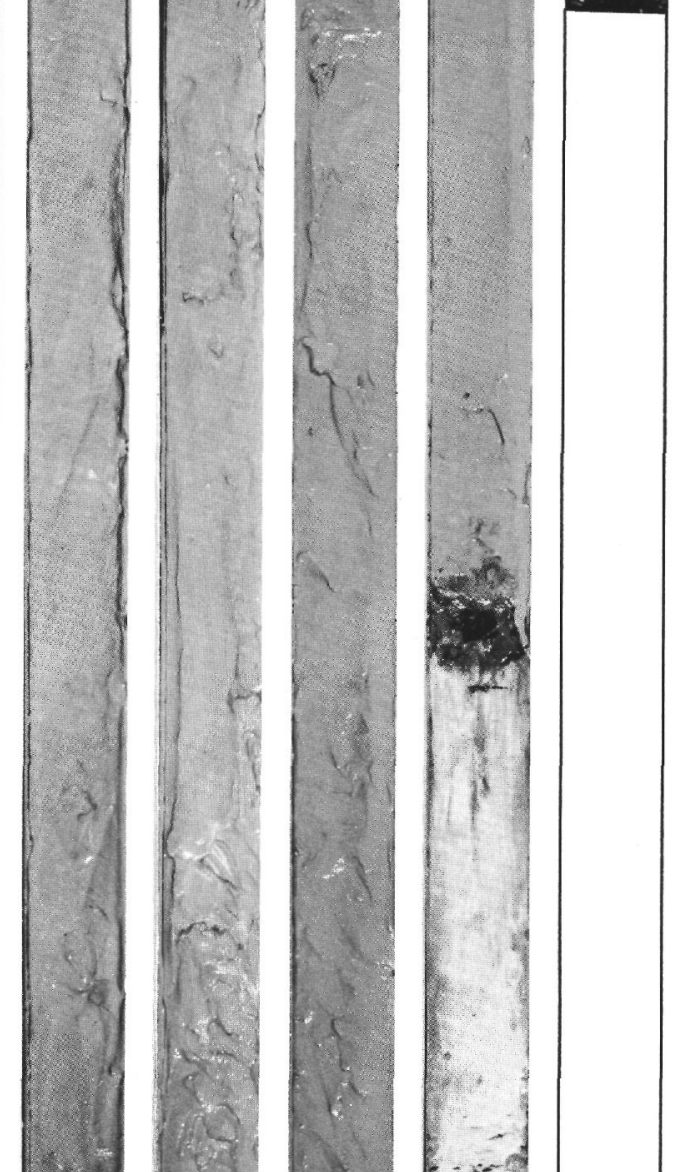
Hole 433A

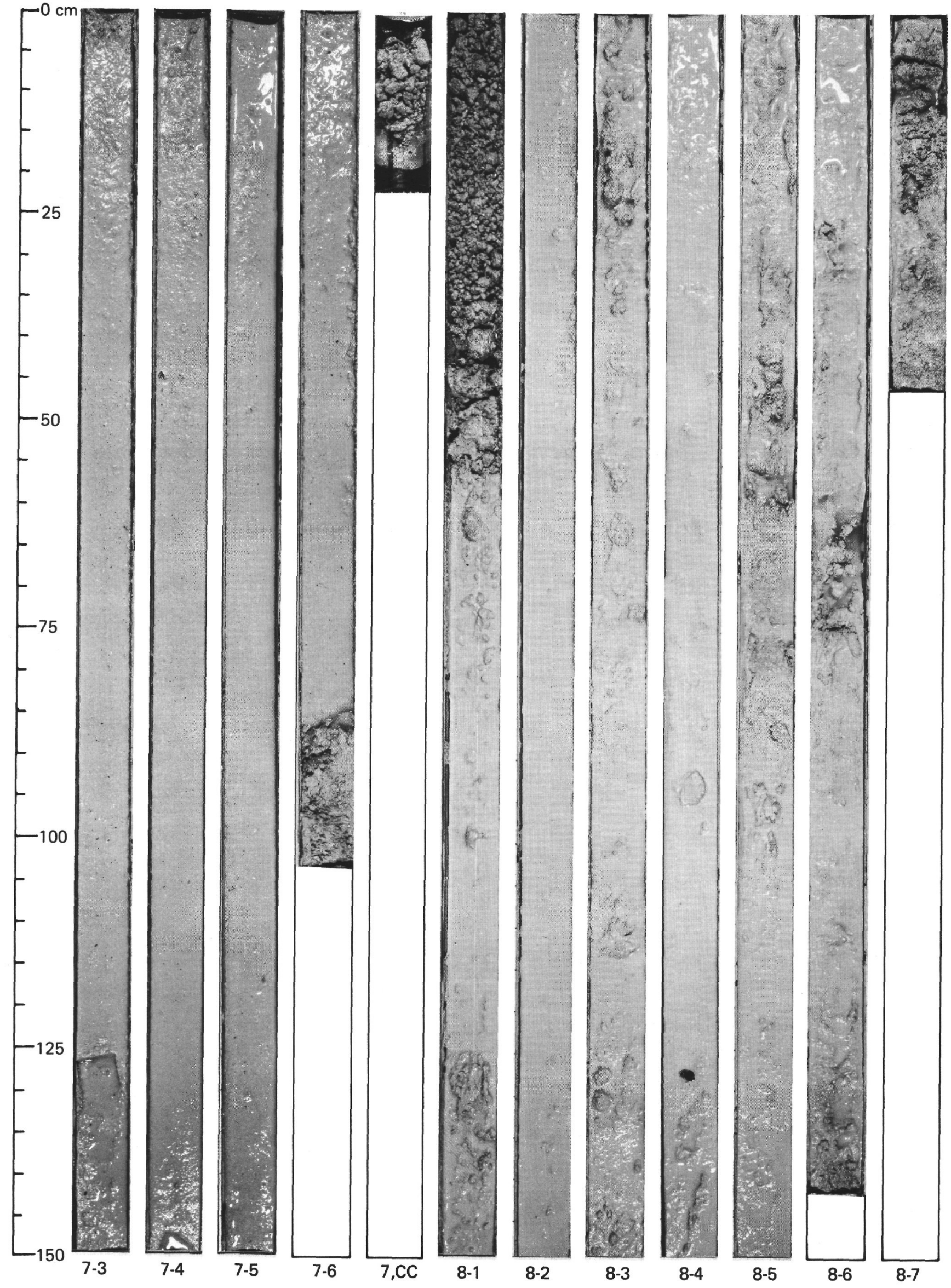


Hole 433A

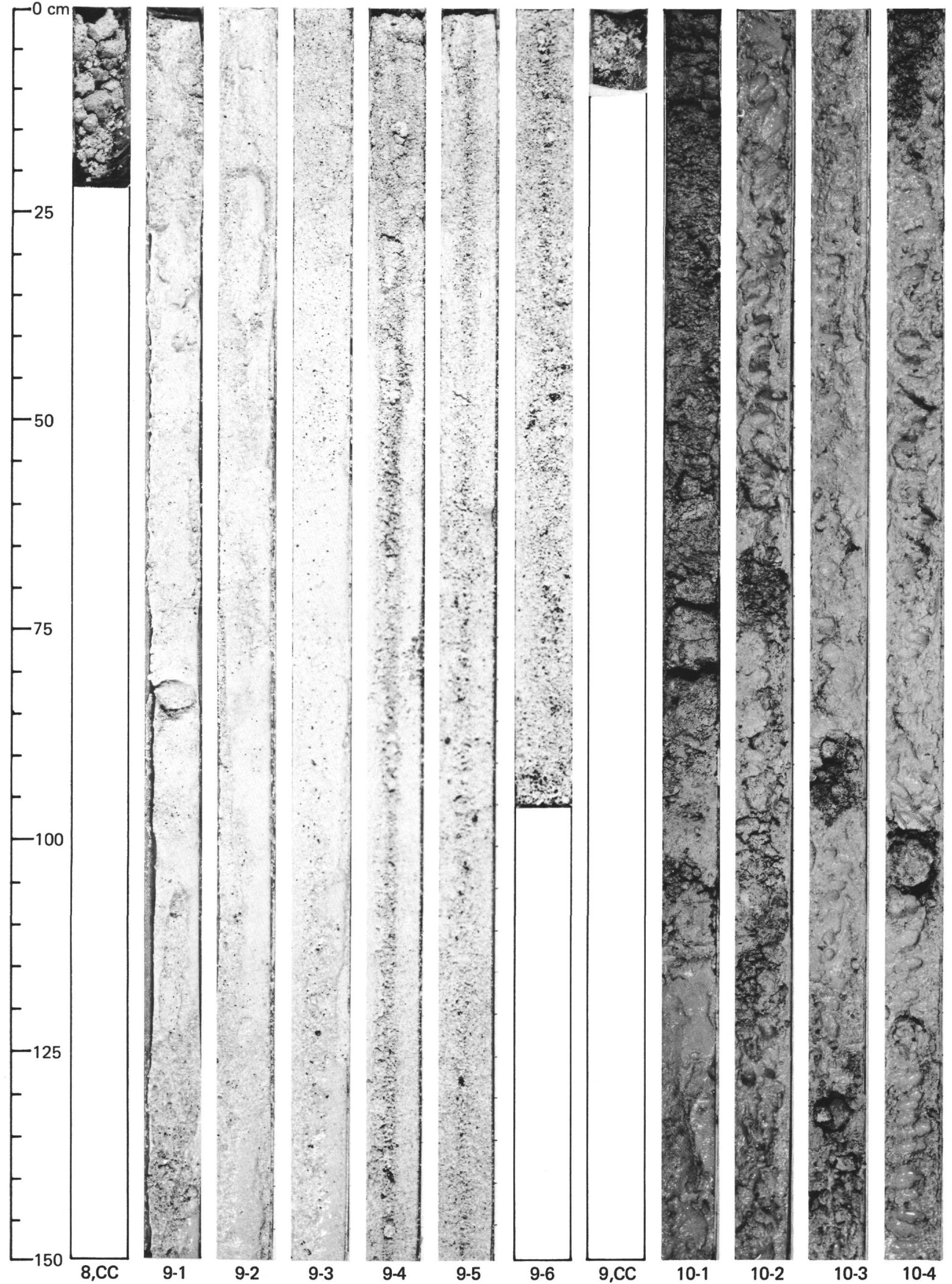


Hole 443A

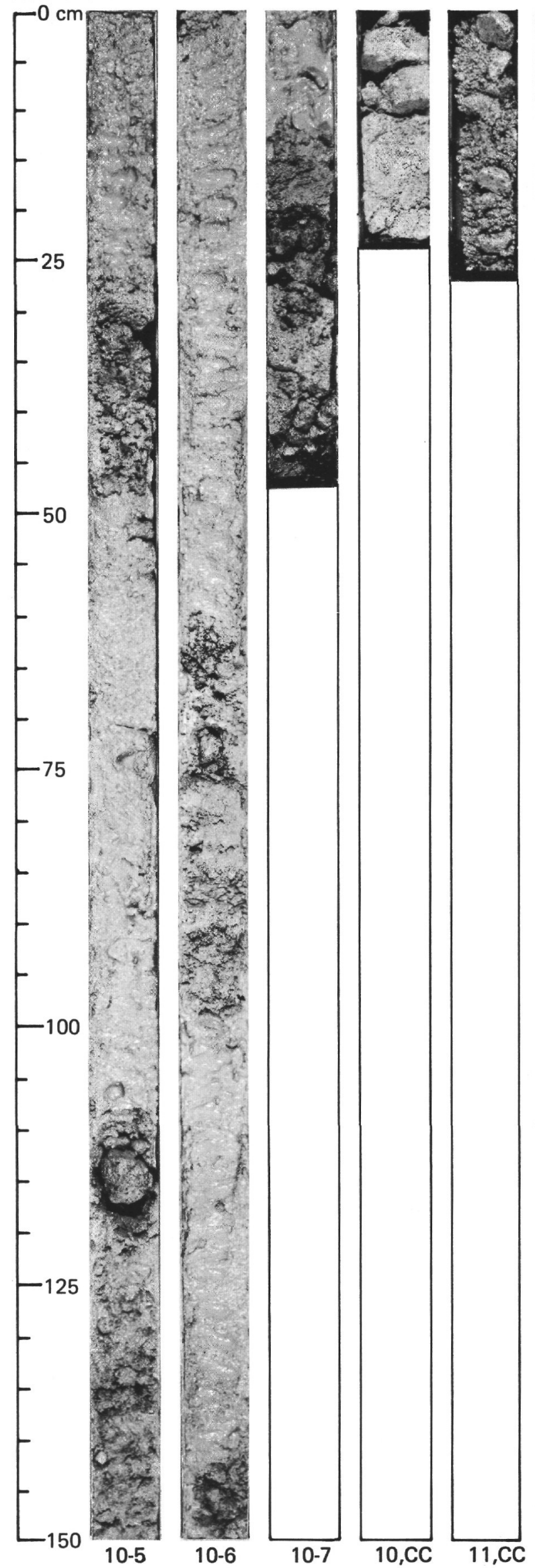

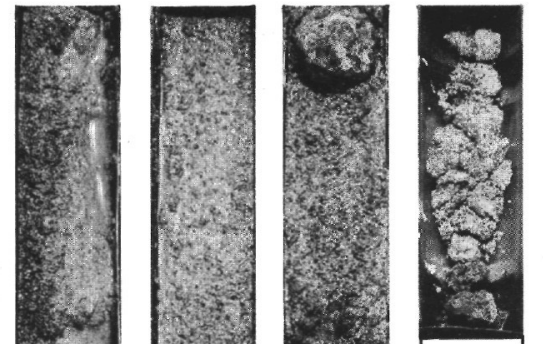
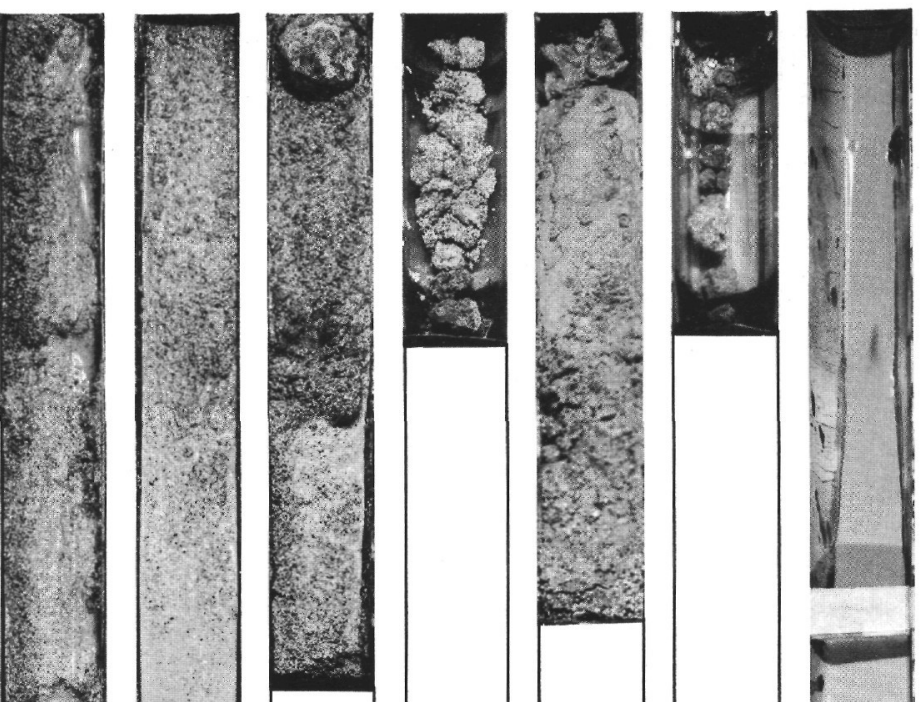

(8:

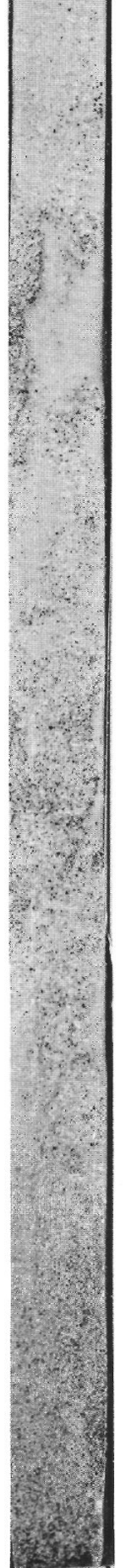

12-2
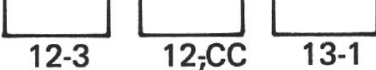
SITE 433

Hole 433A

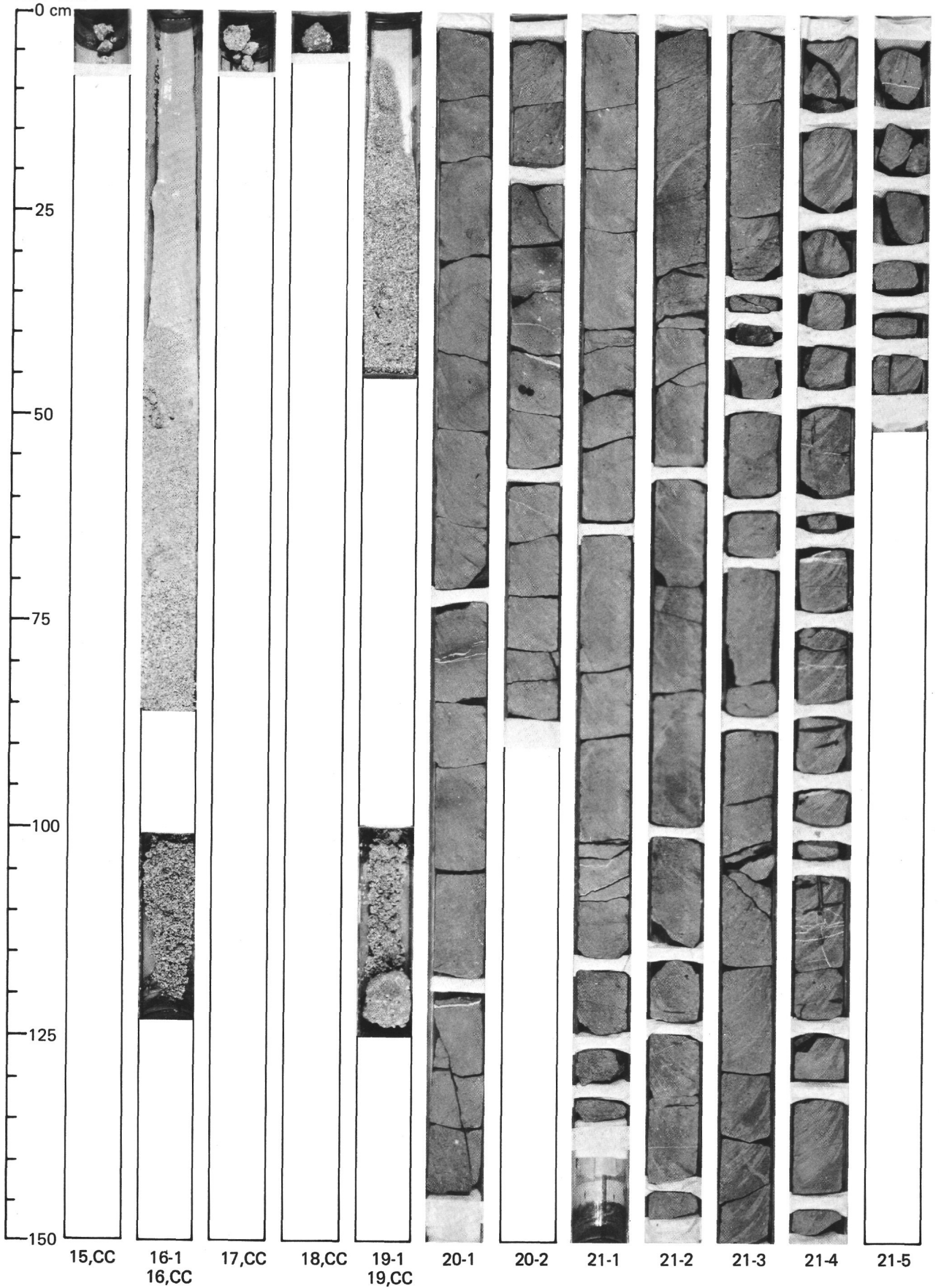


Hole 433B

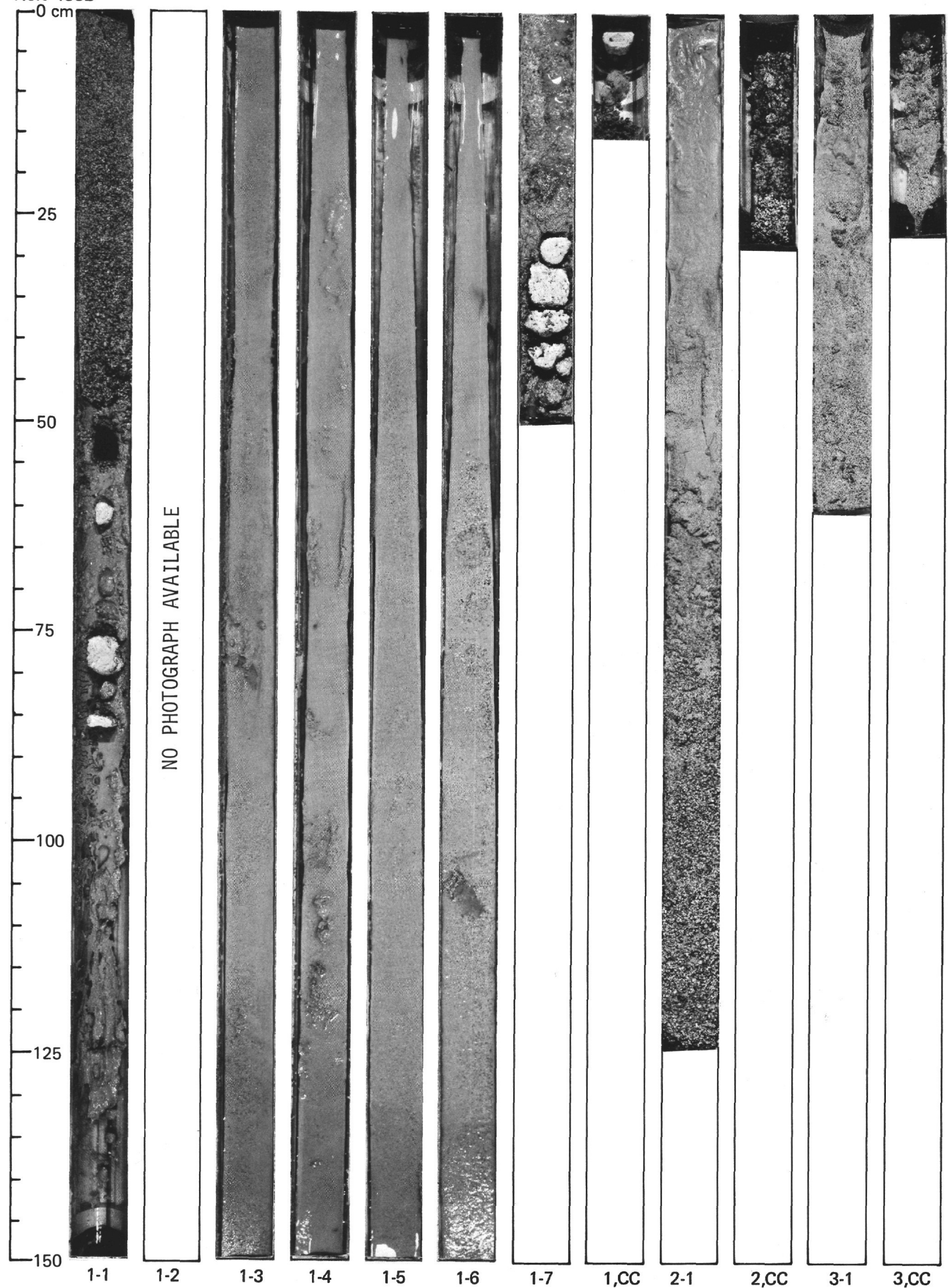


SITE 433

Hole 433B

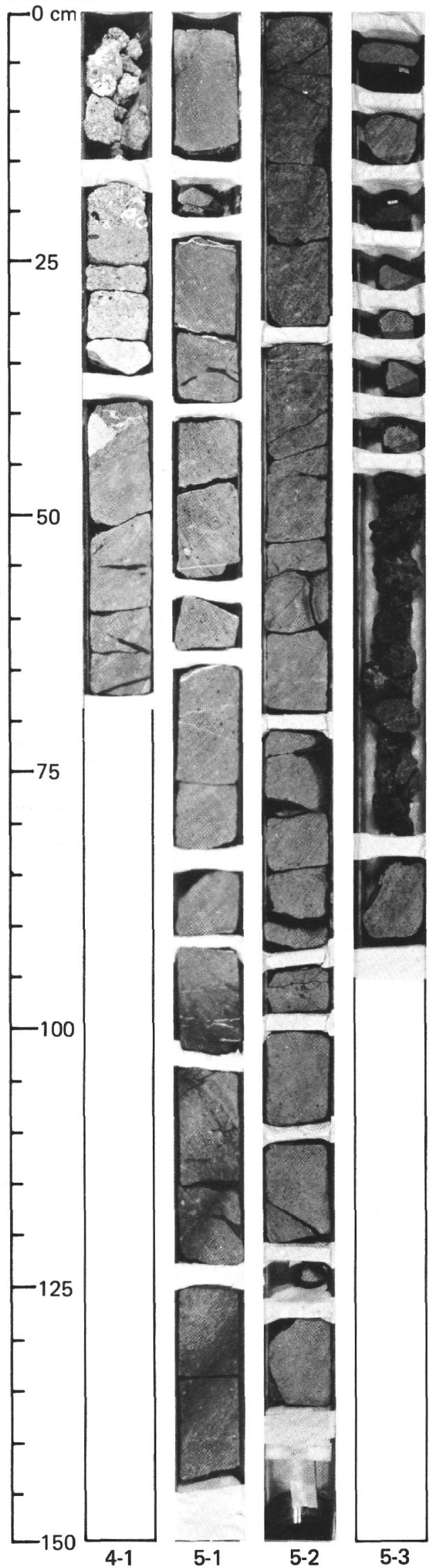


Hole 433C

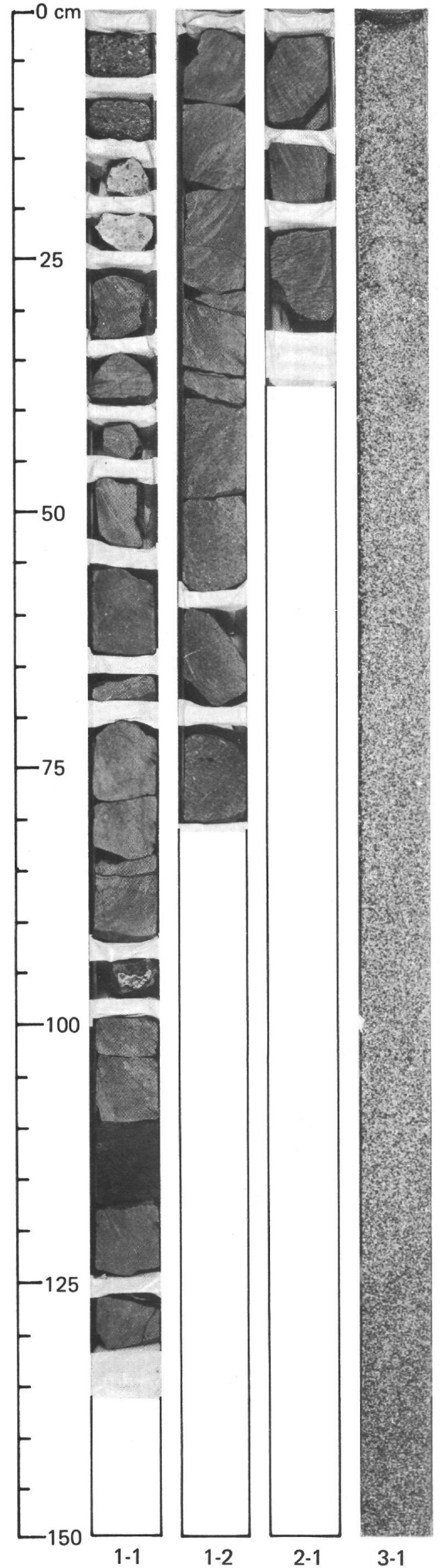

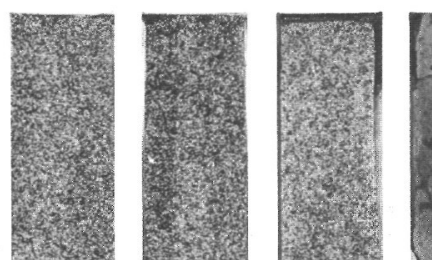
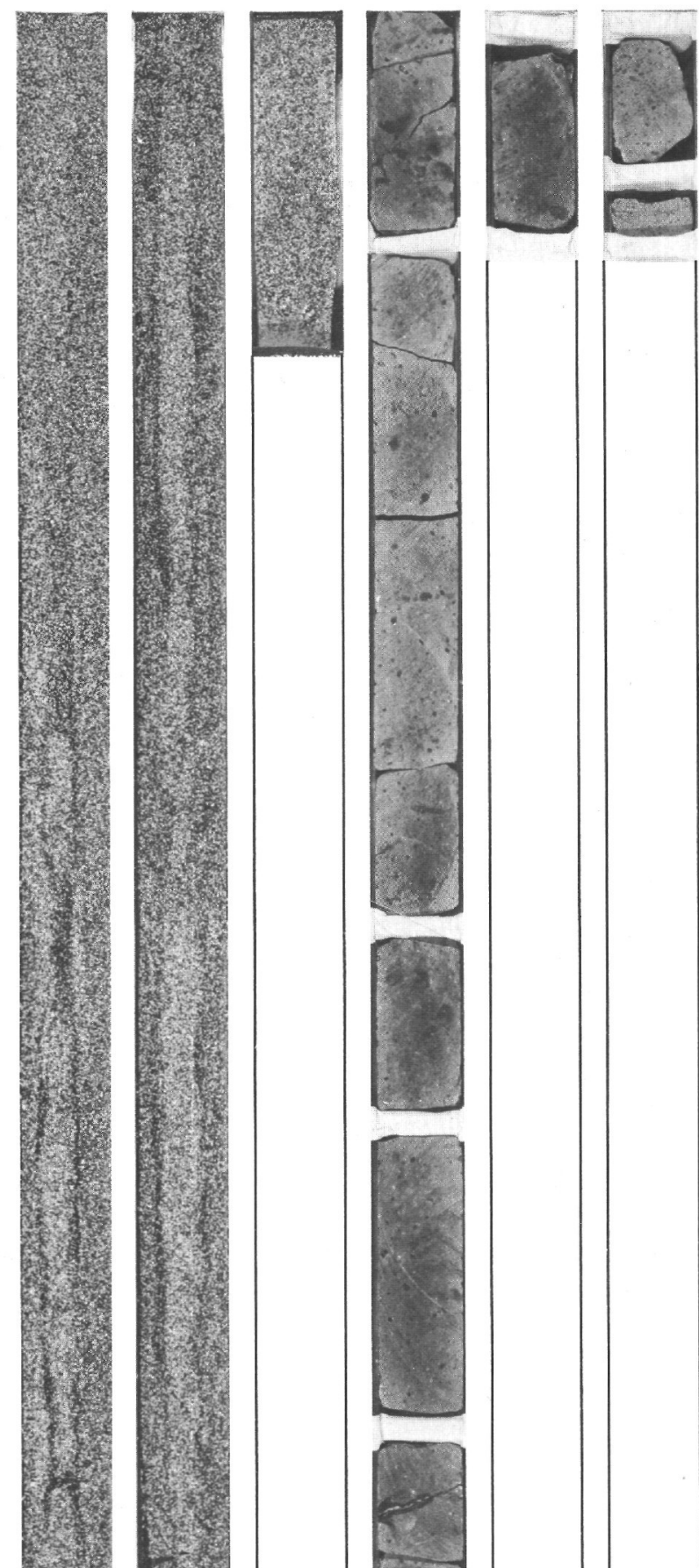

5.
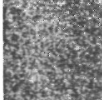

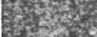
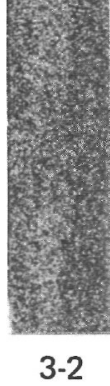

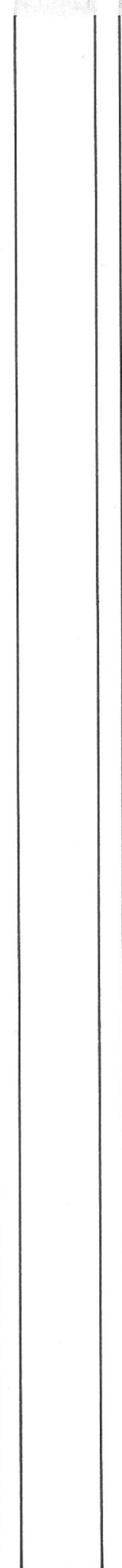

5-1
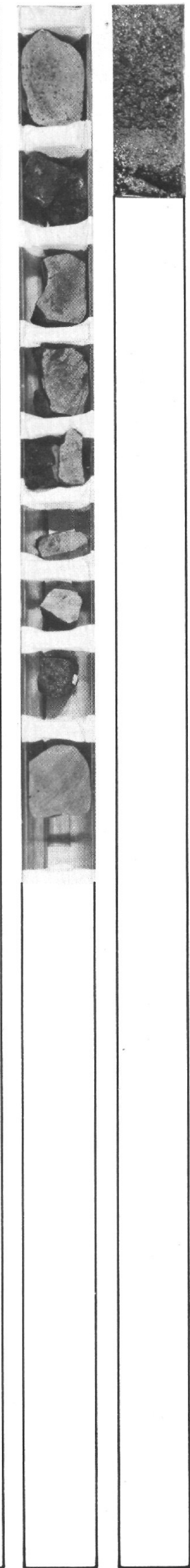

6-1

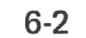

9-1 
Hole 433C

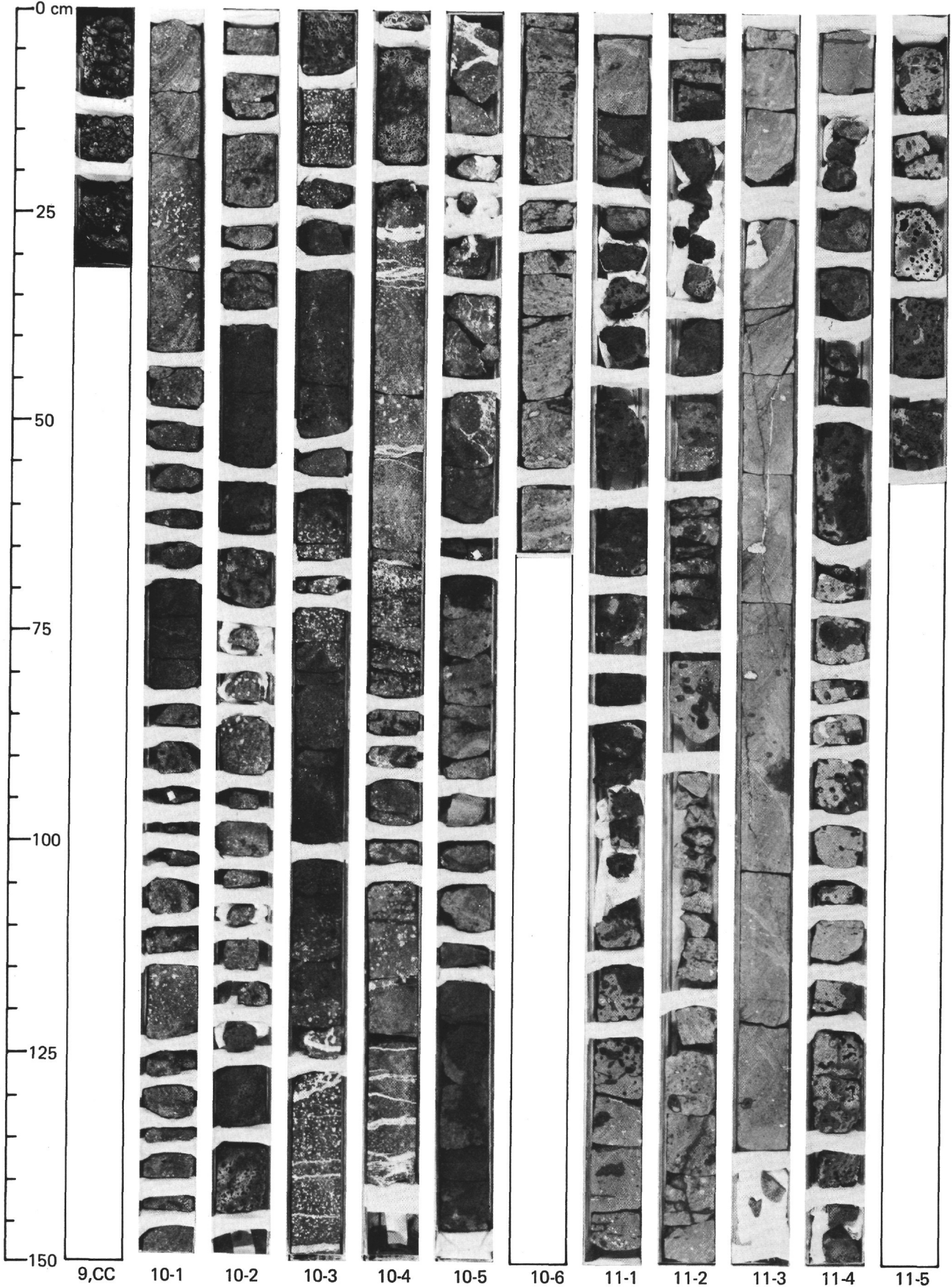


Hole 433C

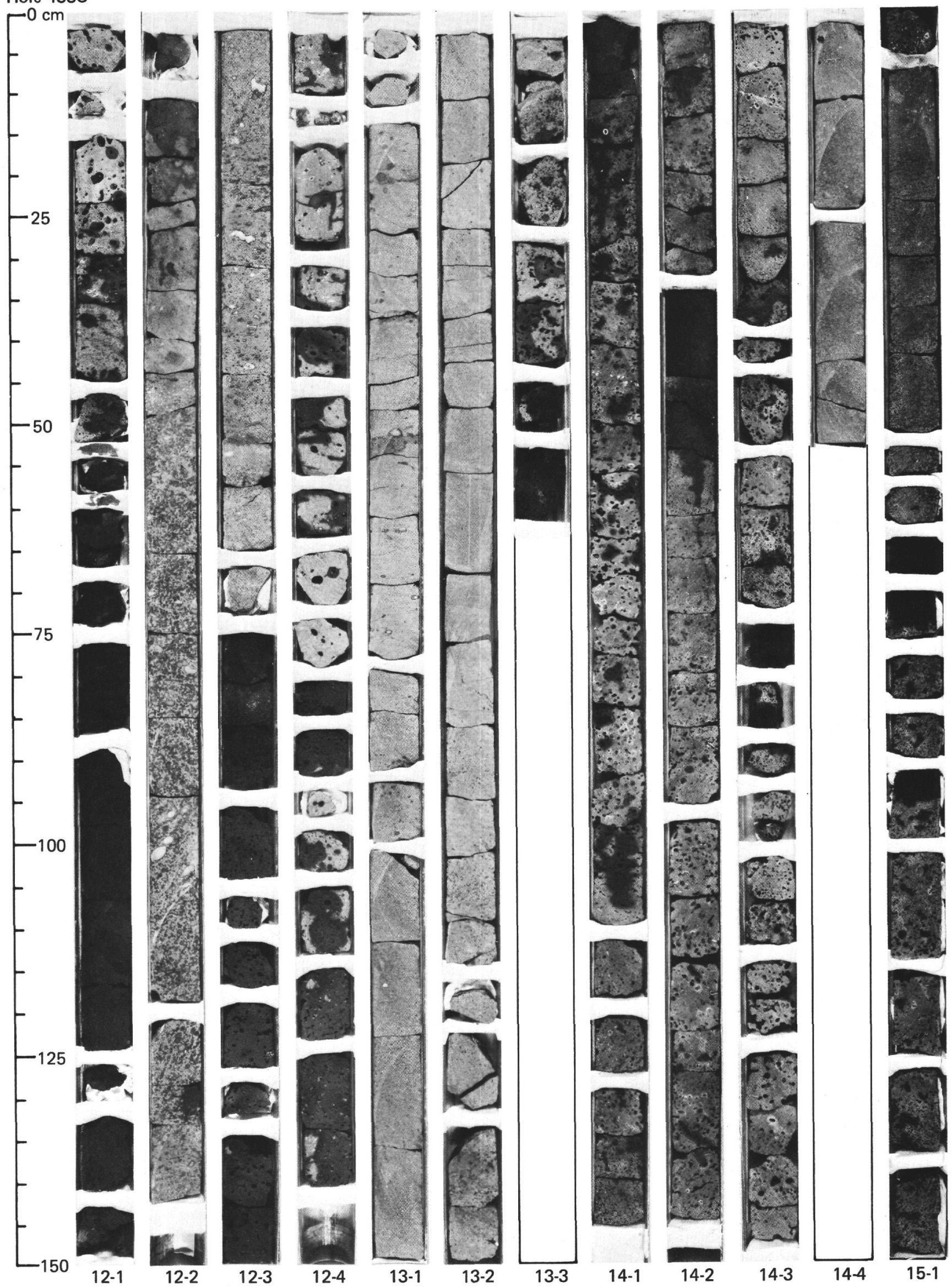


Hole 433C

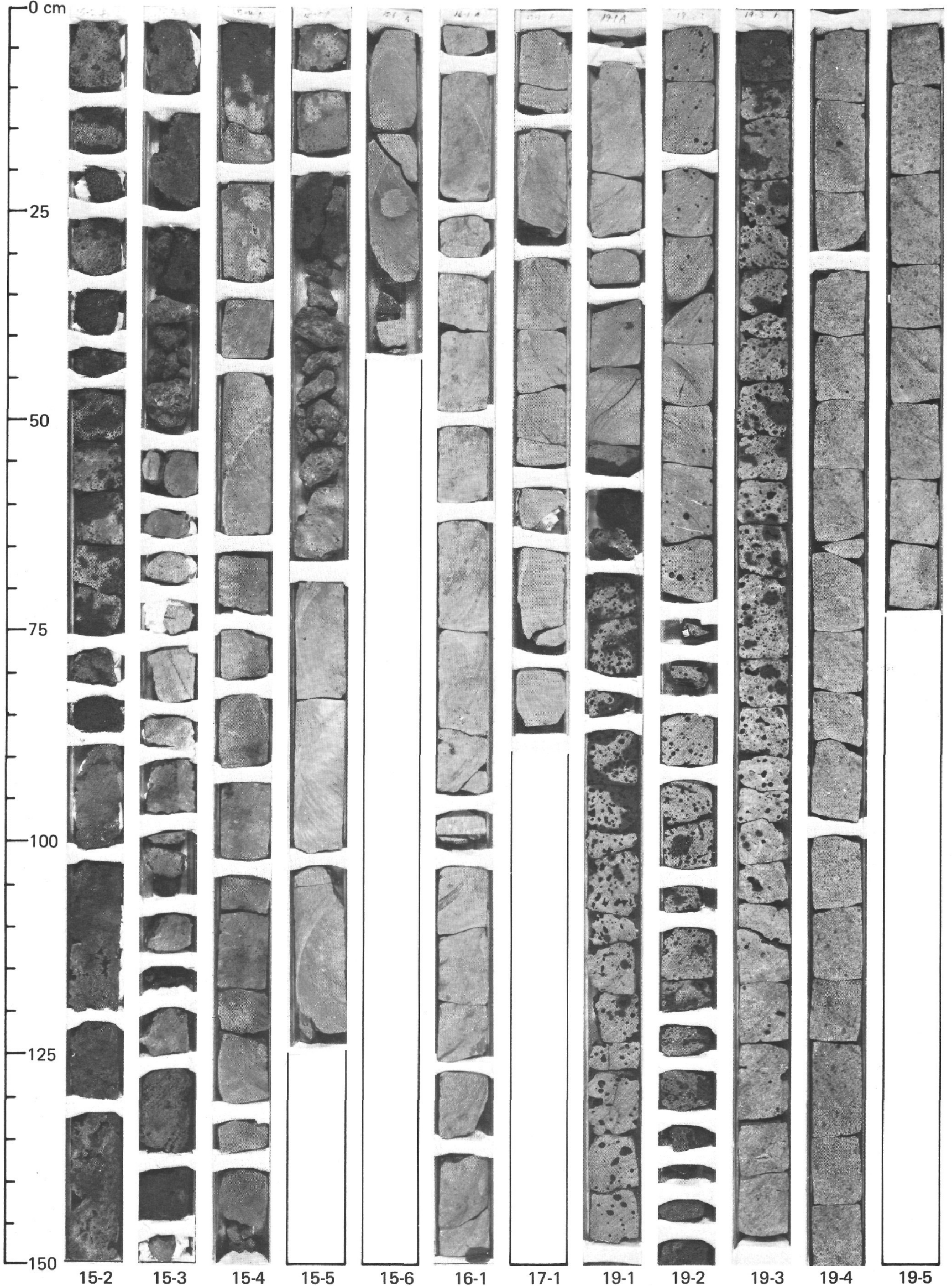


Hole 433C

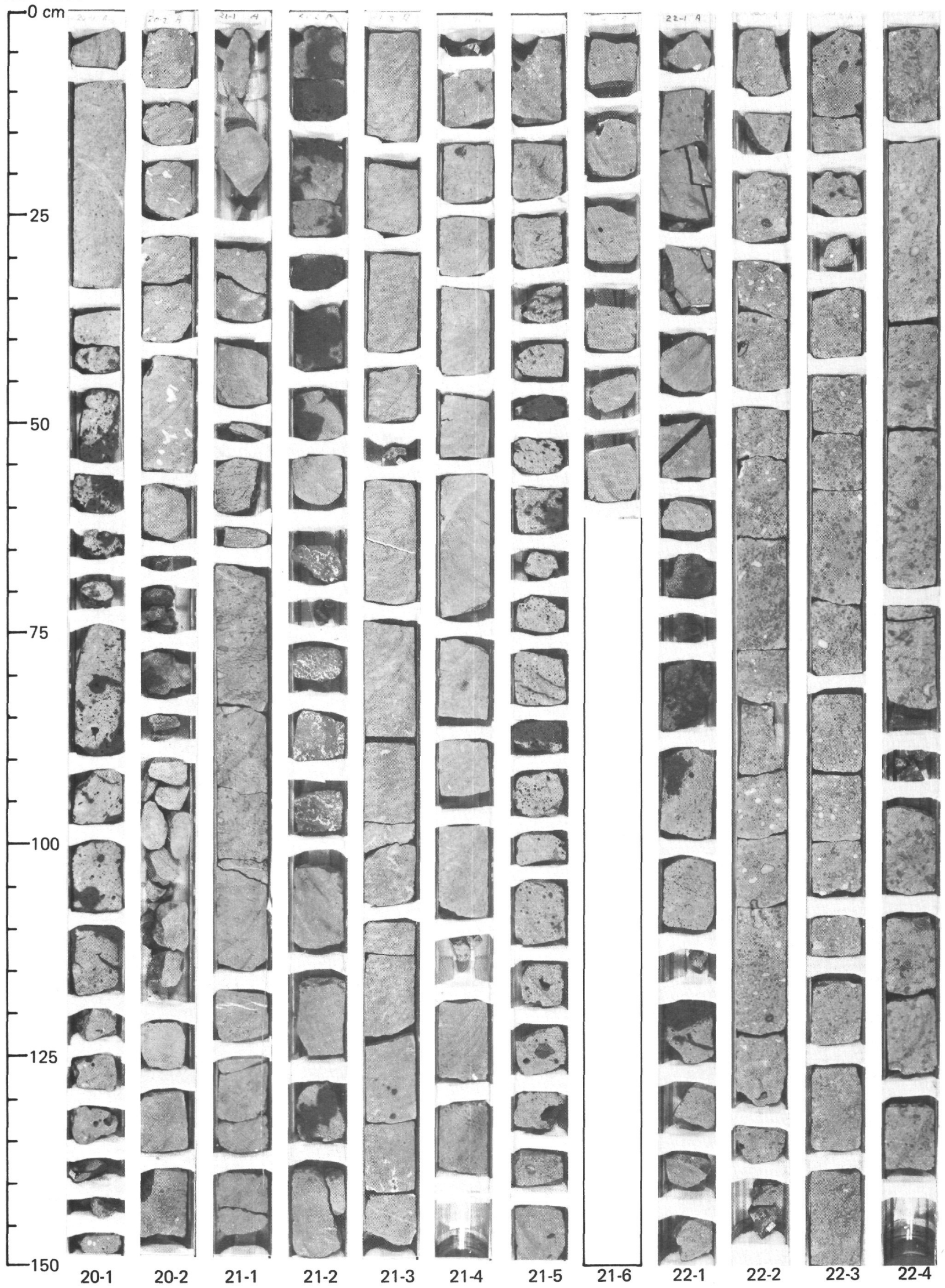




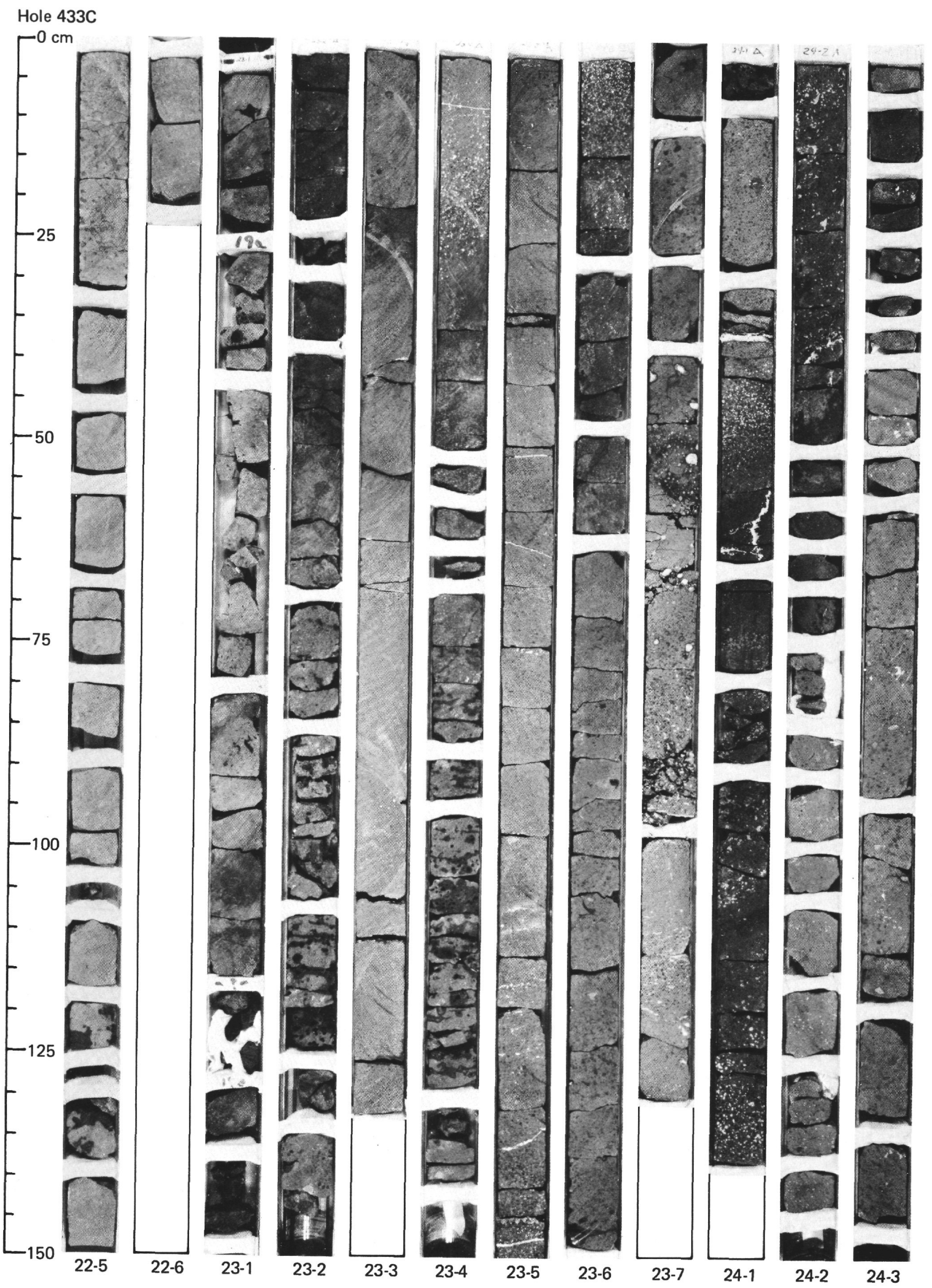


Hole 433C

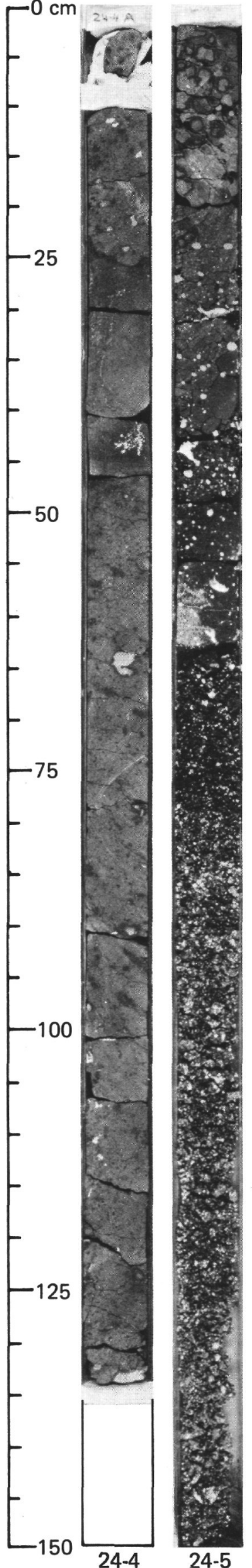

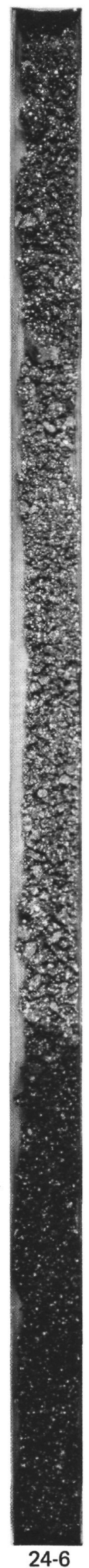

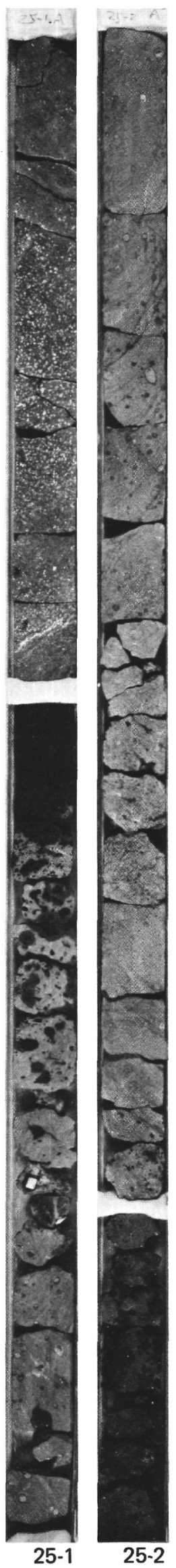

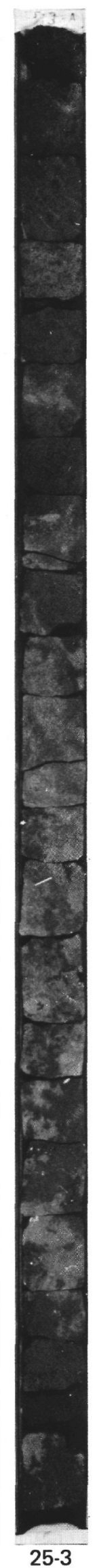
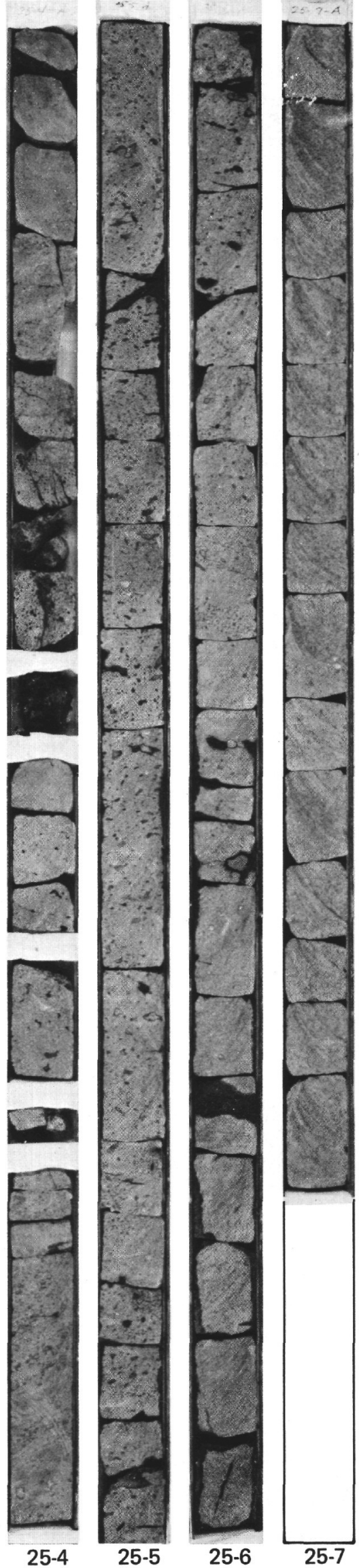
SITE 433

Hole 433C

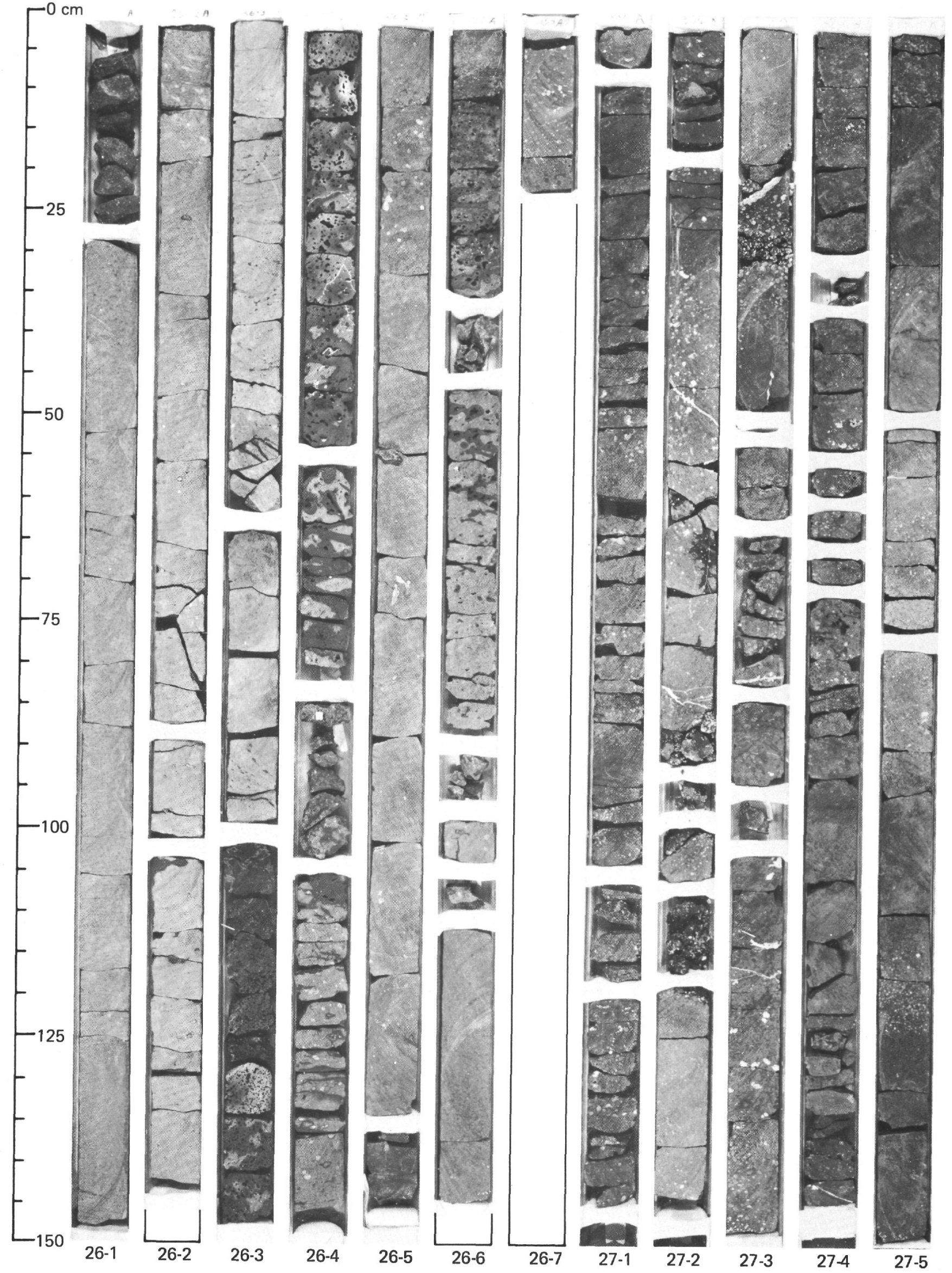


Hole 433C

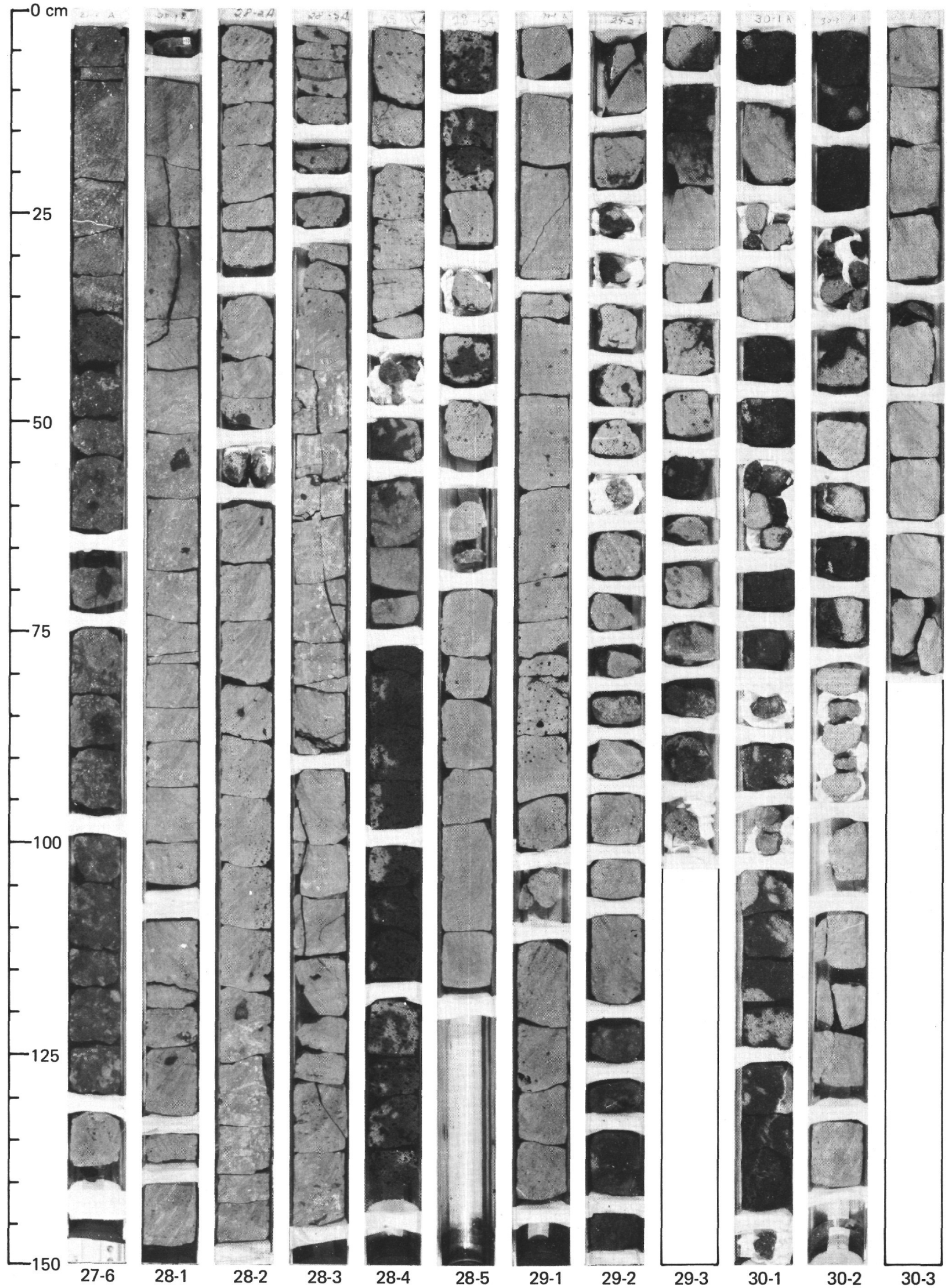


Hole 433C
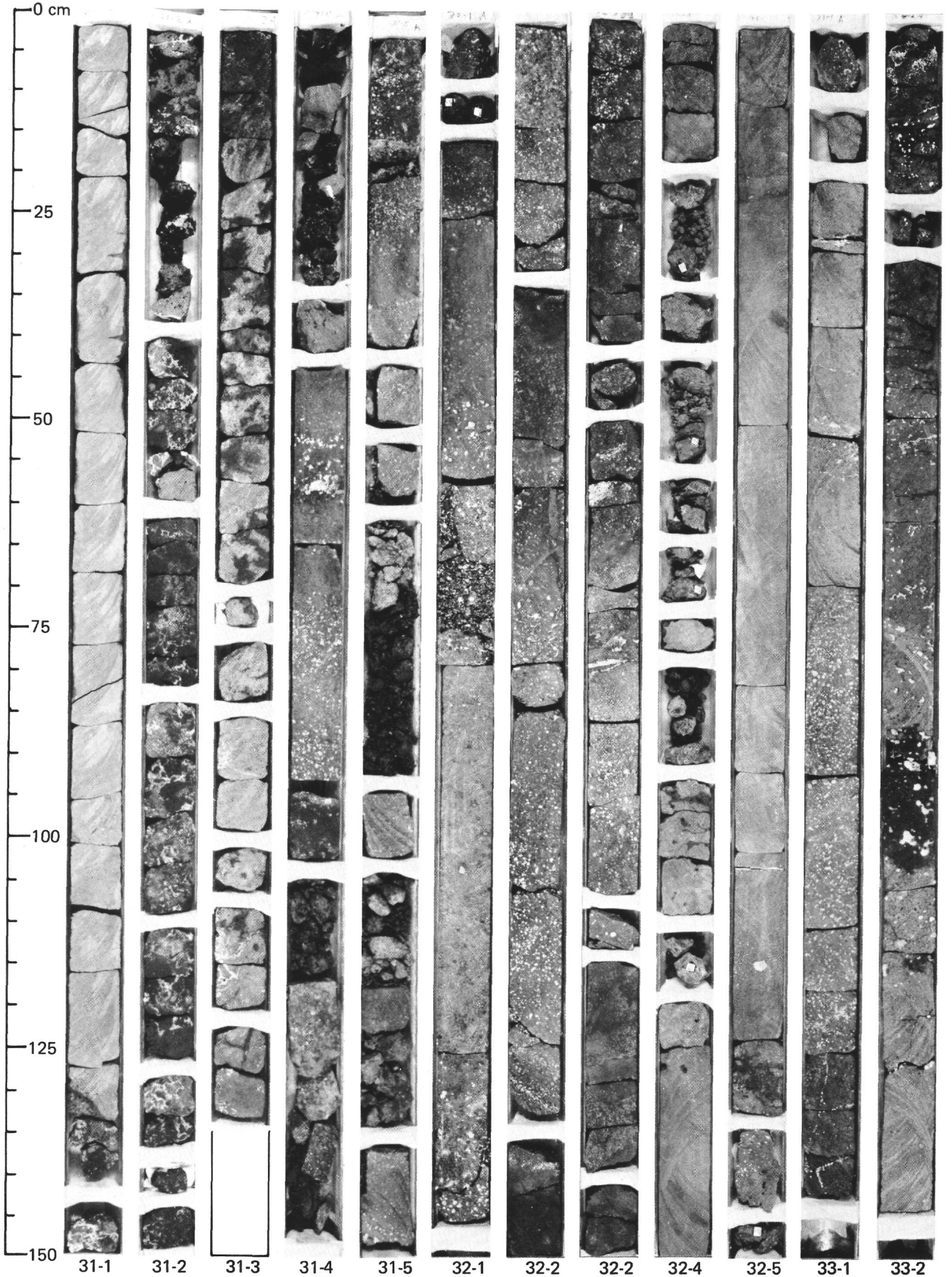

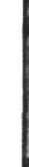
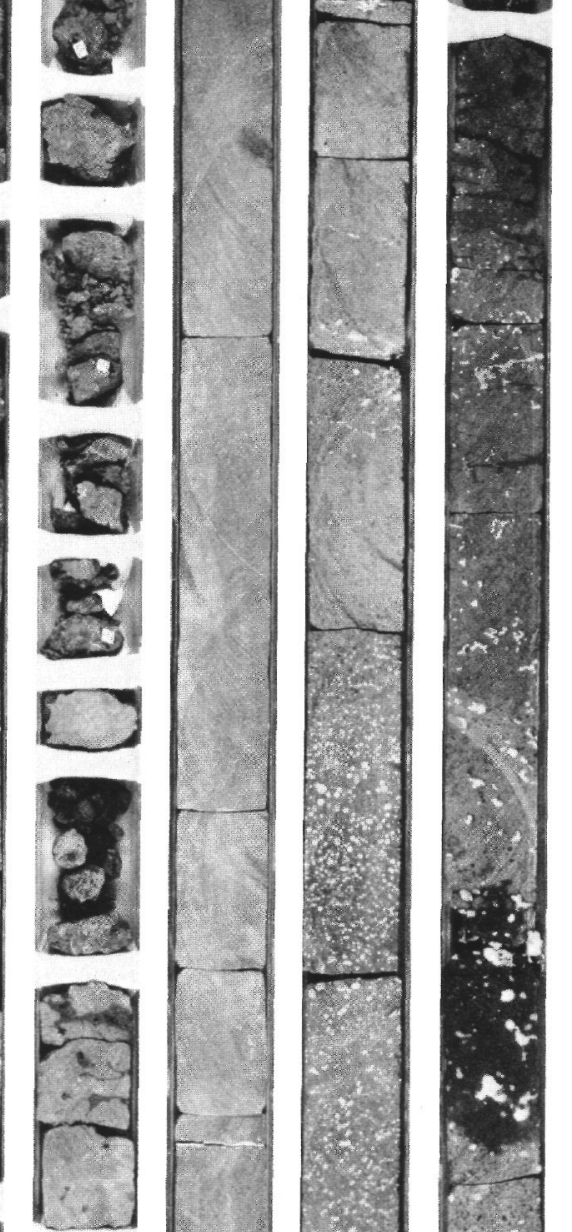
Hole 433C

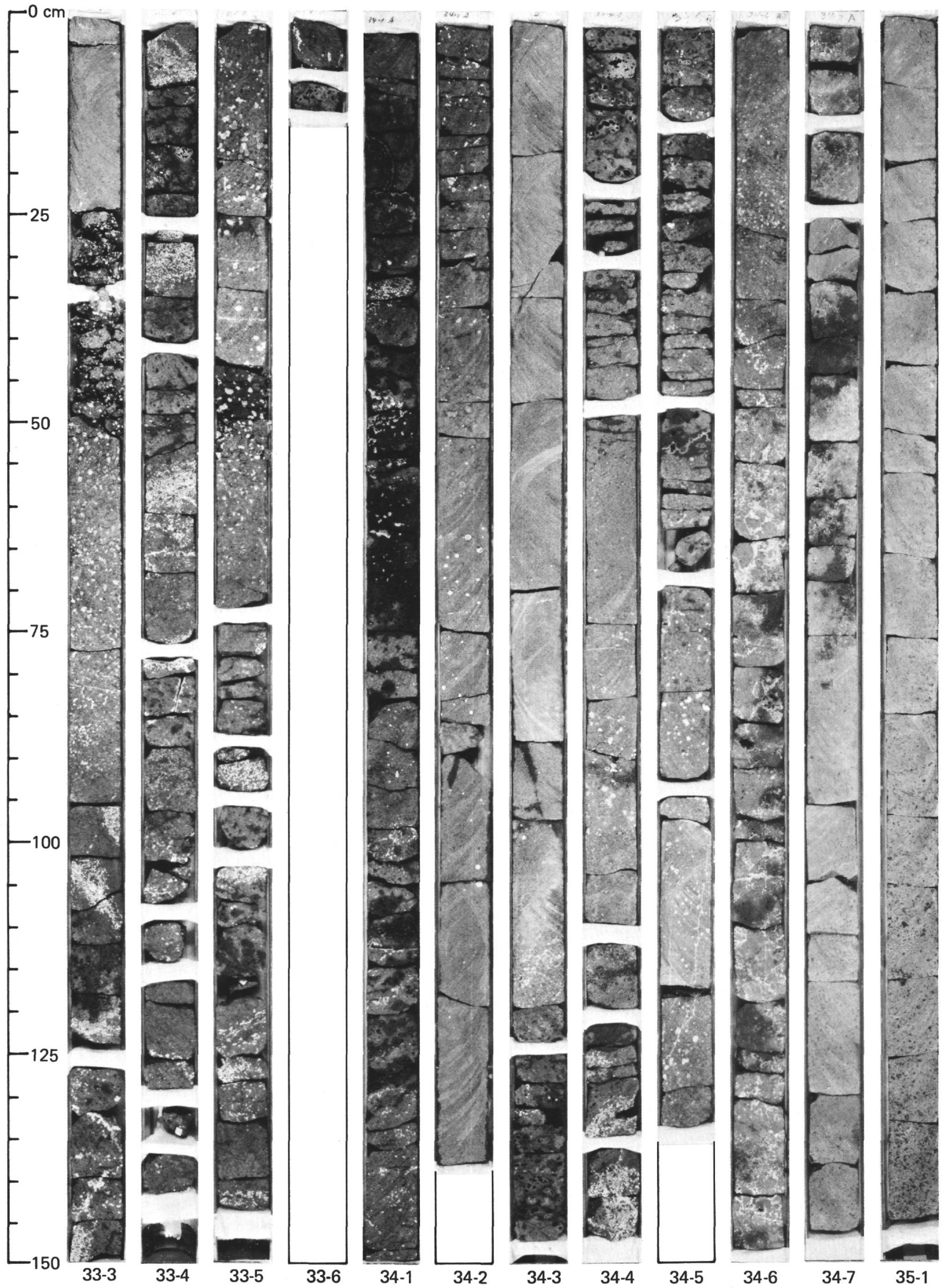


Hole 433C

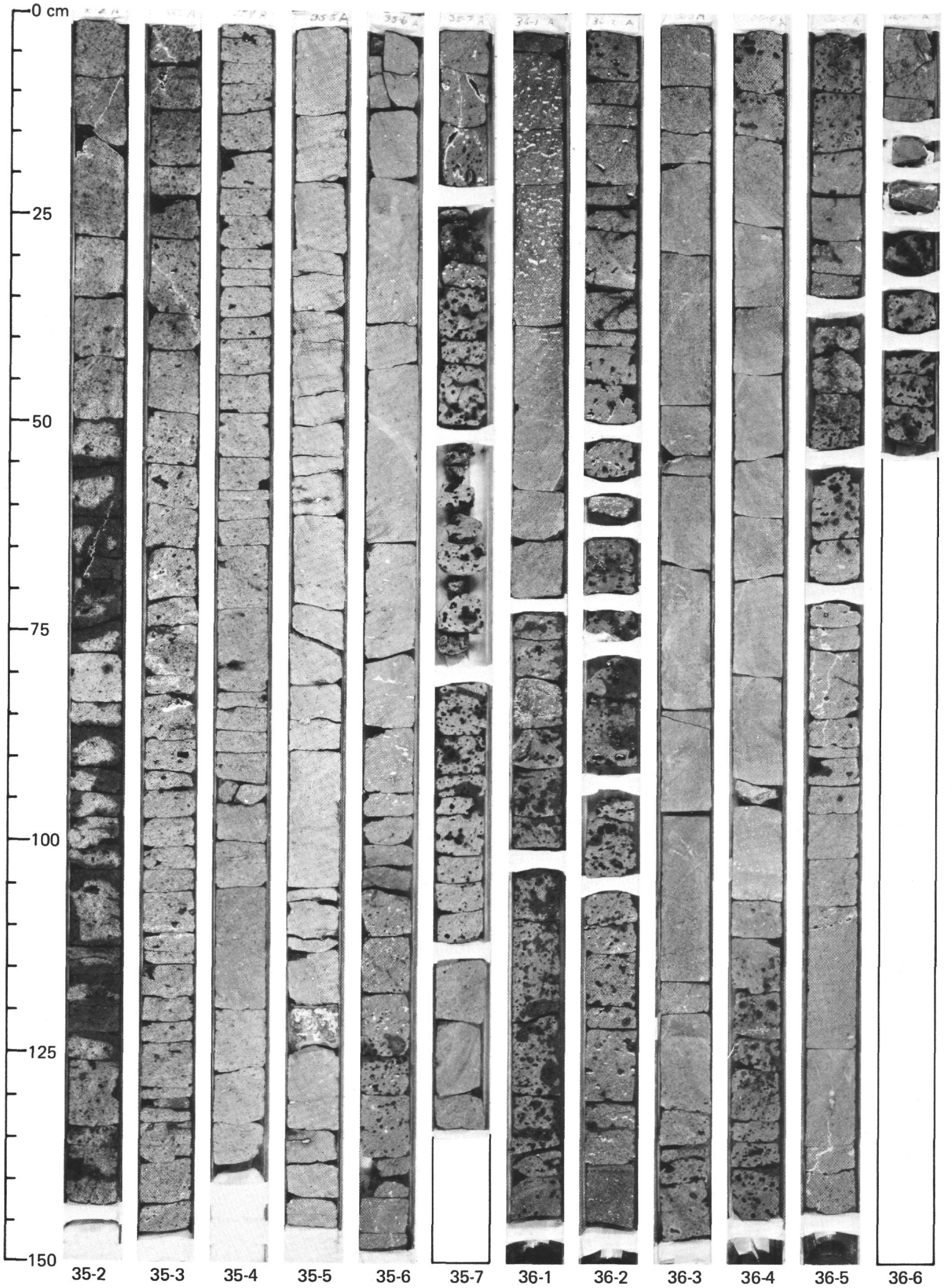


Hole 433C

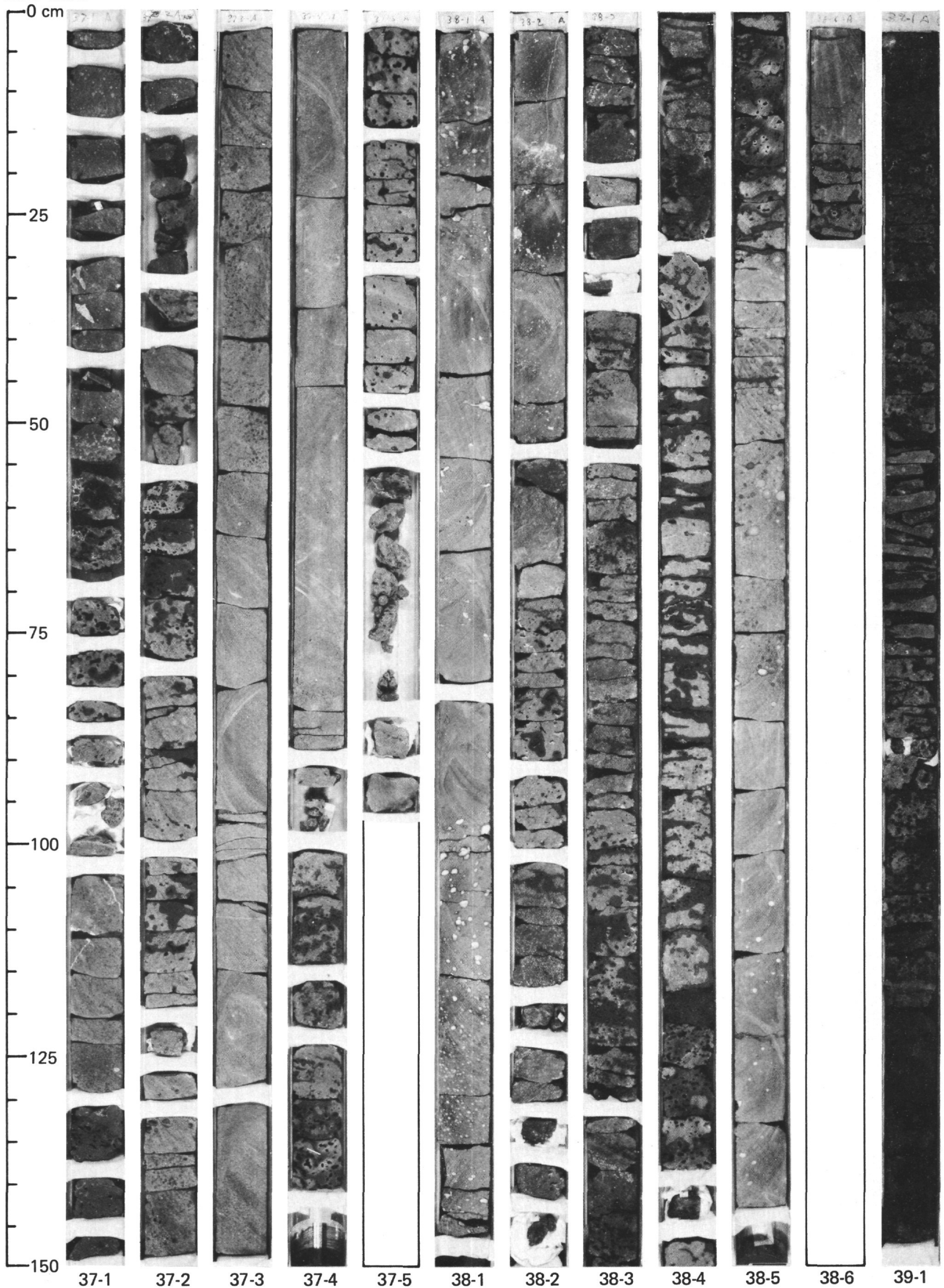


Hole 433C

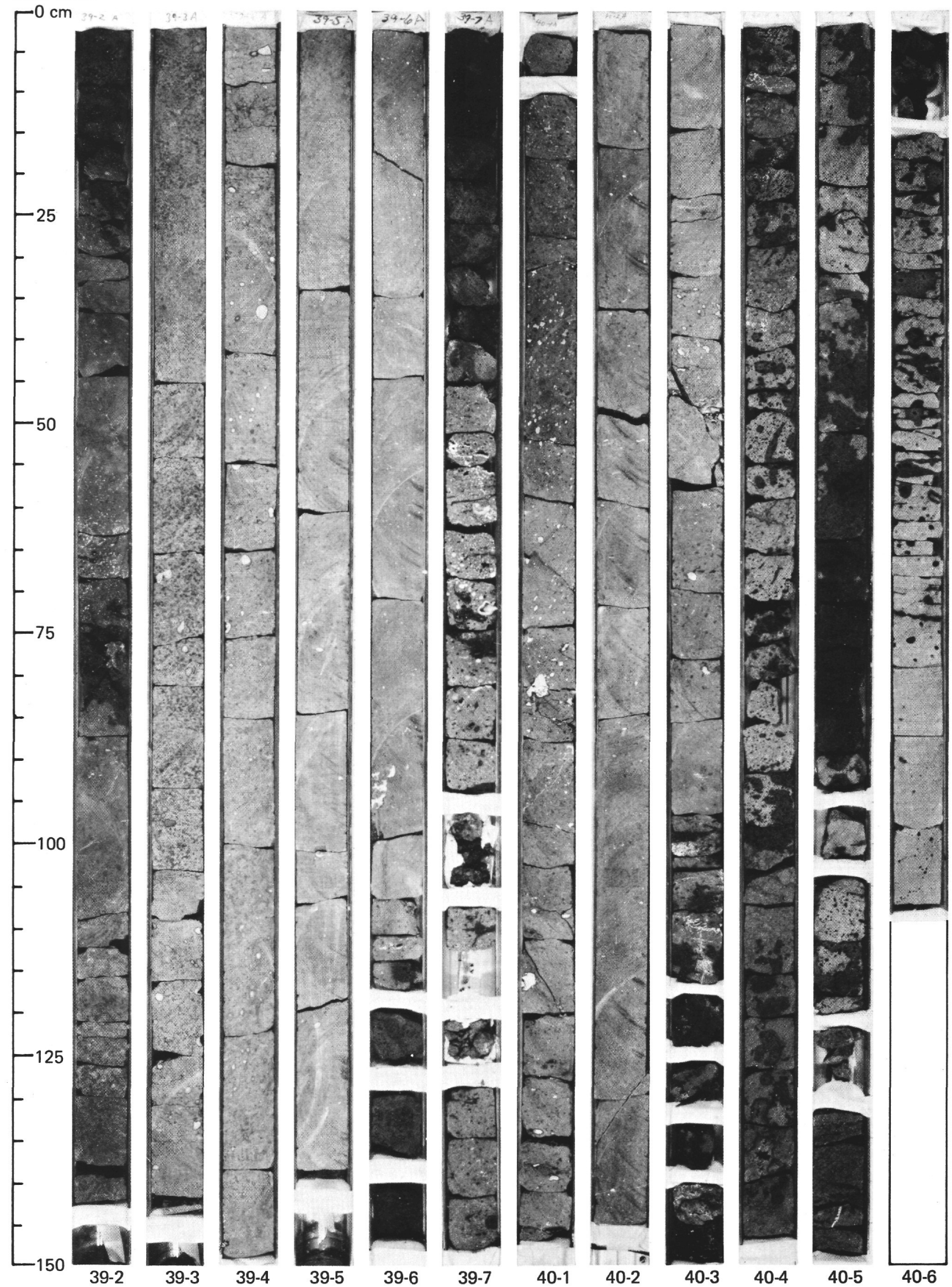


Hole 433C

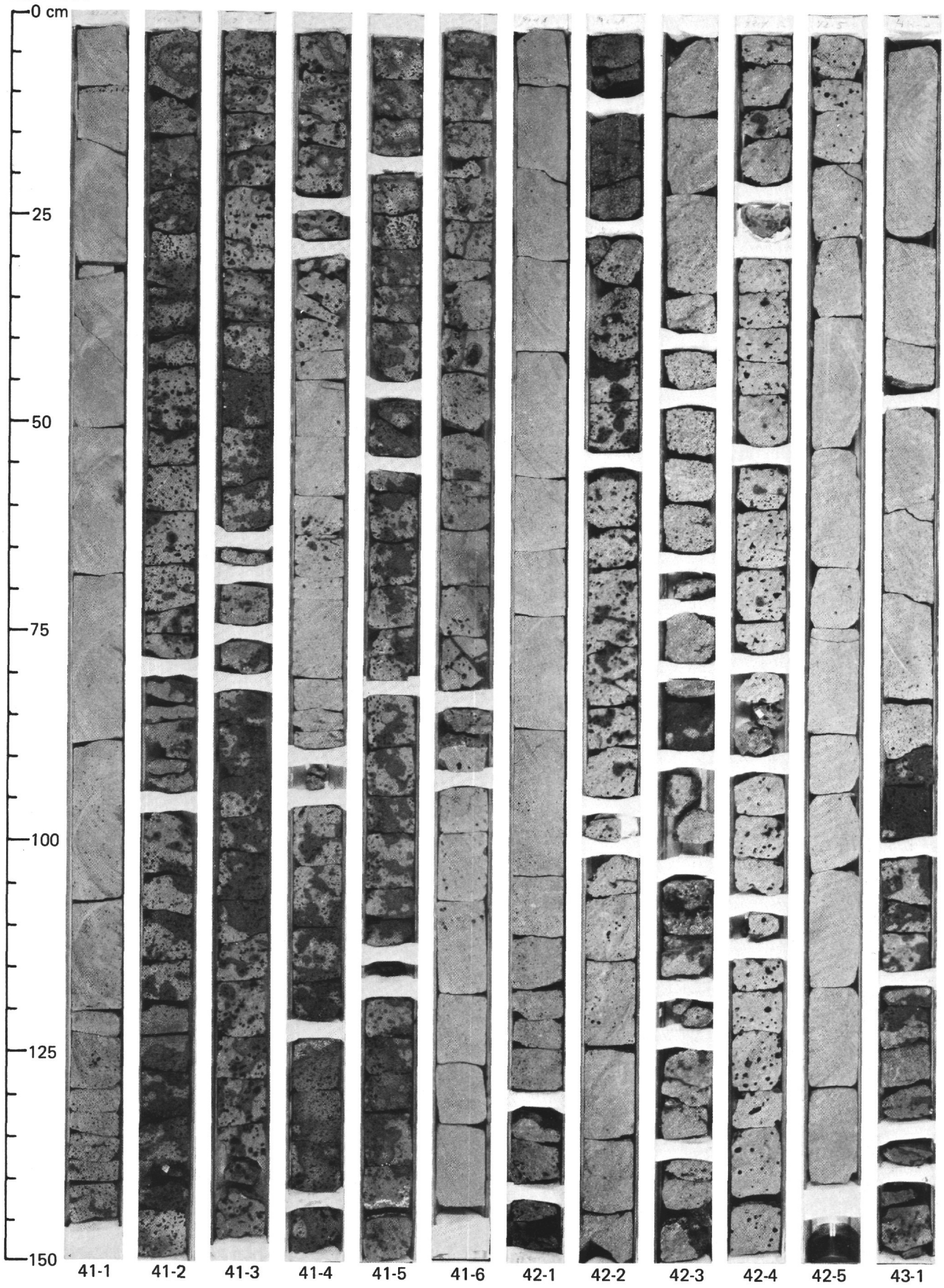


Hole $433 C$

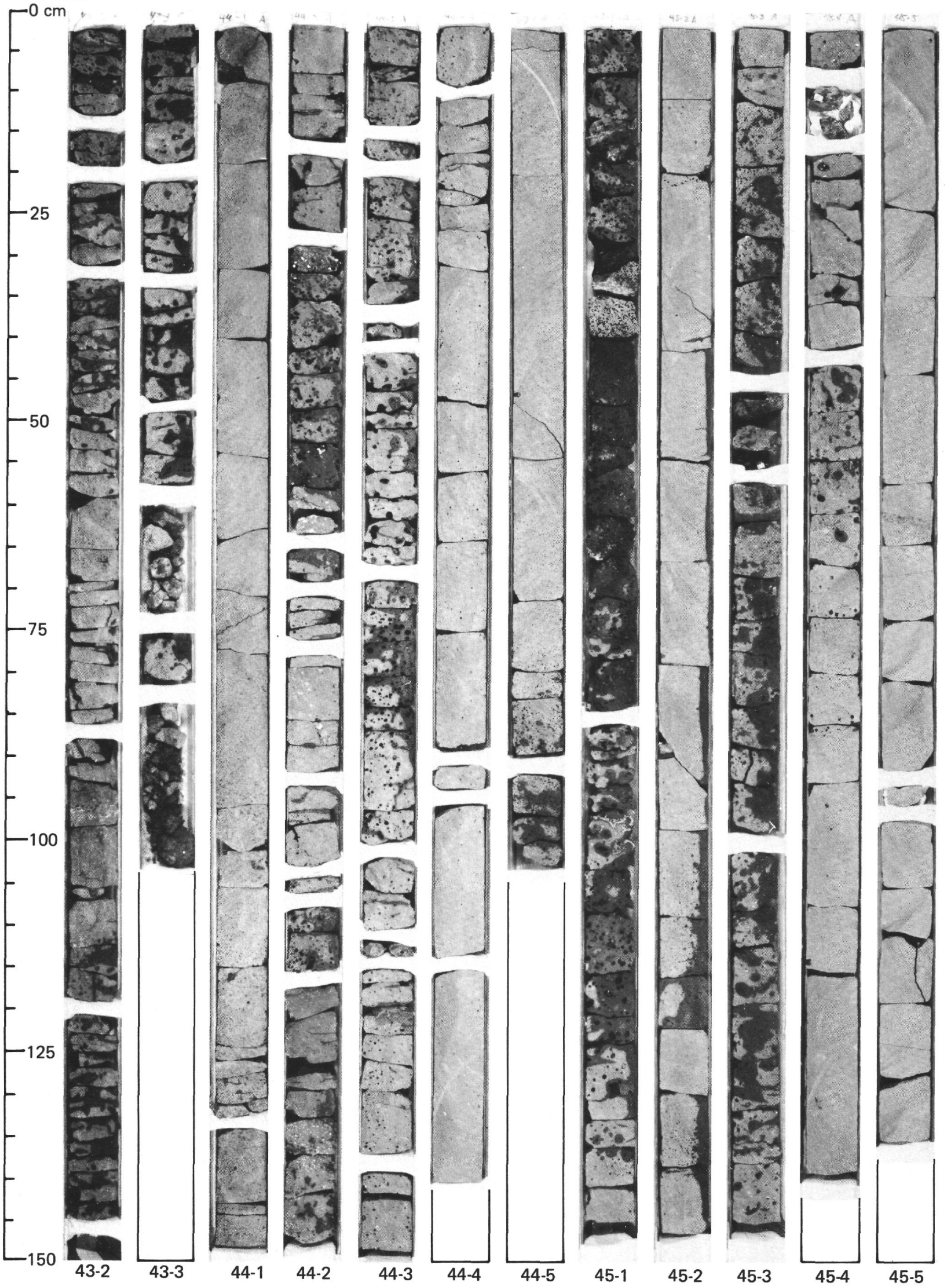


Hole 433C

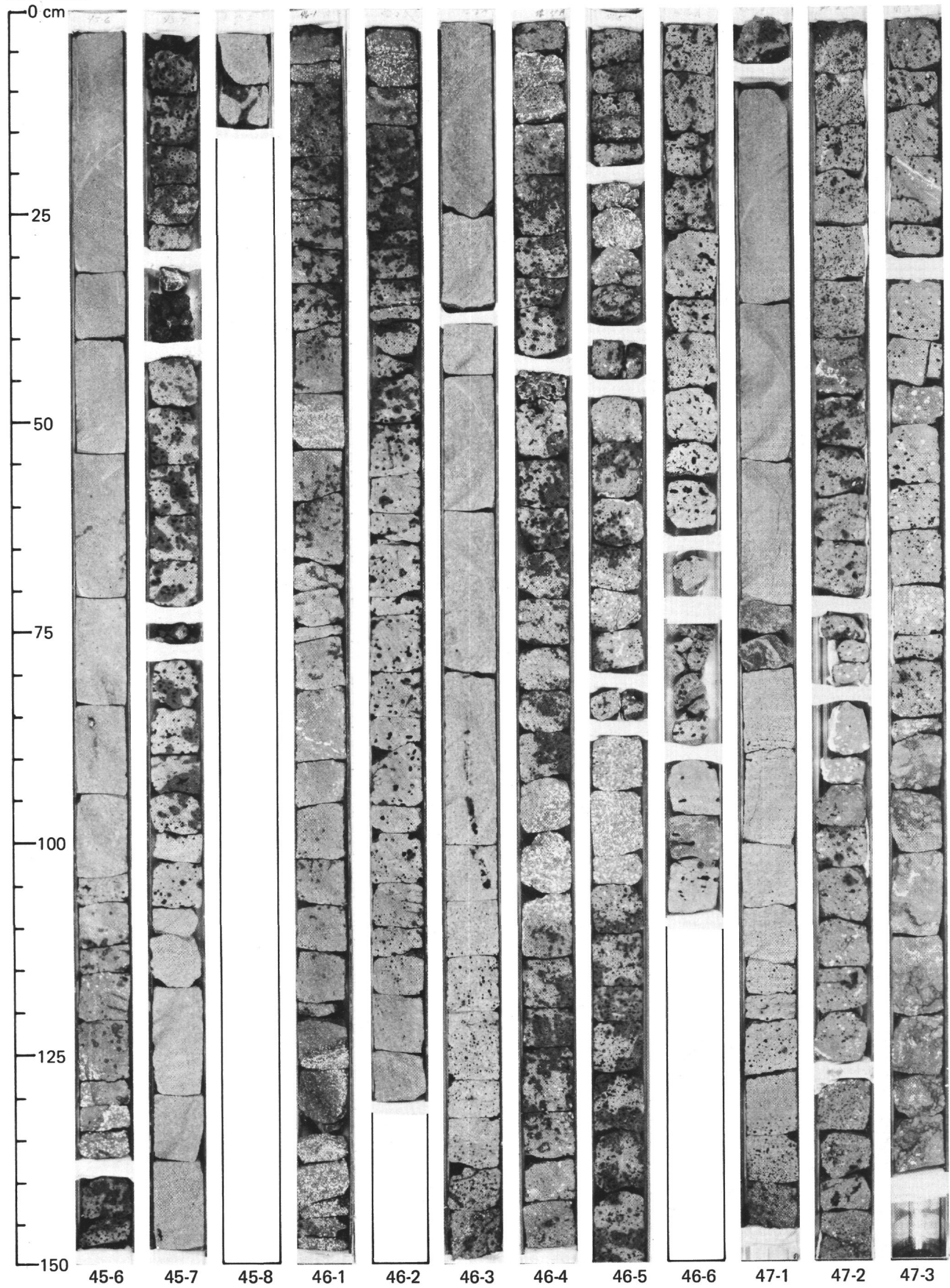


Hole 433C

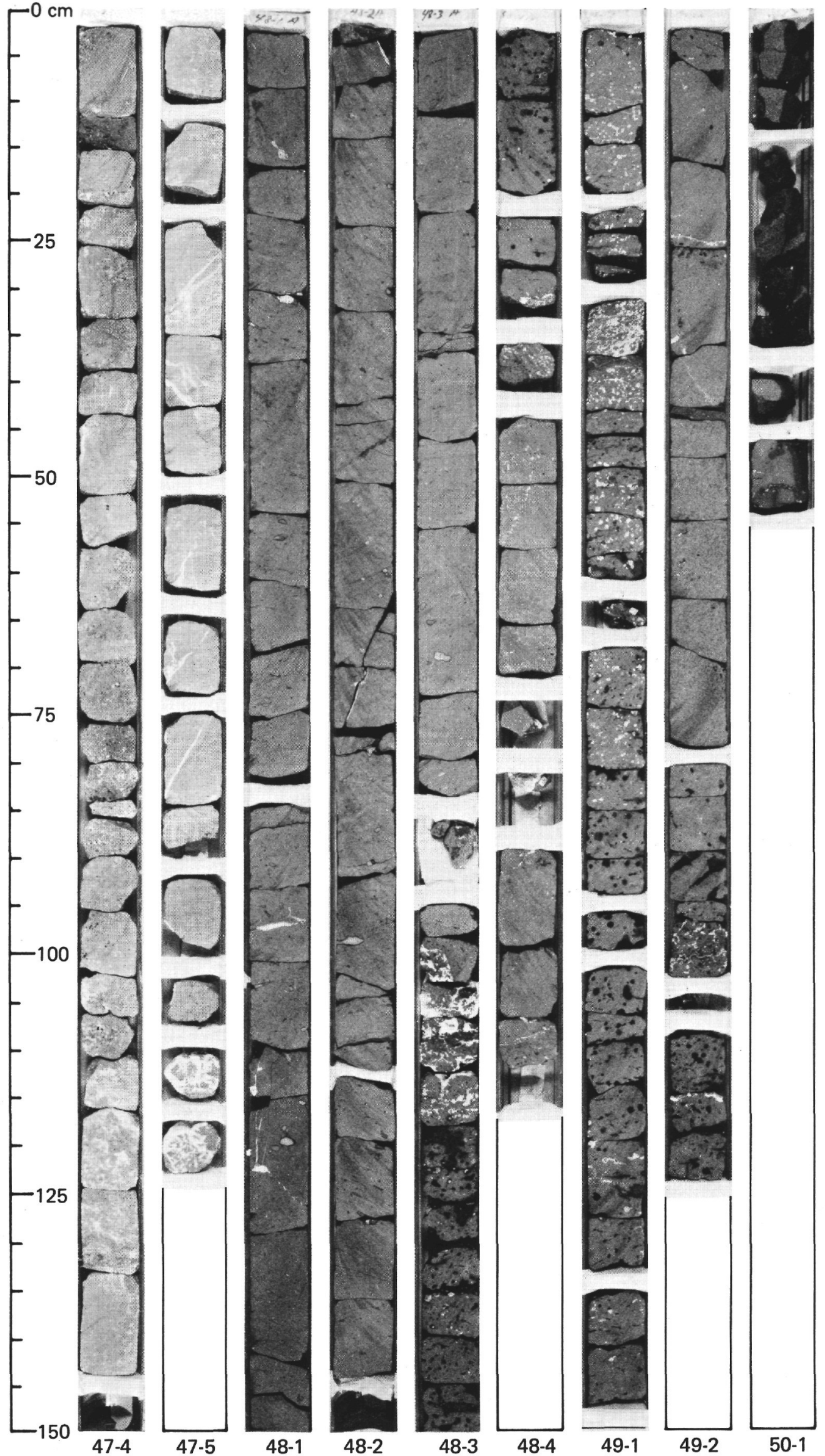

